Candidato: Evandro Fernandes de Pontes

\title{
O CONSELHO FISCAL NAS COMPANHIAS ABERTAS
}

BRASILEIRAS

Dissertação para obtenção do título de Mestre em Direito Comercial no Curso de Pós-Graduação stricto sensu da Universidade de São Paulo.

Orientador: Professor Doutor Erasmo Valladão Azevedo e Novaes França

Faculdade de Direito da Universidade de São Paulo São Paulo 



\section{Convenções}

CVM Comissão de Valores Mobiliários.

Instrução CVM Instrução $n^{\circ} 324$, de 19 de janeiro de 200, editada pela CVM. $324 / 00$

Lei das S.A. $\quad$ Lei Federal $n^{\circ}$ 6.404, de 15 de dezembro de 1976.

Lei de Falências Lei Federal n $n^{o} 11.101$, de 9 de fevereiro de 2005.

Lei de Mercado e

de Valores

Lei Federal $n^{\circ}$ 6.385, de 7 de dezembro de 1976.

Mobiliários

Lei Sarbanes-

Sarbanes-Oxley Act, de 23 de Janeiro de 2002 - ato legislativo da

Oxley ou

Câmara dos Deputados dos EUA (House of Representatives) sob o nr.

SOX 3763.

RDA Revista de Direito Administrativo, editada pela RENOVAR até o volume 242 (dezembro de 2006) e a partir do volume 243 (janeiro de 2007) editada pela ATLAS

RDB Revista de Direito Bancário e do Mercado de Capitais, editada pela REVISTA DOS TRIBUNAIS (também Revista de Direito Bancário, do Mercado de Capitais e da Arbitragem até o volume 22, dezembro de 2003).

RDE Revista de Direito do Estado, editada pela RENOVAR.

RDM Revista de Direito Mercantil, Industrial, Econômico e Financeiro, editada até o volume 104 (dezembro de 1996) pela REVISTA DOS TRIBUNAIS e a partir do volume 105 (janeiro de 1997) pela MALHEIROS.

RDP Revista de Direito Público, editada pela REVISTA DOS TRIBUNAIS.

Resolução CMN Resolução 3.198, de 27 de maio de 2004, editada pelo Conselho 3198

Monetário Nacional e publicada pelo Banco Central do Brasil, conforme alterações.

RT

Revista dos Tribunais, editada pela REVISTA DOS TRIBUNAIS. 


\section{ÍNDICE GERAL}

Introdução.

Capítulo 1: Premissas para um estudo da fiscalização societária nas Companhias Abertas Brasileiras..... 2

Seção 1: O fiscal e a fiscalização: modalidade de poder societário e controle -

entre o conselho fiscal e o comitê de auditoria.

Seção 2: Fiscalização societária, Poder de Controle e Conselho Fiscal no Brasil: Liberdade de Iniciativa, Estado Controlador, Estado Empresário

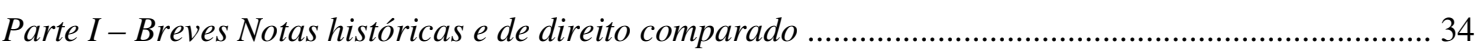

Capítulo 2: Estado Moderno e os modelos de fiscalização societária........................................................ 35

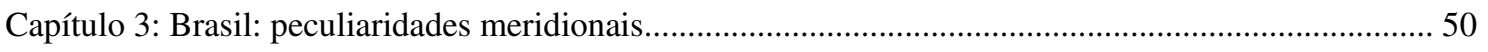

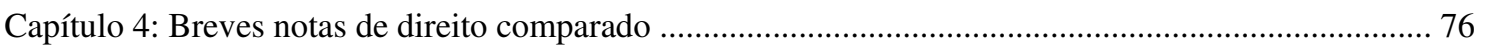

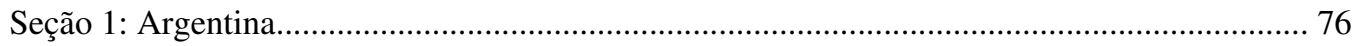

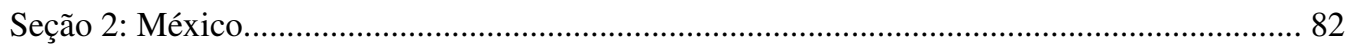

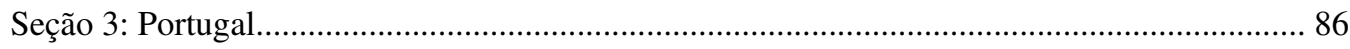

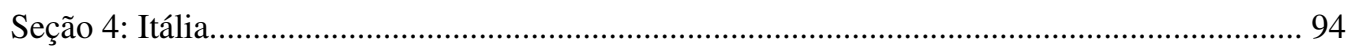

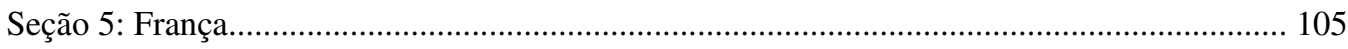

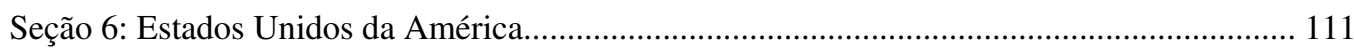

Parte II - O Conselho Fiscal e as Companhias Abertas Brasileiras................................................... 132

Capítulo 5: Composição e Funcionamento:

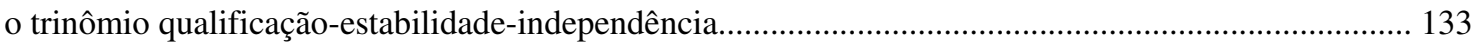

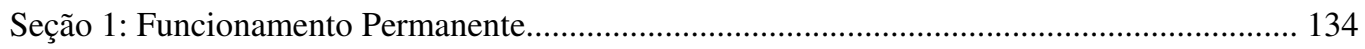

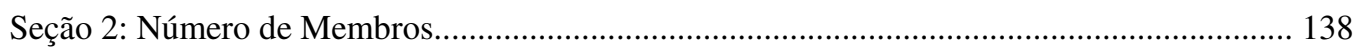

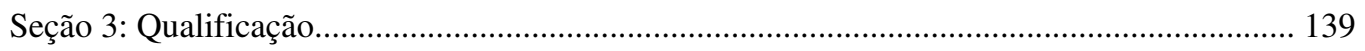

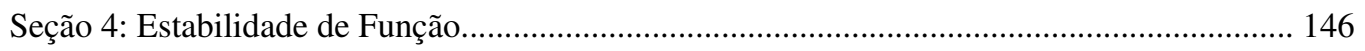

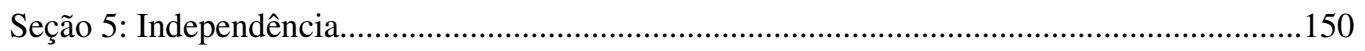

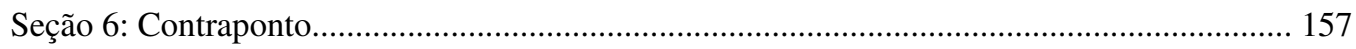

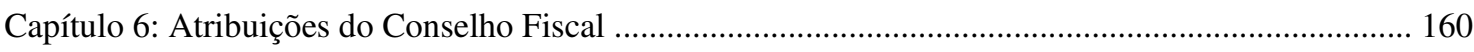

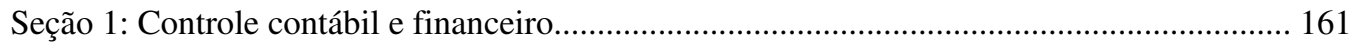

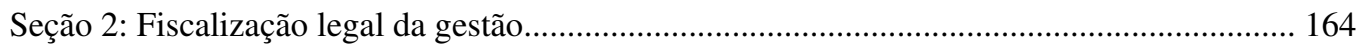

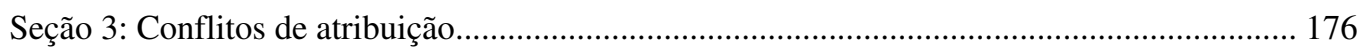

Seção 4: Ausência de procedimento previsto em lei................................................................. 183

Seção 5: Contraponto................................................................................................ 185

Capítulo 7: Direitos, Deveres, Poderes, Representações: notas sobre a responsabilidade

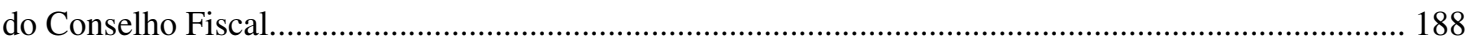

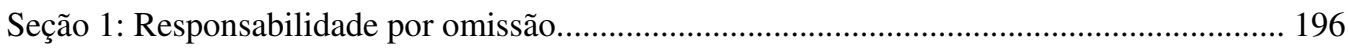

Seção 2: Compartilhamento dos deveres da administração....................................................... 200

Seção 3: Hipóteses de solidariedade no conselho fiscal.......................................................... 207

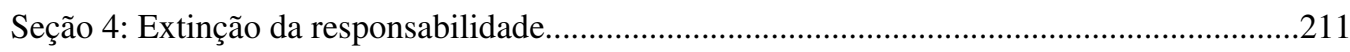

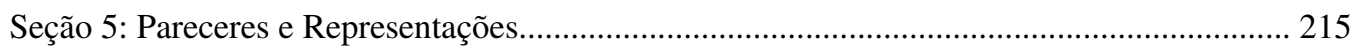

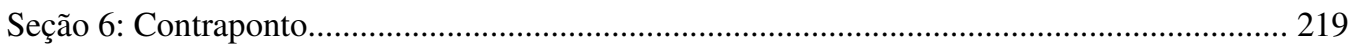

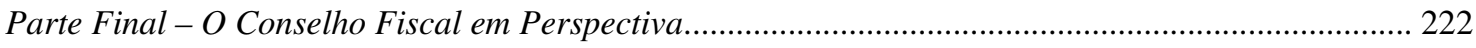

Conclusão: O Conselho Fiscal no universo da cultura e do direito brasileiro............................................. 223 
INTRODUÇÃO 


\section{CAPÍTULO 1: PREMISSAS PARA UM ESTUDO DA FISCALIZAÇÃO SOCIETÁRIA NAS COMPANHIAS ABERTAS BRASILEIRAS}

\section{O fiscal e a fiscalização: modalidade de poder societário e controle - entre o conselho fiscal e o comitê de auditoria}

Este trabalho tem o objetivo de apresentar um estudo atualizado a respeito do papel do conselho fiscal nas companhias abertas brasileiras.

A consecução desse objetivo passa pela necessidade de se compreender qual seria esse papel dentro de um conceito amplo de fiscalização societária, que se pretende brevemente discutir já nesta introdução.

Em um nível maior de concreção e logo que assumida uma certa inteligência do conceito de fiscalização societária, pretende-se investigar quais os elementos históricos que contribuíram para o quadro atual de atribuições que envolvem o papel do conselho fiscal de uma companhia aberta no Brasil, bem como os mecanismos legais disponíveis, sempre em contraponto com as lições do direito comparado.

Por fim, na conclusão, pretende-se explorar, dentro das lições hauridas no estudo de direito comparado, sob qual nível de aprofundamento se depara, atualmente, o aparato jurídico do conselho fiscal das companhias abertas, à luz do que dispõe o direito brasileiro aos seus operadores.

Neste primeiro momento e neste estudo introdutório e preliminar, fixaremos, portanto, as premissas deste trabalho. Estas premissas decorrem de uma compreensão do funcionamento da relação jurídica societária e de sua tipicidade. Adicionalmente, cumpre assumir como se opera, nesse quadro típico, o chamado poder fiscalizatório (em contraposição antitética ao conceito de poder de controle, como se verá).

Preliminarmente, podemos assumir que a relação jurídica societária, dentro de sua tipicidade, é formada por um dever ou ônus articulando poderes, potestatividades ou 
direitos (em sentido subjetivo). Integra deveres ${ }^{1}$, sujeições e obrigações, operando todos esses poderes ${ }^{2}$, potestatividades, direitos (em sentido subjetivo), deveres, sujeições e obrigações dentro de funções jurídicas que se associam reciprocamente por meio de ações (modalidades jurídicas). Essa premissa é importante para a análise do funcionamento específico da modalidade fiscalização e da função de fiscal em um universo próprio do direito societário.

\footnotetext{
${ }^{1}$ A respeito das noções que envolvem o conceito de poder, potestatividade (também tratada em língua portuguesa como potestade) e direitos [em sentido subjetivo], para os fins de identificação de uma relação jurídica em geral, vide Francesco CARNELUTTI. Teoria Generale del Diritto, $3^{\mathrm{a}}$ ed.. Roma: S.E. Foro Italiano, 1951, pp. 7-187. Na mesma linha de CARNELUTTI, mas com maior brevidade, vide Francesco SANTOROPassarelli (Dottrine Generali del Diritto Civile, $9^{\mathrm{a}}$ ed.. Nápoles: Jovene, 2002, pp. 69-102). Em doutrina brasileira, Pontes De Miranda (Tratado de Direito Privado, Tomo I, $3^{\text {a }}$ ed.. Rio de Janeiro: Borsoi, 1970, pp. 3-132) apresenta um escalonamento entre direitos (em sentido subjetivo), potestatividades e poderes na mesma linha de doutrina assentada entre estudiosos de teoria geral do direito em países da civil law. Dá-lhe explicação muito didática, também, Giuseppe LUMIA (Lineamenti di teoria e ideologia del diritto. Milão: Giuffrè, 1973; embora LuMIA fale apenas da existência de direitos em sentido objetivo e de potestatividades, além das expectativas de direito, sem falar em uma suposta terceira categoria, a do poder). Luís RECASÉNS SICHES (Introducción al Estudio del Derecho, $2^{\mathrm{a}}$ ed.. México: Porruá, 1972, pp. 140-147) fala da existência de três categorias: o direito em sentido subjetivo, a pretensão e o poder formativo [equivalente a potestatividade]. Recentemente, Luigi FERRAJOLI (Principia Iuris: teoria del diritto e della democrazia, vol. I - "Teoria del Diritto". Bari: Laterza, 2007, p. 587-723) trata do tema de forma magistral. Para FerRAJOLI poder assim se define: "Potere è la situazione attiva che, ove non sia costituente, è prodotta da una decisione e consistente nella modalità di un atto precettivo i cui effetti si producono nella sfera giuridica altrui e la cui validità dipende dalla sua legittimità" (p. 588). Função se define como: "qualunque potere imputato a un soggetto con l'obligo di esercitalo per sodisfare le aspetative e gli interessi di altri soggetti" ( $\mathrm{p}$. 603); ao passo que a potestatividade assim se define: "Potestà é qualunque potere consistente in una facoltà attribuita al suo titolare non gia nell'interesse di terzi ma nel suo stesso interesse" (p. 604). Essa é a razão pela qual, ao aplicarmos tais conceitos brilhantemente formulados por FERRAJOLI, pouca dúvida resta de que a atividade que investe o conselho fiscal de poder jurídico necessita ser propriamente encarada como uma função e não como potestatividade ou potestade, já que, por lei (artigo $165, \S 1^{\circ}$ da Lei das S.A.), o conselheiro fiscal sempre age no interesse de terceiros, congregados na vontade em síntese da companhia. Com apoio em Hans KELSEN, veremos que essa vontade ou "exclusivo interesse da companhia" se forma por meio de operação dialética que sintetiza as somas e choques de interesses individuais de órgãos que representam a companhia aberta.
}

Mas é com Francesco CARNELUTTI, como se verá, que essa categorização espelha a sua estrutura de forma mais didática e bem acabada.

${ }^{2} \mathrm{O}$ elemento da relação jurídica tem sempre um poder, de um lado, e um dever, de outro. Tomando, o poder, portanto, como "a possibilidade de determinar a conduta de alguém" [possibilità di determinare la condotta altrui] (CARNELUTTI, Ibidem, p. 144), o direito subjetivo é dado como mecanismo para que essa mesma pessoa acione a sua capacidade de determinar conduta alheia nos termos da lei. Um segundo tipo de poder ainda diz respeito à capacidade ou incapacidade de desenvolver ou fazer progredir um interesse próprio. Nessa relação bipolar em que se exprime um ponto ativo e outro passivo, CARNELUTTI faz entender que há uma relação de implicância entre os dois pólos da relação jurídica: porquanto se há poder de um lado, há de ter dever do outro, nestes termos (Ibidem, p. 145): "Dei sei tipi di rapporto giuridico cosi delineati tre sono attivi, cioè sono forme di potere: potestà, diritto soggettivo, facoltà; tre sono passivi, cioè sono forme di dovere: soggezione, obligo, onere. Alle due prime figure del potere (potestà e diritto soggettivo) corrisponde la terza figura del dovere (soggezione). Alla terza figura del potere (facoltá) corrispondono le due prime figure del dovere (onere e obbligo)" (assim). Note-se que as definições que FerRaJOLI e CARNELUTTI emprestam para o termo potestà são diferentes. Na essência, o que CARNELUTTI entende por potestà, FERRAJOLI dá o nome de funzione. Como logo se verá, somos da opinião que a tarefa desenvolvida pelo conselho fiscal é verdadeira função (funzione), no sentido que lhe empresta FERRAJOLI, que, marque-se, é próxima da definição de potestà de CARNELUTTI: poder imputado a um sujeito para que o exerça em nome de outrem. 
As chamadas relações jurídicas compostas são de grande valia para o direito societário. Definem-se pelas combinações entre relações que formam, sobre os poderes, categorias específicas de exercícios ativos de poder, a saber o status e a qualificação. Em direito societário, grande parte das relações é, na acepção "carneluttiana", formada por relações compostas. Grande parte dos poderes, direitos subjetivos e potestatividades praticadas por acionistas, tem na base o conceito de status, mais especificamente o de status socii ${ }^{3}$ ou de qualificações específicas, como ocorre com a combinação dos artigos 161 e 162 da Lei das S.A., em relação ao conselho fiscal. ${ }^{4}$

\footnotetext{
${ }^{3}$ CARNELUTTI lembra da existência, por seu turno, de um poder que ele chama de status societatis (p.177) que, queremos crer, equivalha em forma e conteúdo ao status socii; bem como, de grande interesse para o direito comercial, o chamado estado falimentar (p.178). Noutro contexto (sobre o direito público subjetivo) e ainda em referência ao exercício de direitos coletivos, afirma: "La tutela di qualsiasi interesse collettivo può dar luogo a un fenomeno siffatto. Gli esperti del diritto di società comerciali sanno, in particolare, che vi sono alcuni interessi sociali, la cui tutela si attua anzichè mediante un potere concesso all'assemblea, e cosi ai socii uti universi, col mezzo di un potere attribuito a ciascun socio, cioè al singolo uti socius; vien fatto di pensare, per analogia, all'azione popolare $e$ il richiamo avverte che ci si trova proprio sul terreno, sul quale alligna il diritto pubblico soggettivo" (assim) (pp. 162-163). CARNELUTTI reconhece, a exemplo do direito societário, que as peculiaridades clamam por um tratamento específico com grande aproveitamento de seus conceitos.
}

Sobre os status socii, lembrar da lição de Tullio ASCARELLI é um dever. Tullio ASCARELLI lembra que os stati socii devem ser entendidos como sinônimo da posição de sócio dentro do ordenamento societário de uma sociedade comercial determinada e específica (vide Saggi di Diritto Commercialle. Milão: Giuffrè, 1955, pp.219-227). Nesse sentido, texto e nota acentuam que "La circostanza sulla quale vorrei richiamare l'attenzione è tuttavia un'altra che, a sua volta, si collega con la premessa dalla quale ho preso le mosse circa il referimento dell'azione a uno status o, comunque, a una posizione, pressuposto di una serie di diritti, poteri, obblighi. Nota: E che come tale potrà essere poi suscetible di qualificazioni diverse in relazione alle quali diversi potranno essere i diritti, poteri, obblighi di cui costituisce sul presupposto, como appunto avviene nei riguardi degli azionisti privilegiati o di quanti siano tenuti a prestazione accessorie" (assim). Do mesmo ASCARELLI, vide ainda em Appunti di Diritto Commerciale - società e associazioni commerciale. $3^{\mathrm{a}}$ ed.. Roma: Foro Italiano, 1936, p. 113-140.

Ainda sobre os stati socii vide a lição de António Menezes CoRDEIRo (Manual de Direito das Sociedades, Volume I: Das Sociedades em Geral. Coimbra: Almedina, 2004, pp. 497-507) e Alessandro BeRTINI. Contributo allo studio delle situazioni giuridiche degli azionisti. Milão: Giuffrè, 1951.

${ }^{4}$ Os estados, para CARNELUTTI, são situações jurídicas complexas, ao passo que as qualificações são relações jurídicas pressupostas que atribuem um poder para que um sujeito o pratique sempre em relação a um sujeito específico (Idem, p. 180). Dessa distinção foi possível apartar o conceito de capacidade do conceito de status. A relação jurídica pressuposta de uma qualificação é chamada por CARNELUTTI de legitimação (Idem, pp. 182-183). A legitimação se entrelaça com os critérios jurídicos pressupostos para eleição de duas vias possíveis de legitimação quando referente ao exercício de um direito de outro por alguém, a saber: (i) a representação, ou (ii) a substituição.

Este é, sem dúvida, o ponto mais importante da teoria carneluttiana, sobretudo pela contribuição que ela pode legar ao direito societário, como o próprio CARNELUTTI admite nesta passagem: "il concetto della representanza si è sciolto dal presupposto della procura collocandosi accanto alla rappresentanza volontaria la rappresentanza necessaria, piu comunemente detta rappresentanza legale, in quanto il potere del rappresentante non dipende da un atto del rappresentato; tale $\grave{e}$, in particolare, il potere degli amministratori degli incapaci o delle cosidette persone giuridiche, il quale è pure un potere dipendente da un altro potere attribuito al soggetto complesso, a cui partecipa l'amministratore: non si debbono confondere, in linea di precisa anatomia giuridica, il diritto di proprietà, che spetta non tanto al minore quanto al soggetto formato, come si disse, dal minore e dall'amministratore, con la potestà di quest'ultimo, che ne integra l'esercizio e è in tutto analoga alla potestà del procuratore; su questa analogia, appunto, s'è costruito il concetto generico di rappresentanza, della quale la rappresentanza volontaria e la rappresentanza necessaria sono due sottospecie" (assim, Ibidem, p. 186-187). Dessa lição, é 
Nesse contexto, a relação jurídica (e, antes, cada pólo de atuação dentro da relação jurídica) é operada por uma função, a saber, atuação própria de certos elementos dentro do sistema. Esta peculiaridade é essencial para a compreensão da relação jurídica societária pelo simples fato de que quase todas as relações jurídicas em uma companhia são orgânicas, qual seja, são articuladas entre órgãos. É corrente assumir que a administração, o controle, os conselhos e a assembléia são órgãos da sociedade, justamente porque seus membros atuam no interesse da comunidade corporativa em concorrência com os próprios interesses ou em submissão a eles. Nenhuma atuação em sociedades comerciais pode se dar exclusivamente no interesse da pessoa que assume uma função, em detrimento dos interesses coletivos próprios da comunidade societária ou mesmo dos interesses individuais de outros membros. ${ }^{5}$

importantíssimo, no que se refere ao conselho fiscal, como logo se verá, que raramente se deve falar, sob o ponto de vista técnico, de uma representação, exceto quando a lei dispuser expressamente, como é o caso do artigo $138, \S 1^{\circ}$ da Lei das S.A., com relação aos diretores. Nesse caso específico, ainda, pensando na classificação de CARNELUTTI aplicada aos administradores de companhias, temos uma "representação necessária" ou "representação legal", que absolutamente nada tem a ver com mandato (nesse sentido, vide F. SANTORO-PASSARELLI, Op. cit., Idem, pp. 276-295). No caso do conselho fiscal, a aplicação do conceito de mandato é absolutamente equivocada, ao passo que no caso da fiscalização exercida por auditor independente, ela pode ser pressuposta. Erros clamorosos na jurisprudência têm sido cometidos justamente por ver no conselheiro fiscal um sujeito que exerce suas funções fiscalizatórias sob mandato de quem o elegeu ou, ainda, deixando de ver no auditor independente, um prestador de serviço contratado sob as regras do mandato. A revisão da Teoria Geral do Direito, sempre necessária mas raramente praticada, encontra sempre a solução para debelar esse tipo de erro, razão pela qual buscamos, exaustivamente, revisitar esses temas, tão freqüentes nas opiniões, mas raramente revestidos com a autoridade de estudos consistentes. Por fim, vale lembrar, como teremos a oportunidade de aprofundar no Capítulo 7 desta dissertação, que o conceito de representação encampado nesta nota não tem absolutamente nada a ver com o conceito de representação decorrente da lição de Emilio BetTi (Teoria Generale del Negozio Giuridico, $1^{\text {a }}$ reimp.. Napoli: Edizioni Scientifiche Italiane, 2002; pp. 148-154).

${ }^{5}$ Para essa constatação própria e peculiar do funcionamento das companhias e, por consequiência, do direito societário, Hans KelSEN (Teoria Pura do Direito, $6^{\mathrm{a}}$ ed.. [tradução da primeira edição da obra Reine Rechtslehre, de 1960, por João Baptista Machado]. Coimbra: Arménio Amado, 1984; p.215.) formulou incomparável lição: "Um indivíduo é órgão de uma comunidade porque e na medida em que realiza uma conduta atribuível à comunidade; e uma conduta é atribuível à comunidade quando está determinada na ordem normativa constitutiva da comunidade como pressuposto ou consequêencia. Este é o conceito primário, fundamental da função de órgão, da função de órgão no sentido mais amplo da palavra. Ora, é o conceito de função de órgão e não o conceito de órgão que - particularmente para o domínio da ciência jurídica apreende a essência da situação. No conceito de órgão exprime-se o sujeito ou o «suporte» da função, quer dizer, o elemento pessoal da conduta que representa a função e que, como toda a conduta humana, consiste em um elemento pessoal e em outro elemento material - e, assim, já inclui em si o elemento pessoal. O conceito de órgão como portador ou suporte de uma função diferente do mesmo portador é um conceito de substância (conceito substantivo) que, como tal, deve ser usado com a consciência de que, do ponto de vista do conhecimento científico, a substância deve ser reduzida à função. No conceito de órgão como portador (suporte) da função o elemento pessoal é dissociado do elemento material e autonomizado, se bem que ele esteja inseparavelmente ligado a este. Somente com esta reserva pode o conceito de órgão ser utilizado como um conceito auxiliar que facilita a descrição da situação". Vale ainda estabelecer contraponto desta afirmação com Lorenz FASTRICH ("Raciocínio Jurídico Funcional a Exemplo do Direito Societário", RDM 140/52-85 [out-dez/2005], p. 54), que prega que um dos propósitos do raciocínio jurídico funcional (dentro de sua aplicação ao direito societário) é proteger "a funcionalidade interna da sociedade", ou, em outros termos, proteger o sistema e a lógica desse sistema, garantindo a sua operacionalidade e o seu regular funcionamento. 
Por outro lado, o trabalho inicial de análise do fenômeno da fiscalização induz, de plano, para um estudo sobre o sentido inicial da palavra fiscalização, como decorrência da atribuição central do conselho fiscal na companhia aberta (artigo 163, I da Lei das S.A.). A análise do termo fiscalização, como termo substantivado decorrente do qualificativo fiscal, contudo, não deixaria escapar o estudo para além da velha historieta do cesto de vime usado em Roma por representantes da República, para recolher obrigações impostas perante o titular do exercício do imperium. ${ }^{6}$

Ao invés, pois, de tentar olhar a fiscalização sob um ponto de vista do fiscus, mostra-se mais produtivo analisar a fiscalização a partir da análise da palavra controle e de seus correspondentes contrôle (francês), control (inglês, espanhol e catalão), Kontrolle (alemão) e contròllo (italiano) ${ }^{7}$.

Embora COMPARATO, após percorrer a mesma análise dentro da língua inglesa, advirta que "a evolução semântica, em português, foi influenciada tanto pelo francês como inglês, de tal sorte que a palavra 'controle' passou a significar, correntemente, não só vigilância, verificação, fiscalização, como ato ou poder de dominar,

Nesse mesmo sentido está a proposta de CANARIS (Pensamento Sistemático e Conceito de Sistema na Ciência do Direito, tradução de António M. R. Menezes Cordeiro da segunda edição da obra Systemdenken und Systembegriff in der Jurisprudenz, de 1983. Lisboa: Fundação Calouste Gulbenkian, 1996, pp. 66 e segs) ao defender meios de proteção para a logicidade interna do sistema.

${ }^{6}$ Conta a tradição que o fiscus era o nome dado ao objeto usado pelos funcionários do governo romano do período clássico com a finalidade de colher e guardar os recursos públicos devidos ao Pontifex Maximus. A esses recursos era dado o nome de tributum (vide Francisco TORRINHA. Dicionário Latino-Português, $7^{\mathrm{a}}$ ed., $3^{\text {a }}$ tiragem. Porto: Reunidos, 1997, p. 889). Esse objeto para recolhimento do tributum era geralmente um cesto de vime onde os recursos colhidos eram depositados - a esse cesto de vime dava-se o nome de fiscus (Vide Ernesto FARIA, Dicionário Latino-Português. Belo Horizonte: Garnier, 2003, p. 400; Francisco R. dos SANTOS-SARAIVA. Novíssimo Diccionário Latino-Portuguez, $9^{\mathrm{a}}$ ed.. Rio de Janeiro: Garnier, 1927, p. 489).

7 Nesse sentido, lembramos a (brilhante) análise de COMPARATO a esse respeito (Fábio Konder Comparato. O Poder de Controle na Sociedade Anônima, $4^{\mathrm{a}}$ ed., com glosas de Calixto SAlOMÃo FILHO. Rio de Janeiro: Forense, 2005, pp. 27-28): "Em francês, o primeiro emprego conhecido de contrerole remonta ao século XIV (de contre, preposição, e role do latim rotulus, que no curso do século XVI passou a ser grafado roole, de onde a forma atual role). Significava um rol ou registro duplo. O verbo controller, também da mesma época, indicava, propriamente, 'inscrever no registro dito controle'. No francês arcaico, rôle indicava uma ou várias folhas de pergaminho ou de papel, coladas ou costuradas nas extremidades, sobre as quais escreviam-se decisões, atos, títulos, normas; de onde a denominação dada à célebre compilação de normas marítimas medievais de Rôles d'Oléron. Modernamente, rôle assumiu o sentido de papel ou parte que cada ator representa nas peças de teatro, bem como, de modo geral, a acepção de desempenho ou função. O Dicionário da Academia Francesa indica três acepções principais de contrôle: relação nominal das pessoas pertencentes a um corpo ou a uma tropa (cet oficier a été rayé des contrôles de l'armée; dresser le contrôle d'une compagnie; vous êtes porté sur le contrôle); marca, atestando o contraste de obras de ouro ou de prata (cette pièce de vaisselle est suspecte, elle n'a pas le contrôle; tous les ouvrages d'orfèvrerie sont soumis au contrôle); verificação, sobretudo na linguagem administrativa (être chargé de l'inspection et du contrôle d'une perception, d'une comptabilité, d'une caísse). No figurado, significa exame ou censura. É nesse sentido básico de verificação ou fiscalização que o direito francês fala, classicamente, em contrôle des sociétes anonymes". 


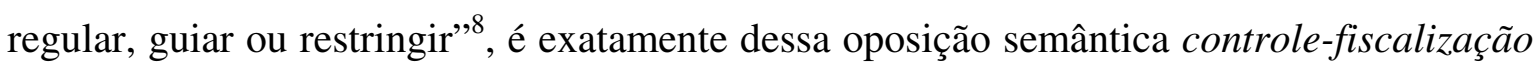
que gostaríamos de analisar mais atentamente o conceito próprio que o direito societário emprega para o conceito de fiscalização. Dessa oposição sobre a unidade do conceito de contre-role, em sua dual acepção domínio-fiscalização, é que as formas de vigilância nas companhias modernas se exercem, sempre tendo envolvido nas relações jurídicas societárias empenhadas na modalidade jurídica da fiscalização, o órgão societário do acionista controlador.

Tanto nas relações tipificadas na lei, que envolvem os órgãos de fiscalização nas companhias abertas ${ }^{9}$, quanto nos vários exemplos práticos envolvendo a atividade do fiscal, o poder de controle tem um papel fundamental em todas as ações fiscalizatórias societárias. Nesse sentido podemos assumir que a fiscalização é sempre uma relação jurídica de meio, razão clara pela qual é quase inescapável a aceitação do exercício do poder fiscalizatório como verdadeira função. ${ }^{10}$

\footnotetext{
${ }^{8}$ Comparato, Poder de Controle..., Idem, Op. cit., p. 29. Essa dualidade na acepção do termo controle, que oscila entre domínio e fiscalização é bastante saliente em passagem do clássico de BERLE e MEANS sobre a influência que o conselho de administração pode exercer sobre a apreensão contábil da realidade societária (vide Adolf Augustus Berle e Gardiner Coit MeAns, The Modern Corporation and Private Property, $4^{\mathrm{a}}$ reimpressão, Nova Brunswick, NJ: Transaction, 2002, pp. 182-183). BERLE e MEANS mostram mui claramente como a contabilidade é uma forma de controle (na acepção de domínio) e como o controle (na acepção de fiscalização) pode ser encarado como verdadeiro poder. As observações empreendidas por BERLE e MEANS podem restar mais claras dentro de um contexto próprio de práticas de controle (na dupla acepção) desenvolvidas por países de tradição jurídica aliada à common law e a um sistema de controle difuso (ex vi, o trecho que assegura que "one of the reasons why the power of the directors in this regard is so wide lies in the fact that accountants themselves have as yet failed to work out a series of standard rules", Ibidem, p. 182).

${ }^{9}$ A saber, o conselho fiscal, o conselho de administração, o comitê de auditoria, a auditoria independente, a auditoria interna executiva e até mesmo o acionista individualizado. Em situações muito especiais e um pouco distantes (mas não menos importantes) do foco das relações jurídicas societárias, não se pode esquecer de outros órgãos de fiscalização interna exigidos por lei, como a CIPA (Comitê Interno de Prevenção de Acidentes), com poder fiscalizatório exercido, da mesma forma, face aos órgãos (funções) de administração e controle da companhia.

Especificamente com relação aos órgãos internos de fiscalização, notadamente o conselho fiscal e as figuras semelhantes em direito estrangeiro, tal qual o collegio sindacale do direito italiano, despontam, como se verá, as relações existentes entre órgão e acionistas, de onde surgem inúmeros conflitos tanto os potenciais, quanto os aparentes quanto os conflitos mais concretos. Quando há quebra de independência e o fiscal se encontra em mesmo contexto de interesses, há gravíssima exacerbação do conflito potencial para o interior da sociedade e de seus outros mecanismos de funcionamento. Nesse sentido, em doutrina estrangeira, vide o brilhante texto de Ricardo ALESSI "Il rapporto dialettico tra collegio sindacale e soci" (In Il Collegio Sindicale - le nuove regole, [org.: Berardino LiBOnATI e Paolo FERRo-LuZZI, coord.: Ricardo ALESSI, Niccolò ABriANI e Umberto MORERA], Milão: Giuffrè, 2007, pp. 7-32).

${ }^{10}$ Em um feliz encontro doutrinário e de idéias entre CARNELUTTI e COMPARATO, poderíamos lembrar que a fiscalização poderia estar no nível superior do exercício de poderes, onde CARNELUTTI identifica duas categorias distintas de poder conforme a espécie de modificação que o exercício do poder resulta no mundo, digamos, real (dos fatos): (i) se a modificação se dá por meio de um agere, (ii) ou se a modificação se dá por meio de um iubere.

O agere, do verbo latino ago [is, ere, egi, actum] (vide Ernesto FARIA. Dicionário..., Idem, p. 53; F. R. SAnTOS-SARAIVA. Novíssimo Diccionário..., Idem, p. 52; Félix GAFFIOT. Dictionnaire Illustré Latin-
} 
Nas companhias abertas, a fiscalização sempre terá a tarefa de interceptar uma outra relação jurídica societária em que o controlador esteja exercendo uma função formativa, face outra função que comporte sujeição. Sempre que ao controle, numa relação jurídica societária, é assegurada a possibilidade de invocar um poder, haverá à fiscalização a possibilidade de surgir como mecanismo de freio ou contrapeso, para não nos distanciarmos do vocabulário próprio que deu origem ao tipo de política do direito societário. A fiscalização, dessa forma, envolve uma relação jurídica societária que representa um meio para o exercício de direitos perante o poder de controle. ${ }^{11}$

Français. Paris: Hachette, 1934, pp. 88-91) pode ter significados diversos e múltiplos, dependendo do contexto em que se emprega. FARIA apresenta duas classes de significado, a saber: (i) em sentido próprio, como "mover adiante", (ii) em sentido figurado, como "agir" ou "fazer". FARIA, com exemplos de CícERO (De Oratore), informa que pode haver um sentido jurídico (sobretudo quando o verbo está intransitivo), como "encaminhar uma ação segundo a lei, agir, proceder segundo a lei, intentar uma ação, advogar, defender". Já, SANTOS SARAIVA apresenta 14 classes de significados possíveis com uma lista bastante exaustiva de empregos (os exemplos superam o número de cem), com a informação etimológica de que o verbo ago decorre da transposição do verbo grego ágo [ ' $\alpha \dot{\gamma} \gamma$ ], que significa "levar", "conduzir". GAFFIOT separa o verbo em quatro classes de significado, apresentando oito subgrupos para a primeira classe, treze subgrupos para a segunda, cinco para a terceira e um para a quarta. O primeiro subgrupo é liderado pelo significado de "pôr em movimento", o segundo, pelo significado de "fazer", o terceiro, pelo significado de "exprimir por movimentos e palavras", e o quarto pelo significado de "viver" ou "passar o tempo". Sob todas essas variantes, adotaremos, aqui, que o sentido de ago, agere para CARNELUTTI seja aquele de "fazer" ou simplesmente "praticar".

Não menos complexa é a lexicologia de iubeo [es, ere, iussi, iussum; também jubeo, es, ere, jussi, jussum], para o qual FARIA (Op. cit., pp. 534-535) dá duas classes de significado: a primeira, em sentido estrito, como "ordenar", "mandar" e a segunda, em sentido figurado, como "convidar" ou "saudar". SANTOS SARAIVA (Op. cit., pp. 644-645) reconhece apenas uma classe de signficado expresso por "ordenar", "dar ordem", "mandar". GAFFIOT (Op. cit., p. 869) reconhece duas classes de significado com uma subclasse para a primeira e doze classes de signficados para a segunda. Na primeira, há o sentido de "convidar", "engajar", "exprimir um desejo" e na segunda, o sentido de "ordenar", "dar ordem", "comandar". Sob todas essas outras variantes, adotar-se-á, aqui, que o sentido de iubeo, iubere para CARNELUTTI seja aquele de "ordenar" ou "comandar" (no mesmo sentido, vide Emilio BetTI. Teoria Generale del Negozio Giuridico, Op. Cit., Idem; pp. 149-150).

Essa classificação se presta a explicar a razão dos liames descritos no quadro acima como, "pertanto la facoltà si distingue dal diritto soggettivo e dalla potestà como potere di agire, no di commandare; e il diritto soggettivo dalla potestà como potere di commandare all'altra parte $e$ non alle parti”" (assim, Op. cit., p. 152). Ainda: "la potestà, pertanto, può definirsi potenza di commandare super partes" (Idem, assim), "come tale essa occupa lo scalino più alto del potere, in quanto è espressione di sovranità", para onde o direito subjetivo aparece como consectário da autonomia (p.155). Essa definição acerca da potestatividade, lembrando ainda o que expôs FERRAJOLI na diferença entre potestatividade e função, pode casar-se perfeitamente com o exemplo do direito societário em vista de uma definição de controle, que por seu turno está fortemente baseado no conceito de soberania, em tributo à insuperável passagem de COMPARATO $(O$ Poder de Controle..., Op. cit., pp. 134-136). Noutra palma, de onde se desdobra o controle em verdadeira fiscalização, que, como vimos, assume caráter de função, tem-se, pois um iubere, que com precisão lembra COMPARATO em nota de rodapé: "É o que certa doutrina de expressão francesa denomina droit-fonction, cf. Breth de la Gressaye e Laborde-Lacoste, Introduction Générale à l'étude du droit, Paris, 1947, p. 333; J. Dabin, Le Droit Subjectif, Paris, 1952, pp. 221 e ss." (p. 135, nota 75).

${ }^{11}$ Para tanto, não é, de forma alguma, intenção deste trabalho buscar um conceito de controle: adota-se aquele já formulado por COMPARATO e atualmente glosado por SALOMÃo FILHO, bem como aquele revisto por Eduardo Secchi Munhoz (Empresa Contemporânea e Direito Societário - Poder de Controle e grupos de Sociedades. São Paulo: Juarez de Oliveira, 2002, pp. 221-260) e, além disso, o conceito da lei, que pode ser resumido no binômio maioria-gestão. Adota essa idêntica postura, para falar de fiscalização, Waldírio Bulgarelli (O Regime Jurídico do Conselho Fiscal das S/A. Rio de Janeiro: Renovar, 1998, p. 48, 
Assim, e nesse contexto de relação jurídica de meio, poder-se-ia assumir que em uma sociedade anônima, todas as pessoas que exercem funções específicas decorrentes do poder de controle (incluindo a gestão) são passíveis de uma vigilância, de uma supervisão, de uma verificação posterior, de uma revisão ou de uma inspeção concorrente. $^{12}$

Em suma, pessoas que funcionalmente integram um poder de controle (e neste caso visto como a somatória da titularidade acionária com o poder efetivo de gestão) podem ter suas relações jurídico-societárias submetidas a um contra-controle de

sobretudo nota 93 nessa mesma página), lembrando também Claude CHAMPAUD (Le Pouvoir de Concentration de la Société par Actions. Paris: Sirey, 1962, que trata do tema da definição do controle em dois momentos de sua obra: entre as pp. 105-107 e entre as pp. 150-163).

Vale notar que essa opção não nega também a existência, a pluralidade, a diversidade e a peculiaridade de muitos outros estudos sobre o tema do controle, que também não podem ser omitidos nem desprezados, a começar pela superior obra de Berle e MeAns, The Modern Corporation..., Op. cit., de que buscaremos tratar mais adiante no momento adequado. Da mesma forma tratar-se-á o texto de Ronald COASE "The Nature of the Firm" (In Economica, volume 4, 16 a edição, Londres: LSE, Novembro de 1937, pp. 386-405).

Abre-se mão, portanto, do conceito formulado por ASCARELLI, para quem o controle não seria uma situação jurídica, mas uma situação de fato derivada de relações jurídicas diversas, tal como participação majoritária e eleição de administradores (Saggi..., p. 252-254). Estamos, nesse caso, com CoMPARATO, a considerar o controle uma situação jurídica especial derivada de outras situações jurídicas, formando uma função jurídica complexa, enfeixada em um cargo societário unitário (O Poder de Controle..., pp. 141-142).

É também digno de nota e atenção o conceito tripartite formulado por Francesco GALGANO (La società per azione, Pádua: CEDAM, 1984, pp. 39-45), na qual acionista, administração e "dependentes" [dependenti], por força das inúmeras distorções havidas na dissociação entre propriedade e controle (como sinônimo de domínio da riqueza) desde BERLE e MEANS, fragilizou a oposição capital-trabalho rumo a uma relação intermediada pelo "administrativismo" [managerialismo].

12 Waldírio Bulgarelli (Regime Jurídico do Conselho Fiscal..., Idem, Op. cit., pp.48-50) explora as especificidades do controle-fiscalização nas sociedades anônimas, de que teremos o dever de fazer neste trabalho nos capítulos supervenientes.

Dentre os exemplos da prática, atente-se ao notável parecer da lavra de Erasmo Valladão Azevedo e Novaes França e Edmur de Andrade Nunes PEREIRA Neto ("Sociedade Anônima - Fraude à Lei Alteração dos Estatutos como intuito de evitar que os acionistas preferencialistas adquiram o direito de voto às vésperas de completar o terceiro exercício social sem o pagamento de dividendos - Abuso do Poder de Controle", In RDM 133/259-275 [jan.-mar./2004]). Note-se, nas partes em que se alude à necessidade imperiosa de participação de Conselheiro Fiscal em determinados atos, como que o escopo dessa participação diz respeito justamente ao exercício de potestatividades a serem desempenhadas com o intuito de informar outras relações jurídicas e municiar outras funções e sujeitos em sua relação com o ente fiscalizado. O conselho fiscal, fica claro no parecer de FRANÇA e NuNES PEREIRA, faz nítida intermediação de outras relações jurídicas para informá-las com os dados necessários para a tomada de providências e o legítimo e transparente exercício de direitos, que, prima facie, são dos acionistas (como exemplo, aludem: "Não há possibilidade, evidentemente, de a assembléia sanar esses vícios, substituindo-se, por exemplo, ao Conselho Fiscal, cuja competência é exclusiva e indelegável" [p.273]).

Nesse mesmo sentido, mas por razões e fatos diversos e sob as mesmas premissas de FrANÇA e NUNES PEREIRA, vide o interessante parecer de Sylvio MARCONDES ("Exame de Livros e Fiscalização de Cooperativa", In Questões de Direito Mercantil. São Paulo: Saraiva, 1977, pp. 67-101), em que chega a conclusão diversa justamente porque os fiscais fazem a intermediação de situações, levando informações para outros sujeitos que se encontram em funções diversas como a de acionista, e, no caso do parecer de MARCONDES, cooperados. MARCONDES concluiu que, pela força dessa natureza intermediatória e considerando a natureza concorrente dos cooperados, certas informações seriam, de prudência, restritas para fiscalização sobretudo quando os atos vigiados não guardam relação com uma função fiscalizatória específica e determinada, sob fundamento plausível de sua necessidade. 
fiscalização, desde que esse contra-controle fiscalizatório venha a ser exercido em favor da companhia (e não de um ou outro centro de interesses), pois a companhia, necessariamente, sintetiza um único centro de interesses (que também integra o controle).

No caso específico da fiscalização societária (interna ou externa, orgânica ou contratual), interessa, especificamente, um aspecto do poder de controle, a saber, a gestão da sociedade ou, como alguns preferem chamar, a governança corporativa em sentido amplo ${ }^{13}$. Neste passo, a função societária mais constante das relações jurídicas que envolvam o exercício de um poder fiscalizatório atribui o pólo passivo ao titular desse poder de gestão. A relação jurídica societária de fiscalização, de que se incumbe o conselho fiscal, portanto, costuma ter no pólo passivo, sujeito ou órgão que exerce função de administração, que não raras vezes é desempenhada por sujeito que acumula a função de acionista controlador (ante a escassa profissionalização da função de administrador), complicando mais ainda o exercício da fiscalização e, conseqüentemente da gestão e do controle, por agregar-lhe, indevidamente, um elemento político.

Todavia, esse intuito de intermediação que existe, a priori, nos atos e funções de fiscalização, por se tratar de um poder motivado por um dever (ou, simplesmente, como muitos preferem, um "poder-dever"), sobretudo no âmbito societário, jamais permite pautar a atuação do fiscal segundo o seu próprio interesse particular. No

\footnotetext{
${ }^{13}$ Sobre o tema, vide o trabalho de Aline de Menezes SANTOS. A governança corporativa das empresas no Brasil: uma abordagem jurídica inspirada na nova economia institucional e na teoria organizativa (dissertação de Mestrado inédita sob a orientação de Paulo Fernando Campos Salles de ToLEDO apresentada junto ao Departamento de Direito Comercial). São Paulo: Faculdade de Direito da Universidade de São Paulo, 2004. Aline Menezes faz percuciente crítica terminológica (pp. 21 e segs) que culmina com a seguinte definição para o termo governança corporativa: "conjunto de instituições que conformam e determinam o equilíbrio, no âmbito das sociedades empresariais, dos interesses mais relevantes ao seu funcionamento" (p. 37). Note-se como a noção de equilíbrio nas relações (que está pressuposta) predomina em sua abordagem. Essa noção relacional intrínseca ao conceito de governança corporativa (como articuladora de funções jurídicas) fica bastante proeminente quando Aline Menezes aborda o conceito de cooperação (pp. 44-51) bem como quando culmina com a conclusão de que "a desigualdade ainda é o traço da Governança Corporativa no Brasil" (p. 235).

Vide, também, Adriana JosuÁ. Governança Corporativa e Teoria da Agência. São Paulo: Faculdade de Direito da Universidade de São Paulo, 2005 (dissertação de Mestrado inédita sob a orientação de Rachel SZTAJN apresentada junto ao Departamento de Direito Comercial).

No direito comparado, é de grande relevância a lição de Michael P. Dooley (Fundamentals of Corporation Law. Brunswick, NY: Carolina University Press, 1995, p.1): “Accordingly, it is readily apparent that any description of corporate governance that focuses solely on legal rules and ignores other incentives is seriously incomplete. Just as legal rules have been developed in response to perceived human needs, so have other institutional arrangements and both are quite often addressed to the same problems. It will be helpful to think of these legal and nonlegal institutional arrangements as comprising a single governance system and to understand that actors in business firms operate in a complex regulatory regime in which laws, private arrangements and competitive market forces all have important roles. This broader perspective should aid in understanding the origin and function of corporate law rules. More importantly, it should assist in understanding that the ultimate concern of corporation law is human behavior" (assim).
} 
âmbito societário, o conselho fiscal deverá sempre informar, apresentar dados e subsídios à assembléia geral, para que os acionistas, individual ou coletivamente, exerçam ações contra a administração ou contra o acionista controlador, conforme o caso. O que se pretende deixar claro, aqui, é que nem sempre o fiscal detém ação (em sentido material e em sentido processual) contra o ente fiscalizado. Muitas vezes caberá ao sujeito que exerce a fiscalização meramente prover a informação haurida no ato fiscalizatório para que outro legitimado, por lei, intente as medidas cabíveis.

Por essa via, a fiscalização relacionada ao exercício de funções societárias específicas centra-se na finalidade de supervisionar, inspecionar e verificar o cumprimento da lei, no desempenho de relações societárias específicas. Trata-se, pois, do segundo e esquecido significado que outrora se deu e se empregou ao conceito de controle. ${ }^{14}$ Essa fiscalização societária de que falamos e que se exerce sobre as relações jurídicas internas de um universo societário pode se dar de forma orgânica ou não. Quando opera de forma orgânica, normalmente se vê por meio do conselho fiscal, do conselho de administração, do comitê de auditoria (como parte do conselho de administração) ou da auditoria interna executiva (como parte da diretoria). Quando opera de forma não orgânica, dá-se por meio do acionista individual ou da auditoria independente. Eis, pois, os canais de fiscalização de uma companhia aberta, articulados de forma integrada ao direito geral e essencial de informação (cf. artigo 109, III da Lei das S.A.).

As duas formas mais completas de fiscalização ocorrem, dentro de uma perspectiva dos órgãos internos, a saber, o conselho fiscal e o conselho de administração (muita vez por intermédio do comitê de auditoria) e, dentro de outra perspectiva, por entidades externas, como a auditoria independente. A fiscalização também pode se dar de forma mediata e diferida, como geralmente ocorre com o conselho fiscal e o acionista individualizado, que normalmente fiscalizam a posteriori ou após a prática de um ato,

\footnotetext{
${ }^{14}$ Antes ainda que pudéssemos ter, após a década de 1960, com Champaud e Paillusseau, um conceito de controle como sinônimo de domínio, tal qual o conhecemos hoje (sem desprezar essa ênfase ocorrida na década de 1930 na obra de BERLE e MEANS), o conceito amplo de controle tinha, de forma mais geralmente aceita, esse pendor que aqui se faz alerta. É nesse sentido que Roger GRANGER (La nature juridique des rapports entre actionnaires et commissaires - charges du controle dans les sociétés par actions. Reims: Matot-Braine, 1951, pp. 17-78) disserta sobre controle. Lembremos também o grande AsCARELLI, que em seus Appunti... (Op. cit., Idem, p. 151), advertia: "Controllo della'amministrazione: - La sorveglianza dell'amministratore sociale è affidata innanzi tutto al socio. I poteri di sorveglianza vengono nelle società per azioni esercitati non tanto direttamente dai socii, quanto da speciali organi a ciò destinati: $i$ sindaci, organo sociale destinato appunto a controllare la gestione sociale" (p. 152).
} 
como também pode se dar de forma imediata e simultânea à prática de um ato, em algumas hipóteses do comitê de auditoria, do auditor independente e da auditoria interna executiva.

Cumpre, entretanto, neste ponto do trabalho, assumir as seguintes premissas, no sentido de que a fiscalização societária divide-se quanto: 1 . ao momento de verificação, a saber, (i) imediato e simultâneo à prática do ato fiscalizado (ou objeto da fiscalização), ou (ii) mediato e sucessivo à prática do ato fiscalizado (ou objeto da fiscalização); e, 2. quanto ao sentido vetorial da fiscalização, a saber, (i) se parte de um órgão ou de uma função interna à sociedade, ou, (ii) se parte de uma função externa à sociedade. Esta última distinção é importantíssima, pois a solução de questões envolvendo uma fiscalização exercida por função interna da sociedade se resolve por meio de regras eminentemente societárias, por se tratar de mecanismo técnico de definição de qualificações; ao passo que a solução de questões envolvendo uma fiscalização exercida por função externa da sociedade se resolve por meio de regras eminentemente contratuais. $^{15}$

Especificamente quanto ao conselho fiscal das companhias abertas, podemos identificá-lo como um órgão de fiscalização interna com atuação mediata e sucessiva. No que se refere ao momento da fiscalização, vale antecipar uma distinção, por ora aparentemente superficial, mas sumamente importante, entre o conselho fiscal e o comitê de auditoria, os dois principais órgãos de fiscalização interna. Essa distinção tem efeitos sobre a classificação do conselho fiscal como mecanismo de fiscalização mediata e sucessiva, em contraposição ao tratamento do comitê de auditoria (e, conseqüentemente, do conselho de administração), como mecanismo de fiscalização imediata e simultânea.

Muito se associa, semântica e funcionalmente, o conceito de conselho ao de comitê, sobretudo no que tange às atribuições legais e modo de atuação, muito por conta de transposições infelizes oriundas de um direito comparado apressado e de uma prática ligeira de tradução (tanto de tradução lingüística quanto de tradução jurídico-institucional e cultural).

\footnotetext{
${ }^{15}$ Nesse sentido, vide Roger GRANGER, Op. cit., pp. 98-101, que fala de uma relação de mandato. Crê-se, entretanto, que a natureza da contratação é muito mais próxima de uma prestação de serviço do que um mandato. Trata-se, como se verá, de um contrato misto atípico, com elementos tanto de prestação de serviço quanto de mandato, mas no qual se nota predomínio da prestação de serviço sobre o mandato. Nesse sentido dispôs a nossa lei societária de 1882 , em seu artigo $14, \S 4^{\circ}$, como veremos oportunamente.

Sobre a relação entre os dois meios de fiscalização, o interno e o externo, vide o brilhante parecer de Luiz Gastão Paes de Barros LEÃEs ("Conselho Fiscal e as Empresas de Auditoria” In Pareceres, vol. 1. São Paulo: Singular, 2004, pp. 597-604).
} 
Há uma distinção prática entre os dois institutos, e nessa distinção pode-se notar, de forma precisa, como o conceito que envolve um conselho irá sempre se direcionar a uma revisão que acontece concomitantemente à prática de algum ato. Aplicado ao conselho fiscal, temos como exemplo a lista de revisões trazida pelo artigo 163 da Lei das S.A. (sobretudo as funções dos incisos II, VI e VII) e como exceções, o $§ 1^{\circ}$ ao artigo 173 bem como o $\S 2^{\circ}$ ao artigo 202, ambos da Lei das S.A., situações em que o conselho fiscal age como verdadeiro comitê. Já no que se refere ao comitê de auditoria, poderíamos, lembrando que a idéia de comitê direciona à visão de algo que ocorre concomitantemente à prática de um ato, temos no exemplo do artigo $15 \mathrm{em}$ seus incisos III e VII em conjunto com o VIII, todos da Resolução CMN 3198, um firme quadro demonstrativo dessa diferença.

Dessa breve distinção, podemos notar que entre um comitê de auditoria e um conselho fiscal há diferenças práticas. Os usos vêm designando uma atuação mais constante e simultânea para os comitês de auditoria e mais diferida aos conselhos fiscais, quando co-existem em uma companhia. Mas essas diferenças de performance prática não se sustentam sob o ponto de vista funcional, nem tampouco operacional, como mostra a nossa lei e a experiência do direito comparado.

Como mecanismo de oposição ao órgão de controle, a profusão, a dispersão e a falta de sistematização do conceito de fiscalização, enfraquece e esteriliza muitas de suas ações e boa parte das formas fiscalizatórias que se exercem em favor da companhia.

Para que essa compreensão se dê de forma clara, é necessário que iluminemos a consciência em torno de um conceito muito peculiar de poder de controle que é próprio da cultura jurídica, sociológica e antropológica brasileira, conforme a seguir.

\section{Fiscalização societária, Poder de Controle e Conselho Fiscal no Brasil: Liberdade de Iniciativa, Estado Controlador, Estado Empresário}

Adotamos acima um conceito técnico de poder de controle que convém, teoricamente, à proposta legal inscrita no artigo 116 da Lei das S.A. COMPARATO ${ }^{16}$, SALOMÃo FILHO ${ }^{17}$ e BULGARElli ${ }^{18}$ notam, entretanto, que esse conceito de poder de

\footnotetext{
${ }^{16}$ O Poder de Controle..., Idem, pp. 75-88, sobretudo a Nota 10 de SALOMÃO FILHO nas pp. 75-76.

${ }^{17}$ O Novo Direito Societário, $3^{\mathrm{a}}$ ed.. São Paulo: Malheiros, 2006, pp. 63-74.
} 
controle que oscila entre os conceitos formulados por BERLE e MEANS, COASE e Champaud recebem, no Brasil, algum tempero especial, por força das circunstâncias peculiares de nosso país a respeito do conceito de poder e do conceito de soberania. ${ }^{19}$

Temos, no Brasil, uma inegável tendência à concentração do poder, o que justifica a adoção dos formuladores da Lei das S.A. por um texto, no artigo 116, que conjuga domínio e efetivo uso do poder aplicado na gestão das atividades sociais. ${ }^{20} \mathrm{~A}$ Exposição de Motivos $n^{0}$ 196, de 24 de junho de 1976, preambular à Lei das S.A., veiculada na Mensagem n ${ }^{0}$ 204, de 1976, mencionou que "a caracterização do 'acionista controlador' é definida no Parágrafo Único do artigo 116 e pressupõe, além da maioria dos votos, o efetivo exercício do poder de controle para dirigir a companhia". Ao pressupor, num ambiente de densa concentração de capitais e riquezas, que o controle decorre de titularidade de ações que detenham a maioria dos votos e o poder de eleger administradores (domínio e poder de escolha dos mandatários) e o efetivo exercício desse poder por intermédio da direção das atividades sociais e orientação de funcionamento dos órgãos da companhia (gestão e poder de decisão), a lei brasileira revela um fenômeno concentracionista tipicamente brasileiro.

Na prática societária, essa peculiaridade no exercício do poder de controle no Brasil faz com que muitos órgãos ou funções sejam exercidos por uma mesma pessoa ou grupo de pessoas ou, ainda, por outras pessoas ligadas a esse grupo ou a esse titular dos poderes do artigo 116 da Lei das S.A. Esse problema toca em questões que envolvem, no Brasil, o conceito de independência. Por ora, lembre-se o que advertiu SALOMÃo FILHO a esse respeito, considerando-se que, no Brasil, a grande parte das companhias é de capital

\footnotetext{
${ }^{18}$ Regime Jurídico do Conselho Fiscal..., Idem, pp. 3-50

${ }^{19}$ Recentemente, Eduardo Secchi Munhoz (Empresa Contemporânea e Direito Societário..., Idem, pp. $237-$ 252) elabora construção a respeito do poder de controle, com vistas à moderna empresa contemporânea organizada em complexos conglomerados, no mesmo sentido e em atenção a essa linha doutrinária.

${ }^{20} \mathrm{O}$ problema do "efetivo uso do poder para dirigir as atividades sociais e orientar o funcionamento dos órgãos da companhia" inscrito na alínea "b" ao artigo 116 é um dos mais espinhosos e acalorados debates reinantes na atual doutrina societária. Revertemos a leitura, à luz desse debate, para a interessante passagem de Munhoz (Op. cit., Idem, pp. 239 e segs.) em confronto às idéias de CoMPARATO (O Poder de Controle..., Idem, pp. 87 e segs.). Nesse mesmo sentido, vide de Mauro Rodrigues PENTEADO, "A Lei n 9.457/97 e a Tutela dos Direitos dos Acionistas Minoritários", In Reforma da Lei das Sociedades Por Ações. São Paulo: Pioneira, 1998, pp. 71-73 [coordenação de Waldírio Bulgarelli]. Ainda, nesse mesmo sentido, vide José Luiz de Bulhões Pedreira e Alfredo LAmy Filho. A Lei das S.A., $1^{\circ}$ vol., $3^{\mathrm{a}}$ ed.. Rio de Janeiro: Renovar, 1997; pp.63-69.
} 
concentrado $^{21}$. E dessa ponderação de SALOMÃo FILHO podemos ter um quadro amplo da compreensão que envolve o problema da fiscalização nas companhias brasileiras.

Como visto, sendo a fiscalização o poder que se exerce em função e na síntese semântica do poder de controle, em um ambiente de controle concentrado em que os mecanismos de fiscalização estejam totalmente vinculados ao controle, passa-se a equivocada impressão, outrora difundida, de que os mecanismos de fiscalização seriam "órgãos inúteis",22. Contudo, a desarrazoada opinião que envolve a fiscalização societária em ceticismo e descrença, se enfraquece mais ainda quando observamos que a fiscalização dota-se de mecanismos que visam tornar equilibrado o exercício de um poder. ${ }^{23}$

Recentes problemas em direito societário no mundo e no Brasil, vagando entre a ineficiência dos órgãos de fiscalização e os lamentos contra comportamentos $\operatorname{corrosivos}^{24}$, só fazem perceber que, sobretudo em nosso País, o poder de controle é, nada mais do que um resultado societário do conceito sociológico de exercício de poder e soberania $^{25}$. Essa forma particular de encarar o conceito de poder, com raízes na noção de

\footnotetext{
${ }^{21}$ A esse respeito, vide os números que SALOMÃo FILHO traz em seu O Novo Direito Societário..., Idem, p. 63. Adicionalmente, lembre-se que "Nas companhias de controle concentrado no Brasil, a composição de todos esses órgãos (Conselho de Administração, Diretoria e Conselho Fiscal) e a contratação da auditoria são livremente definidas pelo controlador. Além disso, a Assembléia Geral é por ele dominada" (Idem, Ibidem, p. 71).

${ }^{22}$ Esta é a opinião de Wilson de Souza Campos BATAlHA, apud Waldírio Bulgarell, Regime Jurídico do Conselho Fiscal..., Idem, p. 7. Profere-a, da mesma forma, e com bastante agressividade, João Eunápio Borges (Curso de Direito Comercial Terrestre, $4^{\text {a }}$ ed.. Rio de Janeiro: Forense, 1969, pp. 486-488), referindo-se ao conselho fiscal, da forma mais delicada, como "órgão meramente decorativo". Na via totalmente contrária e igualmente questionável por conta de sua posição partidária, há quem sustente a máxima importância do conselho fiscal por se tratar de órgão de "defesa de interesse de minoritários". Essa posição se choca com a idéia contida no $\$ 1^{\circ}$ do artigo 165 da Lei das S.A., que reza pela premissa principal que envolve a natureza orgânica da companhia aberta brasileira, como poderemos observar mais adiante. Assim, o conselho fiscal é e sempre será órgão da companhia, jamais podendo ser encarado como órgão de representação deste ou daquele acionista.

${ }^{23}$ Com razão, Bulgarelli (Idem, Ibidem, pp. 48-49) lembra-nos: "O fundamento para a existência de tipos de controles fiscalizatórios, já se viu, relaciona-se com a necessidade de zelar por uma administração correta, sem desvios ou abusos, necessidade essa que atende aos interesses dos acionistas e credores principalmente, embora alcance também o interesse mais geral da proteção ao crédito público e aos investimentos". Essa observação, no âmbito de uma companhia aberta, é de suma importância, sobretudo em companhias com controle difuso.

${ }^{24}$ Duas peças fundamentais de lamento contra essa prática abominável e que, diga-se de passagem, não é predominante, foram parar em telas de cinema por meio de documentários sérios e interessantes, a saber, The Corporation (EUA, 2004, Dirigido por Mark Achbar e Jennifer Abbott e distribuído no Brasil pela Imagem Filmes, como "The Corporation", baseado na obra do prestigiado Professor de Direito Societário da University of British Columbia, Joel BAKAN. The Corporation: the pathological pursuit of profit and power. Nova Iorque: Free Press, 2004) e Enron: the smartest guys in the room (EUA, 2005, Dirigido por Alex Gibney e distribuído no Brasil pela Paris Filmes como "Enron: os mais espertos da sala").

${ }^{25}$ Já se dissertou com maestria sobre o conceito e o exercício muito peculiar de poder no Brasil, cf. André Carvalho NogueIRA, A dissolução do poder econômico como princípio regulatório. (tese de Doutorado inédita sob a orientação de José Tadeu DE CHIARA, apresentada junto ao Departamento de Direito Econômico e Financeiro). São Paulo: Faculdade de Direito da Universidade de São Paulo, 2005.
} 
poder público e na condução da coisa pública, afeta densamente o conceito de livre iniciativa, que muita vez tem no Estado um de seus instrumentos principais. ${ }^{26}$

O exercício do poder de controle, no Brasil, e portanto, a forma com que se dá nas sociedades comerciais o desenvolvimento da norma do artigo 116, alínea "b", nada mais é do que uma das formas de concretização do exercício da livre iniciativa. A concentração de riquezas no Brasil, que é um fenômeno que dispensa maiores comentários, interfere, juridicamente, no exercício e no conceito próprio, em termos constitucionais, do corolário da livre iniciativa. $^{27}$

Se, por um lado, as razões para a não dispersão acionária e conseqüente falta de diluição no exercício do poder de controle podem ser justificadas, em princípio, sob argumentação sócio-econômica com raízes históricas, por outro, vale lembrar que o exercício em si desse poder liga-se a uma cultura secular, arraigada no Brasil, e que tem raízes de ordem política e jurídica.

A concentração de um poder de gestão é uma característica de política societária, no Brasil, que, culturalmente, associa-se ao conceito herdado nestas bandas a respeito de uma gestão política que é, igualmente, centralizada. A democracia societária no Brasil é muito semelhante à democracia política. ${ }^{28}$ Neste pormenor, Estado e iniciativa privada se assemelham como nunca - presidentes de companhias e de conselhos, no Brasil, agem, em diversas circunstâncias, guardadas as exceções e as proporções de praxe, de

\footnotetext{
${ }^{26}$ A. C. NoGUEIRA, Idem, Ibidem, pp. 169-172.

O Estado como patrono da livre iniciativa é uma realidade tipicamente brasileira, desde os primórdios das opções públicas para a exploração colonial da "Empresa Brasil”, se assim podemos dizer. Essa cultura de um Estado que praticamente monopoliza muitas ações empresariais e, portanto, estatiza a priori o conceito de livre iniciativa, vem, ultimamente, embora com alguma timidez, sendo quebrada por insistentes e competentes estudos [vide José Virgílio Lopes ENEI, Project Finance: financiamento com foco em empreendimentos (parcerias público-privadas, 'leveraged buy-outs' $e$ outras figuras afins). São Paulo: Saraiva, 2007, pp. 97-98].

${ }^{27}$ A idéia aqui exposta, embora guarde complexa apreensão por estruturar poder na iniciativa privada e poder na iniciativa pública, intermediados pela livre iniciativa, é facilmente absorvida em estudos sócioeconômicos do desenvolvimento das empresas e da indústria no Brasil. Caio PRADO JUNIOR (História Econômica do Brasil, 42a ed.. São Paulo: Brasiliense, 1995, p. 264) rememora-nos: “A acumulação capitalista ainda é essencialmente no Brasil um fato individual restrito. Aqueles que têm capitais aplicados na indústria são unicamente indivíduos que lograram reunir fundos suficientes para se estabelecerem nela por conta própria e independente". Nesse mesmo sentido, vide a peculiar percepção de COMPARATO (O Poder de Controle..., Op. cit., Idem, p. 39). Nesse pormenor, a livre iniciativa que é legada ao Estado ou aos poucos indivíduos mencionados por PRADO JUNIOR, confunde-se com o poder econômico de que fala A. C. NogueIra (A Dissolução do Poder Econômico..., Op. cit., Idem, p. 83 e segs.), e que, dentro da sociedade comercial, transmuda-se em poder de controle.

28 Comparato ( $O$ Poder de Controle..., Ibidem, pp. 35-39) frisa-nos com distinção, ao relacionar a evolução do conceito de soberania com o desenvolvimento do poder de controle, que a concentração de poder e capitais se prestou para sedimentar o modelo societário.
} 
modo bem semelhante, em termos políticos e nas formas de exercício de poder, aos titulares de cargos públicos no Brasil.

\section{Nem sempre fôra do feitio de quem exerce um poder (público ou privado)}

no Brasil agir com transparência obsessiva. Isso pode ter tornado a físcalização do exercício do poder central, em termos públicos, um substantivo de menor valor e compreensão ao longo do tempo, assim como ocorreu com a fiscalização das companhias. $^{29}$

29 Nesse mesmo sentido, Calixto SALOMÃo FILHO apresentou brilhante glosa à obra de Fábio Konder Comparato ( $O$ Poder de Controle..., Ibidem, Nota de Texto 2, pp. 38-39), vazada nos seguintes termos: "Essa curiosa conjugação entre soberania da Assembléia Geral e realidade paralela do poder de controle decorre sem dúvida da ambigüidade supra ressaltada entre a característica aristocrática da grande companhia colonial e a natureza contratualista individualista da sociedade anônima pós-mercantilista (v. Nota de Texto 1). A prática societária brasileira do século XIX e, de resto, toda a história societária brasileira que se seguiu são herdeiras dessa ambigüidade de fundo, que fortalece sobremaneira o poder do controlador".

Lembremos que por muito tempo o país foi governado por ímpeto despótico, tal qual ocorria nas companhias. Tanto em uma situação quanto em outra, tínhamos um eixo principal em que transitavam as figuras que FAORO sabiamente chama de Donos do Poder. Muita vez, esses “donos do poder" exerciam não apenas o poder político na vida pública, mas exerciam, também, nas companhias, o chamado "poder de controle". Tome-se que as companhias, no alvorecer do capitalismo brasileiro, ainda em período colonial ou monárquico, administravam empresas agrícolas e latifúndios. O controle exercido nas empresas modernas no Brasil aprendeu, por herança, muitas lições de governo desenvolvidas nessa empresa agrícola em que público e privado transitavam não apenas de um cômodo para outro, mas de uma nota para outra, na mesma escrivaninha. Richard GRAHAM (Patronage and Politics in Nineteenth-Century Brazil. Stanford, CA: Stanford University Press, 1990, p. 43), lembra: "Those who owned property in early-nineteenth-century Brazil held ambivalent views about central government. If it offered them an effective tool for keeping them propertyless subordinate, it could also threaten their own authority locally. To solve this dilemma men of substance eventually made sure that they or their friends occupied the positions of power at every level of the state apparatus". Páginas depois (210 e segs.), o autor ainda expõe os canais do patronato e as intrincadas redes de conexão entre poder público político e poder econômico privado, com apoio público. No Brasil, país e exploração empresarial nasceram juntos e não se sabe ao certo quem aprendeu com quem: se a cultura de gestão empresarial carreou seus valores para o Estado ou se a cultura de gestão pública carreou seus valores para dentro das companhias. Aplicado ao problema da independência no conselho fiscal, Haroldo Malheiros Duclerc Verçosa (Curso de Direito Comercial, $3^{\circ}$ vol.. São Paulo: Malheiros, 2008, p.490) nos alertou com esta judiciosa passagem: "Motivos de ordem sociológica e histórica em relação ao ordenamento jurídico brasileiro na sua origem poderiam talvez explicar a proverbial característica de ineficiência, fundada na falta de profissionalismo dos seus membros; no espírito do exercício de tal função como um favor a um amigo dono de uma companhia; na impunidade pelo descumprimento de suas atribuições pelos membros; etc." (grifos do original).

Essa simbiose entre público e privado nos primórdios das sociedades comerciais modernas era uma característica própria e peculiar do modelo de exploração colonial, como nos adverte Tullio ASCARELLI ("Princípios e Problemas das Sociedades Anônimas", In Problemas das Sociedades Anônimas e Direito Comparado. São Paulo: Saraiva, 1945; pp. 336-344), Eduardo Secchi MunHOZ (Empresa Contemporânea..., Idem, pp. 52-63) e Waldírio Bulgarelli (Regime Jurídico do Conselho Fiscal..., Idem, pp. 26-35). Entretanto, no Brasil essa simbiose durou mais: "Tem sido, por certo, essa via que vem influenciando a doutrina, na comparação das companhias com o sistema político, por isso já chamadas de microcosmos políticos, o que, por sugestivo, enriquece o tema, oferecendo novas perspectivas, sobretudo de natureza ideológica. Por esse prisma, verifica-se, desde logo, a demitificação da democracia interna nas companhias. A desigualdade dos acionistas, que se manifesta nas companhias coloniais, ficou durante muito tempo obscurecida pela ilusão da igualdade democrática, do modelo liberal, e hoje, pela ótica da transparência, voltou a ficar translúcida em relação a seus direitos e à sua posição perante o poder" (W. BULGARELLI, Ibidem, p. 26). Enquanto que, por exemplo, nos EUA, essa esclerose de gestão gerada pela resistência à 
Com a evolução do conceito político de democracia no Brasil, cresceu, paralelamente, o conceito de democracia societária, fazendo crer que, também, na iniciativa privada, os mecanismos de freios e contrapesos deveriam imperar.

No caso específico brasileiro, não há como dissociar essas figuras - poder de controle e poder político sempre tiveram as suas semelhanças, justamente porque a cultura no exercício de ambos esses poderes era praticada, em grande parte, pelas mesmas personagens ou, ao menos, por personagens que comungavam e praticavam a mesma cultura e a mesma ética na condução de bens sociais, seja quando se tratavam de bens sociais da sociedade civil, seja quando se tratavam de bens sociais de uma sociedade comercial. $^{30}$

dissociação entre o público e o privado deixou as amarras no século XVIII, como noticia Morton J. HoRwITZ (The transformation of American Law: 1780-1860. Cambridge, MA: Harvard University Press, 1977, pp.111112): "The change in the conception of the corporation marks one of the fundamental transitions from the legal assumptions of the eighteenth century to those of the nineteenth. The archetypal American corporation of the eighteenth century is the municipality, a public body charged with carrying out public functions; in the nineteenth century it is the modern business corporation, organized to pursue private ends for individual gains. By the time of the decision in the Darthmouth College case, holding that a corporate charter was a contract, the conception of the corporation as a public body had been on the decline for almost a generation, although the implications of this trend were only beginning to be explored. The distinction between public and private corporations, so prominent in the Justice Story's concurring opinion, was above all a response to the previous generation. As late as 1780, colonial legislatures had conferred charters on only seven business corporations, and a decade later the number had increased to but forty. However, in the last ten years of the eighteenth century 295 additional corporate charters were granted". Nesse mesmo sentido, vide Lawrence Meir FrIEDMAN (A History of American Law, $2^{a}$ ed.. New York: Simon e Schuster, 1985, pp. 511-531), sobretudo quanto à derrocada da doutrina ultra vires como reflexo de uma passagem do domínio público para a iniciativa privada em matéria de interpretação legal das sociedades anônimas nos EUA.

${ }^{30}$ Alguns vícios fossilizados na prática da condução da coisa pública ainda são, recentemente, assistidos com abundância, sobretudo quando o tema é a fiscalização pela administração, das atividades desenvolvidas no setor produtivo brasileiro. Em recente matéria publicada no Jornal $O$ Globo $\left(\mathrm{n}^{\circ} 27.124\right.$, Ano LXXXIII, Rio de Janeiro, edição de 11 de novembro de 2007, $1^{\circ}$ Caderno, p. 8), intitulada "Um país que em que (muito) pouco se fiscaliza", o jornalista Jailton de CARVALHO tenta investigar as causas que levaram o Brasil, recentemente, a se deparar com escândalos referentes ao controle de qualidade de produtos distribuídos ao consumo geral da população, mais especificamente leite e combustíveis. A matéria identifica que a administração pública comete falhas gravíssimas na fiscalização, mas que o sistema legal dá brechas largas para que o ente fiscalizador falte com os seus deveres por frontal falta de independência resguardada pela legislação. A matéria relata que "os fiscais ficam dentro de alguns laticínios como se fossem funcionários da empresa". No setor de saúde, a matéria ainda informa que "sem dedicação exclusiva, os auditores podem trabalhar na iniciativa privada", ressaltando que "o auditor pode dar expediente num hospital ou clínica submetido à fiscalização do ministério". Ainda nesse setor de saúde, a matéria informa que com relação aos conselhos estaduais e municipais de saúde, "a atuação ... estaria comprometida pela presença de pessoas ligadas aos administradores locais ou pela inércia desses núcleos de poder". Esses graves problemas não escapam, inclusive, à atenção da doutrina jurídica, sobretudo em matéria de direito do consumidor, conforme lembra João Batista de AlmeIDA (A Proteção Jurídica do Consumidor, $5^{\text {a }}$ ed.. São Paulo: Saraiva, 2006, p. 295): "O Poder Executivo, nas esferas federal, estadual e municipal, é o responsável pela fiscalização das normas envolvendo abastecimentos e preços, vigilância sanitária, pesos e medidas. As dimensões territoriais do Brasil impedem que os órgãos fiscalizadores federais estejam presentes em todos os Municípios brasileiros; por vezes até nas Capitais o atendimento é deficiente. Os órgãos estaduais quase sempre padecem do mesmo vício. E os órgãos municipais, quando existem, são vitimados pela inércia, por falta de condições 
Por muito tempo, o Brasil foi governado pelos mecanismos do Poder Moderador, que embora tenha desaparecido formal e legalmente a partir do advento da República, deixa ainda hoje rastros graves de seu exercício em práticas já fossilizadas no Estado e que ainda se assistem recentemente. ${ }^{31}$ Essas mesmas características de um poder central que é moderador via reproduzir-se (agora em menor intensidade) até meados da década de 1980’ no direito societário brasileiro, quando se pensava em poder de controle,

técnicas, pessoal habilitado e recursos financeiros. Conclusão: a fiscalização não funciona como deveria funcionar".

Nesse mesmo sentido e notando as muitas dificuldades que o Estado tem para desempenhar a tarefa de fiscalizar, vide Juliano Sarmaneto BARRA (Fundos de Pensão Instituídos na Previdência Privada Brasileira. São Paulo: LTr, 2008, pp. 161-162); Gustavo TEPEDINO “Quem fiscaliza o fiscal?", In Temas de Direito Civil, $3^{\mathrm{a}}$ ed.. Rio de Janeiro: Renovar, 2004, pp. 551-553, onde, partindo das questões que envolveram o acidente do Bateau Mouche, faz pertinentes reflexões sobre os problemas e falhas que existem no Brasil em matéria de fiscalização.

31 A esse respeito, vide a curiosa obra de Braz Florentino Henriques de SouZA. Do Poder Moderador: Ensaio de Direito Constitucional. Recife: Typographia Universal, 1864. Desde os direitos de escolher Senadores que podiam interferir na escolha dos Ministros de Estado, assim como ocorre com a escolha de Conselheiros que influem na escolha dos Diretores em uma companhia, passando pelo direito de convocação de Assembléias Gerais e pelo direito de livre nomeação e destituição de Ministros de Estado, bem como o direito de sanção, muito distante da sanção presidencial atual e razoavelmente próxima de uma interferência de mérito e gestão na condução das coisas políticas (pp.119-120, salientou: "a sancção imperial, como a definio Malouet, é um direito e uma prerrogativa nacional, conferida ao chefe da nação, para declarar e garantir que uma tal resolução do corpo legislativo é ou não é a expressão da vontade geral”, cf. p. 120). A atividade moderadora guardava grande semelhança com o exercício do poder de controle nas companhias em um ambiente anterior à Lei das S.A., sobretudo no que tange às responsabilidades do moderador e do acionista controlador.

Lembre-se, a propósito, que o moderador não pode ser fiscalizado no exercício de seu poder. Aliás, em tempos de restrição de liberdade, o titular do poder central tem verdadeira ojeriza à transparência e à fiscalização. Repare-se nesta interessante nota histórica trazida por Carlos Fulgêncio da CUNHA PEIXOTO (Sociedades por Ações, $4^{\circ}$ Volume. São Paulo: Saraiva, 1972, p. 149): "Procura-se, por todos os meios, evitar a fiscalização. O Governo, que deveria dar o exemplo de ter como princípio a mais ampla publicidade, em certo período da vida brasileira procurou afastar a fiscalização das sociedades das quais participasse. Em 31 de dezembro de 1940", na virada para o ano de 1941 e três meses após a promulgação do Decreto-lei 2.627, que reformava a lei societária anterior do Decreto 434, "foi promulgado o Decreto-lei $\mathrm{n}^{\circ} 2.928$, cujo art. $1^{\circ}$ dispunha: 'As sociedade por ações, nas quais o Governo Federal intervira diretamente na constituição dos órgãos de sua administração, ou seja, subscritor de parte de seu capital, ficam excluídas da aplicação obrigatória das normas dos arts. 127, I, e 130, do Decreto-lei $n^{0} 2.627$, de 26 de setembro de 1940, e de seus efeitos'. Este diploma legal é produto da ditadura", tanto quanto o Decreto-lei 2.627, diga-se de passagem e, "felizmente, tão logo o país voltou à legalidade os representantes do povo - Executivo e Legislativo reconheceram não ser honesto abrir mão, expressamente, da fiscalização, e o Decreto-lei n ${ }^{\circ} 2.980$ sofreu logo seu primeiro golpe, quando da constituição da 'Petróleo Brasileiro S.A.' . O art. 21 da Lei no 2.004, de 1953, dispôs: 'O conselho fiscal da 'Petróleo Brasileiro S.A.' terá as atribuições constantes do art. 127 do Decretolei $\mathrm{n}^{\mathrm{o}} 2.627$, de 26 de setembro do mesmo ano'. Posteriormente, em $1^{\circ}$ de fevereiro de 1958 , a Lei $\mathrm{n}^{\circ} 3.369$ houve por bem revogar, definitivamente, o Decreto-lei n ${ }^{\circ} 2.928$, de 31 de dezembro de 1940, na parte em que se refere ao art. 127, I, do Decreto-lei n ${ }^{\circ} 2.627$, de 26 de setembro de 1940 (art. $1^{\circ}$ )". Note-se, entretanto, que a citada Lei $n^{\circ} 3.369 / 58$ usa de técnica legislativa idêntica àquela utilizada na chamada Lei Áurea e na Lei de Anistia, editada pelo governo de transição, sob influência do General Golbery do Couto e Silva: apaga-se um passado sem medir-lhe as consequências, dosar-lhe as responsabilidades, impor-lhe um regime de transição e reger-lhe devidamente os casos vindouros, omissos e específicos. Diz-se, com a lei, assim como ocorreu na Lei Áurea e na Lei de Anistia, em períodos interditatoriais, que "aquilo que era, não é mais".

Bulgarelli (O Regime Jurídico do Conselho Fiscal..., Op. cit., Idem, p. 158 e nota 299) faz sadia lembrança do conceito de irresponsabilidade, inimputabilidade e exoneração legal que ocorre com freqüência na lei societária, por conta de "longa tradição no Brasil", que ele já via empregada desde o tempo do Poder Moderador do Império, na letra do artigo 99 da Constituição outorgada de 1824, a qual dispunha: "A pessoa do Imperador é inviolável e sagrada: ele não está sujeito a responsabilidade alguma". 
até que a efetividade judicial do artigo 117 da Lei das S.A. desse os primeiros frutos nos tribunais brasileiros.

Ao lado do Estado-empresário e dos poucos responsáveis pela livre iniciativa no Brasil (seja em parceria com o Estado, de modo formal ou oficial, seja de modo oficioso), o poder de controle, dentro das companhias, se dava com temperos moderadores, sem muita chance de participação aos outros atores societários e sem qualquer espaço para uma fiscalização mais intensa. Uma fiscalização, quando havia, se dava de maneira formal, sendo totalmente dominada pelo exercício do poder de controle. Os mecanismos de fiscalização não guardavam qualquer independência em relação ao exercício daquele poder e, sob o ponto de vista jurídico-funcional, operavam como poder e como meio de intermediação das relações jurídicas apenas por mera formalidade, sem muito efeito prático. Desse cenário surge a idéia de que a fiscalização e, sobretudo, os seus mecanismos, seriam “órgãos inúteis”.

$\mathrm{O}$ acionista controlador, durante muito tempo, funcionou como um poder moderador dentro das companhias; qual seja, um poder soberano e que em muitos casos se utilizava da assembléia para fazer valer os próprios interesses, um poder soberano que, além de pairar sobre ela, prestava-se para interferir em órgãos e no exercício de funções (tecnicamente falando, considerando-se função dentro do conceito aqui proposto), bem como para ditar os desígnios da gestão de forma quase impune e, como ocorria com o Poder Moderador, de forma até irresponsável. A partir dos trabalhos de COMPARATO e do advento da organicidade imposta pelo artigo 116 da Lei das S.A., esse exercício irresponsável começou a se modificar.

Falar de poder de controle, no Brasil, admitindo-lhe a concentração e a quase inexistência de dispersão acionária é admitir, de forma reflexa, que o exercício do poder de controle e o reconhecimento que a lei sabiamente lhe dá para fazer alcançar todas as suas hipóteses, vê no controlador uma figura que conjuga domínio mais gestão efetiva tal qual uma projeção do conceito peculiar de poder que no Brasil se assume. Em outras palavras, o poder de controle pode muito bem ser entendido como um nicho do estamento burocrático e do patronato de que FAORO nos fala e a quem se lhe atribui parte da condução dos desígnios das principais instituições da nação. Pois, assim como o conceito se amolda ao Poder Executivo, não há de falhar quando visto no Acionista Controlador, 
que tem o domínio nas decisões assembleares, o domínio na gestão e a efetiva interferência na atividade social, muita vez com última palavra sobre algo que toca ao objeto social. ${ }^{32-33}$

O poder de controle, no Brasil, sob a ótica de uma sociologia jurídica que ainda clama por vir, pode, nesse contexto moderador, figurar como legítimo herdeiro de um conceito próprio de soberania no país, erigido sob a influência do patrimonialismo patriarcal, que FAORO bem resumiu pela fórmula do estamento burocrático. ${ }^{34}$

\footnotetext{
${ }^{32}$ Waldírio Bulgarelli, em seu parecer intitulado "Fiscalização da Companhia" (In Problemas de Direito Empresarial Moderno. São Paulo: Revista dos Tribunais, 1989, pp.181-196) traz importantíssima notícia acerca da moderna assembléia, notando que não apenas no Brasil, mas nas legislações de França e Itália, a assembléia sempre figurou como um "encontro da maioria", lembrando, inclusive, as regras de assembléia do Banco do Brasil na época de Dom João VI (p.184). Em alguns casos, como o Código de Napoleão, a assembléia não estava guarnecida nem sequer de previsão legal (Idem). Adicionalmente, podemos lembrar que no direito estado-unidense do século XIX, por exemplo, essa afirmação teria que ser temperada por um sistema onde cada Estado impõe as regras que melhor adiram às suas aspirações culturais locais, somada à noção quase milenar da aplicação do instituto de direito real do trustee, no que se refere aos poderes societários. Nesse sistema, acionistas não estavam limitados nos direitos de participar das assembléias, bem como à legitimidade para agir judicialmente contra a administração. No mesmo sentido, vide Lawrence Meir FRIEDMAN (A History of American Law, Op. cit., Idem, pp. 511 e segs., sobretudo 515).

${ }^{33}$ A impressionante biografia do Barão de Mauá, de autoria de Jorge CALDEIRA (Mauá - Empresário do Império, $18^{\mathrm{a}}$ reimpressão. São Paulo: Companhia das Letras, 1995) apresenta uma larga série de exemplos vivos daquele tempo sobre os problemas decorrentes do exercício do poder de controle nas companhias da época do Império e os modelos de assembléias nessas companhias. Essa obra dá, igualmente, um candente relato da simbiose entre público e privado, entre exercício do poder de controle e soberania pública, entre motivações particulares e posturas públicas bem como, e sobretudo, a relação entre livre iniciativa e interesses públicos.

34 “O estamento, quadro administrativo e estado-maior de domínio, configura o governo de uma minoria. Poucos dirigem, controlam e infundem seus padrões de conduta a muitos. $\mathrm{O}$ grupo dirigente não exerce o poder em nome da maioria, mediante delegação ou inspirado pela confiança que o povo, como entidade global, se irradia. É a própria soberania que se enquista, impenetrável e superior, numa camada restrita, ignorante do dogma do predomínio da maioria" (R. FAORO, Donos do Poder, Op. cit., Idem, p. 88). Ainda, nesse mesmo sentido: "O patrimonialismo, organização política básica, fecha-se sobre si próprio com o estamento, de caráter marcadamente burocrático. Burocracia não no sentido moderno, como aparelhamento racional, mas da apropriação do cargo - o cargo carregado de poder próprio, articulado com o príncipe, sem a anulação da esfera própria de competência” (p. 84). Desta última passagem, é extremamente fácil visualizar o conceito de estamento burocrático em uma companhia colonial cujo poder de controle se apropria de cargos ao invés de distribuí-los e usá-los em favor da companhia e em prol de uma segmentação de funções por profissionais específicos. Nas chamadas sociedades familiais é bastante comum observar esse lastro de estamento burocrático sendo estendido e praticado na iniciativa privada por herança cultural de gestão e governo.
}

Para uma linha de aproximação, trazemos observação lapidar de COMPARATO (O Poder de Controle..., Op. cit., Idem, p. 39): “Aliás, a definição dos centros de poder, no Direito atual, parece coincidir, raramente, com a realidade do poder. A declaração constitucional de que 'todo poder emana do povo e em seu nome é exercido', por exemplo, tem se apresentado mais como enunciado de princípio, de valor programático, do que como disposição efetivamente vinculante na prática política, onde a noção de 'povo' se revela exclusivamente abstrata. Analogamente, na pesquisa da realidade do poder, na sociedade anônima, não nos podemos contentar com a afirmação legal de que a 'a assembléia geral, convocada e instalada de acordo com a lei e o estatuto', tem poderes para decidir todos os negócios relativos ao objeto da sociedade e tomar as resoluções que julgar convenientes à sua defesa e desenvolvimento (Lei n ${ }^{\circ}$ 6.404, art. 121). Quem toma, de fato, as decisões em assembléia? O controle manifesta-se através dos poderes decisórios da assembléia de acionistas como necessária legitimação do seu exercício. Mas essa legitimação é meramente formal ou procedimental." 
Esse problema, de fato grave, que demarca as funções societárias com um tropicalismo bastante particular e com poucos paralelos no mundo, permite-nos uma reflexão em retorno ao que já foi exposto até aqui. O capitalismo periférico desenvolvido no Brasil e amadurecido nos tempos de governo militar por meio dos Planos Nacionais de Desenvolvimento (os chamados PNDs) ${ }^{35}$, deram um ambiente favorável à criação de uma cultura muito peculiar, e que tem se dissolvido a passos vagarosos, no sentido de criar nichos de permissões para acúmulo de funções.

De fato, grandes conglomerados empresariais, sobretudo os conglomerados familiares e aqueles em que se nota a presença do Estado, permitem observar que certas funções jurídicas e societárias são muita vez desenvolvidas pela mesma pessoa ou por pessoas pertencentes a um mesmo grupo ou foco de interesse. Em matéria de fiscalização, inclusive, a lei permite, de maneira curiosa, como se verá, que o controlador possa ter maioria, por exemplo, num órgão como o Conselho Fiscal. Normalmente, a técnica utilizada para coibir o abuso de potestatividades societárias que fundem duas funções limita-se sempre à investigação de conflito de interesse, nos termos dos artigos 115 e 156 da Lei das S.A. ${ }^{36}$

Noutro passo, o problema que toca à sobreposição de funções é também muito saliente quando abordamos a postura do Estado-empresário no Brasil.

Até fins da década de 1980’ e início da década de 1990’, o direito, não apenas o brasileiro, mas também boa parte da doutrina estrangeira, se empenhou em relacionar a questão da empresa e do Estado à luz de problemas de nacionalidade, territorialidade e jurisdição. ${ }^{37}$ Entretanto, a evolução das formas associativas, que passam

\footnotetext{
${ }^{35}$ Sobre o interessante impacto dos PNDs, principalmente o II PND da década de 1970' e seu impacto na concentração empresarial e, consequentemente, no exercício do controle societário, vide a análise de Eduardo Secchi Munhoz. Empresa Contemporânea e Direito Societário..., Op. cit., Idem, pp. 97-100, que lembra que, além dos já tradicionais conglomerados dominados por família, a par dos conglomerados controlados pelo Estado, surgiram os conglomerados controlados por grandes multinacionais. Principalmente nos dois períodos de forte tendência de desestatização e desregulamentação de vários setores da economia no Brasil, a entrada de grandes grupos estrangeiros, que deveriam trazer ao Brasil alguma tradição no exercício do poder de controle, acabaram se adaptando rapidamente às maleabilidades que a prática societária brasileira ainda permite em matéria de controle e acúmulo de funções.

${ }^{36}$ Exemplo dessa sobreposição de funções dentro dos direitos de fiscalização pode ser observado no interessante parecer de Waldírio Bulgarelli, sobre "Fiscalização da Companhia" In Problemas de Direito Empresarial Moderno..., Op. cit., Idem, pp.181-196. Outro exemplo disso está no Parecer nr. 201 de Francisco Cavalcanti Pontes De MirandA, In Dez Anos de Pareceres, vol. 8. Rio de Janeiro: Francisco Alves, 1976, pp.34-47.

37 Obra paradigmática no tema foi elaborada por João Grandino RoDAS, quando de sua ascensão à titularidade na cadeira de Direito Internacional Privado no Departamento de Direito Internacional da
} 
pelo conceito de joint venture, ${ }^{38}$ aliadas a um contexto globalizante, permitiram surgir um novo conceito de empresa que Eduardo Secchi MunHOZ, na obra tantas vezes aqui citada, notou estar em pleno funcionamento, com efeitos variados sobre o conceito e o exercício do poder de controle nas diversas legislações do mundo, dentre as quais o Brasil não se alheia. $^{39}$

Restou, portanto, da relação existente entre empresa contemporânea e Estado, uma compreensão que enfoca exclusivamente o papel do Estado como empresário e a sua postura como acionista controlador. A história da formação do capitalismo brasileiro, alvo dos já citados estudos de FURTADO e PRADO JUNIOR, que demonstram como o capitalismo periférico desenvolvido na cultura comercial brasileira se isolou

Universidade de São Paulo (Sociedade Comercial e Estado. São Paulo: Saraiva, 1995). O problema da nacionalidade da sociedade comercial como conseqüência da relação entre sociedade comercial e Estado também é tema da obra clássica de Luiz Olavo BAPTISTA. Empresa Transnacional e Direito. São Paulo: Revista dos Tribunais, 1987. Vale lembrar que ambas as obras foram escritas antes da Emenda Constitucional $n^{\circ}$ 6, de 15 de agosto de 1995, que deu nova redação ao artigo 171 da Constituição Federal de 1988.

Sob um enfoque geopolítico e econômico, vale consultar a obra de Herman M. ScHWARTZ (States Versus Markets - History, Geography and the Development of the International Political Economy. Nova Iorque: St Martin's Press, 1994, pp. 240-258), onde se expõem inúmeras razões (incluindo muitas de ordem jurídica) pelas quais as empresas passaram a adotar um modelo transnacional, apesar de indicativos contrários a respeito de custos de negociação e oportunidade [cost transactions], demonstrando que o modelo exportador poderia sofrer uma revolução com a transnacionalização e a solidificação de certos aspectos jurídicos de direito do trabalho e propriedade intelectual. O papel que os Estados assumiram, sobretudo das nações desenvolvidas da Europa, ao lado dos EUA e do Japão, buscou temperar protecionismo com mercado livre, contribuindo para o estado de globalização atual. Em contraponto a essa interessante discussão, Hendrik SPRUYT (The Sovereign State and Its Competitors. Princeton, NJ: Princeton University Press, 1994, pp. 192194) procura enfocar os efeitos desse quadro sobre o conceito de soberania. As observações de SPRUYT, sobretudo na página 192, casam-se em interessante contraponto àquilo que dissertamos acima a respeito da tradição local no exercício dos poderes, que acaba tornando a fiscalização um mecanismo formal dentro de uma estrutura de conservação de poder: "Political elites in power have few incentives to alter existing institutions and experiment with new systems of rule. What held true for the medieval nobility, which was reluctant to surrender its powers to emerging burghers and centralizing kings, holds equally true for political leaders today. African leaders, for example, who have inherited a state system that was clearly imposed, have shown relatively little desire to reconstitute their authority on grounds other than sovereign territoriality".

${ }^{38}$ Sobre a relação entre as formas associativas de joint venture e o mecanismo do poder de controle que lhes subjazem, vide Eduardo Goulart PIMENTA. Joint Ventures - Contratos de Parceria Empresarial no Direito Brasileiro. São Paulo: Juarez de Oliveira, 2005, pp.28-30; Maristela BASSO. Joint Ventures - Manual Prático das Associações Empresariais, $2^{\mathrm{a}}$ ed.. Porto Alegre: Livraria do Advogado, 1998, p. 188; Osvaldo J. MARZORATI. Alianzas estratégicas y joint ventures. Buenos Aires: Astrea, 1996, p.126-132.

39 L.O. BAPTISTA (Empresa Transnacional..., Ibidem, pp. 26-34) já deixava um embrião daquilo que MunHOZ sedimentou anos depois no seu Empresa Contemporânea... . L.O. BAPTISTA, ao deixar evidente o caráter anômalo das empresas transnacionais, com barreiras de adaptação às peculiaridades de ordenamentos jurídicos ainda despreparados para regular o direito societário em um mundo globalizado, mostrava, já em 1987, que um novo conceito de poder de controle poderia estar surgindo em um universo societário dominado pela empresa contemporânea anos depois descrita por MUNHOZ. L.O. BAPTISTA ainda discorre, já nessa época, aos tipos de tensão existentes entre Estados e empresas transnacionais, bem como entre empresas e entre Estados, aliados a mecanismos de freios e contrapesos para estancar abusos no exercício do poder econômico, que, nada mais são do que excessos cometidos pelo poder de controle com efeitos sobre múltiplas jurisdições, territórios, culturas e acionistas de empresas associadas (pp.35-55). J. G. RoDAS, igualmente, não deixa de se ocupar do problema do poder de controle no âmbito da transnacionalidade das empresas contemporâneas (Sociedade Comercial e Estado, Op. cit., Idem, pp.331-344). 
conceitualmente e em termos práticos, acabou, como bem observou SALOMÃo FILHO e também MuNHOZ, por dar ao conceito de poder de controle e acionista controlador, uma nota muito particular, que ainda se vê nas entrelinhas do artigo 116 da Lei das S.A., bem como do artigo 171, inciso II da Constituição Federal de 1988. Esse histórico ainda construiu esse conceito de acionista controlador e a cultura do poder de controle no Brasil muito por força da simbiose entre Estado e empresa. Essa simbiose, para o caso particular do direito brasileiro, além de ter gerado reflexos na livre iniciativa ${ }^{40}$, fez com que se pudesse permitir, hoje, num âmbito acadêmico, uma aproximação entre política de Estado e democracia societária, dadas algumas semelhanças entre o comando e a governança de algumas empresas e o comando e a governança do Estado.

Nesse paralelo, e tendo em mente sempre a problemática da fiscalização societária, particulares preocupações surgem quando o próprio Estado assume a tarefa de acionista controlador de uma empresa cuja iniciativa lhe pertence. Dessas empresas em que há participação do Estado, sobretudo na qualidade e na função de acionista controlador, a prática acaba obscurecendo o direito societário em favor de regras de direito público, que se impõem por princípio.

Nas empresas controladas pelo Estado (sejam estatais ou de economia mista), compondo o universo da administração indireta, independentemente do objeto social (se atividade econômica de natureza privada ou serviço público) e por força da derrogação parcial do direito privado pelas regras de direito público ${ }^{41}$, o exercício de certas funções societárias, em uma relação jurídica própria de direito societário, também sofre sérias distorções. ${ }^{42}$.

\footnotetext{
${ }^{40}$ Roberto Rosas (“Tendências Atuais da Empresa Pública”, RDP 35-36/143-144 [jul.-dez./1975]) chega a lembrar vários exemplos de projetos que, sem o exercício da livre iniciativa pelo Estado, jamais se concretizariam, tais como a Companhia Urbanizadora da Nova Capital - NOVACAP, responsável por obras em Brasília, o BNDES, o BNH, a EBCT além de muitos outros exemplos.

41 Sem prejuízo e na linha da interpretação infraconstitucional do disposto no artigo $173, \S 1^{\circ}$ da Constituição Federal de 1988, vide Maria Sylvia Zanella Di PIETRO. Direito Administrativo, $17^{\mathrm{a}}$ ed.. São Paulo: Atlas, 2004, p. 385; Celso Antonio Bandeira de Mello. Curso de Direito Administrativo, 20ª ed.. São Paulo: Malheiros, 2006, p. 185-188. Na prática, entretanto, algumas maleabilidades podem ser observadas, sobretudo em matéria de licitação e quando envolve alguma companhia como a Petrobrás, por exemplo. A esse respeito, vide parecer de Luís Roberto BARRoso ("Intervenção no Domínio Econômico - Sociedade de Economia Mista - Abuso do Poder Econômico” RDA 212/306-346 [abr.-jun./1998]).

${ }^{42}$ Como lembra Celso Antonio Bandeira de Mello, sejam tais entidades "instrumentos de ação do Estado" e que, constituindo-se como "auxiliares do Poder Público", de fato, tornam-se "entidades voltadas, por definição, à busca de interesses transcendentes aos meramente privados” (Ibidem, p. 178), e como conseqüência direta na governança das empresas controladas pelo Estado, "estes [os agentes de Estado], quando dirigentes da pessoa, investidos em decorrência de providências governamentais exercidas em nome
} 
Entretanto, a busca pelo interesse público de que nos noticia BANDEIRA DE MELLO, como é de se ver, não é o único fator de distorção das funções societárias nas
empresas controladas pelo Estado. ${ }^{43}$ Mecanismos como a criação da companhia por lei

da supervisão ministerial, na forma do art. 26, parágrafo único, 'a', do Decreto-lei 200, exercem mandatos, representantes que são do sujeito controlador da pessoa", e, por isso "cumulam a dupla função de agentes da empresa estatal e representantes da entidade que a supervisiona" (Ibidem, pp. 203-204).

${ }^{43}$ Neste particular, José Affonso da Silva (Curso de Direito Constitucional Positivo, $22^{\text {a }}$ ed.. São Paulo: Malheiros, 2003, pp. 725-726) acrescenta: “A função de fiscalização, que surgiria com o constitucionalismo e o Estado de Direito implantado com a Revolução francesa, sempre constituiu tarefa básica dos parlamentos e assembléias legislativas. No sistema de separação de poderes, cabe ao órgão legislativo criar as leis, por isso é da lógica do sistema que a ele também se impute a atribuição de fiscalizar seu cumprimento pelo Executivo, a que incumbe a função de administração. Por outro lado, no que tange ao aspecto específico que nos interessa aqui - o do controle da administração financeira e orçamentária - reserva-se ao Legislativo o poder financeiro, como uma de suas conquistas seculares, pela qual firmara mesmo sua autonomia, sendo, portanto, também palmar evidência que a ele há de pertencer, em última análise, aquele controle, denominado controle externo, sem embargo de que se erija e desenvolva, na Administração moderna, eficiente sistema de autocontrole - o chamado controle interno - de que é titular cada um dos Poderes onde ele atua (art. 70 [da Constituição Federal])" (itálicos do autor). Note-se, nessa precisa informação, que não há que se duvidar que o modelo adotado pela Administração Indireta, e portanto, o modelo das empresas em que o estado se apresente como acionista controlador, distorce funções e permite o acúmulo de sujeitos em funções que são, por sua natureza, diferentes e opostas, como a gestão administrativa e a fiscalização. A tónica do autocontrole, expresso pelo controle interno previsto na Constituição Federal (artigo 70, caput) é, bem sabemos, uma fonte de conflitos de competência (negativos e positivos, dependendo das circunstâncias de fato). A fiscalização de que fala J. Affonso da Silva é, prima facie, a fiscalização da atividade política e orçamentária do Estado como Administração Direta; tanto é que, no início da explicação, J. Affonso da SILVA põe as bases do raciocínio na lógica da Revolução francesa. Em sentido contrário, privilegiando os mecanismos de controle e fiscalização da lei societária, sem, entretanto, discutir o conflito de atribuição em face dos Tribunais de Contas, há interessante texto de Leon Frejda SzKLAROwSKY ("Conselho Fiscal de Sociedades Anônimas Comuns e de Economia Mista”, In RDP 78/198-203 [abr.-jun./1986]), lembrando das funções de uma certa Secretaria de Controle das Empresas Estatais (SEST) bem como das funções da Secretaria do Tesouro Nacional, ambas submetidas ao Ministério da Fazenda, conforme, respectivamente, os Decretos $\mathrm{n}^{\text {os }} 84.128$, de 29 de outubro de 1979 e o 92.452 de 10 de março de 1986. Entretanto, independentemente da batalha teórica que se empreende sobre as redes e obrigatoriedades de fiscalização de natureza puramente societária à luz do conceito de bem público, uma vez admitida essa necessidade de fiscalização própria, a prática encontra vácuos de competência que oscilam entre as atribuições do conselho fiscal, do conselho de administração do ente controlado pelo Estado e de atividade própria do Tribunal de Contas a que o ente da administração direta está sujeito.

A questão de se considerar dentro da esfera de bens públicos o acervo patrimonial de uma empresa da administração indireta se presta para forçar a presença fiscalizatória do Tribunal de Contas em detrimento dos mecanismos societários próprios. Ainda que a Lei das S.A. disponha sobre o funcionamento permanente do conselho fiscal para as sociedades de economia mista (artigo 240), refletindo, na doutrina, entendimento bem fincado pela interpretação constitucional do artigo 240 da Lei das S.A., há parte da doutrina que entende ser conveniente privilegiar o Tribunal de Contas. Na primeira esfera, lembramos novamente J. Affonso da SIlva (Comentário Contextual à Constituição, 4 ed.. São Paulo: Malheiros, 2007, p. 719): “O estatuto tem que dispor sobre a constituição e o funcionamento dos conselhos de administração e fiscal, com a participação de acionistas minoritários. O tema não apresenta maior dificuldade. $O$ modelo que a Lei das Sociedades Anônimas prevê para os conselhos de administração e fiscal das sociedades de economia mista pode estender-se, mutatis mutandis, a outras empresas estatais. O art. 239 da citada lei declara que as companhias de economia mista terão obrigatoriamente conselho de administração, assegurado à minoria o direito de eleger um dos conselheiros, se maior número não lhes couber pelo processo de voto múltiplo (art. 141); e acrescenta que os deveres e responsabilidades dos administradores das companhias de economia mista são os mesmos dos administradores das companhias abertas. Estatui, por seu lado, o art. 240 que o funcionamento do conselho fiscal será permanente nas companhias de economia mista; um dos seus membros - e respectivo suplente - será eleito pelas ações ordinárias minoritárias, e outro pelas ações preferenciais, se houver" (grifos nossos). A afirmação é precisa e lapidar, mas nem sempre se casa com o ideal de supremacia da ordem pública sobre a privada, entregando-se essa situação, em raros casos, quando exigências de mercado clamam por esse tratamento essencialmente societário, em detrimento da atrofia do 
(artigo $5^{\circ}$, II e III do Decreto-lei $\mathrm{n}^{\mathrm{o}}$ 200, de 25 de fevereiro de 1967 e artigo 236 da Lei das S.A.), a nomeação da administração da sociedade (artigo 26, Parágrafo Único, alínea "a" do Decreto-lei $n^{\circ} 200$, de 25 de fevereiro de 1967), a sujeição à lei das licitações (artigo $1^{0}$, Parágrafo Único da Lei $n^{0}$ 8.666, de 21 de junho de 1993, fortemente afetada pela Emenda Constitucional $n^{0} 19$, de 4 de junho de 1998) dão uma tónica diferenciada para o modelo societário da empresa controlada pelo Estado, que podem pôr, no exercício dessas funções societárias, um componente político (e muita vez partidário) que nem sempre é sadio sob o ponto de vista da governança societária. ${ }^{44}$ Esse problema, que é histórico no Brasil, ${ }^{45}$

conselho fiscal e do conselho de administração em favor da atuação dos Tribunais de Conta. Em sentido contrário, defendendo a atuação prevalente dos Tribunais de Contas na fiscalização da atividade empresarial das sociedades de economia mista, vide de Gabriela Verona PÉRCIO e Gabriel Guy LÉGER, “A Competência Constitucional dos Tribunais de Contas para fiscalizar as sociedades de economia mista exploradoras de atividade econômica", Informativo de Direito Administrativo e Responsabilidade Fiscal - IDAF, vol. 43, Curitiba: Zênite, fev./2005, pp.647-652. Em reforço a essa posição PÉRCIO e LÉGER apresentam importante decisão do Supremo Tribunal Federal, com voto divergente do Min. Ministro Carlos Velloso, em sustento dessa tese (vide Mandado de Segurança $n^{0}$ 23.875-5/DF, Relator para o Acórdão Min. Nelson Jobim, j.: 10/11/2005). Embora a decisão tenha sido apresentada no sentido de que aos Tribunais de Contas não cabe essa fiscalização societária, PÉRCIO e LÉGER defendem-se pelo posicionamento do voto divergente do Min. Velloso.

Vide, ainda, os brilhantes comentários que Mauro Rodrigues PENTEADO faz à obra de Waldírio BULGARELLI enriquecendo-a com menção a respeito da importância do conselho fiscal face ao sistema criado pela Secretaria de Controle das Empresas Estatais - SEST ("Bibliografia - 'O Conselho Fiscal das Companhias Brasileiras' - Waldírio Bulgarelli, $1^{\text {a }}$ ed., 232 pp., Ed. RT, S. Paulo, 1988”, In RDM 76/109-111 [out.-dez. 1989], com destaque para os problemas de fiscalização nas empresas estatais na p. 110. Vide, nesse mesmo sentido, do mesmo autor, "As Empresas Estatais e os Sistemas de Supervisão e Controle", In RDM 45/20-28 [jan.-mar./1982], com notáveis críticas ao sistema imposto pelo aqui mencionado Decreto 84.128/79).

${ }^{44}$ Essa relação de aproximação se nota quando Celso Antonio Bandeira de MELlo adverte que entre Tribunal de Contas e Poder Legislativo há uma proximidade, sobretudo no que tange às funções fiscalizadoras do Tribunal de Contas ("Função Controlada do Tribunal de Contas", conferência de setembro de 1989, transcrita em RDP 99/160-166 [jul.-set./1991]; sobre a aproximação entre Poder Legislativo e Tribunal de Contas no aspecto fiscalizatório deste último órgão, vide p. 162).

Para comprovar a gravidade e a reprovável descompostura de um certo tipo de atitude abjeta muito comum nas empresas públicas, há matéria jornalística ("Governança Capenga”, por Danilo FARIELLO, In Valor Econômico de 31 de julho de 2007, p. D-1) que destaca, ao falar sobre o uso do conselho fiscal nas companhias abertas: "Muitas das empresas antigas no mercado, porém, já têm o conselho fiscal (...). Antes, as empresas estatais, que preponderavam no mercado, costumavam adotar o conselho, mas, principalmente para abrigar políticos. Isso fez com que muitas empresas que derivaram das estatais no mercado mantivessem a estrutura do conselho fiscal. Contudo, apesar de muitas abrigarem a figura do conselho, a eficiência dos mesmos tornou-se outra questão também discutível" (sic).

${ }^{45}$ Se compararmos o modelo jurídico brasileiro com o modelo jurídico francês, cuja cultura e economia estão fortemente baseadas em algumas empresas, sobretudo as de infra-estrutura controladas pelo Estado, notar-se-á que o componente partidário pode ser menos influente do que no Brasil, por razões históricas. A empresa pública ou controlada pelo Estado começa a ganhar corpo, historicamente, na França, no período entre-guerras e por força das circunstâncias muito peculiares de participação da França na Primeira Guerra Mundial e conseqüentes resultados. Essa talvez seja a diferença mais marcante para as empresas controladas pelo Estado, no Brasil, que na maioria dos casos nasceu em regimes ditatoriais, seja no período Vargas (1937-1945), seja no período Militar (1964-1988).

A razoável independência da administração em relação ao controle societário exercido pelo Estado, por força de mecanismos de ingresso na administração societária e de submissão técnica ao Ministério que exerce o controle sobre a sociedade, faz com que a França, ainda que pesadamente estatista, tenha um nível mais reduzido de conflito de interesses (sob o ponto de vista societário), tendo as funções societárias em um quadro de menor distorção. Esse componente técnico-político (em contraposição ao componente político- 
partidário, ainda muito influente no Brasil), nesse particular, faz com que o modelo brasileiro e a prática de condução da governança corporativa nas empresas controladas pelo Estado, atualmente sofredoras de uma forte influência de negociatas partidárias, se aproxime de alguma forma do modelo soviético, fortemente influenciado pelo conceito de partido e não pelo conceito de política de consenso. Lembramos também as marcas desse extinto sistema com base em segura doutrina jurídica dessa histórica nação, a saber, L. Grigorián e Yuri Dolgopólov (Fundamentos del Derecho Estatal Soviético. Moscou: Editorial Progresso, s/d; versão para o espanhol de O Razinkov e V. Mazuerenko do original russo основы советского ГОСУДАРСТВЕННОГО ПРАВА): "La economía es la base material del avance del País Soviético por el camino de la construcción del comunismo y del desarrollo de la organización política de la sociedad socialista. $Y$, debido a ello, la reforma económica aplicada por el partido tiene una gran importancia para perfeccionar los princípios democráticos de dirección de todos los processos de la construcción del comunismo" (p. 102). Na sequência, GRIGORIÁN e DOLGOPOLÓv explicam qual seria o papel do partido na direção e na fiscalização das organizações estatais, que incluem a indústria, as empresas e as instituições da economia (p.104): " $L a$ segunda variedad fundamental de las formas de actividad dirigente del partido consiste en que éste aspira a promover a los cargos más importantes en los órganos estatales y las organizaciones sociales a hombres fieles hasta el fin a la causa de la construcción del comunismo que pueden ser de hecho conductores del programa, las resoluciones y la política del partido" (p.105). E assim seguem: "Es completamente lógico que el PCUS en tanto que partido gobernante aspire a promover a los cargos más importantes en el aparato estatal y las organizaciones sociales a personas que apliquen estrictamente las decisiones del partido y en las que éste pueda apoyarse siempre en la realización de suas planes. Es lógico también que el partido promueva, en primer término, a comunistas que consideran su obligación directa e incondicional el cumplimiento de sus decisiones. Pero, junto con los comunistas, el partido promueve y apoya a aquellos hombres sin partido, que son grandes especialistas y organizadores. Así, pues, el partido, al seleccionar y distribuir los cuadros, se guía por las cualidades políticas de los hombres" (p. 106). Finalizam, prelecionando: "Los órganos del partido recomiendan para los cargos dirigentes en el aparato estatal y las organizaciones sociales a personas capaces de cumplir las missiones encomendadas a los organismos correspondientes. En este caso, como es lógico, los miembros del partido promovidos a uno u otro cargo asumen una responsabilidad elevada ya que responden de sus actividades no sólo en orden de su subordinación de servicio sino también ante el partido que vela rigurosamente por que los comunistas estén siempre a la altura de las tareas planteadas ante ellos. De ello emana la tercera variedad principal de la direción partidaria: el control, que efectúa el partido, de la labor de los órganos de Estado y las organizaciones sociales y que consiste, en primer lugar, en verificar la actividad de los comunistas, funcionarios de los mismos" (pp. 106-107). Confirmam essa informação acerca do sistema de fiscalização, sob a autoridade do partido oficial, em todos os órgãos do antigo estado Soviético (incluindo as indústrias, as empresas, as cooperativas e todas as formas de associação produtiva, cf. artigos 14, alínea "l" da Constituição Soviética de 1936, que incluía, dentre os órgãos superiores do Poder os órgãos de administração do Estado, "a direção dos Bancos, dos estabelecimentos comerciais e as empresas industriais e agrícolas, assim como das empresas comerciais dependentes dos ministérios da União, e a direção geral da indústria e a construção dependentes dos minstérios de toda a União e das repúblicas"), os juristas A. DENISOV e M. KIRICHENKO (Derecho Constitucional Sovietico. Moscou: Ediciones en Lenguas Estranjeras, 1959, p. 131): “El Partido Comunista selecciona, prepara y coloca a los cuadros del aparato estatal y controla la actividad de los órganos de Poder y de la administración del Estado. Los órganos del Estado no dictan ninguna disposición importante sin la indicación y consejo previos del Partido". Note-se, portanto, como o sistema soviético, nas suas formas de exercício e físcalização do poder estatal sobre a atividade econômica direta pautou-se pela politização, pela partidarização e pela total falta de independência e marcado conflito de interesse entre gestão do objeto social da coisa pública e fiscalização dessa mesma gestão. Um único ente (o partido), controla e fiscaliza. Além do que dispõe o artigo 14, "l" da Constituição Soviética, os artigos 114 a 117 outorgavam ao Ministério Público (órgão independente, mas submisso ao Procurador Geral, que deve satisfações ao Soviet Supremo) ampla função fiscalizatória, mas cuidadosamente controlada pelo partido, pois, ainda que a Constituição declarasse a independência como princípio ("os órgãos do Ministério Público exercem suas funções com independência de qualquer órgão local e unicamente se subordinam ao Procurador Geral da URSS"), a Lei de Controles Fiscais, de 24 de maio de 1955 (promulgada por Decreto do Presidente do Soviet Supremo), em seu artigo $7^{\circ}$ dispunha: "O Procurador Geral da URSS responde e deve prestar contas de sua gestão ante o Soviet Supremo da URSS, e no período compreendido entre as sessões do Soviet Supremo da URSS, ante o Presidente do Soviet Supremo da URSS" (apud, DENISOV e KIRICHENKO, que trazem anexos com extenso material legislativo e jurisprudencial da extinta nação Soviética).

Quanto ao modelo francês, aqui usado como exemplo para comparação, embora tenha muitas regras próximas (submissão às regras de direito privado, com parcial derrogação pelas regras de direito público, quando o conceito de comerciante normal opuser resistências a uma atuação econômica tipicamente estatal; 
produz complicados problemas de fiscalização societária na empresa controlada pelo Estado.

O problema da fiscalização das empresas controladas pelo Estado, que não é apenas histórico, é também um problema técnico-jurídico, aliado a um problema legal, qual seja, de lege lata.

A busca por um interesse público, bem advertida por Bandeira de MELLO, orientou um sistema que peca por excessos e carece de boa lógica. ${ }^{46}$ No que se refere ao problema da fiscalização, sem dar tratamento jurídico aos órgãos internos de fiscalização societária e a outros modelos de fiscalização como a auditoria independente, a legislação brasileira, na Constituição Federal (artigo 71), privilegia amplamente o sistema de Tribunal de Contas e, mediatamente, o Ministério Público (artigo 129, II e VI) ${ }^{47}$, e a supervisão do titular da pasta ministerial responsável pela empresa controlada pelo Estado (Decreto-lei $\mathrm{n}^{\mathrm{o}}$ 200, de 25 de fevereiro de 1967, artigos 19 a 26). No âmbito ainda mais mediato, há o

fiscalização pelos Tribunais de Contas; regime jurídico do trabalhador equiparado ao da iniciativa privada; administração nomeada pelo Estado e sujeita a um estatuto jurídico de Direito Público equivalente ao do cargo de quem fez a nomeação; etc.) pratica um direito societário de empresas controladas pelo estado de forma bastante diversa do modelo brasileiro. Sobre o modelo francês e todas essas peculiaridades, vide Claude DeBBASCH. Institutions et Droits Administratifs, vol 1 - les structures administratives, $3^{\mathrm{a}}$ ed.. Paris: PUF, 1985, pp. 533-583, sobre as entreprises publiques.

A respeito da fiscalização nessas companhias, é importante lembrar que o modelo francês societário, baseado na fiscalização externa não-orgânica, que privilegia o esquema da auditoria independente via commissaires aux comptes (vide R. GRANGER. La nature juridique des rapports entre actionnaires et commissaires..., Op. cit., Idem, pp. 70 e segs.), gera, nas empresas controladas pelo Estado, não apenas a a fiscalização feita por meio dos Tribunais de Contas (C. DEBBASCH, Ibidem, p. 543-544) e as formas de controle interno da administração (tal qual o controle específico do Ministro da Fazenda [Ministre des Finances], cf. pp. 569-570) e o controle parlamentar (pp. 572-573), mas também e sobretudo, uma espécie de controle por comissários nomeados por agentes do governo (p. 570). Esses comissários especiais nomeados por membros do governo excluem os meios de fiscalização do direito comercial francês via commissaires aux comptes (p. 571). A delegação, para uma auditoria externa, ainda que nomeada por titulares do poder de estado (e nesse caso, do poder de controle), minimiza a distorção de nomeação político-partidária para a assunção e o desempenho de funções, na companhia, que tenham natureza orgânica.

${ }^{46}$ Apesar desses excessos, há benefícios necessários que correm em favor de uma limitação das regras de direito societário pela cautela do controle exercido pelo Estado, que na verdade o faz em nome da sociedade civil a quem está a serviço. Bom exemplo disso está em parecer formulado por Eros Roberto GRAU ("Sociedade de Economia Mista - Nulidade de Acordo de Acionistas que importa em mudança de seu acionista controlador" RDA 222/348-357 [out.-dez./2000]) e em parecer de Fábio Konder COMPARATO ("Venda em bolsa de ações da União Federal no capital de Sociedade de Economia Mista e desrespeito às normas disciplinares do Mercado de Capitais", In Novos Ensaios e Pareceres de Direito Empresarial. Rio de Janeiro: Forense, 1981, pp. 290-312). A respeito da questão CEMIG, foco do parecer dado por E. R. GRAU, ofereceu parecer em sentido diverso Adílson Abreu DALlaRI ("Sociedade de Economia Mista - Sócio Estratégico - Acordo de Acionistas" RDA 221/379-440 [jul.-set./2000]) e na mesma linha de argumentos propostos por E. R. GRAU, apresentou parecer Fábio Konder COMPARATO ("Sociedade de Economia Mista Transformada em Sociedade Anônima Ordinária - Inconstitucionalidade”, RTDP - 25/61).

47 Neste particular, vide Márcio Souza GuIMARÃes. "Ministério Público, Ombudsman e Ouvidor na Fiscalização dos Serviços Públicos" In Direito Empresarial Público (orgs. Marcos Juruena Vilella Souto e Carla C. Marshall). Rio de Janeiro: Lumen Juris, 2002, pp. 785-805. 
controle via Ação Civil Pública e, passo além, o controle via Ação Popular. Neste último ponto de controle está o cidadão.

O Tribunal de Contas, como mecanismo de fiscalização societária das empresas controladas pelo Estado, por força de componentes que combinam funções jurídicas que identificam o exercício do poder no Estado, como controlador da companhia, com os mecanismos de fiscalização e os meios de gestão da companhia, apresentam um modelo razoavelmente deletério para a eficiência das empresas controladas pelo Estado, sem contar as inúmeras brechas de prevenção de composição e divulgação de prejuízos. Toda essa sobreposição afeta a governança das empresas controladas pelo Estado e tornam a transparência algo não prioritário.

Além disso, como mecanismo de controle externo geral da atividade estatal previsto na Constituição Federal, os Tribunais de Contas acumulam, dentre outras funções, essa da fiscalização societária. Não são, pois, órgãos tão especializados nessa função específica de fiscalização societária, principalmente quando comparamos os requisitos de ingresso necessários para um Especialista Financeiro de um Comitê de Auditoria com os requisitos formais de indicação de um Ministro de Tribunal de Contas. A fiscalização societária de empresas controladas pelo Estado por via dos Tribunais de Contas, conforme previsto no artigo 71, II da Constituição Federal, está sob o amplo conceito de "julgamento das contas dos administradores e demais responsáveis por dinheiros, bens e valores públicos da Administração direta e indireta...”, bem como, conforme previsto no artigo 71, III da Constituição Federal, na apreciação da "legalidade dos atos de admissão de pessoal, a qualquer título, na Administração direta e indireta"48 e, por fim, com base no artigo 71, $\mathrm{V}$, "fiscalizar as contas nacionais das empresas supranacionais de cujo capital social a União participe, de forma direta ou indireta, nos termos do tratado constitutivo", o que pode, muita vez, não ser suficiente para abarcar todas as hipóteses, fatos e relações jurídicas de natureza societária que clamam por fiscalização. ${ }^{49}$

\footnotetext{
${ }^{48} \mathrm{O}$ inciso III do artigo 71 da Constituição Federal é de redação complexa e por vezes até confusa. José Affonso da SILva (Comentário Contextual à Constituição, Op. cit., p. 466) não poupou-lhe críticas bastante severas, chegando a afirmar que "é um texto feio, mal-feito e mal-redigido", onde, para o jurista da Universidade de São Paulo, "faz-se um confuso jogo de inclusão e exclusão". J. A. da SILVA usa o mesmo texto de reprovação na nota de rodapé 6, da p. 731 de sua obra Curso de Direito Constitucional Positivo, Idem.

${ }^{49}$ Vide também Roberto Rosas (“Tendências Atuais...”, Op. loc. cit., Idem, p. 145).

Destaque-se também o trabalho de Mário Engler PinTo Junior ("O Novo Mercado da Bovespa e o compromisso da Sociedade de Economia Mista com práticas de boa governança corporativa”, RDM 128/54-
} 
Sob um ponto de vista evolutivo, o Tribunal de Contas, como mecanismo geral de fiscalização de contas do Estado, nasce com a República, na Constituição de 1891, tendo, ao longo da história constitucional brasileira, perdido bastante espaço nos documentos de 1967 e 1969, atingindo, todavia, o seu auge, em termos de atribuições, na Constituição de $1988 .^{50}$

Embora a fiscalização da atividade executiva da gestão de Estado esteja na prioridade geral dos Tribunais de Contas, como mecanismo de apoio ao controle externo das atividades da administração direta e indireta, decorrendo do conceito de separação de poderes herdado dos princípios da revolução francesa, como advertiu José Affonso da SILVA $^{51}$, é importante admitir que a preocupação em fiscalizar as atividades desenvolvidas pelos mandatários de Estado é bastante antiga. ${ }^{52}$

65 [out.-dez./2002]) defendendo algumas mudanças de postura e adaptação do regime de sociedades de economia mista a um estatuto jurídico que prime que pela maior transparência dos atos de gestão, conseqüentes de uma ampliação dos mecanismos de fiscalização não apenas previstos no direito privado, mas também previstos em regras especiais de listagem da Bolsa de Valores de São Paulo.

Um caso prático bastante interessante e que marca afirmativamente a participação dos Tribunais de Contas em processos de supervisão de contratos, é o processo que correu no Tribunal de Contas da União sob o n ${ }^{\circ}$ TC-010.659/94-3, relatado pelo Ministro Homero Santos, e cuja decisão em plenário (Decisão ${ }^{\circ}$ 345/95-TCU) de 19 de julho de 1995, foi publicada no Diário Oficial da União de 7 de agosto de 1995, Seção 1, nr. 150, p.11832-11835. Nesse processo, que envolvia contratos de gestão entre coligadas da Companhia Vale do Rio Doce, decidiu-se, dentre outros temas da pauta: "corroborar o entendimento e a orientação normativa desta Corte (cf. Decisão $n^{0}$ 020/94 - Plenário, Ata $\mathrm{n}^{\circ}$ 03/94), no sentido de que as Empresas Públicas e as Sociedades de Economia Mista, mesmo aquelas que visem a objetivos estritamente econômicos, em condição de competitividade com a iniciativa privada, ainda que sob o regime de Contrato de Gestão, estão sujeitas a todas as exigências constitucionais e legais, da mesma forma que as demais entidades integrantes da Administração Pública Federal" (pp. 11834-11835).

${ }^{50}$ Sobre a notícia histórica dos Tribunais de Contas, vide J. A. da Silva. Curso de Direito Constitucional Positivo, Idem, p. 729.

${ }_{52}^{51}$ J. A. da Silva. Curso de Direito Constitucional Positivo, Op. cit., p.725.

${ }^{52}$ Como exemplo disso, há passagens marcantes n'A Constituição de Atenas, de ARISTóteles (XXV, 2), em que o estagirita conta que, quando da reforma de Estado promovida por Efialtes, após as Guerras Médicas, reduziu-se o poder dos Areopagitas por força de supostos problemas de tirania (a palavra usada é

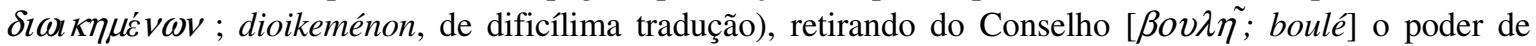
"fiscalizar conforme a constituição" [ $\pi 0 \lambda \imath \tau \varepsilon i \alpha \varsigma \phi v \lambda \alpha \kappa \hat{\text {; }}$; politeías phylaké] (para onde o termo phylaké pode representar uma infinidade de sentidos como "ação de montar guarda", "vigiar", "fazer sentinela", "arrestar, prender, manter em cárcere", "supervisionar", "proteger", "defender" e, por fim, "fiscalizar" [vide Antoine BAILly. Dictionnaire Grec-Français, $39^{\mathrm{e}}$ Ed.. Paris: Hachette, 1985, p. 2103]). No início da obra, na parte histórica da Constituição de Atenas, ARISTÓTELES lembra que o Conselho dos Areópagos, em época muito remota da história ateniense, tinha o fim de fiscalizar o cumprimento das leis (III, 6 e IV, 4), finalidade essa que se subverteu e levou Efialtes, tempos depois, à mencionada reforma (Obs.: em III, 6 menciona que essa

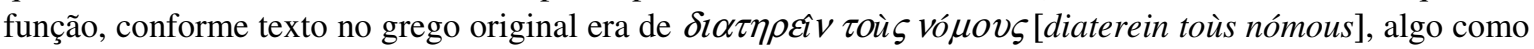
"supervisionar as leis" ou "observar atentamente [o cumprimento] das leis", para o qual o verbo $\delta i \alpha \tau \eta \rho-\varepsilon \omega$, diatereu significa "olhar atentamente", "observar de perto", "vigiar", "supervisionar", cf. BAILLY, Ibidem, pp. 493). Após intervenção de Sólon sobre as reformas de Drácon, a função de "físcal da lei" foi mantida no Conselho dos Areópagos (VIII, 4), para o qual ARISTóteles usa o termo

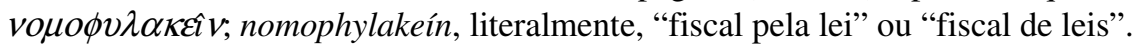


A par das lições da antiguidade e dos princípios modernos de separação dos poderes no Estado, o fato é que a empresa controlada pelo Estado, no Brasil, seja pelo influxo histórico que marca o exercício do poder de controle no Brasil, seja por conta de uma vacilação legal ${ }^{53}$, acaba por deixar o trabalho da fiscalização dessas companhias sem muita guarida doutrinária específica ou legislação precisa. A oscilação e o conflito lógico de regimes previstos na Constituição Federal, na legislação infraconstitucional que cuida do interesse público (como, por exemplo, a Lei $n^{0} 8.666 / 93$ e o Decreto-lei $n^{0}$ 200/67) diante do que dispõe a Lei das S.A., amplia o universo de incertezas e o lastro de conflito e disparidade de opiniões a respeito do melhor regime de gestão empresarial para essas companhias controladas pelo Estado.

No caso das empresas que compõem a administração indireta por conta de um poder de controle previsto, por exemplo, nos termos do artigo 238 da Lei das S.A., seria imperioso que a revisão do modelo levasse em consideração não apenas a conformação e as atribuições específicas do conselho fiscal, do conselho de administração, da auditoria independente e de órgãos como o comitê de auditoria, mas que também e sobretudo, definisse precisamente critérios muito mais rígidos de independência de seus membros. 54

\footnotetext{
53 A Emenda Constitucional $\mathrm{n}^{\mathrm{o}}$ 19, de 04 de junho de 1998, trouxe a exigência de regulação, via lei complementar, do estatuto jurídico das empresas e entidades controladas pelo Estado e que explorem atividade econômica. Ainda que esse vácuo legislativo, que já dura quase dez (10) anos, não se aplique às empresas públicas, sociedades de economia mista e outras entidades da administração pública indireta que explorem serviços públicos (vide J. A. da Silva, Curso de Direito Constitucional Positivo, Op. cit., p. 781), temos ainda uma falta de regras que conflita, nas variadas interpretações analógicas, com todo o regime disposto na Lei das S.A., inclusive na parte que toca às sociedades de economia mista. A fiscalização gera, no mais das vezes, os mais intrincados problemas, como estamos vendo, por força da multiplicidade de mecanismos, todos em sua grande maioria, reféns de princípios e valores que orientam políticas públicas e partidárias, em detrimento da gestão empresarial em obediência ao disposto no art. 238 da Lei das S.A., sobretudo no que tange à orientação das atividades da companhia "de modo a atender ao interesse público que justificou a criação da companhia”.

${ }_{54}$ Há, entretanto, quem advogue contra a necessidade de constituição orgânica nas sociedades de economia mista por problemas de "custo". Marcelo Andrade FERES ("O Estado Empresário: reflexões sobre a eficiência do regime jurídico das sociedades de economia mista na atualidade”, In RDE 6/269-290 [abr.-jun. 2007]), chega a afirmar: "Na companhia em exame, haverá, pois, Assembléia Geral, Diretoria, Conselho de Administração e Conselho Fiscal, todos em pleno funcionamento, além de outros órgãos que o correlato estatuto preveja. Todavia, a impossibilidade de se afastar tal estrutura mínima onera excessivamente a Administração. Pois bem, na prática, essa pluralidade de órgãos reclama gastos às vezes desnecessários com as remunerações de seus agentes. Pequenas companhias fechadas de economia mista não necessitariam, em regra, da complexa estrutura orgânica delineada pela legislação. Por óbvio, a Administração não está adstrita à criação de sociedades de economia mista, pode valer-se de esquemas como o das empresas públicas. Pretendendo, contudo, convocar o concurso do capital privado, deverá, inevitavelmente, empregar a figura da sociedade de economia mista, o que recomenda, pois, a flexibilização dessa matéria. Assinale-se, ainda, que, buscando conciliar os interesses públicos e privados no seio da sociedade, a lei assegura a participação dos minoritários no Conselho de Administração e no Conselho Fiscal, não o fazendo, entretanto, quanto à
} 
Não há quase discussão sobre o tema, mas ao definir o âmbito de atuação dos Tribunais de Contas, legando com precisão as atribuições exclusivamente societárias dessas entidades, seria importante que o legislador buscasse limitar o exercício do poder de controle empenhado pelo Estado, quando interesses de ordem político-partidários entrassem em jogo. Assim, além dos critérios de condução para um munus público e dos critérios previstos pela Lei das S.A., seria importantíssimo, para a eficácia da gestão corporativa desses entes econômicos, que se levasse em consideração, para a nomeação, por exemplo, de conselheiros fiscais que exerçam fiscalização societária específica, que os indicados: (i) não tenham tido qualquer tipo de filiação partidária; (ii) não tenham exercido munus público por um período mínimo de oito (8) anos que anteceda a indicação, seja esse exercício por nomeação, seja por eleição, seja por concurso público ${ }^{55}$; (iii) não tenham qualquer relação de parentesco até quinto grau (pelo menos) com pessoas que se encontrem nas condições anteriores; (iv) ostentem uma experiência mínima de quinze (15) anos em cargos semelhantes em empresas da iniciativa pública ${ }^{56}$ ou privada, com devido registro na Ordem dos Advogados do Brasil, no Conselho Regional de Administração ou no Conselho Regional de Contabilidade de algum Estado da federação e conseqüente titulação em administração de empresas, direito ou contabilidade; (v) tenham participado em cargo de administração para a empresa em que estão sendo nomeados ou tenham participado de equipe de auditor independente que tenha auditado as contas ou prestado serviços, nos últimos oito (8) anos, para a empresa à qual estão sendo indicados; (vi) não sejam detentores de valores mobiliários referenciados em capital social de qualquer companhia aberta ou na empresa para a qual estão sendo indicados.

Diretoria". Esse argumento, vale lembrar, é muito semelhante à reação que se gerou após a edição da Lei Sarbanes-Oxley nos EUA, quando do ambiente de "dia seguinte" gerado pelos colapsos Enron, WorldCom e Global Crossing: a oneração das estruturas produtivas em favor da transparência não justificaria, pelo benefício a ser eventualmente trazido, tamanha carga de responsabilidades e custos. Como se verá, essa justificativa vem desaparecendo nos EUA. No caso aqui trazido das Sociedades de Economia Mista no Brasil, a justificativa do custo e da oneração, embora semelhante, é de natureza diversa: no Brasil critica-se a estrutura imposta pelo modelo da Lei das S.A. não por força do raciocínio do custo-benefício, mas por causa do mau uso das instituições, que geram, como advertido, "gastos às vezes desnecessários com as remunerações de seus agentes”. Nesse caso, com a devida licença, o problema, com freqüência, não reside na estrutura jurídica imposta pela lei, mas na postura do agente indicado pela Administração, pois, mesmo as pequenas companhias fechadas de economia mista não estão livres de cometer grandes equívocos com efeitos deletérios, muita vez mais amplos que o seu próprio tamanho.

55 Qual seja, não tenha tido qualquer vínculo de emprego ou assumido qualquer cargo na administração pública direta ou indireta, que comprometa a isenção da sua função fiscalizatória frente ao poder de controle exercido pelas pessoas investidas na gestão das coisas do estado.

${ }^{56}$ Exceção, aqui, ao previsto no item "(ii)" dessa mesma oração. 
Nos últimos anos, empresas como a Petrobrás, que passou a oferecer seus valores mobiliários em mercados estrangeiros, como a Bolsa de Valores de Nova Iorque, têm sofrido exigências extra-legais para o aperfeiçoamento de mecanismos de fiscalização, e que se impõem mais por força dos investidores estrangeiros do que por uma determinação legal. Mas muitas outras empresas de grande porte, como a Metropolitano de São Paulo S.A. - METRÔ e o Banco do Brasil S.A., apesar de alguma assunção espontânea por um nível mais sofisticado de governança corporativa, não têm logrado ampliar a esteira de sua experiência para outras companhias que a tomem por exemplo e assumam as mesmas condições de transparência. 


\section{PARTE I -}

BREVES NOTAS HISTÓRICAS

E DE DIREITO COMPARADO 


\section{CAPÍTULO 2: O ESTADO MODERNO}

\section{E OS MODELOS DE FISCALIZAÇÃO SOCIETÁRIA}

Embora a tarefa de investigação histórica tenha entrado em desprestígio, em favor de outros modelos de análise legal, tais como a interpretação teleológica e a interpretação sistemática, , a pesquisa para este trabalho conseguiu revelar-nos sensíveis dados sobre o papel da fiscalização societária no direito brasileiro em uma perspectiva histórica.

Muita vez tida como um método conservador de interpretação, o descrédito da pesquisa histórica vem relegando as pesquisas das fontes a leituras de segunda mão, em que a perda do traçado evolutivo do fenômeno fiscalizatório (neste caso) tem permitido discutir-se por sobre idéias preconcebidas.

Ao contrário do que recentemente vem se entendendo, a pesquisa histórica é capaz de apresentar um contexto cultural em perspectiva, que outros modos de interpretação, por sua lógica cerrada, acabam por fazer tabula rasa. ${ }^{57}$ Esse contexto cultural revelado por documentos históricos é importante para nortear as interpretações e revelar o caráter dos destinatários da norma, a fim de se pressupor qual formato ou modelo normativo é mais afeto a uma cultura como a brasileira, avessa não apenas à fiscalização, mas também e, sobretudo, à responsabilidade e ao exercício de poderes de forma independente e longe de conflitos de interesse.

\footnotetext{
${ }^{57}$ A análise da conveniência do transplante de normas tem demandado cada vez mais uma compreensão cultural do direito. Essa força interpretativa vem crescendo nos estudos de direito comercial e, sobretudo, nos estudos de direito societário. Estas são áreas do direito que sofrem diretamente com transplantes equivocados de legislação estrangeira. Bom exemplo disso está nos capítulos 4 e 5 dessa dissertação, em que pudemos analisar algumas fraturas sistêmicas no transplante, para o direito societário brasileiro, de normas e princípios lançados ou reforçados no contexto da Lei Sarbanes-Oxley dos EUA. Em texto brilhante, Érica Cristina Rocha GoRga (Does Culture Matter for Corporate Governance? A Case Study of Brazil, John M. Olin Program in Law and Economics, Working Paper nr. 257 - Palo Alto, CA: Stanford Law School, Maio 2003) analisa os problemas de inserções precipitadas, no direito brasileiro, dentro do contexto da reforma do direito societário de 2001, por meio da Lei 10.303 (pp. 55-79). No mesmo sentido, vide a brilhante dissertação de Cristiane Bernardes Antunes QUITERIO (Concentrated corporate control, legal protections to minority shareholders and development of the capital markets: the Brazilian experience. [dissertação de Mestrado apresentada junto à Faculdade de Direito da Universidade de Virginia, EUA, sob a orientação de George Triantis]. Charlottesville, VA: University of Virginia School of Law, 2002, passim).
} 
A utilidade, e porque não admitir, a necessidade de uma visão histórica e contextual de como surgiu o fenômeno da fiscalização, como pudemos ver na introdução desta dissertação, abre a possibilidade de melhor se compreenderem os limites de aplicação da norma atualmente posta.

Sobre o fenômeno em si da fiscalização, já notamos páginas atrás que não se trata de algo recente. O direito grego e o direito romano clássico ${ }^{58}$ reconhecem formas de fiscalização e vigilância. Entretanto, não é nossa intenção fazer a busca da fiscalização desde o Gênese ${ }^{59}$, pois, invariavelmente, essas formas de fiscalização mais vetustas não recebem a mesma associação do conceito de fiscalização societária que atualmente incumbe a conselheiros fiscais. Embora tenhamos nesses modelos uma gestão de bens comuns nomeada a terceiros, por delegação e, paralelamente, uma superintendência e uma vigilância a outros, não há aproximação possível entre esses modelos jurídicos, não apenas pela distância das fontes e pela brutal distinção de contexto, mas, sobretudo por conta da total diferença entre as relações existentes, na época, entre esses mandatários da gestão pública, seu mandante Pontifex Maximus, e os delegados incumbidos da vigilância e das atuais relações existentes entre acionistas (controladores e não controladores), administradores e fiscais. O risco de uma análise anacrônica, é, portanto, alto, e por essa razão, costuma-se aproximar e voltar os estudos não para a gênese da fiscalização em si, mas para a gênese da companhia e da sociedade por ações. Nisso surge a convenção de estudo do fenômeno da fiscalização societária a partir da idade moderna, buscando formas de fiscalização societária nos

\footnotetext{
${ }^{58}$ Nesse sentido, vide Vicenzo ARANGio-RuIZ (Storia del Diritto Romano, $7^{\mathrm{a}}$ ed.. Napoli: Jovene, 2006, pp. 228-232), a respeito da organização da República e dos vários cargos de representação do poder quiritário com função eminentemente de verificação da observância e cumprimento das leis da parte dos membros da comunidade. Desses vários cargos, cada um com funções distintas e de difícil delineamento, temos os prafecti, os pratori urbi, os prafecti pratorio, os pratori annona, os pratori vigilium e os procuratores Augusti. Todos esses cargos, com funções públicas que se misturavam a funções privadas de interesse do espólio material constituído pelo Senatus Populusque Romanum, embora guardassem um caráter de intermediação e supervisão de cumprimento da ordem pública por terceiros, deram origem a uma infinidade de outras funções públicas como os coletores de impostos, as milícias locais, os magistrados, mas não resta dúvida que é dessas funções que se identifica, desde a gênese da história, essa natureza fiscalizatória lato sensu. Nas companhias modernas, entretanto, a fiscalização que hoje cabe ao papel do conselheiro fiscal segue pelo caminho tortuoso dos modelos evolutivos concernentes aos meios de prestação de contas e formas de contabilização e consulta dos registros por acionistas e seus genuínos mandatários. Embora o modelo atual do conselho fiscal tenha recuado para essas formas de representação orgânica, em algum momento da história tivemos uma compreensão desse fenômeno fiscalizatório por via da prestação de contas e do mandato, como logo se verá.

${ }^{59}$ Não exatamente no Gênese, mas em $N r ., 3: 8$ pode se encontrar uma forma bastante primitiva de "fiscalização" num sentido de gestão e curatela de bens comuns, de que foram incumbidos os levíticos.
} 
empreendimentos renascentistas das primeiras companhias público-privadas que tinham como escopo a exploração colonial.

Entretanto, este também pode não ser um adequado marco histórico, pois embora tenhamos nessas formas societárias primitivas os verdadeiros embriões da moderna sociedade por ações, é fato que a forma de governo dessas sociedades de exploração dos séculos XVI e XVII estava mais próxima da realidade desse período vetusto dos clássicos formatos jurídicos romanos, do que propriamente da realidade de fiscalização atual. ${ }^{60}$

Sem risco, com isso, de equívoco, é seguro afirmar que modelos societários como a da Vereenigde Oost-Indische Compagnie [Companhia Holandesa das Índias Orientais], da West-Indische Compagnie [Companhia das Índias Ocidentais], da Companhia Geral de Comércio do Brasil ${ }^{61}$, da Company of Merchants of London Trading to the East Indies [Companhia Inglesa das Índias Orientais], da Virginia Company [Companhia da Virgínia, certamente uma das mais notáveis empresas de exploração colonial], da Compagnie des Indes, outrora Compagnie Française des Indes Orientales [Companhia Francesa das Índias Orientais], todas com suas constituições ocorridas entre 1600 e 1664, embora tenham seus órgãos internos de prestação de contas, não oferecem experiências satisfatórias para se traçar um histórico preciso do fenômeno fiscalizatório nas sociedades comerciais modernas.

Na busca microscópica de um fiscal (ou algo que se lhe assemelhe) dentro desses modelos societários, muitas anotações históricas acabam perdendo o foco

\footnotetext{
${ }^{60}$ A contrario sensu, importantes notas são dadas pelo tratadista James KENT, que traça um raciocínio evolutivo da companhia moderna não pelo seu influxo histórico a partir das companhias de exploração colonial, mas pela herança advinda do conceito de municipalidade, que para KENT é o verdadeiro embrião da sociedade por ações (Commentaries on American Law, Volume II. New York: O. Halstead, 1827, pp. 216-220) onde há notas claras sobre a relação entre companhia moderna e municipalidade antiga, com argumentação bastante sedutora e largamente admitida entre experts em história do direito (vide Morton J. HoRwITZ. The Transformation of American Law..., Op. cit., Idem, pp. 109-114; Lawrence Meir FrIEDMAN. A History of American Law, Op. cit., Idem, pp. 526-531). Nesse pormenor, relembre-se o estudo notável de A. LAMY Filho e J. L. de Bulhões PedreIRA (A Lei das S.A., Op. Cit., Idem, p. 2842), que por sua vez creditam à Igreja (corpus mysticum) toda origem da idéia de corporation (Ibidem, p.30).

${ }^{61}$ A Companhia Geral de Comércio do Brasil tinha um objeto social bastante amplo, que incluía, entre outras atividades, a de defesa da costa, com escopo essencialmente militar. Embora de capital subscrito integralmente privado, o regime de outorga para concessão e permissões de atividades mercantis suscitava forte intervenção monárquica que sugeria que a Coroa pudesse estar assumindo papel de verdadeiro titular de um poder de controle. Da mesma forma, vide Rui Manoel de Figueiredo MARCOS. As Companhias Pombalinas - contributo para a história das sociedades por acções em Portugal. Coimbra: Almedina, 1997, pp. 159-174.
} 
de uma visão mais ampla e que possa captar as formas mais primitivas de relacionamento entre acionistas e investidores, suas respectivas administrações e funcionários, para concluir ao certo se de algum órgão ou função pode-se extrair um preciso exercício fiscalizatório.

Há, entre muitos, a convenção de que o fenômeno fiscalizatório surge junto dos modelos societários das companhias de exploração colonial, cujas mais notáveis são essas acima citadas. Contudo, uma leitura mais atenta e próxima de recentes teses de historiadores do direito, bem como uma análise direta das fontes revela que entre esses modelos reinavam diferenças enormes relativamente às formas de investimento, os direitos cabíveis a esses investidores, as formas de administração, a relação com o Estado e com os monarcas, a relação com instituições com poderes de intervenção como a Igreja e, consequentemente, as formas de fiscalização, supervisão e prestação de contas e vigilância e superintendência na gestão do capital comum.

As análises históricas mais comuns e que vêm sendo reproduzidas de tempos em tempos, partem de leituras de segunda ordem sobre os modelos de gestão das companhias holandesas, mais precisamente a Vereenigde Oost-Indische Compagnie [Companhia Holandesa das Índias Orientais] $]^{62}$ e a WIC ou West-Indische Compagnie [Companhia das Índias Ocidentais ${ }^{63}$.

\footnotetext{
${ }^{62}$ Podemos lembrar aqui a passagem de Waldemar Martins FerReIRA (Tratado de Direito Comercial, $4^{\circ}$ vol. - "O estatuto da sociedade por ações". São Paulo: Saraiva, 1961, p. 509), que sobre a leitura de Jacques Verley e Roger GRANGER (La nature juridique des rapports..., Op. cit., Idem), chega a afirmar, em referência à criação da Companhia das Índias Orientais, em 1602: "Surgiu então a forma jurídica da sociedade por ações; e logo apareceu a necessidade de fiscalização". Entretanto, rogamos vênia para discordar. Como se verá e como poderemos extrair das comparações entre os diversos modelos das inúmeras companhias com escopo de exploração colonial e ultramarina, o problema da fiscalização é muito mais complexo e não chega a se dar "logo", se é que em algum momento ele vem a existir efetivamente (tanto a necessidade de fiscalização quanto a própria fiscalização em si). Embora Roger GRANGER realmente afirme que "La forme juridique de la société par actions apparissait. Aussitôt apparut la nécessité d'un contrôle" (p. 30), logo adiante admite o total fracasso do modelo societário e a ausência de qualquer indício que assegure ter havido, na história, o cumprimento das propostas reformistas de 1622 implantadas na Companhia Holandesa das Índias Orientais (Idem, pp.31-32). Ao tratar do modelo francês e do sistema da Companhia Francesa das Índias, evoluindo até o modelo das companhias do antigo regime de datação pré-revolucionária, GRANGER chega a intitular o capítulo de sua dissertação como "l'absence de contrôle dans les sociétés par actions a la fin de l'ancien regime" (pp. 34-35), concluindo que "dans la plupart des cas, aucun contrôle sérieux n'existait" (p. 35). Rui M. F. MARCOS salienta, por seu turno, a respeito da reforma de 1622: "Aspecto de muito estrondo foi o da abertura da contabilidade social a um exame isento. Na sequência de reclamações antigas, não só se admitiu o princípio da verificação anual das contas, como se estampou a obrigação dos directores as apresentarem no semestre imediato à cessação do privilégio. Ainda assim, porém, os responsáveis procuraram sempre escapar a esta exposição incómoda através de muitos expedientes. Ora escondendo os registros das Índias ou dando-os por perdidos, ora servindo-se de reconstituições de livros transviados mais ou menos forjadas, valia tudo para impedir a exactidão de uma perigosa conferência numérica. A
} 
Entretanto, a revisão do modelo jurídico das companhias de exploração colonial leva a dados e informações diversas.

Em primeiro plano e numa visão mais genérica, é necessário se compreender, para fins de identificação do fenômeno fiscalizatório em companhias de exploração colonial, não apenas os aspectos existentes nas relações entre monarca, empreendedores e gestores, em suas respectivas funções de controlador, acionista (controlador ou não controlador) e administrador, advindos todos da prudência jurídica da época, mas também e, sobretudo como se dava o desempenho desses papéis, por essas personagens, dentro de uma linha evolutiva que articule essa experiência jurídica com as ciências contábeis e a ciência da administração. Em outras palavras, o problema da fiscalização nessas companhias, que parece inexistir nesse primeiro momento ou, ao menos, ser bem menor do que regularmente se supõe, decorre propriamente das

significar que o avanço normativo em prol dos sócios não obteve a tradução real que faria supor" (Op. cit., Idem, pp. 76-77).

${ }^{63}$ É de Trajano de Miranda Valverde (Sociedades por Ações, Vol. II, $2^{\mathrm{a}}$ ed.. Rio de Janeiro: Forense, 1953, p. 334) a autoria e citação de uma das passagens mais mencionadas em termos de história da fiscalização societária, baseada em leitura de segunda ordem feita sobre a análise que Lehmann imprime a alguns aspectos da WIC. Essa passagem de VALVERDE é sempre reproduzida em textos sobre o conselho fiscal, quando alguma tonalidade histórica carece ser impressa no texto (nesse sentido, vide José Anchieta da Silva. Conselho Fiscal nas Sociedades Anônimas Brasileiras: o conselho fiscal à luz da lei de sociedades anônimas em vigor. Belo Horizonte: Del Rey, 2000, pp. 30-31). VALVERDE, tal qual Waldemar FERREIRA, chega a afirmar: "A necessidade de um órgão controlador da atividade do órgão de direção aparece, pois, no período em que as companhias ainda nasciam por livre ato do Estado e viviam sob sua fiscalização. Entretanto, quando elas passaram para o regime da concessão ou autorização, inaugurado pelo Código Comercial francês de 1807 (n. 9), a legislação silencia sôbre esse órgão, que a prática continuava a introduzir na constituição das companhias” (Idem, pp. 334-335). Nesse ponto, percebe-se como VALVERDE associa, numa mesma linha evolutiva, companhias que são fundadas por iniciativa pública mediante capital público-privado e de caráter totalmente aristocrático, como é o caso da WIC e da Virginia Company, por exemplo, com outro modelo de iniciativa privada e autorização pública, de caráter totalmente burguês, como seria o caso, por exemplo, da Compagnie Le Creusot, exploradora do ramo da siderurgia nos séculos XVIII e XIX e gerida sob o modelo jurídico napoleônico de 1807 (vide R. GRANGER, Op. cit., Idem, p. 34). A diferença entre esses dois modelos não reside na forma como o direito aceitou ou eventualmente suprimiu a fiscalização societária, mas propriamente em como os influxos de organização econômica vieram a impor estruturas mais propícias a um modelo de gestão burguês, em oposição a um decadente modelo aristocrático. Desta forma, nos parece melhor entender que o direito societário apenas se adaptou a uma realidade pré-existente, de onde a iniciativa privada tipicamente burguesa passa a ser a solução para o fracasso do modelo colbertista aristocrático de iniciativa pública. Tanto num quanto noutro modelo, não há que se falar, propriamente, em fiscalização societária, que decorre, como se verá, de outros influxos e da sedimentação tipicamente burguesa das novas relações entre acionistas, que são marcadas pelo controle, pelo investimento especulativo e pelo investimento de longo prazo . Necessário, pois, rever a equivocada idéia de que "a fiscalização não tem origem, pois no relacionamento entre os titulares das participações acionárias; brotou no seio das companhias no momento em que elas eram criadas sob o regime da autorização e dos privilégios concedidos pelo Estado absoluto" (J. A. SILVA, Op. cit., Idem, p. 31). Não há como se admitir que a fiscalização "brota" naturalmente nas companhias, sem um conflito potencial que sustente e promova a implementação de um poder jurídico, como o fiscalizatório. A relação entre acionistas e entre estes e a administração, ultima ratio, é que permite compreender o total desaparecimento da figura da fiscalização durante toda a primeira metade do século XIX, em resposta à mudança do perfil do empreendedor, cujo espaço deixado pelo fracasso do Estado é lentamente ocupado pela burguesia. 
dificuldades que essas companhias enfrentaram para poder apreender a realidade econômica em dados concretos. Embora a técnica das partidas dobradas idealizadas pelo Frei Luca Paciolo já fosse de conhecimento de alguns, nota-se que a falta de uniformidade na aplicação dessas técnicas dificultava sobremaneira os trabalhos de administração social de então. ${ }^{64}$

Em segundo lugar, é necessário ter em mente que essas relações entre os partícipes de uma companhia de exploração colonial eram motivadas por valores e princípios completamente diversos. Essas companhias especiais eram normalmente fundadas por capital privado e tinham, quase sempre, a forte presença do Estado (ou do monarca) no controle das atividades. Em alguns casos, como as companhias italianas, portuguesas e espanholas, a presença de um controle por parte da Igreja era um traço marcante na diferenciação entre as companhias inglesas, francesas e holandesas. Na conformação dessas companhias, os administradores eram nomeados e raramente se confundiam com o próprio investidor, situação freqüente no empreendedorismo burguês, quando o fundador assumia o papel da administração e do controle ao mesmo tempo. Nessas companhias do período da expansão ultramarina, construía-se uma teia de cargos, funções e tarefas, todas separadas, onde a gestão não se confundia necessariamente com o trabalho mecânico de apreensão e tomada das contas. ${ }^{65}$

\footnotetext{
${ }^{64}$ Vide Ananias Charles LitTleton. Accounting Evolution to $1900,2^{\text {nd }}$ ed.. Nova Iorque: Russell \& Russell, 1966, p. 165, para quem não há, antes do século XIX, um verdadeiro domínio de um sistema contábil unificado e razoavelmente padronizado (nesse mesmo sentido, Hilário FRANCO e Ernesto MARrA. Auditoria Contábil, 4ª ed.. São Paulo: Atlas, 2001, p. 39). John C. CofFEE JR. (Gatekeepers the professions and corporate governance. Oxford: Oxford University Press, 2006, p. 108), com reforço no mesmo LITTLETON, mostra como, no início das companhias, os contadores se limitavam à estreita função de "guarda-livros", sem a responsabilidade do verdadeiro contabilista. No Brasil, o amadorismo nos métodos de contabilidade ainda no início do século XIX é exposto com detalhes na já citada biografia do Barão de Mauá (CAldeIRA, Mauá..., Op. cit., Idem, p. 109-122), o que induz que a fiscalização orgânica e sistemática poderia nem sequer ter razão de ser, num período em que faltava mão de obra para execução da simples tarefa de contabilizar a realidade de uma companhia.

Fontes da época induzem haver, pelo menos no que tange a Portugal, um ofício público de contador que congregava de forma até um tanto confusa, tarefas ligadas à conferência e contabilidade de causas em disputa, custas judiciais, salários de funcionários, honorários de procuradores (Vide Ordenações Manuelinas, Livro I, Título LXX). Outras tarefas também despontam atenção como a dos Vereadores (Ordenações Manuelinas, Livro I, Título XLVI), a quem incumbiam, entre outros afazeres, "tanto que os Vereadores começarem servir seus Ofícios, hão de saber, ver e requerer todos os bens do Conselho, assim [as] propriedades, herdades, casas e foros e se são aproveitados como devem, e os que acharem mal aproveitados, fa-los-ão aproveitar e corrigir"; bem como dos Tesoureiros do Conselho (Ordenações Manuelinas, Livro I, Título LI) a quem incumbia "de receber todas as rendas do Conselho e fazer todas as despesas, que pelos Vereadores forem mandadas fazer".

${ }^{65}$ Vide Rui M. F. MARCOS, Op. cit., Idem, pp. 60-65. No mesmo sentido, Francesco Galgano. Lex Mercatoria. Bolonha: Il Mulino, 2007, pp. 78-81.
} 
Nesse sentido e com base nessa teia de relações, profundamente marcada por questões de ordem política da época, cujos valores deviam levar em conta não apenas princípios seculares, mas também e, sobretudo algumas importantes questões de ordem eclesiástica, a gestão dessas companhias não tinha apenas um escopo econômico e de lucro, mas carregava também um profundo papel colonizador com traços militares e até catequéticos. ${ }^{66}$

A marca, portanto, desse período histórico do direito comercial é explicitada por fenômenos como a falta de uniformidade nas técnicas contábeis, a falta de profissionais especializados na tarefa de contabilização, a existência de controles que não necessariamente decorriam de uma vinculação ao capital investido (a exemplo da Igreja e da influência do monarca), a existência de classes de administradores e de classes de acionistas e a multiplicidade de cargos e funções. Esses dados geram companhias de caráter altamente aristocrático, com fortes doses anti-democráticas e excessivamente autoritárias, muito por influência das crenças de uma política absolutista.

Contudo, em uma análise mais próxima das fontes, começa a haver um certo consenso de que entre os vários modelos de companhias de exploração colonial há inúmeras diferenças de origem cultural, principalmente por conta das distinções entre as formas de acesso à informação societária.

Companhias de exploração colonial inglesas, holandesas, portuguesas e francesas, cada qual por si, possuíam diferentes formas de ingresso de capitais, de recesso, de direitos de acesso às informações, de direitos de voto, de métodos de decisão assemblear, de administração e controle, e até mesmo de contabilização e do tratamento dos acionistas, que GALGANO mui sabiamente identifica como modelos de "democracia

\footnotetext{
${ }^{66}$ Vide R. FAORO (Op. cit., vol. 1, Idem, pp. 81 e 115-127). Interessante quadro é também apresentado por Sérgio Buarque de Holanda (Visão do Paraíso - os motivos edênicos no descobrimento e colonização do Brasil, $6^{\mathrm{a}}$ ed.. São Paulo: Brasiliense, 1994, pp. 323-334), onde intuito militar, consequências e fatores econômicos, elementos jurídicos e imaginário mítico se encontram misturados em fontes contemporâneas da época do descobrimento.

De leitura essencial é também o texto de Rinaldo GADDEO intitulado "Il finanziamento dei primo viaggio e l'opera dei capitalisti italiani di Spagna" traduzido para o português por Thomaz Oscar MARCONDES DE SOUZA como "O Financiamento da Grande Êmpresa de Cristóvão Colombo" e publicado em seu volume de textos coligidos intitulado Novas Achegas à História dos Descobrimentos Marítimos (São Paulo: Heder, 1963, pp. 161-172), que contesta duramente o laivo eclesiástico dessas empresas.
} 
econômica" e "socialização do capital"," As diferenças mais salientes residiam entre o modelo holandês e o modelo inglês.

Enquanto o modelo inglês restringia o acesso às companhias aos mercadores e aristocratas, os modelos holandês e francês não tinham tal restrição. ${ }^{68}$ Por outro lado, essa socialização do capital, como lembra GALGANO, não se fez acompanhar por uma socialização do poder econômico, já que nas companhias holandesas, a coleta de valores não oferecia, em contrapartida, o direito de integrar o consenso. ${ }^{69}$

Além dessas diferenças, cumpre também lembrar que todas essas companhias traziam órgãos internos e alguns até com o nome de "conselho" ou "conselho de vigilância"; entretanto, a facilidade da associação entre os cognatos não pode permitir que uma interpretação histórica precipitada coloque esses "conselhos" na mesma linha evolutiva do atual conselho fiscal. ${ }^{70}$ Vale destacar também que a flacidez

\footnotetext{
${ }^{67}$ F. GALGANO. Lex Mercatoria, Idem, p. 141 e segs.

${ }^{68}$ Ibidem. Com base em texto de Tomaso Contarini, GALGANo ainda traz curiosa descrição da composição acionária da Oost-Indische Compagnie, que permitia o acesso de "persone di ogni qualità", incluindo até estrangeiros e mesmo de países concorrentes como Inglaterra e França (dentre eles, o próprio Rei de França).

${ }^{69}$ Idem. Com base em monografia clássica de Ariberto Mignoli, GALGANO transcreve de Mignoli uma comparação preciosa entre o modelo inglês e o modelo holandês, com ênfase para o problema da fiscalização: "La sua organizzazione interna la differenzia nettamente da quella inglese: potere assoluto degli amministratori, nessuna possibilità di far sentire la loro influenza da parte degli azionisti, divisiancorché l'octroi originario non facesse distinzioni tra loro - in "partecipanti principali» $e$ in «sottopartecipanti», questi ultimi spesso considerati come una specie di creditori. La posizione giuridica dei "partecipanti principali» fu legalmente riconosciuta, con il rinnovo dell'octroi nel 1622, conferendo loro il diritto di nominare $i$ «bewindhebbers» [gli amministratori] e un limitato controllo sulla gestione: ancorché la situazione rimanesse di fatto immutata, per la solidarietà di questi verso gli amministratori di cui erano gli eguali sul piano economico e sociale, e di cui speravano di poter occupare un giorno il posto: ma il «sotto-partecipanti», da cui deriverà l'azionista moderno, restano sistematicamente esclusi di ogni forma di controllo" (p. 142).

Para as companhias inglesas (neste caso, pela leitura a East India Company), GALGANo transcreve Mignoli e Ehrenberg nestes termos: "la sovranità appartiene dunque alla collettività dei partecipanti, posti su un piede di parità, "che ogni anno, per alzata di mano, eleggevano gli amministratori, ai quali veniva concessa una gratificazione solo quando gli affari andavano bene e con il consenso dei soci. Al ritorno delle navi, gli azionisti si riunivano e in pubblico si dava lettura delle lettere delle Indie: le merci erano vendute all'asta, e ogni partecipante poteva consultare in ogni momento i libri della compagnia» (R. EHRENBERG, Das Zeitalter der Fugger, II: Die Weltbörsen und Finanzkrisen ecc., Jena, 1922, pp. 328 s.)" (p. 143-144).

Merece também muito destaque o trabalho de comparação entre as companhias inglesas e holandesas desempenhado por Rui M. F. MARCOS (Op. cit., Idem, pp. 49-108), que chegou, em nota, a fazer a seguinte observação a respeito dos esforços de GALGANO: "Galgano foi o primeiro a quem não escapou a necessidade de uma comparação criteriosa ter de levar em conta as observações assinaladas, sob pena de conduzir a resultados distorcidos" (p. 82).

Vide, ainda, A. LAmY Filho e J. L. Bulhões PedreIRA (A Lei das S/A, Op. Cit., Idem, pp. 30-36).

${ }^{70}$ Não se pode, desta forma, buscar paralelos entre o conselho fiscal e outras formas decorrentes de direitos antigos, tais quais os oriundos de textos das Ordenações Manuelinas ou o Conselho Ultramarino. Igualmente, lembre-se que apesar do primeiro e terceiro Charter da Virginia Company mencionarem sobre um "Counsell of the Colony", a associação com formas modernas de fiscalização, ainda que se fale
} 
e a imprecisão do escopo fiscalizatório reinante nesse período das descobertas e navegações até o período pré-Revolução Industrial ${ }^{71}$ é outro fator que pode, aliado aos problemas até então relatados, macular a pesquisa histórica com a marca indelével do anacronismo.

Portanto, e muito apesar das tradições, nos parece mais seguro e distante de uma visão anacrônica, procurar entender o fenômeno da fiscalização societária sob o prisma das funções do conselho fiscal, a partir de um universo de valores, de ética e de princípios jurídicos que envolvam o período posterior à Revolução Industrial. ${ }^{72}$

da fiscalização via conselho de administração, é totalmente anacrônica, por força de total distância funcional entre esses conselhos antigos e as formas modernas e orgânicas de fiscalização societária. Vide Wesley Frank CRAVEN (The Virginia Company of London, 1606-1642. Williamsburg, VA: Virginia 350th Anniversary Celebration Corporation, 1957; e The Dissolution of the Virginia Company: the failure of a colonial experiment. Gloucester, MA: P. Smith, 1964).

${ }^{71}$ Exemplo concreto do acúmulo de funções na experiência pombalina se deu com a criação da chamada Companhia Geral da Agricultura das Vinhas do Alto Douro, cujo relato histórico de Fernando de SouZA [A Real Companhia Velha - Companhia Geral da Agricultura das Vinhas do Alto Douro (1756-2006). Porto: CEPESE, 2006], alinhado com o que já expusemos a respeito da escassez de mão de obra, comprova claramente que a função de "guarda-livros" e de "fiscal" (na imagem e semelhança do atual conselho fiscal) é exercida pelo mesmo encarregado: "Importantes funções eram desempenhadas pelo guarda-livros, uma vez que os livros deviam ser escriturados por partidas dobradas, técnica contabilística ainda pouco utilizada em nosso País, razão pela qual o primeiro guarda-livros da Companhia foi João Frederico de Hecquenberg, como se vê, de origem estrangeira. Em Julho de 1761, este contabilista deslocou-se mesmo a Lisboa, a fim de na Companhia Geral do Grão-Pará e Maranhão ser instruído no método de lançar as contas da Junta anterior e assim poder fornecer aos accionistas a demonstração do estado da Companhia, livro então criado para tal efeito, e que ficava na contadoria à disposição dos mesmos" (p. 78). Outros funcionários, entretanto, estavam incumbidos de exercer fiscalizações mais agressivas, como era o caso dos chamados juízes fiscais: "Já tivemos oportunidade de referir que, tanto o juiz conservador como o juiz fiscal procediam a devassas sempre que estavam em causa as leis da Companhia, no sentido de apurarem os transgressores das mesmas, no que dizia respeito a certas ilegalidades e crimes, como o excesso de preços, a adulteração de vinhos e aguardentes, o não cumprimento dos prazos estabelecidos, vendas e misturas de vinhos, introdução de vinhos na região demarcada, enfim, tudo o que dizia respeito à produção e comercialização de vinhos, aguardentes e vinagres. Desde cedo esses poderes foram exercidos, levantando-se uma devassa, logo em 1758, para apurar as razões de não terem saído sete navios, no tempo estabelecido, para o Brasil. O juiz conservador levantava sempre uma devassa anual o mês de Fevereiro, sem limitação de tempo e testemunhas, contra os transgressores da das leis em benefício da Companhia" (F. de SouZA, Op. cit., Idem, p. 145). Maiores detalhes sobre o papel e função deste tipo de magistrado-fiscal, vide Rui M. F. MARCOS, Op. cit., Idem, pp. 777-798.

$72 \mathrm{O}$ salto para um período pós-revolução industrial segrega, também, as formas societárias do período pós-iluminismo.

$\mathrm{Na}$ Inglaterra, o problema enfrentando pelas formas societárias do período iluminista, embora cuide de graves faltas decorrentes de falhas na fiscalização societária, teve como base o modelo anterior, em um universo de total limitação de responsabilidade e livre transferência das ações em praça (vide F. GALGANO. Lex Mercatoria, Idem, p. 144). Essas duas características geraram a primeira explosão de uma bolha especulativa conhecida por South Sea Bubble, em decorrência das desastrosas negociações havidas entre acionistas da South Sea Company, uma companhia constituída em 1711 em Londres, com objetivo de explorar o comércio com colônias espanholas da América do Sul e que encontrou sua derrocada especulativa em 1720 (sobre o caso da South Sea Company, vide Stuart BANNER. Anglo-American Securities Regulation: Cultural and Political Roots, 1690-1860. Cambridge, UK: Cambridge University Press, 2003, pp. 41-88; e J. C. COFFEE JR., Gatekeepers..., Op. cit., Idem, p. 110). 
O grande traço de inegável mudança que influi diretamente nos modelos jurídicos societários das companhias de comércio e indústria diz respeito diretamente à iniciativa do empreendimento. A Revolução Industrial, de forma inegável, altera o conceito e a forma do "empreendedor", doravante uma associação de interesses entre classes de comerciantes, aristocratas, monarcas, clérigos e militares, rumo a projetos tipicamente burgueses, que irão desaguar no conceito de empreendorismo do tipo "fordista", regidos por um universo juridicamente codificado e articulado por escolas exegéticas, em detrimento dos modelos de interpretação escolásticos, até então reinantes. $^{73}$

Há, neste novo universo, uma radical mudança das relações entre acionistas (controladores e não controladores), entre si e em face da administração e dos demais órgãos e atores das companhias. O contexto anterior, do período que compreende a época das expansões ultramarinas até meados do século XIX, que também pode ser tratado como uma espécie de "antigo regime societário", após o declínio da influência da iniciativa pública, como demonstra F. GALGANO, regia-se por relações completamente distintas, vez que preenchidos os cargos e funções societárias por atores distintos com finalidades, pretensões, valores e princípios completamente diversos daqueles do período pós-Revolução Industrial.

Na França, como bem relata R. GRANGER (La Nature Juridique des Rapports..., Op. cit., Idem, pp. 35 e 38), diversos escândalos financeiros marcaram o período histórico das sociedades contemporâneas da Revolução Francesa. Especulação depreciativa e sobretudo uma prática desenfreada de agiotagem sobre o valor das ações de companhias gerou também escândalo na Nouvelle Compagnie des Indes.

Portugal, por seu turno, reformulou completamente o sistema societário com a criação do modelo das companhias pombalinas. Entretanto, como demonstra mesmo Rui M. F. MARCOS (Ibidem, pp. 601-607), não houve qualquer evolução no sentido de franquear ao acionista direitos positivados de pleno acesso à informação. A prática mudou, mas não se deu por conta da reforma pombalina ou de mudança nas instituições, mas sim, como atestam documentos, em virtude da exigência de alguns acionistas de algumas das principais companhias de comércio de então, que fizeram concessões.

Em relação aos modelos coloniais na América do Norte, saliente-se que os fatores de integração após a compra do território da Louisiana e a anexação de ex-colônias espanholas, que obrigaram os norteamericanos a conviverem com culturas como a espanhola e a francesa, arraigadas nas tradições da civil law, geraram conflitos internos que são sentidos até os dias atuais (sobre o tema, vide Stuart BANNER. Legal Systems in Conflict: property and sovereignty in Missouri, 1750-1860. Norman, OK: Oklahoma University Press, 1998) e atrasaram, de certa forma, a consolidação de um sistema jurídico que já estava aceito no chamado território da Nova Inglaterra.

73 Cf. F. Galgano. Lex Mercatoria, Idem, pp. 179-228. Nesse mesmo sentido e do mesmo F. Galgano, vide Diritto Commerciale (Edizione Compatta), 6 ed.. Bolonha: Zanichelli, 2008, pp. 1-2.

Outro elemento que influi fortemente diz respeito ao papel do Estado na promoção do desenvolvimento econômico, como bem demonstra GALGANO. No caso dos EUA, o marco históricolegal desse desgarramento se dá no famoso Charles River Bridge Case (Charles River Bridge v. Warren Bridge - 36 U.S. 420 [1937], relatado pelo Ministro Taney). Sobre o caso em questão, vide M. J. HORWITZ (Op. cit., Idem, pp. 130-139). 
Por outro lado, inúmeros teóricos do direito e historiadores, influenciados pelas idéias marxistas, focaram as análises desse período nas relações entre trabalhadores e empreendedores, seduzidos pela investigação detalhada dos fenômenos atinentes às lutas de classes, deixando muito de lado outras importantes relações ocorridas no império empresarial, a saber, as relações entre acionistas (controladores e não controladores) e entre estes e a administração. ${ }^{74}$ Nesse universo de relações pressupostas e de conflitos potenciais, notando-se que a partir de então a figura do empreendedor acumularia cargos no controle acionário da companhia, bem como na administração, admite-se um fenômeno concentracionista que em muitos casos subiria ao nível da pessoa física. Nesse contexto, percebe-se porque, neste período da Revolução Industrial até fins do século XIX e início do século XX, permanece escassa matéria histórica que mencione o tema da fiscalização societária. Por outro lado, admite-se largamente que é neste período que se desenvolve e se consolida a profissão do contabilista, que estará, futuramente, no foco das atenções do conselho fiscal. ${ }^{75}$

Neste momento, entretanto, nota-se que os mecanismos de fiscalização e as atividades mais típicas de um conselheiro fiscal ainda estão imiscuídas nas práticas do controller interno das companhias, já que a fiscalização da legalidade dos atos nem sequer era cogitada. Assim, ele não apenas procede à contabilização, mas também presta contas aos acionistas e acompanha (sob o ponto de vista contábil e nunca sob o ponto de vista legal) a gestão social. Não há propriamente uma fiscalização institucionalizada. E até que isso ocorra, por força de lei e não por benevolência estatutária de alguma companhia, as poucas possibilidades de acesso a informações da companhia e de vigilância da gestão social recaem, na maioria das vezes, diretamente nos acionistas. Essa ausência de meios institucionais de fiscalização faz com que todo o

\footnotetext{
${ }^{74}$ Note-se em Eric J. HoBSBAWM (Industry and Empire - from 1750 to the present day, $4^{\text {th }}$ ed.. Londres: Penguin, 1999, pp. 150-156), que a ciência da administração entra mais como fator de investigação do novo papel do trabalhador na sociedade mecanizada do que propriamente na relação dessa mesma administração com outros acionistas ou investidores, sejam eles trabalhadores ou não. Entre nós, e no contexto da industrialização brasileira após o declínio da lavoura cafeeira e de sua arcaica economia no início do século XX, vide a análise de Celso FuRTADo. Formação Econômica do Brasil, $14^{a}$ ed.. São Paulo: Editora Nacional, 1976, pp. 177 e segs.

Sob outro enfoque, mas com lentes voltadas para a estrutura de produção da grande indústria, desde o chão da fábrica ao gabinete do $C E O$, destaca-se a notável obra de John Keneth GALBRAITH (vide $O$ Novo Estado Industrial, tradução de Leônidas Gontijo de Carvalho à primeira edição de The New Industrial State. $3^{\text {a }}$ ed.. São Paulo: Nova Cultural, 1997, pp. 87 e segs.) com o conceito de tecnoestrutura.

${ }^{75}$ Vide H. Franco e E. MARRA (Auditoria Contábil, Idem, p. 40); J. C. COFFEE JR. (Gatekeepers..., Op. cit., Idem, pp. 110-115); R. GRANGER (La Nature Juridique des Rapports..., Op. cit., Idem, p. 47); Francesco Cossu (L'independenza del collegio sindicale e del revisore contabile. Milão: Giuffrè, 2006, p. 13).
} 
modelo de vigilância e fiscalização contábil societária, ainda muito rudimentar, seja sempre em formato de fiscalização interna não orgânica e não institucional.

A verdadeira e concreta inovação no conceito de fiscalização societária surge com a experiência britânica e suas formas de auditoria, por meio do Joint Stock Companies Act, de 1844, e do Companies Clauses Consolidation Act, de 1845, que obrigavam as companhias, para que pudessem ter acesso à negociação pública de seus valores mobiliários, a procederem a auditoria e revisão da contabilidade do exercício por contadores alheios às relações da companhia e eleitos diretamente pelos acionistas. ${ }^{76}$

A motivação para a criação da profissão do auditor propiciava que, pela primeira vez, se pudesse ter um sistema institucionalizado e não orgânico de revisão dos trabalhos de contabilização e controladoria das companhias, com maior efetividade da fiscalização dos negócios sociais por intermédio de uma lente puramente contábil. $\mathrm{O}$ auditor passava a não apenas interpretar a condução e a gestão social pela linguagem contábil, mas também a fiscalizar se a condução e a gestão social estariam sendo corretamente registradas na companhia e informadas aos acionistas que não participassem diretamente dessa gestão social. A criação britânica da profissão do auditor gerava uma revolução notável nos parâmetros de fiscalização societária, dando azo a um modelo de fiscalização externa, desempenhada por pessoas especializadas e contratadas especialmente para esse mister, sem qualquer relação direta com os acionistas (controladores ou não controladores), com a administração ou mesmo com a companhia.

Essa criação motivou outros países e sistemas de direito societário a adotarem formas de fiscalização societária externa, como foi o caso de Holanda, Alemanha, França ${ }^{77}$ e EUA. De outro turno, uma série de outros países também

\footnotetext{
${ }^{76}$ J. C. COFFEE JR. (Gatekeepers..., Op. cit., Idem, p. 111) relata que "neither statute required that the statutory auditor actually be an accountant (there being precious few at the time)", precisando que "as of 1799, there were only 11 practicing accountants in London, but, within fifteen years, this number had risen to 210 ",

${ }^{77}$ Relata R. GRANGER (La Nature Juridique des Rapports..., Op. cit., Idem, p. 41 e segs.) que o controle contábil sobre a atividade empresarial, no sentido fiscalizatório, surge com a Lei de 17 de julho de 1856, na reforma das Companhias em Comandita por Ações. Nesse primeiro momento legislativo a França operou verdadeira fiscalização interna, pois incumbiu a um conselho de vigilância a tarefa da revisão contábil: "La nomination d'un conseil de surveillance composé de cinq actionnaires au moins était obligatoire dans toutes les sociétés en commandite par actions. Le conseil de surveillance devait vérifier la régularité des formalités de constitution de la société. Dans le courant de la vie sociale, il était chargé d'une mission générale de contrôle de la gérance, s'exerçant plus particulièrement par la vérification de la compatibilité sociale et de l'inventaire annuel'. Essa modificação gerou um efeito sensível no declínio
} 
entraram em debate sobre as formas de fiscalização societária e, como Portugal ${ }^{78}$, Espanha, Itália, Argentina ${ }^{79}$, México, Peru e Brasil, optaram por um sistema de

das sociedades em comanditas por ações. Na lei de 23 de maio de 1863 sobre a reforma das sociedades de responsabilidade limitada, se introduziu a figura do comissário de contas ("commissaires aux comptes"), seguida pela reforma da sociedade por ações na lei de 24 de julho de 1867, atingindo as sociedades em comandita por ações, as chamadas sociedades anônimas, com a criação de um terceiro tipo, a sociedade de capital variável ("societé à capital variable"). No modelo de 1863, os comissários tinham um papel subsidiário à assembléia e tinham a função de meramente preparar o material para revisão dos acionistas em conclave. No modelo de 1867, as funções são incrementadas e os comissários não necessitam mais portar a qualidade de acionistas. Aproximam-se, a partir de 1867, do modelo dos auditors ingleses, assumindo um caráter mais afeto ao modelo de fiscalização externa. Cf. R. GRAGER, Ibidem, pp. 41-48.

${ }^{78}$ Portugal entrou em fervoroso debate sobre a conveniência de fiscalização interna (por acionistas) e uma fiscalização externa (por meio de entidades de auditoria nomeadas pelo Estado) em fins do século XIX, sob a vigência da Lei de 22 de junho de 1867, o chamado Código Veiga Beirão, que regulou a fiscalização das sociedades pela primeira vez em Portugal. O Código Veiga Beirão trazia, em seus artigos 21 e 22 o instituto do conselho fiscal, optando pela fiscalização interna.

As atribuições do conselho fiscal eram: 1. examinar, sempre que julgasse conveniente, a escrituração da sociedade; 2 . convocar assembléia quando julgasse necessário, pelo voto unânime de conselheiros, se o conselho fosse formado por três membros ou, pelo voto de dois terços deles, se formado por mais conselheiros; 3. tomar parte, sem direito a voto, nas reuniões da administração; 4. fiscalizar a administração; e 5. dar parecer sobre o balanço, inventário e relatório da administração.

Entretanto, noticia António Menezes CoRdeIRo (Manual de Direito das Sociedades..., Op. cit., Idem, p. 108): "Até 1867, o problema não se pôs, dado o número escasso de sociedades existentes. Também no período de vigência da Lei de 22 de Junho de 1867, nada há a apontar. Porém, no final do século, já sob a vigência do Código Veiga Beirão, o incremento das sociedades e a verificação de crises cíclicas levaram os Governos a reagir. Recorde-se, aliás, que fenómenos semelhantes ocorreram, nesse mesmo período, noutros países europeus".

Quando das iniciativas de reforma do Código Veiga Beirão, surgiu debate após a proposta de modelo de fiscalização apresentada pelo deputado Visconde de Carnaxide, durante o ano de 1892. Nessa proposta, o governo poderia intervir em certas sociedades por meio de comissários especiais. A idéia foi combatida pelo deputado José Benevides, que preferia um modelo que privilegiasse a fiscalização interna, reforçando a responsabilidade civil e criminal de administradores e fiscais. Acabou vitoriosa a proposta do Visconde, por meio dos artigos 15 e 16 da Lei de 3 de abril de 1896, sem vedar, por completo, que as sociedades adotassem uma fiscalização interna em seus estatutos. O debate, entretanto, nunca se aquietou e de tempos em tempos retornava ao palanque parlamentar: reformas em 1936 (durante o Estado Novo Português), 1943 e 1969 reascenderam a discussão sobre a conveniência e a efetividade da intervenção direta do Estado na fiscalização das companhias, ante o número mais alto de companhias a serem fiscalizadas em detrimento do baixo número de fiscais habilitados disponíveis, permitindo um "excesso de intervenção estadual". Sobre esse interessante embate sobre a evolução da fiscalização societária em Portugal, dá preciosa notícia histórica António Menezes CordeIRo. Manual..., Op. cit., Idem, pp. 107113.

${ }^{79}$ Noticia Alberto Victor VERÓN (Auditoría, Sindicatura y Consejo de Vigilancia. Buenos Aires: La Ley, 2007, p.309-317), em detalhado histórico acerca do contexto argentino, que em época colonial, "no se advierten precedentes" (p. 311), ausência que se sentiu quando da redação do Código de Comércio da Província de Buenos Aires (1859), da autoria de Dalmacio Vélez Sársfield e Eduardo Acevedo, base do Código de Comércio argentino (1862). Entretanto, a hipótese de fiscalização pelos sócios já se fazia prever em dispositivo legal que foi repetido na reforma de 1889 e que, atualmente, se encontra, literalmente, no conteúdo do artigo 55 da atual Lei 19.550 (1972). VERÓN noticia que um projeto de lei de 1873, de autoria de Sixto Villegas e Vicente Quesada propunha alinhar a legislação argentina ao modelo britânico (vide trecho da exposição de motivos do citado projeto de lei em VERÓN, Ibidem, p. 312, nota 10). Não tendo vingado o projeto, em 1886 o governo encomenda novo projeto a Lisando Segóvia, entregue em 1887, traçando, na linha da tradição italiana, um sistema de fiscalização privada e interna, via sindicatura. Essa é a estrutura que se manteve na reforma que resultou na vigente Lei de Sociedades Comerciais argentina, a Lei 19.550 de 3 de abril de 1972. 
fiscalização interna, orgânica e institucionalizada na forma de um conselho ou um colégio de fiscais. ${ }^{80}$

No espectro da fiscalização societária, merecem destaque os EUA. Os EUA só vieram a conhecer a obrigatoriedade de uma fiscalização, já adotando de início o modelo da fiscalização externa, por meio das reformas do New Deal, mais precisamente no artigo 13(a)(2) do Securities Exchange Act de 1934, impondo auditoria obrigatória para as companhias como condição de acesso ao mercado de capitais, bem como delegando à Securities and Exchange Commission o poder de regular a atividade dos contadores e auditores ${ }^{81}$.

Até que surgissem os escândalos contábeis da Enron, WorldCom e Global Crossing, envolvendo uma das maiores empresas de auditoria do mundo, a Arthur Andersen, a chamada "América Corporativa" jamais ousou fazer reformas muito profundas no pacote de medidas instituídos pelo New Deal. ${ }^{82}$ Contudo, após o fatídico ano de 2001, a legislação de mercado de capitais estado-unidense sofreu a sua maior reforma em setenta anos - e tal reforma deu-se pela porta da fiscalização societária, marco central da chamada Lei Sarbanes-Oxley de $2002 .^{83}$

\footnotetext{
${ }^{80}$ Curiosamente, os países de tradição mais conservadora, com forte influência absolutista, avessos a movimentos liberais e de colonização marcantemente católica, em oposição aos países de tradição liberal e cultura protestante, optaram por fazer o controle e a fiscalização internamente. A linhagem evolutiva das discussões doutrinárias sobre o melhor modelo de fiscalização deixa transparecer um contido ar autoritário nas escolhas de modelos legais.

${ }^{81}$ Cf. J. C. COFFEE JR., Gatekeepers..., Op. cit., Idem, pp. 123-128; vide também James D. Cox, Robert W. Hillman e Donald C. LANGevoort. Securities Regulation, $3^{\text {rd }}$ ed.. New York: Aspen, 2001, pp. 679 e segs.

82 A esse respeito, advertiu L. M. FrIEdman (A History..., Op. cit., Idem, p. 658): “The New Deal program was immensely popular in its day; and what began in the 1930s has become so deeply ingrained in American life that nobody dares touch the essential New Deal, not even a Republican President as conservative as Ronald Reagan. Social Security, the SEC, some sort of federal housing effort, and national labor legislation are as permanently ensconced in the legal system as anything can be in a changing world".

${ }^{83}$ Embora o problema da fiscalização societária tenha chegado em seu limite naquela série de eventos ocorridos entre 2001 e 2002 envolvendo escândalos na Enron, na WorldCom, na Global Crossing e em muitas outras companhias nos EUA, seguidas por escândalos na Europa, sobretudo na Itália, em companhias como a Parmalat e a Cirio, uma edição anterior do livro de COX-HiLlman-LANGEVOORT (Op. cit., Idem, pp. 679-682) já noticiava sérios problemas na seara da fiscalização societária e nas falhas decorrentes do sistema de fiscalização adotado no Securities Exchange Act de 1934: “... by the late 1990s the SEC had come to believe that more and more issuers were falsifying financial information in an effort to meet rigorous marketplace expectations for earnings growth, or at least making extremely aggressive (and potentially misleading) judgments regarding compliance with GAAP”.
} 
O foco central da Lei Sarbanes-Oxley de 2002, por meio de seu artigo $301^{84}$, trouxe a discussão nos EUA sobre a conveniência do fortalecimento de uma fiscalização interna para cuidar das fragilidades apresentadas pela fiscalização externa. ${ }^{85}$ Um modelo clássico, portanto, de fiscalização externa, passa a buscar internamente as soluções para as fraquezas detectadas em sua experiência.

Noutra experiência, países como a Itália, que ostentam um modelo clássico de fiscalização interna, sofrendo por conta da globalização e da adaptação de seu sistema jurídico aos padrões da Comunidade Européia, acabam abrindo amplo espaço para a fiscalização externa, alternando em seus problemas soluções de fiscalização interna (via collegio sindacale ou comitato per il controllo, este último, equivalente do comitê de auditoria). No caso da Comunidade Européia, o conteúdo da Oitava Diretiva influenciou drasticamente os sistemas de fiscalização societária, por tornar obrigatória a previsão do instituto do comitê de auditoria, forçando a uma ampla revisão do papel do collegio sindacale na legislação societária italiana. ${ }^{86}$

De uma forma ou de outra, o que se tem visto é que os caminhos da história vêm forçando os sistemas a uma convergência híbrida com excesso de canais e sobreposição de poderes, tema este que procuraremos analisar adiante.

\footnotetext{
${ }^{84}$ Embora muito se apregoe ter sido a criação dos chamados "Comitês de Auditoria" (Audit Committees) uma obra do artigo 301 da Lei Sarbanes-Oxley de 2002, CoX-HiLlmAN-LANGEVOORT (Op. cit., Idem, pp.680-682), noticia os esforços da SEC e da Bolsa de Nova Iorque, já em 1999, na criação de canais internos de fiscalização por intermédio de atribuições a conselheiros de administração independentes na função de um Audit Committee (vide as Instruções SEC [Exchange Act Releases] nr. 41987, de 7 de outubro de 1999 e nr. 42266, de 22 de dezembro de 1999, chegando a obrigar, inclusive, que as companhias incluíssem em seus relatórios anuais 10-K um relatório do comitê de auditoria indicando (i) se o comitê teria revisado as demonstrações financeiras adequadamente e, (ii) se o comitê recomendaria ao conselho de administração a publicação das demonstrações financeiras no relatório 10-K.

${ }^{85} \mathrm{O}$ modelo tem recebido muitas críticas de todos os lados, chegando, algumas, a verdadeiramente ridicularizar a proposta desse sistema híbrido com diversos canais de fiscalização (internos e externos). Alan GREENSPAN (The Age of Turbulence. Nova Iorque: Penguin, 2007, p. 431) também afirma: "I readily grant that pre-Sarbanes-Oxley audit committees were not great discovers of executive wrongdoing. But in truth, there is no way for an audit committee, new or old, to uncover wrongdoing short of deploying a vast army of investigators who should smother the firm with costly oversight that would likely stifle corporate risk taking and ultimately threaten the viability of the company."

${ }^{86}$ A esse respeito, vide Stefano POLI. La nuova disciplina del collegio sindacale - la professionalità e l'indipendenza dei sindaci nell' $8^{a}$ direttiva CEE in materia societária. Padova: CEDAM, 1997.
} 


\section{CAPÍTULO 3: BRASIL - PECULIARIDADES MERIDIONAIS}

O conselho fiscal no Brasil, não é o primeiro modelo de fiscalização societária de que se tem notícia na evolução histórica de nosso direito. A fiscalização societária surge por meio da reforma do Código Comercial de 1850, instituída, no que se refere às sociedades por ações, por meio da Lei $\mathrm{n}^{0} 3.150$, de 4 de novembro de 1882 , que regulava "o estabelecimento da companhia e da sociedade anonyma".

A fiscalização societária vinha regulada, na Lei $\mathrm{n}^{0} 3.150 \mathrm{em}$ seu artigo 14, que não falava especificamente de um "conselho físcal", mas da nomeação de fiscais. $^{87}$

Sob o ponto de vista institucional, o conselho fiscal, segundo o formato pelo qual hoje o conhecemos, surge na reforma empreendida nas sociedades anônimas no início da república, por intermédio do Decreto 434, de 4 de julho de 1891, em seus artigos 118 a $121 .^{88}$ Adotou-se, nesse diploma primitivo, o modelo da fiscalização orgânica e interna, em oposição aquele tipo de fiscalização externa exercida por fiscais nomeados por instituições externas à companhia, semelhantes aos atuais Conselhos Regionais de Contabilidade e, em alguns casos, semelhante ao Conselho Federal de Contabilidade no Brasil. Não se restringia apenas à matéria contábil, como ocorria com os auditores independentes do direito inglês e estado-unidense, ou com os comissários de contas do direito francês, mas agregava papel de supervisão formal de legalidade dos atos praticados pela administração. Em outras palavras, a lei, no Brasil, assim como ocorreu em Portugal, Espanha, Itália e Argentina, delegou aos acionistas, por maioria, a

\footnotetext{
${ }^{87} \mathrm{O}$ artigo 14 , caput da Lei $\mathrm{n}^{\circ} 3.150$ dizia que "A assembléia geral nomeará annualmente tres ou mais fiscaes, socios ou não socios, encarregados de dar parecer sobre os negócios e operações do anno seguinte, tendo por base o balanço, o inventário e as contas da administração". Ao longo de todo o artigo 14 a lei fala meramente de "fiscaes", assim procedendo nas referências cruzadas constantes do artigo 16, 2 , $2^{\circ}$; no artigo 27 e seu Parágrafo Único; bem como no artigo 32, §2 ${ }^{\circ}$. Contudo, em um ponto isolado da lei, a saber, no artigo $16, \S 9^{\circ}$, Segunda Parte, assim se dispôs, em relação à convocação da assembléia: "Será motivada a convocação e poderá ser feita pelos próprios acionistas reclamantes, se recusarem-na fazer os administradores e o conselho fiscal". Repentina e isoladamente, a lei usa o termo "conselho fiscal" em um único e isolado ponto. O que importa, entretanto, é convir que, sob o ponto de vista funcional e substancial, o conselho fiscal só toma o corpo orgânico pelo qual o conhecemos hoje a partir da reforma implementada na República no Decreto 434, sendo, na Lei $\mathrm{n}^{\circ}$ 3.150, uma mera "junta de fiscais".

${ }^{88}$ Cf. W. Bulgarelli, Regime Jurídico do Conselho Fiscal..., Op. cit., Idem, pp. 39-40.
} 
incumbência de escolher esses fiscais e de prover-lhes espaço societário, como órgão, sob previsão estatutária. ${ }^{89}$

A fiscalização prevista pelo modelo do Decreto 434 era bem mais estreita do que aquela prevista pelo sistema que lhe sucedeu, do Decreto-lei 2.627. Essa fiscalização previa apenas a revisão de contas, conforme mencionava na época CARVAlHo de MENDONÇA, embora BUlgarelli entendesse em sentido contrário. ${ }^{90}$

Dentre as atribuições, além do exame periódico das contas, já se via no Decreto 434 algumas faculdades hoje previstas na Lei das S.A., como a apresentação do parecer sobre negócios e operações da sociedade, a denúncia de eventuais fraudes praticadas pela administração ${ }^{91}$, a possibilidade de convocação da assembléia em face de motivos graves e urgentes e a apresentação de parecer sobre a proposta da administração para aumento de capital social.

\footnotetext{
${ }^{89}$ Embora alguns juristas apresentem classificação diversa, como é o caso de Carlos Fulgêncio da CunHa PEIXOTO (Sociedades por Ações, Op. cit., Idem, p. 127), que a subdivide em individual, privada e oficial, marcas históricas, conforme pudemos analisar no Capítulo anterior, ratificam o entendimento que a melhor divisão entre as formas e modelos de fiscalização societária oscilam na dualidade existente entre fiscalização externa (de natureza contratual) e a fiscalização interna (de natureza societária). A favor dessa divisão entre fiscalização interna e externa, está W. BULGARELLI (Op. cit., Idem, p. 55 e segs.).

${ }^{90}$ José Xavier CARVAlHo DE Mendonça (Tratado de Direito Comercial Brasileiro, $4^{\mathrm{a}}$ edição, Volume IV. Rio de Janeiro: Freitas Bastos, 1946, p.87), comentando o Decreto 434, previu: "No sistema legal, êste conselho é antes verificador de contas do que fiscalizador dos administradores da sociedade" (itálicos do autor). Mais adiante, CARVALHO DE MENDONÇA repisa no tema, afirmando: "Em o n. 1239, supra, salientamos o caráter do conselho fiscal, cuja missão é a verificação das contas e não a fiscalização permanente dos administradores. São, por isso, limitadíssimas as suas atribuições, ficando êles equiparados quase a uma comissão de guarda-livros" (p.90), lembrando ainda que "é lamentável que se não dessem ao conselho amplas atribuições para inspecionar as operações de liquidação, período delicadíssimo" (p.93). Waldírio BULGARELLI (Op. cit., Ibidem), na leitura do mesmo texto legal, lembra: "Com o que se verifica que a competência do Conselho Fiscal era já bem ampla, não se limitando ao mero exame das contas e podendo se processar fora do trimestre previsto, vale dizer, em caráter contínuo". Essa afirmação de BULGARELLI centra-se na interpretação do artigo 122 do Decreto 434, que, em certa medida, é ainda reproduzido no texto do artigo 163, inciso IV da Lei das S.A. (“... denunciar os erros, fatos e fraudes que descobrirem, expor a situação da sociedade e sugerir as medidas e alvitres qu'entendam, a bem da mesma sociedade..."). No Decreto 434, esse era elemento do Parecer do Conselho Fiscal que seria apresentado na Assembléia Geral. CARVAlHO DE MENDONÇA, ao explicitar os meios de elaboração desse Parecer segundo o Decreto 434, bem como os recursos de investigação, afirmava: "Não tem os fiscais, portanto, um direito permanente de exame" (p. 91), dando a entender, não muito claramente, que apesar do exame das contas poder se dar individualmente pelos conselheiros e em períodos distintos (p.93), não é por isso que o poder de revisão das contas acabe sendo amplo e contínuo, como dá a entender Bulgarelli. Neste passo e diante do confronto dos argumentos desses dois grandes mestres, neste particular, estamos com CARVALHO DE MENDONÇA.

${ }^{91}$ Note-se como CARVALHO DE MENDONÇA já fazia previsão de que a função fiscalizatória opera como intermediador de relações jurídicas entre o titular da ação e o responsável pelo ato, sobretudo no que se refere à já polêmica faculdade de "denúncia de erros e fraudes da administração": "Os pareceres dos fiscais que denunciarem quaisquer crimes dos administradores serão remetidos por cópia ao órgão do Ministério Público para promover o processo penal" (Ibidem, p. 93).
} 
O problema da atuação individual, intimamente ligado às questões que envolvem a forma de composição do conselho fiscal, era visto com menor preocupação na época. ${ }^{92}$

\section{No que diz respeito à composição, a lei deixava a cargo da assembléia a} nomeação desses fiscais, sem qualquer distinção entre focos de poder, recaindo sobre a figura do acionista controlador a possibilidade de nomeação de todos os membros.

92 CARvalho DE MendonçA (Ibidem, p. 93) advertia: “A lei não diz se os fiscais devem obrar coletivamente ou individualmente. Não há dúvida que o parecer deve ser coletivo, assim como a convocação da assembléia geral extraordinária, nos casos mencionados em o n. 1247, supra. Quanto ao exame dos livros, a verificação da caixa e da carteira e à exigência de informações, a opinião geral é que cada um dêles podem fazer individualmente, oferecendo êsse expediente melhor garantia". A esse texto, CARVALHO DE MENDONÇA acrescenta a seguinte nota: "FOLLIET, La verification des comptes dans les sociétés par actions, pág. 68: "S'ils travaillent séparément, il y a beaucoup de chance pour que leur examen porte sur des points différents. Si l'un d'entre eux a laissé passer quelque chose, un autre peut le voir. Par conséquent, il est préférable de donner aux commissaires le droit d'exercer leur mission individuellement”. Essa nota trazida por CARVALHO DE MENDONÇA é importantíssima, pois denota que o problema da atuação individual não passa, nesse período e nesse contexto legal, por questões que envolvem a divergência entre conselheiros devidas pela tensão e os conflitos tipicamente assembleares e políticos carregados para dentro do órgão por força do embate minoria-maioria. A nota mostra que a atuação individual, no caso do Decreto 434, pressupunha a afinidade entre membros do órgão e o seu desiderato era buscar, nessa atuação individual, a melhoria do resultado do coletivo. Embora a atuação fosse individual, o resultado dessa atuação deveria ser sempre coletivo. Vide, nesse mesmo sentido, o interessante comentário de F. C. PONTES DE MiRANDA (Tratado..., Tomo L, Op. cit., Idem, p. 416): “Os atos do Conselho Fiscal são atos do órgão, do colégio. Nenhuma comunicação ou parecer pode ser assinado sòmente por um dos membros. Todos os membros têm de assinar, salvo se algum se recusa, o que é infração de dever, porque lhe cumpria assinar com a exposição das suas razões de discordar. Para os atos que hão de levar à reunião e à deliberação do Conselho Fiscal, como o exame de livros e documentos, a verificação do estado da caixa e da carteira, qualquer dos membros é legitimado". C. F. da Cunha PEIXOTO (Op. cit., vol. 4, Idem, pp. 138-139), ainda que em sentido diametralmente oposto ao de Pontes, VAlVERdE e CARVAlHO DE MENDONÇA, apoia-se na doutrina de Ruy Carneiro GuIMARÃES e na "sombra de VIVANTE" para, dentro do mesmo princípio de revelação da questão maioria-minoria, afirmar: "O conselho fiscal é sempre um órgão opinativo e nunca [de] força executiva, o que lhe tiraria a característica de colegial. Seus pareceres valem como orientação à assembléia geral, que é livre de aprová-los ou não. Ora, no órgão colegial há uma conclusão: a decisão deve ser obedecida por todos. Ademais, no Brasil, fora o nome - conselho fiscal -, não há, na lei, nenhum dispositivo que mostre se tratar de um órgão coletivo. Suas deliberações são opinativas, podendo, mesmo, a assembléia aprovar o voto vencido, em vez daquele subscrito pela maioria. Por outro lado, o art. 127, ao estabelecer suas atribuições, não se refere ao 'conselho' mas aos 'membros do conselho', e seu parágrafo, ao regular a questão do perito, usa também a palavra 'fiscais' e não 'conselho'. A lei fixou atribuições individuais e não coletivas. Os atos, assim, podem ser praticados pelos membros do conselho fiscal, individualmente. E se dúvida pudesse haver, neste particular, a nosso ver, seria bastante o disposto nos arts. 124 e 125 para espancá-la. Com efeito, de conformidade com aquele dispositivo, o conselho fiscal será composto de "três ou mais membros e suplentes em igual número', e esse permite que, embora formulado por apenas três elementos, um pertença à maioria, outro aos dissidentes e o terceiro aos acionistas preferenciais. Portanto, a lei não se preocupa com a maioria nas deliberações do conselho fiscal, pois, do contrário, não permitiria sua formação com a possibilidade de algumas deliberações não alcançarem maioria, o que, na hipótese, pode acontecer, desde que a matéria a ele submetida, como, por exemplo, aumento de capital, se apresentasse diferentemente aos interesses dos três grupos. Assim, não tem nenhuma importância pertencer cada membro do conselho fiscal a um grupo nem haver divergência entre todos, quando, então, cada um apresentará seu parecer. A assembléia geral aceitará qualquer deles, da mesma maneira que pode rejeitar o firmado por todos". Não é bem assim, entretanto, que acaba ocorrendo, conforme se verá. O comentário de CUNHA PEIXOTO merece alguns reparos que oportunamente serão feitos nesta dissertação, sobretudo por conta da questão da influência política que um órgão técnico (e aqui mencione-se órgão, no sentido colegiado, tal qual lhe afirma PONTES nesta mesma nota) acaba sofrendo. 
Além disso, CARVAlHo DE MendonçA lembrava que "não há restrições legais para a nomeação, como as relativas à residência, profissão, incompatibilidade por parentesco ou outra causa". 93

Com essa ampla possibilidade de composição, sem qualquer atenção a um critério mínimo de independência, certamente repousou de forma pacífica a atuação individual dos membros do conselho fiscal, conforme comentamos acima. A atuação individual, nesse caso, como forma de correção de resultados coletivos deletérios, não residia num conflito maioria (vista como administração e controle) contra certa minoria e, sim, meramente numa permissibilidade para que um erro individual comprometesse a atuação do órgão. Dessa lógica bem intencionada, entretanto, não se eximiram os titulares do poder de controle para se apoderar do órgão de maneira indevida, abusando, inclusive, das brechas legais quanto à desnecessidade de independência e formação técnica adequada. ${ }^{94}$

Ainda da brecha legal contida no Decreto 434 a respeito da falta de independência e da falta de formação técnica adequada, certamente identifica-se uma das causas de sua maior carga de ineficiência, doravante combatida pelo próprio CARVAlHo DE MENDONÇA.

Na esteira dessas críticas, associou-se Trajano de Miranda VALVERDE. ${ }^{95}$ Contudo, o ímpeto conciliatório de VALVERDE e a crença em uma necessidade de existência de um poder fiscalizatório no âmbito do direito societário autorizou-lhe rever o instituto, quando autor do anteprojeto do Decreto-lei $2.627^{96}$. Na revisão

\footnotetext{
${ }^{93}$ CARvalho DE MendonÇA, Op. cit, Ibidem, p. 89, salientando ainda que essas limitações, embora a lei não fizesse nenhuma previsão, poderiam ser estabelecidas nos estatutos.

${ }^{94}$ Comentou CARVAlHO DE MENDONÇA (Ibidem, p. 88): "Essa instituição acha-se em plena bancarrota. De um lado, a incapacidade (pois se trata de funções de grande dificuldade), a falta de consciência e a condescendência dos fiscais, do outro, a ausência de contabilidade bem organizada têm desmoralizado tudo".

95 Sociedade por Ações, Op. cit., Idem, pp.336-337: "Falhou o órgão controlador, já pelo sistema de escolha das pessoas, que devem ativar o órgão, pois a maioria que elege os administradores elege também os fiscais, já porque a nomeação recai em indivíduos sem a necessária competência para o exercício das funções, nada reconhecendo de contabilidade, que é o verdadeiro domínio dos fiscais. Que valor tem o parecer dos fiscais sôbre o inventário e o balanço levantados pelos administradores, sôbre as contas por êstes prestadas, se êles são, em regra, incapazes de ler a escrituração mercantil? E, para que êsse trabalho, diz-se, se as pessoas eleitas para os cargos da administração geralmente são os maiores acionistas, que, assim, se nomeiam e escolhem os membros do Conselho Fiscal? Na realidade, os membros do Conselho Fiscal são quase sempre indicados pelos administradores, sem independência suficiente, portanto, para o bom exercício das funções".

${ }^{96} \mathrm{O}$ governo Vargas trouxe inovações no modelo de fiscalização societária, bem como no reconhecimento, ainda que tardio, da profissão do contador no Brasil. Enquanto que outros países como
} 
implementada, VALVERDE levou em consideração a experiência malsinada da falta de independência e qualificação técnica permitida nas brechas do Decreto 434, observando

ainda as dificuldades que a realidade sócio-cultural brasileira apresentava para uma

reformulação mais profunda do instituto, resultando no texto dos artigos 124 a 128

daquele Decreto-lei 2.627. ${ }^{97}$

Inglaterra, França, Itália, EUA e Portugal já reconheciam a profissão de contador, o Brasil veio a regular o tema apenas por meio do Decreto $\mathrm{n}^{\mathrm{o}} 20.158$, de 30 de junho de 1931 , nos artigos 53 e seguintes. Curiosa prerrogativa que as tradições de nosso Ministério da Fazenda ainda mantêm até hoje, ex vi do regime mais rigoroso de fiscalização societária das instituições financeiras e companhias seguradoras, está contida no artigo 73 do Decreto 20.158/31, que diz: "Somente os peritos-contadores ou contadores e os atuários, diplomados por estabelecimentos de ensino técnico ou habilitados perante a Superintendência do Ensino Comercial, terão preferência para o provimento, os primeiros, no cargo de fiscais de bancos e, os últimos, no de fiscais de companhias de seguros e, ainda, quer uns, quer outros, para cuidarem da escrita dos bens administrativos por tutores e curadores e das regulações judiciais ou extra-judiciais de avaliação grossas ou comuns". Exceto por esse artigo, não há no extenso decreto qualquer indício ou menção ao trabalho de auditor, incumbindo-se o decreto mencionado de regular o ensino e a prática do ofício de "guarda-livros" e suas respectivas ramificações.

${ }^{97}$ Suas preocupações e o resultado da reforma, que gerou o texto dos artigos 124 a 128 do Decreto-lei 2.627, podem ser assim resumidas: "O legislador de 1940 não podia, porém, adotar o sistema inglês ou alemão, nem tampouco, como se pretendia, tornar obrigatória a eleição de contadores profissionais para o Conselho Fiscal. A extensão geográfica do país, os seus níveis diferentes de cultura, e a diversidade dos meios econômicos, separados por longas distâncias, impediam, como impedem, a organização de um sistema rígido de fiscalização no aparelhamento das companhias ou sociedades anônimas nacionais. Por outro lado, a maioria das nossas companhias, mesmo as de grande projeção, ainda não se desprendeu dos laços de parentesco e amizade, que prendem os seus acionistas, inicialmente fundadores delas, situação essa que não favorece o bom funcionamento do órgão fiscalizador. Mas apesar de tudo isso, o decreto-lei organizou o Conselho Fiscal de modo a dar o rendimento esperado. Obriga os seus membros a residirem no país; confere aos acionistas dissidentes, que representarem um quinto ou mais do capital social, e aos titulares de ações preferenciais o direito de eleger, separadamente, um dos membros do Conselho Fiscal e seu suplente; cria incompatibilidades e proibições para o exercício das funções; assegura ao Conselho Fiscal o contrôle permanente da gestão social; autoriza os fiscais a escolherem um perito-contador para os assistir no exame dos livros, do inventário, do balanço e das contas da diretoria; equipara a responsabilidade civil dêles à dos diretores" (Ibidem, p. 337).

Entretanto, as observações de VALVERDE merecem algum reparo, sobretudo por conta das críticas que lhe seguiram, forçando reforma do modelo previsto no Decreto-lei 2.627. Como se verá, tal modelo acabou por plantar novos problemas no seio do órgão, que permanecem até hoje e que, diga-se de passagem, foram agravados pela reforma da Lei $\mathrm{n}^{0} 10.303 / 01$. Além disso e a par desses problemas, não foram debelados outros, na esteira das críticas formuladas por CARVALHO DE MENDONÇA quanto ao Decreto 434, gerando ainda algumas fraturas na doutrina quanto à interpretação das regras que diziam respeito ao âmbito de sua competência e à delimitação da função fiscalizatória, bem como quanto às formas de composição desse órgão após a introdução da segmentação da escolha de seus membros pelo critério político da maioria versus minoria.

Inicialmente, incumbe observar que a justificativa da extensão geográfica do país não seria tão preponderante, haja vista o modelo implementado nos EUA, que levou justamente esse item em consideração, ao privilegiar o modelo da fiscalização externa via auditoria independente.

Ademais, esse mesmo argumento não prosperaria mais nos dias de hoje, já que a atuação das empresas para além de fronteiras de países e continentes, permite, mesmo assim, controles razoavelmente eficazes de fiscalização, como é o caso de algumas multinacionais e instituições financeiras rigidamente fiscalizadas interna e externamente, em todas as suas representações extraterritoriais e agências. Nesse aspecto, vide o quadro trazido por H. M. SchwarTZ (States Versus Markets..., Op. cit., Idem, p. 248, tabela 11.1, fonte: Relatório de Desenvolvimento Mundial, do Banco Mundial, de 1992) onde algumas companhias e nações são comparadas, levando-se em consideração o patrimônio líquido de algumas transnacionais e o PIB de algumas nações. Nesse quadro, pode-se ver que empresas como a General Motors, superava nações como a Noruega, a Argentina, a Grécia e Portugal. A Royal Dutch Shell, da 
VALVERDE faz-nos lembrar das dificuldades de romper com os laços de "parentesco e amizade, que prendem seus acionistas, inicialmente fundadores delas", que, como bem admitido pelo saudoso jurista, "não favorece o bom funcionamento do órgão fiscalizador". Essa dificuldade, que nos é cultural ${ }^{98}$, como se pôde ver anteriormente, é o que compromete a independência do órgão e permite contaminá-lo com a dicotomia maioria-minoria, que deveria, ao menos em tese, ficar restrita ao âmbito da assembléia geral. ${ }^{99}$

Holanda, superava os três últimos países e a Ford, a Toyota e a GE superam Grécia e Portugal, ao passo que Portugal ainda era superado por empresas como Daimler Benz (antes da fusão com a Chrysler) e a Mobil (antes da fusão com a Exxon, que nesse quadro aparece com a mesma colocação da Royal Dutch Shell, superando Argentina, Grécia e Portugal).

No caso específico do Brasil, a extensão territorial também não seria bom argumento, se levarmos em conta o detalhe da extensão territorial da concentração econômica. Em primeiro plano, as grandes sociedades comerciais brasileiras concentram-se nos estados de São Paulo (onde se carrega mais da metade das sedes e dos campi operacionais das empresas e indústrias), Rio de Janeiro, Paraná, Minas Gerais e Rio Grande do Sul, formando um quadrilátero do eixo Sul-Sudeste que reduziria consideravelmente essa preocupação com a extensão territorial para organização de um sistema rígido de fiscalização societária. Esses dados, que estão disponíveis no endereço eletrônico do Departamento Nacional de Registro do Comércio (<http://www.dnrc.gov.br/>; último acesso em 27de janeiro de 2009), atestam que a constituição de empresas entre os anos 2000 a 2005 concentram, nas Regiões Sul e Sudeste, $66 \%$ de todas as empresas constituídas no Brasil para ano de 2005, 67\% de todas as empresas constituídas no Brasil para ano de 2001, 68\% de todas as empresas constituídas no Brasil para anos de 2000, 2002 e 2004 e $70 \%$ de todas as empresas constituídas no Brasil para ano de 2003.

${ }^{98}$ A importante observação a respeito da nefasta e reprovável prática do nepotismo privado, ainda hoje muito comum em conselhos fiscais de muitas companhias (abertas, inclusive), onde se vê a presença de pessoas relacionadas com o controlador (e atualmente, pelas brechas, pessoas relacionadas com os minoritários na defesa aberta de seus interesses), apresenta-se, segundo se verá, como o nó górdio que nenhum Alexandre ainda ousou desfazer.

${ }^{99}$ Nessa interferência de uma tradição patriarcal e patronal, demonstrou-se nas páginas anteriores como a cultura jurídica societária no Brasil ainda permite influenciar-se pelo papel do dependente ou do sujeito com relações diretas, que Richard GrahAM (Patronage and Politics..., Op. cit., Idem, pp. 235-240) trata tecnicamente pelo emprego da palavra amigo. No âmbito societário e sobretudo na esfera pertinente à fiscalização, essa prática malsã pode gerar efeitos devastadores na companhia e no capitalismo como um todo, ainda que esse capitalismo se dê exclusivamente num universo de "empresas familiares". A permissão para que as empresas familiares tenham um regime quase que "monárquico", em que a sucessão na administração passa sempre pelo crivo de uma "casa" ou "família", não deve se estender ao nível da fiscalização, em benefício até mesmo dessa sucessão, se assim se desejar governar uma companhia.

Lembra-nos F. C. PonTes de MiRAndA (Tratado..., Tomo L, Op. cit., Idem, p. 413): “O órgão controlante e fiscalizante é distinto do órgão administrativo, porque tal independência é necessária à sua função. O grande mal das sociedades por ações está em que as maiorias escolhem diretores e membros do Conselho Fiscal que estão no mesmo plano de interêsses, de modo que prestam mais colaboração, ou mesmo colaboração subordinada, do que contrôle e fiscalização”. Logo adiante, ao tratar da assistência técnica aos membros do conselho fiscal, afirma: “... a independência dos membros do Conselho Fiscal perante os diretores é o que verdadeiramente importa” (p. 418).

Nesse universo é que surgem revisões de modelos administrativos clamando por uma certa "profissionalização", ainda que esse termo possa representar alguma redundância semântica. Antes de pensar em uma profissionalização, cabe rever os mecanismos que esterilizam a independência dos órgãos que são incumbidos de dar eficácia administrativa e transparência, como é o caso do conselho fiscal. Esse problema, desde o Decreto 434, é enfrentado de forma paralela. Talvez por isso é que o mesmo 
E nas linhas seguintes do comentário de VALVERDE, onde ele manifesta a esperança de ter dado ao conselho fiscal um modelo apto a permitir um "rendimento esperado", nota-se que, na ausência do enfrentamento da falta de independência dos membros do órgão, outras questões foram abordadas, sendo a mais grave de todas, a que se refere à migração da dicotomia maioria-minoria para dentro do órgão.

Paralelamente, deu-se um passo importantíssimo para que o órgão alcançasse a eficácia, por meio da criação de impedimentos e incompatibilidades, o controle permanente sobre a gestão social e a inserção de um regime de responsabilidade civil.

Nos impedimentos e incompatibilidades, o artigo 126 do Decreto-lei 2.627, fez prever corajosamente que: "Não podem ser eleitos para o Conselho Fiscal os empregados da sociedade, os parentes dos diretores até o terceiro grau e os que se acharem nas condições previstas no $\S 4^{\circ}$ do art. 116". ${ }^{100}$ VALVERDE, em seus breves comentários a esse artigo, ressalta que essa incompatibilidade, devida aos laços de subordinação entre o fiscal e o provável fiscalizado, maculava, por presunção legal absoluta, a independência. ${ }^{101}$ Entretanto, o texto de lei não ficou livre de controvérsias em relação ao seu alcance. ${ }^{102}$

VALVERDE admita afirmar (Sociedades por Ações..., Op. cit., Ibidem, p. 335): "Mas, se tècnicamente o órgão controlador ou de fiscalização devia dar um ótimo rendimento, na prática, entretanto, falhou totalmente, salvo, diz-se, na Inglaterra, e isso talvez devido ao temperamento do seu povo, para o qual as leis foram feitas para serem cumpridas".

${ }^{100} \mathrm{O}$ mencionado $\$ 4^{\circ}$ do artigo 116 dizia: "São inelegíveis para os cargos de direção, além das pessoas impedidas por lei especial, os condenados a pena que vede, ainda que temporàriamente, o acesso a cargos públicos, ou a pena por crime de prevaricação, de falência culposa ou fraudulenta, peita ou subôrno, concussão, peculato ou por crimes contra a economia popular ou a fé pública e contra a propriedade".

101 Ibidem, Op. cit., pp. 343-344. VALVERDE usa, apropriadamente, o termo "independência". Entretanto, embora tivesse logrado a lei dar alguma independência do fiscal em relação à administração, manobras do controlador, como se verá, continuaram a interferir na independência do fiscal em desfavor dos demais e da própria companhia, resultando numa nova reforma, que, entretanto, manteve intacto esse ponto.

${ }^{102}$ C. F. Cunha PeiXoto (Sociedade por Ações, vol. 4, Op. cit., Idem, p. 142) tinha essa opinião: "Em geral as leis estrangeiras estendem os impedimentos aos parentes dos diretores. Os Códigos italiano, antigo e atual, bem como a lei francesa, levam a inelegibilidade até o quarto grau. Parece exagero. Mais razoável é a nossa, cuja proibição abrange os parentes até terceiro grau. Realmente não se justifica que o impedimento ultrapasse o tio e o sobrinho, quando não o existe para amigos íntimos. Os laços de amizade são, comumente, mais fortes do que os de parentesco, sobretudo quando este é afastado, como ocorre relativamente aos primos. A incompatibilidade prende-se a uma dependência moral, e esta, no Brasil, não vai além do tio ou sobrinho". Não é o que pensa F. C. PONTES DE MiRAndA (Tratado..., Tomo L, Op. cit., Idem, p. 415): "Inclusive, como pressuposto, o parentesco até o terceiro grau, com cômputo de iure contendo pouco rigoroso, porque parentes na linha colateral até o terceiro grau são apenas irmãos, tios e sobrinhos [sic]. Os primos podem ser diretores e fiscais. A afinidade pode impedir (cunhados, 
O Decreto-lei 2.627 ainda previu o controle constante sobre as contas, que, conforme advertência de CARVALHO DE MENDONÇA, não ocorria no regime do Decreto 434. ${ }^{103}$ Ampliou-se, com isso, o juízo do conselheiro dentre as suas atribuições. Contudo, a ampliação dessas atribuições casada à alteração da forma de composição do conselho, que visava elidir problemas de independência, causou problemas com relação à atuação individual dos conselheiros e os limites dessa competência individual, sobretudo quando exercida "em nome" ou "no interesse", declarado ou sutil, de algum acionista minoritário. ${ }^{104}$

A respeito da forma de composição desse novo modelo de conselho fiscal, fez o Decreto-lei 2.627, por meio de seu artigo 125, garantir a presença de minoritários na composição do conselho, assim: "É assegurado aos acionistas dissidentes, que representem um quinto ou mais do capital social, e aos titulares de ações preferenciais o direito de eleger, separadamente, um dos membros do Conselho Fiscal e o respectivo suplente". A esse novo regime de composição preferiu VALVERDE, em seus comentários, associá-lo ao artigo 78 do Decreto-lei 2.627, que tratava do direito individual de fiscalizar do acionista. Esse direito, entretanto, é de natureza

concunhados, cônjuge do sobrinho ou do tio) [sic]. Na linha reta, o que se há de entender é que não pode haver fiscal que nela esteja com algum diretor (trineto, bisneto, neto, pai ou mãe, avô, bisavô, trisavô)".

${ }^{103} \mathrm{O}$ artigo 127, no inciso I, trazia o seguinte texto: "Aos membros do Conselho Fiscal incumbe: ... examinar, em qualquer tempo...".

${ }^{104}$ W. M. FERREIRA (Tratado..., $4^{\mathrm{o}}$ volume, Op. cit., Idem, p. 520-521) assim coloca-se diante da questão da politização do conselho fiscal: "Para que de tal modo se reúnam e coletivamente deliberem, devem os membros do conselho fiscal preparar-se convenientemente, realizando os exames de livros e papéis pela forma que convencionem e entendam mais profícua. $\quad$ A divisão do trabalho é salutar; mas requer que entre êles exista regime de confiança recíproca. Cada um repousa na atividade do outro; e as tarefas individuais somam-se nas conclusões dos pareceres discutidos e aprovados em sessões prèviamente convocadas. Inexistindo atmosfera de entendimento entre êles, a cada qual é lícito agir individualmente, efetuando o exame dos livros e papéis da sociedade, o estado do caixa e da carteira e solicitando aos diretores, verbalmente ou por escrito, informações e esclarecimentos. Essa coletânea de elementos destina-se a permitir que cada fiscal formule seu juízo sôbre a situação da companhia, de molde a poder debatê-la nas sessões do conselho. Mais se acentua a necessidade dêsse trabalho individual quando, no exercício do direito que lhes atribui o art. 125, os acionistas, que representem o quinto ou mais do capital social, e os titulares de ações preferenciais, hajam eleito, separadamente, um dos membros do conselho fiscal e respectivo suplente. Êstes, precisamente porque eleitos por acionistas dissidentes ou preferenciais, entram a fiscalizar interêsses que não são idênticos aos da maioria dos acionistas, quase sempre os próprios diretores da companhia. Têm êles, como é de ver, a mais ampla liberdade de ação e não se subordinam ao critério e às conveniências dos demais fiscais, representantes do capital majoritário". O comentário, nitidamente, apresenta uma certa inconsistência, pois ¿como pode ser da essência de um órgão o regime da confiança recíproca se lhe permite que seja contaminado pela oposição tipicamente política das controvérsias existentes entre acionistas dissidentes e a maioria, quando àqueles é dada representação específica de seus próprios interesses (discordantes dos interesses da maioria e também, não necessariamente concordantes com um abstrato "interesse da companhia")? Em outras palavras: se é permissível que interesses próprios acessem os órgãos da companhia a ponto de fazer esse órgão agir exclusivamente em função desses interesses próprios (sejam eles da maioria, sejam eles da minoria), então ¿como tal órgão pode existir sob um regime de confiança recíproca entre seus membros? 
completamente distinta da fiscalização orgânica empreendida pelo conselho fiscal. Por essa razão, nos parece com mais razão, neste ponto, BULGARELLI, que fez enxergar na esteira do artigo 125 do Decreto-lei 2.627 um forte mecanismo para reestruturação da noção de transparência e, por isso, eficaz peça para tentativa de fortalecimento de uma cultura de independência para o conselho fiscal. ${ }^{105}$

Por derradeiro, o sistema de 1940 ainda trouxe um regime de responsabilidade civil por empréstimo da administração. Embora seja expressamente admitido que as funções são completamente diversas, tolera-se na doutrina esse empréstimo $^{106}$, ao nosso ver inadequado, de um outro regime de responsabilidade civil cujas funções são tecnicamente opostas. ${ }^{107}$

Contudo, mesmo diante dessas importantes modificações, não escapou o Decreto-lei de ferozes críticas, antes mesmo de ter completado os primeiros vinte anos de vigência. Além das críticas efetivas, já no regime do mesmo Decreto-lei, algumas sociedades adotavam práticas e importavam costumes que condiziam com o regime de fiscalização externo, próprio do modelo franco-anglo-saxão. Controvérsias surgiram sobre a necessidade dessa fiscalização orgânica diante de uma fiscalização por auditoria independente. $^{108}$

\footnotetext{
${ }^{105}$ Vide F. C. PONTES DE MiRAndA, Tratado..., Tomo L, Op. cit., Idem, pp. 413-414.

Com relação à forma de composição e o direito concorrente de minoritários e preferencialistas, o mesmo PONTES DE MIRANDA não deixa (Ibidem, p. 414) de apresentar interpretação controversa: "O art. 124 fixa no número de três o mínimo de membros do Conselho Fiscal e dos suplentes. Não fixou o número máximo. Se os estatutos estabelecem que três hão de ser os membros e a sociedade por ações tem acionistas preferenciais, a maioria sòmente pode eleger um, porque os dois outros hão de ser eleitos pela minoria e pelos acionistas preferenciais, separadamente".

${ }^{106}$ T. M. Valverde, Op. cit., Idem, p. 350; C. F. Cunha PeiXoto, Op. cit., Idem, p. 161; F. C. Pontes DE MIRANDA, Tratado..., Tomo L, Op. cit., Idem, p. 420.

${ }^{107}$ Dessa tolerância decorre atualmente o texto do artigo 165 e parágrafos da Lei das S.A. Sobre esse ponto, pretendemos plantar uma primeira semente, ainda neste capítulo da dissertação, para estudos futuros mais aprofundados.

${ }^{108}$ W. M. FERREIRA (Tratado..., $4^{\mathrm{o}}$ vol., Op. cit., Idem, pp. 517-518) assentou: "Inúmeras companhias contratam com emprêsas de contabilidade sua assistência técnica, permanente ou periòdicamente, se não apenas uma vez por ano, de molde a que as contas do exercício se apresentem ao conselho fiscal com o seu parecer. Essa prática não substitui, nem prejudica a ação permanente dos fiscais, que são, ainda assim, obrigados a cumprir os deveres que a lei lhes impôs". Reforma posterior em 1976 acomodou a situação com o conceito de instalação de conselho fiscal, retirando-lhe o caráter de funcionamento permanente e legando às companhias abertas a obrigatoriedade de auditoria independente (artigo $177, \S 3^{\circ}$ da Lei das S.A.). Esvaziou-se, assim, aquela função primordialmente contábil do conselho fiscal, que hoje fica restrita a pífios pareceres cujo teor não ultrapasse dez linhas de texto, sempre acompanhando o trabalho dos auditores, deixando a cargo desse órgão a ingrata tarefa de representar, no seu âmbito, o embate maioria-minoria, de cunho eminentemente político-societário. W. M. FERREIRA (Ibidem) também afirmava: "O que a prática revela é que os escritórios de contabilistas ou de revisores fiscalizam mui superficialmente. Limitam-se, na generalidade dos casos, a verificar se os lançamentos dos livros se
} 
Dessa prática das auditorias independentes, começou-se a pregar uma certa desnecessidade do conselho fiscal, ainda exercido por pessoas próximas e sob remuneração simbólica. Não faltou, por isso, quem começasse a propugnar, desde logo, por nova reforma da lei que se aplicava ao regime das sociedades por ações. As divergências na doutrina e na jurisprudência, assim como a acomodação da fiscalização aos interesses de controladores, por conta de nova forma de quebra de independência, suscitaram críticas variadas, dentre elas a mais conhecida e feroz foi aquela formulada por João Eunápio BoRGES. ${ }^{109}$

A crítica de Eunápio BORGES, pela sedução de seus argumentos, aparece citada na maioria das monografias sobre o tema (que são poucas), durante os anos 1960' e início dos anos 1970’, sobretudo quando se queria sustentar a necessidade de reforma no tema. Perceba-se, entretanto, que a crítica formulada na nota anterior tinha por foco

acham comprovados por documentos hábeis ou, mesmo, por papeluchos, a que apõem seus carimbos. Contentam-se com isso. Não entram a fundo no exame das contas e, principalmente, do desenvolvimento patrimonial da companhia. Os relatórios, assim elaborados, são inexpressivos. Redigem-se para a diretoria e de acôrdo com as conveniências desta, não para a assembléia geral". Embora essa generalização pudesse ser verdade ao tempo do Tratado de Waldemar FERREIRA, hoje em dia essa afirmação acabou tornando-se inexata à luz das evoluções que ocorreram nas práticas de auditoria. Não se pode mais, hoje em dia, empreender essa generalização pois há empresas de contabilidade que, por método de trabalho, costumam entrar fundo em alguns detalhes da companhia. Adicionalmente, a regulamentação da profissão, sobretudo no âmbito do Conselho Federal de Contabilidade e do Instituto Brasileiro de Contabilidade - IBRACON, evoluiu sobremaneira. Vale lembrar que rígidos critérios de independência exigidos para essa função, como teremos oportunidade de verificar no capítulo 8 desta dissertação, impedem que os contabilistas encarregados de revisão e auditoria independente, ajam somente ou mesmo com alguma conveniência para a diretoria da companhia onde se procedeu à auditoria. Por fim, a superficialidade ou a profundidade do trabalho dos auditores depende totalmente do escopo da auditoria, que é estabelecido no contrato entre auditor independente e sociedade auditada, desde que respeitados os níveis mínimos de investigação previstos em lei e regulamentos aplicáveis.

${ }^{109}$ Curso..., Op. cit., Idem, p. 486-487, cujo azedume e acrimônia do discurso vale a pena lembrar: "O conselho fiscal transformou-se entre nós em órgão meramente decorativo. De fato, é a diretoria, pelo absoluto contrôle que exerce sôbre a assembléia, que escolhe os seus próprios fiscais. E é natural que a criatura seja feita, como o homem, à imagem e semelhança de seu criador. (...) Tal como existe e como funciona, é orgão, ou supérfluo ou absolutamente inútil e inoperante. Se os diretores são honestos, capazes, cumpridores de seus deveres, com ou sem fiscalização, tudo correrá bem para a sociedade. Se, porém, forem maus administradores, desidiosos, sem escrúpulos, saberão escolher fiscais que não os molestem... No primeiro caso será desnecessária, supérflua, qualquer fiscalização; no segundo caso, ainda que não fôsse de fato inexistente, ela seria de todo inoperante. Aliás, por mais compenetrados da importância e responsabilidade de sua função que sejam os membros do conselho fiscal, por mais idôneos e diligentes, a verdade é que, salvo raríssimas exceções, limitam-se êles a assinar, sem ao menos lê-los, os têrmos, atas e pareceres que, em geral, são feitos por empregados da sociedade. Dir-se-á que ainda na hipótese de diretores honestos e competentes, o conselho fiscal prestaria a êles e à sociedade grande serviço, se fiscalizasse não os atos da diretoria - acima de qualquer suspeita - mas os dos contadores ou guarda-livros, responsáveis pela contabilidade da empresa. Acontece, porém, que os membros do conselho fiscal em geral nada entendem de contabilidade, sendo-lhes impossível, por isso, exercer pessoalmente a fiscalização que lhes incumbe. Ainda mesmo que - e isso rarìssimamente acontece quisessem de fato fiscalizar alguma coisa... A lei faculta-lhe, é verdade, contratar um técnico em contabilidade para auxiliá-los no cumprimento de sua missão. Mas, na prática, é a própria diretoria, a fim de controlar a contabilidade da sociedade e a exatidão dos resultados apurados em balanços, que costuma contratar os serviços de escritórios ou empresas especializadas em tais serviços". 
atacar, com maior profundidade, o problema da independência. Ao mencionar que a "diretoria exerce controle absoluto sobre a assembléia", Eunápio BORGES nada mais faz do que revelar, no seio da prática societária brasileira, o problema do acúmulo de funções entre acionista controlador e administração da companhia, pois, esse controle sobre a assembléia só era possível, porque os administradores, na maioria das vezes os próprios fundadores das companhias, soíam deter certa quantidade de ações que lhes garantiam maioria das votações na assembléia, detendo, além do poder de gestão, o poder político nos conclaves. Eunápio BORGES, na verdade, não se insurge contra o órgão ou o instituto, não se insurge contra a lei, mas como o próprio CUNHA PEIXOTO lembra, ao citá-lo, “infelizmente, melhorou a lei, mas não se conseguiu igual proceder com relação ao homem". 110

Entretanto, grande desserviço foi prestado quando uma certa solução apocalíptica foi pregada em alternativa a esse problema da independência. ${ }^{111}$ Essa "proposta de reforma", se assim poderia se referir a crítica tão violenta, chegou a interferir em muita doutrina sobre o tema, quando se assentou, em fins da década de 1970', que era realmente preciso acabar com o conselho fiscal e com qualquer outra forma de fiscalização das sociedades comerciais, por serem inúteis para as "boas" sociedades, e inoperantes para as "más”. Dessa visão maniqueísta e apocalíptica, vimos brilhantes juristas traçarem suas opiniões de reforma. ${ }^{112}$

\footnotetext{
${ }^{110}$ C. F. da Cunha PeiXoto (Sociedade por Ações..., vol. 4, Op. cit., Idem, p. 148).

111 J. Eunápio BoRgES (Curso..., Op. cit., Idem, p. 488) lembrou: "Daí preconizar-se, em doutrina, aqui e em tôda a parte, a radical modificação do sistema de fiscalização das sociedades anônimas. (...) Não creio, porém, na utilidade e na eficácia de qualquer reforma. O órgão é inviável e deve ser suprimido sumàriamente. Escolha a assembléia, se puder, bons diretores. Se isso fôr impossível, devido à supremacia dos maus elementos, cuide cada acionista de vender as suas ações. Ou, se fôr o caso, de bater às portas do Judiciário para a defesa de seus direitos feridos ou ameaçados. Para promover a responsabilidade civil ou penal dos diretores ou, em certos casos, requerer a liquidação judicial da sociedade. A fiscalização sob qualquer modalidade - mesmo feita por pessoas ou órgãos estranhos à sociedade - será sempre, como se disse acima, supérflua ou inoperante. Contra uma diretoria desonesta e prepotente não há possibilidade de defesa. Mesmo que houvesse fiscais dispostos e capazes de fazê-la (e êles seriam imediatamente destituídos...), tôda fiscalização seria ineficaz. Em conclusão: o conselho fiscal é apêndice irremediàvelmente inútil. É melhor extirpá-lo de uma vez do organismo das sociedades por ações".

112 Alfredo LAMY FILHO, “A Reforma da Lei das Sociedades Anônimas”, In RDM 7/123-158, nr. III, 1972, pp. 140-142: "Parece-nos certo, por tudo isso, que as novas regras devem visar no campo privado ao aperfeiçoamento do instituto, e, no campo público ao seu controle mais eficaz por parte das autoridades. Em outras palavras, o problema de assegurar a gestão honesta e responsável às sociedades abertas, de forma a dar maior segurança aos títulos negociados pelo público requer providências de várias ordens, cumprindo examinar as que têm merecido melhor acolhida pelas leis e pelos estudiosos. Assim: (...) auditoria externa obrigatória, através de firmas devidamente fiscalizadas e registradas no Banco Central, e sujeitas à responsabilidade civil e criminal por seus pareceres, com a supressão do Conselho Fiscal (atribuições transferidas ao Conselho de Administração...)".
} 
A idéia da transferência de algumas responsabilidades para o conselho de administração e para a auditoria independente prosperou e mantêm-se na lei até hoje. ${ }^{113}$ Entretanto, a supressão do conselho fiscal foi, pode-se dizer, parcialmente aceita com a inserção do conceito de instalação do conselho fiscal.

O novo regime da Lei das S.A., em modificação do modelo do Decreto 2.627, organizava aperfeiçoamentos na estrutura do conselho fiscal, mas, insistia, como ainda insiste, em premissas que até hoje fazem retornar ao instituto as críticas de outrora, renovadas por textos de desconfiada esperança.

A grande inovação veio com o conceito de instalação do órgão (artigo 161, caput da Lei das S.A.), a par da obrigatoriedade da auditoria independente para as companhias de capital aberto (artigo $177, \S 3^{\circ}$ da Lei das S.A.). Abriu-se a possibilidade do órgão funcionar quando fosse da conveniência da maioria ou de exercício organizado de potestatividade pertencente à minoria (artigo $161, \S 2^{\circ}$ da Lei das S.A.).

Passou-se a exigir, igualmente, certo nível profissional para o exercício dessa função fiscalizatória, na exigência de formação em "curso de nível universitário" ou "experiência de cargo de administrador de empresa". Sendo um ou outro, o requisito poderia estar cumprido inclusive caso fosse indicado um ex-administrador da própria companhia a ser fiscalizada, sem que nenhum requisito adicional de desincompatibilização ou quarentena incidisse sobre o indicado, propiciando uma mínima assepsia nos conflitos de interesse que esse conselheiro pudesse incorrer em relação aos atos recém-praticados na sua qualidade de administrador da companhia.

Surge na nova lei, ainda, uma margem maior e mais ampla de competências, reforçando alguma atuação individual (o que gerou posteriores controvérsias sobre o caráter colegial do órgão) e casando entre suas funções, a de interferência na relação entre administração e auditor independente, caso a companhia venha a ter auditores contratados. A Lei das S.A. ainda pôs, de forma genérica, nas mãos do conselho de administração, função fiscalizatória concorrente com a do conselho fiscal, além de tornar obrigatória para as companhias abertas, a auditoria

\footnotetext{
${ }^{113}$ No bojo das reformas societárias de 1976, a Lei ${ }^{0}$ 6.385, de 7 de dezembro de 1976, em seu artigo 26, regulou o regime dos auditores independentes em substituição ao rudimentar regime anterior de 1965 (assim entendemos, portanto, que há revogação do sistema do artigo 20, §1 $1^{\circ}$, "b" da Lei n ${ }^{\circ} 4.728$, de 14 de julho de 1965, pelo artigo 26 da Lei $\mathrm{n}^{\circ} 6.385$, de 7 de dezembro de 1976), que veio a se tornar de aplicação obrigatória para companhias abertas, por força do disposto no artigo $177, \S 3^{\circ}$ da Lei das S.A.
} 
independente das demonstrações financeiras, por auditores registrados na CVM na forma do artigo 26 da Lei $\mathrm{n}^{\circ}$ 6.385, de 7 de dezembro de 1976, combinado com o artigo $177, \S 3^{\circ}$ da Lei das S.A.

Dessas mudanças, tornou-se emblemático o início do Capítulo XIII do texto da Mensagem $n^{0}$ 204, de 2 de agosto de 1976, publicada pelo chefe do Poder Executivo de então, o General Geisel, incorporando sem reparos o texto da Exposição de Motivos no 196, de 24 de junho de 1976, editada pelo Ministério da Fazenda, na época chefiado por Mário Henrique SIMONSEN: “As modificações introduzidas pelo Projeto no Conselho Fiscal baseiam-se na experiência da aplicação do Decreto-lei $n^{0}$ 2.627. Na maioria das companhias existentes, todos os membros do Conselho Fiscal são eleitos pelos mesmos acionistas que escolhem os administradores. Nestes casos, o funcionamento do órgão quase sempre se reduz a formalismo vazio de qualquer significação prática, que justifica as reiteradas críticas que lhes são feitas, e as propostas para sua extinção. A experiência revela, todavia, a importância do órgão como instrumento de proteção de acionistas dissidentes, sempre que estes usam do seu direito de eleger em separado um dos membros do Conselho, e desde que as pessoas eleitas tenham os conhecimentos que lhes permitam utilizar com eficiência os meios, previstos na lei, para fiscalização dos órgãos de administração. Daí a solução do Projeto, de deixar ao estatuto da companhia discrição para dispor sobre o seu funcionamento permanente, ou apenas quando solicitado por minorias acionárias (art. 162). Quando não funcionar permanentemente, poderá ser instalado, em qualquer Assembléia Geral, a pedido de acionistas que representem, no mínimo, ${ }^{1} / 10$ das ações com direito a voto, ou $5 \%$ das ações sem direito a voto. Por essa via, seu funcionamento poderá ficar restrito às companhias ou nas épocas em que se justifica, pela existência de minoria societária ativa".

Note-se que o texto deixa duas preocupações claras: a primeira, de que à ineficiência histórica do conselho fiscal, subsiste um mecanismo de "proteção de acionistas dissidentes", e a segunda, de que esse mecanismo só apareceria quando na companhia houvesse "minoria acionária ativa". A percepção que aqui se quer levantar a respeito de uma leitura tergiversada que há muito tempo vem se fazendo do conselho fiscal, como solução para a sua já sabida ineficiência, diz justamente ao tema de nossa premissa principal plantada nos capítulos anteriores desta dissertação. Como órgão de 
fiscalização técnica, o conselho fiscal, por ineficiência na fiscalização, permitiu, durante muito tempo, que a conta negativa dessa fiscalização ineficiente fosse apresentada para o prejuízo de acionistas não controladores e desvinculados da administração. Entretanto, ao invés de consertar as peças da engrenagem do poder fiscalizatório, preferiu-se manter a máquina antiga com alguns pequenos e mínimos aperfeiçoamentos de forma, dando-lhe, entretanto, a possibilidade de funcionar com alta dose de combustível de política societária. A evolução do conselho físcal mostra como as reiteradas modificações na lei retiraram desse órgão a sua marca técnica, imprimindolhe uma nova marca, que hoje é totalmente política e dominada pelo embate maioriaminoria, ${ }^{114}$ que é, como sabemos, um elemento da relação jurídica acionista-assembléia e não propriamente da função fiscalizatória.

$\mathrm{Na}$ época da edição da Lei das S.A., a doutrina, entretanto, não antecipou algumas questões que BULGARELLI pôs na pauta com relação ao conselho fiscal. ${ }^{115}$

\footnotetext{
${ }^{114}$ Em J. L. Bulhões Pedreira e A. LAMY Filho (A Lei das S.A., $2^{\circ}$ vol., Op. cit., Idem, pp. 449-456) a associação do conflito político maioria-minoria com o poder fiscalizatório, permitindo, desta feita, que pudesse ser feita uma interpretação política do conselho fiscal, em detrimento de uma interpretação técnica-funcional, é perceptível. Nesse sentido, nota-se, em tom de novidade, o que, adiante, interpretamos, data maxima venia concessa, como um equívoco conceitual e funcional que paira sobre a função fiscalizatória nas sociedades comerciais: "No âmbito da fiscalização interna, a Lei introduziu talvez sua maior inovação, com a criação do conselho de administração, no qual, pelo sistema de voto múltiplo (art. 141), os minoritários podem ter assento. E a esse Conselho (que não é o fiscal, mas o administrativo) atribuiu, de forma expressa a função de: "fiscalizar a gestão dos Diretores...' [omissis]" (p. 452). Mais adiante, notamos nesta passagem o eixo que proclama uma associação que hoje gera menos benefícios do que o esperado: "Como se vê, a Lei introduziu norma inexistente na lei anterior para assegurar a observância do princípio majoritário, fazendo com que a maioria - como é da essência das companhias - tivesse a palavra final. Mas a Lei não tolheu, por via da composição majoritária do Conselho [Fiscal]", a ação do Conselheiro [Fiscal] eleito pela maioria, e expressamente ressalvou no $§ 2^{\circ}$ do citado artigo 163: " $\$ 2^{\circ}$ - O Conselho fiscal, a pedido de qualquer de seus membros... [omissis]"” (p. 453). Por essas passagens em seqüência pode-se despertar para o problema que é abordado nesta dissertação, a saber, que a falta de preocupação com a identificação do conselho fiscal como órgão técnico e não político e que a preocupação contrária em identificá-lo justamente como instância que reproduz a diametrização política maioria-minoria, vêm afetando sensivelmente a eficácia desse órgão e, por consequiência, a eficácia de sua função. A perda da eficácia da função fiscalizatória em favor de uma burocratização e de uma politização do órgão fiscalizatório principal das sociedades comerciais pode, em um universo mais amplo de companhias abertas, comprometer seriamente a governança de sociedades que envolvem interesses diversos, sobretudo quando se tem em vista companhias abertas de grande porte, muita vez concessionárias de serviço público, com ações negociadas em várias jurisdições.

${ }^{115}$ Lembravam José Alexandre TaVARES GuERREIRO e Egberto LaCERDA TeIXEIRA (Das Sociedades Anônimas no direito brasileiro, volume 2. São Paulo: José Bushatsky, 1979, p. 483) naquele tempo: "Apesar das críticas que o Conselho Fiscal sofreu no passado, a lei houve por bem mantê-lo, disciplinando-o nos artigos 161 a 165, os quais configuram o esforço do legislador em aperfeiçoá-lo, tornando-o um instrumento efetivo de fiscalização da vida societária. Salvo honrosas exceções, na maior parte das empresas, o Conselho Fiscal converteu-se em organismo desprestigiado e inexpressivo, composto, as mais das vezes, por pessoas da confiança direta dos acionistas controladores, que se limitavam a assinar pareceres estereotipados, sem necessidade de efetivamente examinar os livros e papéis da sociedade, seu estado de caixa e carteira, o inventário, o balanço e as contas da diretoria. Assim sendo, o Conselho Fiscal comprometeu a confiabilidade que deveria caracterizá-lo. Espera-se que sua
} 
Das inovações trazidas, nenhuma voz, entretanto, chegou a insurgir-se contra a reciclagem do velho modelo, onde, como lembrou Fran MARTINS, houve ampliação da competência do conselho fiscal, permitindo que suas atribuições passassem da mera revisão contábil para uma fiscalização ampla dos atos de gestão da administração. De maneira mais ou menos uniforme, entendeu-se que essa ampliação era necessária para contrabalançar, na sociedade, a voz da minoria. ${ }^{116}$

Contudo, embora tivesse tardado em alguma instância, logo começaram a surgir, tanto na jurisprudência quanto, e sobretudo, na doutrina, opiniões e textos os mais variados, refletindo, por força de problemas que surgiram na prática ${ }^{117}$, sobre os

nova disciplina seja capaz de reabilitá-lo". A comparação desse trecho da obra de GUERREIRO e TEIXEIRA com a famosa passagem de Eunápio BORGES, para ilustrar o clima de desilusão no antigo sistema e esperança no novo, é também utilizada por Osmar Brina CoRRÊA-LimA (Sociedade Anônima, $3^{\mathrm{a}}$ ed.. Belo Horizonte: Del Rey, 2005, pp. 305-307).

Nesse mesmo sentido, a advertência de Fran Martins (Comentários à Lei das S.A., Volume 2, Tomo I. Rio de Janeiro: Forense, 1978, pp. 421-422) também mostra a reação da doutrina às modificações introduzidas na Lei das S.A. e o tom otimista quanto à possibilidade de plenitude no preenchimento dessa importante função fiscalizatória nas companhias: "A lei revogada, inovando o direito que lhe era anterior, deu uma certa amplitude à atuação do Conselho Fiscal, ao permitir que, além de suas atribuições normais de exame e fiscalização dos livros e papéis da sociedade, e tudo o mais que dissesse respeito à contabilidade da empresa, também pudessem os seus membros 'denunciar os erros ou crimes que descobrirem, sugerindo as medidas que reputarem úteis à sociedade' (Decreto-lei n ${ }^{\circ} 2.627$, art. 127, IV). Saía o Conselho Fiscal de mero exame da contabilidade da empresa para fiscalizar, também, a gestão social, o que fez com que os comentadores da lei exultassem com as novas atribuições do órgão. Infelizmente, entretanto, a simples enumeração de atribuições pela lei não fez com que o Conselho Fiscal tivesse atuação eficiente na vigência da lei revogada, causando decepção àqueles mesmos que haviam louvado a medida adotada na lei mas na prática não seguida pelas sociedades. A má remuneração dos fiscais, a sua subordinação à Diretoria, que em regra indicava sua nomeação à assembléia geral, o afastamento quase completo da sociedade a que serviam, a falta de punição para as omissões praticadas pelo Conselho e prejudiciais a acionistas e terceiros - tudo isso fez com que esse órgão, no direito brasileiro anterior à presente lei, fosse sem nenhuma expressão para a vida da sociedade, inteiramente desmoralizado por servir, quase sempre, de simples testa de ferro da Diretoria, que preparava os seus pareceres, aos conselheiros cabendo apenas assinar onde lhes era determinado". Note-se neste trecho que Fran MARTINS, assim como a grande maioria da doutrina, levanta com clareza os três problemas do Conselho Fiscal na época da transição entre o Decreto-lei 2.627 e a Lei das S.A.: (i) falta de profissionalização (problema que a época transparecia ser decorrente meramente de remuneração pífia e má formação dos conselheiros), (ii) falta de independência (problema que se mantém até hoje e que, nos dias atuais, como se verá, está agravado) e (iii) falta de um regime próprio de responsabilidade civil (problema que permanece ainda na lei atual). Na sequiência do texto, Fran MARTINS segue (Ibidem, p. 422), absorvendo, entretanto, a solução proposta na Lei das S.A.: "A tal ponto chegou a ineficiência do Conselho Fiscal que, ao ser discutida a necessidade de elaboração de uma nova lei para regular as sociedades anônimas, não poucas vozes se levantaram para sugerir a exclusão do mesmo ou sua substituição por outro órgão. Contudo, a nova lei manteve o Conselho Fiscal, ampliando, até, as suas atribuições, de modo a caracterizá-lo como órgão capaz de fiscalizar não apenas a contabilidade da empresa mas, igualmente, atos da administração (art. 163)" (sic).

${ }^{116}$ Vide José Alexandre TAVARES GuERREIRO, "O Conselho Fiscal e o direito à informação", In RDM 45/29-34 [jan.-mar./1982] (sobretudo pp. 31 e segs.). Nesse mesmo sentido, J. L. BUlHÕES PEDREIRA e A. LAMY Filho (A Lei das S.A., $2^{\circ}$ vol., $3^{\mathrm{a}}$ ed.. Idem, pp.450), com o escol de Rodrigo URía, fazem semelhante associação entre o direito à informação dos acionistas e a função fiscalizatória do conselho fiscal.

${ }_{117}$ Nelson Lars EIZIRIK, uma das mais importantes vozes pelo rearranjo das atribuições do conselho fiscal de forma compatível com o escopo das funções fiscalizatórias, lembrou em clássico texto sobre o 
limites de atuação do conselho (ou do conselheiro) fiscal. Na maioria desses textos, os três vetores principais do problema que envolve a ineficiência do conselho fiscal, a saber, profissionalização, independência/politização e estatuto próprio de responsabilidade civil, nem sempre são tratados. ${ }^{118}$

Dos três vetores principais da problemática da fiscalização societária via conselho fiscal, no que se refere ao tema da independência e da politização do órgão, é com BulgARELLI que a análise vai mais fundo. ${ }^{119}$

Historicamente, o conselho fiscal se prestava a dar ao acionista controlador um mecanismo a mais de manipulação das instâncias societárias em favor do exercício de seu poder. Muita vez, essa manipulação era neutra, mas não raro, podia ocorrer em desfavor das minorias e em prejuízo de suas posições patrimoniais. Em defesa de seus interesses, as minorias não apenas passavam a investir mais constantemente na estratégia do abuso do poder de acionista controlador, mas passariam a se utilizar, igualmente, das pequenas searas de segurança que a lei lhes franqueava. O emprego da defesa via abuso do poder de acionista controlador, na linha do que dispõe o rol do artigo 117 da Lei das S.A., necessariamente deve se fazer via ação judicial (ou arbitragem, quando os estatutos assim dispuserem), o que dá uma

tema: "Temos observado, na experiência prática da advocacia empresarial, alguns casos em que acionistas minoritários, com participação social expressiva, elegem representantes seus no Conselho Fiscal com finalidades incompatíveis com o atendimento do interesse social. Tais casos manifestam um entendimento equivocado das funções do Conselho Fiscal, as quais devem ser exercidas dentro dos limites legais, sob pena de eventualmente causar, sua atuação, embaraços ilegítimos à gestão empresarial. Com efeito, tratase de órgão de fiscalização, que não deve ser utilizado como instrumento de pressão indevido, em casos de disputas entre os acionistas" ("Limites à Atuação do Conselho Fiscal", In RDM 84/14 [out.dez./1991]). A essa altura, o texto de EIZIRIK já trazia idéias que estamos aqui reforçando, como o caráter intermediador da função fiscalizatória ("A atuação do Conselho Fiscal é basicamente instrumental, uma vez que visa transmitir aos acionistas as informações de que necessitam, quer para exercerem o direito de fiscalizar a gestão dos negócios sociais, quer para que possam votar, na assembléia geral, com conhecimento de causa" [p.13]; fazendo, neste ponto, expressa referência ao texto de TAVARES GUERREIRO). Entretanto, de forma um pouco diferente daquela exposta por EIZIRIK, afirmou-se aqui que esse escopo de intermediação e instrumentalização decorre, como vimos $\log$ na Introdução desta dissertação, da própria noção técnica de potestatividade.

${ }^{118}$ Dissertaram também sobre o tema, com competência e clareza, sem, entretanto, ter abordado os três vetores sobre os quais aqui se discorrem, Raul de ARAÚJo FILHO e Rodrigo Ferraz CunHA ("Limites de atuação do conselho fiscal", In RDM 129/96-107 [jan.-mar./2003]).

${ }_{119}$ José Anchieta da SILVA (Op. cit., pp. 39-41) passa muito ao largo da questão, enquanto que Carlos Augusto da Silveira LoBo ("Conselho Fiscal da Sociedade Anônima: atuação individual e autônoma de seus membros", In $R D B$ 29/165-182 [jul.-set. 2005]) enfrenta o problema, por meio de parecer, mas já com grande proveito da doutrina bulgarelliana sobre o tema, sem entretanto, explorar a questão da dicotomia maioria-minoria no conselho fiscal com efeitos politizantes sobre um órgão que, em tese, teria funções técnicas a desempenhar. 
única alternativa reativa às minorias e que, haja vista o estado atual da organização judiciária no Brasil, nem sempre célere, eficaz ou tecnicamente adequadas.

Decisões no âmbito societário normalmente são tomadas em instantes e um ato que se enquadre em abuso de poder de acionista controlador, muita vez pode ocorrer de forma que uma reação futura, via ação judicial, possa tornar o remédio, um veneno. A espera por uma decisão final de um ato tomado na administração de uma companhia que venha a ultrapassar um exercício fiscal tem grandes riscos de se tornar absolutamente inefetiva e ineficaz, beneficiando quem o praticou. Quanto à arbitragem, ainda que não se fale nos custos, há de se lembrar que essa forma de exercício jurisdicional fraciona o poder judicante relegando ao mesmo Judiciário as providências referentes a temas urgentes e que possam envolver perecimento de direito (artigo 22, $\S 4^{\circ}$ da Lei $n^{\circ} 9.307$, de 23 de setembro de 1996).

Não havia, pois, no sistema, sob o ponto de vista histórico, mecanismos preventivos de natureza societária e interna na companhia, aptos a frear os abusos de atos praticados pelo acionista controlador. Nesse passo, surge naturalmente a ocupação do conselho fiscal como uma espécie de instância revisora de certos atos, propiciando às minorias um mecanismo interno preventivo para ser usado contra medidas tomadas pelo acionista controlador ou pela administração, que prejudiquem as minorias. As várias mudanças ocorridas na lei ${ }^{120}$ com o intuito de franquear às minorias esse acesso a um mecanismo preventivo e de ação interna na companhia via conselho fiscal, permitiram que esse órgão ampliasse o seu rol de competência, ampliasse o rol da competência individual de seus membros, viabilizasse a identificação direta do conselheiro com quem o elegeu (a ponto de hoje ser quase pacífico falar-se em "conselheiro dos minoritários" e "conselheiro do controlador"), resultando, assim, num tertium genus da política societária, afastando-se, desde anos para cá, definitivamente, de questões técnicas e, sobretudo, do conceito técnico de fiscalização societária. ${ }^{121}$

\footnotetext{
${ }^{120}$ Não apenas na lei, mas também no âmbito infra-legal, há exemplos de mecanismos que facilitaram o acesso do minoritário a mecanismos orgânicos das companhias, expandindo o debate político da assembléia para dentro de órgãos como o conselho físcal. Exemplo dessa política de flexibilização do acesso pode ser vista, de alguma forma, no teor da Instrução CVM n ${ }^{\circ} 324$, de 19 de janeiro de 2000, que flexibilizou os critérios para pedido de instalação do conselho fiscal, relacionando-os ao capital social. No mesmo sentido, vide Parecer de Orientação CVM n ${ }^{\circ}$ 19, de de 9 de maio de 1990.

${ }^{121}$ Não é incomum, como se verá, que se afirme, equivocadamente sob o nosso ponto de vista, que o escopo maior do conselho fiscal é proteger este ou aquele acionista. Essa lição enviesada vê-se presente em doutrina e sobretudo na jurisprudência e reforça um dos maiores males existentes hoje na
} 
A ampliação do rol de competência e a elasticidade da atuação individual é o que, sob o ponto de vista técnico, menos preocupa. Embora a atuação individual possa aparecer como uma quebra no conceito colegial do órgão, a experiência mostra, entretanto, que muita vez ela é necessária, haja vista que nem sempre é possível obter uma decisão colegial (e nem sequer referimo-nos a "consenso"), para a tomada de algum ato de sua competência. Grave, sem dúvida, é o problema da identificação do conselheiro com os acionistas que o indicaram ou o elegeram, pois essa é a premissa básica de uma atuação individual, no conselho fiscal, frequientemente contrária à lei e ao espírito da administração empresarial. E, nesse contexto, a doutrina já vem desenvolvendo extensos e interessantes estudos sobre o tema do abuso das minorias. ${ }^{122}$

E falar sobre os problemas decorrentes dessa identificação do conselheiro com o núcleo que o elegeu é a porta de entrada para a discussão do problema da independência no conselho fiscal. ${ }^{123-124}$

compreensão do conselho fiscal como órgão de fiscalização da sociedade para todos os acionistas e não da administração para um ou outro acionista ou grupo de acionistas em específico. Enxergar o conselho fiscal como órgão de verificação de atos praticados na sociedade pode incluir um dos seus máximos desideratos, a saber, a verificação de contas, que não raro são elaboradas por funcionários e meramente revistas por pequena parte da administração. Algumas companhias brasileiras, sob a jurisdição dos artigos 406 e 407 da Lei Sarbanes-Oxley já têm visto essa responsabilidade de forma bastante diferente da que se prega no Brasil. A respeito dessa doutrina que entende que a finalidade maior do conselho fiscal é trabalhar pelas minorias, vide Fábio BUCCiOLI, "Conselho Fiscal das Sociedades Anônimas como órgão 'sui generis' na Lei n. 6404/76 e no anteprojeto da CVM", In RDM 105/134-143 [jan.-mar. 1997], onde se lê: "A instalação do Conselho Fiscal como órgão de fiscalização tem como fundamento, conforme refere a doutrina, a desconfiança dos acionistas minoritários com relação ao exercício do poder de controle e ao exercício das funções diretivas dos administradores da companhia". Apesar da citação feita a Nelson L. EIZIRIK ("Limites...”, Op. cit., Idem), não se encontra no artigo deste autor a menção expressa a essa situação por meio do uso do termo "desconfiança".

${ }^{122}$ Exemplo claro disso está no brilhante e já citado texto de Lorenz FASTRICH, "Raciocínio Jurídico Funcional...", op. cit., Idem. O tema dos abusos da minoria não são de trato frequente na doutrina brasileira, à exceção de notável parecer formulado por Luiz Gastão Paes de Barros LEÃES ("Abuso da minoria em aumento de capital" In Pareceres, $2^{\circ}$ volume, Op. cit., Idem, pp. 1.211-1.225). O tema é bastante comum, entretanto, nas culturas jurídicas da França, dos EUA e da Alemanha.

Ainda sobre o tema do abuso das minorias por meio do exercício ilegal de poderes fiscalizatórios no conselho fiscal no regime anterior às reformas de 1997 e 2001, Alfredo LAMY FILHO emitiu interessante parecer em 1994, apenas recentemente publicado ("O Conselho Fiscal - Abuso de minoria [1994]", In Temas de S.A.. Rio de Janeiro: Renovar, 2007, pp. 225-234), ilustrando como, no direito comparado, o abuso de minoria é tratado de forma mais extensa do que no Brasil, destacando-se o trabalho de juristas como Marcello Foschini (Itália), Rodrigo Uria (Espanha) e Jean Bergier e Dominique Schmidt (França).

${ }^{123}$ Ao analisar os deveres e responsabilidades dos conselheiros fiscais em leitura subsidiária nos deveres e responsabilidades dos administradores (por força do questionável regime imposto pelo artigo 165 da Lei das S.A.), Bulgarelli ( $O$ Regime Jurídico do Conselho Fiscal das S/A, Op. cit., Idem, p. 61) faz interessante leitura do artigo $154, \S 1^{\circ}$ da Lei das S.A., como a primeira marca de uma contradição antinômica no sistema do regime legal do conselho fiscal no direito brasileiro: "à primeira vista, surge como uma certa desvinculação dos conselheiros, na sua atuação, da origem de que promanaram, vale dizer, de seus eleitores".

Contudo, é forçoso admitir que no uso das regras, o exercício dos direitos freqüentemente ignorava essa norma jurídica impositiva, como bem esclarece BuLGARELLI: "No regime instituído pela Lei 
6.404/76, a atuação do Conselho Fiscal, cujos poderes e responsabilidades advêm diretamente da lei, fazse no interesse geral, justificando certa independência mesmo em relação aos que elegeram seus membros. A previsão legal é de que estes independem daqueles que deram causa à sua constituição efetiva e à eleição de seus membros (cf. art. 165, e $\$ 1^{\circ}$ do art. 154); ora, se tudo isso é certo, é inegável também que aqui há um choque entre o objetivo legal e a realidade das coisas, com o componente psicológico que carrega, pois tem sido difícil obter essa independência tanto da parte dos eleitos pela maioria como pela minoria, persistindo ainda, de ambas as partes, uma tendência a se considerarem representantes de suas forças eletivas" (Ibidem, pp. 66-67).

$\mathrm{Na}$ raiz do problema, BULGARELLI identifica, de forma histórica, o dado que aqui se corrobora: "Será talvez por influência ainda viva do regime do Dec.-lei 2.627/40 que, conquanto previsse a participação dos minoritários no Conselho Fiscal, não estatuía correspondentemente um dever de independência de seus membros tão claramente como hoje estando sua responsabilidade prevista mais difusamente através de equiparação genérica à dos diretores (art. 128). Não havia, por certo, uma clara visão de transparência, o que ensejava as contradições havidas, e que parecem ainda perdurar. A toda evidência, a praxis societária das companhias, assim encarada, não absorveu em profundidade o conteúdo da regra do art. 165 , sobretudo em sua referência ao $\$ 1^{\circ}$ do art. 154". Vale lembrar, nesse caso, como se verá logo adiante que, embora claramente estatuído, o dever de independência é ainda muito frágil, se o compararmos com as regras que regem esse mesmo dever em outras legislações. Não basta, como se verá, que o dever de independência esteja prescrito apenas, por subsidiariedade ao regime do conselho fiscal, no $\S 1^{\circ}$ ao artigo 154 da Lei das S.A. É necessária urgente e sensível reforma no artigo 162 para se neutralizar o embate maioria-minoria dentro de um órgão que, teoricamente, deveria ser eminentemente técnico. Além disso, um regime de responsabilidade próprio do conselho fiscal, que faça referência, inclusive, às sanções aplicáveis no caso de quebra da independência e advocacia de questões políticas ou de interesse puramente pessoal dentro da pauta do conselho fiscal, é mais do que necessário para tornar a fiscalização societária algo digno da eficácia empresarial e merecedor da confiança das minorias.

${ }^{124}$ A Lei $n^{\circ} 10.303 / 01$ fez incidir expressamente no regime do conselho fiscal essa obrigação de desvinculação, por meio da inserção de novo parágrafo, o primeiro, ao artigo 165 da Lei das S.A. Embora essa falsa inovação pareça uma redundância técnica à luz de um regime que já existia por conta da combinação e da interpretação sistemática do artigo 165 complementado pelo $\S 1^{\circ}$ ao artigo 154 da Lei das S.A., a norma acabou sendo inserida por conta de interpretações curiosas, sobretudo nas Cortes Brasileiras, no sentido de que conselheiro eleito pela minoria "integra o órgão na condição de representante da facção minoritária dos sócios" (grifamos; TJSP, $8^{\mathrm{a}}$ Câmara Cível, Ap.C. n 62.520-1, Rel. Des. Arthur de Godoy, j. 6.11.1985, In RT 605/58-59 (março de 1986); citado também por Osmar Brina CoRRÊA-LimA, Op. cit., Idem, pp. 319-321). CORRÊA-LiMA faz também menção a um outro precedente na mesma linha, o chamado Caso Fujiminas (Idem, Ibidem, pp.321-322; TJSP, $1^{\text {a }}$ Câm. Civ., Ap. Civ. No 123.032-1, rel. Des. Luis de Macedo, j. 28.08.1990). Esse mesmo caso recebeu os judiciosos comentários de Domício dos SANTOS NeTo (In RDM 107/205-211). Ainda, nesse mesmo sentido, vide o Acórdão TJSP, AC 131.697-1, $1^{\text {a }}$ Câmara Cível - São Paulo, rel. Des. Roque Komatsu, j. 6.12.1990, In RT 670/77; apud [íntegra] Nelson Lars EIZIRIK. Sociedades Anônimas - Jurisprudência. Rio de Janeiro: Renovar, 1996, pp. 738-740, comentado também por Frederico SimiOnATO ("Conselho Fiscal: Ausência de Legitimação Processual de Acionista para a obtenção de informação em nome do conselheiro", In RDM 109/150-156). O erro conceitual na decisão é notável, pois, ainda que não se leve em consideração o regime imposto pela interpretação sistemática do artigo 165 complementado pelo $\S 1^{\circ}$ ao artigo 154 da Lei das S.A., é de se ver que o conceito de "representação" ou de "mandato societário" não incide, tecnicamente, sobre as funções fiscalizatórias e sobre a competência legal descrita na lei atinente aos membros do conselho fiscal. Dai a importância dos estudos feitos no Capítulo 1, pois, grande parte dos erros de interpretação decorre de uma frágil compreensão de teoria geral do direito e de sua respectiva incidência sobre áreas técnicas do direito, como é o caso do direito societário. O rol do artigo 163 não descreve atos que os conselheiros fiscais devem praticar, em conjunto ou isoladamente, em nome de alguém, mas devem, sim, praticá-los dentro do conceito de função societária, a fim de que informem outras relações jurídicas. Mas isso, definitivamente, não configura ato de "representação" nem qualquer outro tipo de "mandato societário". O desempenho da função no conselho fiscal é de natureza eminentemente técnica e independente, não podendo, jamais, compor elemento político de defesa de interesse particular ou privado, que está na base da "representação" ou de "advocacia de interesses particulares" em um universo societário, e que contraria todo e qualquer conceito de exercício técnico de função fiscalizatória societária. Em outras palavras, ao Conselheiro Fiscal é absolutamente vedado agir em favor de minoria (ou representando interesse de minoria), mas contra e em oposição aos interesses dos demais acionistas ou mesmo da própria companhia, quando fora de um escopo eminentemente fiscalizatório. BULGARELLI é rico complemento quando afirmava: "É importante observar, contudo, que a 
Embora a Lei $\mathrm{n}^{0}$ 10.303/01 tenha tornado explícita essa regra de independência, a legislação não logrou evoluir além dessa explicitação, que mais parece, na verdade, uma redundância técnica. Nas várias reformas que se seguiram, não houve por bem minimizar ou esterilizar o problema do embate político maioria-minoria no seio do conselho fiscal, por meio de normas mais eficazes de desvinculação formal entre eleitos e eleitores, a exemplo de inúmeros outros sistemas legais como o de França, Argentina, Estados Unidos, Alemanha, Portugal e México. ${ }^{125}$

Dessa acurada percepção, pode-se notar, de fato, como os mais sensíveis problemas (e, dentre eles, o problema referente ao embate maioria-minoria e conseqüente politização do órgão) passam por uma eficaz revisão do conceito de independência dos membros do conselho fiscal ao longo da evolução legislativa do tema no Brasil. As reformas que se seguiram à Lei das S.A., tanto a de 1997 quanto a de 2001, não lograram enfrentar essa questão, alterando na lei outros pontos que, misturados ao problema da independência (que permaneceu), fomentaram a politização do órgão, muita vez com mau uso de seus mecanismos na prática societária.

questão não se reduz a saber quem está defendendo o interesse social, pois a minoria poderá ter - como geralmente tem - seus próprios interesses, os quais, embora divergentes do interesse da maioria, nem sempre contrariam o interesse social" (Ibidem, p. 69; nesse mesmo sentido, vide, Ibidem, p. 84).

${ }^{125} \mathrm{O}$ olhar preciso de Bulgarelli (Ibidem, p. 68.) identificou, na esteira de erros cometidos pela Jurisprudência, a contradição pulsante na questão da independência dos membros do conselho fiscal como forma de fomento de politização desse órgão: "Parece assim haver uma certa contradição entre a estrutura e a função do modelo legal. Se o Conselho Fiscal foi concebido como instrumento de proteção à minoria (cujo objetivo, entretanto, serve ao interesse maior e, nesse sentido, está diretamente a serviço da sociedade e não de facções como a maioria, a minoria e os administradores) e se as suas funções não pressupõem nem implicam necessariamente deliberações colegiais unitárias (através da aplicação mecânica do princípio majoritário), a previsão de uma necessária maioria adrede constituída através da outorga ao controlador de um membro a mais do que os outros parece deslocada".

E esse problema da composição, como bem se verá, além de exigir da lei uma aritmética curiosa para preservar o princípio da maioria, abre ainda mais para permissões veladas de quebra de independência e exercício político das funções, em detrimento de um exercício técnico. Por isso e não por outra razão, BULGARELLI afirmava, valendo essa afirmação para a atual conformação da norma após a reforma de 2001, via Lei $\mathrm{n}^{\circ}$ 10.303/01: "O modelo legal aparece assim envolto e enredado em várias contradições, que, na perspectiva sistemática do ordenamento jurídico, podem ser consideradas, pela sua incoerência, como antinômicas, e que, somadas às lacunas apontadas, estão a exigir certas correções, esclarecimentos e até sugestões para eventual reforma legislativa" (Ibidem, p. 70). E, nesse mesmo sentido (Idem, Ibidem, p. 76): "Provenientes os seus membros de duas fontes básicas, o controlador e os minoritários, delas devem se desprender a fim de que, atuando com independência, possam velar para que haja uma boa administração, no interesse geral. A lei, como foi visto, limita expressamente a sujeição de seus membros aos interesses específicos dos grupos de que provieram, impondo, por esse aspecto, o caráter de independência com que devem atuar, robustecendo-a através da enunciação pormenorizada de seus poderes e de um regime de responsabilidades" (itálicos não constam do original). 
A reforma empreendida em 1997 na Lei das S.A., por meio da Lei $\mathrm{n}^{\circ}$ 9.457, de 5 de maio de 1997, alterou poucos pontos referentes ao conselho fiscal, quase nenhum deles de relevância verdadeira.

Além de ter dado atribuição individual de supervisão do trabalho da auditoria independente (atualmente o $\S 4^{\circ}$ ao artigo 163 da Lei das S.A.) e de ter cuidado melhor da remuneração (atualmente o $\S 3^{\circ}$ ao artigo 162 da Lei das S.A.), a reforma de 1997 implementou um regime de revisão externa por peritos que esvaziou, por completo, a alçada técnica que o conselho físcal sempre se supôs ter (atualmente o $\S 8^{\circ}$ ao artigo 163 da Lei das S.A.). ${ }^{126}$ A lei de 1997, ao invés de exigir dos próprios conselheiros fiscais que fossem dotados de melhor capacitação para o exercício de suas funções, sobretudo notório conhecimento técnico sobre direito societário, administração de empresas, finanças e ciências contábeis ${ }^{127}$, aperfeiçoando os lindes de independência e estendendo-os até a figura dos acionistas e das gestões anteriores, criou uma figura funicular à do conselho fiscal, jogando todos os requisitos técnicos e a consequiente responsabilidade civil nessa nova figura chamada perito. Não houve, nessa reforma, sequer discussão a respeito do evidente fato de que essas características que a doutrina preencheu com requisitos é que deveriam, por força de lei, estar expressas na figura do fiscal interno orgânico e oficial.

Esse mecanismo reforçou e muito o papel das auditorias independentes que, além do trabalho de auditoria que já prestavam, por força de lei, às sociedades, passaram a poder oferecer serviços de perito do conselho fiscal para dirimir e arbitrar "questões técnicas" que fugissem do conhecimento dos conselheiros, embora, como a própria lei frisa, sejam necessários ao desempenho da função fiscalizatória e ainda tenham total pertinência com os trabalhos desenvolvidos em um conselho fiscal. A lei passou não apenas a atestar, mas a acomodar a total falta de expertise dos membros do

\footnotetext{
${ }^{126}$ Sobre o intuito dessa norma, Nelson Lars EIZIRIK (Reforma das S.A. e do Mercado de Capitais. Rio de Janeiro: Renovar, 1997, p. 114) assim expôs: "O objetivo da norma contida no $§ 8^{\circ}$ do art. 163 da Lei das S.A. é o de permitir que o Conselho Fiscal exerça suas funções eficazmente; para tanto, é indispensável que os peritos indicados pela administração da companhia atendam a dois requisitos básicos: a) tenham notório conhecimento técnico sobre a matéria; b) sejam independentes frente à companhia. Ou seja, devem os peritos ser qualificados profissionalmente e não comprometidos com a companhia ou seus administradores".

${ }^{127}$ Modesto CARVAlhosa (Comentários à Lei das Sociedades Anônimas, $3^{\mathrm{a}}$ ed., $3^{\text {o }}$ volume. São Paulo: Saraiva, 2003, p. 435) chega a afirmar que "no exercício de sua atividade, o perito observará todas as práticas geralmente adotadas pelos auditores independentes e as respectivas normas profissionais impostas pelos Conselhos respectivos (notadamente o Conselho Federal de Contabilidade) e pela Comissão de Valores Mobiliários", estando, logicamente, o próprio conselheiro livre da imposição e do rigor dessas mesmas normas.
} 
conselho fiscal, em verdadeiro retrocesso ao que se esperaria no endurecimento de exigências que venham dizer respeito à qualidade da função.

Não se chegou a levantar argumentos contra esse verdadeiro despautério $\operatorname{legal}^{128}$, mesmo porque, o objetivo da norma de 1997 , por ser outro ${ }^{129}$, atraiu muito mais a atenção de todos pela visão reducionista que trouxe, do que propriamente pelas incongruências que cometeu. ${ }^{130}$

Não há, da mesma forma, o cotejo dessa curiosa previsão a respeito do repasse de trabalho e funções para "peritos do conselho", diante do princípio da indelegabilidade das funções, previsto para o conselho fiscal no $\S 7^{\circ}$ ao mesmo artigo 163 da Lei das S.A.. Na prática, embora o princípio seja o da indelegabilidade, não é raro ver conselhos fiscais se valendo de peritos para o cumprimento da função prevista, por exemplo, no artigo 163, inciso VI ou inciso VII da Lei das S.A.. Mas o problema mais sério com essa mudança de eixo está no regime de responsabilidade civil adjeto a membros de um órgão societário e, por conseguinte, a peritos (geralmente pessoas jurídicas) contratados no âmbito de sua atuação, sobretudo em caso de "omissão no cumprimento dos deveres". Enquanto que os conselheiros respondem no limite do artigo 165 da Lei das S.A. e, no caso do trabalho de peritos do conselho a responsabilidade é contratual, facilmente se encontra um abismo no caso da "omissão no cumprimento de deveres" quando o ato praticado envolve a atuação de um "perito do conselho fiscal". Ainda que a minuta de contrato havida entre companhia e perito traga

${ }^{128}$ Modesto CARvalhosa (Comentários..., Op. cit., Idem, p. 435) debruçou-se nos requisitos de exercício da função de "perito do Conselho Fiscal" além de dar forte atenção à questão da atuação individual.

${ }^{129}$ Em resumo, e isso é sabido por todos, quis o legislador de 1997 desonerar os processos de desestatização de empresas públicas por meio da supressão temporária, que durou até 2001, do tag along para minoritários em alienações de controle, então previstos no já mutilado artigo 254 da Lei das S.A.. Vide também de Mauro Rodrigues PENTEAdo, “A Lei n ${ }^{\circ}$ 9.457/97 e a tutela dos direitos aos acionistas minoritários", In Reforma da Lei das Sociedades Por Ações [coord.: Waldírio Bulgarelli]. São Paulo: Pioneira, 1998, pp. 18-41.

${ }^{130}$ Embora essa questão tenha passado implicitamente desapercebida para Waldírio BULGARELLI, não deixou ele de lembrar que "a reforma da Lei $\mathrm{n}^{\circ}$ 9.457/97 bem poderia ter aperfeiçoado esse controle fiscalizatório, após mais de vinte anos de vigência do regime instituído pela Lei $\mathrm{n}^{\circ}$ 6.404/76" ("Apontamento sobre o Conselho Fiscal na Reforma da Lei n 6.404/76", In Reforma da Lei das Sociedades Por Ações, Op. cit., Idem, p. 188). Mesmo na atualização da obra Regime Jurídico do Conselho Fiscal... (Op. cit., Idem) para fins de absorção das modificações impostas pela Lei $n^{0}$ 6.404/76, BULGARELLI apresentou poucos comentários a respeito dessa mudança de eixo de atribuições e responsabilidades na função fiscalizatória essencial, passando-a dos Conselheiros para uma figura de "perito do conselho" criada sem uma justificativa satisfatória e convincente até hoje e que tornou-se causa de oneração nos chamados "custos de agência" e "custos de fiscalização". Vale lembrar que há, ainda, quem preveja, tal qual Modesto CARVAlHOSA (Ibidem, p. 435), que existiria um "direito individual" de cada conselheiro de se valer de um perito para o pleno exercício de seu "direito-dever de diligência individual". 
exaustivamente as hipóteses de responsabilidade civil, sem os recortes de praxe, dificilmente haverá responsabilidade civil do conselheiro fiscal ou dos membros do órgão indistintamente, de forma objetiva, por falta de total previsão legal nesse sentido e por imposição de uma responsabilidade subjetiva em que o poder de fiscalizar está nas mãos de uns e os deveres que fundamentam essa potestatividade estão nas mãos de ninguém.

No que se refere à reforma de 2001, a Lei no 10.303/01, embora tenha apresentado poucas modificações no regime jurídico do conselho fiscal, operou-lhe um acirramento na cultura politizante imposta ao órgão, com o agravamento da dicotomia maioria-minoria, sobretudo nas companhias abertas. Entre o que se esperava e o que veio a efeito por meio da Lei $\mathrm{n}^{\circ} 10.303 / 01$, o conselho fiscal no direito brasileiro marcou-se pelo aumento considerável das atribuições individuais dos conselheiros e pela regulação preventiva da prática no uso de informações privilegiadas.

Essa reforma de 2001, mais do que reconhecer os efeitos nocivos da politização do órgão e de sua conseqüente "destecnização", abriu mão, mais uma vez, de regular o grave problema da independência dos membros do órgão, agindo em sentido contrário e estimulando a sua politização. ${ }^{131}$ A começar pelo trâmite do projeto de lei que desaguou no texto da Lei $\mathrm{n}^{\mathrm{o}}$ 10.303/01, a idéia básica era retirar do controlador o poder de eleger a maioria dos membros do conselho fiscal. ${ }^{132}$ Com toda a

\footnotetext{
${ }^{131}$ No texto de lei original encaminhado à sanção presidencial, a Lei ${ }^{\circ}$ 10.303/01 continha adições à Lei $\mathrm{n}^{0} 6.385 / 76$ pelos artigos $27-\mathrm{A}$ e seus parágrafos e 27-B. Seria criado, pela proposta original, o Comitê dos Padrões Contábeis (CPC). Entidade sem fins lucrativos, o CPC seria criado com o objetivo de promover o "estudo, elaboração e divulgação de princípios, procedimentos e padrões de contabilidade". O regimento interno do CPC seria aprovado, em última instância, pelo Ministério da Fazenda, que ficaria encarregado de indicar parte de seus membros. A composição do CPC estaria limitada a 9 (nove) membros oriundos de: (i) órgão regulador do mercado de capitais; (ii) órgão federal de fiscalização do exercício da profissão contábil; (iii) entidades nacionais representativas de quem elabora, audita e analisa as informações e demonstrações contábeis; (iiii) universidades e institutos de pesquisas com reconhecida atuação na área contábil e de mercado de capitais. A composição do CPC poderia ainda ter a interferência do Conselho Federal de Contabilidade e da CVM. Nos termos do proposto $\S 6^{\circ}$ ao artigo $27-\mathrm{A}$, bem como do artigo 27-B, ficava transparente que a possível atuação do CPC poderia se cingir à atividade regulatória das funções técnicas de auditoria e fiscalização societária.

O modelo foi vetado no Poder Executivo por estas razões: "o Capítulo VII-A, a ser incluído pelo art. $5^{\circ}$ na Lei ${ }^{\circ}$ 6.385, de 1976, não pode ser acolhido, porque, ao criar o Comitê de Padrões Contábeis, cria o projeto de iniciativa parlamentar entidade no Poder Executivo, como se depreende da regra constante do $\S 4^{\circ}$ do art. 27-A projetado. A proposta é omissa sobre a natureza jurídica da nova entidade, permitindo que seu regimento a fixe $\left(\$ 5^{\circ}\right.$ do art. $\left.27-\mathrm{A}\right)$. Tendo em vista que da criação deverá advir despesa, e isso porque o regimento desta disporá sobre, inclusive, seus recursos, não pode a iniciativa parlamentar ser aceita (art. 61, $\S 1^{\circ}$, II, $e$, da CF)" (Mensagem n ${ }^{\circ} 213$, de 31 de outubro de 2001).

${ }^{132}$ Para os detalhes dos trâmites legislativos referentes à Lei ${ }^{\circ}{ }^{\circ} 10.303 / 01$, veja o detalhado histórico apresentado por Nelson Lars EIZIRIK e Modesto CARvalhosA. A Nova Lei das S/A. São Paulo: Saraiva, 2002, pp. 330-333.
} 
atenção voltada para a forma de composição do conselho fiscal, uma candente discussão tomou conta do processo legislativo que resultou na reforma de 2001, tendo representantes de acionistas controladores de um lado e representantes de minoritários de outro.

Essa discussão, de todo equivocada, levou para dentro da lei e do conselho fiscal, definitivamente, um caráter político que antes era pressuposto, mas não totalmente admitido. A errônea discussão de ampliação de poderes políticos de minorias em órgão técnicos, com possibilidade de interferência nos fundamentos empresariais da administração, permitiu com que a lei reformada chancelasse um caráter que há muito tempo já vinha evoluindo no conselho fiscal do direito societário brasileiro, mas que ainda teimava em resistir, por força de sua especificidade técnica.

Com atribuições individuais sobre a fiscalização da gestão da companhia, a lei permitiu criar em muitas companhias um robusto nicho de poder ocupado por minorias qualificadas e, porque não, "minorias profissionais", cujo intuito é atender os interesses de seus eleitores. Se antes o artigo $154, \S 1^{\circ}$ da Lei das S.A. era alvo de verdadeiro desprezo no regime de atuação individual no conselho fiscal ${ }^{133}$, o regime imposto pela disciplina do artigo $165, \S 1^{\circ}$ da Lei das S.A. é sempre prejudicado, sob um ponto de vista hierárquico e hermenêutico, pelo "poder da fiscalização individual", que muitos já elevaram ao nível de "princípio jurídico", em vetusta prática de sobrepor o que se acha, àquilo que está escrito na lei.

Desde o curso da tramitação do projeto de reforma da Lei das S.A. de 2001, o acirramento do embate maioria-minoria, agravando a posição do conselho fiscal como órgão político e trazendo mudanças na forma de composição, não permitiu atinar para a lógica básica do direito societário em qualquer nação civilizada, qual seja, a de que a regra da maioria prevalece para fins de formação de uma vontade coletiva da pessoa jurídica administrada e gerida. A idéia de se alterar a composição do conselho fiscal vedando a participação do controlador ou diminuindo-lhe o poder de voto soa tão

\footnotetext{
Nesse sentido, lembrou Luiz Leonardo CANTIDIANo (Reforma da Lei das S.A. comentada. Rio de Janeiro: Renovar, 2002, p. 200): "Foi grande a reação de alguns setores do mercado à idéia de fazer com que a maioria do Conselho Fiscal da companhia pudesse ser eleita pelos acionistas não controladores".

${ }^{133}$ Nesse particular, contrariamente ao que defendia W. BULGARELLI, vide o curioso texto de Claudinei de Mello ("O sexto poder interna corporis da sociedade anônima", In RDM 62/69 [abr.-jun. 1986]), que chegou a se referir pretensiosamente à interpretação de linha bulgarelliana como "mero deleite intelectual".
} 
estranha quanto o contrário, qual seja, suprimir da minoria o direito de voto ou o direito de indicar ao menos um membro. Não quis o legislador e não permite a lógica que o princípio da maioria fosse subvertido na companhia, propiciando a criação de nichos de "controle sobre o controle" ou de "controle do controle". ${ }^{34}$ Entretanto, não faz sentido, também, de outro lado, que o controlador possa ter pleno acesso a esse órgão a ponto de poder exercer influência direta no trabalho dos fiscais, manipulando a sua atuação no exclusivo interesse do acionista controlador ou acobertando falhas da administração.

A democracia é a virtude de governar a meio termo, preservando uma vontade comum e coletiva, qual seja, um sinalagma ou symbolaion, como diriam os gregos. E para que esse meio-termo pudesse existir em sede de conselho fiscal, mais plausível seria que as regras de independência fossem mais rigorosas do que flexíveis as regras sobre atuação individual. Seria importantíssimo que o legislador de 2001 pudesse compreender que, sem prejuízo de quem elege e em respeito à regra da maioria que caracteriza o poder de controle, faria muito mais sentido que os requisitos de incompatibilidade para o cargo fossem estendidos para: (i) a pessoa dos acionistas, incluindo o próprio controlador e as minorias, e (ii) os ex-administradores da companhia que tenham atuado nos cinco exercícios anteriores à assembléia de eleição dos conselheiros fiscais. ${ }^{135}$ Com uma previsão legal como essa, pouco iria importar quem

\footnotetext{
${ }^{134}$ Discordamos, portanto, data maxima venia concessa, da posição de SIMIONATO ("Conselho Fiscal: Ausência de Legitimação Processual...”, Op. cit., Idem, p. 153), que afirma: “O postulado é simples: você pode julgar e administrar por maioria, porém, fiscalizar não". Mais uma vez, salientamos: a importância de se "fiscalizar por maioria" perde sentido se as regras de independência e responsabilidade forem severas e rigorosas. Assim, pouco importa quem fiscaliza, desde que fiscalize adequadamente, honestamente e sem influência de conflitos de interesse patentes, aparentes, potenciais ou ocultos. Para se ter uma noção da importância de se suscitar a discussão de conflito de interesses num universo de conselho fiscal absolutamente independente, basta imaginar o debate oriundo do Inquérito Administrativo CVM TA/RJ2002/1153, sobre atos praticados pela SISTEL e pela PREVI, acionistas da Tele Norte Leste Participações S.A., aplicada a atos de físcalização exercidos por membros do conselho fiscal (sobretudo os atos praticados individualmente). Num sistema de rígida independência de conselho fiscal, fatalmente a discussão "maioria-minoria" migraria, com mais lógica, para a investigação sobre a existência de fiscalização em conflito de interesse ou não. Para uma acurada análise do tema, vide os comentários de Erasmo Valladão Azevedo e Novaes FrAnÇA a essa decisão ("Conflito de Interesses: Formal ou Substancial? Nova decisão da CVM sobre a questão", In RDM 128/225-262 [out.-dez. 2002]).

${ }^{135}$ Com muita razão e não de forma diferente, entende a doutrina que as vedações de acesso a cargos no conselho fiscal não atingem a pessoa do controlador, nem tampouco os demais grupos de acionistas que se empenham em eleger outros membros no conselho fiscal. Os obstáculos de acesso e as restrições previstas em lei fazem referência a empresas controladas e, ao se tratar de "sociedade controlada ou do mesmo grupo" ( $\$ 2^{\circ}$ ao artigo 162 da Lei das S.A.), pretende a norma aludir a grupos de direito, nos termos dos artigos 265 e seguintes da Lei das S.A. Exclui-se dessa restrição o controle exercido por meio de grupo de fato, haja vista que a norma, por sua natureza restritiva, neste pormenor, deve ser interpretada restritivamente, não apenas por se tratar de uma norma excepcional, mas por se tratar de mecanismo de redução de direitos e poderes. E para que essas reduções funcionem plenamente, é necessário que a norma traga a restrição de forma clara, precisa e sobretudo expressa. Vide também parecer de Nelson Lars EIZIRIK, "Conselho Fiscal - Composição - Impedimentos - Interpretação do $\$ 2^{\circ}$ do art. 162 da Lei
} 
elegesse os Conselheiros Fiscais, se se pudesse confiar que os eleitos não guardariam relação de dependência com seus eleitores. Como a lei não quis desvirtuar o princípio da maioria, mas sim garantir que o eleito pudesse estar em condições de fiscalizar com isenção, muito mais sentido faria que o "elo de representação" fosse quebrado por meio de sérias e rígidas regras de incompatibilidade, inelegibilidade e impedimentos.

Ademais, para que se pudesse ter uma margem de confiabilidade exata sobre os membros que estivessem no exercício de uma fiscalização societária, tanto da parte dos controladores quanto da parte dos acionistas não-controladores ou minorias, carece-se de um regime exato de responsabilidade civil que impere sobre a atuação dos membros do conselho fiscal de forma a delimitar a sua atuação e os atos danosos causados à companhia e aos acionistas devidos por omissão ou comissão. Um regime de responsabilidade analógico, pautado por um regramento voltado para funções executivas e administrativas não se presta, e isso a jurisprudência e doutrina já atestam, para cobrir a atuação de membros de um órgão societário que exerce funções fiscalizatórias e, portanto, funções de natureza completamente distintas e absolutamente opostas às funções executivas, administrativas e gerenciais.

Assim, além da total perda do contexto técnico em que se insere o conselho fiscal e a função fiscalizatória numa companhia, a reforma de 2001 perdeu a oportunidade de ajustar as regras de "governança corporativa" no Brasil em linha com as demais legislações, agravando, por tabela, o estado de contaminação política de um órgão cuja função necessita ser eminentemente técnica, sob pena de ineficácia e ineficiência.

das Sociedade Anônimas", In Temas de Direito Societário. Rio de Janeiro: Renovar, 2005, pp. 39-52: “O legislador, dessa forma, estabeleceu critérios objetivos, elencando uma série de circunstâncias em que o conflito é inerente, isto é, em que há uma presunção absoluta da existência de conflito" (negritos no original, p. 47). Desta forma, e por isso, defende-se aqui que essa presunção absoluta da existência de conflito seja expressamente ampliada na lei.

Vale lembrar, entretanto, que já em 1973, ainda quando vigente o Decreto-lei 2.627, brilhante texto de Benedito Garcia HILÁRIO ("Conselho Fiscal da Sociedade Anônima”, In RDM 12/55-70 [1973]) tratava da importância da independência dos membros do conselho físcal. Prelecionava HILÁRIO, sobre a "Importância do Conselho Fiscal como órgão independente na gestão administrativa da sociedade anônima", nestes termos: "O Conselho Fiscal é um órgão necessário na administração da sociedade anônima, pela função que lhe cabe, no acompanhamento da probidade com que os negócios sociais devem ser realizados, assegurando aos acionistas plena tranqüilidade, confiança e mesmo certeza, até certo ponto, do acerto da aplicação de seu capital. A necessidade se redobrará quando se tratar de sociedade anônima de capital aberto, onde estará em jogo a poupança popular, cuja fragilidade das condições de vigilância pelos proprietários é manifesta, mas cuja integridade deverá estar absolutamente garantida. Nada mais aconselhável do que atribuir a um Conselho Fiscal essa tarefa" (grifamos). 


\section{CAPÍTULO 4: BREVES NOTAS DE DIREITO COMPARADO}

\section{Argentina}

As notas de direito comparado começam, não por coincidência, por uma das mais ricas fontes para o Brasil: a Argentina. A proximidade, a semelhança dos problemas sofridos, o paralelo das economias, a influência ítalo-germânica na construção de uma doutrina jurídica, enfim, muitos dados convergem para a aproximação das duas culturas, que, desafortunadamente e ao mesmo tempo, ainda estão tão distantes.

Embora a Argentina tenha todos esses e outros pontos a favor, raramente logramos, tanto na doutrina jurídica brasileira quanto na doutrina jurídica argentina ${ }^{136}$, a promover esses estudos paralelos. Oxalá possa esta iniciativa contribuir para corrigir a falha apontada.

Em relação à fiscalização societária, a semelhança é ainda maior. Entre Brasil e Argentina, há muitos pontos em comum, mas nos poucos pontos em que as legislações divergem, ${ }^{137}$ há boa fortuna doutrinária de que o Brasil pode, por seu turno, obter vantagem num estudo comparado. Ao contrário de muitos outros países, o tema da fiscalização societária gera, na Argentina, uma quantidade bastante grande de textos, discussões, jurisprudências, constituindo, para esse assunto, uma fortuna crítica admirável. Recentemente, o tema chamou a atenção de VERÓN ${ }^{138}$, CABANELLAS DE LAS

\footnotetext{
136 A. V. VERÓN (Auditoria..., Op. cit., Idem, p. 310), dedica estas quatro singelas linhas ao direito brasileiro: "Con relación al régimen de fiscalización vigente en Brasil, además de las obras especializadas producidas por tratadistas de dicho país (v. gr. CAMPOS BATALHA, NILSON DE SOUZA [sic]. Comentários à lei das sociedades anónimas [sic], vol. 2, Río de Janeiro, Forense, 1978), puede consultarse el comentário de Ferro (FERRO, HÉCTOR R., La ley brasileña de sociedades por acciones, LL, 1978-B-949 y 950)". Os demais juristas citados não dedicam qualquer menção ao direito brasileiro, em sede de direito comparado no tema da físcalização societária, tendo seus estudos focados no direito italiano, citando, com bastante profusão, as lições de Tullio ASCARELLI, bem como nas lições portuguesas, conforme relata VERÓN (Ibidem, p. 312) a respeito dos modelos que se serviram para estruturar o modelo argentino na virada do século XIX para o século XX.

${ }^{137}$ Um ponto importantíssimo de divergência entre os dois modelos em relação às sociedades por ações de capital aberto, diz respeito à possibilidade de fiscalização societária externa estatal, nos termos dos artigos 299 a 307 da lei societária argentina, por um controler de jurisdição atuante na sede da companhia. Esse modelo explica-se por influxos históricos.

138 VERÓn é, sem sombra de dúvida, o mais importante comercialista argentino que se debruçou com profundidade sobre o tema da fiscalização societária. Além da já citada obra publicada recentemente sobre o tema, Auditoria, Sindicatura y Consejo de Vigilancia (Op. cit., Idem), VERón tratou com muita competência e erudição sobre o tema da fiscalização societária em seus La sindicatura y el delito de
} 
Cuevas $^{139}$, Richard e Muiño ${ }^{140}$, MARTOREll ${ }^{141}$ e Chalupowicz ${ }^{142}$. A doutrina clássica argentina, com a atenção de juristas como HALPERÍN (recentemente glosado por Julio Ortaegui) ${ }^{143}$, Rivarola ${ }^{144}$, Malagarriga ${ }^{145}$, Colombres, ${ }^{146}$ Sasot-Betes e SASOT $^{147}$ também marca grande variedade e profundidade no estudo do tema.

Primeiramente cumpre admitir que a Argentina, como o Brasil, tem um sistema de fiscalização societária interna e orgânica, por intermédio de um órgão interno chamado sindicatura, muito semelhante ao nosso conselho fiscal. ${ }^{148}$ Nesse regime de competências, a doutrina argentina busca vários meios de classificação das mesmas, sendo, dentre as mais notáveis, aquelas propostas por HALPERÍN ${ }^{149}$ e VERÓN. ${ }^{150}$

balance falso (Buenos Aires: Astrea, 1981); Nueva empresa y derecho societario (Buenos Aires: Astrea, 1996); Reformas al régimen de las sociedades comerciales (em conjunto com Jorge ZuNINO, Buenos Aires: Astrea, 1984); no tomo IV de seu Sociedades Comerciales (Buenos Aires: Astrea, 1996); Estados contables y libros de comercio (Buenos Aires: Abaco, 1976); Auditoria y sindicatura societaria (Buenos Aires: Errepar, 1997); no tomo II da obra Los Balances (Buenos Aires: Errepar, 1997); Manual de sociedades comerciales (Buenos Aires: Errepar, 1998) e em seu notável (e infelizmente, pouco conhecido) Tratado de los conflictos societarios (Buenos Aires: La Ley, 2006). Para os fins deste trabalho e para o escopo específico de uma análise de direito comparado, faremos uso apenas dos escritos mais recentes desse grande jurista, que se encontram especificamente em seu Auditoria, sindicatura y consejo de vigilancia.

${ }^{139}$ Guillermo CaBAnellas de Las Cuevas é autor de um dos mais recentes e completos tratados de direito comercial argentino, escrito em 32 tomos (Derecho Societario. Buenos Aires: Heliasta, 1996). O tema da fiscalização societária vai tratado no tomo 20, cujo subtítulo é Sociedades Anónimas Sindicatura y Consejo de Vigilancia. O tema vai também tratado nos tomos 4 e 7, cujos subtítulos são, respectivamente, Los órganos societarios e Contabilidad y Documentación Societaria.

${ }^{140}$ Efraín Hugo RichARD e Orlando Manuel Muiño. Derecho Societario, $5^{\mathrm{a}}$ reimpressão. Buenos Aires: Astrea, 2004.

${ }^{141}$ Ernesto Edoardo MARTORELl. Los síndicos de sociedades anónimas y el consejo de vigilancia. Buenos Aires: Depalma, 1991; bem como Sociedades anónimas, 2a ed.. Buenos Aires: Depalma, 1994.

142 Daniel Chalupowicz. Gobierno Corporativo - un enfoque moderno de direccíon para el cumplimiento con la ley Sarbanes-Oxley y prevención del fraude corporativo. Buenos Aires: Buyatti, 2007.

${ }^{143}$ Isaac HALPERÍN. Sociedades Anónimas, $2^{\text {a }}$ ed. (com glosas de Julio OtAEGUI). Buenos Aires: Depalma/LexisNexis, 1998.

${ }^{144}$ Mario A. Rivarola. Sociedades anónimas, Tomo II, $3^{\mathrm{a}}$ ed.. Buenos Aires: La Facultad, 1935, pp. 330-357.

${ }^{145}$ Carlos C. Malagarriga. Tratado elemental de derecho comercial, Tomo I, $1^{\text {a }}$ Parte. Buenos Aires: TEA, 1951, pp. 493-502.

${ }^{146}$ Gervasio R. Colombres. Curso de Derecho Societário. Buenos Aires: Abeledo-Perrot, 1972.

${ }^{147}$ Miguel SASOT-BeTES e Miguel SASOT. Sociedades anónimas: sindicatura y consejo de vigilancia. Buenos Aires: Ábaco, 1986.

${ }^{148}$ Cf. Artigos 284 a 298, do Decreto-Lei 19.550, de 1972.

${ }^{149}$ HALPERÍN (Sociedades Anónimas, Op. cit., Idem, pp. 631 e segs.), ao explicitar que "la actuación del síndico se concreta a un control de legitimidad" (p. 631), advertindo, antecipadamente, quanto aos limites de atuação em relação à fiscalização de gestão, assim divide as tarefas dos síndicos, de forma categorizada: (i) atos de controle regular (ex.: exame de livros, presença nas reuniões da diretoria); (ii) atos de integração administrativa (ex.: elaboração de parecer para a assembléia, fiscalização da liquidação); e (iii) atos de integração de gestão (ex.: convocação de assembléia, inclusão de assunto na pauta de assembléia).

${ }^{150}$ VERÓN (Auditoría..., Op. cit., Idem, pp. 393 e segs.) propõe a seguinte classificação: (i) atividade de controle da administração (ex.: fiscalização rotineira da administração por força do inciso 1 do artigo 294 da Lei 19.550); (ii) controle contábil (ex.: verificação do estado de caixa); (iii) controle dos órgãos sociais 
Historicamente, assim como ocorreu no Brasil, a Argentina provou diversos problemas que afetavam a eficácia do órgão e que, não por coincidência, fez com que a doutrina argentina também se referisse ao consejo como “órgão inútil”. ${ }^{151}$

As semelhanças ficam por ai, portanto: restritas à forma e à estrutura. No que se refere às exigências e os detalhes de funcionamento, a doutrina argentina apresenta um modelo mais cuidadoso.

A lei argentina reconhece como obrigatória a fiscalização, mas uma vez assumida a estrutura de gestão via consejo de vigilancia, a companhia poderá prescindir da sindicatura, desde que venha a contar com auditoria independente para fins de controle contábil (artigo 283 do Decreto-lei 19.550). ${ }^{152}$ No caso das companhias abertas, comitê de auditoria com critérios de independência deve ser constituído por conselheiros eleitos na assembléia, conforme dispõe o artigo 15 do Decreto 677 de 2001.

Tal qual no Brasil, a sindicatura é um órgão interno, cujos membros são eleitos por acionistas e cujas funções, descritas no artigo 294 da Lei $19.550^{153}$, guardam

(ex.: presença em reuniões); (iv) atividade informativa (ex.: elaboração e apresentação de parecer na assembléia); (v) assistência aos acionistas (ex.: tratamento de denúncias) e (vi) funções contingentes (ex.: manifestação em caso de mudanças estruturais, como mudança de sede, fusão, cisão, transformação, redução de capital, liquidação).

151 Apanhado histórico da evolução do instituto é apresentado com detalhes por A. V. VERÓN (Auditoría..., Op. cit., Idem, pp. 309-317). É de RIVAROLA, entretanto, a afirmação que se assemelha muito a outras afirmações feitas no Brasil com relação à eficácia do conselho fiscal: "Del cuadro de objeciones que queda hecho debe concluirse que la sindicatura instituída por la ley, si no es inútil, por lo menos no llena los fines que tuvieran en vista los autores del proyecto de nuestro código, y que en la práctica es ineficaz. Es preferible sustituirla por una mayor publicidad y un mejor sistema de información de los accionistas, como sería la actividad que bajo la ley inglesa desarrollan los auditors".

${ }^{152}$ Essa medida evita choques entre órgãos e desnecessário acúmulo de funções, com desdobramentos nos conflitos de atribuição, já típicos em direito societário, mas imperceptíveis para os olhos dos técnicos. Vide, nesse diapasão, A. V. VERÓN (Auditoría..., Op. cit., Idem, pp. 751-754). A respeito dos conflitos de atribuição, trataremos em momento específico logo adiante neste trabalho.

${ }^{153}$ Diz o artigo: "Son atribuciones y deberes del síndico, sin perjuicio de los demás que esta ley determina y los que le confiera el estatuto: 1) fiscalizar la administración de la sociedad, a cuyo efecto examinará los libros y documentación siempre que lo juzgue conveniente y, por lo menos, una vez cada tres (3) meses; 2) verificar en igual forma y periodicidad las disponibilidades y títulos valores, así como las obligaciones y su cumplimiento; igualmente puede solicitar la confección de balances de comprobación; 3) asistir con voz, pero sin voto, a las reuniones del directorio, del comité ejecutivo y de la asamblea, a todas las cuales debe ser citado; 4) controlar la constitución y subsistencia de la garantía de los directores y recabar las medidas necesarias para corregir cualquier irregularidad; 5) presentar a la asamblea ordinaria un informe escrito y fundado sobre la situación económica y financiera de la sociedad, dictaminando sobre la memoria, inventario, balance y estado de resultados; 6) suministrar a accionistas que representen no menos del dos por ciento (2\%) del capital, en cualquier momento que éstos se lo requieran, información sobre las materias que son de su competencia; 7) convocar a asamblea extraordinaria, cuando juzgue necesario y a la asamblea ordinaria o asambleas especiales, cuando omitiere hacerlo el directorio; 8) hacer incluir en el orden del día de la asamblea, los puntos que 
alguma proximidade com o nosso artigo 163 da Lei das S.A. Além disso, as funções se estendem a exercícios anteriores ${ }^{154}$. O sistema de responsabilidade faz referência às normas aplicáveis ao regime da administração, entretanto, a doutrina e a jurisprudência dão-lhe trato específico, integrando, a essas prescrições legais, as peculiaridades específicas do cargo de fiscal interno da companhia. ${ }^{155}$

As diferenças chegam logo que se inicia o estudo da conformação do órgão fiscalizatório. De início, o órgão deve ser sempre composto por número ímpar, em se tratando de sociedades de capital aberto. É sempre, para as companhias de capital aberto, órgão de controle necessário, permanente, ${ }^{156}$ indispensável (salvo no caso de constituição de consejo de vigilancia com auditoria externa e comitê de auditoria),

considere procedentes; 9) vigilar que los órganos sociales den debido cumplimiento a la ley, estatuto, reglamento y decisiones asamblearias; 10) fiscalizar la liquidación de la sociedad; 11) investigar las denuncias que le formulen por escrito accionistas que representen no menos del dos por ciento (2\%) del capital, mencionarlas en informe verbal a la asamblea y expresar acerca de ellas las consideraciones y proposiciones que correspondan. Convocará de inmediato a asamblea para que resuelva al respecto, cuando la situación investigada no reciba del directorio el tratamiento que conceptúe adecuado y juzgue necesario actuar con urgencia".. Lembram RICHARD e MUIÑO (com suporte em RIVAROLA [Sociedades Anónimas, Op. cit., Idem, p. 341] e MALAGarRIGA [Op. cit., Idem, p. 460], p. 557, nota 218), que a "ampliación estatutaria no puede desvirtuar sus funciones", o que equivale dizer que, caso os estatutos agreguem competências específicas à sindicatura, essas competências devem estar sempre em linha com a lista de funções tratada pelo artigo 294 da Lei 19.550. Essa questão tem sido muito comum por conta da extensão da competência do conselho fiscal (e, na Argentina, da sindicatura) para sua adaptação ao modelo de fiscalização imposta, por exemplo, pela lei Sarbanes-Oxley, aplicável às companhias argentinas com programa de $A D R$ - American Depositary Receipts registrado perante a US-SEC. Seria plenamente possível que a sindicatura (assim como o conselho fiscal, no Brasil) agregue dentre suas competências a de verificação dos controles internos ou a apuração da efetividade na gestão dos riscos, sem que se entre no mérito desses riscos (vide A. V. Verón. Auditoría..., Op. cit., Idem, pp. 194-195). Aliás, nesse sentido, em direito argentino não é apenas possível, mas recomendável e em alguns casos, obrigatório, que a sindicatura tenha entre suas tarefas a de revisão do controle interno (VERÓN, Ibidem, pp. 83-89 e 194-195, sobretudo quanto ao estudo formulado pelo autor em relação aos impactos legais e doutrinários sofridos na Argentina por força dos eventos que o autor intitula de megafraudes corporativas). Vide também D. ChaLUPOWICZ (Gobierno..., Op. cit., Idem, pp. 21 e segs.)

${ }^{154}$ Cf. artigo 295 da Lei 19.550.

${ }^{155}$ A questão da responsabilidade dos síndicos vem recebendo críticas severas da doutrina, sobretudo no tocante à solidariedade. O primeiro a apresentar críticas ao sistema foi HALPERÍN (Op. cit., Idem, pp. 644 e segs.) com esteio em Suárez Anzorena: "Si la sindicatura es plural, la solidariedad no debe regir, porque la violación de los deberes es personal. No se toma en cuenta que cuando es plural es colegiada (artigo 290), y que por lo tanto la decisión es mayoritaria y el disidente debe proceder conforme al artigo 274, párr. $2^{\circ}$ - ver artigo 298 -; y actuar como prevé el artigo 290, in fine".

VERÓN (Auditoría..., Op. cit., Idem, pp. 561) expõe, também, as fragilidades do sistema argentino com base em casos polêmicos recentemente julgados na Argentina entre 1996 e 1999. Fazendo côro a HALPERÍN, sem citá-lo diretamente, VERÓN lembra os parâmetros interpretativos do artigo 297 da Lei 19.550 devem seguir a experiência sedimentada das teses sobre a interpretação do artigo 2407 do Código Civil Italiano, por ser a lei argentina "una suerte de calco" da lei italiana (p. 563) "el juicio sobre la existencia del nexo de causalidad entre la omissión de vigilancia, de conformidad con las obligaciones de su cargo, por parte del síndico, y la producción del daño comprobado por efecto del comportamiento de los directores, pertenece al juicio de mérito y no es censurable su legitimidad si de modo congruente es correctamente motivado" (p. 564). Vide também as judiciosas e bem fundamentadas críticas de G. Cabanellas de las Cuevas (Derecho Societário, vol. 4, Op. cit., Idem, pp. 687-694).

${ }^{156}$ Inexiste, na lei argentina, o conceito brasileiro de "órgão não permanente" ou de "órgão dependente de instalação". 
colegiado $^{157}$ e de caráter colateral ${ }^{158}$. Para RICHARD e MuIÑO, essas afirmações, em sede de direito argentino, já fazem parte de um lugar comum, sendo muito mais relevante lembrar que a sindicatura "tem uma estrutura preordenada pela lei e uma função preestabelecida a fim de salvaguardar o patrimônio social e garantir a lisura na gestão". ${ }^{159}$ Desponta na doutrina argentina, acompanhada por estruturas mais rígidas encontradas na lei desse país, a insistência na característica da independência dos membros da sindicatura. Os doutrinadores, de forma unânime, interpretam a lei argentina no sentido de que os síndicos não são mandatários da sociedade nem dos acionistas. ${ }^{160}$ E é nesse particular que reside uma das maiores diferenças entre a lei

\footnotetext{
${ }^{157}$ Legislação, complementada pela doutrina, deixam bem claro que a sindicatura é sempre órgão colegiado e que decide por maioria (vide I. HALPERÍN, Op. cit., Idem, p. 619). Entretanto, isso não exclui que os membros da sindicatura desempenhem tarefas individualmente, o que, nesse caso, não deve ser entendido que aos síndicos poderia caber algum poder de atuação individual, como ocorre no Brasil (vide VERÓN, Auditoría..., Op. cit., Idem, p. 374). A preocupação que a doutrina argentina guarda em relação à atuação individual dos síndicos diz muito mais respeito ao conceito de indelegabilidade de funções (cf. artigo 293 da Lei 19.550) do que propriamente à possibilidade do síndico atuar fora do contexto colegiado, em nome deste ou daquele acionista. O caráter colegial é ainda reforçado por uma característica que, parecendo superficial, dá nota da grande importância que o órgão tem em sua característica plural: dispõe o artigo 290 que "cuando la sindicatura fuere plural, actuará como cuerpo colegiado, y se denominará 'Comissión Fiscalizadora"'. Note-se que, toda vez que a sindicatura se faz atuar por mais de um membro, ela necessariamente muda de nome. Considerando que nas sociedades de capital aberto, os órgãos de fiscalização interna são sempre colegiados, para efeitos da lei, a mudança de nome ocorre sempre, marcando não somente um aspecto formal, mas também de conteúdo.

${ }^{158}$ Pois, nos dizeres de RICHARD e MuIÑo (Derecho Societario, Op. cit., Idem, p. 554), "no promueve la actividad social, sino que busca asegurar su regularidad". Vide, no mesmo sentido, I. HALPERÍN, Op. cit., Idem, pp. 617-621.

${ }^{159}$ Cfr. texto original, Ibidem, p. 554: "tiene una estructura pre-ordenada por la ley y una función preestabelecida a salvaguardar el patromonio de la sociedad y a garantizar la corrección de la gestión".

${ }^{160}$ Vide I. HALPERÍN, Op. cit., Idem, p. 620. HALPERÍN ainda entende que a vinculação entre os síndicos e a sociedade se dá pelas regras do contrato de locação de serviços (Ibidem, p. 628). Essa afirmação nos parece absolutamente questionável, pelos exatos mesmos motivos que excluem a aplicação das regras atinentes ao contrato de mandato à relação entre síndicos (e, por conseguinte, conselheiros fiscais) e sociedade. A vinculação é de natureza societária e não cabe observar, nessa relação, analogias com o direito contratual (que ASCARELLI trata como contratos de troca), onde os princípios da autonomia da vontade, livre negociação de disposições, limitações de responsabilidade e responsabilidades ex contrato e in contrahendo regem a interpretação de relações jurídicas instituídas sob o direito contratual. Nesse sentido, vide pertinente observação de G. Cabanellas de las CueVas (Derecho Societario, vol. 4., Op. cit., Idem, pp. 683-684) que ressalta o caráter eminente orgânico da relação existente entre sindicatura e sociedade: "existe así, en relación con los integrantes del órgano de fiscalización, una vinculación básica e necesaria, resultante de la designación del integrante del órgano de fiscalización y por su aceptación del cargo. La relación que así nace es fundamentalmente orgánica y hace que el integrante de la sindicatura o consejo de vigilancia tenga las atribuiciones, obligaciones y responsabilidades inherentes a la participación en esos órganos". Adicionalmente (Idem, p. 684), arremata: "Si, en adición a la relación básica orgánica existe una locación de servicios, la remuneración deberá fijarse dentro del marco contractual propio de tal locación". A respeito de eventual conflito entre o sistema societário e o sistema contratual, dispõe, em nota (Idem, p. 684, nota 126): "Estos casos no plantean mayores dificultades ocasionadas en el conflicto potencial entre las normas societarias y las de las locaciones de servicios. Para que estas últimas sean aplicables, tiene que haber una relación entre el síndico y la sociedad que exceda el marco puramente orgánico. En estos casos poderá entonces distinguirse entre la remuneración del síndico en cuanto tal, que será fijada conforme el artículo 292 de la LSC, y la remuneración por las prestaciones adicionales del síndico, que se regirá por las normas de locación de servicios".
} 
brasileira e a lei argentina: nos critérios de incompatibilidade e inabilitação para o cargo, bem como nos requisitos específicos para assunção das funções.

Dentre os requisitos, dispõe a lei argentina que, para ser síndico de uma sociedade por ações de capital aberto, deve o candidato, além de ostentar "domicílio real no país" (qual seja, efetivamente residir na República Argentina), ser advogado ou contador público. ${ }^{161}$ Além disso, permite a lei argentina que o munus seja exercido por pessoa jurídica, a saber, "sociedade civil com responsabilidade solidária constituída exclusivamente por esses profissionais". ${ }^{162}$

Sobre os critérios formais de independência, podemos destacar, na legislação argentina, que os impedimentos alcançam não apenas as sociedades controladas, mas também o acionista controlador, seus diretores, gerentes e funcionários, bem como os respectivos cônjuges e parentes consangüíneos destes, em linha reta e os colaterais até quarto grau, e os parentes por afinidade até o segundo grau. Além desses, os inabilitados para o exercício de administração também ficam inabilitados para o exercício da fiscalização.

VERÓN (Auditoria..., Op. cit., Idem, pp. 322-323), em linguagem muito técnica e acurada, explicita que a sindicatura comporta uma relación sinalagmática plural y compleja, para expor que "en la sindicatura, el sinalagma importa una concatenación entre las obligaciones asumidas por ésta, los accionistas, los administradores y la sociedad, o sea que cada uno de ellos asume obligación mientras los otros asumen otras de distinta clase". Nesse sentido, VERÓN faz recuperar o sentido vetusto da palavra synalagma, que no grego antigo assumia um caráter mais plurilateral do que o sentido mútuo e bilateral de que hoje se revestiu, para o qual o grego antigo tinha na palavra symbolaion a melhor expressão. VERÓN, por seu turno (p. 380) aceita essa natureza, bem como admite a possibilidade do síndico acumular funções na qualidade de prestador de serviço, sem que isso pudesse implicar quebra da independência (pp. 521-524), por força, principalmente, das proteções de regras de independência e de tratamento de conflitos aplicáveis aos advogados e contadores (p. 524), os dois únicos profissionais capazes de assumir cargo em sindicatura. Entretanto, data maxima venia, é estranho não haver na legislação argentina disposição expressa que vede essa acumulação de funções, pois nos parece existir, nesses casos, um conflito de interesse formal que não pode ser suplantado por critérios subjetivos ou um julgamento "caso a caso" (nesse sentido, o próprio VERÓN em ambos os volumes de seu Tratado de los conflictos societarios..., [Op. cit., Idem, no Volume 1, ao tratar dos problemas de "controle e informação", bem como no Volume 2, ao tratar sobre os conflitos oriundos da responsabilidade dos síndicos] bem como no Auditoría... [Op. cit., Idem, pp. 544 e segs., sobre as proibições de contratar com a sociedade] transparece alguma contradição). Melhor, nesse sentido, a legislação brasileira, cuja vedação para prestação de serviços pelo conselheiro fiscal se encontra mais assentada, por critérios objetivos de conflito de interesses, já que há a possibilidade de haver duplo interesse agindo sobre uma mesma e única relação (remetemos, dentro desse contexto, ao estudo de Erasmo V. A. N. FrançA, "Conflito de Interesses: formal ou substancial? ...”, Op. loc. cit., Idem, mais especificamente nas pp. 247 e segs.).

${ }^{161}$ Ao contrário da lei brasileira, a lei argentina não permite que qualquer diplomado possa exercer o ofício de síndico ou fiscal de uma sociedade comercial (seja ela por ações, de capital aberto ou fechado).

${ }^{162}$ Este é outro tema que gera muita polêmica na doutrina e jurisprudência argentina. Vide VERÓN (Auditoría..., Op. cit., Idem, pp. 367-369); G. Cabanellas de las Cuevas (Derecho Societário, vol. 4, Op. cit., Idem, p. 709). 
Ademais, a eleição dos síndicos pode ser feita: (i) pelo critério chamado eleição por classes, garantidas, às diversas classes, a eleição em separado de um síndico; (ii) pelo modelo do chamado voto acumulativo, semelhante ao nosso sistema de voto múltiplo $^{163}$. Os síndicos, na legislação argentina, ainda podem ser eleitos para um mandato de até três exercícios, podendo sua destituição ocorrer ad nutum, em qualquer tempo, somente por meio da assembléia, desde que não haja oposição de acionistas representantes de pelo menos cinco por cento (5\%) do capital social. ${ }^{164}$ Leva vantagem a legislação brasileira no tocante à regulação da remuneração. ${ }^{165}$

\section{México}

O México, tal qual a Argentina e o Chile, é, culturalmente, um dos países de maior proximidade com o Brasil. ${ }^{166}$ México e Brasil tiveram colonizações muito parecidas, momentos históricos muito semelhantes e hoje gozam de uma economia e de um sistema jurídico muito próximos, para efeitos comparativos. Além disso, de todos os países latino-americanos, o México é o que mais sofre, sob o ponto de vista da cultura jurídica, a influência dos parâmetros da common law estado-unidense, fato esse que vem se tornando cada vez mais comum no meio jurídico brasileiro. Dessa experiência peculiar, há muitas lições de que podemos nos valer.

\footnotetext{
163 A questão da possibilidade de eleição dos síndicos por voto acumulativo [voto múltiplo] envolve igualmente o problema da demissão ad nutum e de sua restrição, com relação aos síndicos eleitos nesse sistema. VERÓn (Auditoría..., Op. cit., Idem, p. 601), com apoio em SASOT-BeTES e SASOT e em ZAMENFELD, sugere que a eleição por voto acumulativo necessita gerar maior estabilidade no cargo de síndico, havendo na lei argentina "un contrasentido legislativo que debe ser reparado cuanto antes".

${ }^{164}$ Salvo, por uma questão lógica e não prescrita na lei, mas admitida na doutrina em casos de eleição por voto acumulativo [voto múltiplo].

165 Além de especificar valores mínimos compatíveis com a função, a lei brasileira regula critérios aplicáveis para a contratação de auxiliares, bem como o reembolso de despesas no exercício de suas funções. A lei argentina trata muito superficialmente da questão da remuneração, deixando o tema muito aberto e livre para diversas formas de interpretação. A Lei 19.550, em seu artigo 292, dispõe: " $L a$ función del síndico es remunerada. Si la remuneración no estuviera determinada por el estatuto, lo será por la asamblea". Essa abertura permite que a doutrina crie sistemas e modos para se convencionar por critérios de remuneração nem sempre convenientes com princípios e requisitos de independência, como, por exemplo, a possibilidade de participação nos lucros que, data maxima venia, entendemos ser totalmente inconveniente para o munus de fiscal de uma companhia (em sentido contrário, defendendo a possibilidade dos síndicos participarem nos lucros, vide, VERón, Auditores..., Op. cit., Idem, pp. 385386).

${ }^{166}$ É fato incontestável que esses quatro países latino-americanos são, dentre todos os demais, aqueles com maior presença no cenário europeu e estado-unidense. São os países latino-americanos com a maior quantidade de empresas listadas em bolsas estrangeiras e as nações com quem EUA, Europa, Japão e China mantêm o maior volume no fluxo de capitais. Brasil, México, Argentina e Chile, atualmente, são tão importantes para EUA, Europa, Japão e China, quanto estes últimos quatro o são para os quatro primeiros.
} 
Pesam contra um direito comparado mais efetivo entre Brasil e México, entretanto, vários fatores: o primeiro deles é a falta de intercâmbio e conhecimento mútuo, tanto na parte cultural, quanto em termos de doutrina jurídica e jurisprudência, ainda que a proximidade das línguas e dos sistemas os facilitem. ${ }^{167}$ Age contra essa aproximação outro fator de ordem puramente quantitativa: a doutrina de direito societário no México parece ser menos extensa do que a encontrada sobre o direito societário brasileiro. ${ }^{168}$ Em tema de fiscalização de sociedades, a doutrina mexicana é ainda mais escassa.

Historicamente, a fiscalização nasce no Código de Comercio, de 1884, por meio do chamado consejo de inspeción. A Ley de sociedades anónimas de 1888 suprimiu o caráter colegiado, por influência do direito italiano, ao passo que o Código de Comercio de 1889 reproduziu essa estrutura, que foi integralmente transferida para a atual lei em vigor, que é de 1934, a chamada Ley General de Sociedades Mercantiles.

Quanto à legislação em si do tema em foco, notou-se, na pesquisa, que a legislação mexicana é a mais defasada entre todas, além de ostentar qualidade técnica inferior à legislação brasileira, inclusive. A qualidade técnica do texto legal é, entretanto, compensada pelo alto nível da doutrina mexicana em direito societário, sobretudo por força dos comentários de Joaquín RoDRIGUEZ Rodriguez.

No México, a fiscalização societária é regida pela Ley General de Sociedades Mercantiles, em seus artigos 164 a 171. A Ley General ou LGSM, como costuma ser chamada, tem um texto original de 4 de agosto de 1934, tendo passado por várias reformas, sendo a última de 28 de julho de 2006. Entretanto, na parte sobre a fiscalização societária, as reformas não alteraram o texto original, que permanece o

\footnotetext{
${ }^{167}$ As maiores fontes para o direito mexicano são, em primeiro lugar, o direito argentino e o direito espanhol. Paralelamente e em segundo plano, os mexicanos se apóiam na doutrina italiana e na doutrina francesa. Nota-se participação pequena da doutrina alemã. Há diminutas referências, nas obras de doutrina mexicana de direito societário, à experiência brasileira; ao passo que não há, entre nós, qualquer menção à doutrina mexicana. Uma das poucas menções que se vê ao direito brasileiro na doutrina mexicana está na obra clássica de Joaquín RoDRIGUEZ RoDRIGUEZ. Tratado de Sociedades Mercantiles, Tomo II, 4ª ed.. México: Porrúa, 1971, p. 149.

${ }^{168}$ Dentre as mais recentes obras que abordam o tema (nem todas em consonância com a última reforma de 2006) temos: Miguel Acosta Romero, Francisco de A. García Ramos e Paola García Alvarez. Tratado de sociedades mercantiles con énfasis en la sociedad anónima. México: Porrúa, 2004; Víctor M. CASTRILlón y LUNA. Ley general de sociedades mercantiles comentada. México: Porrúa, 2007, bem como o seu Sociedades mercantiles. México: Porrúa, 2003. Dentre os clássicos da doutrina de direito societário mexicano, além do excepcional Tratado de J. RODRIGUEZ R., destaca-se a recente reedição de José Héctor MACEDO HERNANDEZ (Ley general de sociedades mercantiles anotada, comentada, concordada con jurisprudencia y tesis. México: Cardenas, 1984).
} 
mesmo desde 1934, que, diga-se de passagem, é plasmado no Código de Comercio de $1889 .^{169}$

Nas características, destaca a doutrina que a estrutura responsável pela fiscalização da sociedade incumbe a um único agente ou a um grupo de agentes chamados comisarios (artigo 164), que apesar do dispositivo legal expor que são agentes "temporarios y revocables" ("temporários e demissíveis a qualquer tempo"), são investidos de função de caráter permanente e personalíssima, podendo ser sócios ou não da sociedade. ${ }^{170}$

Os comisarios do direito mexicano se assimilam ao nosso conselho fiscal pela própria funcionalidade do órgão, conforme disposto na lista de atribuições prevista no artigo 166 da Ley General. ${ }^{171}$

\footnotetext{
${ }^{169}$ Dentre as inúmeras reformas que o direito societário mexicano aprovou, com vistas a tornar o seu modelo mais moderno e em consonância com as exigências do mercado globalizado, essa de 2006 fez também instituir as chamadas Sociedades Anónimas Promotoras de Inversiones, vulgarmente conhecidas como SAPI, por meio de alterações na chamada Nueva Ley de Mercado de Valores. Trata-se de uma regulação diferenciada para holdings e sociedades de participação, aptas a atrair o precioso investimento estrangeiro. Esse modelo societário tem um regime de fiscalização mais rigoroso do que aquele previsto na Ley general de sociedades mercantiles. A Nueva Ley de Mercado de Valores (artigos 15 e 16), no que se refere ao regime de fiscalização das SAPIs, apresenta a possibilidade de uso alternativo de um comitê de auditoria em contraposição a um comisariado. Caso optem por comisarios, o direito previsto no artigo 165 tem seu critério quantitativo baixado de $25 \%$ para $10 \%$, tornando o critério de independência muito mais rigoroso e com afinidade com os números ostentados pela legislação estado-unidense.

${ }^{170}$ Cf. J. RodRIGUEZ R., Tratado..., Op. cit., Idem, p. 150.

${ }^{171}$ Diz o preceito legal mencionado: "Son facultades y obligaciones de los comisarios: I - cerciorarse de la constitución y subsistencia de la garantía que exige el artículo 152, dando cuenta sin demora de cualquiera irregularidad a la Asamblea General de Accionistas; II - exigir a los administradores una información mensual que incluya por lo menos un estado de situación financiera y un estado de resultados; III - realizar un examen de las operaciones, documentación, registros y demás evidencias comprobatorias, en el grado y extensión que sean necesarios para efectuar la vigilancia de las operaciones que la ley les impone y para poder rendir fundadamente el dictamen que se menciona en el siguiente inciso; IV - rendir anualmente a la Asamblea General Ordinaria de Accionistas un informe respecto a la veracidad, suficiencia y razonabilidad de la información presentada por el Consejo de Administración a la propia Asamblea de Accionistas. Este informe deberá incluir, por lo menos: A) la opinión del Comisario sobre si las políticas y criterios contables y de información seguidos por la sociedad son adecuados y suficientes tomando en consideración las circunstancias particulares de la sociedad; B) la opinión del Comisario sobre si esas políticas y criterios han sido aplicados consistentemente en la información presentada por los administradores; C) la opinión del Comisario sobre si, como consecuencia de lo anterior, la información presentada por los administradores refleja en forma veraz y suficiente la situación financiera y los resultados de la sociedad; $V$ - hacer que se inserten en la Orden del Día de las sesiones del Consejo de Administración y de las Asambleas de Accionistas, los puntos que crean pertinentes; VI - convocar a Asambleas ordinarias y extraordinarias de accionistas, en caso de omisión de los Administradores y en cualquier otro caso en que lo juzguen conveniente; VII asistir, con voz, pero sin voto, a todas las sesiones del Consejo de Administración, a las cuales deberán ser citados; VIII - asistir, con voz pero sin voto, a las Asambleas de Accionistas; y IX - en general, vigilar ilimitadamente y en cualquier tiempo todas las operaciones de la sociedad.". Note-se ainda que, com relação a essa lista de atribuições e ao modo de desempenho das funções, J. RODRIGUEZ R. (Tratado..., Op. cit., Idem, pp. 145-146) busca distinguir claramente as tarefas de vigilância e controle.
} 
Entretanto, os problemas na lei mexicana parecem ser diversos. Em primeiro lugar, destacam-se os critérios de exercício do cargo, os requisitos e as regras de impedimento e independência, previstas nos incisos do artigo 165, que veda o cargo de comisarios aos funcionários da companhia, aos funcionários de acionistas da companhia com participação superior a $25 \%$ (vinte e cinco por cento) no capital da companhia, bem como de outras companhias em que a companhia fiscalizada participe no capital em valor superior a 50\% (cinquenta por cento). Esse critério, por si só, já é muito mais rígido do que o critério da lei brasileira e, ainda assim, embora se note na lei mexicana um grande esforço para que o critério de independência, no artigo 165, II, alcance acionistas relevantes da sociedade (incluindo eventualmente o acionista controlador e alguns grupos de interesse relevantes), a lei é omissa com relação aos administradores dessas mesmas companhias, sendo essa participação impossível, conforme a doutrina expõe. ${ }^{172}$

São garantidos, por outro lado, os direitos da minoria para nomeação em separado de comisario, conforme dispõem os artigos 171 combinado com o 144. Ainda no tocante aos impedimentos, a lei mexicana é extremamente rigorosa quanto ao parentesco, assim como ocorre nas leis argentina, italiana e francesa: parentes em linha reta sem limitação de grau, em linha colateral até o quarto grau e em afinidade até segundo grau.

Não há, também, na lei mexicana, qualquer estabilidade de função, por força da possibilidade de demissão ad nutum (artigo 164 é expresso ao usar o termo “revocables", qual seja, "demissíveis"). ${ }^{173}$

O regime de responsabilidade também é confuso, pois enquanto o artigo 169 prevê uma responsabilidade estritamente individual, o artigo 171, por referência aos artigos 160 a 163, cria regras de solidariedade por omissão que, para o caso dos administradores, só é elidida se houver denúncia por escrito da irregularidade cometida pelo outro administrador (no caso, comisarios) a qualquer comisario. Qual seja, a única forma que a lei mexicana dispõe para elisão de solidariedade é por meio de denúncia aos comisarios, mas, no caso específico da solidariedade destes, não cria solução para

\footnotetext{
172 Embora a lei não seja expressa nesse tratamento, a doutrina guarda essa característica como pressuposto óbvio de independência, cf. J. RodRIGUEZ R. (Tratado..., Op. cit., Idem, pp. 151-153, sobretudo p. 152).

${ }^{173}$ J. RoDRIGUEZ R. (Tratado..., Op. cit., Idem, p. 156).
} 
sua elisão. ${ }^{174}$ Assim, os comisarios estão sujeitos ao mesmo tipo de ação de responsabilidade que estariam os administradores, ainda que em exercício de funções completamente distintas e opostas. ${ }^{175}$

Além desses problemas, destacamos a infelicidade na terminologia legal e na forma de exposição de algumas regras, que falam, dentre as atribuições (funções) dos comisarios em "facultades" (faculdades) ${ }^{176}$, além de dispor expressamente que os comisarios podem fiscalizar ilimitadamente, em qualquer tempo, todas as operações da sociedade, o que, sabe-se, pode, se levados às últimas, todas e ilimitadas conseqüências, tornar inviável a consecução do objeto social. Adicionalmente, os comisarios são responsáveis pela averiguação da subsistência da garantia de gestão prestada pela administração. Entretanto, eles próprios, comisarios, podem estar sujeitos à prestação de alguma garantia de gestão (conforme dispõe o artigo 171 em conjunto com o 152), sob a qual não haveria, pela lei, órgão a supervisionar a subsistência. ${ }^{177}$

\section{Portugal}

Portugal, em comparação com a Argentina, possui quantidade menor de escritos em tema de fiscalização societária; em comparação com o México, todavia, Portugal ostenta uma amplitude maior de estudos. A qualidade da legislação portuguesa, em comparação com as duas outras anteriores, influi diretamente na profundidade dos poucos textos sobre o tema. Nesse contexto, a doutrina jurídica de direito societário portuguesa que tratou recentemente do tema limita-se, em muitos instantes, a fazer descrição ampla das estruturas da fiscalização societária, mas em outros momentos, entra muito fundo no tema, com crítica sensível em apanhado técnico muito admirável.

\footnotetext{
174 J. Rodriguez R. (Tratado..., Op. cit., Idem, p. 159), neste particular, salienta: "La ley habla de facultades y obligaciones de los comisarios como si fuesen derechos y obligaciones de los mismos. Sin embargo, cada facultad non es un mero derecho, sino también una obligación para el cumplimiento de otros. Más bien puede decirse que son poderes-deberes, ya que en la medida en que puedan invocarlos, deben ejercelos para la mejor atención de sua misión total de vigilancia".

${ }^{175}$ A solução encontrada por J. RoDRIGUEZ R. (Tratado..., Op. cit., Idem, pp. 162-163) vai pela denúncia à assembléia, ainda que se refira a formas de não comunicação de responsabilidade entre comisarios de exercícios distintos. Mantém-se inerte a doutrina com relação a comisarios de um mesmo exercício, de modo que a questão é, no mínimo, aberta.

${ }^{176}$ J. RodRIGUEZ R. (Tratado..., Op. cit., Idem, pp. 158-159).

${ }^{177}$ Cf. J. Rodriguez R. (Tratado..., Op. cit., Idem, p. 160).
} 
$\mathrm{O}$ assunto, na doutrina e jurisprudência portuguesa parece estar mais assentado, com menos conflitos e uma regulação ampla, talvez a mais completa de todas, como lembra MENEZES CORDEIRO. ${ }^{178}$

Em parte, a quantidade reduzida de críticas se explica, e muito também, pela evolução histórica do texto português e dos debates que já foram superados, ${ }^{179}$ levando o modelo português a uma consolidação de temas em reforma ocorrida recentemente em 29 de março de 2006, por meio do Decreto-Lei $n^{\circ} 76-A / 2006 .{ }^{180}$ Desde a edição do Decreto-Lei $\mathrm{n}^{0}$ 76-A/2006 até a conclusão deste trabalho, ao longo destes dois últimos anos, não houve em doutrina portuguesa uma produção muito acentuada de textos sobre o tema da fiscalização societária, como ocorreu na Argentina ou na Itália (como se verá), exceto pelas judiciosas ponderações de MENEZES CORDEIRO e Gabriela de FIGUEIREDO DiAs ${ }^{181}$.

178 “O Direito português das sociedades é o que mais hipóteses organizativas dá às suas sociedades anónimas" (A. MENEZES CORDEIRO. Manual..., Vol. II, Op. cit., Idem, p. 761).

${ }^{179}$ Desde a edição do Código Veiga Beirão, de 1888, que já impunha sérias modificações no Código Ferreira Borges, de 1867, o tratamento do conselho fiscal e dos modelos de fiscalização interna vinham prevalecendo em Portugal, sob um modelo de organização monista. Entretanto, as reformas de 1969 e de 1986 buscaram flexibilizar esse modelo, com forte impacto sobre os modelos de fiscalização societária, a partir da permissão e adoção, em alguns casos, do sistema dualista ou do chamado sistema monista anglosaxão, que guardava algumas sensíveis diferenças para com o sistema monista franco-ibérico (ou, como prefere MENEZES CordeIro, sistema "latino"). Nesse sentido, vide A. MENEZES CORDEIRO. Manual..., Vol. II, Op. cit., Idem, pp. 749-761.

${ }^{180}$ A reforma tratou de acertar muitos pontos na legislação portuguesa e alinhá-la, de forma bastante ousada, aos preceitos mais modernos da chamada European corporate governance e aos critérios da Comunidade Européia para a capacitação integrativa das nações em relação à tolerância legal que cada nação necessita ter para poder receber, em seu meio, a presença de outras culturas vizinhas (vide A. MENEZES CORDEIRO, Manual..., Vol. II, Op. cit., Idem, pp. 755-756).

O referido autor (Manual..., Vol. II, Op. cit., Idem, p. 756) lembra: "A reforma introduzida pelo Decreto-Lei n ${ }^{\circ}$ 76-A/2006, de 29 de Março, pretendeu actuar profundamente no domínio da organização das sociedades anónimas. Trata-se de uma reforma fortemente empenhada na prossecução de certos ideários. Apontemos algumas linhas de força. O legislador de 2006 começa por, neste domínio, exprimir as intenções: de uma revisão aprofundada do governo das sociedades; de alargar às diversas sociedades regras elaboradas para as sociedades por acções admitidas à negociação em mercados regulamentados (na gíria: acções cotadas); de (aparentemente) juridificar o soft law, isto é: as regras assentes em recomendações e regulamentos da CMVM".

${ }^{181} \mathrm{O}$ principal texto sobre o tema é de autoria de Gabriela de FIGUEIREDO DIAS [Fiscalização de sociedades e responsabilidade civil (Após a reforma do Código das Sociedades Comerciais). Coimbra: Coimbra, 2006]. A. MENEZES CORDEIRo trata do tema nos dois volumes de seu Manual (vol. I, pp. 769773; vol. II, pp. 773-781, com foco na sociedade por ações).

São dignos de nota os textos de J. PINTO FURTADO ("Competências e funcionamento dos órgãos de fiscalização das sociedades comerciais") e de Gabriela de FIGUEIREDO DIAS ("Estruturas de fiscalização de sociedades e responsabilidade civil"), ambos componentes do primeiro volume da obra coletiva intitulada Nos 20 anos do Código das Sociedades Comerciais (Coimbra: Coimbra, 2008), escritos em homenagem ao Prof. Vasco da Gama Lobo Xavier. Da mesma Gabriela de FigueIREDo DiAS é o excelente texto "A Fiscalização Societária Redesenhada: independência, exclusão de responsabilidade e caução obrigatória dos fiscalizadores" (In Reformas do Código das Sociedades, vol. $3^{\circ}$. Coimbra: Almedina, 2007; org.: Jorge Manuel COUTINHO DE ABREU). É de bastante relevância puramente teórica 
Para que bem se compreenda o caráter das regras atinentes à fiscalização societária em Portugal, é crucial que se entenda, antes, o alcance da reforma de 2006 no tocante às fórmulas de organização e administração das companhias, sobretudo das companhias abertas, por meio da criação da Societas Europæea. ${ }^{182}$

No âmbito europeu, se reconhecem dois modelos de organização societária, a saber, o chamado modelo dualista (ou germânico) e o modelo monista (ou latino). ${ }^{183} \mathrm{O}$ impacto dessas modificações na legislação portuguesa permitiu abrir largo espectro de possibilidades para a organização das sociedades em Portugal, com influência direta sobre a fiscalização.

No que se refere à fiscalização, a mens legislatoris (para usar um termo do próprio MENEZES CORDEIRO) que orientou a reforma de 2006 em Portugal resultou no texto final do artigo 278, inciso 1 do Código das Sociedades Comerciais nestes termos: "A administração e a fiscalização da sociedade podem ser estruturadas segundo uma de três modalidades: a) conselho de administração e conselho fiscal; b) conselho de administração, compreendendo uma comissão de auditoria e revisor oficial de contas; c) conselho de administração executivo, conselho geral e de supervisão e revisor oficial de contas". 184

É de se notar que, em qualquer modelo proposto, há sempre um órgão encarregado da fiscalização da companhia, ficando o conselho fiscal no modelo da alínea "a", a comissão de auditoria no modelo da alínea "b" e o conselho de supervisão no modelo da alínea "c", sendo obrigatório o auditor independente nos modelos das

para a questão do conflito potencial entre fiscalização e administração, bem como entre fiscalização e poder de controle, a obra de José VASQUES (Estruturas e Conflitos de Poderes nas Sociedades Anónimas. Coimbra: Coimbra, 2007) em que o autor discute, exatamente, sobre as estruturas de poder nas sociedades e sua natureza orgânica, bem como sobre a complexa descrição em torno da tipicidade de alguns conflitos orgânicos. Com proficiente comparação com o direito alemão, encontra-se o texto de Pedro de Albuquerque (Os Limites à Pluriocupação dos Membros do Conselho Geral e de Supervisão e do Conselho Fiscal. Coimbra: Almedina, 2007), onde o autor lança críticas severas à limitação da lei portuguesa no tocante ao número máximo de companhias que um conselheiro fiscal pode assumir concomitantemente.

${ }^{182}$ Dá-nos boa nota sobre o tema António MenEZES CORDEIRo. Direito Europeu das Sociedades. Coimbra: Almedina, 2005, passim; bem como em seu Manual... (Op. cit., vol. II, Idem, pp. 511-512). Vide também J. VASQuES (Estruturas e Conflitos..., Op. cit., Idem, pp. 35-36).

${ }^{183}$ A proposta de reformulação dos modelos de organização das sociedades européias consolidou-se na $5^{\text {a }}$ Diretiva de Direito das Sociedades. Nesse diapasão, vide A. MEnEZES CordeIRo. Manual..., vol. II, Op. cit., Idem, pp. 752 e ss. MENEZES CORDEIRO dá breve contextualização do tratamento do fenômeno na Europa, com paralelos importantes no direito belga, francês e alemão.

No mesmo sentido, vide F. GAlGANO, Diritto commerciale, Op. cit., Idem, pp. 354-358.

${ }^{184}$ Nessa estrutura do artigo 278, despontam o modelo monista latino na alínea "a", o modelo monista anglo-saxão na alínea "b" e o modelo dualista germânico na alínea "c". 
alíneas "b" e "c", e facultativo no modelo da alínea "a". ${ }^{185}$ Entretanto, no caso das companhias abertas, ainda que tenham optado pelo modelo da alínea "a", a presença do auditor independente, em conjunto com o conselho fiscal, é obrigatória (cf. artigo 413 do Código das Sociedades Comerciais). Não há, no direito português, todavia, qualquer regra de tratamento especial da fiscalização em companhias abertas, por força dos preceitos de publicidade obrigatória e participações qualificadas. ${ }^{186}$

Neste passo, uma vez compreendido o âmbito e os modelos de fiscalização societária em Portugal, é de se notar que o Código das Sociedades Comerciais subdivide o tratamento dessa fiscalização entre conselho fiscal (artigos 413 a 423-A) e comissão de auditoria (artigos 423-B a 423-H). ${ }^{187}$

\footnotetext{
${ }^{185}$ Em apreciação crítica dos modelos, MENEZES CordeIro (Manual..., vol. II, Op. cit., Idem, p. 760) entende que "o modelo monista anglo-saxônico (comissão de auditoria) parece mais rígido, uma vez que não comporta (aliás: por definição) a hipótese de um administrador único (278\%5)".

${ }^{186}$ Sobre o tema da publicidade e das participações qualificadas, vide brevíssimo apanhado feito por MENEZES CoRDEIRo (Manual..., vol. II, Op. cit., Idem, pp. 599-608).

${ }^{187} \mathrm{O}$ revisor oficial de contas, equivalente ao auditor independente brasileiro, é tratado exclusivamente no artigo 446 do Código das Sociedades Comerciais.

Embora haja uma imediata associação lingüística entre o conselho fiscal português e o conselho fiscal brasileiro, é importante que se tenha em mente que o paralelo legal entre os dois sistemas e a associação em direito comparado deve sempre obedecer a um critério funcional. Considerando que as funções do conselho fiscal português, na lista de alíneas do artigo 420 , incisos $1 \mathrm{e} 2$, se assemelham muito às funções previstas no artigo 163 da Lei das S.A. brasileira, a comparação entre órgãos é justa. A questão da equivalência funcional é muito bem explorada por Gabriela FiguEIREDO DiAS (Fiscalização de sociedades..., Op. cit., Idem, pp. 13-36). Embora Gabriela F. DIAS busque identificar, dentro do direito português, algumas formas equivalentes e paralelas de fiscalização societária, a saber, conselho fiscal, conselho de supervisão, conselho de administração, revisor oficial de contas (auditor) e comissão de auditoria, para estudar possíveis sobreposições de funções e existência de conflitos de atribuições societárias, é de se notar que a mesma técnica de equivalência funcional deve ser empregada numa comparação externa a um sistema jurídico, como ocorre em estudos de direito comparado. Importante notar que o resultado das comparações funcionais entre esses órgãos, feita no interior das estruturas do direito português, levou Gabriela F. DIAS a propor uma interessantíssima segregação de funções entre conselho fiscal e revisor oficial de contas, com o comitê de auditoria, por meio da separação entre as funções de fiscalização stricto sensu e revisão de contas (Idem, ibidem, pp. 18 e ss.).

Dentro desse contexto funcional, para efeito de exercício de direito comparado, temos, pois, no artigo 420 do Código das Sociedades Comerciais as seguintes funções, equivalentes àquelas previstas no artigo 163 de nossa Lei das S.A.: "1 - Compete ao fiscal único ou ao conselho fiscal: a) fiscalizar a administração da sociedade; b) vigiar pela observância da lei e do contrato de sociedade; c) verificar a regularidade dos livros, registros contabilísticos e documentos que lhes servem de suporte; d) verificar, quando o julgue conveniente e pela forma que entenda adequada, a extensão da caixa e as existências de qualquer espécie dos bens ou valores pertencentes à sociedade ou por ela recebidos em garantia, depósito ou outro título; e) verificar a exactidão dos documentos de prestação de contas; f) verificar se as políticas contabilísticas e os critérios valorimétricos adoptados pela sociedade conduzem a uma correcta avaliação do património e dos resultados; g) elaborar anualmente relatório sobre a sua acção fiscalizadora e dar parecer sobre o relatório, contas ou propostas apresentados pela administração; h) convocar a assembléia geral, quando o presidente da devida mesa o não faça, devendo fazê-lo; i) fiscalizar a eficácia do sistema da gestão de riscos, do sistema de controlo interno e do sistema de auditoria interna, se existentes; $\mathrm{j}$ ) receber as comunicações de irregularidades apresentadas por accionistas, colaboradores da sociedade ou outros; 1) contratar a prestação de serviços de peritos que coadjuvem um ou vários de seus membros no exercício das suas funções, devendo a contratação e a remuneração dos peritos ter em conta a importância
} 
Dentre as características específicas do conselho fiscal português, destacamos, no tocante à sua composição, que o número mínimo de membros é de 3 (três) para as companhias abertas. O conselho fiscal pode ser composto por sociedades de advogados, de revisores oficiais de contas ou acionistas (tal qual previsto na lei argentina), desde que atendam aos requisitos mínimos de qualificação (artigo 414) por mandato determinado conforme previsão estatutária, mas nunca superior a quatro (4) anos (artigo 415, inciso 1). Os critérios de qualificação exigem que ao menos um dos membros do conselho fiscal tenha "curso superior adequado, conhecimento em auditoria e contabilidade" (artigo 414, inciso 4), devendo o requisito de independência (artigo 414, inciso 5), no caso das companhias abertas, ser exigido da maioria dos membros do conselho fiscal (artigo 414, inciso 6).

Os critérios de independência da legislação portuguesa são um dos mais rígidos do mundo. Cuida, em duas hipóteses exemplificativas, de requisitos mínimos de independência para que o conselheiro seja considerado em absolutas condições de isenção. A regra propõe que seja considerado independente o conselheiro que "não esteja associado a qualquer grupo de interesses específicos na sociedade nem se encontre em alguma circunstância susceptível de afectar a sua isenção de análise ou de decisão, nomeadamente em virtude de: a) ser titular ou actuar em nome ou por conta de titulares de participação qualificada igual ou superior a $2 \%$ do capital social da sociedade; b) ter sido reeleito por mais de dois mandatos, de forma contínua ou intercalada". Note-se então como a legislação portuguesa encampa e lidera um espírito dominante em todas as doutrinas jurídicas mais relevantes do mundo e totalmente contrário ao espírito da lei e doutrina brasileira sobre o mesmo assunto.

Com relação ao tema da responsabilidade dos fiscais, a legislação portuguesa organiza a matéria fora do capítulo em que trata propriamente da fiscalização. Há, no Código das Sociedades Comerciais, um capítulo específico que

dos assuntos a ele cometidos e a situação económica da sociedade; m) cumprir as demais atribuições constantes da lei ou do contrato de sociedade. 2 - Quando seja adoptada a modalidade referida na alínea b) do $\mathrm{n}^{\circ} 1$ do artigo $413^{\circ}$, para além das competências referidas no número anterior, compete ainda ao conselho fiscal: a) fiscalizar o processo de preparação e de divulgação de informação financeira; b) propor à assembléia geral a nomeação do revisor oficial de contas; c) fiscalizar a revisão de contas aos documentos de prestação de contas da sociedade; d) fiscalizar a independência do revisor oficial de contas, designadamente no tocante à prestação de serviços adicionais".

Ademais, lembra MENEZES CordeIRo (Manual..., Op. cit., vol. II, Idem, p. 777) que o preciso desenho de toda a amplitude da competência do conselho fiscal português decorre também de "diversos preceitos dispersos pelo Código". 
trata do tema da "responsabilidade civil pela constituição, administração e fiscalização da sociedade", entre os artigos 71 a 84 . A responsabilidade civil dos membros de órgãos de fiscalização vai tratada exclusivamente no artigo 81, que diz: "Os membros de órgãos de fiscalização respondem nos termos aplicáveis das disposições anteriores. Os membros dos órgãos de fiscalização respondem solidariamente com os gerentes, administradores ou directores da sociedade por actos ou omissões destes no desempenho dos respectivos cargos quando o dano se não teria produzido se houvessem cumprido as duas obrigações de fiscalização".

Tal qual a nossa lei, prevê a lei portuguesa que os fiscais respondam, sob o ponto de vista técnico, da mesma forma e sob o mesmo formato que prevê a lei para que administradores respondam por ato de gestão. Além disso, de forma idêntica à nossa lei, prevê responsabilidade solidária dos fiscais com a administração em caso de omissão. Respondem, pois, os fiscais, da mesma forma com que responderiam os administradores. Entretanto, as perguntas que se fazem são: o conteúdo das funções específicas, exercidas pelos fiscais e pelos administradores, permite que se adote, para ambos, uma forma única no que se refere à responsabilidade civil? A forma unificada de processamento da responsabilidade civil, por fiscalização das sociedades e por administração das sociedades, considerando que as regras de tal responsabilização enfocam funções executivas ou administrativas, estariam facilitando ou dificultando a tarefa de processamento de responsabilidade civil específica relacionada ao poder fiscalizatório, à luz do direito português?

Essas indagações, de maneira objetiva, buscam questionar a necessidade de um regime próprio de responsabilidade civil para fiscais. Tanto na legislação brasileira quanto na legislação de muitos outros países, como Argentina, México, Portugal e Itália, a responsabilidade dos fiscais é processada segundo as regras e as formas da responsabilidade dos administradores. Não há, com precisão, um estudo da responsabilidade civil própria dos fiscais, pois como a lei remete à regra geral da responsabilidade dos administradores, sempre que se encaminha na tarefa de comentar a responsabilidade dos fiscais, inevitavelmente a leitura retorna para o modelo de responsabilidade de administradores e de seus exemplos próprios, voltados para diretores e conselheiros de administração. 
Cumpre notar, entretanto, que os atos praticados por fiscais, dentro de suas funções, podem gerar prejuízo em duas hipóteses: omissão e comissão (assim como ocorre com os administradores). Mas é na responsabilidade por omissão que os danos causados por fiscais mais chamam atenção, ao passo que, no caso dos administradores, é no caso da responsabilidade por comissão.

O regime de responsabilidade dos administradores é portanto, de maneira mais ou menos uniforme em vários sistemas de direito, baseado no dever de diligência (ou dever de cuidado) e no dever de lealdade. É no dever de diligência, entretanto, que mais pode se ver evolução no tocante à responsabilidade civil dos administradores. Por analogia, exige-se dos fiscais esse mesmo padrão de diligência no trato da fiscalização. Contudo, a diligência ou o cuidado na administração e nos atos de gestão evoluiu, nos últimos anos, para o problema do business judgement rule como técnica de investigação de mérito de responsabilidade por prática de atos de gestão que possam gerar danos à companhia. $^{188}$

Como bem notou G. F. DIAS, o business judgement rule fez a doutrina de responsabilidade civil de administradores evoluir do conceito do dever de diligência para um conceito de dever de cuidado, mais amplo que o primeiro e incluído, neste último, o próprio dever de diligência. Com muita sagacidade, questiona a doutrina portuguesa: o modelo de responsabilidade civil de administradores, por meio da doutrina do business judgement rule, é também extensível à fiscalização? ${ }^{189}$ Faz ainda sentido manter na mesma estrutura legal um conceito próprio de responsabilidade pela fiscalização ao lado da responsabilidade pela administração?

Nesse contexto, o direito português, ao absorver em texto legal os princípios da doutrina da business judgement rule no artigo 64 do Código das Sociedades Comerciais, gerou para a responsabilidade de fiscais um dever de cuidado

\footnotetext{
${ }^{188}$ G. F. DiAs (Fiscalização de sociedades..., Op. cit., Idem, p. 70) lembra: “A norma do art. 72, n. 2, constitui uma verdadeira novidade no tecido legislativo societário, que se reputa louvável do ponto de vista da opção legislativa que lhe subjaz - a consagração, no regime jurídico da responsabilidade dos administradores, da regra norte-americana da business judgement rule - e pouco hábil do ponto de vista da técnica legislativa e das soluções que dali resultam".

${ }^{189}$ Ao analisar e interpretar o texto da Proposta de Alteração ao Código das Sociedades Comerciais (uma espécie de "Exposição de Motivos" em direito português que antecede o texto legal da reforma de 2006), G. F. DiAs (Fiscalização de sociedades..., Op. cit., Idem, p. 79) afirma: "Resulta, pois, da Proposta que o legislador teve em mente a subtracção dos órgãos de fiscalização à business judgement rule. Porém, tanto os motivos ali expendidos como solução que concretamente resulta do novo regime se afiguram pouco claros".
} 
distorcido pela lente da lealdade, por meio de preceitos legais bastante criticados pela doutrina em matéria de responsabilidade de fiscais. ${ }^{190}$

Resta, pois, da doutrina portuguesa, uma importantíssima lição que pode permitir o transplante de questionamentos fundamentais para a doutrina brasileira: haveria ou não a necessidade de um regime próprio de responsabilidade civil para os fiscais, de modo autônomo e atendendo, na forma, as funções próprias que são atinentes aos fiscais? Tudo leva a crer que a resposta para essa questão seria $\operatorname{sim} .{ }^{191}$

Disso resulta, entretanto, que as atuais formas de investigação e processamento da responsabilidade civil de membros incumbidos da fiscalização da sociedade, por ainda estarem plasmadas nas regras de processamento de responsabilidade civil de administradores, são interpretadas em padrão elevado de subjetividade e casuísmo. ${ }^{192}$

\footnotetext{
${ }^{190}$ G. F. DiAs (Fiscalização de sociedades..., Op. cit., Idem, pp. 50-51) adverte, com autoridade: "O legislador da reforma quis acolher uma tendência já manifestada nos sistemas anglo-saxônicos no sentido do alargamento explícito do dever de cuidado aos órgãos de fiscalização, prescrevendo agora igualmente para os fiscalizadores, no n. 2 do art. 64, um dever (só aparentemente) simétrico. Numa formulação algo infeliz, esta norma consagra 'deveres de cuidado' a cargo dos titulares de órgãos sociais de fiscalização, a serem cumpridos 'empregando elevados padrões de diligência profissional e deveres de lealdade (...)'. Ou seja: diferentemente do n. 1, onde os deveres de cuidado e os deveres de lealdade dos administradores aparecem claramente autonomizados entre si e consagrados com igual importância e dignidade, no n. 2 do art. 64, para os membros dos órgãos de fiscalização, os deveres de lealdade parecem subalternizados em relação aos deveres de cuidado, constituindo aqueles, segundo a fórmula legal, um simples meio de cumprimento destes".

${ }^{191}$ Nesse pormenor, veja-se afirmação de G. F. DIAS (Fiscalização de sociedades..., Op. cit., Idem, pp. 53-54): "A ilicitude da conduta dos fiscalizadores aferir-se-á, seja como for, em função da violação destes deveres fundamentais de cuidado, aparentemente referidos a elevados padrões de diligência profissional e a deveres de lealdade, necessariamente exercidos no interesse da sociedade. Simplesmente, não é evidente o preenchimento da cláusula geral 'elevados padrões de diligência profissional': se, em relação a um ROC, é possível, com maior ou menos rigor, preencher um conceito desta natureza, o respectivo preenchimento apresenta maiores dificuldades em relação a todos os restantes membros dos órgãos de fiscalização, já que não existe, em relação a estes, um padrão objetivamente avaliável". E assim segue: "O exacto conteúdo daquela cláusula geral só poderá, pois, ser alcançado em conjugação com as normas especiais do CSC onde se consagram os deveres e as funções específicas de cada órgão de fiscalização: os padrões de diligência com que os deveres de cuidado na fiscalização da sociedade devem ser exercidos aferir-se-ão em função da exacta e criteriosa observância dos especiais deveres e funções que, de acordo com aquelas normas, recaem sobre os membros dos órgãos de fiscalização" (itálicos da autora).

${ }^{192}$ Vide exemplos de situações de dever de cuidado pressuposto em fiscalização apresentados por G. F. DIAS (Fiscalização das sociedades..., Op. cit., Idem, pp. 54-55).
}

J. VASQues (Estruturas e Conflitos..., Op. cit., Idem, pp. 197 e ss.), ao explorar o problema da responsabilidade no exercício de poderes orgânicos nas sociedades, divide os conflitos potenciais em dois grandes grupos: os conflitos intra-orgânicos, a saber, aqueles conflitos típicos que ocorrem internamente nos órgãos (que para o caso do conselho fiscal, VASQUES lista conflitos típicos a partir da p. 256); os conflitos inter-orgânicos, a saber, os conflitos entre órgãos, sendo os mais graves, no caso da fiscalização, os conflitos existentes entre assembléia e conselho fiscal (p. 259), conselho de administração e conselho fiscal (p. 261) e o conselho fiscal e o revisor oficial de contas [auditor] (p. 265). Note-se que, em direito brasileiro, o conflito entre diretoria e conselho fiscal, além de constante e freqüente, é o que gera os 


\section{Itália}

De todas as nações estudadas, a Itália é indiscutivelmente um dos países com doutrina mais rica sobre o tema da fiscalização societária. Tal qual o sistema português, a legislação italiana, aliada à força de sua doutrina, oferece um dos instrumentos mais modernos, sob o ponto de vista técnico, em matéria de fiscalização das sociedades, exceto pelo que diz respeito ao regime de responsabilidade civil, em decorrência de uma imprecisão técnica no estabelecimento das atribuições, como teremos a oportunidade de observar. Não por outro motivo, o passado recente da Itália conta com duros golpes em matéria de fiscalização societária, que culminaram por atrair boa parte da atenção de juristas, cientistas contábeis e cientistas de administração de empresas.

O modelo italiano é hoje albergado pelas regras inseridas em seu Codice Civile entre os artigos 2397 a 2409-noviesdecies. Todo o sistema de fiscalização societária, que comportava os antigos artigos 2397 a 2409, foi reformulado nas recentes alterações de $2003^{193}$, ao passar a incluir os temas do controle contábil, bem como a

enfrentamentos mais graves. Nesse mesmo sentido, G. F. DIAS (Ibidem, pp. 58 e ss.) mostra como esses conflitos podem gerar diferentes modelos de responsabilidade dos "fiscalizadores", em relação ao sujeito passivo dos danos, a saber, se a própria sociedade, se a credores, se a acionistas ou se a terceiros de modo geral. E assim esclarece G. F. DIAS (Ibidem, p. 58): “A qualificação da responsabilidade civil pela fiscalização da sociedade é complexa, pois que, dependendo das circunstâncias e dos sujeitos perante os quais seja accionada, esta poderá ter natureza contratual ou extra-contratual. E essa qualificação não é ociosa, uma vez que dela depende a concretização de aspectos como o preenchimento do conceito de ilicitude - constituindo esta a base clássica da distinção entre as duas modalidades de responsabilidade - e a distribuição do ónus da prova (questão particularmente relevante no domínio da fiscalização)". Nesse particular, inclusive, já destacava a doutrina portuguesa a respeito das mudanças no conceito de responsabilidade civil para acomodar os conflitos materiais específicos de uma fiscalização societária, quando de investigação do tema voltado para a questão da responsabilidade dos ROC (revisores oficiais de contas), o equivalente português do auditor brasileiro (vide Manuel Carneiro da FRADA. Uma "Terceira Via” no Direito de Responsabilidade Civil?. Coimbra: Almedina, 1997, passim).

${ }^{193}$ Essas reformas legislativas tiveram seu marco inicial com a Lei 366, de 3 de outubro de 2001, seguidas pelo Decreto Legislativo nr. 6, de 17 de janeiro de 2003. A respeito das recentes reformas no direito italiano, dá-nos excelente nota crítica Diego CORAPI, "Les systémes d'administration et controle en Italie suite à la réforme du droit des sociétés", In RDB 37/107, [jul-set/2007], pp. 107-119. Em outra excelente nota crítica, Diego CORAPI traz foco para a recepção, na Itália, dos modelos de administração da common law ("La riforma italiana della società di capitali: modelli continentali, modelli di common law", In RDB 25/123, [jul-set/2004], pp. 123-143)

O papel das reformas italianas no cenário europeu, com sensível comparação e análise de efeitos alcançados é objeto de exímio trabalho de Giovanni FIORI (Corporate Governance e qualità dell'informazione esterna d'impresa. Milão: Giuffrè, 2003). FIORI, partindo de um contexto econômico muito típico italiano (que, diga-se de passagem, se assemelha bastante ao brasileiro, com a presença de concentração de capitais com limitada separação entre propriedade e controle, baixa dispersão, creditada a grupos familiares e à presença do Estado na economia, existência de elevado número de empresas médias, 
harmonização com os dois modelos de administração, controle e gestão aplicáveis, a saber, o monístico e o dualístico, com a inserção expressa da possibilidade de uso de um comitê de auditoria (comitato per il controlo sulla gestione). ${ }^{194}$ Nas companhias abertas, diferentemente de como ocorre em Portugal e no Brasil, há algumas regras específicas para a fiscalização, por força de princípios de direito comunitário regentes nos modelos societários da Societas Europaa, sobretudo o binômio informaçãoparticipação ${ }^{195}$. A auditoria independente obrigatória (revisione contabile) é a marca principal de distinção na fiscalização das companhias abertas na Itália, bem como os limites para o acúmulo de cargos. ${ }^{196}$

A discussão a respeito do tema, entretanto, não é nova e nem surge com o Código de 1942. Já no modelo previsto no sistema do Codice di commercio de 1882 (artigos 183 e 184), o tema da fiscalização societária, ainda dentro do modelo dos atos de comércio, já guardava larga preocupação com certos temas ${ }^{197}$, alguns corretos, outros nem tanto, como a experiência mais recente pode demonstrar.

pequenas e micro e a falta de liquidez no mercado pela ausência do médio investidor e dos investidores institucionais no lugar da forte presença estatal, cf. p. 109), nota, em comparação com França, Alemanha, Inglaterra e Estados Unidos, a reformulação do papel dos sindaci no novo direito societário italiano. Observando os efeitos da adoção dos diversos sistemas de administração e controle (que chama de "dualístico horizontal", "dualístico vertical" e "monístico" [pp. 119-120], classificados igualmente por CORAPI como "sistema dualístico", "sistema tradicional" e "sistema monístico" [Ibidem, pp. 110-111]), FIORI analisa como tais alterações podem influir na melhoria dos fluxos informativos nas companhias, sobretudo as de capital aberto.

${ }^{194}$ Ao contrário do que poderia se pensar, na Itália não houve crítica, nem desprestígio, pela necessidade de incorporação dos modelos de outras nações européias no sistema italiano e vice-versa. Entende a doutrina italiana que essa reforma não cuidou apenas de um transplante formal de modelos, mas sim de uma verdadeira operação de integração cultural de valores e sistemas, precedidas de muitos debates transnacionais. Lembra-nos CORAPI ("Les systémes...” Op. loc. cit., Idem, p. 111): “Cela dit, il faut préciser que l'introduction de systémes alternatifs d'administration et contrôle de la part du législateur italien n'a pas donné lieu à une simple transplantation de normes étrangères. Au contraire, ces systémes vienent s'integrer parfaitement dans le cadre inspirateur de la réforme, rèsultant en syntonie avec les innovations principales de cette dernière".

195 Trata-se da regência das sociedades comerciais na Europa segundo parâmetros de publicidade obrigatória de certas informações, bem como de regras específicas para as participações qualificadas. Em direito italiano, a respeito da questão do fluxo de informação nas companhias abertas, vide Gian Domenico Mosco, "Conosco, Ergo Sum. L'informazione e la nuova identità del collegio sindacale", In Collegio sindacale..., Op. cit., Idem, pp. 318-322.

196 Vide F. GAlgano (Diritto Commerciale..., Op. cit., Idem, pp. 428 e ss.). Adverte, ainda, GALGANO em nota: "Norme speciali sono dettate, per quanto attiene sia alla composizione del collegio sindacale, sia ai limiti al cumulo degli incarichi" (Diritto Commerciale..., Op. cit., Idem, p. 349). A longa nota explora essas várias hipóteses. Vide também sobre o tema, o excelente texto de Gustavo OLIVIERI, "Prime osservazioni sui controlli 'interni' nelle società quotate dopo la legge sulla tutela del risparmio", In Collegio Sindacale..., Op. cit., Idem, às pp. 295-300.

${ }^{197}$ Cf. Cesare VivanTe. Trattato di Diritto Commerciale, Vol. II - le società commerciali, $4^{\mathrm{a}}$ ed.. Milão: Dott. Francesco Vallardi, 1912, pp. 368-376. 
Nesse antigo modelo, as regras e a forma de funcionamento dos sindaci ${ }^{198}$ eram muito parecidas com o que atualmente se encontra na lei brasileira: composição de três (3) a cinco (5) membros, sócios ou não sócios, com mandato de um exercício renovável por outros subseqüentes (conforme arbítrio da assembléia), podendo o estatuto franquear a certos acionistas o direito de nomear ao menos dois (2) entre cinco (5), impedidos aqueles que fizerem parte da administração, os que ostentarem relação de parentesco com os administradores e os empregados, substituíveis somente por vontade da assembléia e, quando em exercício de mandato em curso, somente por justa causa, responsáveis pessoalmente pelos atos cometidos na forma e sob a mira da analogia para com os administradores.

Entretanto, o ponto mais interessante, sobretudo para o estado atual da legislação brasileira em matéria de conselho fiscal, é atentar para as críticas que se lançavam à lei de $1882 .{ }^{199}$ Ao voltarmos os olhos para essas críticas, poderemos notar que, desde o início do século XX, a Itália já vinha de um processo de superação de críticas e argumentos que o Brasil, desafortunadamente, ainda se vê às voltas nos dias atuais.

E essas críticas giravam todas em torno da real conformação da independência dos sindaci. Essa viga mestra da independência aparecia em três fortes argumentos de crítica, a saber: (i) a presença ou não de sócios e pessoas ligadas aos sócios, dentre os sindaci, ${ }^{200}$ (ii) a não conformação da vigilanza sindacale em forma

\footnotetext{
${ }^{198}$ Novamente, nunca é exagerado repisar, a associação que aqui se faz entre sindaci e conselho fiscal é essencialmente funcional, pois vê-se na função dos sindaci papéis semelhantes aos dos conselheiros fiscais da lei brasileira. Nesse sentido, lembrava C. VivanTE (Trattato..., Op. cit., Idem, pp. 368-369): “I sindaci esercitano un ufficio personale e continuo di vigilanza, penetrante nell'interno di tutta l'azienda sociale. Essi sono i controllori permanenti dell'amministrazione, delegati dagli azionisti che non possono esercitare quell'ufficio personalmente, ed agli azionisti devono rendere il conto dei risultati della loro vigilanza nelle adunanze periodiche dell'assemblea. Il loro riscontro deve seguire di pari passu lo svolgimento dell'azienda sociale, cosicchè gli amministratori, sapendo di essere sorvegliati da una autorità vigile e indipendente, siano costretti, anche senza volerlo, a condursi con onesta diligenza. In pratica però la loro sorveglianza e la loro considerazione restano molto lontane dall'ideale legislativo". A evolução do tema, tal qual pudemos observar nos sistemas da Argentina, México e Portugal, e como se verá do sistema dos EUA, sempre trouxe discussões a respeito da efetividade e até mesmo da utilidade do órgão. A elegância de VIVANTE certamente o impediu de tratar o instituto como inútil, assim como se deu explicitamente no Brasil, no México e na Argentina, mas de uma forma ou de outra, VIVANTE não deixou de questionar a distância entre a prática e o ideal legislativo. Nesse pormenor histórico, todas as legislações ostentam, de uma forma ou de outra, o mesmo rumo de críticas que ocorreu no direito brasileiro, como pudemos notar em capítulo anterior.

${ }^{199}$ As críticas, que logo tomaremos contato, foram lideradas por C. VIVANTE (Trattato..., Op. cit., Idem, Ibidem).

${ }^{200}$ VIVANTE (Ibidem, p. 374): "Se nella pratica i sindaci non hanno acquistato una sufficiente autorità, ciò avvenne probabilmente perchè essi non sono di solito possessori di azioni che possano parlare alto a
} 
colegiada $^{201}$, e (iii) o mandato coincidente com o exercício, ameaçando a continuidade do exercício da função por um período razoável de tempo (necessário e coincidente, muita vez, com o próprio ciclo produtivo de um empreendimento).

O Codice Civile de 1942 debelou essas críticas, consolidando no texto: (i) critérios de independência mais rigorosos, que impedem que pessoas ligadas à administração e ao controlador, incluindo os parentes até o quarto grau (artigo 2399); (ii) o tratamento da vigilância por meio de órgão colegiado, que passava a se chamar collegio sindacale; (iii) aumento do mandato por três exercícios, vedada a demissão ad nutum com estabilidade de função e possibilidade de demissão apenas por justa causa $(\operatorname{artigo} 2400)^{202}$.

difesa del proprio interesse, e perchè il loro ufficio si rinovva ogni anno ed è quindi in balìa degli amministratori, che dominano le assemblee e fanno scontare ai sindaci la soverchia indipendenza colla perdita dell'ufficio. Sarebbe necessario che dovessero prestare anch'essi un'alta cauzione e che, invertite le parti, gli amministratori avvessero piuttosto a temere di non essere confermati per l'influenza dei sindaci. Ma questo non si potrà ottenere se non saranno posti al sicuro contro le loro rappresaglie, ordinando che non possano essere revocati che da un'assemblea costituita con speciali garanzie di soci presenti e votanti'. Neste ponto, VIVANTE identifica um problema da legislação italiana, que se resumia na eterna "Espada de Dâmocles" sobre a cabeça dos sindaci, que tinham o cargo ameaçado caso desempenhassem a vigilância com rigor. Entretanto, a solução proposta pelo grande mestre, com a devida licença e respeito, não satisfaz, como realmente não satisfez, tal qual pode a história comprovar. Em primeiro lugar, exercem os sindaci verdadeira função e o tempero dessa função com interesses pessoais, além de ser tecnicamente reprovável, como pudemos observar da noção de função exposta por L. Ferrajoli (Principia..., Op. cit., vol. I, Idem, pp. 603 e ss.) é, sob o ponto de vista prático, a arquitetura de um verdadeiro desastre político no equilíbrio de forças na companhia (sobretudo nas companhias abertas). A exigência de garantia de gestão para fiscais, por outro lado, não se mostra como um caminho coerente para que a sua independência seja respeitada pelos administradores.

${ }^{201}$ VIVANTE (Ibidem, p. 375): "I sindaci non formano un collegio che deliberi a maggioranza. Ognuno di essi può esercitare di propria iniziativa e secondo i propri criteri le funzione che la legge gli attribuisce, senza essere legato dal voto dei suoi colleghi: in questa indipendenza di indagini e di giuzidi sta la loro difesa contro i pericoli della responsabilità solidale cui sono sposti. Lo si argomenta anche da ciò che la legge sempre composto di parechi membri, con norme collegiali, como fece per gli amministratori, indicano il modo delle loro deliberazioni (artigo 141), e non ha dato alcun provvedimento per la difesa della minoranza dissenziente, como fece per gli amministratori. Di più, se la legge vuole che il numero dei sindaci sia sempre completo per mezzo dei supplenti, ciò significa che la maggioranza non può esercitarne gli uffici". Aqui, ousamos, mais uma vez, discordar do grande mestre. Como ocorreu no evoluir da legislação italiana (sem que este comentário possa parecer "nota de engenheiro de obra feita"), não foi a garantia de exercício de função individual e a dissociação do caráter colegiado que assegurou a interrupção da solidariedade no caso de dissidência. É o próprio registro da dissidência, sem outorga de poderes individuais, que assegura a posição do dissidente. Desta forma, as conclusões que seguem no comentário de VIVANTE parecem não se sustentar.

${ }^{202}$ F. Galgano (Diritto Commerciale, Op. cit., Idem, p. 348) lembra, ainda, que a demissão por justa causa deve sempre ser sujeita a posterior revisão judicial (artigo 2400), pois "può accadere che $i$ sindaci siano revocati, con l'allegazione di una pretestuosa giusta causa, nel momento in cui si accingono a rilevare gravi irregolarità, commessi dagli amministratori con la connivenza della maggioranza e a danno della minoranza". Por isso, "il tribunale deve sentire il sindaco o i sindaci revocati; può cosi rendersi conto della realtà sottostante alla deliberazione di revoca e rifiutarne l'approvazione ove risulti che la revoca è stata deliberata non per avere i sindaci omesso di vigilare sull'amministrazione ma, all'oposto, per lo zelo con il quale essi hanno vigilato". 
A reforma de 2003 aproveitou momento histórico na Itália, na Europa e no mundo, para introduzir no texto legal uma série de outras mudanças que tornaram os critérios de elegibilidade mais rigorosos, reforçando a necessidade de independência no exercício das funções. ${ }^{203}$

Recentemente, o Decreto Legislativo nr. 32, de 2 de fevereiro de 2007, introduziu novo texto no artigo 2409-tercies, para funções específicas do auditor independente e de sua relação com os demais órgãos de fiscalização interna da sociedade (2409-septies, para o caso da relação entre auditores e collegio sindacale), seja ainda no modelo dualista, seja no modelo monista.

Atualmente, a conformação do texto legal do Codice Civile, bem como da Lei de Mercado de Capitais italiana, o chamado Texto Único (Testo Unico), reconhece que o collegio sindacale, como órgão de fiscalização de companhias abertas é: (i) órgão permanente de fiscalização, (ii) de deliberação colegiada, (iii) composto por no mínimo 3 (três) membros, sem que haja, para as companhias abertas, limite máximo ${ }^{204}$, (iv) delineado com expressa limitação ao acúmulo de cargos, no caso das companhias abertas, que pode ser determinada pela Consob (órgão italiano equivalente

Nesse mesmo sentido, em brilhante texto, preleciona Maurizio SCIUTO ("La revoca del sindaco", In Il Collegio Sindacale..., Op. cit., Idem, pp. 385-422). Após expor a necessidade vital do respeito à independência dos sindaci, SCIUTO afirma categoricamente (p. 397): "Se una revoca sia effetivamente assistita da giusta causa è il giudice a doverlo valutare. La legge, invece, non potendo tipizzare ex ante $i$ presupposti di fatto che possono giustificare la revoca, si limita a far ricorso - come spesso accade - ad una clausola generale".

${ }^{203}$ A principal delas, na ótica de F. Galgano (Diritto Privato, $13^{\mathrm{a}}$ ed.. Padova: CEDAM, 2006, pp. 768769) é a relação preexistente com prestadores de serviço da sociedade, sobretudo os consultores: "Degna di nota è l'incompatibilità fra il rapporto continuativo di consulenza e la carica di sindaco, introdotta con la riforma del 2003: si è inteso superare l'antica prassi che faceva tutt'uno della consulenza e del controllo; ciò che depotenziava la funzione sindacale, giacchè $i$ sindaci controllavano atti predisposti o scelte effettuate dagli amministratori secondo i loro consigli o i loro suggerimenti, e perciò finivano col il controllare se stessi. Si è ritenuto di dovere escludere solo il rapporto «continuativo» di consulenza sia perché è questo, e non tanto la sporadica consulenza, a provocare il negativo fenomeno dell'autocontrollo, sia perché la continuità della consulenza pregiudica anche sotto altro aspetto l'indipendenza dei sindaci rispetto al management della società (o del gruppo cui questa appartiene): $i$ compensi che $i$ sindaci ricevono per le consulenze finiscono con il raggiungere un ammontare superiore a quelli che percepiscono in quanto sindaci, rendendoli più interessati alla consulenza che non al controllo". Essa mesma crítica se vê repetida em seu Diritto commerciale, Op. cit., Idem, pp. 347-348.

A crítica de GALGANO é muito perspicaz, e como se verá, se ajusta ao problema ocorrido nas estruturas do direito estado-unidense a partir do escândalo "Enron-Arthur Andersen", iniciado em dezembro de 2001, bem como de alguns outros problemas envolvendo auditoria versus planejamentos fiscais propostos pelas então "Big Five" (hoje, já, as "Big Four") que, no auge de suas respectivas atuações, eram conhecidas como as "Big Eight". A Itália, por seu turno, viveu escândalo de proporções numéricas muito superiores no caso Parmalat, divulgado ao mundo em dezembro de 2003.

${ }^{204}$ Vedada a composição do collegio sindacale em número par ou via único sindaco (cf. Giuseppe AuletTa e Nicolò SALANitro. Diritto Commerciale, 16ª ed.. Milão: Giuffrè, 2008, p. 177), situação esta permitida pela lei argentina. 
à CVM no Brasil) ${ }^{205}$, (v) composto por ao menos um membro eleito pela "minoria", cabendo a esse membro ou a um deles, a presidência do collegio, (vi) com previsão, para seus membros, de requisitos especiais de "honorabilidade" e "profissionalismo", segundo regras especiais emanadas pelo Ministério da Economia (Ministero dell'economia), (vii) com o dever de se reunir ao menos uma vez a cada 3 (três) meses, (viii) incumbido de uma função geral de vigilância, que pode ser acumulada com tarefas de controle contábil.

A título de comparação, a equivalência funcional do collegio sindacale e do conselho fiscal brasileiro é o que permite a aproximação, bem como o aproveitamento da rica experiência italiana. ${ }^{206}$ Em matéria de equivalência funcional vale ainda notar que o direito italiano divide, tecnicamente, as funções do collegio sindacale entre deveres e poderes, ${ }^{207}$ em técnica legislativa que, como pudemos atentar

\footnotetext{
205 Informa, com tendência crítica, GALGano (Diritto Commerciale..., Op. cit., Idem, p. 349): “ $L a$ Consob stabilisce inoltre $i$ limite al cumulo degli incarichi di amministrazione e controllo che possono essere assunti dai sindaci di società quotate o di quelle i cui strumenti finanziari sono diffusi tra il pubblico in misura rilevante. A tal fine si ha riguardo all'onerosità e alla complessità di ciascun tipo di incarico, alla dimensione della società, al numero e alla dimensione delle eventuali imprese consolidate, all'estensione e all'articolazione della struttura organizzativa (art. 148, bis, comma $1^{o}$, Testo unico cit.). I componenti degli organi di controllo delle società quotate o i cui strumenti finanziari sono diffusi fra il pubblico in misura rilevante devono informare la Consob ed il pubblico degli incarichi di amministrazione e di controllo da essi rivestiti presso tutte le società per azioni, a responsabilità limitata ed in accomandita per azioni. La Consob dichiara la decadenza dagli incarichi assunti dopo il raggiungimento del numero massimo previsto (art. 148, bis, comma $2^{\circ}$, Testo unico cit.)".

${ }^{206}$ Ao proceder a comparação com outros países da Europa, Diego CORAPI (“Les systémes...”, Op. loc. cit., Idem, pp. 114-116) lança mão, igualmente, da técnica de equivalência funcional que estamos cuidadosamente utilizando neste trabalho, em todos os pontos de contato entre as legislações estrangeiras e a legislação brasileira. De acordo com o artigo 2403 do Codice Civile, são atribuições do collegio sindacale previstas na lei em texto absolutamente genérico e não descritivo, como ocorre em várias outras legislações: "Il collegio sindacale vigila sull'osservanza della legge e dello statuto, sul rispetto dei princìpi di corretta amministrazione ed in particolare sull'adeguatezza dell'assetto organizzativo, amministrativo e contabile adottato dalla società e sul suo concreto funzionamento. Esercita inoltre il controllo contabile nel caso previsto dall'articolo 2409-bis, terzo comma". Excelente interpretação integrativa do texto do artigo 2403, sobretudo no que tange à interpretação do termo (de difícil tradução para o português, diga-se de passagem) adeguatezza dell'assetto organizzativo, é apresentada por Maurizio IRRERA ("Collegio sindacale e assetti adeguati”, In Collegio sindacale..., Op. cit., Idem, pp. 261-287).

Note-se que o direito italiano deixa claro, na norma, que há uma separação entre a função de fiscalização stricto sensu e a função de controle contábil, assunto que, em Portugal, embora sem expressa designação na lei, já é largamente abordado na doutrina (G. F. DIAS, Fiscalização de Sociedades..., Op. cit., Idem, pp. 18 e ss.).

207 Os poderes do collegio sindacale estão inscritos no artigo 2403-bis, que diz: "I sindaci possono in qualsiasi momento procedere, anche individualmente, ad atti di ispezione e di controllo. Il collegio sindacale può chiedere agli amministratori notizie, anche con riferimento a società controllate, sull'andamento delle operazioni sociali o su determinati affari. Può altresì scambiare informazioni con $i$ corrispondenti organi delle società controllate in merito ai sistemi di amministrazione e controllo ed all'andamento generale dell'attività sociale. Gli accertamenti eseguiti devono risultare dal libro previsto dall'articolo 2421, primo comma, n. 5. Nell'espletamento di specifiche operazioni di ispezione e di controllo $i$ sindaci sotto la propria responsabilità ed a proprie spese possono avvalersi di propri
} 
nos estudos introdutórios sobre teoria geral do direito societário, causam certa confusão. $^{208}$

Apesar desta marca de imperfeição na tópica funcional da lei italiana, a doutrina peninsular destaca ainda inúmeros estudos para chamar a atenção no tocante a três pontos fundamentais em matéria de fiscalização das sociedades, a saber: (i) independência, (ii) estabilidade, (iii) responsabilidade.

No tema da independência, uma das melhores definições é dada pelos parâmetros apresentados por Leonardo QUAGLIOTTI, que pela precisão, fazemos questão de incluir no corpo do texto desta dissertação: "A independência é, por definição, a antítese da consolidação das relações, e não é nem mesmo posto em dúvida que uma atividade de fiscalização exercida por um sujeito não independente não seja apenas inútil, mas efetivamente danosa, na medida em que cria em terceiros a ilusão da presença de uma supervisão"209.

dipendenti ed ausiliari che non si trovino in una delle condizioni previste dall'articolo 2399. L'organo amministrativo può rifiutare agli ausiliari e ai dipendenti dei sindaci l'accesso a informazioni riservate.".

${ }^{208}$ Como repisado, os fiscais exercem uma espécie de poder-dever que, tecnicamente, incumbe-os de uma função jurídica, justamente porque a exercem no interesse de terceiros. Nesse passo, mostra-se de técnica legislativa questionável o texto italiano, ao subdividir a função dos sindaci entre deveres e poderes stricto sensu. Deveriam todas figurar, tecnicamente, tal qual ocorre nos direitos de Portugal, Argentina, Brasil, França e EUA, como verdadeiras atribuições de uma função. Além disso, a linguagem utilizada para conformar a tipicidade desses poderes é igualmente questionável, pois permite uma amplitude de ação que o direito brasileiro já vem mostrando como discutível, tal qual o problema da investigação sem qualquer limite e a qualquer tempo, linguagem adotada na lei mexicana e criticada pela doutrina desse país. Essa formulação reprovável gera efeitos nocivos na conformação da responsabilidade civil dos sindaci, pois, em tese, a responsabilidade por omissão só se aplica no caso de omissão no cumprimento de deveres. A omissão no cumprimento de poderes, se absolutos ou potestativos, não gera, em tese, responsabilidade, pois o seu exercício é necessarimante uma faculdade do titular do poder. Sobre os inúmeros problemas decorrentes, em matéria de responsabilidade civil dos sindaci, da má técnica legislativa empregada no Codice Civile, vide Lorenza Furgiuele ("La responsabilità da controllo", In Collegio sindacale..., Op. cit., Idem, pp. 426 e ss.).

Com relação ao conteúdo da norma, os preceitos são ainda mais reprováveis, pois: (i) permitem que cada membro possa agir, a qualquer tempo, de forma individualizada, quebrando um dos princípios resolvidos pela doutrina italiana, que é a conformação do órgão como verdadeiro ente colegiado da sociedade; (ii) fazem com que os próprios sindaci tenham que arcar com a conta e com as despesas para a contratação de seus peritos, auxiliares e consultores que venham a entrar em serviço da fiscalização. Nesses pontos, entendemos que a legislação brasileira supera a italiana, ainda que a doutrina italiana lance elogios ao novo texto, circunscrito à norma do artigo 2403-bis (vide Stefano AMBROSINI, "I poteri dei sindaci”, In Collegio sindacale..., Op. cit., Idem, pp. 225-257).

Vale lembrar que, tal qual expõe a doutrina brasileira, o mérito dos atos de gestão não está disponível para fiscalização, mas tão só o modo e a forma como são praticados. Embora de redação bastante confusa, o artigo 2403-bis, interpretado pela doutrina italiana, não permite que se entenda estar facultado aos sindaci uma revisão de mérito dos atos praticados pelos administradores. Vide ainda Fabrizio BAVA (Il controllo legale dei conti: collegio sindacale e società di revisione. Milão: Giuffrè, 2005, pp. 35-36).

${ }^{209}$ Leonardo QUAGLIOTTI, "La nomina dei sindaci: equilibrio strutturale e indipendenza sostanziale", In Collegio sindacale..., Op. cit., Idem, pp. 100-101: "L'indipendenza è del resto l'antitesi del consolidamento dei rapporti e non è neppure revocabile in dubbio che un'attività di controllo esercitata 
De fato, como é de se notar pela acuidade científica de QuAGLIOTTI, a independência é o reverso da situação de intimidade ou de relação pessoal consolidada, que o direito brasileiro fez cristalizar em várias práticas historicamente ligadas ao coronelismo e até certa monta, a um feudalismo à brasileira, como pudemos já estudar na parte histórica deste trabalho, por meio de textos de Victor Nunes LEAL, Sérgio Buarque de HOLANDA, Raymundo FAORO e Richard GRAHAM.

Nesse particular do texto italiano, que fixa os critérios de independência no artigo 2399 do Codice Civile, há, visivelmente, o esforço em colocar distantes essas relações consolidadas que afetam diretamente o caráter de independência do ente fiscalizador. QUAGLIOTTI ainda lembra que, historicamente, o direito italiano sempre viveu um déficit de critérios de independência, mas que, na luta contra esse déficit, é que reside a possibilidade de sobrevivência a longo prazo dos mecanismos de fiscalização interna das sociedades, sobretudo do collegio sindacale. ${ }^{210}$

As pessoas impedidas pela lei de ter acesso a cargo no collegio sindacale, sejam sindaci, os consultores, fiscais e auxiliares do órgão, contratados pelos sindaci, são: (i) os administradores da sociedade, de suas controladas ou de suas controladoras, (ii) os cônjuges, os parentes e afins até o quarto grau desses administradores, (iii) aquelas ligadas à sociedade ou a sociedades que a controlam ou são por ela controladas, ou sob controle comum, sob algum tipo de relação continuativa de trabalho, consulta ou prestação de serviços de natureza retributiva, incluindo quaisquer outras relações da natureza patrimonial que possam comprometer a independência.

\footnotetext{
da un soggetto non indipendente non sia soltanto inutile ma addirittura dannosa, nella misura in cui crea nei terzi l'illusione della presenza di un sorveglianza".

${ }^{210}$ Neste pormenor e com vistas a um ângulo histórico, lembrou L. QUAGLIOTTI ("La nomina dei sindaci...", In Collegio sindacale..., Op. cit., Idem, pp. 37-38): "Il sistema dei controlli sulle società di capitali è stato così completamente ridisegnato e il collegio sindacale non ha soltanto perso l'esclusiva dei poteri di sorveglianza sull'intera gestione delle società azionaria. Non è peraltro da considerarsi remoto il 'rischio' che il collegio sindacale, con il suo patrimonio di studi e traversie, possa risultare nel medio periodo convogliato nell'alveo che conduce all'estinzione. Ė infatti molto dubbia l'idoneità anche del rinnovato assetto dei controlli sindacali a conferire efficienza all'instituto; ciò, non solo a causa delle asimmetrie riscontrabili tra i diversi modelli di amministrazione e controllo, ma anche per la persistente presenza dei principali fattori di criticità che l'ultrasecolare esperienza dei sindaci ha da molto tempo messo in luce". Em nota de rodapé na p. 37 (nota 11) QuAGLIOTTI sacramenta: “... il deficit d'independenza che, nella nostra ricostruzione, rappresenta il principale fattore di criticità per la sopravvivenza dell'instituto nel lungo periodo".
} 
De distinto em relação à lei brasileira temos que os impedimentos alcançam as pessoas relacionadas com o controlador, incluindo seus administradores, ao passo que nossa lei restringe as limitações apenas ao âmbito da própria sociedade, sem atingir o controlador. Acresça-se ainda, em relação à lei italiana, que os critérios de independência atingem vedações a prestadores de serviço, consultores, além dos próprios empregados da companhia e de seus controladores. Relações de parentesco são também mais amplas e podem atingir até o quarto grau (relação entre primosirmãos), ao passo que a lei brasileira só as atinge até o terceiro grau (relação entre tio[a] e sobrinho[a]).

Entretanto, na ótica da doutrina italiana, isso ainda não é suficiente. A doutrina reclama de mais critérios para a consolidação de impedimentos que assegurem uma independência substancial. ${ }^{211}$

Em continuidade ao tema da independência, a doutrina centra atenção também no requisito da estabilidade, que para muitos é também um desdobramento da própria independência. $^{212}$

Sobre a estabilidade da função, basta termos em mente que a legislação italiana assegura o desempenho do cargo por pelo menos três (3) exercícios, sendo demissíveis os sindaci somente e tão somente por justa causa, após autorização judicial

${ }^{211}$ Nesse sentido, não apenas L. QUAGLIOTTI ("La nomina dei sindaci...", In Collegio sindacale..., Op. cit., Idem, pp. 43-58), que prega melhores critérios técnicos para o apontamento e os requisitos de máxima profissionalidade e qualificação dos membros do collegio sindacale, na tarefa daquilo que chama de controles endosocietários, mas também Francesco Cossu (L'independenza del collegio sindacale..., Op. cit., Idem, p. 54), crítico contumaz das fragilidades do sistema em relação ao tema da independência.

${ }^{212}$ Nesse sentido, F. GALGANO (Diritto Commerciale..., Op. cit., Idem, p. 348) lembra: 'L'indipendenza che l'art. 2399 tende a realizzare è l'indipendenza dei sindaci rispetto agli amministratori della società o del gruppo cui questa appartiene. Per attuare una certa indipendenza dei sindaci anche rispetto alla maggioranza assembleare che li ha nominati si è, d'altra parte, garantita la stabilità della carica". No mesmo sentido, vide Maurizio SCIUTO (“La revoca...", In Collegio sindacale..., Op. cit., Idem, pp. 385 e ss.).

L. Quagliotti (“La nomina dei sindaci...”, In Collegio sindacale..., Op. cit., Idem, pp. 93-108), com absoluta elegância, e com esteio em interessantíssima leitura dos princípios de gratidão expostos por Plínio, o Velho, no livro XVIII de sua Naturalis Historia, fala no insustentável peso da gratidão, ao tratar da renovação do mandato dos sindaci. No paralelo com o texto clássico de Plínio, QuAGLioTTI traça uma profunda evolução histórica do problema da reeleição dos sindaci no direito societário italiano, para concluir que a estabilidade de cargo e o mandato mais extenso não bastam para garantir a independência, pois a "Espada de Dâmocles" que paira sobre a cabeça dos sindaci, em tempos de reeleição (completamente dominada pelo acionista controlador), são fatores que interferem, no longo prazo das relações, na necessária independência dos sindaci. Por isso, propõe QuAGLIOTTI que os critérios e a forma de escolha migrem do sistema endosocietário para um sistema de escolha exógena, definido por QUAGLIOTTI como regulatory overshooting, a fim de que a escolha dos sindaci recaia sobre um órgão externo à sociedade e da confiança de todos os acionistas. 
por meio de sentença transitada em julgado e processada sob o âmbito do devido processo legal e ampla defesa, conforme entende a doutrina ao interpretar o termo "giusta causa" constante do artigo 2400 do Codice Civile. ${ }^{213}$

No contexto dos principais elementos da fiscalização societária em direito italiano, conclui a lista a questão da responsabilidade dos sindaci. Sobre a responsabilidade, marca, de início, saliente característica sobre o tema as observações que relacionam a responsabilidade com a independência. ${ }^{214}$ Considerando-se que a independência pode ser uma profícua fonte de poder, o contrabalanço legal representado pela responsabilidade de cargo completa, sob o ponto de vista do equilíbrio da lógicajurídica, o eixo de sustentação da fiscalização societária baseada no princípio da independência.

Sobre o conteúdo do artigo 2407 do Codice Civile ${ }^{215}$, prevê a mencionada norma, tal qual o fazem todos os demais países aqui estudados, um regime de responsabilidade civil "emprestado" das regras sobre a responsabilidade da administração, com possibilidade de solidariedade com os administradores em certas circunstâncias. A doutrina de direito societário italiano, entretanto, tal qual ocorre na Argentina e em Portugal, não vê com bons olhos esse regime emprestado ${ }^{216}$,

\footnotetext{
${ }^{213}$ Vide M. ScIUTO (“La revoca del sindaco”, Op. loc. cit., Idem, pp. 397 e ss).

214 Note-se que ao estudarmos a questão das relações dialéticas entre órgãos da sociedade e seus possíveis e potenciais conflitos, assim como José VASQUES propôs para o direito português, há no texto já citado de Ricardo AleSsi (“Il Rapporto dialettico...", In Collegio Sindacale..., Op. cit., Idem, pp. 7 e ss.), uma importante advertência a respeito da assembléia como foro adequado para expressar a relação potencial entre collegio e sócios, evitando-se, assim, que se desenvolvam relações paralelas entre certos grupos de sócios e algum sindaco, em uma relação reprovável de micro-representação ou de endorepresentação de grupos e minorias, em detrimento de outros grupos. Os sindaci deverão sempre desempenhar o ofício em prol da sociedade e comunicar-se com os sócios como um todo, sem privilégio de alguns e detrimento de outros, em foro único, a saber, a assembléia.

215 Diz a mencionada norma: "I sindaci devono adempiere $i$ loro doveri con la professionalità e la diligenza richieste dalla natura dell'incarico; sono responsabili della verità delle loro attestazioni e devono conservare il segreto sui fatti e sui documenti di cui hanno conoscenza per ragione del loro ufficio. Essi sono responsabili solidalmente con gli amministratori per $i$ fatti o le omissioni di questi, quando il danno non si sarebbe prodotto se essi avessero vigilato in conformità degli obblighi della loro carica. All'azione di responsabilità contro i sindaci si applicano, in quanto compatibili, le disposizioni degli articoli 2393, 2393-bis, 2394, 2394-bis e 2395.".

${ }^{216}$ A doutrina entende que a responsabilidade, como forma de garantia da independência, é outro grande fator de preocupação na estrutura legal da fiscalização societária via collegio sindacale. L. QUAGLIOTTI ("La nomina dei sindaci...", In Collegio sindacale..., Op. cit., Idem, p. 38) lembra: "Le fondamenti di tutto il sistema risentono, in particolare, di una cronica 'timidezza' del legislatore rispetto all'annoso problema del deficit d'independenza degli esercenti le funzione di controllo e della sostanziale assenza di un corpus minimo di principii generali e inderogabili finalizzato a definire, in modo coerente e (per quanto possibile) omogeneo, lo status (l'instaurazione e cessazione del rapporto, $i$ requisiti d'independenza e professionalità, i poteri-doveri e le responsabilità) di tutti i soggeti (individuali o colettivi) abilitati allo svolgimento del controllo contabile elo amministrativo sulle società di capitali".
} 
reafirmando, hoje, críticas que já vinham correntes desde antes das reformas de 2003 e $2006,{ }^{217}$ que em nada lograram alterar o sistema de responsabilidade civil dos sindaci.

Tal qual ocorre no direito societário português, notou-se no direito italiano que o regime de responsabilidade civil deve atender materialmente e corresponder formalmente à série de atribuições de um cargo ou função. O empréstimo das regras de responsabilidade civil dos administradores para processar danos ocorridos por força do exercício de cargos e funções de fiscalização é uma imprecisão técnica da lei. A responsabilidade civil dos administradores cuida das normas atinentes a possíveis ilegalidades e danos ocorridos por quebra de um conceito geral de correta administração e gestão dos bens sociais. $^{218}$ Nota a doutrina italiana, tal qual a portuguesa, que o empréstimo de um regime de responsabilidade civil por gestão é insuficiente para o caso da físcalização, sobretudo para a medida de extensão da responsabilidade pela correta vigilância dos negócios sociais. ${ }^{219}$

\footnotetext{
${ }^{217}$ Os críticos não são poucos nem pequenos. FURGIUELE lembra passagens de TEDESCHI, FRANZONI, FERri e CAVAlli (“La responsabilità ...”, In Collegio sindacale..., Op. cit., Idem, p. 426). Mas é numa citação de CAVALLI que o problema se extrai de forma contundente (Ibidem, p. 436, nota 30): “《... se è vero che tale responsabilità appare parzialmente collegata a quella degli amministratori, è altretanto vero che la disciplina positiva pone una serie di problemi riconstruttivi ed interpretativi del tutto autonomi, che necessitano, come tali, di un approfondimento ad hoc»" cfr. G. Cavalli, In "I sindaci: responsabilità diretta e responsabilità solidale con gli amministratori”, apud FURGIUELE, Ibidem).

FERRI, por sua vez, conta com diversas passagens citadas por FURGIUELE e, além das inúmeras passagens lembradas pela autora, recordamos ainda esta, em relação a credores e outsiders da companhia: "La funzione dei sindaci si esaurisce all'interno della società e non puó quindi, a differenza di quanto avviene per gli amministratori, incidire in un rapporto intersoggettivo" (Giuseppe FERRI. Le Società. Turim: UTET, 1971; p. 546).

${ }^{218}$ Sobre as marcantes diferenças materiais entre os deveres de gestão e os deveres de fiscalização e controle contábil, gerando, de forma distorcida, um mesmo regime de responsabilidade para distintos deveres, vide Cosimo SASSO. Irregolarità di bilancio e responsabilità di amministratori e sindaci. Milão: Giuffrè, 2000, pp. 106 e ss. No mesmo sentido, vide Antonio FRANCHI. La responsabilità degli amministratori di S.p.a. nel nuovo diritto societario - $i$ principi per una disciplina 'europea' e $i$ riflessi nell'ambito delle società bancarie. Milão: Giuffrè, 2004, pp. 20 e ss., sobretudo na questão do requisito da específica competência. Salienta essa diferença, também, Salvatore PESCATORE (Manuale di diritto commerciale, $8^{\mathrm{a}}$ ed., org.: Vicenzo Buonocore. Turim: Giappichelli, 2007, p. 299), lembrando que não pode haver para os sindaci outra forma de culpa que não seja a culpa in vigilando, situação essa que não ocorre com os administradores, que estão sujeitos, além da culpa in vigilando e da culpa in eligendo, a culpa própria por ato praticado diretamente pelo agente administrador.

${ }^{219}$ Lorenza FuRGIUELE (“La responsabilità ...”, In Collegio sindacale..., Op. cit., Idem, pp. 425-469) faz contundente crítica a esse respeito, com grande profundidade técnica e precisa análise dos elementos necessários para a caracterização de culpa e dano, no caso dos atos praticados pelos sindaci. Mostra muito bem L. FURGIUELE como as questões atinentes a nexo de causalidade, bem como a solidariedade com os administradores, prevista na lei, quando trabalhadas sobre um texto "emprestado" do sistema de responsabilidade por gestão, gera inúmeras dificuldades operacionais, falhas, erros e loopings interpretativos, vez que se tratam de duas funções conexas (administração e fiscalização) com inúmeros conflitos potenciais. No caso do direito italiano, esses loopings interpretativos ficam mais graves quando se estuda o fenômeno da Societas Europaea, pois tanto no sistema monista quanto no sistema dualista, as questões de responsabilidade multiplicam as incongruências entre os vários órgãos de administração e vigilância. A respeito da solidariedade, ressalta-se a injustiça dos resultados, vez que, como lembra L.
} 
Em matéria de responsabilidade, essa diferença fica ainda mais saliente quando as funções dos administradores e as funções dos fiscais, à luz da responsabilidade civil aplicável para um ou outro caso, se estuda dentro do fenômeno das sociedades em liquidação ou das sociedades em crise. ${ }^{220}$

\section{França}

O direito francês é também umas das mais importantes fontes de comparação com o direito brasileiro, em matéria de fiscalização societária.

Essa importância decorre não apenas do histórico do direito societário francês, que já procurarmos abordar brevemente nas páginas anteriores, mas, sobretudo pela sua estrutura e pelo contexto de seu direito. O direito francês é uma das mais importantes fontes de comparação para países que, como o Brasil, organiza-se de forma codificada. A França é, como se sabe, um dos berços da codificação ocidental moderna e um dos maiores paradigmas jurídicos para os sistemas da civil law.

Em matéria de direito societário, o Code de Commerce, documento de 1807, é a fonte primeira de estudos. Ao longo dos anos, o Code veio sofrendo alterações para que pudesse sempre estar adaptado à realidade de cada momento vivido na história da França.

FURGIUELE (Ibidem, p. 446), "è di tutta evidenza che, sul piano della capacità di produzione del danno, l'efficienza causale de un'attività di secondo grado, como il controllo, è diversa da quela che determina le decisioni gestorie". E, com esteio em CAVALLI, lembra FuRGIUELE que deve haver uma distinção entre quem produz efetivamente o dano e aquele que tem o dever-poder de tomar ações para evitá-lo em tempo (Ibidem, nota 52 na mesma página). Da mesma forma, carrega séria crítica o problema da solidariedade entre si dos sindaci e seus deveres de denúncia ou tomada de ações mediante recebimento de denúncias (a respeito das dificuldades de trato em matéria de responsabilidade civil, quando há denúncias, vide Riccardo BENCINI, "I sindaci tra denuncia di gravi irregolarità ed azione di responsabilità nei confronti degli amministratori”, In Collegio sindacale..., Op. cit., Idem, pp. 471-490).

${ }^{220}$ Silvia TURELLI (Il collegio sindacale nella società per azioni in liquidazione, In Collegio sindacale..., Op. cit., Idem, pp. 493-512) propõe interessantíssimo (e praticamente único) estudo sobre o tema. Notarse-á que não apenas a doutrina brasileira de direito societário, mas a doutrina de vários outros países, contam com graves omissões no estudo das funções e das responsabilidades dos órgãos de fiscalização em sociedades em liquidação, sociedades em estado de crise (ou estado pré-falimentar), sociedades em recuperação e sociedades em processo de falência, sobretudo das companhias abertas que se encontrarem nessa situação. Em matéria de direito brasileiro, como se verá, com o advento da nova lei falimentar em 2005, e o novo sistema de processamento de recuperação de empresas em crise, em que o papel do Estado é sensivelmente diminuído diante dos credores e do fiscal privado, o estudo das funções do conselho fiscal nesses regimes concursais deveria merecer atenção maior. 
$\mathrm{Na}$ parte referente ao direito societário, a primeira grande mudança ocorreu em 1966, por meio da Lei de 24 de julho de 1966, que introduziu texto na legislação francesa que passou a ser chamado popularmente de Code des Societés.

Em matéria de fiscalização societária, entretanto, o direito francês, desde os primórdios, optou pelo modelo de fiscalização externa, por intermédio de auditores de contas, semelhante ao modelo anglo-americano. ${ }^{221}$

Para o direito brasileiro, é, portanto, o direito francês, uma das mais interessantes fontes de estudo, pois, sendo um país de tradição jurídica fortemente atrelada à civil law, optou, no tocante à fiscalização societária, por adotar modelo predominante nos países da common law, a saber, o da fiscalização externa nãoorgânica via auditores. Esse curioso hibridismo da legislação francesa nos revela impressionantes resultados em matéria de independência ${ }^{222}$ e, sobretudo, no tema da responsabilidade.

A fiscalização societária (contrôle des comptes) no direito francês, em relação às sociedades anônimas, é desempenhada pelos chamados commissaires aux comptes (comissários de contas) ${ }^{223}$, como determinado pelo artigo L225-218 do

${ }^{221}$ A respeito da evolução do tema na França, em período anterior à edição da Lei de 24 de julho de 1966, vide R. GRANGER (La nature juridique..., Op. cit., Idem, pp. 25-78).

${ }_{222}$ Vide Georges RIPERT e René RoBlot (Traité de Droit Commercial, $13^{\text {éme }}$ ed., Tomo I. Paris: Librairie Générale de Droit et de Jurisprudence, 1989, pp. 967 e ss.) e Paul Le Cannu (Code des Sociétés, 15émé ed. Paris, Dalloz, 1998, pp. 386-395).

${ }^{223}$ A aproximação funcional entre o conselho fiscal brasileiro e o commissaire aux comptes mostra que a função dos commissaire aux comptes é eminentemente de controle contábil e seu papel fiscalizatório de custos legis é muito menor do que aquele desempenhado pelos conselheiros fiscais de países como Portugal, Itália, Brasil, Argentina e México. Estabelece ainda o artigo L823-10 do Code de commerce: "Les commissaires aux comptes ont pour mission permanente, à l'exclusion de toute immixtion dans la gestion, de vérifier les valeurs et les documents comptables de la personne ou de l'entité dont ils sont chargés de certifier les comptes et de contrôler la conformité de sa comptabilité aux règles en vigueur". Note-se que a exclusão de interferência na gestão, determinada pela lei francesa, retira dos commissaires aux comptes qualquer função que possa se aproximar a uma tarefa de fiscalização geral de cumprimento da legislação por parte da administração, semelhante àquela prevista no artigo 163, I da Lei das S.A. brasileira. Essa fiscalização de legalidade, como o próprio texto legal diz, restringe-se à apreciação da conformidade da contabilidade com as leis aplicáveis. Trata-se, portanto, de uma função mais estreita e totalmente voltada para a revisão contábil, semelhante aos auditors ingleses e norte-americanos, os ROC portugueses e os auditores independentes brasileiros.

Os princípios fundamentais para delinear a atuação do commissaire aux comptes, no exercício de sua missão fiscalizadora, são tratados no Code de déontologie e se regem pelos seguintes parâmetros: integridade, imparcialidade, independência, ausência de conflito de interesses, excelência e qualidade profissional, fraternidade entre os pares e sigilo.

Maurice Cozian, Alain Viandier e Florence Deboissy (Droit des sociétés, 19éme ed. Paris: Litec/Lexis Nexis, 2006, pp. 340-342), ao cuidarem da questão das funções dos commissaires aux comptes, subdividem as funções, de acordo com a abordagem legal, em deveres de controle contábil, deveres de informação e os chamados deveres de alerta. Em relação aos deveres de alerta, trata-se de 
Code. ${ }^{224} \mathrm{O}$ Code ainda, por conta das alterações introduzidas na legislação francesa pela Ordenança de 8 de setembro de 2005, regulamentou inteiramente a profissão dos commissaires aux comptes, acrescentando ao seu texto os artigos L820-1 a L823-18. ${ }^{225}$ Além desses textos, por meio da Lei de 12 de dezembro de 2006, editou-se o Code de déontologie de la profession de commissaire aux comptes. ${ }^{226}$

Por essas informações, nota-se uma primeira e marcante característica da fiscalização societária na França: trata-se de uma tarefa completamente profissionalizada. Ante a profissionalização da missão do controle contábil e da fiscalização societária, os critérios de independência trazidos pela legislação francesa são sensivelmente mais rigorosos que em outros países. Esse rigor, entretanto, não decorre do texto legal, que é razoavelmente abstrato e baseado em princípios gerais de liberdades, deveres e poderes. ${ }^{227}$ Decorre tal rigor da interpretação que a doutrina e a

função regulada fora do contexto do estatuto dos commissaires aux comptes, já que institui dever a esses fiscais no artigo L234-1, dentre as disposições comuns aplicáveis aos diversos tipos de sociedades. Diz o preâmbulo desse artigo: "Lorsque le commissaire aux comptes d'une société anonyme relève, à l'occasion de l'exercice de sa mission, des faits de nature à compromettre la continuité de l'exploitation, il en informe le président du conseil d'administration ou du directoire dans des conditions fixées par décret en Conseil d'Etat'. Essa tarefa, na visão de COZIAN, VIANDIER e DEBOISSY (p. 342), é para os commissaires aux comptes um verdadeiro fardo (fardeau).

${ }^{224}$ Diz o mencionado texto: "Le contrôle est exercé, dans chaque société, par un ou plusieurs commissaires aux comptes".

O atual artigo L.225-218 do Code de commerce corresponde ao antigo artigo 218, que sofreu diversas modificações após a edição da Lei de 24 de julho de 1966, dentre elas aquelas oriundas do Decreto de 23 de março de 1967, do Decreto de 24 de julho de 1984, da Lei de $1^{\circ}$ de agosto de 2003 (sobretudo do seu artigo 104; lei essa também conhecida por Loi de Sécurité Fiancière), da Ordenança de 8 de setembro de 2005 (referente aos commissaires e aplicáveis para conciliar o direito francês com algumas exigências européias).

${ }^{225}$ Trata-se de um texto que introduziu 55 (cinquenta e cinco) novos dispositivos legais articulados para tratar do tema dos commissaires aux comptes e tinha por objetivo cuidar da modernização da profissão dos mesmos.

${ }^{226} \mathrm{O}$ Haut Conseil du Commissariat aux comptes, que aplica as regras do Code de déontologie e estabelece diretrizes de sua atuação em situações práticas, ainda exerce grande parcela de intereferência nesses critérios, de forma objetiva.

${ }^{227} \mathrm{O}$ Artigo 5 do Code de déontologie diz: "Le commissaire aux comptes doit être indépendant de la personne ou de l'entité dont il est appelé à certifier les comptes. L'indépendance du commissaire aux comptes se caractérise notamment par l'exercice en toute liberté, en réalité et en apparence, des pouvoirs et des compétences qui lui sont conférés par la loi.". Ao tratar de impedimentos objetivos, o Code de déontologie estabelece, em seus artigos 27 a 30, uma classificação tripartida entre as formas de impedimento objetivo, a saber, os impedimentos decorrentes de relações pessoais, os impedimentos decorrentes de relações financeiras e os impedimentos decorrentes de relações profissionais.

Os impedimentos pessoais abrangem os familiares e atingem ascendentes, descendentes e colateriais até quarto grau (assim consta do artigo 27 do Code de déontologie: “...il existe un lien familial entre deux personnes lorsque l'une est l'ascendant de l'autre, y compris par filiation adoptive, ou lorsque l'une et l'autre ont un ascendant commun au premier ou au deuxième degré, y compris par filiation adoptive"). Os impedimentos pessoais são mais amplos e incluem "... un lien familial entre conjoints, entre personnes liées par un pacte civil de solidarité et entre concubins". Nesse sentido, COZIAN, VIANDIER e DEBOISSY (Droit des sociétés, Op. cit., Idem, p. 339) fizeram a seguinte (e curiosa) observação: "Ainsi un commissaire aux comptes ne saurait être l'amant de la président de la société; il ne lui est pas interdit de 
jurisprudência empregam nos conceitos de independência, marcadamente quando o tema se aproxima de questões que envolvem algum impedimento objetivo.

Essa profissionalização permite que os commissaires aux compte sejam uma ou mais ${ }^{228}$ pessoas físicas ou jurídicas. Para tanto, basta manter inscrição na lista dos commissaires aux comptes habilitados perante o respectivo órgão de classe. Em caso de pessoa jurídica, as sociedades de commissaires aux comptes devem ser formadas por pelo menos três quartos (3/4) de commissaires aux comptes pessoas físicas devidamente habilitadas e inscritas nesse registro profissional (cf. artigos L822-1 a 8225 do Code de commerce).

A escolha dos commissaires aux comptes é feita na primeira assembléia geral ordinária após o fim do mandato (artigo L823-1 do Code de commerce) e deve durar, pelo menos, seis (6) exercícios. Essa nomeação pode estar sujeita a recusa fundamentada: (i) de acionistas que representem pelo menos cinco por cento (5\%) do capital, (ii) do comitê de remuneração (comitê d'entreprise), (iii) do ministério público, ou da (iv) comissão de valores mobiliários da França (Autorité des marchés financiers). Essa recusa, entretanto, apenas pode se dar por meio de ação judicial que deve ser intentada dentro de trinta (30) dias, contados da assembléia de nomeação. A demanda deve ser proposta com base em motivo justo, que envolva quebra da certeza sobre a competência, a honorabilidade, a imparcialidade ou a independência do comissário. Sua demissão só pode ser proposta nos mesmos moldes e da mesma forma que a ação de recusa. $^{229}$

tomber amoureux, mais il doit alors choisir entre sa passion et sa mission, occasion peut-être de relire Corneille".

Em relação aos impedimentos financeiros, fica claro que o commissaire aux comptes não pode ser acionista da companhia e nem pessoa relacionada a quaisquer de seus acionistas. A vedação vale para credores e quaisquer outros titulares de direitos associativos ou obrigacionais perante a sociedade, incluindo aqueles decorrentes de direitos oriundos de títulos de crédito e valores mobiliários emitidos pela sociedade.

No tocante aos impedimentos profissionais, "Révèle un lien professionnel toute situation qui établit entre le commissaire aux comptes et la personne ou entité dont il certifie les comptes un intérêt commercial ou financier commun en dehors des opérations courantes conclues aux conditions habituelles de marchê".

Outros critérios de independência ainda são tratados de forma bastante detalhada nos artigos L822-10 a L822-16 do Code de commerce.

${ }^{228}$ COZIAN, VIANDIER e DEBOISSY (Droit des sociétés, Op. cit., Idem, p. 340) lembram que não há limite máximo para o número de contratados, mas normalmente é investida uma única sociedade que envolve, em seus trabalhos, dezenas de pessoas com a missão de auditar a companhia.

${ }^{229}$ A não aceitação de demissão ad nutum decorre de conquista creditada a longa evolução doutrinária e jurisprudencial. Vide RIPERT e RoBlot (Traité..., Op. cit., Idem, p. 969). 
Por força dessa profissionalização, dos critérios muito rígidos e particulares de independência e da estrutura jurídica do estatuto legal dos commissaires aux comptes, nota-se que a forma com que os franceses classificam, juridicamente, a relação entre commissaires aux comptes e a companhia não é orgânica, como ocorre com o conselho fiscal no Brasil. Roger GRANGER ${ }^{230}$ propôs, criticando as teorias institucional e orgânica, que a relação entre commissaires aux comptes e a sociedade é de natureza contratual. ${ }^{231}$ Essa posição já é aceita e pacificada, em direito francês, pela doutrina $^{232}$ e pela jurisprudência.

Nessa estrutura, e dentro desse ponto de vista legal, a relação entre commissaires aux comptes e acionistas (bem como os potenciais conflitos) ${ }^{233}$ é positivada na lei francesa de forma muito clara, expondo que aqueles (na qualidade de mandatários da companhia) devem assegurar a equidade no tratamento entre acionistas, bem como entre estes e a administração da companhia. ${ }^{234}$ Essa abordagem técnica, por sua vez, permite que o direito francês veja a disciplina da responsabilidade dos commissaires aux comptes de forma muito avançada em relação a qualquer outro ordenamento jurídico.

O direito francês é o que busca deixar mais claro o regime de responsabilidade civil dos fiscais como regime autônomo. Facilita essa regulação o fato de que, no direito francês, a fiscalização se exerce de forma externa e não orgânica. E dentro desse contexto foi possível ao direito francês, a partir de acurada análise de conflitos potenciais entre commissaires aux comptes e outros titulares de direitos e obrigações em relações jurídicas societárias ${ }^{235}$, desenvolver um regime de

\footnotetext{
${ }^{230}$ La nature juridique..., Op. cit., Idem, pp. 98 e ss.

${ }^{231}$ GRANGER (Ibidem, pp. 98-119) fala da existência de um contrato especial de mandato, tendo como premissa não apenas a característica externa e os critérios de independência dos commissaires aux comptes, mas também a forma de nomeação e de investidura na função.

${ }^{232}$ Pela forma de remuneração, CoZIAN, ViandiER e DEBOISSY (Droit des sociétés, Op. cit., Idem, p. 339) deixam claro e dão mais um argumento como reforço da interpretação, em direito francês, de que a relação dos commissaires aux comptes com a sociedade é de natureza contratual.

${ }^{233}$ A esse respeito, tal qual o fazem José VASQUES (Estruturas e conflitos..., Op. cit., Idem), no direito português, e Ricardo ALESSI (“Il rapporto dialettico...”, Op. loc. cit., Idem), no direito italiano, desponta no direito francês Dominique SCHMIDT (Les conflits d'intérêts dans la société anonyme, Paris, Joly, 2004).

${ }^{234}$ Diz o artigo L823-11 do Code de commerce: "Les commissaires aux comptes s'assurent que l'égalité a été respectée entre les actionnaires, associés ou membres de l'organe compétent".

${ }^{235} \mathrm{Em}$ direito francês, análise bastante precisa dos conflitos potenciais existentes entre commissaires aux comptes e outros partícipes de diversas relações jurídicas societárias deve ser creditada a D. SCHMIDT (Les conflits..., Op. cit., Idem). Ao estudar, dentre outros, conflitos existentes entre minoritários e administração, ou administração e commissaires aux comptes, onde administradores e commissaires aux
} 
responsabilidade civil próprio dos fiscais, nos termos dos artigos L822-17 e L822-18, ambos do Code de commerce. ${ }^{236}$

Esse regime de responsabilidade civil parte do pressuposto de que a comunicação da responsabilidade civil entre commissaires aux comptes e administração deve ser interpretada sempre restritivamente e que, caso seja necessária, o processamento dessa responsabilidade apenas tomará emprestado das ações contra administradores, o prazo prescricional. Nos demais requisitos, mantém-se regime próprio, sendo absolutamente excepcional no direito francês a existência de uma responsabilidade por fato de terceiros ${ }^{237}$, reforçada pela jurisprudência daquele país. ${ }^{238}$

comptes afirmam desconhecer prejuízo, operando de forma negligente, ou ambos, sabendo do risco de dano, assumem a operação conscientemente, SCHMIDT conclui (Ibidem, pp. 356-7): "Carence ou complicité. Dans les deux cas, les administrateurs et les commissaires aux comptes engagent leur responsabilité. Leur faute par omission ou commission a permis le vote de la délibération irrégulière. Leur condamnation à réparer le dommage sanctionne leur faute dans l'exercice de leur mission". No caso, entretanto, de omissão, SCHMIDT deixa claro que cada qual deve responder dentro dos limites de suas funções, de forma específica.

${ }^{236}$ Diz o artigo L822-17: “Les commissaires aux comptes sont responsables, tant à l'égard de la personne ou de l'entité que des tiers, des conséquences dommageables des fautes et négligences par eux commises dans l'exercice de leurs fonctions. Leur responsabilité ne peut toutefois être engagée à raison des informations ou divulgations de faits auxquelles ils procèdent en exécution de leur mission. Ils ne sont pas civilement responsables des infractions commises par les dirigeants et mandataires sociaux, sauf si, en ayant eu connaissance, ils ne les ont pas signalées dans leur rapport à l'assemblée générale ou à l'organe compétent mentionnés à l'article L. 823-1".

A redação desse artigo decorre de uma notável evolução doutrinária e jurisprudencial. RIPERT e RoBlot (Traité..., Op. cit., Idem, p. 986) já haviam notado antes: "La faute des commissaires doit être appréciée par référence à la conduite d'un commissaire diligent et actif, placé dans la même situation. La preuve du lien de causalité entre la faute et le dommage est souvent difficile, parce que la faute des commissaire n'est à peu près jamais la seule cause du dommage, et ne fait que permettre ou aggraver la faute des dirigeants (...). Ils ne sont pas civilement responsables des infractions commises par les administrateurs ou les membres du direcotoire sauf si, en ayant eu connaissance, ils ne les ont pas révélées dans leur rapport à l'assemblée générale (art. 234, al. 2). Cette dernière hypothèse de responsabilité pour autrui est exceptionnelle et doit être interprétée restrictivement: les commissaires ne sont pas responsables des fautes des directeurs et employés de la societé même si, en ayant eu connaissance ils ne les ont pas révélées" (destaques do original).

${ }^{237}$ R. GRANGER (La nature juridique..., Op. cit., Idem, pp. 315-344) disserta longamente sobre esse tema, utilizando-se do regime da responsabilidade civil do contrato de mandato como "chave de leitura" para compreensão da responsabilidade civil dos commissaires aux comptes. Essa responsabilidade deve, portanto, ser semelhante à responsabilidade por inexecução de mandato ou por execução defeituosa. Considerando que o mandato inclui tarefas específicas de revisão contábil, fiscalização e controle (sem tarefas de condução dos negócios) não há, em qualquer hipótese, que se cogitar de uma solidariedade forçada entre faltas cometidas pela administração no exercício próprio de suas funções e as faltas cometidas pelos commissaires aux comptes quando de suas investigações, revisões e fiscalizações. No delineamento das várias hipóteses de conflitos potenciais entre titulares de direitos em companhias, GRANGER nota, na relação com os acionistas e nas relações com terceiros, ser absolutamente excepcional o processamento de uma responsabilidade comum entre commissaires aux comptes e administradores. Nesse passo, GRANGER afirma que esse regime de responsabilidade próprio dos commissaires aux comptes se orienta pelas regras da responsabilidade contratual, que são as mesmas da responsabilidade delitual subjetiva: "L'étude de la responsabilité contractuelle des commissaires envers les actionnaires n'appele pas de marques particulières en ce qui concerne le préjudice et le lien de causalité. Au contraire 


\section{Estados Unidos da América}

\section{Os EUA são, talvez, a fonte mais influente e complexa ${ }^{239}$, não apenas}

para o Brasil, mas também para diversos outros países $^{240}$, seja em termos de fiscalização societária, seja, em um aspecto mais amplo, em termos de direito societário.

la faute contractuelle des commissaires et la réparation qu'ils seront susceptibles de devoir, méritent un examen plus approfondi".

Contrariamente a GRANGER, expõem COZIAN, VIANDIER e DEBOISSY (Droit des sociétés, Op. cit., Idem, p. 342): "En l'absence de relation contractuelle avec la société comme avec les tiers, sa responsabilité ne peut être que délictuelle, ce qui devrait exclure toute référence à l'opposition entre obligation de moyens et obligation de résultat, mais la doctrine oublie volontiers ce détail et qualifie l'obligation du commissaire aux comptes d'obligation de moyens". Nesse mesmo sentido estão RIPERT e RoBlot (Traité..., Op. cit., Idem, p. 985).

Contudo, tanto na visão de GRANGER quanto na visão de COZIAN (reforçada por RIPERT e ROBLOT), nota-se que o regime é o mesmo, qual seja, sempre equivalente - se adepto da teoria contratual, que prima pela visão de uma responsabilidade civil contratual, ou se adepto da teoria orgânica ou institucional, que, no caso do direito francês, prima pela visão de uma resposabilidade delitual, o processamento será sempre idêntico e sob o pálio das regras unificadas da responsabilidade subjetiva. Nesse sentido, GRANGER (Ibidem) lembra: "La responsabilité contractuelle, comme la responsabilité délictuelle, suppose réunies trois conditions, un préjudice causé au créancier, una faute du débiteur et un lien de causalité entre la faute et le préjudice".

${ }^{238}$ GRANGER (La nature juridique..., Op. cit., Idem, pp. 318 e ss.) faz relato extenso da jurisprudência vacilante que operou na França até meados do século XX.

CozIAn, VIANDIER e DeboISSY (Droit des sociétés, Op. cit., Idem, p. 342), por sua vez, em referência a atual jurisprudência francesa, lembram: "En revanche, et dès lors que la mission du commissaire aux comptes n'est pas de refaire la comptabilité, il ne peut pas être tenu responsable de toute irrégularité ou de toute insincérité comptables. Mais on peut lui reprocher un défaut de vérification, des contrôles purement formalistes, la violation des diligences professionnelles, une certification erronée facilitant la poursuite d'une activité déficitaire". Citam, nesse sentido, decisões de cortes de apelação na França ocorridas entre 2003 e 2004 (Ibidem, p. 342, Nota 151) que trataram do tema. Numa delas a administração, tendo agido com suas cautelas, move ação contra os commissaires aux comptes por ter contribuído para sedimentar no mercado uma imagem errada sobre a solvabilidade da companhia. Noutro caso, a negligência de commissaires aux comptes na descoberta de malversações que um exame mais sério poderia permitir identificar, levou o commissaire aux comptes a responder por culpa própria em virtude do reprovável desempenho de suas funções de viligância e fiscalização.

${ }^{239}$ Há quase que um consenso a respeito dessa influência. Recentemente, os estudos de direito societário brasileiro comparado, com muita frequência, têm sempre dedicado um espaço crescente ao sistema estado-unidense, não apenas por se tratar do sistema que rege a maior potência do capitalismo atual, mas, sobretudo pela eficácia de algumas soluções pautadas por esse sistema. Mas como procuraremos demonstrar, nem sempre de sucesso viveu o direito societário estado-unidense (veja-se, nesse sentido, no decorrer da obra $O$ Novo Direito Societário, Idem, de Calixto SALOMÃo FILHO, as análises sobre o papel do neoliberalismo no direito [pp.16-19] e sobre as teorias modernas do contratualismo societário [pp.38-50], a título de exemplo).

E é justamente das experiências tormentosas que se podem extrair lições valiosíssimas. A transposição pura e simples dos mecanismos de um sistema, sem ao menos compreender os problemas e as críticas que compõem a sua estrutura, podem penalizar o receptor incauto com a disseminação de novos problemas ou o agravamento daqueles já existentes. Como procuraremos mostrar, o direito estadounidense sofre por conta de conflitos pelos quais os olhos brasileiros menos acurados costumam passar sem a cautela devida: federalismo, regulação do mercado, intervenção estatal, privatização de funções públicas (dentre as quais se incluem algumas funções fiscalizatórias). Esses são problemas crônicos, que estão muito além dos escândalos pontuais que ocorrem de tempos em tempos, dentre os quais temos, desde a Grande Depressão de 1929, o grave abalo gerado pela quebra da Enron em 2001 e os recentes 
Embora, como bem saibamos, os EUA possuam uma estrutura legal de common law, não há que se negar que, em termos de fonte legislativa (qual seja, texto legal produzido pelo Poder Legislativo), o sistema estado-unidense fornece para o resto do mundo (e para o Brasil inclusive) modelos legislativos que vêm sendo insistentemente $\operatorname{copiados}^{241}$. Em muitos casos, essa transposição de cultura jurídica tem

solavancos que mergulharam a Grande Nação em uma de suas maiores crises financeiras vividas até então.

${ }^{240}$ Os estudos de direito societário comparado centrados na experiência estado-unidense têm se multiplicado em quantidade e se aprimorado em qualidade. Se atentarmos para a evolução nos últimos cinco anos, notaremos que o direito estado-unidense tem desempenhado um papel fundamental para o direito comparado de três países, a saber, França, Alemanha e Japão. Essa atenção fica bastante saliente na obra coletiva organizada por Reinier R. KRAAKMAN, The Anatomy of Corporate Law (Oxford, UK: Oxford University Press, 2004). No Brasil, além do já citado C. SAlomão Filho (O Novo Direito Societário, Idem, passim), há uma grande quantidade de artigos que têm na base da comparação a experiência estado-unidense.

Além desses países citados, a gama de países cuja influência estado-unidense está devidamente documentada é bastante extensa e, em recentes publicações, podemos ter estudos comparados de alta qualidade em face de sistemas jurídicos tão díspares quanto o Sultanato de Oman (Ellen Kerrigan DRY, "Corporate Governance in the Sultanate of Oman", In Richmond Journal of Global Law and Business, vol. 3, Richmond, VA: Richmond Journal of Global Law and Business, Janeiro-Maio, 2003, pp. 45-82), Paquistão (Ali Adnan IBRAHIM, "Corporate Governance in Pakistan: analysis of current challenges and recommendations for future reforms", In Washington University Global Studies Law Review, vol. 5, Washington, DC: Washington University Press, 2006, pp. 323-332) e Coréia do Sul (Jae Yeol Kwon, "The Internal Division of Powers in Corporate Governance: a comparative approach to the South Korean Statutory Scheme", In Minnesota Journal of Global Trade, vol. 12, Minneapolis, MN: Minnesota Journal of International Law, Junho-Agosto, 2003, pp. 299-336). É também abundante e marcante a quantidade de textos produzidos no contexto da Lei Sarbanes-Oxley de 2001 (a chamada "SOX"), investigando os impactos dessa lei sobre as empresas e os sistemas jurídicos de outros países como Alemanha, França, Itália, China, Japão e Brasil. Dentre os textos mais relevantes sobre o tema temos: Detlev F. VAGTS, "Extraterritoriality and the Corporate Governance Law", In American Journal of International Law, vol. 97, Washington, DC: American Society of International Law, Abril, 2003, pp. 289-294; Soo-Jeong SHIN, "The effect of the Sarbanes-Oxley Act of 2002 on foreign issuers listed on the U.S. capital markets", In NYU Journal of Law and Business, vol. 3, Nova Iorque, NY: The New York University Journal of Law and Business, Março-Maio, 2007, pp. 701-739; Kenji TANEDA, "SarbanesOxley, Foreign Issuers and United States Securities Regulation", In Columbia Business Law Review: Columbia Law School Press, 2003, pp. 715-759; Andrea Fernandes ANDREZO, "The Sarbanes-Oxely Act and the rules applicable to foreign companies: the possible impacts on the capital markets", In RDM 132/25-54, Outubro-Dezembro, 2003. Ainda nas publicações brasileiras, encontram-se textos em português sobre o tema, especificamente voltados para os nossos problemas. Dentre eles destacam-se Claudio FINKELSTEIN e Roberta GouveiA, "Lei Sarbanes-Oxley Act 2002 e suas implicações às empresas brasileiras", In Revista de Direito Internacional e Econômico, vol. 4, Porto Alegre: Síntese, JulhoAgosto/2003, pp. 92-102; Luiza Rangel de MORAES, "As novas atribuições do conselho fiscal diante da Lei Sarbanes-Oxley e da legislação brasileira”, In RDB 29/47-65, Julho-Setembro, 2005.

${ }^{241}$ Limitando-nos apenas à recente reforma estruturada pela Lei Sarbanes-Oxley, podemos lembrar que, além da comunidade européia, outros países do mundo também adotaram medidas semelhantes, muita vez copiadas diretamente da lei estado-unidense. Países como Austrália e Canadá adotaram leis bastante parecidas com a chamada SOX. Entretanto, de todos, o mais marcante é o Japão, que em 14 de junho de 2006, promulgou a reforma da "Lei de Instrumentos Financeiros e Mercados de Valores" em resposta aos escândalos ocorridos na gigante de cosméticos Kanebo, bem como na gigante Livedoor. Essa lei japonesa, devido à similaridade com a lei estado-unidense e a grande semelhança dos escândalos Kanebo e Livedoor com as fraudes ocorridas na Enron e WorldCom, foi reconhecida como a versão japonesa da Lei Sarbanes-Oxley e passou logo a ser tratada informalmente como J-SOX. Há uma versão oficial em inglês que o governo japonês editou em paralelo à reforma da Lei de Instrumentos Financeiros e Mercados de Valores (Financial Instruments and Exchange Act nr. 99 de 2007, que entrou em vigor em 1 de Abril de 2008), disponível em <http://www.fsa.go.jp/common/law/fie01.pdf> (último acesso em 27 de 
sido feita até com certo descuido em relação às tradições jurídicas dos países receptores. Em matéria de descuido, o Brasil, desafortunadamente, é sempre um dos pioneiros. ${ }^{242}$

Antes, entretanto, de tratarmos dessas notáveis transposições culturais dos EUA para o Brasil, cumpre-nos, ainda que nos limites da superficialidade desta dissertação, compreender didaticamente como as estruturas de fiscalização societária estão organizadas no sistema jurídico estado-unidense.

Para bem compreendermos o sistema estado-unidense e as suas formas de fiscalização, bem como o embate entre soluções de fiscalização interna versus fiscalização externa, temos que assumir a premissa sistêmica que domina o direito estado-unidense e compreendê-la em visão ampla: portanto, em primeiro lugar, cumprenos observar que os EUA são uma república federativa afiliada aos países do sistema da common law.

Essas premissas, embora óbvias, são importantíssimas, pois os EUA, não sendo uma monarquia tal qual outros países da commow law, como a Inglaterra e alguns países do Oriente Médio, têm uma organização de Estado e poder peculiar (embora com tentativas de imitação por outros países do mundo), que resulta num funcionamento próprio do sistema da common law muito diferente da common law de outros países. Essa singularidade dá ao Poder Judiciário e ao Poder Legislativo da União e dos Estados norte-americanos papel muito particular nas tarefas de criação, execução e interpretação do direito, que a doutrina jurídica estado-unidense costuma chamar de enforceability system.

Em matéria de direito societário, o sistema estado-unidense reconhece jurisdição estadual para algumas matérias e jurisdição federal para outras. Quando o

janeiro de 2009). Sobre mais informações a respeito das recentes mudanças no direito societário japonês, incluindo as modificações a respeito de auditoria, vide Zenichi SHISHIDO ("The Turnaround of 1997: Changes in Japanese Corporate Law and Governance", In Corporate Governance in Japan: Institutional Change and Organizational Diversity, orgs.: Masahiko AOKI, Gregory JACKSON e Hideaki MIYAJIMA. Nova Iorque, NY: Oxford University Press US, 2008; pp. 310-329, com ênfase nas mudanças no sistema de auditoria nas pp. 320-321).

${ }^{242} \mathrm{O}$ dínamo mais eficaz na construção de mitos americanos ao longo desses últimos cinco anos têm sido, sem dúvida alguma, os pequenos fóruns de discussão ligeira surgidos em jornais especializados e em boletins de grandes bancas de advocacia brasileiras e latino-americanas, bem como os informativos de empresas de auditoria independente. O olhar apressado para um problema pontual do capitalismo estadounidense (a saber, o escândalo Enron), e as formas de solução e alteração estrutural promovidas pela Lei Sarbanes-Oxley, ajudaram a construir os mitos sobre o comitê de auditoria, os motivos sobre as falhas na fiscalização societária e os meios de solução interna, que dentre muitos, alguns juristas esforçaram-se em inserir a fórceps em nosso sistema legal. 
tema diz respeito à constituição de companhias, administração, capital, condução do objeto social, responsabilidade de administradores e acionistas, assembléias, a lei do Estado de constituição, bem como as cortes estaduais onde a companhia foi constituída, são aplicáveis em detrimento de regras federais e dos tribunais federais. ${ }^{243}$ Entretanto, quando o tema diz respeito à divulgação obrigatória de informações ao mercado (disclosure) e as regras para circulação dos valores mobiliários, aplicam-se regras federais em concorrência com os tribunais estaduais. Contudo, há comumente uma área de conflito que envolve uma característica adicional à competência federal, ${ }^{244}$ que se sustenta ora por razões técnicas, ora por razões históricas. Dentre essas matérias de competência federal, mas em cuja matriz há um forte componente de matéria estadual, destacamos aquela referente aos crimes federais e à responsabilidade dos administradores, por faltas decorrentes dos deveres fiduciários de informação, e infração às vedações de negociação com ações da companhia em certos períodos (insider trading). Ainda dentro desse leque de temas que oscilam entre a competência federal e a competência estadual, está o problema da fiscalização societária.

A fiscalização societária nos EUA é ora vista como um dever do auditor (com fontes de natureza federal e estadual em alguns casos), ora vista como um direito essencial do acionista, ora como uma das tarefas da administração (mais especificamente, do conselho de administração, o board of directors), e algumas raras

\footnotetext{
${ }^{243}$ Um dos temas mais relevantes no estudo do direito societário estado-unidense, mas de difícil compreensão para um brasileiro, por conta das disparidades sistêmicas, diz respeito à competição entre os Estados da federação por sistemas mais eficazes. De todos os Estados norte-americanos, Delaware é indiscutivelmente a fonte mais rica e importante para as regras de common law estadual de direito societário. Em Delaware desenvolveu-se, tanto na doutrina mas sobretudo na jurisprudência da sua Suprema Corte, uma estrutura de responsabilidade da administração que é tida por muitos como a mais avançada no meio jurídico estado-unidense. Steven EMANUEL (Corporations, $3^{\mathrm{a}}$ ed.. Larchmont, NY: Emanuel, 2000, p. 1) afirma: "The state of Delaware occupies a disproportionately major role in corporate law" [assim].

O debate a respeito da primazia de uma estrutura jurídica elaborada por um Estado em detrimento de outro passa pela discussão da chamada competição estadual por constituições (state competition for incorporation) em que muitos Estados tornam textos padronizados de estatutos e atas de fundação ora em favor dos poderes da administração, ora em favor dos direitos dos acionistas. Essa alternância é conhecida como a corrida para o fundo (race to the bottom) versus a corrida para o topo (race to the top). Há uma quantidade muito grande de estudos sobre o tema, sempre preparados pelos mais importantes juristas estado-unidenses (nesse mesmo diapasão, vide Roberta RoMANO, "State Competition for Corporate Charters: the State Competition debate in Corporate Law", In Foundations of Corporate Law [org.: Roberta RomAno]. Nova Iorque, NY: Foundation Press, 1993, pp. 84-90; Frank H. EASTERBROOK e Daniel R. FISCHEL, The Economic Structure of Corporate Law, 4a reimpressão. Cambridge, Mass: Harvard University Press, 1998, pp. 212-227; S. EMANUEL, Corporations, Op. cit., Idem, pp. 13-18).

${ }^{244}$ Robert Charles ClaRK (Corporate Law, Boston: Little Brown/Aspen, 1986, p. 30) nota como, em certas circunstâncias, há uma intersecção de fontes para regular as relações societárias entre acionistas e administradores, basicamente.
} 
vezes como matéria de atuação do poder regulado (mais especificamente, da Comissão de Bolsas e Valores Mobiliários dos EUA, a Securities and Exchange Commission, no papel de agente de prevenção de fraudes societárias). ${ }^{245}$ O tema da fiscalização societária nos EUA é assunto que clama, muita vez, pelo estudo não apenas de doutrina de direito societário, mas também de doutrina de direito do mercado de capitais e do direito administrativo.

Antes, portanto, de se discutir o problema da fiscalização societária nos EUA como um simples embate pela opção fiscalização interna versus fiscalização externa, é importante ter-se em mente que a prioridade que se dá por uma forma de fiscalização ou outra não comporta apenas um problema de direito societário, mas pode comportar uma opção política que resulta na priorização da estrutura e do arcabouço de normas federais em detrimento de normas estaduais ou vice-versa.

A questão da fiscalização societária nos EUA é portanto, antes de tudo, um problema típico do federalismo estado-unidense - antes mesmo de ser um problema de direito societário. ${ }^{246} \mathrm{O}$ estudo da fiscalização societária que enfoque exclusivamente

\footnotetext{
${ }^{245}$ Vide Joel SELIGMAN, “The SEC at 70: a modest revolution in corporate governance”, In Notre Dame Law Review, vol. 80, Notre Dame, IN: Notre Dame Law Review, Março, 2005, pp. 1159-1185. O autor faz contundentes críticas à forma puramente reativa com que a SEC, como regulador, age diante dos problemas, sem que as iniciativas tenham uma propensão à prevenção e à revisão sistemática da estrutura normativa em vigor.

${ }^{246} \mathrm{O}$ problema das fronteiras do federalismo estado-unidense ressurgiu com muita força no âmbito das discussões que cercam a efetividade e a real competência constitucional das medidas implementadas pela Lei Sarbanes-Oxley. Os problemas que têm surgido na esfera do estudo próximo da Lei Sarbanes-Oxley têm na base uma profunda discussão sobre a predominância dos princípios sobre as regras. O direito estado-unidense é sensivelmente sustentado por princípios que a jurisprudência e as cortes revisam constantemente. Nesse contexto, as maiores e mais profundas críticas à SOX consideram que essa lei fez regras se chocarem com princípios de forma muito contundente (vide James D. Cox, "After the SarbanesOxley Act: the future disclosure system - reforming the culture of financial reporting - the PCAOB and the metrics for accounting measurements", In Washington University Law Quarterly, vol. 81, St. Louis, MO: Washington University Press, junho-agosto, 2003, pp. 301-327).

Muitos criticam severamente o fato de que a Lei Sarbanes-Oxley não apenas usurpou temas que seriam da competência dos Estados, mas também delegou excessivamente ao mercado a ação preventiva e fiscalizatória, reservando para si apenas um rígido aparato punitivo: para muitos, uma fórmula clássica de ineficácia e impunidade. A crítica a essa experiência, que tem sido mal sucedida, não tem sido percebida por muitos doutrinadores de outros países no momento em que os sistemas são copiados e transpostos sem a cautela necessária. Nesse sentido, J. Robert BROWN JR. ("The irrelevance of state corporate law in the governance of public companies", In University of Richmond Law Review, vol. 38, Richmond, VA: The University of Richmond Law Review Association, Janeiro, 2004, pp. 317-380) ataca fortemente a Lei Sarbanes-Oxley sob o ponto de vista sistêmico, notando que a SOX oscila excessivamente entre as searas de competência exclusiva do direito societário de fonte estadual e dos mecanismos federais. Colocando os problemas da SOX dentro do debate sobre a concorrência entre os Estados por regras de constituição, BROWN JR. identifica graves falhas, sobretudo na compreensão sistêmica do direito societário estado-unidense e na parte que diz respeito aos deveres dos administradores (com ênfase no dever de fiscalizar [duty to monitor], pp. 343-347. Sobre outros detalhes a respeito do dever de fiscalizar [duty to monitor], vide também o notável texto de Larry Catá BACKER, "The Duty to Monitor: emerging
} 
a Lei Sarbanes-Oxley é, além de distorcido, um estudo falho, enviesado e obliterado de detalhes importantes. ${ }^{247}$ Mas é partindo dessa lei que os problemas da fiscalização societária nos EUA podem ser mais bem compreendidos.

obligations of outside lawyers and auditors to detect and report corporate wrongdoing beyond the securities laws", In St. John's Law Review, vol. 77, nr. 4, Nova Iorque, NY: St. John's Law Review Association, Setembro-Novembro, 2003, pp. 919-1018). Joel SELIGMAN, em outro artigo ("Conflicts of interest in corporate and securities law: no one can serve two masters - corporate and securities law after Enron", In Washington University Law Quarterly, vol. 80, St. Louis, MO: Washington University, Junho-Agosto, 2002, pp. 449-517), nota que o descuido na implementação de regras que respeitassem os limites de competência legislativa dos Estados planta no presente um problema que o futuro do direito estado-unidense poderá cultivar nas lacunas que a SOX abriu no sistema de responsabilidade civil dos administradores. No mesmo sentido, Jeannie NELSON ("New Corporate Responsability Law increases liabilities for directors, officers, and attorneys, but does it increase protections for investors?", In Texas Tech Law Review, vol. 34, Lubbock, TX: The School of Law Texas Tech University Press, 2003, pp. 1165-1197, para quem a resposta a ser dada à retórica pergunta do título é "não", cf. p. 1196) demonstra com clareza as ineficiências dos mecanismos legais da SOX. Tal qual NELSON, a ineficiência desses mecanismos é também exposta por profundo estudo de Robert Charles CLARK ("Corporate Governance changes in the wake of the Sarbanes-Oxley Act: a morality tale for policemakers too", In Georgia State University Law Review, vol. 22, Atlanta, GA: Georgia State University College of Law, Setembro, 2005, pp. 251-296). CLARK chega a concluir que "much of the reform movement is based on seemingly plausible hypotheses, or a priori theorizing, but not also on serious and methodical study of the facts". Ainda nessa esteira de raciocínio, J. SELIGMAN é particularmente exigente com as inconsistências sistêmicas decorrentes da redação dos artigos 406 e 407 da Lei Sarbanes-Oxley, considerando-os uma das mais draconianas regras de direito societário jamais vistas (p. 501 e nota 117), resultando numa quebra na lógica do sistema do direito societário estado-unidense, principalmente no que se refere à responsabilidade da administração ("Much of the Sarbanes-Oxley Act addressed breakdowns in the system of corporate responsability. As the fervor of Congress increased in late July 2002, the dimensions of legislative response increased exponentially". No mesmo sentido, vide Peter FEROLA "The role of audit committees in the wake of corporate federalism: Sarbanes-Oxley's creep into state corporate law", In Journal of Business and Securities Law, vol. 7, East Lansing, MI, Michigan State University College of Law, Março-Maio, 2007, pp. 143-162). Ainda sob a lente do problema do federalismo, regras de responsabilidade de contadores e advogados foram duramente alteradas, o que, na esteira do texto de SELIGMAN, teve profunda abordagem feita por um dos maiores críticos da SOX, o Professor Larry Catá BAKER ("The Sarbanes-Oxley Act: federalizing norms for officer, lawyer, and accountant behavior", In St. John's Law Review, vol. 76, Nova Iorque, NY: St. John's Law Review Association, SetembroNovembro, 2002, pp. 897-951).

Especificamente com relação ao problema particular da fiscalização societária em si, a questão do federalismo surge com vigor ao se analisar o papel e as funções do comitê de auditoria, tal qual imposto pela SOX e dentro do contexto do direito societário estado-unidense, em que alguns Estados distinguemse no tratamento do papel dados aos auditores e aos conselheiros de administração. Tendo apenas o sistema de Delaware em mente, a sua influência sobre a SOX é considerável. Peter FEROLA ("The role of audit committees..., Op. loc. cit, Idem, pp. 154) lembra que essa reforma "resulted in the federalization of existing Delaware corporate law, specifically with respect to executive loans, composition and responsabilities of audit committees, and the definition of independence".

Larry Catá BACKER, em um de seus mais contundentes trabalhos de crítica ao sistema da SOX, centra-se exclusivamente nos problemas que essa lei traz em matéria de fiscalização societária ("Surveillance and Control: privitizing and nationalizing corporate monitoring after Sarbanes-Oxley", In Michigan State Law Review, Detroit, MI, Law Review of Michigan State University - Detroit College of Law, Junho-Agosto, 2004, pp. 327-440), comparando o sistema de vigilância da SOX ao panóptico de Bentham e aos sistemas de perseguição criticados por Foucault no Vigiar e Punir, mostrando com muita profundidade todos os retrocessos da referida lei em termos técnicos e explicitando a nociva fórmula da prevenção pelo mercado e punição pelo Estado.

${ }^{247}$ J. SELIGMAN ("The SEC at 70...", Op. loc. cit., Idem, pp. 1167-1168) lembra que a primeira regra que impôs a exigência de constituição de comitês de auditoria não foi a SOX, mas sim uma regra da SEC de 1977, que alterava os requisitos de listagem em bolsas de companhias de capital aberto, exigindo que "each domestic company with common stock listed in that exchange [NYSE], 'to establish... and 
A Lei Sarbanes-Oxley, por meio de seu artigo 301, alterou regras de fiscalização interna nas companhias. Essa fiscalização interna passava a ter foco na atividade de fiscalização externa: em outras palavras, a SOX fortaleceu os mecanismos de fiscalização interna em relação ao trabalho dos auditores independentes (fiscalização externa). ${ }^{248}$ Além disso, criou responsabilidades para a administração em relação à efetividade de controles internos da companhia e aos mecanismos de controle de riscos e diversos outros mecanismos de prevenção a fraude corporativa por meio da ampliação de tipos penais. ${ }^{249}$ A esse sistema, que articula mecanismos diversos de recíproca fiscalização da atividade societária, deu-se o nome de gatekeepers system (sistema dos “porteiros" ou "guardiões") ${ }^{250}$, incluídos os próprios administradores, num primeiro nível, os auditores e advogados, num segundo nível, e o próprio Estado, num nível mais remoto, excluídos os acionistas. ${ }^{251}$

maintain... an audit committee comprised solely of directors independent of management and free from any relationship that, in the opinion of the board of directors, would interfere with the exercise of independent judgement as a committee member"'. Além disso, lembre-se a advertência de John C. COFFEE JR. (Gatekeepers..., Op. cit., Idem, pp. 25-26): "Viewed from a distance, Enron had an exemplary audit committee with more financial expertise than virtually any contemporaneous audit committee possessed at that time". É importante assumir que, num estudo comparado com os EUA, os problemas com a fiscalização societária não nascem com o escândalo Enron, nem tanto se encerram com a SOX. Nessa esteira, é equivocada a idéia de que os comitês de auditoria surgem com a SOX ou que estes sejam trazidos como a solução para os problemas identificados no escândalo Enron. A SOX traz muitas novidades em relação aos comitês de auditoria, mas, definitivamente, não os cria nem os trata pela primeira vez em sede de direito estado-unidense.

${ }_{248}$ Do artigo 301 da SOX, a SEC, por intermédio das regras publicadas nos Editais n ${ }^{\circ s} 33-8177$ de 23 de janeiro de 2003 (posteriormente emendada e corrigida pela regra constante do Edital n ${ }^{\circ} 33-8177-\mathrm{A}$ de 26 de março de 2003), 33-8183 de 28 de janeiro de 2003 (posteriormente emendada e corrigida pela regra constante do Edital n ${ }^{\circ} 33-8183-A$ de 26 de março de 2003) e 33-8220 de 9 de abril de 2003, formula o novo modelo de fiscalização no direito societário estado-unidense, pela via do fortalecimento da fiscalização interna, que ficaria responsável por supervisionar o trabalho da auditoria independente, qual seja, a fiscalização externa. Essas regras foram complementadas pela reforma das Regras NYSE de Governança Corporativa, que impunham requisitos mínimos para que as companhias se mantivessem listadas na NYSE, a New York Stock Exchange (Bolsa de Valores de Nova Iorque). A SOX ainda criou o PCAOB (Public Company Accounting Oversight Board - Conselho de Supervisão de Contabilidade das Companhias Abertas). O PCAOB editou, em 18 de Junho de 2004, a sua Instrução nr. 2, que traçou regras rígidas para os procedimentos de auditoria de controles internos e auditoria financeira de companhias abertas, bem como normas de supervisão e fiscalização desses trabalhos de auditoria.

${ }^{249} \mathrm{O}$ novo sistema de direito societário trazido pelas várias modificações implementadas pela SOX, quando vistas sob um ângulo mais genérico e não apenas centrado na questão da fiscalização societária, comporta também um número elevado de estudos críticos que ressaltam as deficiências dessa lei.

${ }^{250}$ Imaginou-se uma teia de relações em que o fluxo de divisas e informações tem sempre um indivíduo que verifica, por último, a entrada ou a saída de algum recurso ou informação. Nessas "portas de entrada" e "portas de saída", o sistema mantém sempre alguma pessoa, investida em órgão, que se responsabiliza por esse movimento de divisas ou informações, seja no sentido de "dentro para fora" da companhia, seja no sentido de "fora para dentro" da companhia. Vide J. C. COFFEE JR. (Gatekeepers..., Op. cit., Idem, pp. 1-5), Michael P. DoOLEY (Fundamentals..., Op. cit., Idem, pp. 118-119); Robert Charles ClarK (Corporations Law, Op. cit., Idem, pp. 129-130).

${ }^{251}$ Vide J. C. COFFEE JR. (Gatekeepers..., Idem, pp. 103-314), que ainda inclui as chamadas "agências de avaliação" (rating agencies), cujo trabalho ainda é muito pouco conhecido e difundido no Brasil. O trabalho desses gatekeepers só passou a ser melhor acompanhado depois que os títulos de dívida emitidos 
Para os fins desse trabalho, entretanto, não são todos esses agentes de fiscalização societária que são passíveis de aproximação com o nosso conselho fiscal.

pelo governo brasileiro passaram a ser avaliados por essas agências, que emitem recomendações de compra ou venda, alterando a demanda e o preço desses títulos públicos. Logo depois que o Brasil atingiu níveis sustentáveis de um índice chamado "risco-país", que levou-o a granjear notas altas dessas agências e inclusive o chamado "grau de investimento" (investment grade), o interesse pelo trabalho desses profissionais cresceu muito. Mas é sempre bom lembrar que, nos EUA, o trabalho desses agentes de informação vem desde 1909, quando a agência Moody's passou a publicar as suas opiniões ao mercado (vide J. C. COFFEE JR., Gatekeepers..., Idem, pp. 284 e ss.).

Larry C. BACKER ("Surveillance and control...", Op. loc. cit., Idem, p. 426) consegui descrever resumidamente os mecanismos desse sistema de fiscalização (system of surveillance norms) nestes termos: "Monitoring occurs on three levels: internal, external and governmental. Internal controls focus on two of the critical actors in the governance of corporations, officers, and directors. (...) External controls revolve around gatekeepers, specifically lawyers and auditors monitoring the company, its officers, its directors, and each other. (...) The state looms over this surveillance enterprise. Governmental controls are grounded in enforcement. Enforcement must be understood here in two distinct senses. First, the state has increased the breadth of its power to discipline those persons it has deputized with surveillance duties. Indirectly, this is accomplished by the construction of a system in which the state sits at the top of a pyramid of monitoring by others. With SOX, the SEC can more effectively control and process information through its web of deputies, especially whistle-blowing employees, officers faced with certification requirements, outside directors with fiduciary duties, auditors and outside counsel with detect and report obligations" (p. 342-345)..

Note-se que, no exemplo de BACKER, a fiscalização pelos acionistas não compreende, efetivamente, essa estrutura de fiscalização. Já há um consenso nos EUA de que as formas de investimento já alcançaram o que Robert Charles CLARK chama de quarto estágio do capitalismo, qual seja, aquele estágio em que a decisão de investimento não está mais nas mãos dos investidores que aplicam seus recursos, mas sim nas mãos de grandes administradores e gestores de fundos de investimento e fundos de pensão (vide "The four stages of capitalism: reflections on investment management treatises" In Harvard Law Review, vol.94. Boston: Harvard University Press, 1981; pp.561-582). Portanto, a tão propalada dispersão acionária estado-unidense tem gerado sérios conflitos por força da concentração das fortunas de investimento em mãos de poucos gestores, que tomam as decisões em nome de acionistas (via proxy machinery system), e de muitos quotistas desses fundos que administram. $\mathrm{O}$ visível e crescente absenteísmo, aliado a uma questionável estratégia de voto por parte de muitos gestores de fundos, têm gerado forte questionamento sobre a pujança e a possibilidade de contar com o acionista como parte ativa na difícil tarefa fiscalizatória (vide F. EASTERBROOK e D. FISCHEL, The Economic Structure of Corporate Law, Idem, pp. 88-89).

Esse embate levou muitos estudiosos a questionarem publicamente o chamado "mito da mobilização da comunidade acionária" (shareholder franchise myth). Há textos que invocam esse problema, voltado à questão prática da impossibilidade de remoção tempestiva de conselheiros que não atuam, eventualmente, no exclusivo interesse da comunidade societária (vide Lucian Ayre BEBCHUK, "The Myth of Shareholder Franchise", In Virginia Law Review, vol. 93, Charlottesville, VA: Virginia Law Review Association, Maio, 2007, pp. 675-732). Esse problema, quando refletido exclusivamente sob a ótica da fiscalização, mostra o quanto o acionista individual, ainda em um sistema de Judiciário eficaz como o dos EUA, tem se tornado cada vez mais mítico. Em inteligente resposta divergente ao texto do Prof. BEBCHUK, a Professora Lynn A. STOUT publicou, no mesmo volume da mesma revista jurídica, notável artigo ("The Mythical Benefits of Shareholder Control", In Virginia Law Review, vol. 93, Charlottesville, VA: Virginia Law Review Association, Maio, 2007, pp. 788-809), apresentando a seguinte observação em relação ao problema da fiscalização e do colapso da Enron no contexto do "mito da mobilização da comunidade acionária": "This response - we might call it the 'Enron Effect' - fails to appreciate both the causes of corporate fraud and the lessons of business history. Enron did not collapse because its shareholders did not have enough power. In fact, an outside observer might have easily concluded that the firm was a model of 'good corporate governance', with a large majority of (supposedly) independent directors, an independent audit committee, no staggered board provision, and stock option compensation to tie both director and executive pay to 'performance'. More generally, Enron's collapse - and the recent scandals at other firms - occurred at a time in history when shareholders enjoyed more influence over boards than ever before". 
Dentre eles, se destacam, basicamente, dois: (i) os auditores independentes; e (ii) o conselho de administração, por meio de um comitê de auditoria.

No caso dos auditores independentes, é necessário termos em mente que a relação jurídica entre os auditores e a companhia é de natureza contratual e não societária. Portanto, tal qual ocorre com os commissaires aux comptes na França, os deveres dos auditores nos EUA se regem por meio das regras aplicáveis aos mandatos. Trata-se, portanto, de uma fiscalização externa ao contexto das relações societárias de uma companhia, sem qualquer instauração orgânica de deveres e responsabilidades. $O$ número de auditores é sempre definido - basta que as companhias façam suas relações serem revistas por uma firma de auditores. Entretanto, o trabalho pode ser desempenhado por um grupo de auditores que varia conforme a grandeza da empresa auditada: nos casos das companhias menores, esse número raramente se dá com um grupo de agentes inferior a dez. Em caso de grandes companhias e de multinacionais com negócios em mais de uma região ou país, o número de revisores oficiais atuando por uma firma de auditoria chega às centenas.

A qualificação para ser auditor é normalmente definida pelas regras próprias e inerentes à profissão: auditores de grandes firmas são normalmente agentes de altíssima qualificação acadêmica, com graduação em ciências contábeis e alguma complementação educacional nas áreas de administração de empresas, economia, direito, finanças ou contabilidade. Nos EUA, para ser auditor é necessário, antes, certificar-se como contador público (certified public accountant ou CPA), cujo processo leva o recém-graduado em ciências contábeis a prestar o exame do AICPA (sigla de American Institut of Certified Public Accountant, ou Instituto Americano de Contadores Públicos Certificados). O exame do AICPA, conhecido vulgarmente como "CPA Exam" habilita o candidato a exercer a profissão de contador em suas vertentes e especialidades, dentre as quais se destaca a de auditoria.

O trabalho do auditor é sempre limitado ao escopo de uma auditoria, cujos lindes são determinados pelo objeto do contrato em que o auditor é investido das funções revisoras e fiscalizatórias pela administração da companhia objeto. O conteúdo mínimo do contrato é estabelecido pelos padrões mínimos de auditoria, construídos segundo a prática e a jurisprudência decorrentes das obrigações previstas para tal, nos termos da Lei de Bolsas e Mercados de 1934 ('34 Securities and Exchange Act). A 
fiscalização desempenhada pelo auditor deve seguir os padrões exigidos por essa lei e garantir ao público investidor que as informações que a companhia leva ao mercado sejam equalizadas com as informações que a companhia dispõe internamente. Devem assegurar, outrossim, que as informações que a administração da companhia compartilha com o mercado sejam suficientes para que as tomadas de decisão de investimento decorram de uma interpretação de fatos que realmente revelam o estado financeiro e de negócios de uma companhia. ${ }^{252}$ Eventuais impactos negativos devem ser revelados pelo auditor ao mercado, por meio da SEC, segundo as novas regras impostas pela SOX. Nessa esteira, as obrigações do auditor não apenas dizem respeito à análise das demonstrações financeiras e ao relatório da administração, mas também aos controles internos e à avaliação dos riscos. É, portanto, uma fiscalização mais ampla do que o de uma mera auditoria contábil, mas, certamente, mais restrita do que a fiscalização que a lei brasileira investe o nosso conselho fiscal, com verificação do cumprimento de deveres legais e estatutários por parte dos administradores.

Merece atenção o sistema estado-unidense, no tocante às regras de impedimento de atuação e responsabilidade civil. As normas de responsabilidade civil são mais intrincadas, pois o sistema em questão, por força de oscilações em seu federalismo, reconhece uma responsabilidade tipicamente federal (de origem legislativa e relacionada aos deveres do auditor à luz de leis federais como o '34 Act e a SOX) e

\footnotetext{
${ }^{252}$ Esse fenômeno, que equaciona informação e decisão de investimento, é tratado na teoria jurídica societária estado-unidense com a hipótese do mercado eficiente (ECMH, do termo em inglês efficient capital markets hypothesis). Essa teoria é desenvolvida com brilhantismo no artigo de Ronald GILSON e Reinier H. KRAAKMAN, "The mechanisms of market efficiency", In Virginia Law Review, vol. 70. Charlottesville, VA: Virigina Law Review Association, 1984, pp. 549-644. Em complemento às idéias de GILSON e KRAAKMAN, Saul LEVMORE ("Efficient Markets and Puzzling Intermediaries", In Virginia Law Review, vol. 70. Charlottesville, VA: Virigina Law Review Association, 1984, pp. 645-667) estendeu muitos argumentos do ECMH formulados por GILSON e KRAAKMAN. Ainda sobre a teoria da ECMH, vide S. EMAnuel, Corporations, Idem, pp. 269-270 e M. P. Dooley, Fundamentals..., Idem, pp. 473483.

Dentro de um outro contexto, que pode se ligar às reformas implementadas pela SOX, Frank H. EASTERBROOK e Daniel R. FISCHEL ("Mandatory disclosure and the protection of investors" In Virginia Law Review, vol. 70. Charlottesville, VA: Virigina Law Review Association, 1984, pp. 669-715) analisam o papel do sistema federal de divulgação obrigatória de informações, à luz de uma necessidade peremptória de prevenir fraudes e reduzir a diferença de tempo entre a ocorrência do fato e a sua divulgação ao mercado. Particularmente em relação às possibilidades de fraudes em decorrência do poder fiscalizatório detido pelos auditores de uma companhia, EASTERBROOK e FISCHEL marcaram suas idéias com esta interessante passagem (p. 688): "We have emphasized before that accountants reduce the cost of verifying information because they put their reputations behind the accuracy of a firm's disclosures. Moreover, to the extent accountants agree on a common languague, they serve the funcion of standardizing (reducing the costs of) any amout of disclosure. Accountants spread over all firms the costs of creating and maintaining the standard language. Of course accountants may face pressures from individual firms to misuse their language, or they may be unable to agree on a common language at all; governmental intervention may reduce these costs of agreement and enforcement".
} 
uma responsabilidade tipicamente estadual (decorrente de lide entre a companhia e o auditor por força de descumprimento de regras de mandato $)^{253}$. A multiplicidade de exceções e de regimes de responsabilidade não permite que se desenhe, de forma sistemática, um regime de responsabilidade civil único, com um parâmetro geral de onde decorrem deveres subsidiários. Raramente se transporta aos auditores, por analogia, o regime de responsabilidade dos administradores, estruturado sobre os deveres de lealdade (duty of loyalty) e diligência (duty of care), interpretados sob o pálio

\footnotetext{
${ }^{253}$ Em matéria de responsabilidade civil de auditores independentes, o leading case é o Ernst \& Ernst $v$. Hochfelder (425 U.S. 185; 1976 - relator: Ministro Powell). Trata-se de uma ação movida por um pequeno grupo de investidores contra firma de auditoria que, na época, compunha o grupo das "Big Eight" (hoje, as "Big Four"). A firma de auditoria era responsável por auditar as contas de uma pequena corretora de valores, que durante anos arquitetou um esquema criminoso e fraudulento de manipulação de informações e de uso das contas de investidores para o benefício próprio e particular do presidente dessa corretora. Após o suicídio do presidente de tal corretora, a First Securities Co., e de sua completa iliquidez e incapacidade para saldar as indenizações dos investidores prejudicados, buscaram os mesmos indenização contra a empresa de auditoria com base em grave negligência, descumprimento de deveres fiscalizatórios, falhas e imperícias na prestação e condução dos serviços de auditoria. A Suprema Corte dos EUA julgou a ação improcedente, provendo o apelo da firma de auditoria com base na tese do "scienter needed". Entendeu a Suprema Corte que, se a firma de auditoria não agiu com intenção de fraudar, manipular ou prejudicar terceiros alheios à relação contratual entre auditor e companhia auditada, os auditores não são responsáveis pelo prejuízo sofrido por terceiros (acionistas de uma companhia auditada, por exemplo), em virtude de fraudes não detectadas pelo auditor. Robert Charles CLARK (Corporate Law, Idem, pp. 326-328) entendeu que a solução apresentada pela Suprema Corte representou um grande atraso no direito societário estado-unidense, seja na compreensão dos limites do insider trading, seja na compreensão dos deveres do auditor. No mesmo sentido, S. EMANUEL, Corporations, Idem, pp. 298-300.
}

Num outro case muito importante em matéria de responsabilidade de auditores independentes, o Desembargador Federal e jurista Richard PosNER foi relator em Cenco Inc. v. Seidman \& Seidman (686 F.2d 449, Corte Federal de Apelação do $7^{\circ}$ Circuito, 1982). Nesse caso, uma série de fraudes foram perpetradas pela administração da Cenco entre 1970 e 1975. Após mudança na administração da companhia, os sucessores identificaram as fraudes e as reportaram à SEC, por meio do então novo diretor financeiro da Cenco. Entretanto, decidiram também buscar perdas e danos contra a firma de auditoria que esteve encarregada da revisão dos trabalhos, durante a gestão administrativa em que as fraudes e os crimes ocorreram. Em uma linha de raciocínio muito mais técnica do que a do leading case "Ernst \& Ernst", POSNER remodela e estrutura toda a teoria de responsabilidade civil contratual e extracontratual, à luz dos deveres fiduciários e fiscalizatórios dos auditores. Ao investigar os temas da contributory negligence e da implied liability, POSNER passa por temas clássicos do Torts Law estado-unidense para concluir que "if Seidman failed to police its people, Cenco failed as or more dramatically to police its own", concluindo que "in such a case the corporation should not be allowed to shift the entire responsability for the fraud to its auditors". M. P. DOOLEY (Fundamentals..., Idem, pp. 291-300) estuda e comenta este caso e lembra que houve, por parte da Corte e do juiz relator, um acerto ao remeter a questão para os lindes da responsabilidade civil contratual e, portanto, para o direito comum que trata apropriadamente da interpretação do contrato. Por outro lado, deixou a decisão de encarar o problema dos efeitos decorrentes dos danos, omitindo-se no aspecto que tange à alocação das perdas segundo os graus de responsabilidade, pela qual não se pode negar uma certa parcela exclusiva para os auditores, por negligência ("Lacking an explicit allocation by the parties, a court inclined to hold the auditors liable would have to resort to tort law to determine the extent of their liability", p. 299).

Desta forma, tanto no caso "Ernst", quanto no caso "Cenco", temos um amplo quadro para concluir que a questão da responsabilidade dos auditores ainda está em aberto na doutrina e na jurisprudência estado-unidense - mas, de forma unânime, não há que se questionar que aos auditores, como fiscais, deve-se tratar a responsabilidade por uma doutrina particular, sem analogia com a doutrina de responsabilidade da administração. 
da doutrina do business judgement rule. Os deveres inerentes à profissão de contador público (CPA) propõem um regime próprio e de difícil tratamento sistemático.

Em relação às regras de impedimento, não há como no Brasil, uma lista extensiva de situações objetivas de impedimento, mas uma construção legal e jurisprudencial do conceito de independência, do qual muita lição se pode tirar.

Basicamente, o problema da independência está no centro das reformas promovidas na profissão por meio da SOX. ${ }^{254}$ Os problemas mais graves de vulneração

${ }^{254}$ Este é mais um ponto em que boa parte da doutrina estado-unidense deitou sérias críticas à SOX. Os
artigos 201 a 209 da SOX trataram de parâmetros de independência, sem que definissem, objetivamente,
em quais situações específicas os auditores estariam impedidos de exercer a fiscalização prevista em lei.
Basicamente, a SOX: (i) listou algumas atividades que passariam a ser vedadas às empresas de
consultoria (201); (ii) criou o sistema de requisito de pré-aprovação para prestação de serviços que não
sejam relacionados com a auditoria e nem sejam vedados pela SOX (202); (iii) criou o sistema de
rotatividade, a cada cinco (5) anos, de equipes e sócios para a prestação de serviços de auditoria por uma
mesma empresa (203); (iv) exigiu relatórios para o comitê de auditoria (204); (v) proibiu que uma
empresa de auditoria preste serviços para uma companhia quando conta com ex-administradores da
companhia auditada que tenham exercido tais cargos de administração durante os doze (12) meses
anteriores à auditoria (206). Como visto, é muito pouco e, se comparado com o Brasil, que impõe a
rotatividade das empresas de auditoria e busca critérios mais rígidos de impedimento objetivo (como no caso de ex-administradores participando da auditoria), a rigidez do sistema estado-unidense é menor.

Adicionalmente, William W. BRATTON ("Shareholder value and auditor independence", In Duke Law Journal, vol. 53, Durham, NC: Duke Law Journal, Novembro, 2003, pp. 439-488) lembrou: "A shift to this positivist concept of auditor responsibility will not by itself solve the crisis of confidence".

Matthew J. BARRETT (“'Tax Services' as a Trojan Horse in the auditor independence provisions of Sarbanes-Oxley", In Michigan State Law Review, Detroit, MI: Law Review of Michigan State University - Detroit College of Law, Junho-Agosto, 2004, pp. 463-503) destaca que, ao ter que se considerar o auditor como um verdadeiro fiscal ("the audit requires the accounting firm to act as a watchdog of management at the same time that the firm must act as an advocate for the officer in the tax matter", $\mathrm{p}$. 468), as medidas implementadas pela SOX mais prejudicam do que auxiliam o trabalho fiscalizatório dos responsáveis pela tarefa de supervisão. Nesse mesmo contexto, BARRETT prega, de forma radical, uma independência total do auditor, chegando a afirmar que os serviços de consultoria devem ser expressamente vedados de serem prestados por uma empresa de auditoria. Isso porque, na grande maioria dos casos, o auditor acaba por ter que revisar e fiscalizar o seu próprio trabalho e certificar as suas próprias recomendações feitas em consultorias. Esse conflito de interesses, para BARRETT, é intransponível enquanto as firmas de auditoria continuarem a cumular seus serviços com os de consultoria: "In addition to avoiding conflicts of interest, a restriction on tax services could help restore, or at least preserve, the auditing profession's integrity, which has suffered severely following the wellpublicized audit failures involving the recent financial frauds. Given the recent revelations of fraud in the mutual fund industry and the travel billing scandal involving the largest accounting firms, (...) audit committees, the accounting profession, the PCAOB, and the SEC should proactively seek to prevent another crisis in confidence and should try to identify any situation in which an auditing firm could place its or its employees' interests ahead of the investing public. Unfortunately, the auditing profession cannot afford another crisis in public confidence. Recalling the Trojan horse, the auditing profession has more to lose from a further decline in the public's trust than it has to gain from the additional fees"..

Embora esse venha a ser um problema bastante proeminente nos EUA, vale ainda lembrar que, dada a natureza transnacional de muitas firmas de auditoria, suas práticas não se limitam àquele país e este problema acaba contagiando outras nações, dentre as quais o Brasil não escapa. Embora em menor escala que nos EUA, esse problema também está presente em nosso País e, não sem certa freqüência, ocorre e é realizado ao arrepio do disposto no artigo $1^{\circ}$, II, da Lei 8.906, de 4 de julho de 1994 (o Estatuto da OAB), sobretudo quando a consultoria jurídica envolve matéria tributária e a possibilidade ou não da aplicação de leis tributárias e suas sanções, em situações específicas das companhias que solicitam a consultoria no 
dos parâmetros de independência e de quebra de impedimentos legais se deu por conta de um fenômeno ligado ao crescimento da profissão de auditor nos EUA, a saber, a possibilidade de prestar consultoria em assuntos que sofriam a revisão, a fiscalização e a auditoria, pelas mesmas firmas que prestaram consultoria e fizeram recomendações. ${ }^{255}$ Os problemas de independência trazidos pela confusa normatização federal da SOX ${ }^{256}$ também não estão alheios às críticas centradas no argumento federalista e que vê nos sistemas estaduais (sobretudo de Delaware), uma estrutura muito mais sofisticada e aparelhada para a prevenção de problemas referentes à eficácia dos impedimentos da fiscalização exercida pelo auditor. ${ }^{257}$

E é justamente na doutrina dos impedimentos e na exploração do conceito de independência que o direito societário estado-unidense deu uma guinada completa em direção ao fortalecimento dos meios de fiscalização interna.

bojo de certas auditorias. Entretanto, em comparação com os EUA, a questão da independência do auditor é vista com mais rigor pelas autoridades contábeis brasileiras, sobretudo o Conselho Federal de Contabilidade (CFC) e o Instituto dos Auditores Independentes do Brasil (IBRACON), ex vi da Resolução CFC n ${ }^{\circ}$ 961, de 16 de maio de 2003, recentemente revogada pela consolidação geral das normas de independência do auditor, por meio da nova Resolução CFC n 1034, de 26 de agosto de 2005.

${ }^{255}$ Em termos genéricos, vide as advertências de M. P. DoOLEY (Fundamentals..., Idem, pp. 113-119). Note-se que o acúmulo de funções não ligadas à auditoria - e que hoje estão absolutamente proibidas pela SOX (tal qual os serviços de escrituração) - poderiam abrir um amplo leque de atuação sob conflito de interesse, pois a auditoria em si, como lembra DOOLEY, não é um certificado de veracidade (p. 114): “The important point, frequently misunderstood, is that accountants do not calculate the numbers appearing in the company's financial statements. Neither do they keep the company's financial records. The records and the numbers therein are management's. The purpose of the audit is not to certify the financial representations of the management as true; rather, the purpose of the audit is to enable the accountants to express an opinion with respect to the fairness of the presentation in financial statements" (marcas do autor).

Nesse contexto, em relação às formas promíscuas de confusão de papéis que eclodiram após os escândalos em Enron e WorldCom e que ficaram muito além da quebra da "fairness opinion", W. W. BRATTON ("Shareholder value...", Op. loc. cit., p. 441), lembrou: “... Enron scandal crossed the line that separates mere financial failure from criminality ...".

${ }^{256}$ As previsões sobre independência do auditor foram complementadas por uma Regra SEC divulgada pelo Release 33-8177, que trata do agravamento do rigor dos requisitos impostos pela SEC em relação à independência do auditor (Final Rule Strengthening the Commission's Requirements Regarding Auditor Independence). Essa regra detalhou com profundidade as vedações impostas pela SOX nos artigos 201 a 209.

${ }^{257}$ Vide o artigo de Harvey GELB ("Corporate Governance and the Independence Myth", In Wyoming Law Review, vol. 6, Laramie, WY: University of Wyoming Press, 2006, pp. 129-163). O Professor GELB, com base em casos recentes debatidos na Suprema Corte de Delaware (como o "Oracle case" - In re Oracle Corp. Derivative Litigation, 824 A.2d 917 [Del. Ch. 2003] e o Oracle Corp. v. Barone, 829 A.2d 141 [Del. 2003]), lembra que até o critério da "amizade" chegou a ser parte de discussão relativamente à inclusão de critérios para determinação dos impedimentos objetivos e das quebras formais de independência em auditorias. Nesse caso recente, lembra GELB (pp. 145-149) que "the court dealt with the impact of non-financial and non-familial pressures on director independence", que, ultima ratio, são aplicáveis, em muitas situações, aos auditores independentes. 
O desenvolvimento de um novo regime de fiscalização, por meio dos já conhecidos comitês de auditoria (audit committees), trouxe compulsoriamente para dentro da companhia alguns deveres fiscalizatórios que outrora se situavam como mera faculdade. ${ }^{258}$

O novo regime para os comitês de auditoria foi implementado pelo artigo 301 da SOX e complementado pelas Regras SEC divulgadas no Release 33-8220. Nesse novo regime, a SEC define algumas características formais, aproximando o modelo de muitos órgãos internos previstos em legislações de outros países. A diferença, entretanto, está justamente no escopo de atuação dos comitês de auditoria. ${ }^{259}$

Tanto as leis federais dos EUA, quanto as regras emanadas pela SEC, não determinam número preciso de membros que devem compor um comitê de auditoria. Entretanto, as Regras de Governança Corporativa editadas pela Bolsa de Nova Iorque (NYSE Corporate Governance Rules) ${ }^{260}$, por meio de seu artigo 303A, item 7(a), estabeleceu que o comitê de auditoria constituído para os fins de cumprimento da SOX teria que ser composto por um número mínimo de três (3) membros, sem limite máximo.

Para se qualificar como membro de comitê de auditoria, a pessoa necessitaria, primeiramente, fazer parte do conselho de administração na forma de

${ }^{258}$ M. P. DoOley, Fundamentals..., Idem, p. 187; R. C. ClARK, Corporate Law, Idem, pp. 105-106, faculdades que, dentro dos limites do poder fiscalizatório que naturalmente pertencem ao conselho de administração e podem ser delegados para comitês específicos, varia conforme o tratamento dado por cada Estado ao poder de fiscalização que cabe ao conselho de administração (vide nota 6 no texto de Clark); S. EMANUEL, Corporations, Idem, p. 70.

${ }^{259}$ Note-se que insistimos, aqui, em salientar que a SOX impõe um novo regime para os comitês de auditoria, sem criá-los, pois já existiam em sede de direito estado-unidense. Conforme expusemos acima, com suporte em SELIGMAN e J. C. COFFEE JR., a SOX alterou profundamente o regime dos comitês de auditoria, mas desde a década de 1970' os EUA já comportavam uma idéia e uma prática de uma fiscalização interna, em oposição à sua tradição pela fiscalização externa via auditoria.

${ }^{260}$ Conforme já explicitou Larry C. BACKER ("Surveillance and control...", Op. loc. cit., Idem, p. 426), o sistema de fiscalização na era Pós-SOX é escalonado. Esse escalonamento é visível na forma com que as delegações regulatórias são feitas. A SOX, em seu artigo 301, item 1-A, determina que "Effective not later than 270 days after the date of enactment of this subsection, the Commission shall by rule, direct the national securities exchanges and national securities associations to prohibit the listing of any security of an issuer that is not in compliance with the requirements of any portion of paragraphs (2) to (6)". Em 25 de abril de 2003, a SEC editou a regra publicada no Release 33-8220, em que deu às bolsas de valores prazo até 15 de julho de 2003 para que submetessem as regras finais à SEC. Dentro desse período, a SEC se incumbiria de aprovar as regras das bolsas de valores com tempo necessário para que as companhias emissoras cumprissem totalmente as determinações da SOX até 31 de outubro de 2004 (prazo válido para todas as companhias estado-unidenses, exceto as companhias de pequeno porte) ou 31 de julho de 2005 (prazo válido para as companhias estrangeiras e as companhias estado-unidenses de pequeno porte). Em 11 de maio de 2003, a NYSE, a principal bolsa de valores dos EUA e do mundo, apresentou a versão final de sua regra, que completava a estrutura do novo direito societário imposto pela SOX. 
conselheiro independente. Portanto, todo membro do comitê de auditoria é, em primeiro lugar, membro da administração da companhia. A mesma regra NYSE (seguida por muitas outras bolsas de valores e associações de corretoras como a NASD) ainda determina que os membros do comitê de auditoria devem ser "financially literate" (letrados em finanças), de acordo com os critérios estabelecidos pela própria administração, dentro dos limites legais de um "business judgement". ${ }^{261}$ Dessa forma, os membros são eleitos pelos conselheiros de administração, sem que os acionistas possam interferir nessa decisão. Ao menos um dos membros, entretanto, deve se qualificar como expert financeiro ("financial expert"). Esse expert financeiro deve ter "reconhecida experiência em contabilidade e finanças", segundo possa cada conselho de administração entender, pelos seus critérios próprios de negócio, no que consista tal "reconhecida experiência". ${ }^{262}$ Portanto, as regras de qualificação mínima para membros de conselho fiscal expressas na lei brasileira, por pior que possam ser, não conseguiram atingir nível tão baixo no estabelecimento de parâmetros. Deixar a cargo da administração de cada companhia qual o critério desejável de qualificação de seus fiscais, ainda que essa decisão venha a ser balizada por critérios de "business judgement rule", soa tão extraordinário para a cultura brasileira quanto um aluno corrigindo a sua própria prova.

Entretanto, o segundo e principal critério para a devida qualificação de um membro do comitê de auditoria está na complexa estrutura de impedimentos e requisitos de independência. Nessa forma absolutamente admirável de descrição de impedimentos por quebra de independência, parece que pouca atenção acabou sendo voltada para a primeira lista de critérios objetivos. De todas as nações estudadas, os EUA é a única que não exige expressamente sequer o segundo grau como critério de

\footnotetext{
${ }^{261}$ Não há padrões objetivos a respeito do que seja "letrado em finanças": não há como saber se isso significa que os membros devem ter experiência prática, formação acadêmica específica ou uma soma dos dois fatores. Cada companhia poderá estabelecer os seus critérios segundo o "business judgement" de sua administração. Essa mesma regra NYSE ainda determina que o membro ainda possa ser eleito sem que tenha os requisitos de ser "letrado em finanças", desde que "must become financially literate within a reasonable period of time after his or her appointment to the audit committee". Comentadores em matéria de comitê de auditoria dos EUA não tratam de parâmetros sobre essa qualificação específica (vide Arthur H. BILl. Audit Committee Guide, $2^{\mathrm{a}}$ ed.. Nova Iorque, NY: Bowne, 2004, pp. 27 e ss.; Gerald S. Backman e Anne Marie Salan. Audit Committees: Regulation and Practice. Nova Iorque, NY: Aspen Law, 2005, passim).

${ }^{262}$ Diz a regra NYSE, in litteris: "at least one member of the audit committe must have accounting or related financial management expertise, as the company's board interprets such qualification in its business judgement".
} 
qualificação de um membro do comitê de auditoria. Por outro lado, é de todas a mais completa ao traçar critérios de impedimento por quebra da independência.

Para tanto, a legislação estado-unidense exige que o conselheiro independente $^{263}$, para se qualificar como membro de comitê de auditoria, não deve: (i) aceitar direta ou indiretamente qualquer tipo de remuneração por consultoria; (ii) qualificar-se como pessoa relacionada com a companhia (conforme definição prevista para "pessoa relacionada" [affiliated person]); (iii) manter outro tipo de relação material com a companhia, direta ou indiretamente, incluindo, entre as relações indiretas, na qualidade de acionista ou diretor de alguma outra companhia que esteja em relação material com a companhia para a qual esteja a serviço; (iv) figurar como empregado, diretor ou membro da família de qualquer empregado ou diretor da companhia ou de suas coligadas, por um período inferior a três (3) anos contados de sua nomeação, desde que esse empregado, se membro da família, tenha percebido salário anual superior a US\$100,000.00 (cem mil dólares); (v) figurar como empregado ou sócio, ou tenha membro da família que seja empregado ou sócio, do auditor indepedente da companhia, por um período inferior a três (3) anos, contados de sua nomeação; (vi) figurar como empregado ou sócio, ou tenha membro da família que seja empregado ou sócio, de qualquer prestador de serviço da companhia que receba honorários superiores a US\$1

\footnotetext{
${ }^{263}$ Donald C. ClARKE ("Three Concepts of Independent Director", In Delaware Journal of Corporate Law, vol. 32. Wilmington, DE: Delaware Law School of Widener University, Inc., 2007, pp. 73-111) analisa profundamente os problemas técnicos e conceituais do formato adotado pela legislação estadounidense para a figura do "conselheiro independente". Fazendo um estudo comparado com as legislações da Alemanha, Inglaterra, Japão e China, o autor identifica inúmeros problemas na legislação estadounidense e formula várias alternativas de reparo, sobretudo com base na experiência germânica. Assume que conceitualmente o "conselheiro independente" poderia receber esta simplória definição, quando se pensa em um conselheiro com funções fiscalizatórias: "A major theme in corporate governance writing is the need for non-management directors on the board to serve as a check on management in the interests of shareholders. In other words, non-management directors are there to help shareholders solve the agency problem. If such directors are to monitor management effectively, they must be independent of management. From this contemplated role stems the typical definition of "independent director": one who has no need or inclination to stay in the good graces of management, and who will be able to speak out, inside and outside the boardroom, in the face of management's misdeeds in order to protect the interests of shareholders" (p.84). Contudo, nota CLARKE que essa definição, advinda da prática de muitas outras jurisdições (vide os comentários de CLARKE na página seguinte sobre a função do conselheiro nomeado pelos trabalhadores segundo a legislação alemã), não foi bem aproveitada pela SOX: "The SOA has no role for independent directors other than as audit committee members, but requires the audit committee to have quite substantial powers, including the sole authority to hire, oversee, compensate, and fire the outside auditor. Its definition of independence is quite strict compared with others" (p. 87). Adverte, também, na linha de leading cases como o famoso Zapata v. Maldonado (430 A.2d 779 [Del. 1981]) e de outros cases menos conhecidos de Estados como Indiana, que o conselheiro independente não poderá ser, na prática, jamais, uma forma de "conselheiro desinteressado" (desinterested director, uma forma mais amena de "independência", não tão rigorosa quanto aquela imposta pela SOX), embora a jurisprudência sobre este último tema seja mais farta e favorável do que a jurisprudência sobre a atuação de conselheiro independente (pp. 102-108).
} 
milhão (um milhão de dólares) anuais em qualquer exercício da história dessa companhia, ou ainda o equivalente a $2.0 \%$ (dois por cento), em um mesmo ano, da receita bruta dessa mesma companhia. Para os fins da vedação prevista no item "(ii)" acima, a Regra SEC sobre comitê de auditoria implementou o seguinte conceito: é considerada relacionada com a companhia emissora qualquer pessoa, física ou jurídica, que, direta ou indiretamente, por meio de um ou mais intermediários, controle, seja controlada ou esteja sob o controle comum da companhia a ser fiscalizada.

Em relação às funções do comitê de auditoria, a legislação estadounidense (artigo 303A, Item 7, (c)) encarrega seus membros, de forma colegiada, de: (i) auxiliar o conselho de administração na supervisão, 1. da integridade das demonstrações financeiras da companhia, 2. do cumprimento pela companhia e sua administração da lei e dos estatutos, 3. da correta qualificação e independência do auditor, 4. da correta performance dos auditores internos e externos; (ii) elaborar um parecer anual sobre os itens assinados em “(i)" acima, a ser encaminhado à SEC e aos acionistas quando da convocação da assembléia ordinária anual (company's annual proxy statement); (iii) elaborar um relatório de auto-avaliação; (iv) rever, anualmente, o relatório do auditor independente, abordando, no mínimo, os seguintes itens -1 . os controles internos do auditor, 2. questões arguidas por relatórios emitidos nos últimos cinco (5) anos por pares (peer review) ou por autoridades governamentais em relação a qualquer procedimento de auditoria liderado pelo auditor, bem como os passos seguidos pelos auditores para conduzir a firma de auditoria a semelhante glosa de procedimentos por pares ou pelas autoridades governamentais e regulatórias, 3. $e$ bem assim todas as relações travadas entre o auditor e a companhia; (v) discutir com a administração e com o auditor independente os relatórios anuais e trimestrais e respectivas demonstrações financeiras, incluindo os fatos relevantes publicados pela companhia; (vi) discutir todas as informações levadas a público em relação aos ganhos obtidos pela companhia, bem como em relação às informações prestadas para analistas e agências de rating; (vii) discutir previamente, com poder de opinião, a respeito de todas as políticas de análise de risco e gerenciamento de riscos; (viii) reunir-se periodicamente com a administração, os auditores internos e os auditores independentes; (ix) rever e discutir com a auditoria independente quaisquer questões relacionadas à auditoria ou quaisquer dificuldades ou problemas enfrentados em decorrência da comunicação com a administração; (x) formular políticas de contratação de ex-funcionários e ex-sócios da firma de auditoria 
independente; (xi) elaborar relatórios periódicos para o conselho de administração, a respeito das atividades desenvolvidas; (xii) ter voz ativa na contratação dos auditores independentes. ${ }^{264}$ Adicionalmente, o comitê de auditoria poderá ter orçamento especial para contratar seus próprios peritos e consultores, a exemplo do que ocorre na lei brasileira.

Em relação às funções a serem desempenhadas pelo comitê de auditoria, podemos facilmente associá-las àquelas desempenhadas por órgãos internos de companhias como o conselho fiscal do Brasil e de Portugal, o consejo de vigilancia da Argentina, os comisarios do México e o collegio sindacale da Itália. Essa associação permitiu com que a SEC, em um de seus pronunciamentos, revelasse, em troca de correspondências com presidentes de Comissões de Valores Mobiliários de muitos outros países ${ }^{265}$, todas as semelhanças entre esses órgãos de fiscalização, reservando um comentário especial a esses paralelos de direito comparado na Nota 160 do Release 33$8220 . .^{266}$

\footnotetext{
${ }^{264}$ A respeito da possibilidade de ter uma palavra final sobre a contratação e o correto cumprimento dos requisitos de independência do auditor, J. C. COFFEE JR. (Gatekeepers..., Idem, p. 352) lança percuciente observação a respeito de outros gatekeepers, sobretudo os advogados: "if we assume that the attorney (or at least one attorney performing a specialized role) can be converted into a gatekeeper, the final question is: who should monitor this new agent?". Após interessante raciocínio, conclui: "this proposal contemplates that the dialogue between the attorney and the audit committee would be priviliged, and no 'whistle-blowing obligation' is here imposed". Isto porque o sistema proposto pela SOX impôs aos advogados, como já pudemos observar, uma obrigação de delação incompatível com o exercício da advocacia e com os parâmetros da ética dos profissionais que lidam com questões legais. Entretanto, é assente que o sigilo profissional não pode permitir que haja receptáculo inviolável para detalhes a respeito do cometimento de crimes e fraudes e, por isso, uma maior aproximação entre advogados e comitê de auditoria seria a solução proposta por COFFEE JR. Neste passo, há também algum sentido lógico na assunção de um controle maior da contratação desses profissionais, ao menos para que o órgão de fiscalização possa analisar requisitos formais de independência do prestador de serviços jurídicos.

${ }^{265}$ Houve troca de correspondências, inclusive, com o então presidente da CVM brasileira, Luiz Leonardo Cantidiano, endereçadas ao então presidente da US-SEC, William H. Donaldson, em que Cantidiano chega a afirmar: "Many of the oversight functions envisaged for the audit committee are in fact exercised by the Fiscal Council of a Brazilian company" - acessível em <http://www.sec.gov/rules/proposed/s70203/llcantidiano1.htm>, último acesso em 27 de janeiro de 2009.

${ }^{266}$ Essa nota, com o fito de trazer exemplos de companhias com seus valores mobiliários negociados nos EUA, mas com sede em países estrangeiros cujas legislações dispunham de mecanismos semelhantes e que, por isso, poderiam se qualificar para uma dispensa da constituição obrigatória de um comitê de auditoria, diz: "...under current Japanese law, we understand that large Japanese corporations must maintain a board of corporate statutory auditors, a legally separate and independent body from the corporation's board of directors that is elected by shareholders. See, e.g., Law for Special Exceptions to the Commercial Code Concerning Audits, etc. of Corporations (Law No. 22, 1974, as amended). Further, we understand that effective April 1, 2003, Japanese corporations will have the option to elect either a governance system with a separate board of directors and board of corporate auditors or a system based on nominating, audit and compensation committees under the board of directors. We also understand that the Italian corporate governance regime provides for an independent board of statutory auditors ("Collegio Sindicale") and the Brazilian corporate governance regime allows a Fiscal Council ("Conselho Fiscal"). See, e.g., the Letters of Assonime; Brazilian Securities Commission. As noted
} 
É de se notar, entretanto, que a profundidade e a especificidade das tarefas a serem desempenhadas por membros de um comitê de auditoria fazem da legislação dos EUA, de todas aquelas aqui estudadas, a mais moderna, profunda, abrangente e bem escrita. Talvez essa elevação e sofisticação, em termos técnicos, rivalize apenas com a legislação de Portugal, um dos mais louváveis textos legais em matéria de fiscalização societária.

Surgem problemas, entretanto, quando o estudo das funções do comitê de auditoria no modelo estado-unidense se voltam para as hipóteses de mapeamento da responsabilidade civil.

Não há na jurisprudência, nem na doutrina estado-unidense, qualquer linha sobre o tema. Contudo, uma atenção maior sobre o cotejo das funções frente aos requisitos mostra que a jurisprudência e a doutrina dos EUA enfrentarão muitos e sérios problemas para mapear corretamente os limites e o conteúdo da responsabilidade dos membros do comitê de auditoria.

Isto porque os membros do comitê de auditoria são, antes, membros do conselho de administração e por isso, são, de fato e de direito, administradores da companhia. Como administradores, exercem uma função administrativa e uma função de monitoramento das atividades executivas (estas, desempenhadas pela diretoria). A função de monitoramento é desenvolvida à semelhança de um juiz, imparcial e independente, que avalia a legalidade dos atos praticados por outros administradores. Entretanto, ainda que qualificados como "conselheiros independentes", é possível que esses membros do comitê de auditoria, na qualidade de conselheiros de administração, sejam chamados a tomar parte em decisões cruciais da companhia e que, posteriormente, na qualidade de membros do comitê de auditoria, corram o risco de atuar como "juízes de atos próprios". Podemos exemplificar com as discussões a respeito da distribuição de dividendos ou constituição de reservas, que em certa medida

previously, the examples provided in this release are for illustrative purposes only. The exemption provided in the final rule for boards of auditors or similar bodies will be available to any foreign private issuer that meets the exemption's requirements because of the issuer's home country regime".

Esta nota salienta, no exemplo japonês, uma lição muito importante que as autoridades estadounidenses ignoraram, a saber: a opção por um sistema com conselhos separados, distinguindo funções, qual seja, a separação entre um conselho de administração e um conselho de auditoria e fiscalização. O acúmulo da função fiscalizatória com as funções próprias de um conselho de administração recebeu, por parte da doutrina estado-unidense, sérias críticas, sobretudo quando se entrou no estudo dos regimes de responsabilidade civil aplicáveis para esse tipo de fiscal especial, qual seja, o membro do comitê de auditoria. 
podem se constituir decisões políticas, mas que muita vez podem ser tomadas no limite da lei. Como admitir, então, que um conselheiro e membro do comitê de auditoria, que eventualmente tome parte na votação dessas matérias, tenha suficiente imparcialidade para avaliar a acurácia das demonstrações financeiras da companhia? Como exigir, então, que o conselheiro se abstenha de votar nessa e em outras matérias, para que possa exercer a sua função de membro do comitê de auditoria de forma mais isenta? Qual o sentido, então, de se cumular em um mesmo órgão (o conselho de administração, board of directors) semelhantes funções? Como julgar, num momento posterior, se esse membro do comitê de auditoria agiu corretamente e qual regime de responsabilidade civil a ele deve ser imposta, considerando que ele tem de agir com diligência para administrar e ao mesmo tempo monitorar a administração? É bastante certo que, como vimos, do membro do comitê de auditoria, ao contrário de um conselheiro fiscal, é esperado que aja concomitantemente aos fatos ou que ao menos aja a priori, mas como exigir imparcialidade de quem tem a obrigação de decidir em consonância com a business judgement rule e, ao mesmo tempo, avaliar se essa decisão transcorreu dentro de padrões mínimos de controles internos? ? $^{267}$

Todas essas são ameaças palpáveis, mas não completamente mensuráveis, do regime de fiscalização por comitê de auditoria nos EUA, com foco no aspecto da responsabilidade civil e da funcionabilidade dos atos praticados, como um todo, pelos membros do comitê de auditoria (inclusive na qualidade de administradores e conselheiros de administração).

\footnotetext{
${ }^{267}$ Todas essas seríssimas críticas e questionamentos são levantados por R. C. CLARK (“Corporate Governance Changes...", Op. loc. cit., Idem, pp. 271-274) e vistos como uma agressão à verdadeira função dos conselheiros de administração: "Both of these reactions miss the importance of the directors' participation on the ex ante behavior of managers. The mere fact that the top executives know they have to make formal presentations about key issues on a regular basis to an audience that may probe and criticize, and that has formal power to remove them, elicits a great deal of valuable behavior. Facts are gathered more carefully and completely, ideas and judgements are made more explicit, competing considerations are anticipated and dealt with, and modes of articulation that can withstand scrutinity outside the inner circle are found. The consequence of all these efforts to better 'explain and sell' the executive viewpoint may well be to clarify strategic thinking and improve decision making. Thus, having to go to the board may have a vital impact on the business, compared to a world in which there is no comparable obligation on the part of the managers. The impact of the process is subtle and diffuse, and therefore hard to prove and measure definitively, but it may well constitute the most valuable consequence of having a board of directors" (grifos do autor, p. 273). E assim arremata: "Assessing the supposed threat is a difficult matter of judgement. It may well be a nontrivial cost of the SOX-related governance changes. But there are some countervailing considerations".
} 


\section{PARTE II - \\ O CONSELHO FISCAL \\ E AS COMPANHIAS ABERTAS BRASILEIRAS}




\section{CAPÍTULO 5: COMPOSIÇÃO E FUNCIONAMENTO - O TRINÔMIO QUALIFICAÇÃO -ESTABILIDADE- INDEPENDÊNCIA}

Por meio dos estudos de direito comparado desenvolvidos na parte anterior desta dissertação, pudemos ter um panorama razoavelmente amplo do estado teórico da questão da fiscalização societária e de seu tratamento legislativo.

Cumpre-nos, então, resgatar no texto da legislação brasileira, à luz do que já pudemos extrair a respeito de nossa cultura e de nossas peculiaridades históricas na introdução desta dissertação, as principais características de nossos mecanismos de fiscalização, suas vicissitudes e lacunas e as devidas correções para melhoria.

A análise jurídico-positiva do conselho fiscal das companhias abertas estará, obediente à lógica Lei das S.A., dividida em três partes - num primeiro momento, analisaremos o conselho fiscal das companhias abertas sob a sua ótica formal; num segundo momento, sob a ótica funcional; e num último momento, sob a ótica operacional. Nesse contexto, trataremos neste capítulo dos critérios legais de composição e funcionamento do conselho fiscal no Brasil, bem como dos requisitos formais para a investidura no cargo e os impedimentos legais para o exercício das funções fiscalizatórias.

Estes são temas que estão tratados em nossa legislação nos artigos $161 \mathrm{e}$ 162 da Lei das S.A. e em relação às companhias de capital aberto, as regras de composição expostas no artigo $161, \S 2^{\circ}$, da Lei das S.A., recebem tratamento específico segundo a Instrução CVM 324/00.

Temos, portanto, para as companhias abertas brasileiras, dois artigos de lei sobre o tema na Lei das S.A. e outros dois artigos na Instrução CVM 324/00, que abrigam um total de treze (13) dispositivos sobre a matéria, se somarmos as regras contidas nos artigos e parágrafos. Desses treze (13) dispositivos, seis (6) dizem respeito 
diretamente à questão do funcionamento não-permanente desse órgão e sete (7) aos critérios de instalação da fiscalização nas companhias abertas. São eles o caput do artigo 161 e seus $\S 2^{\circ}, 3^{\circ}, 4^{\circ}$ (e incisos), bem como os artigos $2^{\circ}$ e $3^{\circ}$ da Instrução CVM $324 / 00$.

\section{Funcionamento permanente}

Neste primeiro aspecto relativo ao funcionamento, o Brasil é um caso isolado no direito comparado. Nos países estudados e incluídos nesta pesquisa, a saber, Argentina, México, Portugal, França, Itália e EUA, bem como em outras legislações examinadas, mas não trazidas nesta pesquisa a título de comparação formal, como Alemanha, Espanha, Chile, Suíça, Inglaterra, Canadá, Austrália e Japão, não há dispositivo, no que se refere às companhias abertas e, em alguns casos, no que tange ao direito societário como um todo, que permita essa figura bizarra de um conselho fiscal "não instalado".

A fiscalização, sobretudo das companhias abertas em outros países, é algo permanente, obrigatório, ininterrupto e inescapável. O Brasil, entretanto, por meio da Lei das S.A., criou mecanismo que obriga que as companhias tenham um conselho fiscal, mas permite que ele não trabalhe e que, de fato, nem sequer exista. ${ }^{268}$ Para acomodar essa situação, a Lei das S.A. contemplou instituto jurídico único no mundo: o pedido de instalação. ${ }^{269}$ Esse é um elemento da lei brasileira cuja explicação, para um estrangeiro, é de dificílima exposição e de demorada compreensão. É necessária uma certa aclimatação com a cultura brasileira para compreender que nossa lei impõe a existência obrigatória de um conselho fiscal para todas as companhias, sem exceção ("a companhia terá um conselho fiscal...", cf. artigo 161, caput da Lei das S.A.), mas que,

\footnotetext{
${ }^{268}$ Historicamente, o funcionamento da fiscalização nasce de forma permanente, conforme disposto no caput do artigo 14 da Lei $\mathrm{n}^{\circ} 3.150$ de 1882.

${ }^{269}$ A Lei das S.A., em seu artigo 240, prevê uma única exceção à regra do conselho fiscal não permanente, a saber, no conselho fiscal das sociedades de economia mista (já que até no estado de liquidação espontânea é possível processar a liquidação da companhia sem a presença de um fiscal em paralelo aos trabalhos do liquidante, ex vi do artigo 208, caput e seu $\S 1^{\circ}$ ). Note-se que essa característica de conselho fiscal permanente para sociedades de economia mista não está ligada ao fato de se tratar de patrimônio público, pois as empresas públicas não contam com essa exigência. Portanto, não sendo o fato de se tratar de bem público a impor essa exigência, caímos no traço peculiar dessa cultura local, de que já tivemos a oportunidade de discorrer no capítulo 1 desta dissertação: o uso do cargo para fins partidários.
} 
ao mesmo tempo, faculta a essas mesmas companhias (o que é feito por quase todas, em seus estatutos) o seu funcionamento não permanente (“... e o estatuto disporá sobre o seu funcionamento, de modo permanente ou nos exercícios em que for instalado a pedido dos acionistas") - qual seja, as companhias tratam do tema, formalmente, em seus documentos, sem precisar efetivamente cuidar da existência do órgão, se esse for o desejo de algumas maiorias acionárias. ${ }^{270} \mathrm{O}$ órgão existe, portanto, sob o ponto de vista puramente formal e na prática nem sequer se constitui, pois se não houver, nas companhias com conselho fiscal não permanente, pedido expresso e aceito de instalação do órgão, não há nem mesmo conselheiros eleitos para o mister.

Esse instituto esquisito e tipicamente brasileiro permite que as companhias (e isso não é incomum na prática) constituam verdadeiros conselhos fiscais ad hoc que funcionam por um exercício a fim de verificar apenas questões pontuais, deixando de lado todas as outras atribuições (deveres) que a lei confere ao conselheiro. Num segundo passo, por força do $\$ 3^{\circ}$, do artigo 177, da Lei das S.A., acaba recaindo parcela considerável do dever de fiscalização das companhias abertas em mãos do auditor independente. Portanto, na prática, sobretudo no que tange ao dever de fiscalização que inclui a atribuição prevista no artigo 163, VII da Lei das S.A., nas companhias abertas, é comum notar-se que boa parte dos conselhos fiscais no Brasil exercem uma fiscalização insatisfatória ${ }^{271}$, justificada pelo trabalho dos auditores.

\footnotetext{
${ }^{270}$ Aqui, o termo "maiorias acionárias" é absolutamente proposital. Parece até ser tema inquestionável na doutrina que a formulação legal do conselho fiscal no Brasil reserva espaço para as minorias. Entretanto, na prática, sabe-se que a proteção é falaciosa. Embora o tema da tensão maioria vs. minoria tangencie a questão do conselho fiscal, não é o foco deste trabalho explorar esse tema deveras atraente e complexo. A jurisprudência ostenta excelentes exemplos que envolvem esse tema, no âmbito do conselho fiscal, sendo os mais relevantes os acórdãos, respectivamente, do Tribunal de Justiça do Rio Grande do Sul (TJRS, Apelação Cível no 70010250165, 10 Câmara Cível, Relator Desembargador Luiz Ary Vessini de Lima, v.u., j.: 30/06/2005) e do extinto Tribunal de Alçada de Minas Gerais (TAMG, Agravo de Instrumento no 0392463-8, 6ª Câmara Cível, Relator Juiz Belizário de Lacerda, v.u., j.: 22/05/2003).

Não podemos nunca nos esquecer, entretanto, que as minorias formam, atualmente, grupos bastante coesos nas companhias, e que as dicotomias políticas típicas da relação controle-minoria é reproduzida dentro dos grupos minoritários. Por isso, é muito comum termos minorias de minorias dentro das companhias (vide CORRÊA-LIMA, Osmar Brina. O Acionista Minoritário no Direito Brasileiro. Rio de Janeiro: Forense, 1994; passim). O tema é palpitante, pois envolve o conceito e a compreensão dos aspectos políticos (no sentido aristotélico do termo) na vida societária das companhias abertas brasileiras. A respeito desse desdobramento político, no âmbito societário, já dissertou Dominique ScHMIDT (Le Droits de la minorité dans la société anonyme. Paris: Sirey, 1970; p. 67 [§96]), cuja influência aristotélica se nota de forma bem saliente.

${ }^{271}$ A esse problema atribuímos várias causas, além da possibilidade de um funcionamento esporádico e não sistemático e da existência de um auditor altamente qualificado para exercer a tarefa de exame formal das demonstrações financeiras: (i) falta de independência dos membros; (ii) inexigibilidade de qualificação condizente com a função; (iii) regime confuso de responsabilidades; (iv) falta de conteúdo mínimo para os pareceres do órgão; (v) atribuições diluídas em outros órgãos conflitando com o veto de
} 
Embora tenhamos no Brasil um sistema de fiscalização interna formalmente previsto, na prática, a fiscalização externa, principalmente no caso das companhias abertas, é mecanismo mais utilizado e mais eficaz de averiguação de obrigações legais e fiscalização societária.

A primeira crítica que se faz, portanto, ao modelo brasileiro é a possibilidade de existência de companhias abertas sem fiscal. O regime jurídico do conselho fiscal não instalado é de saúde legislativa questionável, de praticidade duvidosa e de uso criticável. ${ }^{272}$ Companhias abertas não podem contar com o beneplácito legal a fim de albergarem-se em qualquer isenção fiscalizatória. A fiscalização é elemento essencial da democracia e do estado de direito, além de ser um dever e uma responsabilidade que contrabalançam o exercício de um poder público, que é o da gestão de companhias abertas ${ }^{273}$ e administração de recursos da poupança popular

outorga de atribuições para outros órgãos ( $\$ 7^{\circ}$ do artigo 163 da Lei das S.A.); (vi) instabilidade de função; (vii) mandatos muito curtos. Buscaremos tratar dessas causas nos momentos adequados dentro desta dissertação. A respeito do papel exercido pelo auditor nas companhias abertas, em face dos deveres do conselho fiscal, BULGaRelli (Regime Jurídico do Conselho Fiscal..., Op. cit., Idem, p. 87) lembra com razão: "o legislador parece ter julgado suficiente a imposição de auditoria independente para as companhias abertas, acrescida da fiscalização, em termos societários, da Comissão de Valores Mobiliários, e do Banco Central, em se tratando de fiscalização operacional".

${ }^{272}$ A crítica de Bulgarelli (Regime Jurídico do Conselho Fiscal..., Op. cit., Idem, pp. 87-88) é digna de nota, dada a sua presente atualidade, haja vista que o direito societário brasileiro e estrangeiro sofreu por conta de sérios escândalos, pela pura e simples falta de fiscalização efetiva. Se, ao tempo da dissertação de BULGARELLI, tínhamos "Coroa-Brastel, Auxiliar, Maisonnave, Habitasul e outros" (cf. nota 160, na página 87, do texto de BULGARELLI), em tempos de Enron e WorldCom, o Brasil já se deparou, dentre as debutantes no novo mercado de capitais brasileiro desta era pós 2004/2007, com o problema das fraudes supostamente ocorridas na Agrenco e outras companhias brasileiras que se beneficiam do regime dos Brazilian Depositary Receipts (os BDRs), do sistema da Instrução CVM 332/00. Ainda em tempos mais recentes, temos os sérios problemas envolvendo o uso de derivativos atingindo companhias como Sadia, Aracruz e Vicunha. A essas questões, trazemos estas notas de BuLGARELLI: “... dada a evolução verificada desde aquela época, com o aprimoramento dos esquemas legais societários e tendo em vista a realidade brasileira de nossos dias, não se resiste questionar se a existência do conselho fiscal não teria impedido ou, pelo menos, dificultado e amenizado os recentes desastres ocorridos no sistema financeiro nacional, que tomaram dimensões alarmantes e até escandalosas. Veja-se que há uma espécie de unanimidade em se reconhecer a necessidade de fiscalização das contas e da gestão societária. Se as preferências recaem em confiá-la a um órgão do tipo do Conselho Fiscal; se as críticas feitas a este incidem apenas sobre alguns aspectos da sua eficiência, principalmente quanto à submissão de seus membros aos dirigentes, torna-se difícil não pensar na necessidade da existência de um tal órgão, com funcionamento permanente, sobretudo em certos tipos de companhias, como as abertas e aquelas que administram atividades voltadas para a captação, guarda e aplicação das poupanças populares". Neste último item, que notoriamente inclui as instituições financeiras e assemelhadas ou equiparadas, envolveríamos ainda as companhias responsáveis pela gestão do Sistema de Pagamentos Brasileiro, que estão sob a égide da Lei ${ }^{\circ} 10.214$, de 27 de março de 2001, notadamente as empresas de processamento de crédito e de liquidação de operação com cartões de crédito, as empresas responsáveis pelas liquidações multilaterais, as câmaras de compensação e as empresas que operam ordens em futuros e mercadorias, por meio do uso de instrumentos de derivativos.

${ }^{273}$ Causa espanto lembrar que o regime jurídico do nível mais sofisticado de governança corporativa das empresas de capital aberto negociadas na Bolsa de Valores de São Paulo, qual seja, o Novo Mercado, reproduz, nas regras constantes de seu capítulo $\mathrm{V}$, a teratologia legislativa do sistema brasileiro, 
em produtos e prestação de serviços de grande porte. ${ }^{274}$ Este é, portanto, um ponto para

o qual a doutrina reclama, há muito tempo, um melhor tratamento legislativo, principalmente no caso das companhias abertas. ${ }^{275}$ Além disso, nunca é demais repetir: em relação aos países aqui trazidos nas lições de direito comparado, bem como às outras

admitindo a hipótese de termos uma companhia aberta com inscrição naquele mercado, mas sem um conselho fiscal devidamente "instalado".

${ }^{274}$ Vide BULGARELLI, Ibidem, pp. 86-87.

${ }^{275}$ BULGaRelli (Ibidem, p. 88) afirma: "Parece que a medida - certamente concebida a nível de lege ferenda - seria tão oportuna quanto útil, como reforço substancial interno à atuação dos órgãos governamentais incumbidos da fiscalização, quer das instituições financeiras, quer das companhias abertas, podendo se cogitar da adoção de um modelo mais aperfeiçoado com o agravamento das responsabilidades dos conselheiros, inspirado amplamente na experiência dos vinte anos de vigência da Lei 6.404/76 e também nos lamentáveis episódios ocorridos nesse período". A essa afirmação de BULGARELLI, somem-se novos episódios recentes e mais doze anos de vigência da lei.

Manifestou-se contra M. CARVAlHoSA (Comentários..., Idem, pp. 417-418), afirmando, em relação às companhias abertas: "Esses respeitáveis argumentos esbarram, no entanto, com a constatação histórica de que os Conselhos Fiscais que funcionam sem a participação de representantes da minoria são totalmente ineficazes, servindo apenas para o eventual acobertamento de fraudes dos administradores que recebem o órgão fiscalizador, por omissão, atestando a regularidade. A obrigatoriedade faria com que se voltasse ao formalismo anterior. Esse argumento parece irrefutável. Por isso, conduziu-se bem o legislador, neste passo, não criando a obrigatoriedade do funcionamento permanente nas companhias abertas".

Estamos, nesse particular, entretanto, com BulgaRelli e ousamos discordar, item por item, dos argumentos de Modesto CARvalHosa, com a devida licença e respeito, e à luz do que já pudemos analisar, neste trabalho, sobre os influxos histórico-culturais que informam o conselho fiscal e suas perspectivas futuras. Poderemos, mais adiante, notar que não é a participação de "representantes da minoria" (algo tecnicamente questionável, como poderemos verificar melhor nas próximas páginas) que garante a eficácia do órgão. Em muitos casos, é justamente esse conceito de "conselheiro que representa minoritários" que acaba por comprometer a eficácia e a efetividade do órgão e não a sua falta. $\mathrm{O}$ problema da presença do minoritário liga-se a uma questão de independência. Oportunamente, esperamos comprovar que não é por essa presença que a independência se garante. Uma breve passada em revista pelas regras do direito comparado já demarca essa característica. Mas, mesmo que deixemos de lado essa questão de princípio e admitamos que a presença dos minoritários assegura melhor eficácia e garante independência, não é a obrigatoriedade de funcionamento permanente do conselho fiscal que, em tese, impediria a participação de minoritários. A composição do conselho fiscal, segundo o $\S 4^{\circ}$ do artigo 161 , é claramente uma faculdade legal dada àqueles acionistas. A alínea "a" diz, "os titulares de ações preferenciais sem direito a voto, ou com voto restrito, terão direito de eleger..." e não diz "...deverão eleger...", da mesma forma que a alínea "b" diz, "...os demais acionistas com direito a voto poderão eleger...". Desta forma, caso se altere a redação do caput do artigo 161 para que as companhias abertas passem a ter o dever de contar com uma fiscalização permanente, o direito desses acionistas continuará inalterado, não sendo seguro afirmar que os conselhos fiscais teriam a participação dos "representantes dos minoritários" prejudicada. O direito a esses postos permaneceria sem modificações. Além disso, caso ainda esses acionistas não exerçam os seus direitos, não se pode assumir, de forma absoluta, que o órgão se tornaria um avalizador de irregularidades pelo simples fato de ser composto por conselheiros ligados ao controlador. Para tanto, é necessário fazer leitura do regime de responsabilidade, que, diga-se de passagem, é o mesmo para todos os conselheiros, sejam eles eleitos pelo controlador ou por qualquer outro grupo de acionistas. Portanto, por essas razões, ousamos, com a devida licença, discordar do grande jurista para filiarmos a nossa orientação à opinião de Waldírio BULGARELLI e Benedito Garcia HILÁRIO ("Conselho Fiscal da Sociedade Anônima", Idem, pp. 57 e ss.). Vale lembrar, ainda, que o tema foi objeto de discussão quando da última reforma da Lei das S.A. durante a tramitação dos projetos de lei que resultaram na Lei ${ }^{\circ}$ 10.303/01 (vide N. EIZIRIK e M. CARVALHOSA, A Nova Lei..., Idem, pp. 330-331). Ademais, semelhante alteração na lei, que nos parece mais do que necessária, retiraria a necessidade e a existência da Instrução CVM 324/00, que perderia o seu objeto diante de obrigação uniforme de funcionamento permanente do conselho fiscal nas companhias abertas. 
nações estudadas, mas não descritas neste trabalho, o Brasil mostra-se muito mais leniente na fiscalização das companhias abertas.

\section{Número de membros}

Em segundo lugar, referente ao número de membros, este é o tema que não comporta qualquer tipo de discussão. Embora tenha surgido, durante os debates que culminaram com a promulgação da Lei $n^{0} 10.303 / 01$, proposta para a limitação do número de membros do conselho fiscal das companhias abertas para três (3), o calor das disputas foi mais ocupado por conta da forma de composição do que, efetivamente, por força da limitação do número de membros. ${ }^{276}$

Dentre os treze (13) dispositivos sobre o tema, o $§ 1^{\circ}$ do artigo 161 da Lei das S.A. diz: "O conselho fiscal será composto de, no mínimo 3 (três) e, no máximo, 5 (cinco) membros, e suplentes em igual número, acionistas ou não, eleitos pela assembléia geral". Note-se que esse dispositivo trata do número de membros em sua primeira parte, pois, na sequiência do texto, há um item sutilmente relacionado à sua independência (“... acionistas ou não...”), de que teremos a oportunidade de cuidar oportunamente abaixo.

Este segundo ponto é o que menos preocupa, pois, como se nota em boa parte da doutrina brasileira e nos fartos exemplos do direito comparado, o texto da lei brasileira está em linha com o das demais legislações de outros países do mundo. ${ }^{277}$

\footnotetext{
${ }^{276}$ Vide EIZIRIK e CARVAlHosA, A Nova Lei..., Idem, pp. 332-336.

${ }^{277}$ Note-se que a série de comentários que se fazem a respeito do número de membros têm suas atenções voltadas muito mais para os critérios de composição (se o número de conselheiros for maior que três [3], quantos caberiam aos acionistas mencionados no $\$ 4^{\circ}$ do artigo 161?). Não se trata, efetivamente, de um problema quantitativo (qual seja, se o número de conselheiros é de três, quatro, cinco ou mais, como até defendem alguns), mas meramente qualifitativo: se forem quatro, quantos caberiam aos acionistas mencionados no $\$ 4^{\circ}$ ao artigo 161 ? Portanto, este é um problema típico do tema atinente à independência e aos critérios de isenção objetiva para exercício do cargo e não propriamente de um problema com relação ao número efetivo de membros que a lei permite a uma companhia assumir. Esse problema de independência foi durante muito tempo confundido com o problema aritmético, mas, justiça seja feita, não culpemos os números pela imperfeição das letras (vide CARVALHOSA [Comentários..., Idem, pp. 420421] e Bulgarelli [Regime Jurídico do Conselho Fiscal..., Idem, pp. 97-102]). "De três a cinco membros", ou meramente termos o número fixo de três membros, é algo absolutamente condizente com toda a experiência de direito comparado analisada a respeito do tema. Dos exemplos mais contundentes, vimos Itália, EUA, Portugal, Argentina e México, descritos à exaustão neste trabalho. Além deles, podese acessar Suíça, Alemanha, Espanha, Japão, Chile, Uruguai, Paraguai e Canadá a título de comparação
} 


\section{Qualificação}

O terceiro ponto, que diz respeito à qualificação mínima dos membros de um órgão de fiscalização interna também comporta polêmicas. Dos treze (13) dispositivos sobre o tema, nossa lei se ocupa dele em dois (2), a saber, o caput do artigo 162 e o $§ 1^{\circ}$ desse mesmo artigo, ambos da Lei das S.A.

Para poder se qualificar como membro do conselho fiscal, o aspirante ao cargo deve preencher os seguintes requisitos: (i) ser pessoa física ${ }^{278}$; (ii) residente no País $^{279}$; (iii) diplomadas em curso de nível superior ou que tenham exercido cargo de administrador de empresa ou conselheiro fiscal por pelo menos três (3) anos.

Em relação aos dois primeiros itens, a saber, residência e qualificação como pessoa física natural plena e capaz ${ }^{280}$, identificamos um certo consenso. Contudo,

para se concluir que, para fins de fiscalização interna, possuirmos regra que fixa em três, ou "de três a cinco" membros, não destoa do que se pratica no resto do mundo.

${ }^{278}$ Nesse ponto, a nossa legislação não destoa da maioria dos regimes implementados para fiscalização interna por outros países. Uma das raras exceções é a Argentina, que, como visto, permite que o conselho fiscal seja ocupado por pessoas jurídicas. Portugal também, por seu turno, permite que o órgão seja ocupado por sociedades de advogados ou de auditores independentes (os chamados ROCs ou Revisores Oficiais de Contas). Entretanto, o tema não está livre de discussões e controvérsias, tanto na doutrina quanto na jurisprudência dos países irmãos, como pudemos observar no estudo constante do capítulo 4, seção 1 desta dissertação. Os demais países têm regime voltado para a pessoa física, mesmo porque as atribuições são exercidas, ultima ratio, por pessoas físicas e a responsabilidade pelo exercício da função é melhor processada se o regime girar em torno da premissa de que a função só pode ser desempenhada por pessoas físicas. Portanto, a causa desse requisito, assumido corretamente pela lei brasileira, liga-se ao regime próprio de responsabilidade civil dos fiscais nas companhias abertas.

${ }^{279}$ Há falsa controvérsia sobre a necessidade de exigir-se que o fiscal resida na comarca onde a companhia tem sede. Essa exigência é não apenas desnecessária, mas também excessiva. Há fiscais de companhias abertas que exercem suas atribuições, de forma isenta, em mais de uma companhia, cujas sedes se situam em municípios distintos. Essa limitação traria o risco de "regionalizar" os padrões de fiscalização, cujos critérios são necessariamente federais. Ainda que esse argumento possa não proceder, pois bastaria que o conselheiro se limitasse a exercer o seu mister em companhias do município de sua residência, podendo ainda seguir um padrão nacional uniforme, podemos lembrar que as dificuldades antes decorrentes das grandes dimensões continentais de nosso País já vêm sendo superadas pelo avanço da tecnologia, que permite que essa fiscalização seja exercida com muita eficácia e presença constante, ainda que o conselheiro fiscal resida em outra cidade ou até mesmo em outro Estado da federação.

Contudo, vale lembrar que a regra principal sobre o tema, qual seja, "residência no País", pode acabar, por força dos mesmos argumentos, sofrendo a mesma flexibilização. O único impedimento que ainda vemos para a flexibilização dessa regra, que é impedimento sério, diz respeito a problemas de efetiva jurisdição para o processamento da responsabilidade civil dos conselheiros fiscais, bem como às formas de processamento de demanda judicial e aos clássicos obstáculos para a consecução de uma citação válida e eficaz. Permitir que se conte com conselheiros residentes no estrangeiro dificultaria a defesa de interesses de acionistas prejudicados por conta de atos praticados por aqueles.

${ }^{280}$ Lembre-se (por mero zelo ao argumento) que os incapazes não apresentam os requisitos legais necessários para o exercício do cargo em conselho fiscal e que, portanto, menores, pródigos, ébrios, 
séria polêmica reina no tocante ao requisito legal imposto pelo caput do artigo 162, in fine, e seu respectivo $\S 1^{\circ}$.

Tratemos, primeiramente, do requisito mais delicado, a saber, a exigência de "diploma em curso de nível universitário" e os respectivos critérios de dispensa dessa condição formal.

A lei brasileira, como se sabe, fala meramente em "diploma em curso de nível universitário". A gama de titulações possíveis, principalmente por força da aceitação e reconhecimento, pelo Ministério da Educação e Cultura, de inúmeros cursos como aptos à conferência de título de bacharel, aumentou sobremaneira nos últimos dez (10) a quinze (15) anos. É fato notório que, nos dias atuais, é permitido, no Brasil, que um cidadão obtenha o grau de bacharel em cursos ministrados em regime de período parcial (ou seja, o "meio-período") ao longo de dois (2) anos de créditos e avaliações. Em outras palavras, é possível no Brasil, tornar-se bacharel e titulado em curso universitário assistindo aulas durante dois anos em período noturno.

O requisito "diploma em curso de nível universitário" é, pois, principalmente se levada em consideração a larga experiência em direito comparado, um requisito simples de ser preenchido, na prática, pelas empresas. A norma brasileira não trata com nenhum rigor o requisito de qualificação formal do conselheiro fiscal, principalmente se levarmos em consideração os exemplos de Argentina, Portugal, Itália, EUA e México, para os quais há requisitos expressos a respeito da qualificação dos fiscais, limitando a possibilidade de atuação nesses cargos para advogados, contadores, administradores, economistas e profissões afins.

O Brasil é um dos únicos países do mundo que está dotado de mecanismos para, inclusive, permitir uma dispensa formal de um critério de qualificação mínima. O $\S 1^{\circ}$ do artigo 162 diz: "nas localidades em que não houver pessoas habilitadas, em número suficiente, para o exercício da função, caberá ao juiz dispensar a companhia da satisfação dos requisitos estabelecidos neste artigo". Qual seja, à companhia é permitido desvencilhar-se do requisito de qualificação formal, por meio de um procedimento de jurisdição voluntária.

excepcionais e todos os outros que possam estar sob o alcance dos artigos $3^{\circ}$ e $4^{\circ}$ do Código Civil não reúnem condições necessárias para tal mister. 
Esse cenário formal, previsto na nossa lei, tem se tornado cada vez mais raro de ocorrer, não apenas pelo incremento no número de cursos de nível universitário formalmente reconhecidos pelo Ministério da Educação e Cultura, mas também pela própria consciência dos administradores de que não dá para permitir que a fiscalização societária venha a ser exercida, independentemente do local em que se encontra a companhia, por alguém que não conte com mínimas qualificações técnicas para o exercício das funções descritas no artigo 163, que, convenhamos, são todas de caráter altamente técnico.

Grande parte dos problemas históricos apontados em relação à ineficiência dos conselhos fiscais decorre não apenas da falta de independência dos conselheiros fiscais, mas também e, sobretudo, da ausência de qualificação técnica e de um requisito mínimo de profissionalidade, necessários para o exercício dessa função absolutamente vital para a democracia acionária. Como pudemos observar no capítulo 2 desta dissertação, tivemos, ao longo da evolução do direito societário brasileiro, algumas tentativas de profissionalização desse órgão. O atual texto é o nível máximo que conseguimos para atingir melhores condições dessa profissionalização.Passados mais de trinta (30) anos de vigência da Lei das S.A., esse requisito inserido no caput do artigo 162 já está completamente obsoleto se comparado com a legislação de outros países. $^{281}$ Os argumentos para sustentar essa falta de especificação (insuficiência de profissionais com essa qualificação ${ }^{282}$, diversidade cultural e regional, restrição aos

\footnotetext{
${ }^{281}$ Além do exposto no capítulo 4 desta dissertação, vide CARVALHOSA, Comentários..., Idem, pp. 428430.

${ }^{282}$ Se nos concentrarmos apenas nos bacharéis em direito, ciências contábeis, administração de empresas e economia, notaremos que o "mercado universitário" brasileiro projeta no "mercado de trabalho" centenas de milhares de profissionais diplomados anualmente. Se contarmos apenas com as faculdades de direito do Brasil inteiro, notaremos que, anualmente, há mais bacharéis de direito sendo formados do que efetivamente possam haver vagas em conselhos fiscais de companhias abertas. Se englobarmos os contadores, os administradores e os economistas, esse número cresce em progressão geométrica. Se incluirmos nesse cálculo todo e qualquer bacharel titulado em qualquer curso de nível universitário, o universo de candidatos possíveis pode ser, anualmente, muito superior ao número de vagas prováveis em companhias abertas. Em cálculo superficial, incluindo todas as companhias abertas e as companhias abertas com registro de "incentivadas", multiplicadas pelo número máximo de cinco vagas por companhia, em razão proporcional ao número de bacharéis que são entregues anualmente pelas faculdades de direito, ciências contábeis, economia e administração de empresas, temos uma razão de mais de quinze (15) novos potenciais habilitados por cada vaga de conselheiro fiscal no país por ano. Se diminuirmos o número para três conselheiros por companhia e excluirmos as companhias abertas "incentivadas", esse número pode subir para até uma média de 53 (cinqüenta e três) novos potenciais habilitados por cada vaga de conselheiro fiscal. Lembremos, também, que anualmente temos um número muito menor de novas companhias abertas do que de novos bacharéis.

Noutra matriz, há quem sustente que as universidades não preparam adequadamente os seus alunos para que possam exercer esse mister com a competência necessária e com a experiência requerida. Entretanto, não é o baixo nível de alguns cursos que pode se sustentar como argumento para conservar o
} 
direitos de minoritários ${ }^{283}$, elitização da função ${ }^{284}$ ) não resistem à gravidade e à seriedade das atribuições dadas aos conselheiros fiscais.

Podemos ter como exemplo abstrato o cardiologista. Trata-se, como bem se sabe, de uma das mais notáveis especialidades de uma das mais nobres profissões. Cardiologistas (sobretudo os cirurgiões cardíacos) são profissionais cujo preparo demanda décadas de intenso estudo e trabalho, uma quantidade imensa de leituras e de horas trabalhadas. Seria absolutamente improvável imaginar que um profissional com tão elevadas qualificações pudesse, ainda, ter conhecimentos aprofundados de administração de empresas, direito societário, finanças e contabilidade, com conhecimentos razoáveis, por exemplo, de como funciona uma estrutura de hedging por contratos derivativos.

Entretanto, a contrario sensu, a educação formal de contadores e administradores, e, ultimamente, dos advogados inclusive, propicia instrumentos adequados para o correto exercício das funções de conselheiro fiscal. Nessa linha, tomemos como exemplo a atribuição do artigo 163, VII: “examinar as demonstrações financeiras do exercício social e sobre elas opinar".

É de se admitir que muitos profissionais e bacharéis titulados por outras áreas do conhecimento desconhecem por completo a noção de "demonstrações financeiras", mal sabendo, por exemplo, diferenciá-las da "escrituração contábil".

baixo nível de preparação requerida para assunção de cargo em conselho fiscal, sobretudo em se tratando de companhias abertas.

${ }^{283}$ Nesse sentido, não comungamos da opinião de CARvalhosa (Comentários..., Idem, p. 429), de que certa exigência estatutária de qualificação específica à luz do atual texto da Lei das S.A. acarretaria "agravamento dos direitos da eleição de representantes dos minoritários", caso esse requisito estatutário fosse imposto para todos os membros do conselho fiscal e não apenas para aqueles indicados pelos acionistas descritos no $\S 4^{\circ}$, do artigo 161 , da Lei das S.A. Entendemos que essa exigência estatutária seria simplesmente contra legem e que, para a melhoria dos requisitos formais de qualificação, não há outra solução que não seja a de modificar a lei nesse sentido.

${ }^{284}$ BULGARELLI chegou a afirmar (Regime Jurídico da Proteção às Minorias nas S/A (de acordo com a reforma da Lei 6.404/76. Rio de Janeiro: Renovar, 1998, pp. 154-155) que a melhoria na qualificação dos membros do conselho fiscal, gerando uma "exigência elitista", não seria o caminho correto para aperfeiçoar o instituto no Brasil, pois, o conselho fiscal, "podendo ou não ser instalado", agregado ao fato de que "a verdadeira fiscalização estaria com os auditores independentes, como ocorre em outros países", representaria, "por certo, em muitos casos, uma forma cômoda de o controlador se eximir de certas obrigações para com os acionistas". Em obra anterior e específica sobre o tema do conselho fiscal (Regime Jurídico do Conselho Fiscal..., Idem, pp. 77-81), essa crítica ao "elitismo" no exercício da função de conselheiro fiscal não se acha inscrita, encontrando-se, pelo contrário, citações ao texto de TEIXEIRA e Guerreiro e de Sampaio de LACERDA (p. 78, nota 139) em que há críticas em sentido contrário (na letra de BULGaRelLI, "como, por exemplo, a crítica de que muitos diplomas de nível universitário (tais como os de enfermagem, línguas exóticas, etc.) não guardam relação alguma com a função de conselheiro [fiscal]", Ibidem). 
Outros, por sua vez, não saberiam identificar o conceito de "exercício social" e alguns, não saberiam identificar nem o que são "demonstrações financeiras" nem o que é um "exercício social". Mesmo com o requisito técnico de titulação preenchido, se ao indicado faltar esses conhecimentos, como poderá ele "opinar" sobre algo cujo conceito não domina?

A formação técnica específica não é garantia de desempenho - contudo, é indubitável que o treinamento acadêmico adequado para o exercício das funções descritas no artigo 163 da Lei das S.A. reduz severamente a possibilidade de erros na tarefa fiscalizatória.

A Lei das S.A. coloca ainda como alternativa a experiência mínima de exercício, por três (3) anos, de cargo em administração ou conselho fiscal de companhia.

Não cuidou a lei, entretanto, de formular esse dispositivo com melhor redação, assegurando que a sua interpretação mais correta seria no sentido de que essa experiência deva ter sido desempenhada recentemente e que o prazo de três (3) anos tenha ocorrido de forma ininterrupta. Portanto, a melhor forma de ler esse dispositivo seria admitir que os três (3) anos tenham se dado ininterruptamente e dentro dos últimos cinco (5) anos, pelo menos. Contudo, o texto de lei propicia a interpretação de que a falta de qualificação técnica específica possa ser suprida por um agregado de tempo equivalente a três (3) anos, ainda que segmentado por várias interrupções e que a soma dos últimos momentos com alguma experiência com administração ou fiscalização de companhia tenha se dado muitos anos antes da data da nomeação.

O ideal, para articular uma lídima exigência técnica para tão complexas funções como as descritas no artigo 163 seria exigir, além da qualificação técnica específica, uma experiência mínima ininterrupta e recente de pelo menos três (3) anos de prática na administração (diretoria estatutária ou conselho de administração) ou na fiscalização (em conselho fiscal ou em empresa de auditoria registrada na Comissão de Valores Mobiliários, nos termos do caput do artigo 26 da Lei de Mercado de Valores Mobiliários) de companhias de capital aberto, no caso dos conselhos fiscais de companhias abertas. 
Ademais, cumpre acrescentar que certos setores da economia demandam conhecimento técnico ainda mais específico e, para que se possa ter uma fiscalização eficaz, seria importante que a lei exigisse que nessessetores, o candidato a conselheiro fiscal trouxesse em sua bagagem algum conhecimento mínimo a respeito dos mesmos, como, por exemplo, naqueles regulados por agências como o Banco Central do Brasil (instituições financeiras), a ANEEL (setor elétrico), a ANATEL (telecomunicações), a SUSEP (seguros), a ANP (petróleo e gás) e a ANVISA (saúde, produtos médicos, alimentos, produtos farmacêuticos e outros).

Essa experiência é sumamente importante sob o aspecto funcional do órgão fiscalizador, pois uma de suas atribuições, a saber, a constante no artigo 163, I, da Lei das S.A., só comporá fiscalização eficaz para certas empresas de determinado setor, caso o fiscal tenha razoável conhecimento das numerosas disposições regulamentares que essas autarquias promulgam cotidianamente, bem como à forma correta de desempenho do objeto social. Portanto, o fiscal de uma instituição financeira só terá plenas condições de fiscalizar a atuação da administração de um banco se tiver razoável familiaridade com as normas do Conselho Monetário Nacional e com a regulamentação de Banco Central do Brasil. Adicionalmente, é absolutamente vital que o fiscal de uma instituição financeira esteja familiarizado com as exigências do chamado "Basiléia II", para verificar plenamente se os administradores estão cumprindo os seus deveres legais. $^{285}$

Dispensas de experiência específica em determinados setores poderia, em certos casos, compor autorização do órgão regulatório específico, já que, reconhecese, certos setores de nossa economia ainda carecem de profissionais especializados, ainda que agências de rating e empresas de auditoria comportem grandes times de profissionais especializados nos vários setores da economia. Paralelamente, semelhante demanda de mercado exigiria que as universidades acompanhassem essas necessidades específicas, propiciando melhor formação aos profissionais ingressantes no mercado de trabalho.

\footnotetext{
${ }^{285}$ Para que limitemos os exemplos à complexidade regulatória do mercado financeiro, vide obra de Otavio YAZBEK (Regulação do Mercado Financeiro e de Capitais. Rio de Janeiro: Elsevier, 2007), bem como de Haroldo Malheiros Duclerc VERÇOSA (Bancos centrais no direito comparado: o sistema financeiro nacional e o banco central do Brasil (o regime vigente e as propostas de reformulação). São Paulo: Malheiros, 2005). Especificamente em relação à regulação própria em tema relacionado à fiscalização de companhia do setor financeiro, vide, de H. M. D. VERÇOSA, "Conselho Monetário Nacional: competência reguladora: as auditorias independentes", In RDM 124/208.
} 
Desnecessário aprofundar, em passo seguinte, os argumentos contrários à existência do curioso texto inserido no $\$ 1^{\circ}$, do artigo 162 , da Lei das S.A. A possibilidade de ampla mobilidade de um conselheiro devidamente qualificado, cujas despesas de locomoção cabem à companhia (cf. estabelece o $\S 3^{\circ}$, do artigo 162, da Lei das S.A.), os diversos recursos tecnológicos atualmente à disposição para tornar a sua atuação mais efetiva, ainda que resida em outra cidade ou estado, a não restrição à residência na mesma cidade da sede da companhia: estes são todos argumentos de fato, que se somam àqueles já trazidos por conta da especificidade de função. Manter na lei dispensa de qualificação técnica não específica, "nas localidades em que não houver pessoas habilitadas, em número suficiente", admitindo que ainda as haja, é compactuar com uma mediocridade que não faz mais parte do país em que vivemos.

Ainda que se conceda, por apego à discussão, que essa hipótese possa fazer parte de nossa realidade, o texto ainda é criticável pela forma com que soluciona a questão. Em muitos outros pontos da lei é delegada, especificamente em relação às companhias abertas, jurisdição regulatória própria exercida pela CVM. Neste caso, a regra, válida também para as companhias abertas, dá solução absolutamente vetusta, burocrática e complexa para o problema, a saber: o uso obrigatório da jurisdição voluntária.

Ao menos no caso das companhias abertas, admitindo-se por hipótese que a vontade seja a de manter esse mecanismo legal, dever-se-ia abrir a alternativa para que a dispensa fosse analisada caso a caso pela CVM e, concedida ou não, por meio de decisão fundamentada de seu órgão colegiado, agregado a parecer elaborado pela área técnica competente.

Acrescente-se, ainda, que a lei brasileira somente prevê responsabilidade para o acionista controlador, caso este escolha fiscal que sabe inapto, moral ou tecnicamente, para o exercício da função. No caso dos acionistas inscritos no $\S^{\circ}$, do artigo 161, todavia, a lei não prevê qualquer sanção. Esse desequilíbrio visível na alocação de responsabilidade pela escolha do fiscal somente serve para reforçar ainda mais o argumento de que a lei deve, a todo custo, combater formas alternativas de acomodação de fiscais que não sejam preparados para o exercício dessa função, abrindo oportunidades práticas para que companhias se componham com conselhos mambembes. 
A esse pormenor, agregue-se também o argumento de que a indelegabilidade de funções previstas na lei (cf. $\S 7^{\circ}$ do artigo 161 , reprisado no $\S 7^{\circ}$ do artigo 163, todos da Lei das S.A.), traz nessa exclusividade para o exercício da função, um traço da exigência de qualificação específica implícita para melhor delimitação da responsabilidade pela prática dos atos e total afastamento dos regimes de culpa in eligendo e de culpa in vigilando, típicos de funções que não demandam habilidades específicas. $^{286}$

Por essas razões, esse terceiro ponto, alvo das críticas aqui presentes, é um dos mais sensíveis e carentes de mudanças, mas, desafortunadamente, não é o último.

\section{Estabilidade de função}

Um quarto ponto sob o qual pairam críticas diz respeito à estabilidade da função, tratada singelamente ao fim de um único dispositivo, dentre os treze (13) aplicáveis para o regime do conselho fiscal no Brasil. O final do $\S 2^{\circ}$ do artigo 161 diz que “... cada período de seu funcionamento terminará na primeira assembléia geral ordinária após a sua instalação", o que nos permite concluir que o exercício do cargo de conselheiro fiscal nas companhias cujo funcionamento do conselho seja não permanente, não excede a um exercício, qual seja, a um (1) ano ${ }^{287}$. Essa regra está em consonância com o disposto no próprio caput do artigo 161 que, ao tratar das companhias com conselhos não permanentes, refere-se aos “... exercícios em que for instalado a pedido de acionistas". 288

${ }^{286}$ Em relação à indelegabilidade de funções como reforço da autonomia e como resultado da especificidade das atribuições, vide BULGarelli (O Regime do Conselho Fiscal..., Idem, pp. 73-74).

${ }^{287}$ M. CARvalhosa (Comentários..., Idem, p. 423) lembra que em raros casos pode-se ter um mandato pouco superior a um (1) ano. Entretanto, por força de algum atraso na convocação de assembléia geral ordinária, esse mandato não passa de um (1) ano e dez (10) meses. Lembremos que, se houver falha na convocação da assembléia geral ordinária em companhia com conselho fiscal instalado, poderemos estar diante de um caso típico de responsabilidade solidária do conselheiro fiscal por descumprimento de seu dever, inscrito no artigo $163, \mathrm{~V}$, da Lei das S.A.

288 A lei não dispõe sobre a duração do mandato em companhias cujo estatuto tenha previsão de funcionamento do conselho em caráter permanente. A raridade da opção por essa alternativa talvez justifique a total ausência de textos doutrinários que tratem dessa evidente lacuna na lei. No exercício da profissão, pudemos conhecer apenas um caso de conselho fiscal com funcionamento permanente estabelecido no estatuto social. Contudo, somos da franca opinião que, nas companhias que optarem pelo 
A experiência do direito comparado mostra claramente que este é também um dado de nosso sistema que está completamente em desacordo com a experiência de outros países. ${ }^{289}$

Há urgência em se reconhecer, no direito brasileiro, pelo menos no que se refere às companhias abertas, que os mandatos dos conselheiros fiscais sejam, no mínimo, coincidentes com o período máximo da auditoria por uma mesma firma, a saber, cinco (5) anos, conforme dispõe o artigo 31 da Instrução CVM n ${ }^{0}$ 308, de 14 de maio de 1999. Se, como diz a nota explicativa à regra do referido artigo, "a prestação de um serviço de auditoria para um mesmo cliente, por um prazo longo pode comprometer a qualidade desse serviço", é de se admitir que um mandato muito curto e incompatível com o período de auditoria enfraquece sobremaneira a fiscalização.

Um conselheiro eleito para apenas um exercício, por mais experiente e erudito que seja, não adquire condições, em menos de um ano, de tomar conhecimento seguro de todas as práticas de negócio, políticas, resultados e desempenhos financeiros de uma companhia aberta, ainda que se debruce com dedicação integral a esse mister. Além do mais, se forem seguidos critérios rígidos de independência, o conselheiro com mandato de apenas um exercício tem condições de diálogo muito mais restritas com auditores (internos e externos) e administração.

Ademais, não dispõe a nossa lei, pelo mesmo motivo trazido pela nota explicativa ao artigo 31 da Instrução CVM n ${ }^{\circ}$ 308, de 14 de maio de 1999, de critérios que limitem ou impeçam a reeleição de um mesmo conselheiro por consecutivos mandatos. Essa mesma nota explicativa, ao tratar dos auditores, destaca que mandatos longos sem rotatividade são também fator de grave desestabilização da independência perante o público externo. O exemplo do comitê de auditoria da Enron, conforme descrito por J. C. COFFEE JR., é emblemático. ${ }^{290}$

regime de funcionamento permanente do conselho fiscal, não há regra que impeça que se estabeleça no estatuto que o mandato dos conselheiros fiscais pode perdurar por mais de um exercício ou por período superior a um (1) ano. O impedimento de funcionamento por mais de um exercício, a nosso ver, só se aplica para as companhias que tenham optado pelo regime de funcionamento não permanente do conselho fiscal. Portanto, não compartilhamos da opinião de CARvalHosA (Comentários..., Idem, pp. 422-423).

${ }^{289}$ Para ficar dentro do panorama escolhido para direito comparado neste trabalho, temos: Argentina (até três exercícios, podendo alcançar, no desempenho da função, exercícios passados), México (ilimitado, porém demissíveis a qualquer tempo, sem necessidade de justa causa), Portugal (até quatro anos) e França (no mínimo seis exercícios). O único país que dispõe de um regime limitado a um (1) exercício é a Itália.

${ }^{290}$ John C. COFFEE JR. Gatekeepers..., Op. cit., Idem, pp. 25 e ss. 
Mandatos mais extensos e com limitações permitiriam, com apenas uma simples modificação: (i) maior envolvimento do conselho fiscal com estímulo à profissionalização; e (ii) incremento da independência por força de uma rotatividade mínima de membros. ${ }^{291}$

Aliado a esse problema do regime de tempo de mandato e da possibilidade de reeleições ilimitadas, temos ainda a questão da destituição dos membros do conselho fiscal.

Importa reconhecermos que o direito brasileiro não é dotado de um regime seguro de destituição dos membros do conselho fiscal. Segundo o artigo 122, II, da Lei das S.A., os fiscais são destituíveis pela assembléia geral “a qualquer tempo". É assente na doutrina, portanto, que os membros do conselho fiscal são demissíveis ad nutum, qual seja, independentemente de justa causa.

Preocupação reside, contudo, em saber se os conselheiros eleitos pela minoria podem ser demissíveis ad nutum pelo controlador e vice-versa. Nesse particular, também é assente, por força de pura construção doutrinária, que o conselheiro indicado pelo controlador não pode ser demitido ad nutum pela minoria, nem o eleito pela minoria ser demitido ad nutum pelo controlador. ${ }^{292}$

\footnotetext{
${ }^{291}$ Vale lembrar que a doutrina, por sua vez, vem historicamente negligenciando a importância desse tema, eximindo-se de criticar, no nosso sistema, a falta de mandatos mais extensos, bem como limitações à possibilidade de recondução após certo período.

${ }^{292}$ CARvalhosa (Comentários..., Idem, p. 423), no tocante à destituição dos conselheiros, lembra: "Compete privativamente à assembléia geral destituir, a qualquer tempo, os conselheiros fiscais eleitos pelos controladores da companhia. São eles demissíveis ad nutum". Em relação aos conselheiros eleitos pela minoria, destaca (p. 424): "Não pode, no entanto, a assembléia geral destituir os conselheiros fiscais eleitos, em separado, pelos acionistas minoritários votantes e pelos preferencialistas. Isto porque eles não são eleitos pela assembléia geral, que apenas homologa os seus nomes. Os minoritários votantes e os não votantes, separadamente, por sua vez, têm o direito de, em votação separada, deliberar a destituição dos conselheiros por eles eleitos, devendo a mesa promover a eleição, também apartada, dos substitutos por aqueles minoritários que estiverem presentes ao conclave". Em outras palavras, só podem ser demitidos ad nutum os conselheiros indicados pela minoria se a forma de destituição seguir o mesmo rito da eleição. Em acurada percepção, assim propôs W. Bulgarelli (Regime Jurídico do Conselho Fiscal..., Op. cit., Idem, p. 127): "Pondo de lado, por um instante, essa persistente tensão maioria-minoria que absorve a meditação, e voltando o olhar para o interesse social, podem-se imaginar as hipóteses, ainda que como casos-limite, de conselheiro eleito pela minoria, desqualificado para o cargo, ou que prevarique ou, ainda, que abuse de seu poder, casos em que, com a recusa da minoria em afastá-lo, a Assembléia Geral poderia (deveria mesmo) fazê-lo". Estamos completamente de acordo com a visão do saudoso mestre. Contudo, a prática faz-nos lembrar que os casos de conselheiro eleito pela minoria em atos de "abuso de poder" são os que mais geram polêmica em relação à possibilidade de a Assembléia Geral (leia-se, acionista controlador) destituí-lo, ainda que a causa seja justa e boa. O limite entre o abuso de poder e o esmero exagerado no exercício da atribuição é visto com grande carga de subjetividade e, muita vez (para a infelicidade dos que cercam a companhia), com alta carga de emotividade (algo que o capitalismo, diga-
} 
Parafraseando o mestre BULGARELli, se pusermos de lado, por um instante, a persistente tensão maioria-minoria que absorve a meditação, iremos notar que o regime de destituição do membro do conselho fiscal é, na regra, um regime de destituição ad nutum, qual seja, um regime de demissão que prescinde de justa causa.

E este, antes do problema de saber quem tem autoridade para demitir qual conselheiro, é o centro da questão. Os regimes da Itália (por força de disposição legal expressa), França (por força de longa construção jurisprudencial e doutrinária) e Portugal (por força de disposição legal expressa) contemplam formas interessantes de estabilidade de função. Contudo, a estabilidade de função não é uma unanimidade entre os vários regimes jurídicos estudados, apesar de os argumentos usados pelos países que a adotam e defendem serem mais convincentes do que os argumentos daqueles que não a adotam (quando algum argumento há).

Não há, também, uma uniformidade de regime para o tratamento da estabilidade, estando na ponta mais rigorosa de formalidade a Itália, que só admite a demissão por justa causa, aprovada pelo Judiciário. Mais flexível é Portugal, que só exige justa causa e procedimento judicial quando o fiscal é eleito judicialmente; caso contrário, não pode haver obstáculo para a substituição do conselheiro, mas a sua destituição deve obedecer a procedimento interno que ofereça oportunidade de defesa por parte do destituído.

Dentre os vários regimes estudados, o brasileiro caracteriza-se pela omissão, enquanto a doutrina que lhe incumbe interpretar talha pelo caminho do embate maioria-minoria. Seria muito importante, entretanto, que alguma estabilidade fosse prevista em nossa lei, bem como um regime objetivo de regras que contemplassem formas de destituição do conselheiro fiscal, principalmente os limites para que ocorresse a demissão ad nutum. ${ }^{293}$

se de passagem, repugna). Vale lembrar que o regime de responsabilidade civil por desvio de poder (cf. artigo 154 e $\S \S$ ) é o único que, por analogia imperiosa imposta pelo artigo 165, fica mais claramente aplicável ao regime de atribuições de um conselheiro fiscal. O abuso de poder, uma das formas mais cristalinas de "justa causa" para demissão perde espaço de discussão técnica por excesso de subjetivismo, emotividade e, sobretudo, pela contaminação política de um órgão de fiscalização, cuja função maior deveria ser exercida de forma técnica e não política. Teremos, logo, a oportunidade de explorar esse tema nas páginas seguintes desta dissertação.

${ }^{293}$ Essas regras de estabilidade são importantíssimas num regime de independência total, quando o conselheiro, sem compromisso em proteger acionistas do bloco de controle ou agradar acionistas nãocontroladores, busca fazer um trabalho de fiscalização sério e correto. É essencial que haja algum regime 
Essa bandeira não é levantada, porém, pois como lembrou BULGARELLI, "persistente tensão maioria-minoria absorve a meditação". E é sob a proposta de recuperação de uma meditação isenta que sugerimos abordar o quinto ponto sobre o qual pairam críticas ao regime jurídico brasileiro, no tocante ao aspecto formal do conselho fiscal, a saber, a independência.

\section{Independência}

O tema da independência é tratado, dentre os treze (13) itens que se aplicam à estrutura formal do conselho fiscal no Brasil, em um deles, qual seja, o $\S 2^{\circ}$ do artigo 162. De forma indireta, como poderemos notar, o $\$ 3^{\circ}$ do artigo 162 , que trata da remuneração, também está englobado no tema da independência. Tangencia o tema, contudo, o polêmico texto do $\S 4^{\circ}$ do artigo 161 , que faz loteamento de cargos no conselho fiscal entre os feudos de uma companhia.

Todo o debate e as páginas e mais páginas de controvérsia a respeito do embate maioria-minoria e das várias tentativas de reforma do $\S 4^{\circ}$ do artigo 161 decorrem de uma infeliz e péssima redação dada ao texto do $\S 2^{\circ}$ do artigo 162.

Atentemos, entretanto, de imediato, que o nosso regime de independência ${ }^{294}$ alcança apenas e tão somente: (i) legalmente inelegíveis (artigo 147), (ii) os administradores e empregados da própria companhia fiscalizada, de suas controladas e de outras companhias do mesmo grupo, além dos parentes desses mesmos administradores até terceiro grau.

de estabilidade para que o conselheiro que nota deslizes na companhia (seja por parte da administração, seja por parte do controle, seja por parte da auditoria, seja por parte de duas ou mais dessas entidades) possa desempenhar o seu papel sem o risco de ter o trabalho interrompido ou esterilizado por ameaças de demissão ad nutum. Se a lei quer confiar um trabalho preventivo ao fiscal, deve dar-lhe condições para que a prevenção de ilegalidades seja desempenhada.

294 Vale lembrar que, para muitas legislações, não basta observar as incompatibilidades para que os critérios de independência estejam devidamente preenchidos. Muitos sistemas legais separam o conceito de independência, dos critérios de inelegibilidade, incompatibilidades e dos impedimentos legais, tratando, cada qual, em regime fechado, que pressupõe a independência mas não a exaure. Exemplo disso é o direito português, a respeito do qual a lição de G. F. DIAS (Fiscalização de sociedades..., Op. cit., Idem, p. 26), com apoio em Paulo Olavo CunHA (Direito das Sociedades Comerciais, $2^{\mathrm{a}}$ ed.. Coimbra: Almedina, 2006, p. 696), lembra que não se confunde "a independência com a mera observância das incompatibilidades ali prescritas". 
Os critérios de impedimento para preservação da independência na lei brasileira, em comparação com os outros regimes jurídicos aqui estudados, é de longe o mais flexível, leniente, tolerante e indolente de todos. Toda essa leniência deu azo, historicamente, para que muitos abusos fossem cometidos pelo controlador para indicar membros que lhes fossem servis.

A principal lenidade reside no nepotismo societário. O Brasil tem a regra mais frágil de impedimento por parentesco e só não permite que os pais, avôs, bisavôs, tios, filhos, netos, sobrinhos, bisnetos, genros, sogros e cunhados fiscalizem companhias em que seus filhos, netos, bisnetos, sobrinhos, pais, avôs, tios, bisavôs, sogros, genros e cunhados, respectivamente, atuem como administradores. Se atuarem no bloco de controle e não tiverem participação na administração, a lei não veda. Primos, tios-avôs, sobrinhos-netos, concunhados e amigos íntimos estão liberados dessa restrição. Nossa lei tem, dessa forma, impedimento até o terceiro grau de parentesco, seja na linha ascendente, descendente, colateral ou por afinidade. A lei argentina, mexicana, portuguesa, italiana e francesa reconhecem impedimento até o quarto grau de parentesco, havendo no caso, por exemplo, da legislação mexicana, impedimento total entre ascendentes e descendentes sem limite de grau. Outras legislações, como a francesa, reconhecem que esse impedimento possa vir a atingir relações de união estável não formalizada e relações de intimidade que extrapolem a cordialidade típica de meros "colegas de trabalho". Certos regimes legais de determinados Estados dos EUA também incluem obstáculos que podem atingir até o quinto grau de parentesco.

Em muitas oportunidades o tema voltou à discussão, mas em nenhuma delas prosperou em prol de maior rigidez.

Tem-se entretanto que admitir, com humildade, que o Brasil, no que tange à influência que as relações de parentesco podem exercer nas relações de trabalho, é um país diferenciado - e para pior. Demonstramos nos capítulos anteriores, por meio das leituras de Raymundo FAOro, Victor Nunes LEAL, Caio PRADO JR., Richard GRAHAM e Sérgio Buarque de HolAndA, que a família brasileira, por força de elementos históricos muito peculiares, é dotada de uma coesão diferenciada, incluindo, 
dentro de seu núcleo, amigos e agregados, padrinhos e apadrinhados, que escapam da ação do elemento sanguíneo. ${ }^{295}$

Em muitos casos notamos que parentes distantes na consangüinidade, mas próximos na influência diária das relações de apadrinhamento, são correntemente eleitos para o conselho de companhias abertas, inclusive, dentro do permissivo legal e dos lindes de incompatibilidade.

O segundo e mais grave fator que envolve os requisitos objetivos de independência estão justamente nas limitações de condução ao cargo a membros ligados a concorrentes. $^{296}$

Um terceiro e não menos grave elemento que fragiliza os requisitos objetivos de independência diz respeito aos membros ligados ao controlador. Este outro assunto também já foi alvo de exaustivas discussões a respeito de se deixar o conselho fiscal nas mãos da minoria, impedindo o acesso ao acionista controlador. ${ }^{297}$ O cerne da questão passa antes por um problema que não está nem no texto do $\S 2^{\circ}$ do artigo 162 , nem no texto do $\S 4^{\circ}$ do artigo 161 , mas sim no $\S 1^{\circ}$ do artigo 161 , qual seja, a qualidade de acionista.

Uma completa independência para o cargo de conselheiro fiscal deveria passar pela vedação expressa de acesso desse cargo a acionistas da companhia. As atribuições de conselheiros fiscais são atribuições eminentemente técnicas e não se justificaria a necessidade de ter, entre os membros do conselho fiscal, acionistas da

\footnotetext{
${ }^{295}$ Não é o intuito desta dissertação analisar as peculiaridades da família brasileira, mas é absolutamente notório que o Brasil padece de graves problemas históricos devidos por força do apadrinhamento, da amizade, do compadrio e, porque não, do nepotismo. O Brasil ainda é uma sociedade injusta pois trata os iguais, diferentemente. Esse problema não é exclusividade do Congresso Nacional ou do Poder Judiciário. Muitas empresas também lançam mão sutilmente desse mecanismo. Esse problema, na iniciativa privada, não é tão grave exceto quando abordamos temas específicos como o da fiscalização societária. A reação legislativa, como no caso do conselho fiscal, vai sempre no sentido de se conciliar pequenas vassalagens dentro de um instituto. No caso do conselho fiscal, ao invés de termos uma lei que proíba o acesso de pessoas com a independência afetada, optamos por permitir que o órgão seja composto por mais pessoas em tal condição, cada um representando um nicho específico de interesse.

${ }^{296}$ Por incrível que possa parecer, a jurisprudência registra um caso de disputa entre companhia e certo acionista que indicou para assumir cargo em conselho fiscal, membro ligado a empresa concorrente. Trata-se, de forma óbvia e inquestionável, de um clássico exemplo de atentado à independência do órgão, não tendo o Acórdão, entretanto, sequer entrado no tema da independência formal do órgão por essa razão específica (vide Superior Tribunal de Justiça, Recurso Especial n ${ }^{\circ}$ 88.584/SP, $4^{\mathrm{a}}$ Turma, Relator Ministro Barros Monteiro, v.u., j.: 12/06/2001, publicado DJ 24/09/2001, p. 306). A questão deixou de ser analisada por "falta de prequestionamento", reafirmando-se entendimento da corte recorrida no sentido de que "se dá realce ali à inércia com que se comporta o referido membro do Conselho Fiscal".

${ }^{297}$ Vide N. EiziriK e M. CARvalHosa, A Nova Lei..., Idem, p. 334.
} 
companhia, maxima venia concessa para discordar da clássica opinião de VIVANTE. Mais: no caso das companhias abertas, seria muito salutar que, para a profissionalização da função, fosse vedada a conselheiros fiscais a possibilidade de investimento em ações de companhias abertas ou em fundos de ações cuja administração seja nãodiscricionária $^{298}$. Assim como magistrados são impedidos de exercer cargos na administração de companhias, pois seria incompatível com a exigência de dedicação de ambos os cargos, e bem assim com a pressuposição de independência que a judicatura demanda $^{299}$, faria sentido que a lei impusesse impedimento objetivo de investimento, por conselheiros fiscais, em ações e fundos de ações de administração nãodiscricionária $^{300}$. Contrario sensu, não haveria porque se justificar essa permissão, nem porque sustentar algum benefício para a companhia, pelo simples fato do conselheiro ser acionista da companhia ou contumaz investidor no mercado de ações e opções.

Adicionalmente, o impedimento não deveria ser restrito exclusivamente às pessoas ligadas direta ou indiretamente ao acionista controlador, mas sim a quaisquer pessoas que, direta ou indiretamente tivessem qualquer ligação com acionista que detivesse parcela significativa de ações, que poderia ser equivalente a dois por cento (2.0\%) do capital total de companhia aberta, para ficarmos com os critérios já em vigor da Instrução CVM 324/00 e com a experiência do direito português.

\footnotetext{
298 A legislação brasileira permite que se constituam fundos de investimento chamados "fundos exclusivos" (cfr. Instrução CVM n 409, de 18 de agosto de 2004, artigo 111-A, conforme redação dada pela Instrução CVM no 450 , de 30 de março de 2007). Os fundos exclusivos são fundos de investimento para apenas um único quotista constituídos para aqueles investidores que possam atender aos critérios de "investidores qualificados" (cfr. artigos 108 e 109 da Instrução CVM n 409/04). Nesse tipo de fundo de investimento, o quotista pode ter liberdade para discutir com o gestor desse fundo a alocação de recurso em determinados valores mobiliários, interferindo, assim, na capacidade do fundo para vender ou comprar valores mobiliários específicos, incluindo a quantidade, o momento da compra (ou venda) e o valor. Por esse mecanismo, ainda que o investimento seja feito por um fundo de investimento, o quotista pode exercer grande influência nas decisões negociais que o fundo toma.

${ }^{299}$ Embora, formalmente, um magistrado que pudesse atuar como conselheiro de administração de companhia aberta não seria menos independente (cf. vedação expressa contida na Lei Complementar $\mathrm{n}^{\circ}$ 35, de 14 de março de 1979, ex vi, artigo 36, I e II) do que os magistrados que hoje já aceitam atuar em conselhos deliberativos de clubes de futebol (em interpretação flexível do contido no disposto no artigo 36, II, da mencionada Lei Complementar $\mathrm{n}^{\circ} 35$, de 14 de março de 1979). Em outras palavras, o exercício em cargo técnico de companhia aberta não afetaria, a nosso ver, nem a imparcialidade do magistrado, nem a lisura do Judiciário, nem tampouco a independência do órgão societário e dos membros que a integram. Incompatível seria, sim, o tempo que ambas as atividades demandam de uma mesma e só pessoa: portanto, o problema não é técnico.

${ }^{300} \mathrm{Na}$ prática atual, muitos profissionais e firmas que lidam, no seu dia-a-dia, com companhia abertas, já impõem sérias restrições, por meio de políticas internas, a que seus funcionários, sócios, colaboradores e associados invistam em semelhantes mercados.
} 
E, nesse particular, lembramos o exemplo do direito português, que não permite que o conselheiro esteja "associado a qualquer grupo de interesses específicos na sociedade nem se encontre em alguma circunstância susceptível de afectar a sua isenção de análise ou de decisão, nomeadamente em virtude de ser titular ou actuar em nome ou por conta de titulares de participação qualificada igual ou superior a $2 \%$ do capital social da sociedade" (sic, artigo 414, inciso 6, do Código das Sociedades Comerciais). Além disso, reconhece o direito português que a qualidade de acionista é incompatível com a qualidade de fiscal.

Desta feita, se assim estivessem estabelecidas regras de impedimento e inelegibilidade do conselho fiscal, não haveria, em tese, porque se discutir a respeito da imposição de um regime de eleição ${ }^{301}$, na forma de nosso $\$ 4^{\circ}$, do artigo 161 , da Lei das S.A. ${ }^{302}$

Não se presta a outra finalidade esse dispositivo que não seja reproduzir no corpo de um órgão técnico um embate que é, por natureza, político - o polêmico embate maioria-minoria, que tanto desmoraliza o funcionamento do órgão. Já tivemos oportunidade de, durante a exposição histórica, abordar a total impertinência técnica dessa incongruência funcional em reproduzir o embate maioria-minoria para dentro do conselho fiscal. Não pudemos, ao longo da pesquisa, identificar outra forma de interrupção desse embate que não fosse pelo total e brusco corte do problema por meio do alheamento do conselheiro fiscal em relação ao embate político maioria-minoria existente na companhia, e sobretudo nas companhias de capital aberto. ${ }^{303}$

\footnotetext{
${ }^{301}$ Vide Parecer de Orientação CVM n ${ }^{\circ} 19$, de 9 de maio de 1990, bem como o teor do PAS CVM n ${ }^{\circ}$ 20/04, cujo pedido de termo de compromisso é negado por decisão do colegiado com voto do Diretor Wladimir Castelo Branco Castro, em reunião do Colegiado da CVM de 25 de outubro de 2005.

${ }^{302}$ No caso das sociedades organizadas em grupo, as regras são diferentes e devem seguir o disposto no artigo 277 da Lei das S.A., ao passo que nas sociedades de economia mista, a regra está no artigo 240, segunda parte.

${ }^{303}$ A nosso juízo, as tentativas de condução do processo por meio da interpretação do artigo $165, \S 1^{\circ}$, da Lei das S.A., no tocante à atuação "no exclusivo interesse da companhia" têm se mostrado, na prática, insuficientes, haja vista que não suprimiram o embate maioria-minoria, nem tiveram o condão de transformar o órgão num centro de excelência técnica da companhia. A pretensa inovação, trazida no âmbito da reforma da Lei das S.A. por intermédio da Lei $\mathrm{n}^{\circ}$ 10.303/01, que criou a figura do "abuso de função", a nosso ver, já deve estar considerada no âmbito de um regime mais coerente de responsabilidade civil do conselho fiscal que aqui se propõe. O grande problema que se tem notado nessa inovação é que a configuração do abuso só se constata se houver provada finalidade de causar dano à companhia. Qual seja, esse abuso só se configura na modalidade dolosa, rejeitando-se a configuração de um "abuso de função" gerado por responsabilidade objetiva (vide CARVALHOSA e EIZIRIK, A Nova Lei..., Op. cit., Idem, p. 347, que consideram que a responsabilidade objetiva nesses casos poderia configurar "argumento ad terrorem para o cerceamento indevido de sua função fiscalizadora"). Ideal seria que, para
} 
Não cabe ao órgão técnico estar a serviço de quem quer que seja, por qualquer motivo que possa ser, pois, acima de tudo, o conselheiro fiscal de companhia aberta deve estar a serviço da companhia, do mercado e da segurança da economia popular. ${ }^{304}$ Ofende até ao bom senso que um órgão técnico, cujas opiniões devem estar embasadas em experiência na área de atuação e reconhecida habilidade técnica, contenha entre os seus membros "representantes" de facções políticas internas da companhia e que se manifestam nas assembléias gerais.

Por isso, não faz sentido que seja acionista, muito menos que tenha relação com qualquer acionista de relevo da companhia ou de qualquer outra companhia, direta ou indiretamente coligada à companhia fiscalizada, sobretudo na linha de controle; ou ainda que a eles deva "representar" ou "prestar contas especificamente", por se tratar de um fiscal deste ou daquele acionista, ao invés de ser tido como fiscal da companhia. ${ }^{305}$

Mas esse regime, que poderia ser tomado de empréstimo do regime português, acrescentado de critérios mais rígidos e extensos de impedimento por parentesco que atingisse, pelo menos, até o quarto ou quinto grau, não bastaria. Seria ainda necessário que a lei dispusesse sobre outros impedimentos objetivos para assunção do cargo que tocassem credores, fornecedores e prestadores de serviço de alto

a consideração da interpretação do artigo $165, \S 1^{\circ}$ da Lei das S.A., seguíssemos o conceito já assentado de interesse da companhia tal qual formulado por Erasmo Valladão Azevedo e Novaes FRANÇA (Conflito de Interesses nas Assembléias de S.A.. São Paulo: Malheiros, 1993, pp.54-67).

${ }^{304}$ Exemplo clássico de um desfecho prejudicial a todos, em virtude de embates entre maioria-minoria no seio do conselho fiscal, está em acórdão do STJ no caso da Tabacow (vide Recurso em Mandado de Segurança $\mathrm{n}^{\circ}$ 3.245-0/SP, $3^{\mathrm{a}}$ Turma, Relator Ministro Cláudio Santos, v.u., j.: 07/03/1995, publicado DJ 10/04/1995, p. 9270), no qual dois membros do conselho fiscal da mencionada companhia impetraram Mandado de Segurança contra liminar concedida em medida cautelar em favor de outro membro desse mesmo conselho (representante de "minoria") suspendendo as reuniões do órgão fiscalizador, bem como as funções específicas do órgão e de cada conselheiro, por força de "desinteligência verificada entre seus membros". Esta foi a solução dada ao caso: "Não vislumbro nenhuma lesão a direito ou ameaça sofrida pelos impetrantes, ora recorrentes. Não há, na verdade, direito dos requerentes a merecer a proteção pretendida. As reuniões do Conselho estão suspensas por ordem do Juiz, por força de desentendimento entre os membros do órgão de fiscalização. Como está consignado no acórdão, em virtude de desinteligência, faz-se necessária a intervenção judicial. Os conselheiros não perderam o cargo para o qual foram eleitos, nem sua remuneração; tão pouco sofreram qualquer sanção. Por outro lado, a ausência de cumprimento do dever está plenamente ressalvada, mercê da ordem judicial: nenhum prejuízo moral ou patrimonial poderá decorrer para eles da medida judicial".

${ }^{305}$ Lembremos que o conselheiro fiscal não presta conta aos acionistas, de forma específica, mas sim à assembléia geral dos acionistas, que é um órgão distinto das pessoas que estão investidas da função de acionistas, ex vi do $\S 1^{\circ}$ do artigo 165 , apesar da polêmica e reprovável regra constante do $\S 6^{\circ}$ do artigo 163, que deve ser sempre lida com muita cautela, sobretudo por força do dever de sigilo e de lealdade para com a companhia que os conselheiros fiscais devem guardar em relação a acionistas de forma geral. Em outras palavras, ao buscar o cumprimento do previsto no $\$ 6^{\circ}$ do artigo 163 , os conselheiros fiscais devem se abster de praticar o insider information em favor de determinado grupo de acionistas. 
relevo da companhia aberta, tais como escritórios de advocacia, auditores independentes, assessores financeiros e os consultores de todo o gênero, que possam ter tido influência direta nas decisões da administração ou na elaboração de documentos vitais da companhia, como o seu estatuto social, contratos relevantes e as demonstrações financeiras. E atualmente, acredita-se, há no mercado profissionais o bastante para preencher todas essas funções sem que precisem acumular tarefas. Portanto, aos conselheiros fiscais competiria apenas e tão somente as atribuições da lei, sem acúmulo com outros trabalhos paralelos para a companhia que incrementam a receita desses stakeholders.

Adicionalmente, a lei ainda deveria impedir que pessoas exercendo cargo de administração em qualquer outra companhia pudessem atuar como conselheiros fiscais de outras. São funções, em si, pela sua natureza, incompatíveis, seja na forma, seja na disponibilidade exigida.

E, ainda em matéria de independência e remuneração, restaria comentar o texto do $\$ 3^{\circ}$ do artigo 162. A regra vital de independência geral começa pela independência financeira e pela equiparação, ao menos financeira, entre vigilante e vigiado. $^{306}$ Não há como se exigir que o vigilante tenha coragem e empenho nas suas investigações se o vigiado é remunerado até dez (10) vezes mais. A profissionalização da função passa, também, pela necessária compreensão de que se muitas restrições forem impostas, requisitos exigidos e um alto ônus no exercício das atribuições for cobrado, uma remuneração equivalente deverá ser necessariamente reconhecida, e em equiparação mais justa com a administração.

Reconhece-se que tantas medidas de melhora aqui propostas e que resultam das críticas formuladas ao texto legal podem gerar significativo aumento dos custos da máquina fiscalizatória de uma companhia aberta. Estaríamos, portanto, ingressando numa discussão de custos de agência no Brasil, mas, atentando ao ritmo de

\footnotetext{
${ }^{306}$ Recentemente, a CVM deparou-se com interessante caso a respeito da matéria, nos autos do Proc. RJ2004/5792, que trata de um pedido de um conselheiro fiscal a respeito de informações sobre a remuneração da administração da Companhia Vale do Rio Doce, com o intuito de cotejar, na média percebida pelos administradores, se o parâmetro do artigo $162, \S 3^{\circ}$ da Lei das S.A. estaria sendo respeitado. Em decisão exarada em reunião do colegiado de 7 de dezembro de 2004, o então diretor Wladimir Castelo Branco Castro proferiu voto neste sentido: "No exercício de sua função fiscalizadora, um conselheiro fiscal tem interesse não só de verificar a adequação do valor por ele percebido ao patamar mínimo da lei, como, eventualmente, a regularidade, legal e estatutária, da remuneração global e individual de cada um dos administradores da companhia".
} 
nosso mercado de capitais, mais cedo ou mais tarde, essa discussão surgirá e se não for por via legislativa, poderá ocorrer por força de conflitos e em via judicial, o que seria menos apreciável.

\section{Contraponto}

Em resumo, pudemos observar pela leitura formulada dos treze (13) dispositivos aplicáveis, que a crítica em direito comparado e o resultado das pesquisas indica para seis pontos de incongruência formal no regime do conselho fiscal das companhias abertas no Brasil, a saber: (i) o conselho fiscal das companhias abertas deveria ter funcionamento permanente, sempre; (ii) a qualificação dos membros deve contar com requisitos de formação acadêmica e experiência que comportem o exercício das atribuições a contento; (iii) os mandatos devem ser mais extensos e abranger, pelo menos, três (3) exercícios; (iv) os mandatos necessitam ter maior estabilidade e os critérios de destituição deveriam ser mais rígidos; (v) os critérios de inelegibilidades e impedimentos precisam ser mais rigorosos e, adicionalmente, incrementados por uma definição clara de independência que impeça o acesso ao cargo de pessoas próximas de acionistas ou grupo de acionistas; e (vi) por fim, deve haver piso de remuneração condizente com as exigências. ${ }^{307}$

Assim, entendemos que a lei brasileira deveria conter textos que garantissem o seguinte quadro formal:

\footnotetext{
${ }^{307}$ Em um regime de independência total, com funcionamento permanente, a recente discussão travada na CVM a respeito dos quóruns mínimos para exercício de direitos de pedido de instalação de conselho fiscal perderia totalmente o seu objeto (cf. Procs. RJ2007/3246, RJ2006/5701 e RJ2007/11086, nos casos "Souza Cruz" e "Villares"). Não é nossa intenção entrar nessa polêmica, apesar da omissão ser uma falta mais grave do que erro em comissão, ao menos em matéria fiscalizatória. Nesse sentido, nos parece iníqua a solução dada pela CVM no caso em questão, já que a decisão pressupõe que um único acionista, detentor de uma única ação da companhia, teria o direito de falar e exercer direitos em nome dos demais acionistas não-controladores ausentes de assembléia-geral em que surja pedido nos termos do $\S 4^{\circ}$ ao artigo 161 da Lei das S.A. A lei, ao dizer que esse direito cabe aos acionistas que "...representem em conjunto..." não franqueia margem para interpretação tão extensiva ao ponto de se permitir que um fale por todos, vote por todos, escolha fiscal em nome de todos. Quando a lei determina que esse direito deve ser exercido em conjunto, pressupõe (não claramente, como sói com os defeitos dessa parte da lei) que estejam todos presentes em assembléia, seja fisicamente, seja por meio de representante. Se o minoritário que deseja fiscalizar e instalar conselho fiscal, nos termos de nossa defeituosa lei, corre o risco de não contar com a presença de outros acionistas não-controladores que, em conjunto, lhe franqueariam o direito de requerer essa instalação, seria prudente solicitar procurações para votar, legitimamente, em nome dos demais, nesse sentido. Fora dessa situação, não nos parece adequada a decisão proferida pela CVM na sua interpretação do $\S 4^{\circ}$, do artigo 161, da Lei das S.A.
} 
I. a companhia aberta terá um conselho fiscal de funcionamento permanente (e o estatuto da companhia fechada poderia dispor sobre seu funcionamento, de modo permanente ou nos exercícios sociais em que for instalado a pedido de acionistas que representem pelo menos $1 \%$ (um por cento) do capital social da companhia);

II. o conselho fiscal será composto de três (3) membros e suplentes em igual número, eleitos pela assembléia geral, por um mandato de no mínimo três (3) exercícios e no máximo cinco (5) exercícios, sendo vedada a reeleição;

III. para ser eleito conselheiro fiscal, o candidato deverá apresentar todas as seguintes características: (i) ser pessoa natural residente no Brasil; (ii) possuir título de graduação em direito, ciências contábeis, administração de empresas ou economia; (iii) ter tido comprovada experiência em administração, consultoria ou auditoria de sociedades comerciais nos três (3) anos que antecederem à nomeação ao cargo de conselheiro fiscal e, no caso de companhias abertas atuantes em setores regulados da economia, ao menos um (1) desses três (3) anos que antecederam à nomeação tenha sido empregado em companhias do mesmo setor;

IV. os critérios previstos no item III-(iii) acima poderão ser dispensados pela Comissão de Valores Mobiliários em casos específicos e a pedido da assembléia-geral que eleger o conselheiro, devendo, o pedido, ser apresentado na Comissão de Valores Mobiliários pelo Diretor de Relações com Investidores da companhia, quando houver, ou pelo Diretor Presidente, no prazo de quarenta e oito (48) horas contados da data da assembléia-geral e, no caso da experiência em setores regulados, o mesmo procedimento de dispensa poderá ser empregado perante a autarquia com atribuição regulatória sobre a companhia em questão;

V. são inelegíveis para o cargo de conselheiro fiscal: $(i)$ os acionistas da companhia ${ }^{308}$ ou sócios de sociedades que exerçam, direta ou indiretamente, em conjunto ou isoladamente, poder de controle sobre a companhia fiscalizada ${ }^{309}$, (ii) membros de órgão de administração da própria companhia ou de qualquer outra sociedade comercial em atividade no mercado, bem como os gerentes e empregados da própria companhia

\footnotetext{
${ }^{308}$ Sem prejuízo de outras restrições aqui sugeridas, como o impedimento objetivo de investimento, por conselheiros fiscais, em ações e fundos de ações de administração não-discricionária.

${ }^{309}$ Semelhante alteração na lei demandaria reformulação do caput do artigo 116-A da Lei das S.A. para excluir o termo "... membro do conselho fiscal...", bem como reformulação do $\S 3^{\circ}$ do artigo 117 para exclusão do termo “... ou fiscal...”.
} 
ou de qualquer acionista que, direta ou indiretamente, possua mais do que dois por cento (2\%) do equivalente ao capital total da companhia fiscalizada, (iii) prestador de serviço, consultor, fornecedor, credor ou seus respectivos funcionários, sócios ou credores que tenham atuado em face da companhia em obrigações únicas ou sucessivas, cujo valor agregado seja equivalente ou superior a dois (2\%) da média da receita bruta anual dos últimos três (3) anos anteriores à nomeação, (iv) cônjuge ou parente, até o quarto grau, de quaisquer das pessoas mencionadas nos itens anteriores, $(v)$ pessoa associada a qualquer grupo de interesse específico na companhia que se encontre em alguma circunstância suscetível de afetar a sua isenção de análise ou de decisão, (vi) pessoa associada a qualquer grupo de interesse específico contrário ao da companhia ou que envolvam companhia concorrente, de modo a afetar qualquer isenção de análise;

VI. o conselheiro fiscal só poderá ser destituído por justa causa em assembléia-geral convocada para esse fim específico, com prazo de convocação que não poderá ser inferior a quinze (15) dias, na forma do artigo 124 da Lei das S.A., sendo garantido ao conselheiro o uso da palavra nessa assembléia-geral para exercício de sua ampla defesa;

VII. os acionistas terão direito de acesso a qualquer defesa produzida por escrito pelo conselheiro, sendo permitido ao presidente da assembléia-geral de destituição adiar a deliberação para leitura de peças com fundamento no $\S 2^{\circ}$, do artigo 134 , da Lei das S.A., por prazo não superior a quinze (15) dias;

VIII. a remuneração dos membros do conselho fiscal, além do reembolso obrigatório de despesas de locomoção e estadia necessárias ao desempenho das funções, será fixada pela assembléia-geral que os eleger e não poderá ser inferior, para cada membro em exercício, a oitenta por cento da que, em média, for atribuída a cada conselheiro de administração em exercício, no caso das companhia abertas, ou, a cada diretor em exercício, no caso das companhias fechadas com conselho fiscal instalado, não computados benefícios próprios do cargo e sendo vedada a participação nos lucros da companhia. 


\section{CAPÍTULO 6: ATRIBUIÇÕES DO CONSELHO FISCAL}

Diante da análise empreendida no quadro do regime formal do conselho fiscal, cumpre agora tratar, com a brevidade necessária, as características do órgão em relação às suas atribuições e em relação às atribuições de outros órgãos previstos na legislação brasileira.

A Lei das S.A., em seu artigo 163, apresenta oito tarefas que cabem ao conselho fiscal, coletivamente ou por meio de qualquer um de seus membros, desempenhar. Aos conselheiros fiscais cabe desempenhar individualmente apenas as tarefas previstas nos incisos $\mathrm{I}^{310}$ e $\mathrm{IV}^{311}$, bem como nos $\$ \S 1^{0^{-312}}$ e $3^{\text {o }}{ }^{-313}$, nos limites previstos no $\$ 2^{\circ}-314$ do mesmo artigo. Além disso, poderá, individualmente, supervisionar o trabalho do auditor independente conforme consta do $\S 4^{\circ}$ do mesmo $\operatorname{artigo~}^{315}$. Os demais atos previstos para a competência do conselho físcal são de competência sempre colegial, embora ainda parte da doutrina entenda que a atuação individual possa extrapolar as hipóteses acima previstas ${ }^{316}$, posição essa que, com o devido respeito e apesar dos fortes argumentos, não conta com o nosso entusiasmo.

Paralelamente a essa classificação, podemos notar ainda que as tarefas atinentes ao conselho físcal são de duas naturezas, a saber, (i) revisional ou (ii)

\footnotetext{
310 ... "fiscalizar, por qualquer de seus membros, os atos dos administradores e verificar o cumprimento dos seus deveres legais e estatutários", que aqui designaremos por fiscalização legal da gestão.

311 ... "denunciar, por qualquer de seus membros, aos órgãos de administração e, se estes não tomarem as providências necessárias para a proteção dos interesses da companhia, à assembléia-geral, os erros, fraudes ou crimes que descobrirem, e sugerir providências úteis à companhia", que aqui designaremos por denúncia de erros ou fraudes.

312 "Os órgãos de administração são obrigados, através de comunicação por escrito, a colocar à disposição dos membros em exercício do conselho fiscal, dentro de 10 (dez) dias, cópias das atas de suas reuniões e, dentro de 15 (quinze) dias do seu recebimento, cópias dos balancetes e demais demonstrações financeiras elaboradas periodicamente e, quando houver, dos relatórios de execução de orçamentos".

313 "Os membros do conselho fiscal assistirão às reuniões do conselho de administração se houver, ou da diretoria, em que se deliberar assuntos em que devam opinar (n ${ }^{\text {os }}$ II, III e VIII)".

314 “O conselho fiscal, a pedido de qualquer dos seus membros, solicitará aos órgãos de administração esclarecimentos ou informações, desde que relativas à sua função fiscalizadora, assim como a elaboração de demonstrações financeiras ou contábeis especiais".

315 "Se a companhia tiver auditores independentes, o conselho fiscal, a pedido de qualquer de seus membros, poderá solicitar-lhe esclarecimentos ou informações, e a apuração de fatos específicos", que aqui designaremos por supervisão da auditoria independente, que será tratada como elemento do controle contábil e financeiro.

${ }^{316}$ Modesto CarvalhosA, Comentários..., Op. cit., Idem, pp. 436-442.
} 
executiva. $^{317}$ A única tarefa de natureza eminentemente executiva reside no inciso $\mathrm{V} .{ }^{318}$

Todas as demais funções têm natureza eminentemente revisional.

\section{Controle contábil e financeiro}

De todas as funções revisionais colegiadas, aquelas referentes à contabilidade, finanças e controle de contas acabam sendo as que menos polêmicas geram, ao se tratar das atribuições do conselho fiscal. As tarefas que compreendem "opinar sobre o relatório anual da administração..." (inciso II), "opinar sobre propostas

\footnotetext{
${ }^{317}$ Vale lembrar que W. BULGARELLI propõe classificação distinta, bipartindo entre função fiscalizatória e de controle de contas (O Regime Jurídico do Conselho Fiscal..., Op. cit., Ibidem, pp. 129-173). Já, TAVARES Guerreiro e LaCERDA TEXeIRA (Das Sociedades Anônimas..., Op. cit., Idem, p. 489) propõem uma divisão em quatro classes distintas de competências, a saber: (i) fiscalização (incisos I, IV e VI ao artigo 163), (ii) opinativas (incisos I, III e VII), (iii) convocatória (inciso V) e de liquidação (inciso VIII). BULGARELLI (Ibidem, p. 136) ainda noticia que Sampaio Lacerda dividia essas funções entre fiscalização e opinião.
}

Nosso reparo alcança, em primeiro lugar, todas essas classificações, na medida em que se vê nas tarefas do conselho fiscal, constantemente, uma função fiscalizatória. Seja emitindo opinião, seja examinando documentos, seja denunciando, seja sugerindo, convocando, analisando, verificando ou praticando qualquer outra ação prevista e descrita na lei, a função (tecnicamente falando, à luz dos princípios lançados no Capítulo 1) será sempre de natureza fiscalizatória. O fato de emitir uma opinião não desnatura o ato como atribuição precipuamente fiscalizatória. $\mathrm{O}$ mesmo pode-se dizer quando faz denúncia - denunciando, não deixa, ainda, no ato de denunciar em si, de proceder a uma tarefa fiscalizatória. Essa é razão pela qual notamos que o conselho fiscal sempre fiscaliza, podendo exercer essa fiscalização por meio de uma revisão de atos, qual seja, por meio de uma análise a posteriori de atos já praticados ou, ainda, por meio da execução de atos que lhes são próprios e de competência exclusiva ou concorrente (como no caso do inciso V). Por essa razão, não nos parece precisa a divisão de BULGARELLI, pois o controle de contas é um ato de fiscalização de natureza revisional, semelhante à fiscalização legal da gestão. TAVARES GUERREIRO e LACERDA TEIXEIRA, por seu turno, propondo classificação não estanque em que uma competência pode ser vista sob o ângulo de duas naturezas distintas (caso do inciso I), sujeitam a classificação proposta a um provável enfraquecimento sistêmico. Além disso, vêem natureza distinta em atos de liquidação quando, na verdade, o inciso VIII diz que são as mesmas competências, independentemente do estado jurídico e patrimonial da empresa.

318 ... "convocar assembléia geral ordinária, se os órgãos da administração retardarem por mais de 1 (um) mês essa convocação, e a extraordinária, sempre que ocorrerem motivos graves ou urgentes, incluindo na agenda das assembléias as matérias que considerarem necessárias", que aqui designaremos por convocação supletiva.

Além da convocação supletiva, admite-se que a emissão de parecer anual, prevista indiretamente no inciso II (“... fazendo constar de seu parecer") e no parágrafo único do artigo 164 (“Os pareceres e representações do conselho fiscal, ou de qualquer um de seus membros, poderão ser apresentados e lidos na assembléia-geral..."), tenha natureza eminentemente executiva. A respeito do conceito de "representação" trazido no corpo do mencionado parágrafo, embora a doutrina silencie sobre o tema, é nosso entendimento que tal conceito associa-se à noção de "declaração representativa" ou "declaração enunciativa" com efeitos formativos, na linha do que dispõe o estreito texto do caput do artigo 219 do Código Civil Brasileiro ("As declarações constantes de documentos assinados presumem-se verdadeiras em relação aos signatários"). Sobre o conceito de declaração representativa, vide Emilio BETTI. Teoria Generale..., Op. cit., Idem; pp. 148-154. BETTI chega a afirmar que "da noi manca una trattazione di questo tema" (p. 150, nota 3). Ousamos acrescentar que, entre nós, brasileiros, também não há, como já pudemos dissertar alhures. 
da administração..." (inciso III), "analisar o balancete..." (inciso VI) e "examinar as demonstrações financeiras..." (inciso VII) ${ }^{319}$, são, na essência, as funções fiscalizatórias mais importantes do conselho fiscal, como mostra a experiência estado-unidense, argentina, francesa e italiana, mas que, no Brasil, são as que menos atenção acabam tendo dos conselheiros fiscais na prática. A essas atribuições, agregadas à atribuição do $\S 4^{\circ}$ do artigo 163 ("solicitar dos auditores independentes esclarecimentos, informações e a apuração de fatos específicos"), chamaremos de controle contábil e financeiro.

Infelizmente, como se disse, essas são as tarefas menos prioritárias nas agendas de muitos conselhos fiscais, seja por desconhecimento, seja por falta de habilidades técnicas, seja por crer que a tarefa pode ser melhor desempenhada por uma auditoria executiva interna, um auditor independente ou um "perito" do conselho fiscal (na forma do $\S 8^{\circ}$ ao artigo 163 da Lei das S.A.). Quando não lançam mão desses "peritos" ou auxiliares, seja dentro de vias formais, quanto por vias informais, essa tarefa revisional é normalmente feita pro forma, sem muito compromisso com o resultado das análises, refletidos em pareceres que nada atestam e pouco falam em suas dez ou doze linhas. ${ }^{320}$

Essa prática é decorrência, muito provavelmente, da qualificação dos conselheiros fiscais e de sua respectiva falta de habilidade específica em assuntos de direito societário, finanças, administração de empresas ou ciências contábeis, de que já tivemos a oportunidade de abrir combate neste trabalho. ${ }^{321}$

Embora, então, não haja polêmica acerca dessas importantes (talvez as mais importantes) tarefas na função fiscalizadora, o desmembramento da capacidade

\footnotetext{
${ }^{319}$ Historicamente, a Lei $n^{\circ} 3.150$, de 1882 , já dispunha em seu artigo $14, \S 1^{\circ}$, em relação à aprovação das contas anuais em AGO: "É nulla a deliberação da assembléia geral approvando as contas e o balanço, se não for precedida de relatório dos fiscaes".

${ }^{320}$ José Edwaldo Tavares BorBA (Direito Societário, $10^{\mathrm{a}}$ ed.. Rio de Janeiro: Renovar, 2007, p. 437) lembra: "A atuação do conselho fiscal sempre se caracterizou pela omissão, sendo os seus pareceres, em muitos casos, preparados por prepostos da própria companhia”. Como demonstrou A. V. VERÓN (Auditoría..., Op. cit., Idem, pp. 395 e ss.), a nossa leniência com as contas é semelhante à leniência dos argentinos com a fiscalização legal da gestão. Na Argentina, há maior rigor com a parte contábil do que há, no Brasil, com a parte administrativa, como se verá no próximo item.

${ }^{321}$ Eis ai a conseqüência do defeito na lei brasileira, contra o qual aqui fizemos crítica e que até hoje não se logrou consertar, pois enquanto ela admite que. dentre os requisitos de exercício do cargo em conselho fiscal basta comprovar "diploma em curso de nível universitário", muitas companhias ainda continuarão a preencher os cargos em conselhos fiscais com profissionais de áreas estranhas que, na maioria das vezes, ostentam membros comprometidos com o controlador ou com grupos de acionistas e muita vez dependentes destes nas relações pessoais, sem o discernimento teórico suficiente para empenhar essa fiscalização revisional de forma confiável, seja para a minoria, seja para a própria administração que é fiscalizada, comprometendo e abalando a eficácia do órgão.
} 
técnica na figura de um "perito" fez diminuir e muito a tarefa da doutrina na análise dessas competências de natureza precipuamente revisional, ainda que o problema da indelegabilidade e da responsabilidade civil permaneça em aberto.

Adicionalmente, essa função específica, de natureza puramente fiscalizatória, encontra alguns pontos de conflito de atribuição no âmbito da legislação brasileira.

O primeiro ponto de intersecção entre a natureza fiscalizatória do conselho fiscal, referente aos incisos que tratam do controle contábil, reside na figura do auditor independente. As competências inscritas nos incisos II, VI e VII do artigo 163 ingressam, muita vez, no escopo da auditoria. Dessa sobreposição de trabalho resulta, atualmente, no Brasil, uma prática corrente entre conselhos fiscais no tocante a essas atribuições, a saber: a formulação de um parecer genérico "confirmando" o entendimento emitido em parecer pela auditoria independente. Principalmente no caso das companhias abertas, obrigadas por lei e regulamento ${ }^{322}$ a apresentar demonstrações financeiras trimestrais padronizadas e auditadas, o trabalho do conselheiro fiscal, dentro dos limites da atribuição prevista no inciso VI, torna-se uma revisão pro forma.

Em segunda ordem, vale lembrar que a CVM também guarda competência fiscalizatória sobre registros contábeis, livros, documentos da companhia e papéis de trabalho dos auditores independentes que envolvam companhias abertas. ${ }^{323}$ É silente a norma, entretanto, no que diz respeito ao trabalho fiscalizatório de conselhos fiscais instalados que, ao menos em tese, deveriam ter função preventiva para evitar fraudes suscetíveis da esfera regulatória daquela autarquia.

Em terceiro plano, cumpre lembrar que alguns diplomas infralegais (como vamos ter a oportunidade de estudar logo abaixo) obrigam certas companhias reguladas à constituição de um comitê de auditoria.

Os comitês de auditoria são órgãos do conselho de administração formados por conselheiros classificados como "independentes". Entretanto, membros de um comitê de auditoria são administradores e agindo como membros de comitê, não

\footnotetext{
322 cf. artigo 16, VIII, da Instrução CVM no 202, de 6 de dezembro de 1993.

323 cf. artigo $9^{\circ}$, I, "b" da Lei ${ }^{\circ}$ 6.385, de 7 de dezembro de 1976 c/c o artigo 10, I, "b" da Portaria MF no 327, de 11 de julho de 1977 (Regimento Interno da Comissão de Valores Mobiliários).
} 
deixam de estar sob o pálio dos deveres que são ínsitos à atividade de administrador não-executivo. Esse problema, que envolve um conflito substancial de atribuições, jaz dormente em segundo plano, pois ainda necessita de tempo de experiência e mercado para que as questões de conflito amadureçam no dia-a-dia das companhias.

Enquanto esse tema, que é mediato, não ocupa as reflexões presentes, mais voltadas para o imediato, preocupam os estudiosos as questões que envolvem a sobreposição de funções, principalmente no que se refere ao tema do controle contábil e financeiro.

Muitas regras infralegais tratam de atribuições específicas do comitê de auditoria (e, portanto, de certos conselheiros de administração) com escopo profundamente contábil e financeiro, mas com uma tendência acentuadamente apriorística, qual seja, com maior capacitação para que o conselheiro de administração se antecipe e possa tratar de problemas ex ante facto. ${ }^{324}$

Desse universo, cumpre lembrar que há, em tais normas, uma sobreposição de funções por conta do conteúdo referente às competências de controle contábil e financeiro próprias do conselho fiscal.

\section{Fiscalização legal da gestão}

Provocam maiores polêmicas, justamente por serem o fulcro do exercício do embate maioria-minoria, as competências revisionais que digam respeito à fiscalização revisional de atos de administração ou, como nomeamos, a fiscalização legal da gestão, sobretudo por se tratar de competência que pode ser exercida individualmente, propiciando uma atuação em representação de interesses remotos.

Em primeiro plano, cumpre, para identificar a profundidade e o detalhamento sobre o qual podem os conselheiros fiscais se debruçar para $\mathrm{o}$ desempenho da fiscalização legal de gestão, compreender, exatamente, o objeto dessa fiscalização.

\footnotetext{
${ }^{324}$ Cf. artigo 15 da Resolução CMN 3198 e artigo 17 da Resolução CNSP 118.
} 
A norma faz referência expressa a "atos de administradores". Os atos praticados pelos administradores podem compreender: (i) atos de administração stricto sensu, bem como (ii) atos de gestão empresarial. Nessa divisão, os atos praticados por administradores podem compreender desde o agendamento de uma reunião por um conselheiro de administração, passando pela assinatura de cheques de pequena monta por um diretor executivo, a redução ou aumento do preço dos produtos da companhia e podendo chegar até ao uso do caixa ou de contas de resultado para a aquisição de controle de companhia concorrente.

A amplitude que compreende, formalmente, o conceito de "atos praticados por administradores" é bastante grande e muita vez abarca atos que podem estar ligados à consecução do objeto social e praticados, tanto no âmbito da diretoria quanto no âmbito do conselho de administração. ${ }^{325}$

\footnotetext{
325 "Visualizando a atuação dos administradores pela perspectiva do poder, tem-se que está encaminhada para a prática de todos os atos que entram no objeto social e que se põem em relação de meio como fim a ser alcançado pelo ângulo do escopo social" (BULGARELLI. O Regime Jurídico..., Op. cit., Idem, p. 144). Adicionalmente, "esses atos", adverte BULGARELLI, "voltam-se para a administração propriamente dita, para a execução de decisões assembleares e para a execução de específicas atividades impostas pela lei" (Ibidem), tais como os deveres "de manter os livros sociais (artigo 100); de promover o levantamento das demonstrações financeiras (artigos 176, 177 e 243); de providenciar a publicação e o registro (artigos 87, $\S 4^{\circ}, 94$ e 99)" (Ibidem). Para limitar o escopo dos atos compreendidos pela diretiva legal inserida no inciso I do artigo 163, BULGARELLI (Ibidem, pp. 136-149) entende que os atos praticados pela administração podem ser divididos em (i) atos relacionados com a organização societária e (ii) atos relacionados com a direção da empresa.
}

Outros, porém, como Modesto CARvalhosa (Comentários..., Op. cit., Idem, p. 179) e Fran MarTinS (Comentários à Lei das S/A, vol. $2^{\circ}$, Tomo I, $3^{\mathrm{a}}$ ed.. Rio de Janeiro: Forense, 1989, pp. 307-308) preferem caracterizar os atos da administração entre duas espécies distintas, a saber, (i) atos de gestão ordinária e (ii) atos de gestão extraordinária, cabendo, como matéria de distinção, o fato da prática do ato revestido em exercício de poder depender de autorização prévia de outro órgão ou não. Adapta-se ao direito societário uma espécie de emulação de ato discricionário e ato vinculado conforme proposto em doutrina de Direito Administrativo, em terminologia e leitura própria da administração de bens públicos, da coisa pública e dos atos jurídicos compreendidos na esfera do Estado. Entretanto, ao proceder à leitura da competência fiscalizatória revisional do conselho fiscal quanto aos "atos praticados por administradores", tanto a doutrina quanto a jurisprudência pátria oscilam dentro da mesma amplitude semântica, vendo limites na atuação do conselho fiscal desde as situações mais específicas e detalhadas, indo até as situações mais genéricas e objetivas.

Nelson EIZIRIK ("Limites à Atuação do Conselho Fiscal", Op. cit., Idem, p. 17) foi o que apresentou as ponderações mais razoáveis sobre o tema: “... a lei não atribui ao Conselho Fiscal competência para opinar sobre a orientação geral dos negócios estabelecida pelo Conselho de Administração, nem sobre os atos de nomeação e destituição de diretores, muito menos qualquer poder para manifestar-se previamente sobre atos ou contratos que venham a ser firmados. Ou seja, a elaboração das políticas empresariais prescinde de qualquer análise prévia ou de aprovação por parte do Conselho Fiscal. Da mesma forma, embora prevendo a lei expressamente a competência do Conselho Fiscal de fiscalizar os atos dos administradores (artigo 163, I), não conferiu ao órgão qualquer poder de interferir na gestão ordinária dos negócios da companhia, conduzida pelos diretores. A fiscalização exercida pelo Conselho Fiscal sobre os atos dos administradores centra-se na verificação do atendimento dos seus deveres legais e estatutários. O órgão de fiscalização não tem poderes para apreciar o conteúdo da gestão societária, ou seja, não lhe cabe entrar no julgamento do mérito e da conveniência das decisões empresariais tomadas pelos 
administradores. Com efeito, a fiscalização exercida pelo Conselho Fiscal refere-se à legalidade e regularidade dos atos dos administradores, não à sua conveniência e oportunidade, exceto nos casos expressa e taxativamente elencados no inc. III do artigo 163 da Lei das S/A.". Nesse mesmo sentido, Nelson EIZIRIK revisitou o tema (Reforma das S.A. e do Mercado de Capitais..., Op. cit., Idem, p. 114), nestes termos: "Em princípio, não cabe ao Conselho Fiscal manifestar-se sobre a conveniência e oportunidade dos atos dos administradores, exceto quando opina nas seguintes hipóteses: proposta de modificação de capital; emissão de debêntures ou bônus de subscrição; planos de investimentos ou orçamentos de capital; distribuição de dividendos; transformação, incorporação, fusão ou cisão (artigo 163, III). Eventuais solicitações de informações sobre a política de preços da companhia, estratégia de venda dos produtos, 'marketing', ou outras que não sejam necessárias ao desempenho das funções do Conselho Fiscal, podem ser legitimamente recusadas pelos Diretores ou pelo Conselho de Administração". Em seu trabalho conjunto com Modesto CARVAlHOSA (A Nova Lei das S/A, Op. cit., Idem, p. 341), reprisou: “Assim, o órgão fiscalizador não possui competência para apreciar o conteúdo da gestão societária, ou seja, não lhe cabe entrar no julgamento do mérito e da conveniência das decisões empresariais tomadas pelos administradores. Embora a Lei das S/A tenha previsto a competência do conselho fiscal para fiscalizar os atos dos administradores (artigo 163, I), não conferiu ao órgão qualquer poder para interferir na gestão ordinária dos negócios da companhia, conduzida pelos diretores. Com efeito, a Lei das S/A não atribui ao conselho fiscal competência para opinar sobre a orientação geral dos negócios da companhia, estabelecida pelo conselho de administração, nem sobre os atos de nomeação e destituição de diretores, muito menos sobre os atos ou contratos que venham a ser firmados. Ou seja, a elaboração das políticas empresariais não carece de qualquer análise ou aprovação por parte do conselho fiscal."

É de se notar que EIzIRIK analisa os níveis de aprofundamento da fiscalização exercida pelo Conselho Fiscal nos atos de gestão administrativa da companhia sob o eixo dos mesmos princípios que regulam a business judgment rule estadounidense. Nesse sentido, vide, no direito português, os judiciosos estudos de G. F. DiAS (Fiscalização de sociedades..., Op. cit., Idem, pp. 70 e ss.). A respeito da doutrina da business judgment rule cumpre lembrar que, nos EUA, é um dos mais importantes instrumentos de interpretação da lei societária. Parte-se do pressuposto de que os deveres dos administradores comportam, legalmente, uma assunção consciente, bem informada e razoavelmente adequada dos riscos empresariais. Não cabe, e isso veda a doutrina da business judgment rule, interferir no mérito da decisão tomada pelo administrador; qual seja, não importa se a decisão é boa ou ruim, mas sim se a decisão foi bem tomada ou mal tomada, independentemente do resultado obtido. E bem tomada ou mal tomada, em doutrina de business judgment rule, significa, invariavelmente, analisar se o ato do administrador foi tomado sob o pálio do dever de diligência (duty of care) e do dever de lealdade (duty of loyalty). A doutrina do business judgment rule teve o início de seu desenvolvimento no curioso e interessante precedente Shlensky v. Wrigley (Corte de Apelação de Illinois, 1968, relatado pelo Juiz Sullivan e publicado no volume 95 da Revista da Corte de Apelação de Illinois ( $2^{\mathrm{a}}$ ed.), pp. 173 e ss). O caso tratava de uma ação movida por um acionista de uma empresa chamada Chicago National League Bal Club, Inc., que era, na época, a companhia holding que operava o time de baseball "Chicago Cubs" bem como o seu estádio local, o Wrigley Field. Pretendia o acionista que aquela companhia, realizando prejuízos há algum tempo, iluminasse o estádio Wrigley para que o Chicago Cubs pudesse receber jogos noturnos e, assim, melhorar a presença no estádio local e otimizar a renda pelos jogos, seguindo o exemplo de todas as outras equipes da liga nacional desse esporte, que tinham sempre públicos muito mais elevados pelo fato de realizar as partidas no horário noturno. Afirmou-se, nesse caso, que "it cannot be said that directors, even those of corporations that are losing money, must follow the lead of the other corporations in the field. Directors are elected for their business capabilities and judgment and the courts cannot require them to forego their judgment because of the decisions of directors of other companies. Courts may not decide these questions in the absence of a clear showing of dereliction of duty on the part of the specific directors and mere failure to "follow the crowd" is not such a dereliction". No desenvolvimento dessa doutrina, teve importante papel o precedente Smith v. van Gorkom (Suprema Corte de Delaware, 1985, relatado pelo Juiz Horsey e publicado no volume 488 da $2^{\mathrm{a}}$ edição do Anuário da Suprema Corte de Delaware, pp. 858 e ss.). No caso van Gorkom houve uma decisão que gerou, por muito tempo, a imposição às administrações das companhias, de que todas as decisões e atos de administração fossem tomados com base em informações consistentes, caso contrário, na hipótese de prejuízo, a administração poderia ser responsabilizada perante os acionistas. Nesse caso van Gorkom, tratava-se de uma operação de aquisição de controle de uma companhia em que os acionistas entenderam que a administração não procedeu ao ato em uma informed business judgment basis (situação de razoável consciência sobre a informação comercial). Impõe-se, na aplicação deste princípio, o dever do administrador estar devidamente informado de todos os riscos, fatos, detalhes e dados acerca dos atos que 
Contudo, pelo fato das opiniões a respeito do que pode ser objeto da competência descrita no artigo 163, I da Lei das S.A. serem bastante díspares, surge dificuldade natural em dissertar sobre esse assunto, tão polêmico e tão incômodo, justamente num ambiente em que as regras de independência inexistem ${ }^{326}$ e o que os limites para esse tipo de atuação acabam entrando numa casuística que, não raro, fere a segurança jurídica, tão cara ao direito societário. ${ }^{327}$

envolvem a decisão que vai ser tomada, sobretudo aquelas informações que seria de seu dever, ter conhecimento. Sobre esse precedente e as implicações na doutrina do business judgment rule e no dever de diligência (duty of care), vide Michael P. DoOLEY, Fundamentals..., Op. cit., Idem, pp. 249-275; sobre o reflexo dessa doutrina na responsabilidade civil societária, no declínio da doutrina ultra vires e no impacto sobre o uso das derivative suits, vide Frank EASTERBROOK E Daniel FISCHEL, The Economic Structure of Corporate Law..., Op. cit., Idem, pp. 93-108.

Pouco ou quase nada há, à exceção dos trabalhos de Gabriela de Figueiredo DiAs em Portugal e de Nelson L. EIZIRIK no Brasil, no que se refere ao estudo da doutrina do business judgement rule aplicada aos princípios de fiscalização societária.

${ }^{326}$ Ainda que tomemos as sugestões de trabalho a respeito da independência do conselheiro, é de se admitir que, embora uma grande melhoria pudesse ser vista, as atuações "interessadas" não iriam desaparecer por completo. Bom exemplo disso é o curioso caso julgado na CVM nos autos do Proc. RJ2004/5792, em recurso de conselheiro contra a CVRD.

${ }^{327}$ A combinação de regras e interpretações acerca das funções do conselho fiscal no Brasil tornou a exegese do artigo 163, I, da Lei das S.A., uma das mais complicadas de ser ser feita na prática, desafiando a ousadia até dos espíritos mais criativos. O contrabalanço dessa questão, sem dúvida, reside totalmente na combinação entre a flacidez de nossas regras de independência e a identificação, na prática, de certos atos de fiscalização serem ou não "desinteressados" ou "no interesse específico" de algum acionista. A incapacidade de se compreender o mandato do conselheiro fiscal longe das regras do mandato do Código Civil, no artigo 653 e seguintes, a dificuldade em se admitir que o conselheiro fiscal não é procurador de acionista ou grupo de acionistas, torna muita vez a interpretação do artigo 163, I da Lei das S.A., uma opção (indevidamente) política.

A prática está farta de exemplos a esse respeito e, no caso de companhias abertas, a CVM oferece um amplo cabedal de julgados, sobretudo após a reforma de 2001, quando passou-se a permitir uma atuação individual do conselheiro de forma mais constante e menos compromissada com o conceito colegial do órgão. Na busca de soluções para encontrar-se um equilíbrio lógico entre a prática de eventuais abusos, o limite preciso da atividade investigatória e o favorecimento individual de acionistas, a CVM lança mão do sistema de responsabilidade civil aplicável ao órgão que, como sabemos, é muito falho. Nesse sentido, vide o Proc. RJ2005/2734, envolvendo questão sobre atividade exercida pelo conselheiro fiscal da Companhia Força e Luz Cataguazes-Leopoldina, relator Diretor Sergio Weguelin, por decisão em reunião de colegiado de 30 de agosto de 2005. Nesse caso, dúvida a respeito da independência do conselheiro foi assim resolvida: "Por fim, em relação à alegação da Cataguazes de que o conselheiro fiscal Jorge Lepeltier poderia estar solicitando informações adicionais com o objetivo de beneficiar a Alliant Holdings do Brasil em sua disputa judicial pelo controle da Cataguazes, é importante salientar que a própria Lei 6.404/76 prevê no $\S 1^{\circ}$ do art. 165 a figura do abuso do exercício da função. Logo, o remédio para esse desvio não é a recusa de prestação de informações, e sim a eventual responsabilização do conselheiro" (grifamos). Neste caso, é muito importante se observar como se articulam os itens independência, limites ao exercício de fiscalizar, responsabilidade por abuso e conteúdo do parecer, temas todos abordados nesta dissertação e criticados na medida de seu âmbito. Semelhante é a decisão prolatada no Proc. RJ2001/12253, que envolve discussão a respeito dos limites de investigação de conselheiro fiscal eleito por acionistas que estavam em litígio com a própria companhia fiscalizada, a saber, a Newtel Participações S.A., relatado pelo Diretor Wladimir Castelo Branco Castro, por decisão em reunião de colegiado de 9 de julho de 2002, com pedido de reconsideração negado na reunião de 15 de outubro de 2002. Nesse caso, o conselheiro fiscal alegou que "seria indispensável, para a boa transparência dos atos de gestão dos diretores, serem imediatamente disponibilizados os documentos evidenciando os contratos de prestação de serviços jurídicos contratados pela companhia e executados desde 01.01.2001, bem como as respectivas faturas apresentadas pelos profissionais do direito ou por suas sociedades civis, contendo o 
De um modo geral, essa oscilação colhe opiniões que partem desde uma análise mais técnica até uma análise mais principiológica e abstrata do intuito normativo em termos de "razão de ser" da fiscalização societária. ${ }^{328}$

detalhamento dos serviços prestados; a comprovação efetiva da prestação dos aludidos serviços; e, finalmente, os comprovantes da necessidade e da pertinência dos serviços prestados em benefício da Newtel". A companhia "prestou esclarecimentos à SEP (fls. 44/46), no sentido de que o conselheiro fiscal em questão estaria representando os interesses de acionistas que litigam com a sociedade, em diversos processos, a seu ver, infundados". Por sua vez, a CVM se posicionou afirmando que "devem os contratos solicitados pelo Conselheiro Fiscal Recorrente ser disponibilizados consoante o requerido, eis que dizem respeito a despesas da companhia, que lhe incumbe fiscalizar. Descabe a alegação da SEP, no sentido de que o conselheiro somente deva se manifestar diante do que lhe for apresentado. Tal restrição teria como resultado impedir o exercício do mister inerente ao conselheiro, que ficaria completamente à mercê do que a companhia decidisse que deveria ser apresentado. Além do mais, contrariaria a posição adotada pela CVM, por ocasião de seus Inquéritos Administrativos".

${ }_{328}$ Restringindo os mesmos níveis de aprofundamento, mas por razões completamente distintas, construindo um argumento menos técnico do que o de EIZIRIK, mas totalmente centrado na questão da ética empresarial, está a lição de Luiz Leonardo CANTIDIANo (Reforma da Lei das S.A. ..., Op. cit., Idem, pp. 206-207): "A lei limita o direito que tem o membro do conselho fiscal de solicitar aos administradores da sociedade esclarecimentos ou informações, exigindo que tais pedidos sejam relativos à função fiscalizadora desempenhada pelo requerente, para proteger a companhia de eventual ação do conselheiro que tem outros interesses a defender. Não cabe ao conselheiro fiscal, por exemplo, indagar que estratégia de produção ou de distribuição de seus produtos está sendo desenvolvida pela companhia. Também não compete ao membro do Conselho Fiscal pedir aos administradores planos de negócio, incluindo os investimentos a serem realizados. A atuação do conselheiro fiscal deve ficar cingida à verificação dos atos já praticados pelos administradores, tendo por objetivo atestar, ou não, a conformidade dos mesmos às regras legais e estatutárias vigentes".

Outros, porém, como Modesto CARvalhosa (Comentários..., Op. cit., Idem, p. 442), vêem na atuação do conselho fiscal, segundo o artigo 163, I da Lei das S.A., um lastro mais amplo de poder de ingerência nas coisas da administração: "Além do controle das contas, cabe ao Conselho Fiscal o controle da gestão financeira, ou seja, o exame não só da estrita regularidade das contas, como também de sua oportunidade. É o caso, v. g., de despesas que, embora feitas dentro dos poderes da administração, são exorbitantes, em face da conjuntura financeira ou das perspectivas de sua utilidade ou proveito".

Fran MARTINS (Comentários..., $2^{\circ}$ vol., Tomo I, Op. Cit., Idem, p. 435) parece querer retirar o que é nuclear na fiscalização, sob o argumento da existência de uma auditoria independente: "Essa verificação de documentos ou propostas, emanadas da administração, antes submetidas à assembléia geral, mostra que o Conselho é sobretudo um órgão de fiscalização dos administradores, não de mero exame contábil da sociedade, o que, em princípio, deve caber aos auditores".

Nenhum, entretanto, chega a ter visão tão ampla quanto Waldírio Bulgarelli, que defende $(O$ Regime Jurídico do Conselho Fiscal..., Op. cit., Idem, p. 149): "Em termos de fiscalização de deveres dos administradores, em geral, há que se mencionar a função social da empresa, referida no artigo 154. A apreciação crítica do Conselho Fiscal sobre a atuação dos órgãos administrativos deverá levar em conta também esse aspecto que, certamente pelas implicações previsíveis, é de suma importância e ainda mais por seu aparente aspecto de novidade".

Sob o ponto de vista prático, as orientações contidas no Manual do Conselho Fiscal, editado pelo COREF - Coordenação de Responsabilidades Financeiras e Haveres Mobiliários, da Secretaria do Tesouro Nacional, apresentam lúcida compreensão dos limites dessa revisão de atos administrativos ou de gestão: "A fiscalização deverá ocorrer por meio da análise de atas da Diretoria e do Conselho de Administração. O conselho deverá destacar para exame algumas decisões que resultem em relevante valor de despesa, comprometimento de seu patrimônio, ou, ainda, outras medidas aprovadas por aqueles órgãos que sejam estratégicas ou demonstrem inobservância aos preceitos legais, solicitando, se necessário, a documentação complementar sobre a matéria" (cf. SECRETARIA DA RECEITA FEDERAL / COREF. Manual do Conselheiro Fiscal. Brasília (2007), p. 12). O mesmo pode-se dizer em relação às pertinentes recomendações feitas no Guia de Orientação para o Conselho Fiscal, editado pelo Instituto Brasileiro de Governança Corporativa, sob a coordenação de Roberto LAMB e João Verner JUENEMANN, que formula extensa lista de sugestões de atividades decorrentes das atribuições (cf. InSTITUTO BRASILEIRO DE Governança CoRPORATIVA - IBGC. Guia de Orientação para o Conselho Fiscal, $2^{\mathrm{a}}$ ed., Coord.: 
Sobre essa oscilação, a prática e a jurisprudência (sobretudo as decisões de juízos "não especializados") normalmente se aproximam de um espectro mais amplo de permissibilidade, do que efetivamente técnico ${ }^{329}$, ficando muitas advertências como

Roberto LAMB e João Verner Juenemann. São Paulo: IBGC, 2007, pp. 13-15), cuja leitura é recomendável para qualquer pessoa que queira se envolver no tema, sobretudo e principalmente os próprios conselheiros fiscais em exercício.

Dentre as recomendações listadas pelo IBGC, há inúmeras muito interessantes e já testadas na prática. Destaca-se a recomendação que trata de "acompanhar, durante o exercício, a evolução das contas refletidas nos balancetes analíticos, incluindo controladas e coligadas" (Ibidem, p. 14). Nesse sentido, já houve decisão da CVM favorável ao entendimento do IBGC. No caso dos autos do Proc. RJ2003/7703, conselheiro fiscal da Usina Costa Pinto S.A. (UCP) solicitou detalhes sobre as demonstrações financeiras da coligada Cosan S.A. Indústria e Comércio. O relator, diretor Luiz Antonio de Sampaio Campos, em voto apresentado na reunião do colegiado de 18 de novembro de 2003, sedimentou a questão nestes termos: "A meu ver os membros do conselho fiscal da companhia devem poder examinar os documentos contábeis que serviram de base para a elaboração das demonstrações financeiras da companhia. Nesse contexto, inserem-se aqueles que se referem às sociedades coligadas e que foram postos à disposição da companhia para que esta elaborasse as suas demonstrações financeiras".

Adicionalmente, vale ainda lembrar a importante recomendação do IBGC para que o conselho fiscal faça "acompanhar operações de hedge, operações com derivativos e instrumentos financeiros", já que esse tema, ainda preliminar ao tempo em que esta dissertação está sendo escrita, já é, hoje, alvo de grande polêmica que assola companhias abertas no Brasil e que se dissemina, no clima da crise mundial alçada pelos sub-primes estado-unidenses. O efeito colateral devastador no Brasil, que associa práticas inconsequentes de uso de instrumentos de derivativos que se tornam grandes problemas em períodos de oscilação cambial, já atingiu companhias abertas de grande porte e conglomerados industriais que operaram semelhantes instrumentos sem respaldo de política de investimento adequadas. Vem se tornando comum, desde os meses de agosto a outubro de 2008, uma "investigação tardia" por parte de conselhos fiscais para verificar o teor desses instrumentos e a associação dessas práticas com políticas de investimento e controles internos das companhias. Neste pormenor, o brocardo "antes tarde do nunca" não vem surtindo efeito, pois a obrigação fiscalizatória do conselho fiscal deve ter caráter nitidamente preventivo, para que, ao investigar e notar inconsistências no uso desses mecanismos, possa o mencionado órgão exarar parecer representando o problema para a assembléia ou para a administração, notadamente o conselho de administração. Este há de ser um caso clássico de omissão na fiscalização, que decorre, ora por falta de conhecimento da questão por parte de quem exerce o cargo, ora por falta de independência, ora por práticas recorrentes e assentadas de fiscalização no Brasil que permitem uma atuação mais superficial e menos efetiva.

Sob o ponto de vista histórico, podemos lembrar também o interessante texto do artigo $14, \S 3^{\circ}$ da Lei $\mathrm{n}^{\mathrm{o}} 3.150$, de 1882, com balizas razoavelmente seguras para a época, em relação aos limites de investigação dos fiscais internos de companhias: "Os fiscaes durante o trimestre que precede a reunião ordinária de assembléia geral têm o direito de examinar os livros, de verificar o estado de caixa e da carteira, exigir informações dos administradores sobre as operações sociais e convocar extradordinariamente a assembléia geral".

${ }^{329} \mathrm{Na}$ jurisprudência especializada formulada pela CVM, há bons exemplos de temperança na identificação dos limites de atuação do conselheiro fiscal, como temos visto. Dentre esses exemplos, há decisões com grande apuração técnica, como a do caso do Proc. RJ2005/0134, que trata de recurso formulado por conselheiro fiscal da Têxtil Renaux S.A. com vistas à obtenção de lista de acionistas na forma do artigo $100, \S 1^{\circ}$ da Lei das S.A., relatado pelo diretor Sérgio Weguelin em reunião do colegiado de 29 de agosto de 2006. Nesse caso, o relator, manifestando-se pela recusa, chegou a afirmar: "Devo dizer que em princípio não vejo relação entre as atribuições fiscalizatórias do conselho fiscal ou de seus membros e a obtenção da lista de acionistas da companhia. Com efeito, é possível afirmar que, via de regra, a gestão da companhia não depende da composição do seu capital social. Tanto que o fornecimento da lista sequer é mencionado pelos arts. 161 e seguintes da LSA". Nesse sentido, em decisão unânime, a CVM, por meio de seu órgão colegiado, sedimentou: "O Relator esclareceu que a recusa pela companhia não se justificaria caso o conselheiro tivesse fundamentado minimamente a necessidade da obtenção da lista para o pleno desempenho de suas funções fiscalizatórias. O Relator esclareceu que seu entendimento, no caso concreto, não decorre de 'caráter confidencial' que, segundo a Têxtil Renaux, a Lei teria atribuído ao conteúdo do registro. Para o Relator, não cabe falar em sigilo ou confidencialidade quanto ao livro de registro e transferência de títulos de emissão das companhias. Pelo contrário, o livro tem caráter 
posições de um extremo que a prática não visita, muito por força das distorções formais que já tivemos a oportunidade de apontar.

Nota-se, entre esses comentários, claramente, que a linha que divide a pertinência e a profundidade da fiscalização em relação a atos de gestão, antes de residir num conceito preciso do que sejam atos de gestão, ou atos de administração, ou, simplesmente, como prefere a lei, atos dos administradores, procura discernir, inclusive sob a ótica da doutrina da business judgment rule, se a conveniência e a oportunidade dos atos praticados pela administração estão, a posteriori, sob o pálio revisional do conselho fiscal. Não há que se duvidar que ao conselho fiscal é absolutamente vedada a atuação a priori com relação a atos da administração (ao contrário do que ocorre com o comitê de auditoria) ${ }^{330}$, pois não há na lei nenhum preceito que faça entender que ao conselho fiscal poderia ser facultada qualquer "autorização prévia" ou acompanhamento periódico da implementação de uma recomendação, nem mesmo nas matérias em que o conselho fiscal emite parecer anterior à conclusão da operação (ex vi artigo $173, \S 1^{\circ}$ da Lei das S.A.). ${ }^{331}$

nitidamente público, ainda que sua publicidade dependa da observância de procedimento próprio, sendo portanto acessível a todo aquele que dele necessite para efeito da defesa de direitos e esclarecimento de situações de interesse pessoal ou dos acionistas ou do mercado de valores mobiliários. Segundo o Relator, essa não é a hipótese dos autos. No caso concreto, o conselheiro em nenhum momento demonstrou ligação entre a necessidade de obtenção da lista e o desempenho das diversas competências estatuídas no art. 163 da LSA. E, ainda segundo o Relator, se recorrêssemos no caso concreto à previsão geral do art. $100, \S 1 .^{\circ}$, da Lei $6.404 / 76$, tampouco caberia melhor sorte ao conselheiro, já que não fundamentou, sequer sucintamente, o pedido da lista, indo de encontro, desse modo, à orientação da CVM sobre o assunto".

${ }^{330}$ Exemplo disso é o teor do inciso V, do artigo 15, da Resolução CMN 3198 (“...avaliar o cumprimento, pela administração da instituição, das recomendações feitas pelos auditores independentes ou internos;").

${ }^{331}$ Nesse sentido, vide a decisão da CVM nos Procs. RJ2006/0594 e RJ2005/0147, que tratam da necessidade de oitiva prévia do conselho fiscal em redução de capital do Banco do Estado do Sergipe S.A., o Banese, relatado pelo então presidente Marcelo Fernandez Trindade, em brilhante voto proferido na reunião de colegiado de 10 de julho de 2007. Do voto, extrai-se: "Nas companhias não há norma específica quanto ao tema, embora talvez, de lege ferenda, se pudesse considerar a prévia manifestação como recomendável em qualquer caso, para evitar que acionistas minoritários fossem surpreendidos com a proposta, e não dispusessem de meios para examiná-la adequadamente. Mas a lei não distingue as situações de companhias fechadas e abertas no particular, talvez porque a relevância do parecer para estas últimas tenha the escapado, talvez porque tenham, ainda outra vez, como tantas vezes fez, privilegiado a celeridade nas relações mercantis."

A competência esparsa do artigo $173, \S 1^{\circ}$ da Lei das S.A. para oitiva de conselho fiscal antes de operação de redução de capital é um dos dispositivos mais criticados em relação às competências do conselho fiscal (vide M. Carvalhosa, Comentários..., vol. 3º, Op. cit., Idem, pp. 598-599). Adicionalmente, cumpre notar que essa competência só se justifica na lei por força de "importante modificação patrimonial da companhia", argumento esse usado pelo mesmo CARVALHOSA (Ibidem, p. 443) para sustentar a necessidade de oitiva prévia do conselho fiscal em operações que envolvam hipóteses circunscritas ao âmbito dos artigos 154 e 156 da Lei das S.A. Embora a lei disponha expressamente qual órgão tem essa competência de oitiva prévia (p. ex., no caso do artigo 154, §2, "b", a 
O nível de aprofundamento da fiscalização em relação aos atos de gestão e de toda a fiscalização legal da gestão, como um todo, é a grande porta de entrada para a politização do conselho fiscal e uma das maiores razões de ser das distorções formais aqui combatidas, sobretudo a do $\$ 4^{\circ}$ do artigo 161. O Brasil, ao lado de Portugal e Itália, está dentre os poucos países que têm dispositivos amplos e abertos, já que França $^{332}$, Estados Unidos ${ }^{333}$, Argentina $^{334}$ e México $^{335}$ não contém dispositivo de

Lei das S.A. dá competência expressamente ao conselho de administração e à assembléia geral), concordamos, de lege ferenda, com o argumento de CARVALHOSA, mas não de lege lata, fazendo uso do mesmo raciocínio traçado na decisão formulada por Marcelo Fernandez Trindade no caso da redução de capital do Banco do Estado do Sergipe acima tratado.

Vale lembrar, ainda, que pelo mesmo argumento, operações circunscritas no âmbito do artigo 264 da Lei das S.A. deveriam receber, igualmente ao artigo $173, \S 1^{\circ}$, opinião do conselho fiscal a respeito do cálculo da relação de troca. Essa medida seria extremamente saudável para companhias abertas, sobretudo se praticadas dentro do âmbito das competências próprias do conselho fiscal em matéria de "transformação, incorporação, fusão e cisão" (artigo 163, III da Lei das S.A.) e certamente evitaria medidas preventivas de tecnicidade questionável, tal como a tentativa abrangida pelas "recomendações" oriundas do polêmico Parecer de Orientação CVM no 35 , de $1^{\circ}$ de setembro de 2008, que emulou soluções advindas de outra polêmica, a saber, aquela que envolve o caso Weinberger v. UOP, Inc. (457 A.2d 701 [Del. 1983]; a respeito do tema, vide Mauro Bardawil PENTEADO, "The efficacy of intra-corporate approvals in negotiated mergers between controlling shareholder and its corporation under Delaware and Brazilian law", In RDM 143/76). Ao invés de propor modificações na Lei das S.A. para exigir que nessas operações seja formulado laudo de avaliação segundo critérios especiais (medida que, diga-se de passagem, estaria dentro da competência da CVM por delegação expressa constante do artigo 264 da Lei das S.A.) ou ainda que a operação esteja sujeita a parecer prévio do conselho fiscal, optou a autarquia pelo texto do Parecer, que segue na linha da responsabilidade por dever fiduciário, reforçando o regime de responsabilidade cuja crítica seguirá no próximo capítulo desta dissertação. Além disso, o Parecer opta por uma solução importada, pois, a seu ver, “....a própria lei adotou conceitos genéricos baseados no direito anglo-saxão; (...) a CVM tem competência para dar concretude [sic] a esses conceitos, assim como as cortes norte-americanas; (...) os procedimentos concretos sugeridos podem ser inferidos da própria lei, principal fonte do direito em sistemas jurídicos de tradição romano-germânica" (cf. Memorando de 30 de maio de 2008 do Relator Marcos Pinto, anexo à minuta de Parecer de Orientação submetida à audiência pública, divulgado na Reunião do Colegiado da CVM de 02 de junho de 2008). Vale lembrar que, na linha de Weinberger, a CVM passa a sugerir que companhias abertas componham comitê especial formado por conselheiros de administração que se qualifiquem como independentes para que estes, no lugar da diretoria, negociem efetivamente em nome da incorporada buscando uma "efetiva relação de troca". Qual seja, a CVM interpreta que, na busca de uma melhor alternativa para a compreensão dos deveres fiduciários da administração de companhia aberta, deve o conselho de administração se imiscuir na execução da operação, agindo em nome da incorporada para minimizar o self dealing. Entretanto, data maxima venia e com todo o respeito, parece não ser essa a melhor alternativa, pois pelo direito brasileiro (cf. artigo 144, caput da Lei das S.A.), a representação de uma companhia é de competência exclusiva de sua diretoria, não sendo coerente que um Parecer de Orientação da CVM possa sugerir que, em certas operações, a companhia possa ser representada por outro órgão e que possa negociar por ela outra pessoa que não seja diretor da companhia ou seu mandatário direto. Não poderia, também, a CVM, criar esse "mandato tácito" que permitisse que conselheiros de administração representassem, em negociações, a companhia controlada. A questão, aqui, desta forma, é efetivamente de fiscalização e não de negociação de instrumento contratual (considerando que os termos dessas operações são resumidos em um Protocolo, nos termos do artigo 224 da Lei das S.A.) que, repita-se, é incumbência exclusiva da diretoria da companhia.

${ }^{332}$ A França é dotada do texto de mais alto nível técnico dentre as legislações estudadas, cf. o artigo L823-10 do Code de commerce, que veda revisão de atos de gestão, proibindo o comissário de contas de imiscuir-se, ainda que como espectador, na administração da companhia lato sensu. Vide M. CozIAN, A. VIANDIER e F. Deboissy. Droit des sociétés, Op. Cit., Idem, pp. 340-342.

${ }^{333}$ Seja para o caso dos auditores, seja para o caso dos membros do comitê de auditoria (cf. artigo 303A, Item 7, (c) da Lei Sarbanes-Oxley). 
fiscalização tão amplo, dando feições muito mais técnicas aos seus respectivos órgãos de fiscalização (a saber, os comissários de contas na França, os auditores e os membros do comitê de auditoria nos EUA, os síndicos na Argentina e os comissários do México).

Essa atribuição, atrelada às frágeis regras de independência e de responsabilidade, tem propiciado que boa parte das chamadas "atuações ad terrorem" (seja a favor da minoria, seja a favor da maioria) passem incólumes pelo crivo da lei.

E, em complemento dessa atribuição de fiscalização legal da gestão, associam-se as atribuições de denúncia de erros ou fraudes. Embora BULGARELLI note que a denúncia de erros ou fraudes seja uma atribuição decorrente das funções fiscalizatórias decorrentes do exame de $\operatorname{contas}^{336}$, a denúncia pelo conselheiro fiscal pode naturalmente envolver atos de gestão que tenham sido praticados fora do âmbito dos estatutos ou da lei, tais como a prática, pela administração, de atos não previstos dentre aqueles que englobem o objeto da companhia, ainda que admitidos em lei. ${ }^{337}$ Além disso, podem envolver atos praticados por funcionários da companhia, prepostos, prestadores de serviço, acionistas e outras funções que possam estar relacionadas com o acervo da companhia, ao passo que a denúncia por erro ou fraude decorrente da prestação de contas envolverá, no mais das vezes, atos praticados pelos administradores, que são os responsáveis pela elaboração de tais contas.

\footnotetext{
334 A fiscalização dos atos da administração, na lei argentina, é atrelada ao que efetivamente constar como obrigação legal de escrituração ou transcrição em livros (artigo 294, inciso 1, da Lei 19.550). Assim explana VERÓN (Auditoría..., Op. cit., Idem, p. 396), notando que na Argentina, atualmente, a fiscalização dos atos de administração se limita a investigar o reflexo contábil de certos atos de maneira passiva, conforme já expusemos acima. O problema, na Argentina, é contrário ao do Brasil: quando aqui temos excessos cometidos em algumas companhias, na Argentina o que se vê é uma atitude mais passiva que leva a uma físcalização menos rigorosa, sob o ponto de vista do controle dos atos de gestão (Ibidem, $\mathrm{p}$. 396-397). VERÓN afirma que o controle de gestão "é um dos temas mais escabrosos do instituto da sindicatura nas sociedades anônimas” (p. 395: “... uno de los temas probablemente más escabrosos de la institución de la sindicatura de sociedades anónimas: el alcance que debe otorgársele a la función de fiscalizar la administración social"). Entendemos, entretanto, que o meio-termo necessário para se identificar, tecnicamente, esse limite, está no reflexo imediato que um eventual ato ilegal pode trazer para as finanças da companhia. Exemplo: em uma companhia do setor regulado elétrico, é necessário que o conselheiro fiscal saiba qual seria o impacto no balanço da companhia, caso a administração opte por cumprir alguma resolução da ANEEL de forma diferente daquela praticada por outras companhias no mercado.

${ }^{335}$ No mesmo sentido da lei argentina está a mexicana, por força do texto do artigo 166, inciso III, da Ley General (vide J. RodRIGUEz R. Tratado..., Op. cit., Idem, pp. 145-146).

${ }^{336}$ O Regime do Conselho Fiscal..., Op. cit., Idem, p. 153.

337 Exemplo disso é a celebração de um contrato de corretagem ou comissão mercantil em que uma empresa age como comissária de outra, sem que o estatuto da empresa que age como comissária traga, expressamente, a possibilidade de prática desse tipo de ato ou serviço.
} 
Entretanto, em relação ao mérito legal que envolve essa atribuição específica ao conselheiro fiscal (já que a atribuição do inciso IV é uma das poucas que não envolve ato colegiado), apesar da histórica reiteração dessa linguagem, é de se notar a sua impropriedade técnica. A lei parece investir no conselheiro fiscal um poder que o assemelha, por analogia, a uma espécie de "promotor de justiça interno da companhia".

É de se notar que o verbo "denunciar", nesse caso, está sendo empregado muito mais em sentido leigo do que em sentido técnico. O conselheiro fiscal, ao tratar de erros, fraudes ou crimes, não "denuncia" ninguém, qual seja, não apresenta peça de "acusação" contra ninguém. O conselheiro fiscal, de fato, usa de sua competência para informar alguém sobre determinada ocorrência.. Por isso, a legitimação para agir sobre fatos "denunciados" pelo conselho fiscal pode recair sobre outros órgãos ou funções societárias, mas certamente jamais reside entre os atos de legitimidade do próprio conselho fiscal ou de qualquer conselheiro isoladamente. ${ }^{338}$

A competência a respeito da denúncia de erros ou fraudes, além disso, impõe ao conselho fiscal uma atribuição cujo regime de responsabilidade civil não acompanha adequadamente, como teremos a oportunidade de verificar no capítulo seguinte.

A Lei das S.A. ainda trata de outras atribuições que estão esparsas em seu texto e que certamente incrementam a lista de competências do conselho fiscal para além do artigo 163 da Lei das S.A. Todas essas atribuições incluem-se no âmbito da fiscalização legal da gestão.

A primeira delas diz respeito à oitiva prévia do conselho fiscal em caso de redução de capital. Em linhas gerais, podemos afirmar que essa é uma atribuição colegiada do órgão, de caráter revisional e uma das poucas de natureza apriorística, se assemelhando muito à função de um comitê interno da companhia.

Neste ponto, o conselho fiscal funciona como verdadeiro comitê, pois opina de antemão, com a possibilidade de interferir na decisão dos acionistas. Sua opinião, entretanto, em matéria de redução de capital, deve se limitar exclusivamente a

\footnotetext{
${ }^{338}$ Carvalhosa, Comentários..., vol. $3^{\circ}$, Op. cit., Idem, p. 445. Vide ainda outras situações em que se nota a questionável legitimidade de conselheiros fiscais para agir em substituição dos direitos e potestividades próprias dos acionistas (cf. Erasmo Valladão Azevedo e Novaes FRANÇA. Invalidade das Deliberações..., Op. cit., Idem, p. 120, nota 137).
} 
questões técnico-contábeis e legais, sendo absolutamente vedado e inconveniente que o conselho fiscal interfira em questões políticas ou de mérito sobre a modificação do capital.

Nesse mesmo sentido estão os casos de aumento de capital efetuados na forma do artigo 166, I, II e IV, combinado com o disposto no $\S 2^{\circ}$ ao mesmo artigo, todos da Lei das S.A. Ambos, aumento e redução de capital, são casos de regras específicas de participação do conselho fiscal em casos de modificação de capital, conforme disposto no artigo 163, III da Lei das S.A. E em todas essas hipóteses, a oitiva prévia é obrigatória e sem ela o ato é inválido. ${ }^{339}$

Noutro ponto da lei o conselho fiscal também atua de forma semelhante às modificações de capital: trata-se da não distribuição de dividendo obrigatório por força de incompatibilidade com a situação financeira da companhia ( $\left(4^{\circ}\right.$ ao artigo 202 da Lei das S.A.).

Tal qual ocorre no contexto da redução de capital, o conselho fiscal atua, mais uma vez, com funções de comitê interno da companhia. Seu dever é verificar, de forma técnica e isenta, a respeito da informação que fundamenta a não distribuição, a saber, a situação financeira da companhia que estaria tornando-a incompatível.

Tecnicamente, incumbe ao conselho fiscal verificar se os valores decorrentes das contas de resultado da companhia foram devidamente obtidos e se os impostos estão sendo devidamente aplicados e recolhidos, de modo a conduzir a companhia a uma apresentação de lucros que não permita cumprir com o valor de dividendo obrigatório na forma da lei e de seu estatuto.

Uma terceira atribuição diz respeito às informações obrigatórias que o conselho deve fornecer, na forma do $\S 6^{\circ}$, do artigo 163 , da Lei das S.A. Incumbe lembrar, primeiramente, a total impertinência dessa norma relativamente ao regime jurídico das companhias abertas. No que se refere aos aspectos de fluxo de informações

\footnotetext{
${ }^{339}$ Cf. Mauro Rodrigues Penteado. Aumentos de capital das sociedades anônimas. São Paulo: Saraiva, 1988, pp. 179-181. Contra, CARvalhosa (Comentários..., vol. $3^{\circ}$, Op. cit., Idem, p. 487 [em relação ao aumento] e p. 599 [em relação à redução]), que fala de ineficácia do ato. Estamos, nesse particular, com Mauro PENTEADO, pois, sendo, neste caso, eventual aprovação de alteração de capital (seja em aumento, seja em redução) sem oitiva prévia de conselho fiscal, uma violação de texto expresso de lei (especificamente, o artigo 166, $\S 2^{\circ}$ e o artigo $173, \S 1^{\circ}$, ambos, respectivamente, da Lei das S.A.), o caso é de invalidade do ato (a deliberação da assembléia será anulável, nos termos do art. 286) e não de ineficácia.
} 
da companhia para seus acionistas, a companhia aberta deve obedecer a um regime absolutamente rigoroso de divulgação dessas informações, nos termos da Instrução $\mathrm{CVM} \mathrm{n}^{\circ} 358$, de 3 de janeiro de 2002.

Um fluxo de informações que privilegie uma pequena parcela de acionistas, ou, ainda que seja, uma grande parcela e não a sua totalidade afronta toda e qualquer lógica de mercado baseada no princípio da teoria da eficiência de mercado, que já tivemos a oportunidade de estudar nas páginas anteriores.

As informações da companhia devem ser as únicas e as mesmas para todos os acionistas. Não há, em regime de companhias abertas, argumento que justifique ou sustente esse privilégio exclusivo para grupo de acionistas solicitantes de informações.

A forma correta de fornecer informações a acionistas de companhias abertas, representem eles pouco ou muito da parcela de capital, é por meio de fato relevante. Além desse meio, as informações só podem ser prestadas diretamente aos acionistas em assembléia, razão de ser do artigo 164, caput, da Lei das S.A. O conselho fiscal não pode se prestar a esse tipo de papel, diretamente e em favor de certos acionistas e em detrimento de outros, fora de uma assembléia geral.

Ademais, cumpre lembrar que a decisão a respeito da conveniência de se fornecer certas informações ou não é de competência colegiada e, portanto, majoritária. ${ }^{340} \mathrm{O}$ cumprimento desse dever, em detrimento das obrigações previstas na Instrução CVM no 358 , de 3 de janeiro de 2002, deve ser observado com muita cautela e parcimônia pelos membros do conselho fiscal. Nem toda informação estaria sujeita a esse fluxo em favor de alguns acionistas, ainda que se trate de matéria de competência do referido órgão. Um bom exemplo disso são as informações financeiras - toda companhia aberta tem um momento certo de divulgação dessas informações de maneira uniforme para todo o mercado. Não pode jamais o conselho fiscal, com base no $\S 6^{\circ}$ do artigo 163, compartilhar com certos acionistas, informações financeiras ainda não divulgadas ao mercado. Neste pormenor, aplica-se o artigo $8^{\circ}$ da Instrução CVM $n^{\circ}$ 358 , de 3 de janeiro de 2002 , em detrimento do $\S 6^{\circ}$ do artigo 163 , pois "cumpre aos (...) membros do conselho fiscal e de quaisquer órgãos com funções técnicas ou consultivas,

\footnotetext{
${ }^{340}$ Vide Carvalhosa, Comentários..., Op. cit., Idem, p. 452.
} 
criados por disposição estatutária, e empregados da companhia, guardar sigilo das informações relativas a ato ou fato relevante às quais tenham acesso privilegiado em razão do cargo ou posição que ocupam, até sua divulgação ao mercado, bem como zelar para que subordinados e terceiros de sua confiança também o façam, respondendo solidariamente com estes na hipótese de descumprimento". ${ }^{341}$

\section{Conflitos de atribuição}

Uma vez identificadas as precisas atribuições do conselho fiscal e observadas algumas sobreposições funcionais em relação ao conselho de administração, (seja na sua função geral administrativa, seja na sua função específica em comitê de auditoria), bem como em relação ao auditor independente, à Comissão de Valores Mobiliários e outras instâncias de fiscalização, decorre logicamente afirmar que a conformação funcional do conselho fiscal, tal qual presente na Lei das S.A., permite concluir por uma presença evidente de potenciais conflitos de atribuição societários.

O tema dos conflitos de atribuição são atualmente estudados no âmbito do direito público. O direito privado desconhece-lhe o conceito, mas toda a emulação de uma estrutura estatal na qual o direito societário está historicamente atrelado, permite pensar no problema das sobreposições de competência do conselho fiscal em relação a outros órgãos da companhia sob o regime dos conflitos de atribuição. ${ }^{342}$

Neste pormenor, é imperioso admitir que o regime jurídico-funcional do conselho fiscal padece de uma precisa delimitação do poder fiscalizatório que se quer

\footnotetext{
${ }^{341}$ Portanto, aqui, neste pormenor, ousamos respeitosamente divergir da afirmação de CARVALHOSA (Ibidem). Admitimos, no caso das companhias abertas, hipóteses em que o conselho fiscal possa legalmente retardar ou procrastinar ou, sob esse pretexto, negar tais informações, na forma e na extensão eventualmente requeridas por alguns acionistas, antes que as informações tenham sido veiculadas na forma de fato relevante ao mercado.

Em relação à experiência do direito comparado, é interessante notar o direito argentino, que não apenas é dotado de provisão semelhante como permite que essa informação seja compartilhada com um grupo mais restrito ainda de acionistas, pois a lei permite que acionistas detentores de, pelo menos, 2,0\% (dois por cento) do capital total da companhia, sejam beneficiados por informações prestadas pela sindicatura, dentro das atribuições desta.

${ }^{342}$ Mesmo em direito público a quantidade de estudos sobre o tema é bastante escassa, exceto pela obra paradigmática do jovem processualista Daniel Guimarães ZvEIBIL (Contribuição para uma análise processual dos conflitos brasileiros de atribuição. São Paulo: FADUSP, 2006 [Dissertação de Mestrado sob a orientação do Prof. Titular José Ignácio Botelho de Mesquita]).
} 
ver exercido, com exclusividade, pelo aludido órgão (ex vi do teor do $§ 7^{\circ}$ do artigo 163 e do $\S 7^{\circ}$ do artigo 161 , ambos da Lei das S.A.).

Não há, na lei brasileira, uma precisa delimitação do poder fiscalizatório e de sua superação formal (como já pudemos notar pelas falhas de ordem formal de que a nossa lei padece, sobretudo no âmbito da independência) em relação ao que é controle (que se exerce sobre a administração) e o que é fiscalização (que se exerce em face da administração).

Esse é um problema principiológico que a nossa lei convive e a cada passo em que se ruma na cópia das estruturas jurídicas estado-unidenses, essa fissura legal vai se tornando cada vez mais profunda.

Um adequado regime jurídico não apenas formal, mas também funcional do conselho fiscal é medida imperiosa para diminuir todo e qualquer conflito (positivo ou negativo) de atribuição entre pólos de poder em uma companhia.

Dentre todos os conflitos de atribuição, o mais grave diz respeito às atribuições fiscalizatórias do conselho de administração. Como órgão político por excelência, o conselho de administração recebe atribuição semelhante (artigo 142, III da Lei das S.A.). Mas ao conselho fiscal, desde há muito, a mesma função, de natureza eminentemente política, é também atribuída, de forma, diga-se de passagem, inconveniente. $^{343} \mathrm{O}$ conselheiro fiscal, dispersando-se de suas atribuições técnicas,

\footnotetext{
${ }^{343}$ Discordamos, pois, da afirmação de Fran MARTINS (Comentários..., Op. cit., Idem, p. 291) que alega haver invasão da competência do conselho fiscal na hipótese do artigo 142, III da Lei das S.A.. Conforme estamos analisando, não nos parece ser da natureza fiscalizatória própria de um órgão técnico como o conselho fiscal, a intervenção em atos e relações jurídicas que comportem o mérito de decisões administrativas e a aplicação de uma doutrina semelhante à da business judgment rule. Parece caber mais ao conselho de administração essa tarefa, com tendência política societária, que ao conselho fiscal, a quem incumbe fiscalizar atos formais. Fábio Ulhôa COELHo (Curso de Direito Comercial, vol. 2, 10 ed.. São Paulo: Saraiva, 2007, pp. 236-237) afirma: "cabe distinguir as competências fiscalizatórias atribuídas pela lei ao conselho de administração (LSA, artigo 142, III) e ao conselho fiscal (163, I), destacando maior amplitude da primeira relativamente à segunda. Em outros termos, o conselho de administração, ao fiscalizar diretores, exerce competência não limitada à legalidade ou adequabilidade contábil dos atos praticados, mas também abrangente da sua economicidade, conveniência, oportunidade e quaisquer outros aspectos que tomar por relevantes. Ao conselho fiscal não cabe entrar no mérito da decisão adotada pelos diretores na condução dos negócios sociais, porque ele não os pode substituir na administração da empresa. Já o conselho de administração, ao fiscalizar a diretoria, tem poderes para questionar qualquer ato praticado, na forma ou no conteúdo, bem como determinar as correções possíveis, se entender pertinente, ou sustar providências em andamento. Convém recordar, a propósito, que, no Brasil, o conselho de administração, embora detenha poderes para tanto, não costuma ingerir-se nos assuntos da diretoria".

Nesse mesmo conceito fiscalizatório estão os dispositivos constantes do $\S 3^{\circ}$, do artigo 46 , da Lei das S.A., que trata do direito de fiscalizar a companhia por parte dos detentores de partes beneficiárias, bem
} 
quando agindo em favor de algum acionista ou grupo de acionistas (minoritários ou não), tende a atuar de modo a favorecer, politicamente, os interesses daqueles a quem o conselheiro se vê ligado.

Isto porque a opção pela justificação política de suas decisões é da natureza dos atos e das atribuições inerentes ao conselho de administração. Não cabe ao conselho de administração, ainda que na pessoa dos conselheiros independentes, garantir que suas decisões sejam tomadas ou ainda que atos sejam praticados exclusivamente sob orientação técnica e não política.

O conselho fiscal, por sua natureza, é um órgão técnico e não político. Com maior incidência de regras de independência, o caráter técnico do órgão tornar-seia mais marcante.

O problema se complica quando o conselho de administração assume funções fiscalizatórias por intermédio do comitê de auditoria.

No direito brasileiro, o comitê de auditoria surge no contexto da Lei Sarbanes-Oxley, da qual já tivemos ampla oportunidade de tratar no capítulo anterior. Surge, nominalmente, pela primeira vez em nossa estrutura legal, por intermédio do Edital de Audiência Pública do Banco Central do Brasil n ${ }^{\circ}$ 18, de 13 de dezembro de 2002, que tratou, dentre outros assuntos, do comitê de auditoria entre os artigos $6^{\circ}$ a 11 do regulamento anexo ao Edital da mencionada proposta de Resolução.

O foco principal do Edital se concentrou nas questões que envolvem a lisura dos procedimentos de auditoria desempenhados pelo auditor independente das

como do artigo 109, III, que trata do direito essencial do acionista de fiscalizar a companhia sponte propria. São, sem sombra de dúvida, métodos de fiscalização distintos daqueles empreendidos pelo conselho fiscal. O conselho fiscal revê atos, conforme estamos entendendo na análise empreendida neste trabalho, ao passo que o direito essencial do acionista e do detentor de parte beneficiária está diretamente ligada à obtenção de informações e ao dever de informar (disclosure e transparência) da companhia, sobretudo das companhias abertas (vide CARvalhosa, Comentários..., vol. 2º Op. cit., Idem, pp. 350352). O direito individual de fiscalizar dos acionistas (e da mesma forma, dos titulares de partes beneficiárias) está, portanto, sempre atrelado a alguma medida preliminar da qual possa depender eventual ação judicial para que seja devidamente instruída. É, portanto, direito individual de acionista juridicamente interessado (sob o ponto de vista técnico e processual) e não cabe a acionista curioso ou desinteressado o exercício de inspeção aleatória, inadequada e desnecessária. Assim entende CARVAlHOSA: "Os direitos de informação, de fiscalização e de inspeção, e correspondentes direitos de ação, exercidos pelos acionistas individualmente ou na qualidade de minoritários, fundam-se no princípio da verificação da legalidade e da legitimidade (abuso e desvio de poder) dos atos praticados pelos órgãos da companhia e pelos controladores". Nesse mesmo sentido, vide W. Bulgarelli, Regime Jurídico da Proteção às Minorias..., Op. cit., Idem, pp. 83-94. 
companhias que atuam sob atuação regulatória do Conselho Monetário Nacional e Banco Central do Brasil; na fidelidade e fidedignidade dos números lançados em demonstrações financeiras por diretores dessas companhias; e, por fim, na consistência dos controles internos criados e utilizados pela diretoria dessas companhias.

Após consulta pública, o Edital de Audiência Pública do Banco Central do Brasil $n^{\circ}$ 18/2002 foi convertido na Resolução do Conselho Monetário Nacional $\mathrm{n}^{\circ}$ 3081 , de 29 de maio de $2003^{344}$. Por conta de diversas críticas, o Conselho Monetário Nacional editou nova Resolução em 4 de fevereiro de 2004, sob o ${ }^{\circ} 3170$, reformando boa parte dos princípios, premissas e requisitos que balizavam a Resolução $\mathrm{CMN} \mathrm{n}^{\circ}$ $3081 / 03$.

Algumas incongruências persistiram e a Resolução CMN, que tratava do comitê de auditoria, sofreu nova modificação, tendo o seu texto sido consolidado na Resolução CMN 3198, acima citada.

Paralelamente ao Conselho Monetário Nacional, o Conselho Nacional de Seguros Privados (CNSP) trabalhou em uma minuta de Resolução em Edital de Audiência Pública, válida para todas as sociedades sob sua jurisdição regulatória. Nesse âmbito, foi editada, com base nos comentários ao Edital mencionado, a Resolução CNSP n ${ }^{\circ} 118$, de 24 de dezembro de $2004 .^{345}$

Entretanto, esse complexo emaranhado de normas não surgiu de um debate ou de um contexto sócio-econômico específico do direito brasileiro. O debate atrelado ao contexto do Edital BC 18 supracitado é posterior à importação da idéia. Em outras palavras, ambas as autarquias, inseridas no sistema regulatório de competência do Ministério da Fazenda, não regularam as características de uma atividade em resposta a problemas ou necessidades de solução nascidas de um contexto comercial típica ou isoladamente brasileiro. O Ministério da Fazenda brasileiro, em um contexto de sérias exigências internacionais para melhoria da transparência na administração de empresas ao redor do mundo, se antecipou e inseriu no ordenamento brasileiro um instrumento totalmente moldado segundo debates, problemas e tentativas de soluções nascidas em outra jurisdição sócio-econômica.

\footnotetext{
${ }^{344} \mathrm{O}$ Comitê de Auditoria foi regulado entre os artigos 10 a 16 do Regulamento Anexo à Resolução.

${ }^{345}$ O texto da Resolução CNSP 118/04 é praticamente idêntico ao texto da Resolução CMN 3198.
} 
E apesar dos debates terem continuado e persistido, a legislação local não logrou acompanhá-lo, mantendo o regime como está. Atualmente, as atribuições que oscilam entre os órgãos configuram um dos maiores exemplos de conflito de atribuição societária.

Esse esforço de adequação a um contexto de origem estrangeira, por conta da rapidez da disputa e da implantação de argumentos alheios ao direito brasileiro, acabou por produzir o comitê de auditoria como novo instituto, que regula e interfere na relação jurídica existente entre administração e auditoria independente num país cuja auditoria independente não surge por tradição, mas por imposição da Lei $n^{\circ} 6.385$, de 7 de dezembro de 1976 e seguidas emendas.

De fato, os problemas específicos atinentes à relação jurídica estabelecida entre esses dois órgãos societários surgem nos Estados Unidos da América, durante todo o ano de 2001 e boa parte do ano de 2002, em decorrência de escândalos e fraudes contábeis ocorridas em grandes companhias como a Enron, WorldCom e Global Crossing e renomadas empresas de auditoria e consultoria como Arthur Andersen.

O Brasil, em meio a essa sensível experiência legislativa e recém-saído de uma reforma na Lei das S.A., optou por absorver parte das propostas norteamericanas no âmbito infralegal. Deixou, neste passo, de investir em novas alterações na Lei das S.A., que decorreriam de um contexto de problemas atinentes à estrutura sócio-política e jurídica brasileiras.

Quando da regulamentação, no direito norte-americano, do artigo 301 da Lei Sarbanes-Oxley, a US-SEC, por intermédio das regras publicadas nos Editais $\mathrm{n}^{\circ \mathrm{s}}$ 33-8177 de 23 de janeiro de 2003 (posteriormente emendada e corrigida pela regra constante do Edital n ${ }^{\circ} 33-8177-A$ de 26 de março de 2003), 33-8183 de 28 de janeiro de 2003 (posteriormente emendada e corrigida pela regra constante do Edital $\mathrm{n}^{\circ} 33-8183-\mathrm{A}$ de 26 de março de 2003) e 33-8220 de 9 de abril de 2003, formula o modelo que seria posteriormente absorvido pelo direito brasileiro.

No cerne do modelo brasileiro de comitê de auditoria, esse colegiado acabou se caracterizando pelas seguintes funções, sempre se reportando ao conselho de administração e de forma supletiva ao próprio conselho: i) recomendar e opinar sobre a contratação do auditor independente ou sobre a sua substituição; ii) revisar as 
demonstrações contábeis semestrais, os relatórios da administração e o parecer do auditor independente antes do envio para publicação; iii) avaliar a efetividade do trabalho dos auditores independentes; iv) avaliar o cumprimento, pela administração da instituição, das recomendações feitas pelos auditores internos ou independentes, reunindo-se com a administração e os auditores, no mínimo trimestralmente, para tratar da relação entre administração e auditores; v) estabelecer procedimentos internos para viabilizar a comunicação com a instituição e permitir o recebimento de informações a respeito do descumprimento de leis ou regulamentos, bem como a proteção à confidencialidade e ao prestador da informação; vi) recomendar à administração a adoção, correção ou aprimoramento de políticas internas e procedimentos de cumprimento de normas ligadas às atribuições descritas nas mencionadas Resoluções CMN 3198 e CNSP 118; vii) reunir-se com o conselho fiscal e com o conselho de administração, a pedido destes, para discutir as políticas, práticas e procedimentos referentes às atribuições descritas nas resoluções mencionadas.

Note-se que, embora as atribuições dos membros do comitê de auditoria façam previsão de um relacionamento com o conselho fiscal, não se pode deixar de perceber que boa parte dessas funções tem alguma previsão expressa na Lei das S.A.

E é dessa indefinição entre atribuições específicas do comitê de auditoria (que é função específica de órgão de administração da companhia, a saber, o conselho de administração) e as atribuições legais do conselho fiscal que padece, em estado embrionário, um grave conflito de atribuição entre órgãos da companhia. ${ }^{346}$

\footnotetext{
${ }^{346}$ Nos recentes estudos sobre o tema, a doutrina restringe-se a debater sobre a conveniência de acumulação de órgãos ou de alocação de competência para o conselho fiscal (o que, no jargão corrente, já vem sendo tratado como "conselho fiscal turbinado"). Nada se comenta sobre o intrincado problema do conflito de atribuições.

O volume 62 da Revista RI, editada pelo IBRI - Instituto Brasileiro de Relações com Investidores (São Paulo: IBRI, Abril de 2003) dedica-se integralmente ao tema das diferenças entre o comitê de auditoria e o conselho fiscal, as vantagens e semelhanças jurídicas, bem como a pertinência legal de cada figura, não apenas à luz da Lei Sarbanes-Oxley, mas também e sobretudo diante das novas exigências de transparência na gestão das companhias abertas. Dentre os textos apresentados, destacam-se os trabalhos de Luiz Leonardo CANTIDIANo ("Comitê de Auditoria X Conselho Fiscal", pp. 7-8), Ivan Clark ("Conselho Fiscal ou Comitê de Auditoria? Opção?"; pp. 9-10) e Aline de Menezes SANTOS ("Próximos Itens da Agenda de Governança Corporativa”; pp. 15-16).

Adicionalmente, veja-se ainda Rui Fernando Ramos ALVES, “As responsabilidades dos membros do Comitê de Auditoria das instituições financeiras" In RDB 25/372-378 (jul.-set. 2004); Claudio FINKELSTEIN \& Roberta GouveIA, "Lei Sarbanes-Oxley Act 2002...", Op. loc. cit; Luiza Rangel de MorAes, “As novas atribuições do Conselho Fiscal ...”, Op. loc. Cit.; Andréa Fernandes AndrEzO, "The Sarbanes-Oxley Act ...”, Op. loc. cit..
} 
Não se vê outra forma de dirimir esse potencial conflito de atribuição que não seja por uma previsão expressa na Lei das S.A. das atribuições que os regulamentos infralegais embutiram no conselho de administração (via comitê de auditoria) dentro do rol do artigo 163 da Lei das S.A. Adicionalmente, seria importante prever ao conselho fiscal que atue de forma mais próxima em muitos eventos da vida das empresas e que seja etimologicamente mais comitê e menos conselho. Exemplo dessa atuação próxima diz respeito especificamente às funções de controle contábil e financeiro, de verificação de controles internos e de acompanhamento dos trabalhos da auditoria independente. Essas são funções do conselho fiscal, por natureza, mas que atualmente são desempenhadas com muito mais competência por comitês de auditoria.

O grande problema dessa atuação via comitê de auditoria está na função própria de conselheiro de administração, que também incumbe ao membro do comitê, na sua qualidade de administrador. Melhor seria que a pessoa investida dessas funções não tivesse qualquer função administrativa em paralelo e que sua atuação fosse pautada exclusivamente por deveres e obrigações de caráter técnico e fiscalizatório, sem qualquer atribuição como administrador. Essa separação é fundamental, como se verá, na identificação de responsabilidades.

Comente-se, ainda, que essa sobreposição de atribuições é vista de maneira muito crítica pela doutrina estado-unidense, cujo modelo de fiscalização está cada vez mais se voltando para os órgãos internos, mas que, com resistência, vem penetrando nas funções do conselho de administração. ${ }^{347}$

Por essa razão é que os presentes estudos migraram no sentido de se extrair lição que recomenda, também, a alteração das normas sobre conselho fiscal sob

\footnotetext{
${ }^{347}$ Essa crítica é formulada de maneira séria e firme por ninguém menos que Robert Charles CLARK (“Corporate Governance Changes...”, Op. loc. cit., Idem, pp. 271-274).

No direito português, essa crítica é também replicada no âmbito das funções específicas da comissão de auditoria. Confira G. F. DIAS (Fiscalização de sociedades...,, Op. cit., Idem, pp. 88-90): "Sendo irrecusável a bondade dos objectivos prosseguidos com um tal modelo de governo societário, aos quais preside um ideal de auto-controlo e auto-fiscalização da administração da sociedade, a duplicidade de funções assumida pelos membros não executivos do conselho de administração que integram a comissão de auditoria coloca problemas sobre os quais conviria reflectir com alguma urgência. Nomeadamente, o de saber se estes sujeitos, no momento de sua actuação enquanto administradores / decisores, devem pautar-se por critérios próprios de administração ou de fiscalização; saber, isto é, se ao participarem nas deliberações do conselho de administração, decidem ou fiscalizam; se lhes é exigível que analisem o acto sujeito a deliberação na perspectiva de álea e de risco de um administrador ou na perspectiva técnica e estática de um fiscalizador. Sob que chapéu actuam, afinal? E é possível que o administrador não executivo vote favoravelmente uma decisão de gestão que depois vem a rejeitar no âmbito de sua actividade de fiscalização?" (p. 89).
} 
o seu aspecto funcional e, por conseqüência, propor modificações em todo o espectro da fiscalização societária visando concentrar o poder fiscalizatório em um órgão societário interno. Paralelamente, para que se conclua a tarefa de redução de todos os potenciais conflitos de atribuição, seria necessário também rever todas as tangentes fiscalizatórias da lei que possam eventualmente escapar da atribuição específica do conselho fiscal, a saber: (i) a companhia em seu estado de liquidação ${ }^{348}$; (ii) a fiscalização em favor de debenturistas e de titulares de partes beneficiárias ${ }^{349}$; (iii) a "pseudo-fiscalização" do acionista individual; (iv) a supervisão política exercida pelo conselho de administração, ainda que com caráter fiscalizatório geral e não específico. ${ }^{350}$

\section{Ausência de procedimento previsto em lei}

Eis outro tema que a doutrina, com suas raras e louváveis exceções ${ }^{351}$, não aborda.

Ao contrário do que ocorre com outros órgãos previstos na lei, como a assembléia geral, ela não prevê um procedimento específico para a formação legítima das decisões, das representações e das peças informativas geradas por conta dos trabalhos desenvolvidos no conselho fiscal.

\footnotetext{
${ }^{348} \mathrm{O}$ tema é deveras intrincado, pois envolve a função do conselho fiscal nas companhias em estado de liquidação. Não apenas por força do disposto no artigo 217 da Lei das S.A., o qual teremos a oportunidade de debater logo adiante, no próximo capítulo, mas também e sobretudo no âmbito dos regimes de transição impostos pela Lei n 11.101, de 9 de fevereiro de 2005.

${ }^{349}$ A fiscalização societária no Brasil distingue, de forma muito preliminar, a fiscalização em favor dos titulares de equity, da fiscalização em favor dos titulares de debt instruments. É de se notar que a fiscalização em favor dos acionistas é mais desenvolvida do que a fiscalização em favor dos debenturistas (que conta com um regime intermediado por um agente fiduciário) e dos beneficiaristas (cujo regime se dá por preguiçosa analogia com a situação dos acionistas, ex vi do $\S 3^{\circ}$, do artigo 46, da Lei das S.A.). Estes, por sinal, apesar da analogia com a situação do acionista, não têm os mesmos direitos deste em face do conselho fiscal. Ao beneficiarista cabe o direito do artigo 109, III da Lei das S.A., que se exerce por meio de direito à informação, como já tivemos a oportunidade de analisar acima. Contudo, seria conveniente que o seu regime se aproximasse mais da situação do debenturista do que do acionista, necessitando reformar o regime de escrituração das partes beneficiárias para que o agente de certificação do artigo 43 (por força do disposto no $§ 2^{\circ}$, do artigo 50, da Lei das S.A.) possa se aproximar do agente fiduciário dos debenturistas na forma do regime imposto pelos artigos 66 a 68 da Lei das S.A.

Historicamente, vale lembrar o conteúdo do artigo 32, $\$ 2^{\circ}$, da Lei $\mathrm{n}^{\circ} 3.150$, de 1882 , que dizia, de forma até mais precisa que a lei atual: "Os portadores de obrigações podem nomear um fiscal, que funcione conjuntamente com os de que trata o art. 14, e com as mesmas atribuições".

${ }^{350}$ Cf. Fábio Ulhôa CoElHo (Curso..., Op. cit., Idem, pp. 236-237).

${ }^{351}$ Bulgarelli, Regime Jurídico do Conselho Fiscal..., Op. cit., Idem, pp. 199 e ss.
} 
A imposição de um procedimento minuciosamente previsto em lei não apenas garante legitimidade às decisões, mas assegura que os atos praticados no seio do órgão respeitem elementos mínimos de formação de um ato jurídico perfeito (tal qual o respeito ao contraditório no caso de decisões colegiais) e permite que o ato seja produzido mediante condições especiais de validade. ${ }^{352}$

A Lei das S.A. não se valeu desse sistema. Essa lacuna ${ }^{353}$ pesa sobremaneira quando se necessita compreender o funcionamento desse órgão em situações anômalas da companhia, como no caso da liquidação, da intervenção extrajudicial (para o caso das instituições financeiras), da falência e da recuperação judicial ou extrajudicial. Essa omissão legal também reflete na forma das representações e na extensão das responsabilidades, bem como no termo legal e prescricional de atos praticados no âmbito dessas funções.

Entretanto, na experiência de outros regimes legais, apenas o direito estado-unidense e o francês dispõem de alguma regulação a respeito dos procedimentos de fiscalização. Analogamente, no Brasil, a regulamentação da profissão de auditor prevê regras a respeito dos procedimentos de auditoria, mas quando se trata de fiscalização orgânica, a única legislação que prevê regras procedimentais de fiscalização do órgão interno é a estado-unidense.

A par de toda essa escassez, algumas companhias, na prática, optam pela auto-regulação de forma espontânea, mas é na ausência total dessa auto-regulação que os conflitos maioria-minoria encampam, muita vez, completa paralisação do órgão por conta de artifícios extensamente usados na lacuna procedimental. ${ }^{354}$

\footnotetext{
${ }^{352}$ Vide E. V. A. N. FRANÇA, Invalidade das Deliberações..., Op. cit., Idem, pp. 37 e ss..

Vale ainda lembrar que, sob o ponto de vista técnico, o conselho fiscal é órgão e, portanto, tem funcionamento orgânico. Para que os atos praticados por um órgão possam ter plena validade, eficácia e legitimidade, é sempre necessário que sejam praticados segundo a observância de procedimentos, que o sociólogo do direito Niklas Luhmann imortalizou sob o rótulo de "legitimação pelo procedimento". A falta de um procedimento sempre põe em risco os atos praticados por órgãos em cumprimento de funções. Lembre-se ainda que os atos praticados pelo conselho fiscal não podem livremente ser constituídos como atos jurídicos decorrentes da emanação da vontade, como ocorre com os contratos. São atos de natureza completamente distinta, pois enquanto um ocorre segundo vontade de partes, o outro ocorre segundo função jurídica prevista em lei. Aqui valem de maneira incalculável os estudos do primeiro capítulo.

${ }^{353} \mathrm{E}$ aqui nos posicionamos em relação ao questionamento formulado por BULGARELLI (Ibidem, p. 200 e ss.).

${ }^{354}$ Exemplo disso é o já citado caso Tabacow (vide Nota 304 deste trabalho).
} 


\section{Contraponto}

Diante da experiência extraída das lições de direito comparado, pudemos notar, no primeiro contraponto desta segunda parte do trabalho, que o regime do conselho fiscal sob a ótica formal padece de inúmeras fissuras que não apenas chamam a atenção do estudioso, mas também sugerem reparos para a melhoria da funcionabilidade do instituto. Historicamente, falhamos, no Brasil, como visto na parte anterior, em abordar os temas arteriais do conselho fiscal; optamos por conviver com a sua ineficiência, ministrando ao aludido órgão alguns paliativos que lhe permitem sobrevida, de tempos em tempos.

Neste segundo contraponto, a experiência internacional demonstra que o direito brasileiro padece com inúmeras incongruências, sobretudo sob o seu ponto de vista funcional. Em outras palavras, é marcante notar como a função fiscalizatória é malparada no direito brasileiro e como as funções do conselho fiscal são tratadas de maneira confusa em nossa lei. Em comparação com a experiência internacional, a lei brasileira é uma das que ostenta, nas funções do conselho fiscal, preceitos demasiadamente abertos e com linguagem muito abrangente, à semelhança do que ocorre com a lei mexicana.

Legislações como a da Argentina já bastariam para expor a fragilidade funcional do direito brasileiro. Entretanto, experiências como a de França, Portugal, Japão, Alemanha, Itália, Inglaterra, EUA (algumas delas aqui descritas com certos detalhes), expõem a fragilidade funcional do sistema fiscalizatório brasileiro de forma ainda mais saliente.

Agregam a esse quadro as inconformidades próprias da lei brasileira, que solta, de maneira esparsa, regras sobre fiscalização e responsabilidade por fiscalizar dentro de relações jurídicas específicas (como na distribuição de dividendos obrigatórios, nas reduções de capital, na emissão de debêntures e de partes beneficiárias) ou dentro de outros órgãos ou institutos cuja função é quase que oposta à do conselho fiscal (conselho de administração, por exemplo).

Neste contraponto, portanto, somos forçados a concluir que, sob o ponto de vista funcional, a lei brasileira: (i) não enfatiza adequadamente o caráter de controle 
contábil e financeiro, típico dos órgãos de fiscalização em todos os regimes de direito comparado estudados, sobressaindo mais a função da fiscalização legal da gestão num universo formalmente falho ${ }^{355}$; e (ii) não concentra as funções fiscalizatórias da companhia no conselho fiscal, permitindo ou alocando para outros órgãos, funções fiscalizatórias que em tese e pela lógica deveriam ser tratadas como competências ${ }^{356}$ típicas do conselho fiscal.

Para tanto, considerando um conselho fiscal com quadro formal que contenha itens de qualificação e independência que acompanhem a experiência do direito comparado, a lei brasileira poderia ainda conter textos que garantissem o seguinte quadro funcional ao conselho fiscal:

I. a companhia aberta contará com um conselho fiscal cujas funções, além daquelas estabelecidas no artigo 163, II, III, V, VI, VII e VIII, contenha competências previstas para o comitê de auditoria nos termos da Resolução CMN 3198, artigo 15, com enfoque na matéria revisional contábil e financeira, incluindo os tipos jurídicos ${ }^{357}$ em que o conselho venha a atuar de forma antecipada à realização de certos atos;

II. a fiscalização legal da gestão posta nos termos do artigo 163, I deverá ter foco eminentemente contábil, financeiro e legal, devendo ser vedado, de forma expressa, qualquer exame de mérito;

III. a denúncia de erros ou fraudes deve ser substituída por sistema de recebimento, tratamento e envio de informações em regime de sigilo total e absoluto, que envolvam aqueles vícios, devendo ser absolutamente vedado ao conselho fiscal das companhias

\footnotetext{
${ }^{355}$ Como visto, o universo formalmente falho decorre de problemas como a devida qualificação dos conselheiros fiscais, bem como de sua independência, para ficarmos nos dois principais problemas.

${ }^{356}$ Neste ponto, fazemos questão de voltar ao capítulo introdutório desta dissertação para afirmar que essas competências, por terem caráter potestativo (qual seja, de verdadeiros poderes-deveres), representam, por outro lado, uma séria responsabilidade no caso de omissão.

357 A utilização do termo "tipo jurídico" é absolutamente proposital, pois acredita-se que cada função circunscrita ao poder fiscalizatório do conselho fiscal se constitui, sob o ponto de vista jurídico, como verdadeiro tipo jurídico (ou, como preferem os alemães, Tatbestand). Cada tarefa, função ou competência se articula, no exercício de uma potestatividade, como verdadeiro tipo que deve ser exercido pelo órgão na exata medida descrita pela lei - o exercício do poder fiscalizatório, portanto, não se pode dar nem em medida inferior ao que descreve a lei (sob pena de responsabilidade por omissão) nem em medida superior (sob pena de responsabilidade por abuso de poder). Para melhor compreender a natureza de "tipo jurídico" que as funções de um conselheiro fiscal pode ter, vide PONTES DE MIRANDA, Francisco Cavalcanti. Tratado ..., Tomo 1 (Op. cit., Idem), pp. 19 e ss ( $\$ 7$ a 13, sobretudo, 22 a 32 e 39 a 42), bem como o interessantíssimo "Prefácio" para a mesma obra (pp. IX a XXIV). Vide também Márcio Bernardes de Mello, Teoria do fato jurídico, $6^{\text {a }}$ ed.. São Paulo: Saraiva, 1994; pp.33-74, e, do mesmo autor a obra Teoria do fato jurídico - plano da validade, $4^{\text {a }}$ ed.. São Paulo: Saraiva, 2000; pp.9-10.
} 
abertas compartilhar informações de que tenha conhecimento com qualquer acionista, ainda que verse sobre matéria de sua competência, antes que a informação seja objeto de fato relevante ou comunicado ao mercado; e

IV. o uso de "peritos" só deveria ser autorizado dentro de orçamento aprovado anualmente pela assembléia e destinado para os trabalhos do conselho fiscal que não dissessem respeito a matérias de sua competência específica; e

V. na ausência de um procedimento previsto em lei, demandar-lhe a edição de um regulamento interno que faça previsão expressa de regras e procedimentos para a formulação das decisões do órgão, sobretudo a respeito do tratamento de informações da companhia, para a companhia e pela companhia, bem como o tratamento dos trabalhos, da agenda, das metas e dos objetivos do órgão. 


\section{CAPÍTULO 7: DIREITOS, DEVERES, PODERES, \\ REPRESENTAÇÕES: NOTAS SOBRE A RESPONSABILIDADE DO \\ CONSELHO FISCAL}

O tema da responsabilidade civil no âmbito do direito atual é um dos temas mais complexos tratados hodiernamente nos estudos jurídicos. Seu âmbito, há tempos, já extrapolou os lindes da teoria jurídica de direito civil e preocupa as várias áreas do direito.

Em uma discussão que envolva fiscalização societária, o problema não seria diferente, pois o poder de fiscalizar é acompanhado por um regime de responsabilidades que, como teremos a oportunidade de notar, encerra disciplina confusa, por conta da redação dada ao caput e parágrafos ao artigo 165, bem como por conta dos artigos $117, \S 2^{\circ} ; 134, \S 3^{\circ} ; 201, \S 1^{\circ}$ e 217 , todos da Lei das S.A.

O regime da responsabilidade civil na fiscalização também ocupa boa parte dos estudos de doutrina em Portugal, Itália e EUA, cujas lições nos foram valiosas na condução deste trabalho.

Primeiramente, é necessário admitir que o nosso regime geral de responsabilidade civil está assentado na disciplina dos artigos 927 e seguintes do Código Civil, que remonta à disciplina do artigo 159 em conjunto com os artigos 1519 e seguintes do Código Civil de 1916.

O regime de responsabilidade civil adotado no Brasil obedece, doutrinariamente, à evolução construída sobre os parâmetros e premissas de uma sociedade moderna. ${ }^{358}$ Entretanto, as premissas e valores que levaram, ao longo do

\footnotetext{
${ }^{358}$ Assim, um dos maiores parâmetros lógico-jurídicos a respeito das premissas que regem a disciplina da responsabilidade civil na sociedade moderna é descrita com profundidade inigualável por Georges RIPERT (Le Régime Démocratique el le Droit Civil Moderne. Paris: Librairie Générale de Droit et de Jurisprudence, 1936; pp.327-395). RIPERT organiza seu raciocínio com base no conceito de res perit domino e a lógica da partilha de riscos na sociedade moderna, ponto de partida sob o qual o autor critica o regime de responsabilidade civil do Code Civil francês. Nesse sentido, lembra (p. 328): "L'évolution de la théorie de la responsabilité civile a été bien souvent décrite, mais on ne peut, je crois, la comprendre pleinement qu'en mettant en pleine lumière l'idée politique que l'inspire. Il ne faut pas oublier que
} 
século XX, à construção de uma doutrina moderna de direito privado e responsabilidade civil vêm continuamente sofrendo revisões profundas, sobretudo em vista do conceito de pós-modernidade, ${ }^{359}$ que substitui inúmeros valores da modernidade. ${ }^{360}$

Nessa substituição de valores, em que a franquia prevalece sobre o maquinário, em que a gestão prevalece sobre a propriedade, houve uma multiplicação

pendant un siècle les régles du Code civil ont été appliquées sans qu'on en ait discuté la valeur et que c'est seulement au début de ce siècle que tout a été remis en question. On attribute l'évolution des idées sur la responsabilitè civile au développement de la grande industrie et du machinisme. La transformation de l'industrie est en réalité bien antérieure au changement des idées juridiques. Sur ce point, comme sur biens d'autres, le facteur politique est prépondérant". RIPERT, dessa forma, ao admitir mudança de valores e de conceitos em uma sociedade industrializada e mecanizada, nota que o direito se modificou em matéria de responsabilidade civil, sobretudo em suas formas de identificar a pessoa responsável, o seu grau de responsabilidade e as formas fictícias de vínculo mediato entre vítima e responsável, numa sociedade em que as relações se dão de forma a desconsiderar o fato de um conhecimento prévio entre responsável e vítima. Seu grande ponto de leitura, é, portanto, a sociedade de consumo, cujas relações contratuais, que foram alteradas por força das modificações na economia, refletem em uma modificação dos princípios e valores reinantes em matéria de responsabilidade civil.

${ }^{359} \mathrm{O}$ tema da pós-modernidade foi abordado, no direito brasileiro, com muito êxito por Eduardo Carlos Bianca BitTAR (O Direito na Pós-Modernidade. Rio de Janeiro: Forense Universitária, 2005). A erosão e o desatino de instituições vetustas frente a certas realidades contemporâneas, atingindo frontalmente alguns institutos codificados e a própria necessidade de codificação, são tratadas por Fernando DE Trazegnies GRANDA (Postmodernidad y Derecho. Santa Fe de Bogotá, Col: Temis, 1993), com muita ênfase para o problema na América Latina (sobretudo Chile, Peru e Colômbia). Analisando o problema do conceito atual de segurança jurídica, DE TRAZEGNIES GRANDA investiga como a lenta reação do direito civil busca acompanhar os fenômenos atuais, principalmente no contexto de uma América Latina em desenvolvimento (pp. 20-69). Especificamente em relação ao problema da responsabilidade civil na sociedade contemporânea pós-moderna, o autor lembra: "La responsabilidad extracontratual no debe sentir que el área de los accidentes más usuales (accidentes de tránsito, accidentes de trabajo, etc.) ya no lo pertenece - o lo pertenece solo marginal y supletoriamente - porque, aplicando la teoría de la distribuición del riesgo, estos daños han pasado a ser indemnizados por sistemas de seguros obligatorios (publicos o privados). Por el contrario, la responsabilidad del Codigo Civil no puede limitarse a la culpa y ni aun a la responsabilidad objetiva, sino que debe compreender el seguro, no solo como un respaldo de una responsabilidad previamente determinada por el Derecho Civil, sino también como una instituición del propio Derecho Civil: como una forma directa - y no necesariamente ajena a su propia logica - de hacer frente a la reparación (particularmente en el caso de los seguros no-fault). Este esfuerzo integrativo debería alcanzar al Derecho Comercial, intentando recuperar dentro del marco fundante del Derecho Civil a este hijo pródigo que dejó la casa paterna del civilismo en la Edad Media: Italia se ha orientado en tal dirección y algunos países de America Latina está también estudiando la posibilidad de reunir el Código Civil y Código Comercial en uno solo" (pp. 59-60). A respeito dessas observações, considerando que o texto de DE TRAZEGNIES GRANDA foi escrito antes de 1993, e antes, portanto, da implementação de reformas em Códigos Civis na América Latina (incluindo o Brasil, que optou pelo modelo italiano na promulgação de 2001), notou-se, em nosso País, que a unificação formal foi mais fácil do que a unificação conceitual e teórica, esta muito mais polêmica e complicada do que a unificação formal. Por outro lado, tem razão o jurista peruano ao lembrar da idéia que envolve a distribuição de risco como técnica de construção de uma teoria de responsabilidade civil, tema, aliás, profundamente desenvolvido por L. M. FRIEDMAN (Total Justice. Nova Iorque, NY: Russell Sage Foundation, 1994, passim). E nesse pormenor, como bem advertido por FRIEDMAN, os contratos de seguro ganham relevo especial. No que se refere especificamente ao direito comercial e, com ênfase no direito societário, o tema da responsabilidade dos administradores vem sendo discutido, no Brasil, com crescente associação ao tema do seguro de responsabilidade civil de administradores, os chamados " $D \& O$ 's" (abreviação do inglês directors and officers insurance).

${ }^{360} \mathrm{O}$ direito societário não ficou alheado dessa discussão e a maior chave de leitura que nos é fornecida para compreender essas alterações é dada por Eduardo S. MuNHOZ (Empresa Contemporânea..., Op. cit., Idem, pp. 55-102). 
de entes e uma diversificação de pessoas dentro da cadeia produtiva, dificultando mais ainda a identificação de um responsável por um dano, bem como a identificação de uma precisa partilha de riscos dentro da vida moderna. Há, nitidamente, uma multiplicação de fases na cadeia produtiva, com conseqüente diluição de responsabilidades.

Em matéria contratual, o novo Código Civil buscou regular essa partilha de riscos, mas essa revalorização do tema gerou reflexos na responsabilidade contratual não apenas no Brasil, mas no mundo, principalmente em países como os EUA (liderando a doutrina jurídica em países de tradição jurídica ligada à common law) e França (liderando a doutrina jurídica em países de tradição jurídica romano-francogermânica ligada à civil law).

No tocante ao tema da fiscalização societária, ambos os países orientamse por meio de uma fiscalização externa, conduzida pelos auditors, no caso dos EUA ${ }^{361}$ e pelos commissaires aux comptes, no caso da França ${ }^{362}$, como pudemos notar anteriormente. Essa relação entre companhia e auditores (ou comissários de contas) é estabelecida contratualmente, o que permite observar a influência das modificações nos regimes de responsabilidade civil contratual, o que não é o caso do Brasil.

Nosso regime de fiscalização é interno e orgânico e por isso não logra aproveitar a experiência contratual estado-unidense e francesa sobre a evolução da responsabilidade civil na fiscalização societária. ${ }^{363}$

\footnotetext{
${ }^{361}$ Sem prejuízo, entretanto, do esforço que ambos os países e principalmente os EUA vêm fazendo para internalizar a fiscalização societária. Como visto, o esforço de internalização da fiscalização societária nos EUA vem desde fins da década de 1960 e início da década de 1970. Para o regime de responsabilidade civil, como a fiscalização passa para o conselho de administração (board of directors) faz todo o sentido que a responsabilidade civil siga os parâmetros do regime aplicável para os administradores não-executivos, fato esse que, como veremos, no Brasil não faz tanto sentido assim, pois conselheiro fiscal não é administrador, nos termos da nossa lei.

${ }^{362}$ R. Granger (La Nature Juridique..., Op. cit., Idem, pp. 321-345) identifica dois universos distintos de responsabilidade dos fiscais: (i) a responsabilidade perante os acionistas, (ii) a responsabilidade perante terceiros estranhos à companhia. No primeiro caso, sua preocupação é identificar como o direito francês se ocupa do problema diante do que poderia ser considerado uma falta contratual do fiscal (p. 320: "la responsabilitè des commissaires envers les actionnaires sera donc gouvernée par les règles générales de la responsabilitè contractuelle". Entretanto, GRANGER já notava os questionamentos do regime contratual justamente pela qualidade orgânica que os commissaires representavam perante a companhia (pp. 317-318).

${ }^{363}$ Em Portugal, cujo regime de fiscalização societária é bem próximo do brasileiro, boa parte da doutrina associa a responsabilidade civil em matéria societária com as regras da responsabilidade contratual. Confira o pensamento de G. F. DiAs, Fiscalização de sociedades..., Op. cit., Idem, pp. 58-60, nesse sentido. Agregou, G. F. DIAS, com apoio em Menezes Cordeiro e Raul Ventura, dentre outros: "Com esta amplitude, a responsabilidade contratual cobre todas as morfologias possíveis das obrigações dos fiscalizadores perante a sociedade, pelo que se assume, com a doutrina dominante, a natureza
} 
E, apesar de todas essas diferenças, não resiste a nossa doutrina a admitir influência imediata de um regime de responsabilidade civil estado-unidense que parece inaplicável ao universo da fiscalização societária brasileira, seja por força do próprio influxo evolutivo inerente à realidade estado-unidense ${ }^{364}$, seja pela natureza orgânica com que a fiscalização societária no Brasil é desempenhada. Além disso, funcionalmente, o atual texto de lei que rege os tipos jurídicos que constituem as competências do conselho fiscal (sobretudo o inciso I do artigo 163 da Lei das S.A.) apresentam uma fiscalização que, sob o ponto de vista funcional, também difere bastante da matriz estado-unidense.

contratual da responsabilidade dos administradores e fiscalizadores perante a sociedade pela violação dos deveres legais e contratuais emergentes do negócio (qualquer que seja) que os legitima para o exercício dessas funções ou dos deveres que a lei lhes prescreve" (Ibidem, p. 60).

${ }^{364}$ É de se notar que a evolução do tema nos EUA segue um universo completamente distinto de valores e se orienta por uma técnica jurídica muito diversa daquela conhecida no Brasil e nos países de orientação romano-franco-germânica. Apesar dos EUA terem seus princípios e valores arraigados no direito romano, a doutrina estado-unidense sobre responsabilidade civil obedece aos princípios do caueat emptor, da implied liability e da contributory negligence, que por aqui desconhecemos e, geralmente, fazemos paralelo com o regime da responsabilidade objetiva "versus" responsabilidade subjetiva (vide, os judiciosos comentários de James B. THAYER para a Lex Aquilia [Lex Aquilia - text, translation, and commentary. Cambridge, Mass: Harvard University Press, 1929, pp. 52-122]). Na raiz dessa evolução, há o case Brown v. Kendall (60 Mass. [6 Cush] 292; 1850 - vide Richard EPSTEIN, Charles GERGORY e Harry CAlven JR. Torts, $4^{\mathrm{a}}$ ed.. Boston, Mass: Little, Brown \& Co., 1984, pp. 55-87; Lawrence Meir FrIEDMAN. A History of American Law..., Op. cit., Idem, pp. 467-487). Sob o ponto de vista histórico, questões de ordem racial tiveram séria influência no direito da responsabilidade civil nos EUA, inclusive com resultados sobre o regime de responsabilidade civil no direito societário (sobre a influência dos Civil Rights Cases, vide Lawrence Meir FrIEDMAN. Law in America - a short history. Nova Iorque, NY: Modern Library, 2004, pp. 44-48, 129-146). Contemporaneamente, a grande obra sobre o estado atual da teoria jurídica da responsabilidade civil na pós-modernidade estado-unidense é de Lawrence Meir FRIEDMAN (Total Justice, Op. cit., Idem, passim). FRIEDMAN repassa, sob o ponto de vista histórico, as modificações que sofreram os principais institutos de responsabilidade civil nos EUA por conta de recentes ações envolvendo a indústria do tabaco, as questões de intimidade e privacidade, os casos de "assédio sexual", questões envolvendo os limites do dano moral e do dano estético. FRIEDMAN tem o cuidado de mostrar como as alterações no comportamento social atingem a doutrina jurídica e como ela pode ser influenciada, alterando a forma pela qual outras áreas do direito (tal como o direito societário) são interpretadas. Em relação ao direito societário, é fundamental compreender a evolução da responsabilidade civil dos administradores no contexto histórico que permitiu a devida e adequada formulação de um regime próprio de responsabilidade civil na gestão do bem comum e que culminou com um sistema de total separação entre propriedade e controle, na criação do controle difuso e do controle pela administração. Na base desta evolução está a responsabilidade civil da administração. E essa evolução nasce, no direito estado-unidense, dentro dos princípios mais vetustos do direito britânico aplicáveis ao regime do comércio marítimo e do direito marítimo. A questão da liability dos administradores é, historicamente, uma evolução da liability construída sobre os cases de direito marítimo inglês e de comércio marítimo britânico. O valor que os norte-americanos dão ao tema dos seguros como mecanismo de consolidação de exoneração de responsabilidade civil decorre da experiência advinda dos cases de direito marítimo. Para compreender muitas razões a respeito de princípios jurídicos aplicáveis à responsabilidade civil na gestão da mercancia, é necessário atentá-la sob a luz desses princípios de direito marítimo, construídos segundo uma experiência secular de cases em matéria de admiralty law. Vide George CAINES. An Inquiry into the Law Merchant of the United States - Lex Mercatoria Americana on several heads of commercial importance, vol. I. Nova Iorque, NY: Isaac Collins, 1802, pp. 73 e ss. (volume republicado em edição facsimilar pela Lawbook Exchange, Clark, NJ, 2006). 
No Brasil, essa influência é notada de forma muito veemente pela doutrina pátria. ${ }^{365}$ Essa influência fatalmente afetou a leitura de nossas regras sobre responsabilidade civil ${ }^{366}$, principalmente quando ela se dá em regime próprio não sujeito (ao menos totalmente) ao regime do Código Civil ${ }^{367}$ - e esta é exatamente a hipótese da responsabilidade civil do conselho fiscal. Raras são, entretanto, as tentativas de compreensão única do problema da responsabilidade civil aplicada ao fenômeno societário, em atenção a esse fluxo de dados e informações que, sendo as mesmas, deveriam propiciar revisão mais profunda do fenômeno no âmbito societário. ${ }^{368}$

\footnotetext{
${ }^{365}$ Caio Mário da Silva PereIRA (Responsabilidade Civil, $9^{\mathrm{a}}$ ed., $3^{\mathrm{a}}$ tiragem. Rio de Janeiro: Forense, 1999, pp.13-25) é um dos primeiros juristas a abordar a influência que o direito brasileiro sofre por conta das constantes modificações nos conceitos de responsabilidade civil decorrentes das doutrinas nos EUA e na França. Nota o grande jurista todo o grau de distorção que essas influências geram na lógica de nosso direito, cuja cultura local que o sustenta nem sempre compartilha dos mesmos valores e princípios éticos que movem essas alterações na doutrina de responsabilidade civil. José de Aguiar DIAS ( $D a$ Responsabilidade Civil, $11^{\mathrm{a}}$ ed.. Rio de Janeiro: Renovar, 2006), na atualização de sua clássica obra por Rui B. Dias, repassa os mesmos temas abordados por Caio Mário S. PEREIRA, ressaltando, na mesma linha de evolução (pp. 21-98), os efeitos gerados não apenas na seara material, mas também no universo do direito processual civil em matéria de prova (pp. 99-116), bem como em matéria de efeitos do julgamento e coisa julgada material, sobretudo quando o dano é oriundo de matéria penal (pp. 10571022). Em matéria de conselho fiscal, esse tema é absolutamente fundamental, principalmente quando o dano causado aos acionistas de uma companhia decorre de crimes praticados pela administração e de cuja prática a fiscalização se omite. No Brasil, esses vetores de influência jurídica são absolutamente fundamentais para que se possa investigar, em tese, os caminhos da responsabilidade civil dos fiscais em situações semelhantes ao caso Agrenco, recentemente trazido ao publico pela imprensa local e internacional.

${ }^{366}$ Relembre-se a obra de Giselda Maria Fernandes Novaes HirONAKA (Responsabilidade Pressuposta. Belo Horizonte: Del Rey, 2005), que busca na linha evolutiva da doutrina de responsabilidade civil, saídas viáveis a partir do fenômeno jurídico brasileiro (pp.13-155). Nessa busca, a autora cerca as questões teóricas necessárias para a identificação de um fenômeno local de responsabilidade objetiva extracontratual, na linha do mise en danger do direito francês e italiano, mais próximos da matriz jurídica brasileira e, portanto, mais propícios para formação de uma doutrina de responsabilidade pressuposta ou objetiva que não contrarie a lógica de nosso direito. Não apenas entra em campo a noção de periculosidade, mas também a de prevenção. Cf. G. M. F. NovAES HIRONAKA (Ibidem, pp. 281 e ss.).

${ }^{367}$ Cf. G. M. F. Novaes HironaKa, Ibidem, pp. 353-357. Com sustento nas lições de Geneviève Schamps, a autora lembra com precisão: "Certamente que também se enquadram dentro desse padrão de excepcionalidade as normas gerais contidas sempre em específicas legislações especiais, e que visam organizar um regime de responsabilidade civil objetiva que se contenta com a existência de um liame causal assim estabelecido entre o dano e um fato determinado. Contudo, lá como aqui, a maior queixa que pode ser desenhada, num sistema de responsabilidade civil concebido desta maneira, é o fato de o legislador não ter organizado um sistema de responsabilidade civil suficientemente claro, coerente e abrangente que pudesse ser adaptado às exigências da sociedade moderna. Tal circunstância gerou, como não poderia mesmo ter deixado de gerar, um corpo disciplinar extremamente complexo e muito criticado, em razão dessa falta de visão do todo. Soma-se à confusão - diz a autora [Schamps], e tem toda a razão o fato da doutrina e da jurisprudência adotarem com frequiência concepções divergentes" (itálicos do original, p. 286). A crítica é extremamente pertinente e cabe com perfeição ao regime de responsabilidade civil do conselho fiscal, como veremos. Não houve, na formulação de uma responsabilidade civil do conselho fiscal, a construção de um regime sistêmico claro, coerente e abrangente, mas, em prol da abrangência pretendida, uma referência ao regime de responsabilidades próprias da administração e algumas esparsas intervenções em momentos distintos da legislação, tal qual a redução de capital, a distribuição de dividendos e a liquidação da companhia.

${ }^{368}$ Vide Marcelo Vieira VON ADAMEK. Responsabilidade Civil dos Administradores de S/A (e as ações previstas na Lei 6.404/76 para efetivá-la). (dissertação de Mestrado inédita sob a orientação de Erasmo
} 
O que, entretanto, por outro lado, assegura uma leitura em paralelo entre o regime estado-unidense e a atual situação teórica da responsabilidade civil no Brasil é justamente a técnica que aloca a quantidade de responsabilidade segundo um critério sócio-econômico de distribuição de riscos e de estabelecimento de responsabilidade pressuposta, para ficarmos com o vocabulário de G. M. F. NovaEs HiRonaKA. A liberdade de iniciativa permite que o empreendedor tenha melhores condições de conhecer os riscos decorrentes da construção de um negócio segundo o modelo jurídico que arquiteta relações jurídicas entre entes da cadeia produtiva, nos quais a assunção dos riscos pelo empreendedor é otimizada, em termos financeiros. A lei, ao estabelecer que o empreendedor responda diretamente por certos resultados, independentemente da averiguação de culpa, não apenas revisa o papel da culpa na pós-modernidade, mas também faz com que o empreendedor se mantenha em constante estado de alerta, buscando meios de evitar certos resultados e pressupor, com certa segurança jurídica, uma determinada responsabilidade diante de uma precisa função jurídica.

O efeito dessa técnica no dia-a-dia das empresas induz o empreendedor a manipular o desempenho de seus negócios em busca de um resultado que lhe seja lucrativo mas que, ao mesmo tempo, não seja prejudicial a outros. Em direito societário, é justamente essa técnica que jaz diante dos princípios que regem os temas da sustentabilidade bem como da responsabilidade social e ambiental da empresa.

No âmbito da fiscalização societária, a técnica é a mesma: crescentemente vem se notando que dos conselheiros fiscais é esperado que se mantenham em constante estado de alerta em relação aos negócios da companhia, pois em caso de omissão, falha ou erro grave, o conselheiro fiscal há de responder pelo dano resultante. O grande problema, portanto, não estaria no conceito de responsabilidade

Valladão Azevedo e Novaes FrANÇA apresentada junto ao Departamento de Direito Comercial). São Paulo: Faculdade de Direito da Universidade de São Paulo, 2006; pp. 175-179 e as notas 11 e 12 na p. 178.

Merecem destaque, também, os notáveis trabalhos de Alexandre Couto Silva (Responsabilidade dos Administradores de S/A - Business Judgement Rule. Rio de Janeiro: Elsevier, 2007), que discorre com precisão sobre as peculiaridades técnicas que envolvem a responsabilidade civil das funções dos administradores (pp. 13-121), Luiz Felipe Duarte Martins COSTA (Contribuição ao estudo da responsabilidade dos administradores de companhias abertas [dissertação de Mestrado inédita sob a orientação de Paulo Salvador FronTinI apresentada junto ao Departamento de Direito Comercial]. São Paulo: Faculdade de Direito da Universidade de São Paulo, 2006) e de Osmar Brina CorRÊA-LiMA (Responsabilidade Civil dos Administradores de Sociedade Anônima. Rio de Janeiro: AIDE, 1989, pp. 71-139). 
baseado nesse estado de alerta, mas sim, como se verá, na medida em que o conselheiro fiscal deva responder diretamente pelo dano, caso seja constatada a sua omissão.

\section{Esse constante estado de alerta que se espera do conselheiro fiscal nada}

tem a ver com a motivação que rege a responsabilidade de um administrador executivo,

bem como de um administrador não-executivo. E é justamente neste ponto que a crítica

ao texto do artigo 165 da Lei das S.A. toma partido. ${ }^{369}$ E essa necessária revisão de uma

369 Não admitem alguns juristas, como W. BulgARELli (Regime Jurídico do Conselho Fiscal..., Op. cit., Idem, pp. 228-229), a importância de se precisar os lindes e a natureza própria desse regime de responsabilidade na fiscalização societária. Por outro lado, não se pode negar que as históricas críticas que se fazem à "ineficiência" do conselho fiscal decorrem de um certo consenso a respeito da impunidade que paira sobre práticas menos cuidadosas no exercício das funções fiscalizatórias. O órgão, para muitos, parece "ineficiente", pois um desempenho aquém do esperado e que não logra cumprir com o seu papel preventivo não estaria sendo sancionado de maneira adequada. Por isso, muitos questionam: se nada ocorrer caso o fiscal deixe de fiscalizar, para que incorrer no custo de um fiscal que não é punido se agir de forma desleixada no desempenho de sua função? A essa questão, de forma inescapável, é imprescindível analisar sob a ótica da responsabilidade civil, da forma mais completa e profunda, a começar pela natureza dessa responsabilidade.

As lacunas na identificação de tal natureza (lacunas essas, inclusive, admitidas pelo próprio BULGARELli na obra citada, pp. 229-230) induzem a doutrina a complementar a compreensão da responsabilidade dos fiscais segundo padrões e standards que se encontram fora da lei. Afirmou CARvalhosa (Comentários..., Op. cit., Idem, p. 468-469): “A responsabilidade pela inobservância da lei ou do estatuto ou a ação ou omissão prejudiciais do conselheiro fiscal não se pode fundar no aspecto psicológico, mas, sim, na análise comparativa da sua conduta. À semelhança do que ocorre com os administradores (artigo 158), nas relações extracontratuais entre conselheiro fiscal e a companhia, contam os padrões de conduta geralmente aceitos no exercício de tais funções". Neste ponto, ousamos, com o devido respeito, divergir, pois os padrões comparativos dos atos praticados pelos administradores encerram resultados societários que envolvem a concorrência natural que o mercado lhes impõe. Dessa forma, em regime de concorrência comercial, os administradores irão pautar suas ações, comparativamente, segundo resultados otimizados e um padrão de conduta regido pela business judgement rule, sobretudo os administradores com funções executivas. Já no caso dos conselheiros fiscais, não há funções executivas ou competências que os obriguem a apresentar um resultado melhor que o de outras companhias ou de outros fiscais, dentro de um padrão comum de fiscalização. Os fiscais precisam garantir que os resultados, sejam eles quais forem, estejam expressos de forma correta e legal. É, portanto, obrigação de meio e não de resultado, o que por si só já impõe diferenciar e afastar a técnica da comparação e dos "padrões geralmente aceitos". Na seqüência, o autor afirma: "Prevalece o critério do comportamento do conselheiro fiscal, em comparação com os usos e costumes geralmente admitidos para tal espécie de atividade. Se consentânea com os padrões profissionais adotados em circunstâncias semelhantes, não estará configurada a responsabilidade dos conselheiros físcais. Será o caso, v.g., da aprovação pelos auditores externos, sem ressalvas, das contas da administração. A sua aprovação posterior pelo Conselho Fiscal, fundada no laudo dos auditores, faz presumir a observância de procedimento geralmente aceito" (Ibidem, p. 468-469). Ainda neste ponto, com a devida licença e respeito, insistimos na discordância, pois é justamente esse padrão geral de comportamento aquém do esperado, uma espécie de "pacto tácito de mediocridade", que permite que conselheiros fiscais fiscalizem com padrão de qualidade questionável sem que sejam por isso responsáveis, pois o "padrão de mercado" permite que conselheiros fiscais se omitam na sombra das auditorias independentes ou que integrem o cargo com intenções outras que não seja realmente fiscalizar a companhia. A jurisprudência apresenta um curioso caso nesse sentido (vide o já citado REsp $\mathrm{n}^{\circ}$ 88.584/SP): certa companhia se insurgiu contra decisão assemblear que determinou a instalação do conselho fiscal e permitiu conduzir entre seus membros pessoa ligada a companhia concorrente da companhia fiscalizada. O Acórdão do STJ não reconheceu a quebra de independência, nem sequer chegando a fundamentar-se em tal tema, mas em eventual direito de preservação de seus "segredos contábeis", concluindo que não haveria problema para a companhia fiscalizada em tolerar nos quadros de seu conselho fiscal membro ligado a companhia concorrente, pois "se dá realce ali à inércia com que se comporta o referido membro do Conselho Fiscal". 
segregação de regimes de responsabilidade civil, justamente por se tratar de funções societárias distintas e, muita vez, opostas, serve inclusive para operar em detrimento de membros de conselho fiscal, que acabam respondendo por atos que nada têm a ver com as suas funções específicas. ${ }^{370}$

Nesse pormenor, não se discutiu a quebra da independência formal que a presença de um membro ligado a companhia concorrente poderia acarretar, mas sim a sua postura "inerte" no cumprimento de suas funções específicas de fiscalização.

Por outro lado, no exemplo expresso dado por CARVALHOSA especificamente em relação à ratificação de trabalho de auditor, ousamos, também discordar, pois a obrigação dos $\S \S 2^{\circ}$ e $4^{\circ}$ ao artigo 163 da Lei das S.A. impõe ao conselheiro fiscal (sem embargo da locução “... poderá solicitar-lhes esclarecimentos ou informações..." do $\S 4^{\circ}$ ao artigo 163 da Lei das S.A., que dá a impressão de se tratar de uma "faculdade" ao invés de uma "função"), sobretudo nas companhias que optaram pelo modelo do conselho fiscal com atribuições de comitê de auditoria, de cuidar atentamente da formulação e do processo de auditoria das demonstrações financeiras. A aprovação pelo conselho fiscal de parecer de auditor independente emitido com aprovação sem ressalvas, caso tenha sido gerado por conta de procedimento de auditoria fraudulento, duvidoso ou descuidado, não poderia exonerar o conselho fiscal de responsabilidade. Além disso, o único ponto de parcial exoneração legal da responsabilidade do fiscal estaria na aprovação pela assembléia geral e não na "aprovação pelos auditores externos" (cf. artigo 134, $\S 3^{\circ}$ da Lei das S.A.). Parece, portanto, maxima venia concessa, que essa opinião conflita com o texto de lei nos pontos aqui citados.

${ }^{370}$ Exemplo fatal disso está inscrito nos artigos 36 a 49 da Lei n ${ }^{\circ} 6.024$, de 13 de março de 1974, a Lei Intervenção e Liquidação Extrajudicial de Instituições Financeiras. Por esse diploma, respondem administradores e conselheiros fiscais pelos atos de gestão praticados em instituições financeiras. Lançase na mesma vala a situação de um administrador de instituição financeira e um conselheiro fiscal, como se o resultado dos atos pudesse compreender atos originados, indistintamente, pela atuação funcional da administração e da fiscalização. A técnica legislativa utilizada para se criar um regime de responsabilidade civil em decorrência de liquidação de instituição financeira e intervenção pelo Banco Central nessa lei pressupõe, justamente, a falta de independência entre conselho fiscal e controle, confundindo aquele com a administração, em um sistema em que ambos respondem para o controlador. Se não bastasse a própria complexidade da responsabilidade de membros de diretoria executiva de instituição financeira (vide o comentário de Ivo WAISBERG ao Acórdão REsp n ${ }^{0} 447.939 / \mathrm{SP}, \mathrm{STJ}, 3^{\mathrm{a}}$ Turma, Relatora Ministra Nancy Andrighi, v.u., j.: 4/10/2007, publicado no DJU de 25/10/2007 e RDB 40/186, "A evolução da jurisprudência sobre a responsabilidade civil dos administradores de instituições financeiras sujeitas a regimes especiais", bem como, de Arnold WALD, "A culpa e o risco como fundamentos da responsabilidade pessoal do diretor de banco", $R D B$ 40/345) a lei ignora a distinção de funções e lega um mesmo regime de responsabilidade civil, fazendo com que os conselheiros fiscais respondam por atos cuja execução, tecnicamente, cabe com exclusividade à administração, como se os conselheiros praticassem, também, os mesmos atos, contribuindo para a situação que gera a liquidação ou a intervenção. Não responde, nos termos e na letra dessa lei, pelas falhas e omissões graves que possam ter levado à liquidação ou poderiam tê-la evitado. Vide o Recurso Especial no 172.736/RO (STJ, $2^{\text {a }}$ Turma, Relator Ministro Francisco Peçanha Martins, v.u., j.: 10/06/2003, publicado DJ 22/09/2003, p. 278, RSTJ 174/223) em que membro do conselho fiscal de instituição financeira sob regime de intervenção requer levantamento de arresto por ausência de prova literal de dívida líquida e certa contra o membro do conselho fiscal. O acórdão repele o argumento, mas insiste na tese da responsabilidade da administração da instituição financeira, equiparando, para fins de intervenção extrajudicial, o fiscal ao administrador sem tratar das funções daquele de maneira específica, avaliando se falhou ou se eventualmente se omitiu na fiscalização. Essa decisão acompanhou os argumentos dados em caso conexo no Recurso Especial n ${ }^{\text {1 }}$ 170.272/RO (STJ, $1^{\text {a }}$ Turma, Relator Ministro Garcia Vieira, v.u., j.: 08/06/1999, publicado DJ 02/08/1999, p. 278, RSTJ 124/130). 


\section{Responsabilidade por omissão}

Como visto, o regime de competências do conselho fiscal opera (ou, ao menos, deveria ser operado) por meio de tipos jurídicos fechados. Cada competência necessita ser descrita de forma que o ato, que compõe um dever ou potestatividade, venha a ser praticado de maneira precisa pelos membros do conselho fiscal.

A lei não pode conter um regime aberto de fiscalização, sob pena de ineficácia ou abuso no exercício da função. A cada dever incluído na lei, deve corresponder uma ação que seja praticada de forma exata à descrição nela prevista.

Essa técnica não é nova e comporta o cerne de um regime de controle de legal de atos praticados em benefício de terceiros, tal qual ocorre com as funções e os deveres-poderes. Em outras palavras, o exercício de certos poderes funciona sob o regime de estrita legalidade e taxatividade ${ }^{371}$ : não podem ser exercidos nem além do que descreve a norma, nem aquém.

É natural, portanto, que o regime de responsabilidade pela fiscalização seja orientado em virtude do estabelecimento de nexo causal entre o resultado (dano) e falta cometida (não observância dos deveres). Na investigação da falta cometida, fatalmente se descreve a pressuposição de culpa num âmbito de omissões.

É parcialmente correta a redação dada à segunda parte do caput do artigo 165 , ao afirmar que os conselheiros fiscais “... respondem pelos danos resultantes de omissão no cumprimento de seus deveres e de atos praticados com culpa ou dolo, ou com violação da lei ou do estatuto". Nesse universo, o regime de responsabilidade civil se pauta pela "omissão no cumprimento dos deveres" - em outras palavras, na falta de um estado de alerta que não tenha sido suficiente para que o conselheiro fiscal pudesse

${ }^{371}$ L. FerRAJOLI (Principia Iuris..., vol. 1, Op. cit., Idem, pp. 267 e ss.). Em matéria de exercício de funções em sociedades comerciais, FERRAJOLI lembra que o vínculo de materialização do ato (potestativo ou funcional), por um representante de um órgão em nome de terceiros, comporta uma visão orgânicainstitucional da relação jurídica estudada. Para se compreender como funciona a responsabilidade pela prática desses atos, é necessário compreender como esses atos são ou devem ser praticados (pp. 605 e ss.). A certas funções especiais, FERRAJOLI dá o nome, correta e tecnicamente de competência (competenza). Para o notável jurista, "la 'competenza' è lo status giuridico di una persona artificiale elo di un suo organo nonché dei loro funzionari, prodotto da un atto istitutivo e richiesto, quale requisito di forma, agli atti precettivo imputabili ai primi ed attuabili dai secondi nell'esercizio di funzioni di cui i primi sono titolari e i secondi imputati" (p. 619). As chamadas normas de competência (caso do artigo 163 da Lei das S.A.) funcionam como se fossem "guias de ação" para seus destinatários, pois descrevem as situações que compõem obrigações preceptivas em forma de competências (pp. 424-432 c/c 622-626). 
atuar preventivamente e evitar que a administração ou o controle da companhia possa gerar danos inesperados aos acionistas. Na outra mão, a lei fala de "prática de atos com culpa ou dolo", que preferimos deixar para mais adiante, junto com o problema do compartilhamento “... dos deveres dos administradores de que tratam os artigos 153 a $156 . . . "$

Concentrando-se no problema da “omissão no cumprimento dos deveres", a primeira dificuldade que surge é a ausência e o silêncio quase tumular da doutrina sobre o problema da "responsabilidade orgânica por omissão". Antes sob o regime do artigo 159 do Código Civil de 1916, a responsabilidade por omissão aparece agora na letra do artigo 186 do Código Civil. A doutrina especializada em direito de responsabilidade civil contribui pouco sobre o tema, dificultando o trabalho de investigação da responsabilidade por omissão. ${ }^{372} \mathrm{Na}$ jurisprudência, o tema aparece em raras decisões que tratam da responsabilidade do Estado. ${ }^{373}$

Impõe-se admitir, de início, que a responsabilidade por omissão comporta valores diferentes da responsabilidade por comissão. Os atos jurídicos que comportam deveres (tais como as funções e as potestatividades obrigatórias, para ficarmos com os termos de FERRAJOLI e CARNELUTTI, respectivamente) trazem ínsita uma responsabilidade por força da obrigatoriedade da prática desse ato. Essa responsabilidade gira em torno da omissão, assim como o ato, na maioria das vezes, gira sob o eixo da função ou da potestatividade. Não há que se aceitar, de forma absoluta, os parâmetros da responsabilidade civil por culpa ou dolo em virtude de atos praticados cujo resultado seja um dano, no regime da responsabilidade pelo cumprimento de um dever, orientado pela falta decorrente de omissão. ${ }^{374}$

De plano, ao atentarmos para as funções próprias do conselho fiscal (seja sob o âmbito colegiado, seja sob o âmbito individual), cumpre notar que essas funções apontam para um modelo de responsabilidade civil objetiva e não de culpa

\footnotetext{
372 O problema da omissão, em doutrina, aparece sempre estudado dentro do âmbito do resultado da ação, por se tratar, para muitos, de uma questão de investigação do dano e não do pressuposto jurídico da culpa, até por própria deferência à letra expressa de nossa lei, que emulou o Code civil de Napoleão (vide José de Aguiar DiAs. Responsabilidade Civil, Op. cit., Idem, pp. 569-571). Raramente se vê um estudo em que a omissão se analisa atrelada a uma questão de imputação de responsabilidade a priori, independentemente do dano concreto provado pela vítima.

${ }^{373}$ Vide Recurso Especial n ${ }^{\circ}$ 738.833/RJ, Rel. Min. Luiz Fux, T1 - Primeira Turma, J.: 08/08/2006, DJ 28/08/2006 (p. 227).

${ }^{374}$ L. FURGIUELE, "La responsabilità dal controllo", Op. loc. cit., Idem, pp. 425-428.
} 
pressuposta. $^{375}$ Além disso, é necessário distinguir o regime de responsabilidade objetiva do conselho fiscal dos demais - enquanto a doutrina navega entre um tipo de responsabilidade objetiva de natureza delitual em contraposição a uma natureza contratual $^{376}$, é necessário admitir que o conselho fiscal se pauta por um tipo de responsabilidade própria que chamaremos de responsabilidade civil orgânicoobjetiva. $^{377}$

A importância da compreensão das responsabilidades do conselho fiscal em regime próprio de responsabilidade objetiva se presta para correlacionar idealmente o âmbito da competência orgânica do fiscal e a sua devida efetividade prática. A lista de atribuições deve servir como roteiro prático do desempenho de um conselho fiscal. Todas as funções devem ser cumpridas à risca e não deve haver margem de manobra para que o conselheiro opte por fazer ou não fazer qualquer uma dessas competências, ou, ainda, fazê-la com menor profundidade apenas para checar en passant o cumprimento de um dever.

A lista do artigo 163 deve ser encarada, portanto, como o primeiro ponto da formulação da agenda anual do órgão. Dúvidas surgem, entretanto, no âmbito mais complexo dos estudos de responsabilidade civil, a saber, a quem caberia provar se os

\footnotetext{
${ }^{375}$ Sobre a diferença entre os dois conceitos, vide José de Aguiar DiAs, Responsabilidade Civil, Op. cit., Idem, pp. 99-100.

${ }^{376}$ O tema, como já teve a oportunidade de dissertar ADAMEK, não é simples e por si só demandaria um trabalho à parte (Responsabilidade Civil dos Administradores..., Op. cit., Idem, pp. 175-6). Na linha do direito francês e estado-unidense, a experiência de um regime de responsabilidade civil da fiscalização societária regulada pela responsabilidade contratual tem raízes históricas em nosso direito, por conta do disposto no artigo $14, \S 4^{\circ}$ da Lei $\mathrm{n}^{\mathrm{o}} 3.150$, de 1882 , que dispunha: "Os efeitos da responsabilidade dos fiscaes para com a sociedade são determinados pelas regras do mandato".

${ }^{377}$ A responsabilidade orgânica não é uma responsabilidade objetiva delitual, pois se expressa sempre na responsabilidade pelo não cumprimento (voluntário ou não) de um dever. É um tipo de responsabilidade especial, que decorre da natureza do ato envolvido, a saber, uma função ou potestatividade, cuja formulação da culpa (no sentido lato de descumprimento de um dever) se dá dentro de uma noção orgânica de direitos e obrigações, deveres e potestatividades. A questão é realmente intrincada e envolve uma correlação entre fonte das obrigações, efeitos das obrigações e a classificação da responsabilidade segundo um liame pré-existente entre as partes em relação (no caso, a marca da responsabilidade contratual, e, ao mesmo tempo da responsabilidade do conselho fiscal perante os acionistas, que não é uma responsabilidade, propriamente, de natureza contratual). Vide José de Aguiar DiAS (Responsabilidade Civil, Op. cit., Idem, pp. 155-163); ainda, atente-se para a evolução dos conceitos próprios de uma responsabilidade civil orgânica do Estado (pp. 775-903), que podem fundamentar uma revisão do regime de responsabilidade civil no âmbito do direito societário, à semelhança histórica decorrente do influxo dos valores de governança pública versus a governança privada.
} 
deveres foram cumpridos e de que forma essa comprovação deve ser validamente feita. $^{378}$

Nesse regime de responsabilidade civil objetiva que encerra a gama de competências do conselho fiscal, o correlato entre o cumprimento efetivo do dever e a comprovação de seu cumprimento está exatamente no conteúdo de seu parecer e no âmbito de suas representações, nos exatos termos do parágrafo único, do artigo 164, da Lei das S.A. Nesse sentido, o regime de prova de responsabilidade orgânica estaria limitado à investigação dos meios liberatórios de um dever de indenizar. ${ }^{379}$

Não haveria, pois, porque se falar de uma responsabilidade pela "prática de atos com culpa ou dolo", pois se o ato praticado não encerra qualquer dos deveres impostos ao órgão, o conselho fiscal ou o conselheiro em específico agiu fora de suas funções e, portanto, mediante abuso de poder; se, entretanto, praticou algum ato da lista do artigo 163 da Lei das S.A. de forma incorreta, imprudente, negligente, inábil ou dolosamente em oposição à lei ou aos estatutos (como, por exemplo, ao admitir redução de capital que esteja fora das hipóteses previstas no caput ao artigo 173 da Lei das S.A.), o membro ou o conselho se omitiu no cumprimento escorreito de sua função: em outras palavras, agiu objetivamente em violação da lei. Nesta última hipótese, da prática de uma função de forma voluntariamente oposta à letra da lei ou do estatuto,

\footnotetext{
${ }^{378}$ Não se trata, portanto, de ter que se investigar ônus de prova ou extensão de culpa, ou, ainda, prova da culpa. Um regime de responsabilidade civil orgânico-objetiva independe da existência de culpa stricto sensu, mas sim de uma violação objetiva no cumprimento de seus deveres. Não se trata, na análise da responsabilidade do conselho fiscal, de notar se o órgão agiu de forma culposa (negligente, imprudente ou imperita) ou dolosa, se houve dano concreto ou não. A prudência e a perícia são pressuposições formais, das quais já tivemos a oportunidade de tratar anteriormente: é, pois, um problema de qualificação e uma vez atendida, não há que se investigar se, de fato, o expert não atendeu às expectativas. Deve haver um resultado que a lei pretendeu prevenir ao instituir uma fiscalização, como, por exemplo, demonstrações financeiras produzidas de forma oposta àquela determinada por lei - por mais que não haja, com isso, um resultado financeiro prejudicial para os acionistas, deve o conselho fiscal ser responsabilizado pelo não cumprimento de um dever e ressarcir a companhia por essa falta objetiva. O material probatório, na prática, será sempre o mesmo e terá início pelo parecer do conselho fiscal, que deverá conter as representações que comportem os deveres cumpridos. Para cada dever, há de haver um documento que lhe corresponda (ainda que admitamos, por hipótese, a conveniência de um tipo aberto como o do artigo 163, I, da Lei das S.A.). A prova de não cumprimento não pode ser trabalhosa nem de difícil obtenção, mas, em cada caso, a interpretação do ato praticado pelo conselho fiscal à luz do que foi representado deve solver a questão da prova do ato (sobre os lindes a respeito da prova em matéria de responsabilidade civil em regimes especiais de culpa, vide José de Aguiar DIAS, Responsabilidade Civil, Op. cit., Idem, pp. 110-115).

${ }^{379}$ Sobre o tema, vide G. M. F. NovaEs HiRonAKA, Responsabilidade Pressuposta, Op. cit., Idem, pp. 304 e ss.
} 
estaremos, ultima ratio, diante de uma omissão de um dever, sempre ${ }^{380}$, ou melhor, de uma falta no cumprimento de uma função, portanto, de uma disfunção.

Em relação ao artigo 165-A, introduzido pela reforma de 2001, como já tivemos a oportunidade de observar anteriormente, lembramos que, no universo hipotético aqui proposto, a norma seria desnecessária. Na defesa de uma estruturação formal do órgão sem a presença de acionistas, com as vedações expressas de investimento em mercado de ações (à vista ou a termo) e fundos de ações de administração não-discricionária por conselheiros fiscais, a norma em questão não teria razão de ser.

\section{Compartilhamento dos deveres da administração}

Reside neste ponto o cerne da discussão a respeito do regime próprio de responsabilidade civil do conselho fiscal que, de forma exígua, é proposto por poucos, mas, que com a licença da ousadia, clamaremos em favor, criticando o regime atual. ${ }^{381}$

Como visto, o artigo 165, caput dispõe que "os membros do conselho fiscal têm os mesmos deveres dos administradores de que tratam os artigos 153 a 156...". Com isso, pretende a lei investir o fiscal de responsabilidade por (i) diligência, (ii) desvio de poder, (iii) lealdade e (iiii) conflito de interesses.

Tratam-se de deveres da administração. São deveres, portanto, que norteiam e marcam funções executivas e de gestão da sociedade. A linguagem utilizada nos artigos citados volta-se totalmente para funções típicas de gestão e governança da companhia e pouco ou nada têm a ver com as funções fiscalizatórias ${ }^{382}$. Os atos

\footnotetext{
${ }^{380}$ Pode-se ainda entender que o conselheiro agiu em violação do artigo 154 da Lei das S.A., em desvio de poder e vulneração da finalidade de suas atribuições e competências. Entretanto, defendemos aqui que o conselho fiscal seja dotado de um regime próprio de "finalidade das atribuições e desvio de poder", não cabendo aplicar, integralmente, o regime do artigo 154 da Lei das S.A. ao conselho fiscal.

${ }^{381}$ As críticas, aliás, são constantes, como pudemos observar, na doutrina italiana, francesa, argentina e estado-unidense.

382 As normas usam termos como “...empregar na administração dos seus próprios negócios...”; “...praticar ato de liberalidade à custa da companhia..."; “...tomar por empréstimo recursos ou bens da companhia...”; “... prática de atos gratuitos em benefício dos empregados ou da comunidade de que participe a empresa...”; “...usar (...) as oportunidades comerciais de que tenha conhecimento...”; “...deixar de aproveitar oportunidades de negócio...”; “...intervir em qualquer operação social...”; "...contratar com a companhia...”; “...transferir para a companhia as vantagens que dele tiver auferido...”. Essa terminologia,
} 
vedados, inscritos no âmbito desses artigos. relacionam-se diretamente com atos próprios da mercancia, como o aproveitamento de oportunidades comerciais, a obtenção de lucro em seus negócios e o alcance de vantagens próprias de quem transita no meio dos negócios. O fiscal (pelo menos no formato que estamos tentando apresentar aqui) não é um mercador, não é um empreendedor, não é um comerciante. O fiscal é um zelador da companhia, um funcionário (no sentido que atribui FERRAJOLI ao termo função) a quem incumbe velar pela consecução legal do objeto social. Admitir que o fiscal tenha experiência de empreendedor, mercador ou comerciante não significa dizer que, no exercício da função de fiscal, sua qualidade de mercador permanece. Uma vez fiscal, o conselheiro fiscal deve deixar de ser administrador, seja da companhia fiscalizada, seja de qualquer outra. Fiscalizar é um ofício que demanda dedicação exclusiva e expertise particular para o desempenho da função.

Uma vez assumida essa premissa teórica, podemos iniciar o estudo do emprego dos deveres da administração sobre as funções fiscalizatórias. Nesse estudo, buscaremos iniciar a análise pelo conteúdo dos artigos 156 e 155, que cuidam, respectivamente, do conflito de interesses e do dever de lealdade.

$\mathrm{Na}$ visão formal aqui proposta, defendeu-se a instituição de um órgão de fiscalização com total independência em relação aos eixos políticos da sociedade que fiscaliza. Nessa visão formal, sugeriu-se que a independência ocorresse dentro de um universo de elegibilidade, para o conselho fiscal, que comportasse diversas restrições e vedações. Essas restrições e vedações ora propostas têm a finalidade de legar ao órgão uma característica puramente técnica, sem que ele tangencie qualquer função administrativa da companhia.

Desta forma, o fiscal, no cumprimento de suas funções, não toma decisões sobre as oportunidades comerciais da companhia, mas meramente tem o dever de verificar se as decisões sobre as oportunidades comerciais da companhia foram tomadas em respeito às regras de controles internos da companhia, bem como à lei e ao estatuto. Imaginemos um fiscal que, tendo conhecimento de uma oportunidade comercial da companhia, avisa terceiro (mormente concorrente, pois a quem mais interessa uma oportunidade comercial da companhia?) para que este se beneficie dessa

de forma patente, aponta para atos típicos de gestão de uma companhia e não de sua fiscalização independente, razão pela qual defendemos que o compartilhamento desses deveres, nem sequer por analogia, seria passível de operar um sistema lógico de responsabilidade típica da fiscalização. 
oportunidade em detrimento da companhia que fiscaliza. Imaginemos ainda que, em troca da gentileza apresentada, o fiscal receba quantia em dinheiro.

Teoricamente, estamos falando da violação do dever constante no artigo 155, I da Lei das S.A. ${ }^{383}$ Note-se que pelo exemplo dado, a única alternativa que os acionistas ou a administração poderiam lançar mão seria uma ação de responsabilidade por quebra do dever de lealdade.

Ainda que imaginemos a prática de tal ato em um universo de conselho fiscal com o grau de independência requerido pela atual redação da Lei das S.A., imaginando ainda que esse fiscal, acumulando funções em companhia aberta, seja diretor de operações de companhia que exerce o controle sob a companhia fiscalizada (o que, em tese, é permitido pela nossa lei), pratica esse ato em favor da companhia controladora, caberia ao minoritário da companhia fiscalizada apenas e tão somente acionar esse conselheiro fiscal por quebra de seu dever de lealdade.

Seria claro que em universo de independência máxima, nos moldes aqui propostos, que a conseqüente gravidade na prática desse ato fosse maior; mas isso não retira, à luz do formato atual da lei, o caráter reprovável de tal atitude.

É sintomático que, no caso do administrador, semelhante ato envolva uma responsabilidade de ordem civil, haja vista a própria natureza dos atos praticados pelo mesmo e a pressão que existe sob a sua função em torno de resultados. Já, no caso do fiscal, a pressão é pela forma. Não se exige do fiscal um resultado positivo, mas que o resultado da companhia (positivo ou negativo) tenha sido apurado de forma transparente e nos estritos termos da lei e do estatuto. Ao fiscal exige-se uma vigilância, um estado de alerta sobre a condução da companhia.

\footnotetext{
${ }^{383}$ Entendemos que o dever de lealdade, na letra do artigo 155, II, é inaplicável ao conselho fiscal, ainda que dentro do âmbito da omissão "no exercício ou proteção de direitos da companhia". O conselho fiscal deve responder única e exclusivamente pela omissão no exercício de seus deveres, inscritos no âmbito do artigo 163, nem mais, nem menos. A "proteção de direitos da companhia" é um dever da administração, que, dentro de um conceito de cuidado, deve se valer de assessores jurídicos, constantemente, para que essa proteção seja assegurda. Legalmente, a proteção legal e legítima de direitos é uma tarefa do profissional da advocacia e cabe à administração da companhia se valer de assessores legais que cumpram essa função. À fiscalização nada incumbe no âmbito da referida "proteção de direitos da companhia", mas única e exclusivamente advertir a administração, caso tenham conhecimento de algum direito da companhia que está sendo, ou está em vias de ser vulnerado ou violado, ou, ultima ratio, informar a assembléia. O dever, portanto, é de natureza completamente distinta: o administrador responde por não tomar medidas a tempo; já, o fiscal, responde por não ter comunicado à administração ou à assembléia em tempo - são deveres completamente distintos e se perfazem de maneira diversa.
} 
Ao faltar com a sua lealdade no âmbito da fiscalização, o fiscal pratica verdadeira apropriação indébita. A responsabilidade por quebra da lealdade, assim como por prática de ato fiscalizatório em conflito de interesse é sobremaneira grave. Se considerarmos que, por questão de elegibilidade, pudesse ser vedado ao fiscal administrar a companhia fiscalizada ou outras, contratar com a companhia (em condições eqüitativas ou não), deter valores mobiliários da companhia ou de outras, a responsabilidade pela quebra de deveres impostos em razão de lealdade ou abstenção de conflito de interesses (na letra dos artigos 155 e 156) se aproximaria dos atos violadores de uma fidúcia comum semelhante às violações de fidúcia protegidas no âmbito da apropriação indébita qualificada. ${ }^{384}$

Assim, exclusivamente em relação à perspectiva formal do conselho fiscal, aqui defendida, e exclusivamente em relação à perspectiva funcional do conselho fiscal aqui analisada, nos parece que a quebra da lealdade por um fiscal ou ainda a fiscalização de uma companhia aberta em interesse conflitante com o da companhia, não sanado em prazo razoável ou não sanado por meio de exoneração imediata das funções, deve ser tema a preocupar estudos na área do direito penal. Nos parece, à luz de tudo o que aqui defendemos, que a quebra de lealdade na fiscalização é uma questão muito mais próxima de valores que orientam o direito penal societário do que a responsabilidade civil nessa matéria.

\footnotetext{
${ }^{384}$ Neste caso, o ato praticado pelo conselho fiscal se assemelha a um desvio (tal qual ocorre, por semelhança, na Unterschlagung alemã) - vide Heleno Cláudio FrAGOSo (Lições de Direito Penal, $2^{\circ}$ volume. São Paulo: Bushatsky, 1958, pp. 248 e ss.). O conselho fiscal se vale da fidúcia depositada em seu cargo para obter vantagem própria ou para outrem. Se vale, portanto, de sua posição de confiança para se apropriar, indevidamente, de informação que pertence à companhia, fazendo uso dela como se a informação pertencesse ao membro do conselho fiscal, na qualidade de terceiro desinteressado. Agindo assim, o conselheiro não apenas vulnera os requisitos formais de investidura, não apenas ofende a independência do cargo, não apenas age em oposição à sua função fiscalizatória, mas sobretudo usa da função para agir em favor de interesse próprio ou de terceiro, oposto ao interesse da companhia. A atitude é muito grave e não há como deixar de situá-la dentro de uma matriz criminal, por se tratar de uma traição inaceitável. No caso, há uma posse lícita da informação que seria prévia ao cometimento do ato danoso, pois se o membro comete o ato antes de ser investido no cargo, tem a investidura viciada e a posse da informação, por conseqüência, não é lícita. Nesse caso falamos de membro do conselho fiscal que deliberadamente age em desfavor da companhia, após investidura regular no cargo. Não há registro na jurisprudência, muito por conta da influência que os escritos de Nelson HunGRIA legaram para a matéria (vide Comentários ao Código Penal, $2^{\mathrm{a}}$ ed., Vol. VII - arts. 155 a 196. Rio de Janeiro: Forense, 1958, pp. 133-135), de modelo de "apropriação indébita de informação", haja vista que a tendência de interpretação vetusta do assunto em nossos tribunais resiste em considerar a "informação" ou a "oportunidade de negócio" uma "coisa alheia móvel", passível de mensuração econômica, por conta de seu caráter imaterial. Argumentava HungRIA: "tal como no furto, não podem ser objeto do crime em questão as coisas imateriais, como sejam os direitos e ações" (Ibidem, p. 134, itálicos do original). Portanto, embora ato de considerável gravidade, não há no ordenamento penal brasileiro norma que considere esse ato um ilícito de natureza penal, pois a exceção dada pelo próprio HUNGRIA, no exemplo do título ao portador (Ibidem, pp. 134-135), nos parece insuficiente para que se faça a ponte, por analogia, para a situação de posse e uso malicioso da informação.
} 
Em relação ao regime atinente à finalidade das atribuições e ao desvio de poder, ressalta mais profundamente o caráter executivo desses deveres. Não se fala no artigo 154, assim como nos artigos 155 e 156 (todos da Lei das S.A.), em atos de natureza fiscalizatória. Da mesma forma que nos deveres acima estudados, em um universo formal de independência máxima, a norma do $\S 1^{\circ}$, do artigo 154 , da Lei das S.A., figuraria como uma verdadeira redundância decorrente dos critérios formais de elegibilidade. No mais, em relação aos $\S \S 2^{\circ}, 3^{\circ}$ e $4^{\circ}$, o cuidado da redação legislativa em relação às atribuições típicas da administração são evidentes e a impossibilidade de assimilação dessas responsabilidades e deveres, por extensão, às competências do conselho fiscal, apenas intensificam a falha sistêmica no trato do regime da responsabilidade civil do conselheiro.

Assim como ocorre em relação à descrição específica das hipóteses de responsabilidade por quebra de lealdade, a tipificação que o artigo 154 da Lei das S.A. descerra, em relação ao desvio de poder, no caso específico dos fiscais, nos parece muito mais um problema que deveria ser tratado na esfera penal do que na esfera civil. Fiscal que viesse a "praticar ato de liberalidade à custa da companhia"; "tomar", ainda que por empréstimo, com ou sem a autorização da assembléia, "recursos ou bens da companhia"; usar "em proveito próprio, de sociedade em que tenha interesse, ou de terceiros", bens, serviços ou créditos da companhia; "receber de terceiros", com ou sem autorização estatutária ou de assembléia geral, "qualquer modalidade de vantagem pessoal, direta ou indireta, em razão de exercício do seu cargo", não faz outra que não seja praticar uma espécie de "estelionato societário". Esses atos não são tipificados como crime em relação a fiscais da companhia, mas, ultima ratio, assim deveriam ser, pois constituem verdadeiro delito, processável na esfera de uma ação penal privada, com legitimidade de proposição exclusiva para acionistas da companhia ou pela própria companhia, sem prejuízo de reparação por eventuais danos daí decorrentes.

Regime específico de "desvio de poder" ou "abuso de poder", por parte dos fiscais, deveria ser tratado de forma completamente diferente daquele previsto no artigo 154, mas preservando, desse artigo, o espírito de que todos os atos de obrigação funcional daqueles seja praticado "no interesse da companhia". Qual seja: a própria Lei 
das S.A. deveria conter regras mais claras, num regime mais evidente de freios e contrapesos ao exercício do poder fiscalizatório. ${ }^{385}$

Por fim, cumpre analisar a responsabilidade dos fiscais dentro de um conceito de dever de diligência, talvez o mais complexo de todos os deveres da administração.

Em princípio, parece que o texto que rege o dever de diligência poderia ser entendido no âmbito das funções do conselheiro fiscal - "o fiscal da companhia deve empregar, no exercício de suas funções, o cuidado e a diligência que todo homem ativo e probo costuma empregar na fiscalização e na vigilância dos seus próprios negócios". Fatalmente, tal reversão do dever de diligência, em vista das funções específicas do fiscal da companhia, iria ter o condão de tornar a responsabilidade dos fiscais em uma responsabilidade por culpa in vigilando positivada.

Entretanto, não é meramente de uma culpa in vigilando pressuposta que o dever de diligência trata.

Na esteira da experiência de reforma do direito português, nota-se que lá o antigo e já conhecido dever de diligência foi substituído por um dever de cuidado, na linha da doutrina anglo-saxônica do duty of care. Esse novo dever de cuidado da legislação portuguesa englobaria o dever de diligência, numa certa ampliação e

${ }^{385}$ Vide Nelson L. EIZIRIK ("Limites à Atuação do Conselho Fiscal”, Op. cit., Idem, passim) bem como N. L. EIZIRIK e M. CARvalhosa (A Nova Lei..., Op. cit., Idem, pp. 340-343). No mesmo sentido, vide Raul de ARAúJo FILHO e Rodrigo Ferraz CUNHA ("Limites de atuação do conselho fiscal”, Op. cit., Idem, passim).

Por um regime próprio de "desvio de poder", nas atribuições típicas do conselho fiscal, o texto de EIZIRIK e CARVALHOSA oferece excelente ponto de partida: "Tal acréscimo na redação do citado parágrafo reforça o entendimento já existente de que a fiscalização deve ater-se aos deveres legais e estatutários previstos como competência para o conselho fiscal, motivo pelo qual os requerimentos de informações que não sejam necessários ao desempenho das funções do conselho fiscal podem ser legitimamente recusados pelos diretores ou pelo conselho da administração da companhia [sic]. Do mesmo modo, como o âmbito de fiscalização do conselho fiscal não inclui a política empresarial da companhia, as eventuais solicitações de informações sobre a política de preços desta, estratégias de venda dos produtos, marketing ou outras que não sejam necessárias ao desempenho das funções do conselho fiscal, não precisam ser atendidas pelos administradores da sociedade" (itálicos do original). Adicionalmente ao que disseram os autores, ousaríamos dizer que eventuais solicitações de informações sobre a política de preços desta, estratégias de venda dos produtos, marketing ou outras que não sejam necessárias ao desempenho das funções do conselho fiscal, não devem ser atendidas pelos administradores da sociedade. Nesse passo, o atendimento a semelhantes solicitações seria forte indício de quebra de lealdade, sobretudo quando realizadas em cumprimento ao disposto no $\S 6^{\circ}$, do artigo 163 , da Lei das S.A., funcionando os conselheiros fiscais, nesses casos, como verdadeiros veículos de práticas reprováveis. Eis mais um motivo pelo qual defendemos, aqui, a revogação do referido dispositivo legal ou a sua transformação em preceito de vedação ao conselho fiscal, sobretudo quando formado exclusivamente por membros independentes. 
extensão dos limites anteriores de tal dever, pois além de exigir que o ato seja praticado com boa-fé e no interesse da companhia, o ato deve ser praticado sob uma "actuação informada, profissionalmente competente, da qual resulte que o administrador considerou, ao praticar um acto, todas as outras possibilidades alternativas e razoáveis de actuação, tendo optado por aquela que justificadamente (embora não necessariamente) lhe tenha surgido como a mais adequada"386.

A doutrina brasileira, entretanto, salvo as raras exceções aqui citadas, caminha a passos lentos no reconhecimento de um regime mais próximo do dever de cuidado, em contraposição ao vetusto dever de diligência, que se põe como uma atuação geral e padronizada de um bonus pater familiae, ao invés de tratar o administrador como um profissional competente.

A doutrina, no Brasil, vem paulatinamente reconhecendo o valor da doutrina do business judgement rule, mas em relação ao poder fiscalizatório, ainda que tratemos o duty of monitoring ou o duty to monitor como uma das facetas do duty of care, o tema apresenta problemas, como já pudemos analisar anteriormente neste trabalho. ${ }^{387}$

A atuação informada do fiscal e os elevados padrões de profissionalidade devem ser tratados como requisito formal de elegibilidade, como vimos. A atuação não informada ou a atuação segundo padrões questionáveis de profissionalidade estariam, em tese, dentro do conceito de omissão. Deveriam ser, por si só, uma vulneração do próprio cumprimento objetivo das competências específicas de fiscalização e não um medidor de qualidade dessa atuação, para fins de responsabilização ou não do fiscal que atuou abaixo dos padrões. Diferentemente do administrador, o fiscal, ao praticar um ato, não deve ficar entre a consideração de possibilidades ou alternativas razoáveis, nem tanto a ele deve ser facultada a possibilidade de escolher entre atos ou funções que julgar mais adequado praticar. Como falamos, a lista do artigo 163 deve ser encarada como um "guia de atuação" e todas as competências ali inscritas devem cumprir uma agenda criteriosa de atuação dos fiscais.

Essa é a razão pela qual, ainda que nos deparemos à frente de um dever de diligência transformado em dever de cuidado, o regime de diligência de fiscais deve

\footnotetext{
${ }^{386}$ G. F. DiAs, Fiscalização de sociedades..., Op. cit., Idem, pp. 43-44.

${ }^{387}$ Vide o brilhante texto de Larry Catá BACKER, "The Duty to Monitor...", Op. cit., Idem, passim.
} 
atentar, especificamente, às funções que lhes são atinentes, evitando-se neles investir a responsabilidade de um mero bonus pater familiae (ou de "homem ativo e probo") na "condução de seus negócios". Para se estabelecer a responsabilidade pela fiscalização, a lei não pode recorrer a fatores que sejam externos às competências previstas pela própria lei, tais quais os padrões que os "homens ativos e probos costumam empregar em seus próprios negócios".

Mesmo em textos mais modernos e avançados, como ocorre na legislação portuguesa, essa associação do dever de cuidado às funções típicas de fiscalização não se livram totalmente de críticas. ${ }^{388}$

Neste passo, a preocupação aqui aventada a respeito da impertinência da associação em paralelo dos deveres da administração, aplicáveis em forma reciclada às funções típicas do conselho fiscal, serve para explicitar o total descompromisso sistêmico que as normas sobre responsabilidade no referido órgão estão postas na Lei das S.A. Seria fundamental termos uma correção de rumo, com um regime próprio de deveres e responsabilidades que se encaixem dentro de funções fiscalizatórias e de competências típicas de fiscalização, haja vista que o regime de responsabilidades dos artigos 153 a 156 da Lei das S.A. se associam às competências previstas no artigos 138, 139, 142 e 144 da Lei das S.A., nada tendo a ver com as competências do artigo 163.

\section{Hipóteses de solidariedade no conselho fiscal}

Outro ponto importante em relação às competências do conselho fiscal diz respeito ao tema da solidariedade.

\footnotetext{
${ }^{388}$ Num primeiro âmbito de críticas, G. F. DiAs (Fiscalização de sociedades..., Op. cit., Idem, pp. 50-53) notou falha na formulação técnico-legislativa do texto português, que gera uma certa subalternalização do dever de lealdade ao dever de cuidado. Além disso, lembra a jurista: "O exacto conteúdo daquela cláusula geral só poderá, pois, ser alcançado em conjugação com as normas especiais do CSC onde se consagram os deveres e as funções específicas de cada órgão de fiscalização: os padrões de diligência com que os deveres de cuidado na fiscalização da sociedade devem ser exercidos aferir-se-ão em função da exacta e criteriosa observância dos especiais deveres e funções que, de acordo com aquelas normas, recaem sobre os membros dos órgãos de fiscalização" (p. 54).
} 
No âmbito do conselho fiscal, há três tipos de solidariedade previstas na lei: (i) a solidariedade dos fiscais entre si; (ii) a solidariedade dos fiscais com a administração; e (iii) a solidariedade dos fiscais com os controladores.

Aqui, neste ponto, tecnicamente, deve-se retornar à natureza da responsabilidade civil do conselho fiscal que, oscilando entre contratual e extracontratual, encontrou, nestes estudos, caracterização mais lógica e adequada em regime híbrido que chamamos de responsabilidade orgânico-objetiva.

Se a própria responsabilidade extracontratual encontra o fundamento de sua solidariedade na letra do artigo 186 do Código Civil, a responsabilidade contratual decorre do disposto nos artigos 275 e seguintes. A lei societária, ao tratar dos diversos tipos de solidariedade aplicáveis ao conselho fiscal, demanda regime de responsabilidade solidária decorrente do regime do artigo 186 do Código Civil ou do regime dos artigos 275 e seguintes?

De plano, cumpre rechaçar a hipótese de que as solidariedades que a lei societária impõem ao regime de fiscalização de companhias devam ser orientadas pelo regime de solidariedade destes últimos artigos. Definitivamente, as funções de fiscalização não permitem compreender que a vítima de atos lesivos praticados por conselheiro fiscal possa fundamentar sua pretensão jurídica à indenização com base nesse regime de solidariedade. Eis uma das fortes razões pelas quais é muito difícil aceitar o argumento de que a responsabilidade pela fiscalização de companhias tem natureza puramente contratual.

Por outro lado, recaímos na solidariedade que decorre da responsabilidade extracontratual que, como bem lembrou J. A. DiAS, com apoio em Mazeaud et Mazeaud: “...se o violador do direito ou causador do prejuízo já não é uma pessoa, mas um grupo de pessoas, estão todas e cada uma de per si obrigadas a reparar o dano. Elas aparecem, em relação ao fato danoso, como '[...] a cauda para o efeito $e$, como o acontecimento é um e um só o mal produzido, o mal de um será, necessariamente, o mal dos outros, sem divisão possível [...]'. Assim, cada um dos 
agentes que participam no ato ilícito é considerado pessoalmente como produtor do dano e, conseqüientemente, obrigado à reparação integral". 389

Note-se, entretanto, que esse raciocínio é válido para todos os tipos de solidariedade trazidos pela lei, pois encerram modelos de responsabilidade civil orgânico-objetiva, já que ela imputa diretamente ao órgão toda e qualquer responsabilidade pela faltas diretamente praticadas em seu âmbito.

De fato, a responsabilidade dos conselheiros entre si decorre das faltas cometidas no âmbito do cumprimento de seus deveres e no desempenho de suas competências. As regras constantes do $\S \S 2^{\circ}$ e $3^{\circ}$, do artigo 165, da Lei das S.A., são umas das poucas regras de apreciável caráter técnico, pois além de reforçarem a natureza colegiada do órgão de fiscalização, criam culpa pressuposta dentro do espectro dessa responsabilidade orgânico-objetiva, bem como forma de exoneração dessa responsabilidade por parte daqueles que ativamente se opuseram a praticar ou se omitir na prática de alguma competência específica do órgão.

No caso dos dividendos, é de se notar que a atuação do fiscal faz parte integrante do sistema legal que estabelece o procedimento adequado para distribuição dos dividendos. ${ }^{390}$ Embora a Lei das S.A. mencione a necessidade de manifestação prévia do conselho fiscal em matéria de distribuição de dividendo apenas no $\$ 4^{\circ}$, do artigo 202, da Lei das S.A., ${ }^{391}$ é importante lembrar que o dividendo é parte da pauta da assembléia geral ordinária, onde a presença de membro de conselho físcal é obrigatória, além de se cuidar de matéria que é de competência do conselho fiscal, por força do disposto no artigo 163, III. ${ }^{392}$ Desta forma, como a atividade do fiscal faz parte do processo de declaração desse dividendo, melhor seria, então, que o $\S 1^{\circ}$, do artigo 201 , da Lei das S.A., estabelecesse a solidariedade do conselheiro com a administração no

\footnotetext{
${ }^{389}$ Responsabilidade Civil, Op. cit., Idem, p. 1078.

${ }^{390}$ A Lei n ${ }^{\circ}$ 3.150, de 1882 já dispunha em seu artigo 27, Parágrafo Único: "Os fiscaes que deixarem de denunciar nos seus relatórios annuais (art. 14) a distribuição de dividendos não devidos e quaisquer outras fraudes praticadas no decurso do anno e constantes dos livros e papéis sujeitos ao seu exame, serão havidos como cumplices dos autores desses delitos e, como taes, punidos".

${ }^{391}$ Ideal seria que a lei dispusesse, de forma clara e precisa, que, no caso das companhias abertas, nenhum dividendo pudesse ser declarado pela administração da companhia sem que fosse precedido de parecer do conselho fiscal dado sobre balanço específico levantado para essa finalidade (declaração de dividendo) e devidamente auditado pelo auditor independente da companhia. A atuação do conselho fiscal deveria ser prévia em relação à declaração dos dividendos e, nesse sentido, iria fazer maior sentido a solidariedade estabelecida no $\S 1^{\circ}$, do artigo 201 , da Lei das S.A.

${ }^{392}$ Neste ponto, como já tivemos a oportunidade de tratar, o conselho fiscal atua na forma de um verdadeiro comitê, pois atua a priori da prática do ato e pode influenciar na decisão dos acionistas.
} 
âmbito de tal declaração, cujo processo de formulação deve ser integrado por parecer prévio do conselho fiscal.

A mesma questão se dá, teoricamente, no estabelecimento da mesma responsabilidade ao fiscal no caso de distribuição de participações, sobretudo no caso da das partes beneficiárias, na forma dos artigos 190 e 47 e seguintes da Lei das S.A.. O parágrafo único, do artigo 190, da Lei das S.A., estabelece as mesmas responsabilidades aos fiscais, na forma do artigo $201, \S 1^{\circ}$. Entretanto, não há regra que trate do procedimento pelo qual o conselho participa da fiscalização do destaque desse valor. ${ }^{393}$ O único pormenor que se pode afirmar é que, como no caso dos dividendos, a atuação do fiscal é parte do processo de atribuição de participações, e melhor seria, igualmente, que o $\S 1^{\circ}$ do artigo 201, combinado com o artigo 190 da Lei das S.A., estabelecessem a solidariedade do conselheiro com a administração na esfera da declaração dessa participação, cujo processo de formulação deveria também ser integrado por parecer prévio do conselho fiscal.

No caso do regime de solidariedade entre o conselho fiscal e o acionista controlador, por força do disposto no $\$ 2^{\circ}$, do artigo 117 , da Lei das S.A., a excelente técnica legislativa empregada no texto desse parágrafo, conjugado com o conteúdo do $\S 1^{\circ}$, alínea "e", do mesmo artigo, prevê solidariedade por ato praticado em conjunto com outro membro de órgão da companhia, em detrimento desta ou de seus acionistas.

A hipótese prescrita na lei responsabiliza o acionista controlador por danos causados a terceiros, em virtude de ato praticado com abuso ou desvio de seus poderes, dentre eles, a indução ou tentativa de indução de fiscal ou administrador a praticar ato ilegal ou em descumprimento de seus deveres. Adicionalmente, a promoção desse ato lesivo à ratificação pela assembléia-geral também acarreta responsabilidade do acionista controlador.

\footnotetext{
393 Para complicar mais a questão, sendo o titular de parte beneficiária uma espécie de credor da companhia, não pode ele se valer dos direitos de acionista, exceto pelo direito de fiscalizar, nos termos da lei, os atos dos administradores (artigo $46, \S 3^{\circ}$ da Lei das S.A.). Contudo, esse direito de fiscalizar do acionista refere-se ao artigo 109, III, da Lei das S.A. e não estaria se referindo, numa primeira instância, a eventual direito do titular de parte beneficiária de participar do conselho fiscal, como ocorria na Lei de 1882. Entretanto, pode-se entender que o direito de fiscalizar do acionista não estaria limitado ao âmbito restrito de uma fiscalização pessoal, mas incluiria, no caso de conselhos fiscais "instalados", a possibilidade de interagir com o conselho. Não justificaria, entretanto, nesse sentido, que solicitações do artigo $163, \S 3^{\circ}$, da Lei das S.A., estivesse restrita a pequenos grupos de acionistas em detrimento dos titulares de direitos de participação, nos termos do artigo 190 da Lei das S.A. A questão é complexa e envolve um debate histórico excitante, reproduzido com maestria por CARVALHOSA (Comentários..., $1^{\circ}$ vol., Op. cit., Idem, pp. 507-510).
} 
Nessa área, não é difícil imaginar atos em que o fiscal se torna solidário com o acionista controlador, ou com o administrador, ou com ambos, por compartilhar da prática de um ato que configure abuso de poder de controle - são, tipicamente, os pedidos feitos pelo acionista controlador ou pela administração para que os membros do conselho fiscal façam "vistas grossas" ou que elaborem pareceres em que "omitam" ou “peguem leve" em certas críticas à administração e assim por diante.

Fatalmente, pedidos desse jaez, que sejam aceitos e praticados pelos fiscais, podem levar a assembléia-geral à ratificação de muito ato ilegal ou danoso à companhia, principalmente quando tais atos ilegais representem um reflexo direto na realidade desta, à luz do que se encontrar expresso nas suas demonstrações financeiras.

\section{Extinção da responsabilidade}

Preliminarmente, cumpre distinguir os termos de encerramento segundo o direito envolvido - para compreender o termo de extinção da responsabilidade civil do conselho fiscal, é necessário saber diferenciar esse termo daquele outro que diz respeito à extinção do mandato.

O mandato de um conselheiro fiscal se extingue com o fim do termo assinalado para o exercício da função, por renúncia, por demissão, por morte ou por impedimento. O impedimento é, de todos, o termo de encerramento mais complexo, pois pode envolver perda das qualidades formais previstas como requisito de investidura. Trata-se, aqui, da perda de qualidades que afetem a independência dos membros do conselho fiscal, pois ninguém perde qualificação formal, segundo a definição de qualificação formal a que aludimos no Capítulo 5 desta dissertação. Entretanto, não é com o encerramento do mandato que se encerra a responsabilidade do conselheiro fiscal. ${ }^{394}$

\footnotetext{
${ }^{394}$ Esta simples observação muita vez não incorpora premissas de solução de conflitos vistos na jurisprudência e no quotidiano das companhias. Como exemplo desta afirmação, vide Acórdão do Superior Tribunal de Justiça, nos autos do Recurso Especial n ${ }^{\circ}$ 471.048/PR (STJ, $3^{\mathrm{a}}$ Turma, Relatora Ministra Nancy Andrighi, v.u., j.: 10/06/2003, publicado DJ 04/08/2003, p. 296, RSTJ 184/270), em que se discutiu ação onde o autor requereu a nulidade de ato societário que aprovou a eleição de membro para o conselho fiscal ligado ao controlador, em fraude aos requisitos de elegibilidade do artigo 163 da Lei das S.A. Na mencionada ação, foi deferida tutela antecipada autorizando o autor a substituir o membro
} 
A responsabilidade do conselheiro fiscal sobrevive ao término de seu mandato. Sobrevive, portanto, pelo prazo prescricional previsto no artigo 287, II, "b", n. 2, da Lei das S.A. e, portanto, por três (3) anos adicionais à data de publicação da ata que aprova o balanço referente ao exercício em que a violação possa ter ocorrido. A respeito desse termo específico de contagem de prazo prescricional, trataremos oportunamente, tentando concentrar o foco do estudo nas hipóteses possíveis de confronto e conflito com tal prazo legal.

O primeiro ponto de conflito reside no teor do artigo $134, \S 3^{\circ}$, da Lei das S.A., que exonera fiscais de qualquer responsabilidade, nos termos do artigo 287, II, "b", n. 2, da Lei das S.A., quando as demonstrações financeiras são aprovadas sem reserva. No indigitado artigo $134, \S 3^{\circ}$, da Lei das S.A., a única exceção prevista diz respeito às ações decorrentes de erro, dolo, fraude ou simulação, portanto, as ações do artigo 286 da Lei das S.A. e não aquelas do artigo 287. A controvérsia não é nova ${ }^{395}$ e, no caso das responsabilidades dos conselheiros fiscais, a inconsistência se agrava justamente por força da natureza da responsabilidade que órgãos fiscalizatórios têm sobre a companhia. Nesse diapasão,colocar-se-ia a seguinte questão: conselho fiscal que age de forma omissa, mas sem dolo, tendo demonstrações financeiras que fiscalizou com desdém aprovadas sem ressalvas pela assembléia, tem sua responsabilidade exonerada a partir da aprovação ou permanece com a possibilidade de ter que responder pelos danos causados pelo prazo prescricional de três (3) anos?

Em princípio, como entendemos que qualquer omissão efetivamente constatada no âmbito do conselho fiscal deve ser considerada uma violação (sob o ponto

indicado por outro que preenchesse o requisito legal de independência. Assim, "em data posterior, por sentença, julgou extinto o processo sem julgamento do mérito, ao fundamento de que, durante o curso do processo, o Conselho Fiscal já houvera sido renovado com novos membros eleitos, em razão da expiração dos mandatos do Conselho anterior, o que caracteriza a superveniente perda do interesse de agir", perda essa que motivou a interposição do citado recurso especial, que não foi conhecido em votação unânime. Ocorre que, em meio à solução proposta, o Tribunal propôs que "com a extinção do processo, a tutela antecipada deferida não mais subsiste, o que autoriza a ora recorrente, em procedimento extrajudicial, a confirmar a validade da eleição de membro indicado por BTM e outros (Sr. Vicente Pegoraro e suplente), o qual, na condição de membro eleito para um mandato já expirado, poderá ratificar, ou não, os atos praticados (junto ao Conselho Fiscal) pelo membro que o substituiu (José Miranda e suplente) em razão da tutela antecipada deferida”. Entretanto, sob a ótica da responsabilidade civil dos membros do conselho fiscal, havendo ou não votos divergentes (artigo 165 , $\S 2^{\circ}$ e $3^{\circ}$ da Lei das S.A.), como deve ser encarado, juridicamente, o ato de "ratificação" ou de "oposição a ratificação" em relação aqueles outros atos praticados por outra pessoa?

${ }^{395}$ Vide M. V. ADAMEK (Responsabilidade Civil dos Administradores..., Op. cit., Idem, pp. 226-255). Sobre a controvérsia que envolve o artigo $134, \S 3^{\circ}$, da Lei das S.A., vide, em especial, as contundentes críticas nas pp. 229-232. 
de vista funcional) da lei e do estatuto, não poderia o equívoco a que foram levados os acionistas a aprovarem as contas de companhia aberta sem ressalvas, servir, nesse caso, como atestado liberatório de responsabilidade de fiscal que induziu a assembléia a cometer esse equívoco, ainda que culposamente.

Esse conflito interno na Lei das S.A. pode, talvez, não ser tão patente no caso dos administradores, que respondem nos termos dos artigos 153 a 156. Mas, no caso dos fiscais, cuja adaptação aos regimes de tais artigos , como vimos acima, é bem mais complicada, acrescentando-se que, na essência, o conselho fiscal na maioria das vezes responde por omissão no exercício das competências, esse conflito entre o regime de exoneração da responsabilidade pelo artigo $134, \S 3^{\circ}$, e o prazo de prescrição do artigo 287, II, "b", n. 2 fica mais evidente. A solução interpretativa pode não ser simples e um reparo na lei para suprimir esse conflito potencial parece ser o melhor caminho, nesse caso.

Agrava-se o problema em um universo de responsabilidade dentro de regimes societários em períodos de anormalidade, como a liquidação, a intervenção extrajudicial (para as instituições financeiras), a falência, a recuperação judicial, a recuperação extrajudicial e os estados de crise (nos termos do artigo 47 da Lei de Falências) solucionados por acordos privados. ${ }^{396}$

No caso específico da liquidação, temos a letra do artigo 217 da Lei das S.A., incrementando o quadro controverso. Entretanto, nos parece que houve uma tremenda infelicidade na escolha das palavras e dos termos técnicos para definir o termo final da responsabilidade de fiscais nas companhias em liquidação.

De fato, os "deveres e responsabilidades" permanecem pelo prazo de prescrição, se entendidos tais "deveres e responsabilidades" como sinônimos de responsabilidade civil do órgão. O que subsiste apenas até a liquidação são as competências, qual seja, as funções ou "poderes-deveres", e, portanto, os "deveres" que

\footnotetext{
${ }^{396}$ Bulgarelli (Regime Jurídico do Conselho Fiscal..., Op. cit., Idem, pp. 165 e ss.) considera que “a análise de sua composição e funcionamento, nas fases anormais, se feita na profundidade requerida, alongaria o trabalho em demasia, considerando que cada período anormal apresenta peculiaridades de monta" (p. 165). Concordamos integralmente com o mestre, razão pela qual alocamos o tema para o capítulo das responsabilidades, talvez o mais sério e candente problema envolvendo a fiscalização em períodos de anormalidade. BULGARELli lembra, com razão (pp. 166-169), que a aquisição de direito de voto pleno para todos os tipos de ação em períodos de anormalidade pode interferir no regime de eleição politizada de membros do conselho fiscal adotada em nossa lei (e duramente criticada nesse trabalho).
} 
estão ligados ao pleno exercício daquelas. Essas competências se encerram com a extinção da companhia e o órgão se extingue, sob o ponto de vista funcional, juntamente com ela. Mas, sob o ponto de vista operacional e das responsabilidades pelo exercício dessas funções, tais responsabilidades devem sobreviver à extinção da companhia pelos prazos de prescrição previstos na Lei das S.A. Portanto, os fiscais, mesmo em tempo posterior à extinção da companhia, permanecem responsáveis pelos atos praticados ao seu devido tempo, pelo prazo prescricional de cada ato, dentro do termo legal fixado pela lei. ${ }^{397}$

Em relação ao regime de competências do conselho fiscal em companhias que estejam sob a égide da Lei de Falências, a lacuna é ainda mais profunda, pois ambas, tanto a Lei das S.A. quanto a Lei de Falências são omissas a respeito.

Em tese, vale para os estados anormais as mesmas regras que seriam aplicáveis às companhias em situação normal. Contudo, sabemos, o regime jurídico de administração em companhias em crise é completamente diverso e, sobretudo, o regime de fiscalização, que é mais atípico ainda. Seria prudente, então, pensar-se, igualmente, numa revisão do regime jurídico do conselho fiscal, sobretudo de suas responsabilidades, dos termos de extinção dessas responsabilidades, da cessação dos deveres e competências e dos prazos prescricionais em relação a medidas que necessitem ser tomadas contra fiscais. ${ }^{398}$

Por fim, cumpre comentar ainda a forma de extinção e exoneração de responsabilidade por divergência, conforme trata o $\S 3^{\circ}$. do artigo 165 , da Lei das S.A. A divergência publicada e consignada a tempo exonera o conselheiro fiscal que se nega

\footnotetext{
${ }^{397}$ Vide Carvalhosa, Comentários..., $4^{\text {o }}$ Vol., Op. cit., Idem, p. 166.

398 Nesse sentido, em relação, especificamente, aos prazos prescricionais, a Lei de Falências agrega ainda mais um fator de conflito. Trata-se do disposto no artigo $82, \S 1^{\circ}$, daquela lei, que traz prazo prescricional menor do que o previsto para ações em que a companhia estiver em situação sadia, nos termos do artigo 287 da Lei das S.A. No caso dos fiscais, a Lei de Falências é silente e expressamente alude à "responsabilidade pessoal dos sócios de responsabilidade limitada, dos controladores e dos administradores da sociedade falida" (itálico nosso). Não há como considerar, para os efeitos dessa lei, que o fiscal ou o conselheiro fiscal deva estar englobado no conceito de administrador. Administrador, tecnicamente, não é fiscal e, portanto, conselheiro fiscal não é administrador, mas está, em algumas circunstâncias a ele equiparado e apenas para certos efeitos. Ainda assim, não há como negar que o prazo prescricional de dois (2) anos (e, portanto, mais curto nos períodos de crise) gera conflito e controvérsia à luz do disposto no artigo 287 da Lei das S.A., sobretudo no caso da responsabilidade dos administradores. Nesse diapasão, vide Carlos Klein ZANINI (Comentários à Lei de Recuperação de Empresas e Falência: Lei 11.101/05, coord.: Francisco Satiro de Souza Junior e Antonio Sérgio A. de Moraes Pitombo. São Paulo: Revista dos Tribunais, 2005, p. 351).
} 
a compactuar com ato que considerar vulneração de suas funções. Trata-se, portanto, de um raro momento de acerto na formulação legal que, ao lado do $\S 2^{\circ}$ do artigo 165 , excluindo a solidariedade como regra e a impondo a conivência, procura fixar a responsabilidade do conselheiro fiscal toda vez que houver omissão, seja a omissão própria em relação ao cumprimento de um dever, seja em relação a apresentação de divergência em relação à omissão do órgão.

\section{Pareceres e Representações}

Embora a Lei das S.A. cuide do tema das representações do conselho fiscal em item separado e de redação simples, é importante notar que, sob o ponto de vista técnico, esse tema das representações deve ser considerado parte integrante do regime de responsabilidades do conselho.

As representações do conselho fiscal são o elo de ligação concreta e material entre as atribuições e competências do órgão e a materialização específica das tarefas desempenhadas. Na relação entre competências abstratas (previstas na lei) e tarefas desempenhadas (previstas em documentos elaborados pelo órgão), paira, em tese, todo o regime de responsabilidade desse órgão e de seus respectivos membros.

Nesse contexto, cumpre notar que a Lei das S.A., em seu artigo 164, parágrafo único, ao fazer uso do termo representação alude, expressamente, ao conceito teórico de representação na forma construída pela teoria geral do direito. O termo representação, aqui, não tem a mesma carga que outras esferas do direito geralmente empregam, seja no sentido de uma atuação a rogo de outrem, seja no sentido de acusação, muito típico do direito público, administrativo e processual penal. Não é essa a representação de que trata a lei e não é dessa forma que o termo representação deve ser entendido na leitura do artigo 164, parágrafo único, da Lei das S.A. ${ }^{399}$

Lembremos, portanto, que o conselho fiscal não tem atribuições acusatórias, no sentido técnico do termo. Já tivemos a oportunidade de criticar a impropriedade do termo "denunciar" no âmbito do inciso IV, do artigo 163, da Lei das

\footnotetext{
${ }^{399}$ Ousamos, data maxima venia, discordar da posição de CARVAlHoSA (Comentários..., Op. cit., Idem, p. 458) e José Anchieta da Silva (Conselho Fiscal..., Op. cit., Idem, p. 112).
} 
S.A. ${ }^{400}$. Portanto, assumindo que a tarefa do conselho fiscal é sempre desempenhada por meio de um exercício constante de solicitação de informações, esclarecimentos e prestação de informações, não havendo legitimidade do conselho fiscal para agir em nome de terceiros, cumpre notar que o emprego do termo "representações", no contexto do artigo 164, parágrafo único, da Lei das S.A., decorre da compreensão da "representação" como sinônimo de "declaração". 401

Desta forma, no contexto das funções desempenhadas ao longo de um exercício ou de um mandato, os conselheiros fiscais materializam suas ações em documentos escritos onde representam, formalmente, as situações de fato vividas.

Portanto, o conselho fiscal deve, também, ser responsável não apenas pela omissão no cumprimento de uma função, mas também pela falta de representação em casos em que, instado a declarar e representar, deixa de fazê-lo.

Há casos, logicamente, em que se deve relevar a responsabilidade do conselho fiscal quando a administração da companhia opera de forma a omitir-lhe,

\footnotetext{
${ }^{400}$ Nessa mesma linha está Bulgarelli (Regime Jurídico do Conselho Fiscal..., Op. cit., Idem, pp. 157158), que, tratando dos efeitos dos pareceres do conselho fiscal, admite que, na hipótese de parecer contrário, "não está a Assembléia Geral (rectius: o controlador) obrigada formalmente a acatar a desaprovação prévia do órgão fiscalizador", o que reforça a idéia de se admitir que as representações do conselho fiscal terão sempre o caráter informativo, sem qualquer conotação constitutiva ou desconstitutiva de direitos.

${ }^{401} \mathrm{O}$ conceito de representação como espécie de declaração é algo absolutamente assentado nos meios práticos e teóricos que envolvem a alienação de controle de companhias, pois em boa parte dos instrumentos que tratam desse tema há um emprego extenso de "representações, declarações e garantias" que as partes se prestam mutuamente. Essa espécie de representação, também conhecida como declaração enunciativa, está prevista em nossa lei civil no artigo 219, parágrafo nico. As representações prestadas pelos conselheiros fiscais, são, portanto, da mesma categoria jurídica que as declarações enunciativas e as chamadas garantias contratuais, pois os conselheiros, ao informarem os acionistas a respeito de certos detalhes de sua competência específica, visam assegurar que, à luz daquela documentação que lhes foi colocada à disposição, "o estado de caixa apresentado nas demonstrações financeiras é verossímil", "os controles internos da companhia obedecem aos padrões de risco assumido e convencionado nas políticas da companhia", "os contratos celebrados atenderam aos requisitos legais mínimos", "as políticas de contingenciamento atendem à regulamentação aplicável", "a redução de capital apresentada pela administração da companhia se justifica regularmente pelo excesso de capital detectado" e assim por diante. Qual seja, ao transmitir uma opinião favorável ou desfavorável, o conselheiro necessita afirmar um estado de fato, sempre. Esse estado de fato só se afirma por meio de uma declaração e, no caso de opiniões semelhantes de um conselho fiscal, se dão por meio de declarações enunciativas.

As declarações enunciativas, também conhecidas como declarações representativas ou meramente "representações" são, no entender de Emilio BETTI, as chamadas declarações de ciência [dichiarazione di scienza] (Teoria Generale..., Op. cit., Idem, pp. 19-22; 148-154) e, dentro do contexto próprio das representações do conselho fiscal, têm mero valor de prova (p. 151). Nessa linha, a representação feita pelo conselheiro fiscal não pode ser tomada como um "atestado de veracidade" ou "atestado de qualidade" dos fatos representados. Quando representam, os conselheiros não garantem a informação nesse sentido, mas sim no de atuar, na qualidade de fiscais internos da companhia, de forma preventiva e, muita vez, corretiva.
} 
deliberada e maliciosamente, certas informações. Mas estes são casos extremos em que o direito societário estabelece diálogo com o direito penal.

Num âmbito geral, entretanto, peca a lei, neste item, mais uma vez, por não estabelecer qual o conteúdo mínimo que o parecer do conselho fiscal previsto, por exemplo, no artigo 133, IV, da Lei das S.A., necessitaria conter para que as decisões tomadas em assembléia sejam efetuadas sob atos devidamente fiscalizados.

O mesmo pode-se dizer em relação ao parecer previsto no artigo $173, \S 1^{\circ}$ da Lei das S.A. ou no parecer que fundamenta operações de incorporação, fusão ou cisão na forma do artigo 163, III, ou ainda e em relação a pareceres que comumente se dão, ainda que não previstos em lei, como no caso da distribuição de dividendos prevista no artigo 204. Não há na legislação brasileira parâmetros mínimos para a produção desses pareceres, bem como o conteúdo esperado das representações, prejudicando, desta forma, a eficácia do desempenho das funções no órgão, sua devida comprovação e documentação, e, consequentemente, os meios de identificação de responsabilidades.

Nessa linha, o maior exemplo que dá a nossa legislação a respeito do conteúdo mínimo de um parecer emitido por órgãos de fiscalização da companhia está no teor do artigo 17, da Resolução CMN n 3198/04, que requer no relatório anual do comitê de auditoria das instituições sob a jurisdição regulatória do Banco Central do Brasil, descrição minuciosa e detalhada: (i) das atividades exercidas no âmbito das atribuições no período; (ii) avaliação da efetividade dos sistemas de controles internos da instituição, com destaque para eventuais deficiências detectadas; (iii) descrição das recomendações apresentadas à diretoria, com destaque para aquelas que não tenham sido acatadas e respectivas justificativas; (iv) avaliação da efetividade das auditorias independente e interna, inclusive quanto à verificação do cumprimento de dispositivos legais e normativos aplicáveis à instituição, além de regulamentos e códigos internos, com destaque para deficiências detectadas; (v) avaliação da qualidade das demonstrações contábeis relativas aos respectivos períodos fiscalizados, com ênfase na aplicação das práticas contábeis adotadas no Brasil e no cumprimento de normas editadas pelo Banco Central do Brasil, com destaque para deficiências detectadas. 
Esta tipificação para o parecer anual de conselho fiscal ainda não seria o bastante, mas, em comparação com o artigo 164, parágrafo único, da Lei das S.A., oferece melhores parâmetros de como materializar os trabalhos de fiscalização desempenhados em um mandato ou ainda em relação a um ato específico que demande a atenção do órgão fiscalizador (como no caso das reduções de capital).

Adicionalmente, cumpre lembrar ainda que as companhias abertas, em seus deveres de ampla divulgação e transparência, deveriam tornar públicas todas e quaisquer manifestações de seus respectivos conselhos fiscais.

A questão da publicidade das representações do conselho fiscal é outro ponto pouquíssimo explorado pela doutrina e sem tratamento na legislação, na jurisprudência e até no direito comparado. Contudo, este tema não pode ser desprezado ou tratado sem uma atenção mais especial.

Ainda que a lei dispense a publicação prévia para sua apresentação, leitura e inclusão na pauta de assembléias, não faz sentido que, uma vez exarados não haja obrigatoriedade de ampla divulgação, ao menos no caso das companhias abertas. Muita vez, matéria tratada pelo parecer anual do conselho fiscal não diz respeito apenas a interesse exclusivo de acionistas, mas também pode tocar em interesses de credores e em deveres autárquicos da CVM e de outros órgãos regulatórios como o Banco Central do Brasil, a ANEEL, a ANATEL, a ANVISA e outras autarquias com competência regulatória em determinados setores. ${ }^{402}$

Além disso, para o fim de uma fixação mais justa do termo inicial do prazo de prescrição da responsabilidade específica dos fiscais, faria muito mais sentido que esse termo se desse a partir do momento em que o conselho emite e torna pública uma representação ou opinião, ao invés de atrelar esse termo inicial, como propõe o artigo 287 da Lei das S.A., à "data da publicação da ata que aprovar o balanço referente ao exercício em que a violação tenha ocorrido".

Muitos atos, competências, opiniões e consequentes responsabilidades não ocorrem no contexto da aprovação do balanço referente a exercício em que tenha ocorrido omissão do conselho fiscal, nem estão necessariamente ligados a ele, como no caso das opiniões emitidas em reduções de capital, em incorporações, em incorporações

\footnotetext{
${ }^{402}$ Desde que observada e respeitada a advertência de FERRI, objeto, neste trabalho, da Nota 218.
} 
de ações, em distribuição de dividendos intermediários, no pagamento de participações e assim por diante.

Talvez não faça sentido exigir uma publicação física desses documentos, mas seria extremamente importante que fosse requerido, em relação às companhias abertas, que os colocassem em seus domínios eletrônicos, destinados a investidores (os chamados "sites de RI"), bem como naquele destinado à CVM, via sistema IPE (Informações Periódicas e Eventuais). Por outro lado, o termo inicial para contagem de prazo prescricional, previsto no artigo 287 da Lei das S.A., poderia continuar a ser utilizado no caso de ausência total de publicação de parecer ou representação por escrito sobre o fato objeto da ação de responsabilidade ali tratada.

\section{Contraponto}

Analisando o conselho fiscal sob o seu aspecto operacional, notamos que o regime de responsabilidade do conselho fiscal ressente-se de um regime próprio, que trate adequadamente das funções desempenhadas pelo órgão de fiscalização interna das companhias.

O direito comparado, principalmente nas lições do direito português e estado-unidense, oferece análises muito consistentes que demonstram que a opção do direito brasileiro por um regime de fiscalização orgânica separado do da administração seria uma escolha adequada.

É necessário que o sistema de responsabilidade civil crie mecanismos que garantam que o conselheiro trabalhe em constante estado de alerta e dê contínua atenção aos negócios da companhia e aos fatos da administração.

Por intermédio das lentes dos artigos 153 a 156 da Lei das S.A., essa visão fica distorcida no tocante ao conselheiro fiscal, razão pela qual, seja em casos de 
patente omissão, seja em casos de abuso de autoridade, as formas de responsabilização do mesmo beiram a inefetividade total e asseguram certa impunidade, tanto no mais quanto no menos.

Considerando, desta feita, um quadro operacional de conselho fiscal como descrito nos Capítulos 6 e 7, a lei brasileira parece carecer, sobretudo em relação às companhias abertas:

I. de um regime de responsabilidade civil para os conselheiros fiscais que the seja próprio e corresponda exatamente à natureza de suas funções, que precisam ser descritas e tipificadas com mais precisão e rigor no rol do artigo 163 da Lei das S.A.;

II. de que esse regime de responsabilidade civil seja construído, tecnicamente, com base em um conceito de responsabilidade civil orgânica-objetiva, tomando-se o devido cuidado para não colocá-lo em um universo exclusivamente centrado na culpa ou nos conceitos típicos da responsabilidade contratual, de difícil transposição para o o conselho fiscal;

III. de que esse regime de responsabilidade civil próprio tenha critérios de solidariedade que condigam, exatamente, com a parcela de participação que o conselho fiscal tem ou deve ter em cada item específico de sua competência;

IV. de que esse regime de responsabilidade civil tenha, não apenas sob o ponto de vista procedimental, um conjunto de regras que corresponda à natureza fiscalizatória própria do órgão, mas que também tenha um formato e um termo de encerramento que seja adequado às várias situações de fato que as empresas possam estar vivendo;

V. adicionalmente, de que esse regime de responsabilidade seja diferenciado em momentos diferenciados da companhia, qual seja, em situações que envolvam estados 
de liquidação ou intervenção extrajudicial, bem como em situações de crise que comportem reorganizações societárias, recuperações judiciais ou extrajudiciais e acordos privados dentro do regime jurídico da Lei de Falências;

VI. de que, ainda, proponha a lei um modelo formal e típico de pareceres e representações para todos os casos em que o conselho é chamado a opinar, prevendo, em cada situação, qual o conteúdo mínimo que tais documentos devem conter, as informações e as avaliações obrigatórias que o órgão tem de, necessariamente, representar em face do público que cerca os interesses de uma companhia; e

VII. de que, nesse sentido, se reconheça que a estrutura dos artigos 164 e 165 e respectivos parágrafos é, com poucas dúvidas, uma das partes mais carentes de reforço teórico constantes da Lei das S.A. 


\section{PARTE FINAL -}

\section{O CONSELHO FISCAL EM PERSPECTIVA}




\section{CONCLUSÃO: O CONSELHO FISCAL NO UNIVERSO DA CULTURA E DO DIREITO BRASILEIRO}

Inquestionavelmente, a Lei das S.A. foi, ao seu tempo, e ainda é, em muitos aspectos, uma das mais modernas e bem escritas leis societárias de que se tem notícia.

A condução elegante e ao mesmo tempo precisa do texto capitaneado por Alfredo Lamy Filho e José Luiz de Bulhões PedreIRA permitiu que o Brasil tomasse emprestado desses dois geniais juristas, um ordenamento societário ao mesmo tempo técnico e didático.

Contudo, passados trinta e dois anos, a lei que, em 1976, marcava, com algumas raras imprecisões, um novo período no direito societário e no mercado de capitais brasileiro, já apresenta aspectos de desatualização. Após duas reformas sensíveis, a lei ganhou sobrevida. Entretanto, há pontos em que está desatualizada.

Ao longo deste trabalho procuramos, à exaustão, estudar o fenômeno da fiscalização societária com foco no conselho fiscal das companhias abertas.

Nosso histórico nunca nos favoreceu e a cultura brasileira sempre se mostrou avessa à fiscalização, seja sob o ângulo de quem fiscaliza, seja sob o ângulo de quem é fiscalizado. Definitivamente, não há no Brasil uma tradição fiscalizatória, seja porque o brasileiro não é simpático à tarefa de fiscalizar, seja porque o brasileiro, definitivamente, detesta ser fiscalizado. Há, em nossa cultura, um pendor maior para a tolerância de vícios e deslizes, privados ou públicos.

A história do direito de outras nações como os EUA e a França mostra que, nesses países, a intolerância com os vícios e com os deslizes é muito menor, o que leva o exercício do direito, nesses países, a um rigor maior e, consequentemente, a uma fiscalização mais efetiva e empenhada. 
Contudo, em sede de direito comparado notou-se que, embora efetiva e empenhada, essa fiscalização nem sempre é eficaz, fato que se atestou visivelmente no caso dos EUA.

Nossa tradição, historicamente, sempre levou a fiscalização societária a um regime, digamos, "caseiro", de onde temos, hoje, a nossa estrutura de fiscalização interna.

Com a evolução de nosso mercado de capitais e com a chegada dos investidores e empreendedores estrangeiros, um outro modelo de fiscalização societária correu em paralelo, para que o investidor estrangeiro não precisasse se acostumar com o "arroz com feijão" dos conselhos fiscais: adotamos um regime de auditoria e, mais recentemente, de fiscalização por comitê de auditoria. Mas nunca pensamos de forma sistêmica a respeito do nosso regime de fiscalização, nem tampouco sobre a pertinência dessas formas paralelas, em vista de uma tradição de fiscalização interna.

Ao lado disso, nosso eixo de fiscalização interna se politizou e a essência da fiscalização societária se perdeu entre funções esparsas e um regime de responsabilidade incoerente com as necessidades do mercado de capitais brasileiro.

Em outras palavras, o conselho fiscal, sob o ângulo técnico-jurídico, esclerosou. Tornou-se um órgão senil, cujas funções se perderam em meio à defesa de interesses específicos de grupos qualificados que orbitam em volta da administração das companhias.

As legislações do mundo, a começar pela Europa e pelos EUA, vêm, desde 2001 até muito recentemente (2006), implementando regimes de fiscalização mais coerentes com a complexidade crescente do direito societário e do mercado de capitais desse Admirável Mundo Novo - exceto o Brasil, que trata o seu regime de fiscalização societária da mesma forma que há pelo menos cem anos, o que o torna um “órgão inútil”.

Os estudos empreendidos mostraram que, em matéria de fiscalização societária, a nossa lei ficou desatualizada, exceto pelas poucas intervenções em que o conselho fiscal foi usado como "moeda de troca legislativa" em tema de "direitos de minoria". Sacrificou-se, portanto, a independência. 
O direito comparado chama muito a atenção do estudioso pela acelerada evolução que o tema vem tendo e pela profundidade dos estudos e das crescentes alterações que as legislações vêm sofrendo, como reflexo dos mesmos.

O Brasil, por sua vez, mantém um texto que, praticamente, carrega de forma congelada um espírito de fiscalização que teve início com a República. Desde lá, os reparos substanciais nas funções fiscalizatórias das companhias abertas lograram apenas acentuar as divisões políticas nas companhias, sem trazer benefício, sob o ponto de vista prático, para o conteúdo das informações fiscalizadas e sobre o material que é objeto da vigilância do técnicoo fiscal).

O estudo pormenorizado do conselho fiscal na Lei das S.A. mostrou um órgão, sob o ponto de vista formal, defeituoso: com graves problemas em seu formato de funcionamento e duração do ofício, nos requisitos mínimos de qualificação de seus membros e respectiva estabilidade e, sobretudo, com problemas profundos de independência.

\footnotetext{
Sob o ponto de vista funcional, outros sérios defeitos foram identificados, sobretudo por conta dos conflitos de atribuição e imprecisão das competências.
}

Para concluir, notamos também que, sob o ponto de vista operacional, o órgão padece de ineficácia, muito por conta de seu confuso regime de responsabilidade civil, incluindo as regras sobre extinção de responsabilidades, a ausência de regras sobre a responsabilidade do fiscal em regimes especiais como o da empresa em crise ou em liquidação, os conflitos substanciais entre os prazos de prescrição e a indefinição do papel preciso das representações do órgão perante a comunidade acionária e o público em geral.

Incumbe questionar, portanto, se está adequado o regime que temos em vigor para a fiscalização societária, diante de um mercado de capitais intensamente modificado pelo ímpeto incrível das aberturas de capital que inundaram o Brasil entre 2003 e 2007 e pela crença cega nos cânones neo-liberais que agora enfrentam a sua primeira crise séria, atingindo muitas empresas em função das políticas pouco ortodoxas de investimento em futuros e derivativos. 
O Brasil, em meio a esta atual crise que assola uma quantidade considerável de companhias abertas por conta do "sub prime brasileiro dos derivativos" (como vem sendo chamada), ostenta instrumentos preventivos suficientes, com um nível de fiscalização adequada em relação a contratos celebrados fora da órbita do objeto das companhias atingidas?

Estaria o ordenamento societário brasileiro preparado, sob outros aspectos, para prevenir-se e precaver-se contra outros reflexos dessa mesma crise ou ainda contra crises futuras, no tocante à fiscalização das companhias? O conselho fiscal se mostra um órgão adequado para desempenhar essas funções, nesse contexto? Enfim: o conselho fiscal, tal qual desenhado pela lei, está preparado para efetivamente fiscalizar?

Pelo visto, não.

E, ao que parece, salvo melhor juízo, poderia minimizar essa ineficiência se: fosse de funcionamento permanente para as companhias abertas, guarnecido de requisitos mínimos de qualificação para seus membros, aos quais deveria ser assegurada estabilidade e independência, com uma descrição mais clara de suas competências e representações bem como um regime adequado de responsabilidade civil.

Esta é uma discussão que não poderia ficar para depois. O primeiro passo tentou-se dar aqui, neste trabalho - o de reiniciar a discussão, aberta anos atrás nesta mesma Casa pelo saudoso mestre de todos nós, o Professor Waldírio BULGARELLI.

Cumpre agora seguir o debate, "porque ao dizer palavras que nunca tinha dito antes, aprendi o que antes não sabia". 


\section{BIBLIOGRAFIA}




\section{Doutrina estrangeira}

Acosta Romero, Miguel; García Ramos, Francisco de A.; García Alvarez, Paola. Tratado de sociedades mercantiles con énfasis en la sociedad anónima. México: Porrúa, 2004.

Albuquerque, Pedro. Os Limites à Pluriocupação dos Membros do Conselho Geral e de Supervisão e do Conselho Fiscal. Coimbra: Almedina, 2007.

AsCARELli, Tullio. Appunti di Diritto Commerciale - società e associazioni commerciale. $3^{\mathrm{a}}$ ed.. Roma: Foro Italiano, 1936.

. Saggi di Diritto Commercialle. Milão: Giuffrè, 1955.

Auletta, Giuseppe; SAlAnitro, Nicolò. Diritto Commerciale, $16^{\mathrm{a}}$ ed.. Milão: Giuffrè, 2008.

Backman, Gerald S.; Salan, Anne Marie. Audit Committees: Regulation and Practice. Nova Iorque, NY: Aspen Law, 2005.

BAVA, Fabrizio. Il Controllo legale dei conti: collegio sindacale e società di revisione. Milão: Giuffrè, 2005.

Berle, Adolf Augustus; Means, Gardiner Coit. The Modern Corporation and Private Property, $4^{\mathrm{a}}$ reimpressão, Nova Brunswick, NJ: Transaction, 2002.

BERTINI, Alessandro. Contributo allo studio delle situazioni giuridiche degli azionisti. Milão: Giuffrè, 1951.

BILL, Arthur H.. Audit Committee Guide, 2a ed.. Nova Iorque, NY: Bowne, 2004.

BRUNETTI, Antonio. Sociedades mercantiles. México: Juridica Universitaria, 2001.

Cabanellas de las Cuevas, Guillermo. Derecho Societario. Buenos Aires: Heliasta, 1996.

CASTRILlón y Luna, Víctor M.. Sociedades mercantiles. México: Porrúa, 2003. . Ley general de sociedades mercantiles comentada. México: Porrúa, 2007.

Chalupowicz, Daniel. Gobierno Corporativo - un enfoque moderno de direccíon para el cumplimiento con ley Sarbanes-Oxley y prevención del fraude corporativo. Buenos Aires: Buyatti, 2007.

Champaud, Claude. Le Pouvoir de Concentration de la Société par Actions. Paris: Sirey, 1962.

ClARK, Robert Charles. Corporate Law, Boston: Little Brown/Aspen, 1986. 
COFFEE JR., John C.. Gatekeepers - the professions and corporate governance. Oxford: Oxford University Press, 2006.

Colombres, Gervasio R.. Curso de Derecho Societário. Buenos Aires: Abeledo-Perrot, 1972.

Cossu, Francesco. L'independenza del collegio sindicale e del revisore contabile. Milão: Giuffrè, 2006.

Cox, James D.; Hillman, Robert W.; Langevoort, Donald C.. Securities Regulation, $3^{\text {rd }}$ ed.. Nova Iorque: Aspen, 2001.

Cozian, Maurice; Viandier, Alain; Deboissy, Florence. Droit des sociétés, 19éme ed. Paris: Litec/Lexis Nexis, 2006.

Cunha, Paulo Olavo. Direito das Sociedades Comerciais, $2^{\mathrm{a}}$ ed.. Coimbra: Almedina, 2006.

DoOLEY, Michael P.. Fundamentals of Corporation Law. Brunswick, NY: Carolina University Press, 1995.

EASTERBROOK, Frank H.; FISCHEl, Daniel R.. The Economic Structure of Corporate Law, $4^{\mathrm{a}}$ reimpressão. Cambridge, Mass: Harvard University Press, 1998.

EMANUEL, Steven. Corporations, $3^{\mathrm{a}}$ ed.. Larchmont, NY: Emanuel, 2000.

EPSTEIn, Richard; Gergory, Charles; CALven JR., Harry. Torts, $4^{\mathrm{a}}$ ed.. Boston, Mass: Little, Brown \& Co., 1984.

FERRI, Giuseppe. Le Società. Turim: UTET, 1971.

FIGUEIREDO DiAs, Gabriela. Fiscalização de sociedades e responsabilidade civil (Após a reforma do Código das Sociedades Comerciais). Coimbra: Coimbra, 2006.

FIORI, Giovanni. Corporate Governance e qualità dell'informazione esterna d'impresa. Milão: Giuffrè, 2003.

FRADA, Manuel Carneiro. Uma "Terceira Via" no Direito de Responsabilidade Civil?. Coimbra: Almedina, 1997.

FRANCHI, Antonio. La responsabilità degli amministratori di S.p.a. nel nuovo diritto societario - i principi per una disciplina 'europea' e $i$ riflessi nell'ambito delle società bancarie. Milão: Giuffrè, 2004.

GALGANO, Francesco. La società per azione, Pádua: CEDAM, 1984. Diritto Privato, $13^{\mathrm{a}}$ ed.. Padova: CEDAM, 2006. Lex Mercatoria. Bolonha: Il Mulino, 2007. Diritto Commerciale (Edizione Compatta), 6 ed.. Bolonha: Zanichelli, 2008. 
GRANGER, Roger. La nature juridique des rapports entre actionnaires et commissaires - charges du controle dans les sociétés par actions. Reims: Matot-Braine, 1951.

HalPerín, Isaac. Sociedades Anónimas, $2^{\mathrm{a}}$ ed. (com glosas de Julio OtAegui). Buenos Aires: Depalma/LexisNexis, 1998.

Le Cannu, Paul. Code des Sociétés, 15émé ed. Paris, Dalloz, 1998.

MACEDo Hernandez, José Héctor. Ley general de sociedades mercantiles anotada, comentada, concordada con jurisprudencia y tesis. México: Cardenas, 1984.

MalagarRiga, Carlos C.. Tratado elemental de derecho comercial, Tomo I, $1^{\text {a }}$ Parte. Buenos Aires: TEA, 1951.

MARTORELl, Ernesto Edoardo. Los síndicos de sociedades anónimas y el consejo de vigilancia. Buenos Aires: Depalma, 1991. Sociedades anónimas, $2^{\mathrm{a}}$ ed.. Buenos Aires: Depalma, 1994.

Marzorati, Osvaldo J.. Alianzas estratégicas y joint ventures. Buenos Aires: Astrea, 1996.

Menezes Cordeiro, António. Manual de Direito das Sociedades, Volume I: Das Sociedades em Geral. Coimbra: Almedina, 2004. . Direito Europeu das Sociedades. Coimbra: Almedina, 2005.

Poli, Stefano. La nuova disciplina del collegio sindacale - la professionalità $e$ l'indipendenza dei sindaci nell' $8^{a}$ direttiva CEE in materia societária. Padova: CEDAM, 1997.

Richard, Efraín Hugo; Muiño, Orlando Manuel. Derecho Societario, $5^{\text {a }}$ reimpressão. Buenos Aires: Astrea, 2004.

RIPERT, Georges; RoBlot, René. Traité de Droit Commercial, $13^{\text {éme }}$ ed., Tomo I. Paris: Libreirie Générale de Droit et de Jurisprudence, 1989.

Rivarola, Mario A.. Sociedades anónimas, Tomo II, $3^{\mathrm{a}}$ ed.. Buenos Aires: La Facultad, 1935.

Rodriguez RodrigueZ, Joaquín. Tratado de Sociedades Mercantiles, Tomo II, $4^{\mathrm{a}}$ ed.. México: Porrúa, 1971.

SAsOt-Betes, Miguel; SASOT, Miguel. Sociedades anónimas: sindicatura y consejo de vigilancia. Buenos Aires: Ábaco, 1986.

SASSO, Cosimo. Irregolarità di bilancio e responsabilità di amministratori e sindaci. Milão: Giuffrè, 2000.

SCHMIDT, Dominique. Le Droits de la minorité dans la société anonyme. Paris: Sirey, 1970.

Les conflits d'intérêts dans la société anonyme. Paris, Joly, 2004. 
VASQUeS, José. Estruturas e Conflitos de Poderes nas Sociedades Anónimas. Coimbra: Coimbra, 2007.

VERÓN, Alberto Victor. Estados contables y libros de comercio. Buenos Aires: Abaco, 1976.

La sindicatura y el delito de balance falso. Buenos Aires: Astrea, 1981.

. Nueva empresa y derecho societario. Buenos Aires: Astrea, 1996.

Sociedades Comerciales. Buenos Aires: Astrea, 1996.

Auditoria y sindicatura societaria. Buenos Aires: Errepar, 1997.

Los Balances. Buenos Aires: Errepar, 1997.

. Manual de sociedades comerciales. Buenos Aires: Errepar, 1998.

Tratado de los conflictos societarios. Buenos Aires: La Ley, 2006.

Auditoría, Sindicatura y Consejo de Vigilancia. Buenos Aires: La Ley, 2007.

VERÓN, Alberto Victor; ZUNINO, Jorge. Reformas al régimen de las sociedades comerciales. Buenos Aires: Astrea, 1984.

Vivante, Cesare. Trattato di Diritto Commerciale, Vol. II - le società commerciali, $4^{\mathrm{a}}$ ed.. Milão: Dott. Francesco Vallardi, 1912.

\section{Doutrina estrangeira (obras coletivas)}

AlESSI Ricardo; et alli. Il Collegio Sindicale - le nuove regole. [org.: Berardino Libonati e Paolo Ferro-Luzzi, coord.: Ricardo Alessi, Niccolò Abriani e Umberto Morera], Milão: Giuffrè, 2007.

AOKI, Masahiko; et alli. Corporate Governance in Japan: Institutional Change and Organizational Diversity [orgs.: Masahiko Aoki, Gregory Jackson e Hideaki Miyajima]. Nova Iorque, NY: Oxford University Press US, 2008.

BUONOCORE, Vicenzo; et alli. Manuale di diritto commerciale, $8^{\mathrm{a}}$ ed.. Turim: Giappichelli, 2007.

Coutinho De ABReu, Jorge Manuel; et alli. Reformas do Código das Sociedades, vol. $3^{\mathrm{o}}$. [org.: Jorge Manuel Coutinho de Abreu] Coimbra: Almedina, 2007.

KRAAKMAN, Reinier R.; et alli. The Anatomy of Corporate Law. Oxford, UK: Oxford University Press, 2004.

Pinheiro Monteiro, António Joaquim de Matos; et alli. Nos 20 anos do Código das Sociedades Comerciais, Vol. I [org.: António Joaquim de Matos Pinheiro Monteiro]. Coimbra: Coimbra, 2008.

Romano, Roberta; et alli. In Foundations of Corporate Law [org.: Roberta Romano]. Nova Iorque, NY: Foundation Press, 1993. 


\section{Doutrina nacional}

AsCarelli, Tullio. Problemas das Sociedades Anônimas e Direito Comparado. São Paulo: Saraiva, 1945.

BAPTISTA, Luiz Olavo. Empresa Transnacional e Direito. São Paulo: Revista dos Tribunais, 1987.

BARrA, Juliano Sarmaneto. Fundos de Pensão Instituídos na Previdência Privada Brasileira. São Paulo: LTr, 2008.

BAsso, Maristela. Joint Ventures - Manual Prático das Associações Empresariais, $2^{\mathrm{a}}$ ed.. Porto Alegre: Livraria do Advogado, 1998.

Borba, José Edwaldo Tavares. Direito Societário, 10 ed.. Rio de Janeiro: Renovar, 2007.

Borges, João Eunápio. Curso de Direito Comercial Terrestre, $4^{\mathrm{a}}$ ed.. Rio de Janeiro: Forense, 1969.

Bulgarelli, Waldírio. O Regime Jurídico do Conselho Fiscal das S/A. Rio de Janeiro: Renovar, 1998.

. Regime Jurídico da Proteção às Minorias nas S/A (de acordo com a reforma da Lei 6.404/76. Rio de Janeiro: Renovar, 1998.

Bulhões Pedreira, José Luiz de; LAmy Filho, Alfredo. A Lei das S.A., $1^{\mathrm{o}}$ vol., $3^{\mathrm{a}}$ ed.. Rio de Janeiro: Renovar, 1997.

CANTIDIANO, Luiz Leonardo. Reforma da Lei das S.A. comentada. Rio de Janeiro: Renovar, 2002.

Carvalho de Mendonça, José Xavier. Tratado de Direito Comercial Brasileiro, $4^{\mathrm{a}}$ edição, Volume IV. Rio de Janeiro: Freitas Bastos, 1946.

Carvalhosa, Modesto. Comentários à Lei das Sociedades Anônimas, $3^{\mathrm{a}}$ ed.. São Paulo: Saraiva, 2003.

Coelho, Fábio Ulhôa. Curso de Direito Comercial, 10ª ed.. São Paulo: Saraiva, 2007.

Comparato, Fábio Konder. O Poder de Controle na Sociedade Anônima, $4^{\mathrm{a}}$ ed. (com comentários de Calixto Salomão Filho). Rio de Janeiro: Forense, 2005.

CORRÊA-LIMA, Osmar Brina. Responsabilidade Civil dos Administradores de Sociedade Anônima. Rio de Janeiro: AIDE, 1989. O Acionista Minoritário no Direito Brasileiro. Rio de Janeiro: Forense, 1994. Sociedade Anônima, $3^{\mathrm{a}}$ ed.. Belo Horizonte: Del Rey, 2005.

Cunha Peixoto, Carlos Fulgêncio da. Sociedades por Ações, $4^{\circ}$ Volume. São Paulo: Saraiva, 1972. 
DIAS, José de Aguiar. Da Responsabilidade Civil, $11^{\text {a }}$ ed.. Rio de Janeiro: RENOVAR, 2006.

EIZIRIK, Nelson Lars. Reforma das S.A. e do Mercado de Capitais. Rio de Janeiro: Renovar, 1997.

EiziriK, Nelson Lars; CARVAlhosa, Modesto. A Nova Lei das S/A. São Paulo: Saraiva, 2002.

ENEI, José Virgílio Lopes. Project Finance: financiamento com foco em empreendimentos (parcerias público-privadas, 'leveraged buy-outs' e outras figuras afins). São Paulo: Saraiva, 2007.

FerreIRA, Waldemar Martins. Tratado de Direito Comercial, $4^{\circ}$ vol. - "O estatuto da sociedade por ações". São Paulo: Saraiva, 1961.

FrançA, Erasmo Valladão Azevedo e Novas. Conflito de Interesses nas Assembléias de S.A.. São Paulo: Malheiros, 1993.

Marcondes, Sylvio. Questões de Direito Mercantil. São Paulo: Saraiva, 1977.

Martins, Fran. Comentários à Lei das S.A.. Rio de Janeiro: Forense, 1978.

Munhoz, Eduardo Secchi. Empresa Contemporânea e Direito Societário - Poder de Controle e grupos de Sociedades. São Paulo: Juarez de Oliveira, 2002.

Novaes HironaKa, Giselda Maria Fernandes. Responsabilidade Pressuposta. Belo Horizonte: Del Rey, 2005.

Penteado, Mauro Rodrigues. Aumentos de capital das sociedades anônimas. São Paulo: Saraiva, 1988.

PereIRA, Caio Mário da Silva. Responsabilidade Civil, $9^{\mathrm{a}}$ ed., $3^{\mathrm{a}}$ tiragem. Rio de Janeiro: Forense, 1999.

PimentA, Eduardo Goulart. Joint Ventures - Contratos de Parceria Empresarial no Direito Brasileiro. São Paulo: Juarez de Oliveira, 2005.

Pontes De Miranda, Francisco Cavalcanti. Tratado de Direito Privado, $3^{\mathrm{a}}$ ed.. Rio de Janeiro: Borsoi, 1970.

RoDAS, João Grandino. Sociedade Comercial e Estado. São Paulo: Saraiva, 1995.

Salomão Filho, Calixto. O Novo Direito Societário, $3^{\mathrm{a}}$ ed.. São Paulo: Malheiros, 2006.

SILVA, Alexandre Couto. Responsabilidade dos Administradores de S/A - "Business Judgement Rule”. Rio de Janeiro: Elsevier, 2007. 
Silva, José Anchieta da. Conselho Fiscal nas Sociedades Anônimas Brasileiras: o conselho fiscal à luz da lei de sociedades anônimas em vigor. Belo Horizonte: Del Rey, 2000 .

Tavares Guerreiro, José Alexandre; TeIXeIrA, Egberto Lacerda. Das Sociedades Anônimas no direito brasileiro. São Paulo: José Bushatsky, 1979.

VAlVERDE, Trajano de Miranda. Sociedades por Ações, $2^{\mathrm{a}}$ ed.. Rio de Janeiro: Forense, 1953.

VerÇOSA, Haroldo Malheiros Duclerc (Bancos centrais no direito comparado: o sistema financeiro nacional e o banco central do Brasil (o regime vigente $e$ as propostas de reformulação). São Paulo: Malheiros, 2005.

. Curso de Direito Comercial, vol. 3. São Paulo: Malheiros, 2008.

YAZBeK, Otavio. Regulação do Mercado Financeiro e de Capitais. Rio de Janeiro: Elsevier, 2007.

\section{Doutrina nacional (obras coletivas)}

Bulgarelli, Waldírio; et alli. Reforma da Lei das Sociedades Por Ações [coord.: Waldírio Bulgarelli]. São Paulo: Pioneira, 1998.

Souto, Marcos Juruena Vilella; et alli. Direito Empresarial Público [orgs.: Marcos Juruena Vilella Souto e Carla C. Marshall]. Rio de Janeiro: Lumen Juris, 2002.

SouZA Junior, Francisco Satiro; et alli. Comentários à Lei de Recuperação de Empresas e Falência: Lei 11.101/05 (coord.: Francisco Satiro de Souza Junior e Antonio Sérgio A. de Moraes Pitombo). São Paulo: Revista dos Tribunais, 2005.

\section{Artigos (doutrina estrangeira)}

BACKER, Larry Catá. "The Duty to Monitor: emerging obligations of outside lawyers and auditors to detect and report corporate wrongdoing beyond the securities laws", In In St. John's Law Review, vol. 77, nr. 4, Nova Iorque, NY: St. John's Law Review Association, Setembro-Novembro, 2003, pp. 919-1018.

. "The Sarbanes-Oxley Act: federalizing norms for officer, lawyer, and accountant behavior", In St. John's Law Review, vol. 76, Nova Iorque, NY: St. John's Law Review Association, Setembro-Novembro, 2002, pp. 897-951.

"Surveillance and Control: privitizing and nationalizing corporate monitoring after Sarbanes-Oxley", In Michigan State Law Review, Detroit, MI: Law Review of Michigan State University - Detroit College of Law, Junho-Agosto, 2004, pp. 327-440.

BARRETT, Matthew J.. "Tax Services' as a Trojan Horse in the auditor independence provisions of Sarbanes-Oxley", In Michigan State Law Review, Detroit, MI: Law Review of Michigan State University - Detroit College of Law, Junho-Agosto, 2004, pp. 463-503. 
BeBCHUк, Lucian Ayre. "The Myth of Shareholder Franchise", In Virginia Law Review, vol. 93, Charlottesville, VA: Virginia Law Review Association, Maio, 2007, pp. 675732.

BRATTON, William W.. "Shareholder value and auditor independence", In Duke Law Journal, vol. 53, Durham, NC: Duke Law Journal, Novembro, 2003, pp. 439-488.

BROWN JR., J. Robert.. "The irrelevance of state corporate law in the governance of public companies", In University of Richmond Law Review, vol. 38, Richmond, VA: The University of Richmond Law Review Association, Janeiro, 2004, pp. 317-380.

ClARK, Robert Charles. "Corporate Governance changes in the wake of the SarbanesOxley Act: a morality tale for policemakers too", In Georgia State University Law Review, vol. 22, Atlanta, GA: Georgia State University College of Law, Setembro, 2005, pp. 251-296.

. "The four stages of capitalism: reflections on investment management treatises" In Harvard Law Review, vol.94. Boston, Mass: Harvard University Press, 1981; pp.561582.

Clarke, Donald C.. "Three Concepts of Independent Director", In Delaware Journal of Corporate Law, vol. 32. Wilmington, DE: Delaware Law School of Widener University, Inc., 2007, pp. 73-111.

COASE, Ronald. "The Nature of the Firm", In Economica, volume 4, $16^{\mathrm{a}}$ edição, Londres: LSE, Novembro de 1937, pp. 386-405.

CORAPI, Diego. "Les systémes d'administration et controle en Italie suite à la réforme du droit des sociétés", In Revista de Direito Bancário e do Mercado de Capitais, vol. 37. São Paulo: Ed. Revista dos Tribunais, jul-set/2007, p.107.

- "La riforma italiana della società di capitali: modelli continentali, modelli di common law", In Revista de Direito Bancário e do Mercado de Capitais, vol. 25. São Paulo: Ed. Revista dos Tribunais, jul-set/2004, p.123.

Cox, James D.. "After the Sarbanes-Oxley Act: the future disclosure system reforming the culture of financial reporting - the PCAOB and the metrics for accounting measurements", In Washington University Law Quarterly, vol. 81, St. Louis, MO: Washington University Press, junho-agosto, 2003, pp. 301-327.

EASTERBROOK, Frank H.; FISCHEL, Daniel R.. "Mandatory disclosure and the protection of investors" In Virginia Law Review, vol. 70. Charlottesville, VA: Virigina Law Review Association, 1984, pp. 669-715.

FASTRICH, Lorenz. "Raciocínio Jurídico Funcional a Exemplo do Direito Societário" (traduzido por Nilson Lautenschleger Junior), In Revista de Direito Mercantil, Industrial, Econômico e Financeiro, volume 140. São Paulo: Malheiros, out-dez/2005, p. 52 .

FEROLA, Peter. "The role of audit committees in the wake of corporate federalism: Sarbanes-Oxley's creep into state corporate law", In Journal of Business and Securities 
Law, vol. 7, East Lansing, MI, Michigan State University College of Law, Março-Maio, 2007, pp. 143-162.

GELB, Harvey. "Corporate Governance and the Independence Myth", In Wyoming Law Review, vol. 6, Laramie, WY: University of Wyoming Press, 2006, pp. 129-163.

KRAAKMAN, Reinier H.; GILSON, Ronald. "The mechanisms of market efficiency", In Virginia Law Review, vol. 70. Charlottesville, VA: Virigina Law Review Association, 1984, pp. 549-644.

LeVMore, Saul. "Efficient Markets and Puzzling Intermediaries", In Virginia Law Review, vol. 70. Charlottesville, VA: Virigina Law Review Association, 1984, pp. 645667.

NELSON, Jeannie. "New Corporate Responsability Law increases liabilities for directors, officers, and attorneys, but does it increase protections for investors?", In Texas Tech Law Review, vol. 34, Lubbock, TX: The School of Law Texas Tech University Press, 2003, pp. 1165-1197.

PENTEADO, Mauro Bardawil. "The efficacy of intra-corporate approvals in negotiated mergers between controlling shareholder and its corporation under Delaware and Brazilian law", In Revista de Direito Mercantil, Industrial, Econômico e Financeiro, volume 143. São Paulo: Malheiros, jul.-set. 2006, p. 76.

SELIGMAN, Joel. "The SEC at 70: a modest revolution in corporate governance", In Notre Dame Law Review, vol. 80, Notre Dame, In Notre Dame Law Review, Março, 2005, pp. 1159-1185.

" "Conflicts of interest in corporate and securities law: no one can serve two masters - corporate and securities law after Enron", In Washington University Law Quarterly, vol. 80, St. Louis, MO: Washington University, Junho-Agosto, 2002, pp. 449-517.

Stout, Lynn A.. "The Mythical Benefits of Shareholder Control”, In Virginia Law Review, vol. 93, Charlottesville, VA: Virginia Law Review Association, Maio, 2007, pp. 788-809.

\section{Artigos (doutrina nacional)}

Alves, Rui Fernando Ramos. "As responsabilidades dos membros do Comitê de Auditoria das instituições financeiras" In Revista de Direito Bancário e do Mercado de Capitais, vol. 25. São Paulo: Ed. Revista dos Tribunais, jul.-set. 2004, p.372.

ArAúso FILHO, Raul de; CunHA, Rodrigo Ferraz. "Limites de atuação do conselho fiscal", In Revista de Direito Mercantil, Industrial, Econômico e Financeiro, vol. 129. São Paulo: Malheiros, jan.-mar. 2003, p. 96.

Bandeira De Mello, Celso Antonio. "Função Controlada do Tribunal de Contas", In Revista de Direito Público, vol. 99. São Paulo: Ed. Revista dos Tribunais, jul.-set. 1991, p.160. 
BuCcioli, Fábio. "Conselho Fiscal das Sociedades Anônimas como órgão 'sui generis' na Lei n. 6404/76 e no anteprojeto da CVM", In Revista de Direito Mercantil, Industrial, Econômico e Financeiro, vol. 105. São Paulo: Malheiros, jan.-mar. 1997, p. 134.

CAntidiano, Luiz Leonardo. "Comitê de Auditoria $X$ Conselho Fiscal", In Revista RI, São Paulo: IBRI, Abril de 2003, pp. 7-8.

Clark, Ivan. "Conselho Fiscal ou Comitê de Auditoria? Opção?", In Revista RI, São Paulo: IBRI, Abril de 2003; pp. 9-10.

EIZIRIK, Nelson Lars. "Limites à Atuação do Conselho Fiscal", In Revista de Direito Mercantil, Industrial, Econômico e Financeiro, vol. 84. São Paulo: Ed. Revista dos Tribunais, out.-dez./1991, p. 14.

FERES, Marcelo Andrade. "O Estado Empresário: reflexões sobre a eficiência do regime jurídico das sociedades de economia mista na atualidade", In Revista de Direito do Estado, vol. 2, nr. 6. Rio de Janeiro: Renovar, abr.-jun. 2007, p. 269.

FinKelsteIN, Claudio; GouveIA, Roberta. "Lei Sarbanes-Oxley Act 2002 e suas implicações às empresas brasileiras", In Revista de Direito Internacional e Econômico, vol. 4, Porto Alegre: Síntese, Julho-Agosto/2003, pp. 92-102.

FrAnÇA, Erasmo Valladão Azevedo e Novaes. "Conflito de Interesses: Formal ou Substancial? Nova decisão da CVM sobre a questão", In Revista de Direito Mercantil, Industrial, Econômico e Financeiro, vol. 128. São Paulo: Malheiros, out.-dez. 2002, p. 225.

HILÁRIO, Benedito Garcia. "Conselho Fiscal da Sociedade Anônima", In Revista de Direito Mercantil, Industrial, Econômico e Financeiro, vol. 12. São Paulo: Ed. Revista dos Tribunais, 1973, p. 55.

LAmy FILHo, Alfredo. "A Reforma da Lei das Sociedades Anônimas", In Revista de Direito Mercantil, Industrial, Econômico e Financeiro, vol. 7. São Paulo: Ed. Revista dos Tribunais, nr. III, 1972, p. 158.

Loвo, Carlos Augusto da Silveira. "Conselho Fiscal da Sociedade Anônima: atuação individual e autônoma de seus membros", In Revista de Direito Bancário e do Mercado de Capitais, vol. 29. São Paulo: Ed. Revista dos Tribunais, jul.-set. 2005, p. 165.

Mello, Claudinei de. "O sexto poder interna corporis da sociedade anônima", In Revista de Direito Mercantil, Industrial, Econômico e Financeiro, vol. 62. São Paulo: Ed. Revista dos Tribunais, abr.-jun. 1986, p. 62.

MORAES, Luiza Rangel. "As novas atribuições do conselho fiscal diante da Lei Sarbanes-Oxley e da legislação brasileira", In Revista de Direito Bancário e do Mercado de Capitais, vol. 29. São Paulo: Ed. Revista dos Tribunais, jul.-set. 2005, p. 47. 
Penteado, Mauro Rodrigues. "Bibliografia - 'O Conselho Fiscal das Companhias Brasileiras' - Waldírio Bulgarelli, $1^{\mathrm{a}}$ ed., 232 pp., Ed. RT, S. Paulo, 1988”, In Revista de Direito Mercantil, Industrial, Econômico e Financeiro, vol. 76. São Paulo: Ed. Revista dos Tribunais, out.-dez. 1989, p. 109.

. "As Empresas Estatais e os Sistemas de Supervisão e Controle", In Revista de Direito Mercantil, Industrial, Econômico e Financeiro, vol. 45. São Paulo: Ed. Revista dos Tribunais, jan.-mar. 1982, p. 20.

PÉrCIO, Gabriela Verona; LÉGER, Gabriel Guy. "A Competência Constitucional dos Tribunais de Contas para fiscalizar as sociedades de economia mista exploradoras de atividade econômica", Informativo de Direito Administrativo e Responsabilidade Fiscal -IDAF, vol. 43, Curitiba: Zênite, fev. 2005, pp.647-652.

Pinto Junior, Mário Engler. "O Novo Mercado da Bovespa e o compromisso da Sociedade de Economia Mista com práticas de boa governança corporativa”, In Revista de Direito Mercantil, Industrial, Econômico e Financeiro, vol. 128. São Paulo: Malheiros, out.-dez. 2002, p. 54.

Rosas, Roberto. "Tendências Atuais da Empresa Pública", In Revista de Direito Público, vol. 35. São Paulo: Ed. Revista dos Tribunais, jul.-dez. 1975, p. 143.

SAntos, Aline de Menezes. "Próximos Itens da Agenda de Governança Corporativa", In Revista RI, São Paulo: IBRI, Abril de 2003; pp. 15-16.

Simionato, Frederico Augusto Monte. "Conselho Fiscal: Ausência de Legitimação Processual de Acionista para a obtenção de informação em nome do conselheiro", In Revista de Direito Mercantil, Industrial, Econômico e Financeiro, vol. 109. São Paulo: Malheiros, jan.-mar. 1998, p. 150.

SzKLAROwsky, Leon Frejda. "Conselho Fiscal de Sociedades Anônimas Comuns e de Economia Mista”, In In Revista de Direito Público, vol. 78. São Paulo: Ed. Revista dos Tribunais, abr.-jun. 1986, p. 203.

TAVAREs Guerreiro, José Alexandre. "O Conselho Fiscal e o direito à informação", In In Revista de Direito Mercantil, Industrial, Econômico e Financeiro, vol. 45. São Paulo: Ed. Revista dos Tribunais, jan.-mar. 1982, p. 29.

WAISBERG, Ivo. "A evolução da jurisprudência sobre a responsabilidade civil dos administradores de instituições financeiras sujeitas a regimes especiais", In Revista de Direito Bancário e do Mercado de Capitais, vol. 40. São Paulo: Ed. Revista dos Tribunais, abr.-jun. 2008, p. 186.

WALD, Arnold. "A culpa e o risco como fundamentos da responsabilidade pessoal do diretor de banco", In Revista de Direito Bancário e do Mercado de Capitais, vol. 40. São Paulo: Ed. Revista dos Tribunais, abr.-jun. 2008, p. 345.

VerçosA, Haroldo Malheiros Duclerc. "Conselho Monetário Nacional: competência reguladora: as auditorias independentes", In In Revista de Direito Mercantil, Industrial, Econômico e Financeiro, vol. 124. São Paulo: Malheiros, out.-dez. 2001, p. 208. 


\section{Teoria Geral do Direito}

BeTtI, Emilio. Teoria Generale del Negozio Giuridico, $1^{\mathrm{a}}$ reimp.. Napoli: Edizioni Scientifiche Italiane, 2002.

BITTAR, Eduardo Carlos Bianca. O Direito na Pós-Modernidade. Rio de Janeiro: Forense Universitária, 2005.

CARnElutTI, Francesco. Teoria Generale del Diritto, $3^{\mathrm{a}}$ ed.. Roma: S.E. Foro Italiano, 1951.

De Trazegnies Granda, Fernando. Postmodernidad y Derecho. Santa Fe de Bogotá, Col: Temis, 1993.

Ferrajoli, Luigi. Principia Iuris: teoria del diritto e della democrazia, vol. I - "Teoria del Diritto". Bari: Laterza, 2007.

Kelsen, Hans. Teoria Pura do Direito, $6^{\mathrm{a}}$ ed.. [tradução da primeira edição da obra Reine Rechtslehre, de 1960, por João Baptista Machado]. Coimbra: Arménio Amado, 1984.

LUMIA, Giuseppe. Lineamenti di teoria e ideologia del diritto. Milão: Giuffrè, 1973.

Mello, Márcio Bernardes. Teoria do fato jurídico, 6 a ed.. São Paulo: Saraiva, 1994. Teoria do fato jurídico - plano da validade, $4^{\mathrm{a}}$ ed.. São Paulo: Saraiva, 2000.

RECASÉNS SicheS, Luís. Introducción al Estudio del Derecho, $2^{\mathrm{a}}$ ed.. México: Porruá, 1972.

Santoro-Passarelli, Francesco. Dottrine Generali del Diritto Civile, $9^{a}$ ed.. Nápoles: Jovene, 2002.

\section{Direito Público e temas relacionados (nacional e estrangeiro)}

AlmeIDA, João Batista de. A Proteção Jurídica do Consumidor, $5^{\mathrm{a}}$ ed.. São Paulo: Saraiva, 2006.

Bandeira de Mello, Celso Antonio. Curso de Direito Administrativo, 20 a ed.. São Paulo: Malheiros, 2006.

DebBASCH, Claude. Institutions et Droits Administratifs, vol 1 - les structures administratives, $3^{\mathrm{a}}$ ed.. Paris: PUF, 1985.

Denisov, A.; Kirichenko, M.. Derecho Constitucional Sovietico. Moscou: Ediciones en Lenguas Estranjeras, 1959.

Di PIETRo, Maria Sylvia Zanella. Direito Administrativo, $17^{\mathrm{a}}$ ed.. São Paulo: Atlas, 2004. 
Fragoso, Heleno Cláudio. Lições de Direito Penal, $2^{\circ}$ volume. São Paulo: Bushatsky, 1958.

GRIGORIÁN L.; DOLgOPÓLOV, Yuri. Fundamentos del Derecho Estatal Soviético (versão para o espanhol de O Razinkov e V. Mazuerenko do original russo ОСНОВЫ СОВЕТСКОГО ГОСУДАРСТВЕННОГО ПРАВА). Moscou: Editorial Progresso, s/d.

Hungria, Nelson. Comentários ao Código Penal, $2^{\text {a }}$ ed., Vol. VII - arts. 155 a 196. Rio de Janeiro: Forense, 1958.

Silva, José Affonso da. Curso de Direito Constitucional Positivo, $22^{\text {a }}$ ed.. São Paulo: Malheiros, 2003.

. Comentário Contextual à Constituição, $4^{\mathrm{a}}$ ed.. São Paulo: Malheiros, 2007.

SouZA, Braz Florentino Henriques de. Do Poder Moderador: Ensaio de Direito Constitucional. Recife: Typographia Universal, 1864.

\section{Pareceres}

BARroso, Luís Roberto. "Intervenção no Domínio Econômico - Sociedade de Economia Mista - Abuso do Poder Econômico", In Revista de Direito Administrativo, vol. 212. Rio de Janeiro: Renovar, abr.-jun. 1998, p. 306.

Bulgarelli, Waldírio. "Fiscalização da Companhia", In Problemas de Direito Empresarial Moderno. São Paulo: Revista dos Tribunais, 1989, pp.181-196.

COMPARATO, Fábio Konder. "Venda em bolsa de ações da União Federal no capital de Sociedade de Economia Mista e desrespeito às normas disciplinares do Mercado de Capitais", In Novos Ensaios e Pareceres de Direito Empresarial. Rio de Janeiro: Forense, 1981, pp. 290-312.

. "Sociedade de Economia Mista Transformada em Sociedade Anônima Ordinária - Inconstitucionalidade", In Revista Trimestral de Direito Público, vol. 25, São Paulo: Malheiros, 1999, pp. 61-68.

DAllari, Adílson Abreu. "Sociedade de Economia Mista - Sócio Estratégico - Acordo de Acionistas", In In Revista de Direito Administrativo, vol. 221. Rio de Janeiro: Renovar, jul.-set. 2000, p. 379.

EIZIRIK, Nelson Lars. "Conselho Fiscal - Composição - Impedimentos - Interpretação do $\S 2^{\circ}$ do art. 162 da Lei das Sociedade Anônimas", In Temas de Direito Societário. Rio de Janeiro: Renovar, 2005.

FranÇA, Erasmo Valladão Azevedo e Novaes; PEREIRA Neto, Edmur de Andrade Nunes. "Sociedade Anônima - Fraude à Lei - Alteração dos Estatutos como intuito de evitar que os acionistas preferencialistas adquiram o direito de voto às vésperas de completar o terceiro exercício social sem o pagamento de dividendos - Abuso do Poder de Controle", In Revista de Direito Mercantil, Industrial, Econômico e Financeiro, vol. 133. São Paulo: Malheiros, jan.-mar. 2004, p. 259. 
GRAU, Eros Roberto. "Sociedade de Economia Mista - Nulidade de Acordo de Acionistas que importa em mudança de seu acionista controlador", In Revista de Direito Administrativo, vol. 222. Rio de Janeiro: Renovar, out.-dez. 2000, p. 348.

LACERDA, Galeno. "Parecer sobre legitimidade processual do conselho fiscal [1977]", In Direito Comercial, vol. IX - sociedades mercantis: casos selecionados. Rio de Janeiro: Forense, 2004, pp. 7-10.

LAMY FILHO, Alfredo. "O Conselho Fiscal - Abuso de minoria [1994]", In Temas de S.A.. Rio de Janeiro: Renovar, 2007, pp. 225-234.

LEÃES, Luiz Gastão Paes de Barros. "Conselho Fiscal e as Empresas de Auditoria", In Pareceres, vol. 1. São Paulo: Singular, 2004, pp. 597-604.

“Abuso da Minoria em Aumento de Capital", In Pareceres, vol. 2. São Paulo:

Singular, 2004, pp. 1.211-1.225.

Pontes de Miranda, Francisco Cavalcanti. "Parecer nr. 201", In Dez Anos de Pareceres, vol. 8. Rio de Janeiro: Francisco Alves, 1976, pp.34-47.

\section{Teses e Dissertações}

Costa, Luiz Felipe Duarte Martins. Contribuição ao estudo da responsabilidade dos administradores de companhias abertas (dissertação de Mestrado sob a orientação de Paulo Salvador Frontini apresentada junto ao Departamento de Direito Comercial). São Paulo: Faculdade de Direito da Universidade de São Paulo, 2006.

GoRgA, Érica Cristina Rocha. "Does Culture Matter for Corporate Governance? A Case Study of Brazill", John M. Olin Program in Law and Economics, Working Paper nr. 257 - Palo Alto, CA: Stanford Law School, Maio 2003.

JosuÁ, Adriana. Governança Corporativa e Teoria da Agência (dissertação de Mestrado sob a orientação de Rachel Sztajn apresentada junto ao Departamento de Direito Comercial). São Paulo: Faculdade de Direito da Universidade de São Paulo, 2005 .

QUITERIO, Cristiane Bernardes Antunes. Concentrated corporate control, legal protections to minority shareholders and development of the capital markets: the Brazilian experience. (dissertação de mestrado sob a orientação de George Triantis, apresentada junto à Faculdade de Direito da Universidade de Virginia, EUA). Charlottesville, VA: University of Virginia School of Law, 2002.

NogueIRA, André Carvalho. A dissolução do poder econômico como princípio regulatório (tese de Doutorado sob a orientação de José Tadeu De Chiara, apresentada junto ao Departamento de Direito Econômico e Financeiro). São Paulo: Faculdade de Direito da Universidade de São Paulo, 2005.

SANTOS, Aline de Menezes. A governança corporativa das empresas no Brasil: uma abordagem jurídica inspirada na nova economia institucional e na teoria organizativa 
(dissertação de Mestrado sob a orientação de Paulo Fernando Campos Salles de Toledo apresentada junto ao Departamento de Direito Comercial). São Paulo: Faculdade de Direito da Universidade de São Paulo, 2004.

VON ADAMEK, Marcelo Vieira. Responsabilidade Civil dos Administradores de S/A (e as ações previstas na Lei 6.404/76 para efetivá-la) (dissertação de Mestrado sob a orientação de Erasmo Valladão Azevedo e Novaes França apresentada junto ao Departamento de Direito Comercial). São Paulo: Faculdade de Direito da Universidade de São Paulo, 2006.

ZveIBIL, Daniel Guimarães. Contribuição para uma análise processual dos conflitos brasileiros de atribuição (dissertação de Mestrado sob a orientação de José Ignácio Botelho de Mesquita apresentada junto ao Departamento de Direito Processual). São Paulo: Faculdade de Direito da Universidade de São Paulo, 2006.

\section{Obras de interesse geral}

AlenCAStro, Luiz Felipe; et alli. História da vida privada no Brasil, vol. 2 [org.: Luiz Felipe Alencastro]. São Paulo: Companhia das Letras, 1997.

Arangio-RuIz, Vicenzo. Storia del Diritto Romano, $7^{\mathrm{a}}$ ed.. Napoli: Jovene, 2006.

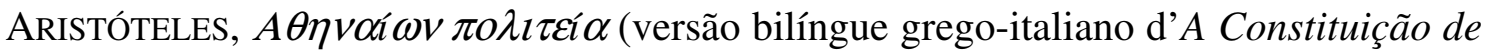
Atenas, organizada por Giuseppe Lozza. Milão: Mondadori, 2006).

BAKAN, Joel. The Corporation: the pathological pursuit of profit and power. Nova Iorque: Free Press, 2004.

BAnNer, Stuart. Anglo-American Securities Regulation: Cultural and Political Roots, 1690-1860. Cambridge, UK: Cambridge University Press, 2003.

. Legal Systems in Conflict: property and sovereignty in Missouri, 1750-1860.

Norman, OK: Oklahoma University Press, 1998.

CAINES, George. An Inquiry into the Law Merchant of the United States - Lex Mercatoria Americana on several heads of commercial importance. Nova Iorque, NY: Isaac Collins, 1802 (volume republicado em edição facsimilar pela Lawbook Exchange: Clark, NJ, 2006).

CAldeIRA, Jorge. Mauá - Empresário do Império, $18^{\mathrm{a}}$ reimpressão. São Paulo: Companhia das Letras, 1995.

CÆSAR, Gaio Iulius. De bello civili (versão bilíngue latim-italiano d'A Guerra Civil, organizada por Carlo Carena. Milão: Mondadori, 2008).

Craven, Wesley Frank. The Virginia Company of London, 1606-1642. Williamsburg, VA: Virginia 350th Anniversary Celebration Corporation, 1957.

The Dissolution of the Virginia Company: the failure of a colonial experiment. Gloucester, MA: P. Smith, 1964. 
FaOro, Raymundo. Os Donos do Poder - Formação do Patronato Político Brasileiro, $10^{\text {a }}$ ed.. Rio de Janeiro: Globo, 1996.

Franco, Hilário; MARRA, Ernesto. Auditoria Contábil, 4ª ed.. São Paulo: Atlas, 2001.

FreYre, Gilberto. Casa-Grande \& Senzala, 32a ed.. Rio de Janeiro: Record, 1997. . Sobrados e Mucambos, 9a ed.. Rio de Janeiro: Record, 1996.

FRIEDMAN, Lawrence Meir. A History of American Law, $2^{\text {a }}$ ed.. Nova Iorque: Simon e Schuster, 1985. . Total Justice. Nova Iorque, NY: Russell Sage Foundation, 1994. . Law in America - a short history. Nova Iorque, NY: Modern Library, 2004.

FurTado, Celso. Formação Econômica do Brasil, 14ª ed.. São Paulo: Editora Nacional, 1976.

Galbraith, John Keneth. O Novo Estado Industrial (tradução de Leônidas Gontijo de Carvalho à primeira edição de The New Industrial State), $3^{\text {a }}$ ed.. São Paulo: Nova Cultural, 1997.

GRAHAM, Richard. Patronage and Politics in Nineteenth-Century Brazil. Palo Alto, CA: Stanford University Press, 1990.

GreEnSPAn, Alan. The Age of Turbulence. Nova Iorque: Penguin, 2007.

HoBSBAWM, Eric. Industry and Empire - from 1750 to the present day, $4^{\text {th }}$ ed.. Londres: Penguin, 1999.

Holanda, Sérgio Buarque de. Visão do Paraíso - os motivos edênicos no descobrimento e colonização do Brasil, $6^{\text {a }}$ ed.. São Paulo: Brasiliense, 1994.

HoRwiTz, Morton J.. The transformation of American Law: 1780-1860. Cambridge, MA: Harvard University Press, 1977.

Kent, James. Commentaries on American Law. Nova Iorque: O. Halstead, 1827 (volume republicado em edição facsimilar pela Lawbook Exchange: Clark, NJ, 2005).

LEAL, Victor Nunes. Coronelismo, enxada e voto: o município e o regime representativo no Brasil, $2^{\text {a }}$ ed.. São Paulo: Alfa-Ômega, 1975.

LitTleton, Ananias Charles. Accounting Evolution to 1900, $2^{\mathrm{a}}$ ed.. Nova Iorque: Russell \& Russell, 1966.

MARCondes DE SouZA, Thomaz Oscar. Novas Achegas à História dos Descobrimentos Marítimos. São Paulo: Heder, 1963.

Marcos, Rui Manoel de Figueiredo. As Companhias Pombalinas - contributo para a história das sociedades por acções em Portugal. Coimbra: Almedina, 1997. 
MendonçA, Joseli Maria Nunes. Entre a mão e os anéis - a lei dos sexagenários e os caminhos da abolição no Brasil. Campinas: EdUnicamp, 1999.

Prado Junior, Caio. História Econômica do Brasil, 42ª ed.. São Paulo: Brasiliense, 1995.

RIBEIRo, Darcy. O Povo Brasileiro: a formação e o sentido do Brasil, $2^{\mathrm{a}}$ ed., $12^{\mathrm{a}}$ reimpressão. São Paulo: Companhia das Letras, 1995.

RIPERT, Georges. Le Régime Démocratique el le Droit Civil Moderne. Paris: Librairie Générale de Droit et de Jurisprudence, 1936.

Schwartz, Herman M.. States Versus Markets - History, Geography and the Development of the International Political Economy. Nova Iorque: St Martin's Press, 1994.

SouzA, Antônio Cândido de Mello. Parceiros do Rio Bonito. Rio de Janeiro: José Olympio, 1964.

SouzA, Fernando de. A Real Companhia Velha - Companhia Geral da Agricultura das Vinhas do Alto Douro (1756-2006). Porto: CEPESE, 2006.

SouZA, Laura de Mello; et alli. História da vida privada no Brasil, vol. 1 [org.: Laura de Mello e Souza]. São Paulo: Companhia das Letras, 1997.

SPRUYT, Hendrik. The Sovereign State and Its Competitors. Princeton, NJ: Princeton University Press, 1994.

THAYER, James B.. Lex Aquilia - text, translation, and commentary. Cambridge, Mass: Harvard University Press, 1929.

VIRGÍlio Maro, Publius. Aneis (versão bilíngue latim-italiano da Eneida, organizada por Luca Canali. Milão: Mondadori, 2000).

\section{Dicionários}

BAILly, Antoine. Dictionnaire Grec-Français, 39e Ed.. Paris: Hachette, 1985.

CunHA, Antonio Geraldo da. Dicionário Etimológico Nova Fronteria da Língua Portuguesa, $2^{\mathrm{a}}$ ed., $11^{\mathrm{a}}$ reimpressão. Rio de Janeiro: Nova Fronteira, 1999.

FARIA, Ernesto. Dicionário Latino-Português. Belo Horizonte: Garnier, 2003.

GAFFIOT, Félix. Dictionnaire Illustré Latin-Français. Paris: Hachette, 1934.

MORRIS, William. The American Heritage Dictionary, $2^{\text {nd }}$ ed.. Boston, MA: Houghton e Mifflin, Co., 1991.

Nouveau Petit Larousse. Paris: Larousse, 1968. 
Santos-Saraiva, Francisco R.. Novíssimo Diccionário Latino-Portuguez, $9^{\mathrm{a}}$ ed.. Rio de Janeiro: Garnier, 1927.

Torrinha, Francisco. Dicionário Latino-Português, $7^{\mathrm{a}}$ ed., $3^{\mathrm{a}}$ tiragem. Porto: Reunidos, 1997.

\section{Decisões (tribunais estrangeiros)}

Brown v. Kendall (60 Mass. [6 Cush] 292, Massachusetts, 1850, Rel. Pres. Lemuel Shaw).

Cenco Inc. v. Seidman \& Seidman (686 F.2d 449, Corte Federal de Apelação do $7^{\circ}$ Circuito, 1982, Rel. Richard Posner).

Charles River Bridge v. Warren Bridge (36 U.S. 420, Suprema Corte, 1937, Rel. Ministro Roger Taney).

Ernst \& Ernst v. Hochfelder (425 U.S. 185, Suprema Corte, 1976, Rel. Ministro Lewis Powell).

In re Oracle Corp. Derivative Litigation (824 A.2d 917, Delaware, 2003, Rel. VicePresidente Leo Strine).

Oracle Corp. v. Barone (829 A.2d 141, Delaware, 2003, Rel. Carolyn Berger).

Shlensky v. Wrigley (95 Ill. App. 2d 173, Illinois, 1968, Rel. Thomas Sullivan).

Smith v. van Gorkom (488 A.2d 858, Delaware, 1985, Rel. Henry Horsey).

Weinberger v. UOP, Inc. (457 A.2d 701, Delaware, 1983, Rel. Andrew Moore).

Zapata v. Maldonado (430 A.2d 779, Delaware, 1981, Rel. William Quillen).

\section{Decisões (tribunais brasileiros)}

STF, Mandado de Segurança $n^{0}$ 23.875-5/DF, Relator para o Acórdão Min. Nelson Jobim, v.v., j.: 10/11/2005, In Revista Trimestral de Jurisprudência, vol. 191, nr. 3, Brasília, DF: Imprensa Nacional/Supremo Tribunal Federal, p. 887.

STJ, $4^{\text {a }}$ Turma, REsp n ${ }^{\text {o }}$ 88.584/SP, Rel. Min. Barros Monteiro, v.u., j.: 12/06/2001, publicado DJU 24/09/2001, p. 306.

STJ, $3^{\text {a }}$ Turma, RMS no 3.245-0/SP, Rel. Min. Cláudio Santos, v.u., j.: 07/03/1995, publicado DJU 10/04/1995, p. 9270.

STJ, $3^{\text {a }}$ Turma, REsp n ${ }^{\text {o } 447.939 / S P, ~ R e l ~}{ }^{a}$. Min ${ }^{a}$. Nancy Andrighi, v.u., j.: 4/10/2007, publicado DJU 25/10/2007, p. 166. 
STJ, $2^{\text {a }}$ Turma, REsp no 172.736/RO, Rel. Min. Francisco Peçanha Martins, v.u., j.: 10/06/2003, publicado DJ 22/09/2003, p. 278.

STJ, $1^{\text {a }}$ Turma, REsp no 170.272/RO, Rel. Min. Garcia Vieira, v.u., j.: 08/06/1999, publicado DJ 02/08/1999, p. 145.

STJ, $1^{\text {a }}$ Turma, REsp n ${ }^{\text {7 } 738.833 / R J, ~ R e l . ~ M i n . ~ L u i z ~ F u x, ~ v . u . ~ j .: ~ 08 / 08 / 2006, ~ p u b l i c a d o ~}$ DJU 28/08/2006, p. 227.

STJ, $3^{\text {a }}$ Turma, REsp no 471.048/PR, Rela ${ }^{\text {a }}$ Min $^{\mathrm{a}}$. Nancy Andrighi, v.u., j.: 10/06/2003, publicado DJ 04/08/2003, p. 296.

TAMG, 6 ${ }^{\text {a }}$ Câm. Civ., AI n ${ }^{\text {0 }}$ 0392463-8, Rel. Juiz Belizário de Lacerda, v.u., j.: 22/05/2003, publicado DJMG 11/06/2003.

TJRS, 10ª Câm. Cív., Ap. Civ. no 70010250165, Rel. Des. Luiz Ary Vessini de Lima, v.u., j.: 30/06/2005, publicado DJRS 12/07/2005.

TJSP, $8^{\text {a }}$ Câm. Cív., Ap.Civ. no 62.520-1, Rel. Des. Arthur de Godoy, v.u., j.: 6/11/85, In Revista dos Tribunais, vol. 605. São Paulo: Ed. Revista dos Tribunais, março de 1986, p. 58.

TJSP, $1^{\text {a }}$ Câm. Civ., Ap. Civ. no 123.032-1, Rel. Des. Luis de Macedo, v.u., j. 28/08/90, dados de publicação indisponíveis.

TJSP, $1^{\text {a }}$ Câm. Cív., Ap. Civ. no 131.697-1, rel. Des. Roque Komatsu, v.u., j. 6/12/90, In Revista dos Tribunais, vol. 670. São Paulo: Ed. Revista dos Tribunais, 1991, p.77.

\section{Decisões administrativas nacionais}

CVM, Inquérito Administrativo CVM TA/RJ2002/1153, Rel. Dir. Wladimir Castelo Branco Castro, j.: 6/11/2002.

CVM, PAS n ${ }^{0}$ 20/04, Rel. Dir. Wladimir Castelo Branco Castro, j.: 25/10/05.

CVM, Proc. CVM RJ2001/12253, Rel. Dir. Wladimir Castelo Branco Castro, j.: 9/07/02 (com pedido de reconsideração negado em 15/10/02).

CVM, Proc. CVM RJ2003/7703, Rel. Dir. Luiz Antonio de Sampaio Campos, j.: 18/11/03.

CVM, Proc. RJ2004/5792, Rel. Dir. Wladimir Castelo Branco Castro, j.: 7/12/04.

CVM, Proc. CVM RJ2005/2734, Rel. Dir. Sergio Weguelin, j.: 30/08/05.

CVM, Proc. CVM RJ2005/0134, Rel. Dir. Sérgio Weguelin, 29/08/06.

CVM, Proc. CVM RJ2005/0147, Rel. Pres. Marcelo Fernandez Trindade, 10/07/07. 
CVM, Proc. CVM RJ2006/0594, Rel. Pres. Marcelo Fernandez Trindade, 10/07/07.

CVM, Proc. CVM RJ2007/3246, Rel. Pres. Marcelo Fernandez Trindade, j.: 10/07/07 (com pedido de reconsideração negado em 11/03/08, Rel. designado Dir. Marcos Barbosa Pinto).

CVM, Proc. CVM RJ2006/5701, Rel. Pres. Marcelo Fernandez Trindade, j.: 10/07/07 (com pedido de reconsideração negado em 11/03/08, Rel. designado Dir. Marcos Barbosa Pinto).

CVM, Proc. CVM RJ2007/11086, Rel. Dir. Marcos Barbosa Pinto, j.: 06/05/08 (com pedido de reconsideração negado em 23/09/08).

TCU, Proc. $n^{0}$ TC-010.659/94-3, relator Ministro Homero Santos, Decisão $n^{0}$ 345/95TCU, j.: 19/07/95, DOU 7/08/95, Seção 1, nr. 150, p.11832-11835.

\section{Manuais}

SeCretaria da ReCEItA Federal / COREF. Manual do Conselheiro Fiscal. Brasília, 2007.

InSTITUTO BRASILEIRO DE GOVERnANÇA CORPORATIVA - IBGC. Guia de Orientação para o Conselho Fiscal, $2^{\text {a }}$ ed., Coord.: Roberto LAMB e João Verner JuEnEMAnN. São Paulo: IBGC, 2007.

\section{Artigos e matérias jornalísticas}

Carvalho, Jailton. "Um país que em que (muito) pouco se fiscaliza", In O Globo, $\mathrm{n}^{\mathrm{o}}$ 27.124, Ano LXXXIII, Rio de Janeiro, edição de 11 de novembro de 2007, $1^{\circ}$ Caderno, p. 8.

FARIELlo, Danilo. "Governança Capenga”, In Valor Econômico de 31 de julho de 2007, p. D-1.

TEPEDINO, Gustavo. "Quem fiscaliza o fiscal?” (inicialmente publicado n'O Globo), In Temas de Direito Civil, 3ª ed.. Rio de Janeiro: Renovar, 2004. 